


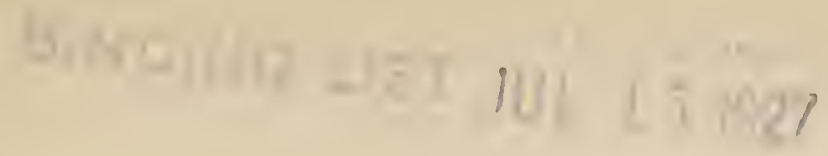



Digitized by the Internet Archive in 2008 with funding from Microsoft Corporation 

MORPHOLOGY OF GYMNOSPERMS 
THE UNIVERSITY OF CHICAGO PRESS CHICAGO, ILLINOIS

\section{Fgents}

THE BAKER \& TAYLOR COMPANY

NEW YORK

CAMBRIDGE UNIVERSITY PRESS

LONDON AND EDINBURGH 


\title{
MORPHOLOGY OF GYMNOSPERMS
}

\author{
BY \\ JOHN M. COULTER, Ph.D. \\ PROFESSUR OF BOTANY IN THE UNIVERSITY ( HICAGO \\ $A$ ND \\ CHARLES J. CHAMBERLAIN, Ph.D. \\ ASSISTANT PROFESSOR OF BOTANY IN THE UNJVERSITY OF CHICACO
}

W ITH +62 FIGURES

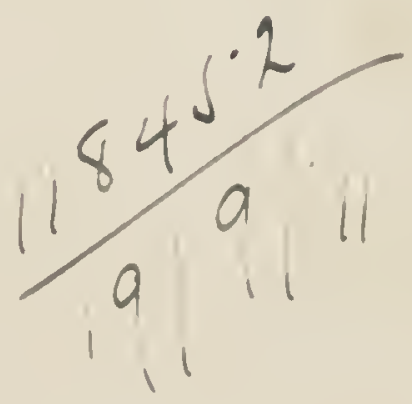

THE UNIVERSITY OF CHICAGO PRESS CHICAGO, ILLINOIS 


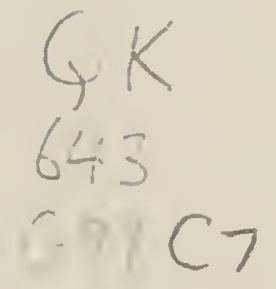

Copykight $1910 \mathrm{By}$

The University of Chicngo

All Rights Reserved

Published October Igro 
In I90 a our Worphology of Spermato phytes, Part I, was published. which comprised a presentation of the gymnosperms. It had grown out of a special course given to graduate students for several successive years, and although most of the ground had been traversed in this way sereral times, the larger part of the material in the book was taken from the contributions of other investigators. There was some new material included, but the chief contributions of the book were certain illustrations and the organized presentation of the group as a whole for research students.

During the last decade the special course referred to has been continued for successive generations of graduate students, with a constantly widening range of material and from new points of view. In addition to this extensive and repeated critical examination of material, a number of special investigations have been carried on in the laboratory. These investigations have been planned so that there might be not only a research contact with all regions of the gymnosperm series, but also a clearing up of unknown or doubtful forms. These special contributions from the laboratory hare agrgregated twenty-six since rgor, and have dealt with fourteen genera, distributed as follows: in Cycadales, Dioon. Vicrocycas, Encephalarlos. Ceratozamia, and Zamia; in Ginkgoales, Ginkgo; in Coniferales, Pinus, Thuja, Torreya, Phyllocladus, Podocarpus, and Dacrydium; in Gnetales, Ephedra and Gnetum. This has enabled us to present the living groups from an entirely different standpoint, and to use many illustrations prepared in this laboratory. The present account, therefore, is based upon our own work, supplemented by the work of other investigators, rather than a compilation from literature, supplemented by occasional personal observations.

Furthermore, the last decade has been one of unprecedented activity in the investigation of gymnosperms, as a comparison of the bibliography of the volume of I9o I with that of the present one will indicate. In this period the number of titles has increased from I 2 to +20 , some of the additions being accounted for by the larger 
inclusion of paleobotanical material. Aside from a far more complete knowledge of the living groups, including as it does now at least the salient facts in reference to almost every genus, there have been two notable advances. In the first place, during this period vascular anatomy has developed as a subject of first importance, and some of its most conspicuous contributions have been in connection with the origin and relationships of gymnosperms. In the second place, paleobotany has brought to light during the last decade more facts of importance in reference to the history of gymnosperms than in reference to any other group of plants. This has enabled us to treat of the extinct groups in a way that was impossible ten years ago.

Attention is called to the fact that on the basis of new knowledge we have reorganized our presentation of the gametophyte, by recognizing the spore as its first cell, rather than the mother cell, as in the previous volume. This needs no explanation, as it seems clear that the sporophyte generation ends and the gametophyte generation begins with the appearance of the spore. The plan of grouping the special literature of each great division in chronological order at the end of its presentation, and the general literature of gymnosperms in alphabetical order at the end of the volume, is continued. Such illustrations as have been copied are not only credited, but also referred to the publications in which they first appeared.

The authors appreciate, perhaps more keenly than anyone, that a book of this nature in a certain sense is out of date as soon as it has left the press. Papers will continue to appear which would have been of great service in this volume, and yet perhaps no great group of plants is just now in better condition for a presentation which professes to be only a concise summary of knowledge, useful in stimulating and guiding further research.

John M. COUlter

Charles J. Chamberlain

The Lxiversity of Chicago May igro 


\section{CONTENTS}

Cinapter I. Cycadofilicales . . . . . . .

r. Vegetative organs . . . . . 3

Vascular anatomy of Pteridophytes . . . . 4

Vascular anatomy of Cycadofilicales . . . . I2

Leaf . . . . . . . . . $2 \mathrm{I}$

2. Spore-producing members . . . . . 25

Microsporangium . . . . . . . . 25

Megasporangium . . . . . . 31

3. Gametophytes . . . . . . . . 48

Female gametophyte . . . . . . . . 48

Male gametophyte . . . . . . . 49

4. History and distribution . . . . . 5 I

5. Relationship to ferms . . . . . . 5 . . .

Paleozoic ferns . . . . . . . . 52

Origin of Cycadofilicales . . . . . . . 55

6. Relationship to other gymnosperms . . . . . . 58

Literature cited . . . . . . . . 60

Chapter II. Bennettitales . . . . . . . 65

r. Vegetative organs . . . . . . . . . 66

Vascular anatomy . . . . . . 70

Leaf . . . . . . . . 7 I

2. Spore-producing members . . . . 72

Strobilus . . . . . . . . 7?

Microsporangium . . . . . . . . . 75

Megasporangium . . . . . . . 78

3. Gametophytes . . . . . . . 82

4. Embryo . . . . . . . $8_{3}$

5. History and distribution . . . . 85

6. Relationship to other gymnosperms . . . . S6

Literature cited . . . . . . . . . 89 
Chapter III. Cicadiles

I. Vegetative organs

Vascular anatomy

Leaf

Root

IOS

I I 2

2. Spore-producing members

Microsporangium

I I 4

Megasporangium

3. Gametophytes

Female gametophyte.

Male gametophyte

Fertilization.

4. Embryo . . . . . . . . . . I50

5. History and distribution . . . . . . . I 56

6. Relationship to other gymnosperms . . . . I57

Literature cited . . . . . . . . . $15 S$

Chapter IV. Cordaitales . . . . . . . . 163

I. Vegetative organs . . . . . . . . I64

Vascular anatomy . . . . . . . . . $\quad$ I 65

Leaf . . . . . . . . . . 68

Root . . . . . . . I . II

2. Spore-producing members . . . . . . 172

Strobilus . . . . . . . . . I 72

Microsporganium . . . . . . . . 172

Megasporangium . . . . . . . 174

3. Gametophytes . . . . . . . I 7 S

4. History and distribution . . . . . . . ISo

5. Relationship to other gymnosperms . . . . . ISo

Literature cited . . . . . . . . $\mathrm{I}_{3}$

Chapter V. Ginkgoales . . . . . . . IS5

I. Vegetative organs . . . . . . . . IS 5

Vascular anatomy . . . . . . . . . I $\mathrm{I}_{7}$

Leaf . . . . . . . . . . IS9 
2. Spore-producing members

Microsporangium

Megasporangium

3. Gametophytes.

liemale gametophyte . . . . . . 203

Male gametophyte

206

Fertilization.

4. Embryo . . . . . 2 210

5. History and distribution . . . 2 I5

6. Relationship to other gymnosperms . . . 2 . 26

Literature cited . . . . . . . . 2 I7

Chapter VI. Coniferales (Pinaceae) . . . . . 220

I. Vegetative organs . . . . . . . . . 222

Viscular anatomy . . . . . . . . . . . $22 \mathrm{~S}$

Leaf . . . . . . . . . . . 235

2. Spore-producing members . . . . . . 238.

Microsporangium . . . . . 240

Megasporangium _ . . . . . . . 244

3. Gametophytes . . . . . . . 259

Female gametophyte . . . . . . . . 259

Male gametophyte . . . . . . 272

Fertilization . . . . . . . . $\quad 2 S_{4}$

4. Embryo . . . . . . . . . 287

Proembryo . . . . . . . . $28 S$

Suspensor and embryo _. . . . . . . 295

5. Distribution . . . . . . 3OI

6. History . . . . . . . . 303

7. Interrelationship of tribes . . . 308

S. Relationship to other gymnosperms . . . . 300

Chapter VII. Coniferales (Taxaceae) . . . 3 3 3

I. Vegetative organs . . . . . . 3 . . 35

Vascular anatomy . . . . . . 315

Leaf . . . . . . 317 
2. Spore-producing members

PAGE

Microsporangium

Megasporangium

3. Gametophytes.

Female gametophyte

Male gametophyte

Fertilization.

4. Embryo

Proembryo

Suspensor and embryo

348

5. History and distribution

6. Relationship to other gymnosperms 350

List of genera

Literature cited

Chapter VIII. Gnetales

I. Vegetative organs

Vascular anatomy

366

Leaf

2. Spore-producing members . . . . . . 370

Microsporangium . . . . . . . 37 I

Megasporangium . . . . . . . . 376

3. Gametophytes . . . . . . . . 384

Female gametophyte . . . . . . . . $3 \mathrm{~S}_{4}$

Male gametophyte . . . . . . . . $3 \mathrm{~S}_{9}$

Fertilization . . . . . . . 39

4. Embryo . . . . . . . . . . 393

5. History and distribution . . . . . . 402

6. Relationships . . . . . . . 402

Literature cited . . . . . . . . . . 404

Cimater IX. Evolutionary tendencies aMong gimosperms 406

Phylogeny . . . . . . . . . . . 407

Vascular anatomy . . . . . . . . . 4II

Leaf . . . . . . . . . . . 4 $4 \mathrm{I} 2$

Strobilus . . . . . . . . . . . $4 \mathrm{I} 3$ 
Stamen

P.1.F.

Ovule

415

Female gametophyte

416

Male gametophyte

Fertilization

42 I

Embryo

423

426

SUMMARY OF LITERATURE CITED

INDEX 



\section{CHAP'TER I}

\section{CYCADOFILICALES}

The discovery of this paleozoic group of ermnosperms has been one of the remarkable achierements of the present decade. Including as it does, the most fernlike assemblage of seed plants, the discovery is of enormous importance to phylogeny. A brief slictch of the development of our knowledge of the group will serve as an introduction to the fuller account.

The Carboniferous period is notable for its fernlike vegetation (I I), which has been estimated (56) to make up at least one-half of the known flora. The classification of the leaves is based upon form and renation, and a number of frond genera have been descrilsed. which, although necessarily artificial, are sufficient for the cataloguing of material. The association of sporangia with these fronds is by no means general; in fact, an enumeration (II) of the frond species from the British Carboniferous showed an association of fronds and sporangia in less than one-fifth of them. It was assumed, without question, that the sporangium-bearing fronds must be those of ferns, and the opinion became current that the sporangia indicated that these ferns were of the general Marattia type. Hence there arose the belief that the most dominant regetation of the Carboniferous could be spoken of as a Marattia plexus, including a far greater diversity of forms over a far wider geographical range than do the Marattiaceac of the present flora. This riew involved also the belief that the relative age of eusporangiate and leptosporangiate ferns had been settled by the sure testimony of history.

In $188_{3}$ STuR ( 7 ) had become so impressed by the fact that the large majority of the carboniferous fronds remained persistently sterile, in spite of the increasing accumulation of material, that he suggested that these forms might not be ferns. In view of the sul)sequent discoveries, this statement, based only upon persistent negative evidence, appears like a prophecy. However, a few years later (II) sporangia were discovered upon the persistently sterile fronds of a species of one of the largest of the frond genera (Sphenopteris), 
which seemed to represent clearly the synangial habit of the Marattiaceae. Furthermore, the anatomy of the petioles of other frond genera was described as being much like that of the petioles of the Marattiaceae. Such results seemed to confirm the old view that the sterile frond genera were not only ferns, but also ferns of the Marattia type.

In 1887 WillliausoN (5, p. 299) first recognized "the presence in the carboniferous flora of plants combining the characters of ferns and cycads" (86); and in I896 Williamsos and Scott (I8) described the anatomy of Lyginodendron and Heterangium. In the same year Weber and Sterzel ( $\mathrm{I}_{\gamma}$ ) described the anatomy of Medullosa. These are prominent stem genera, which belong to some of the sterile frond genera; and these observers discovered in them an anatomical structure distinctly intermediate between that of ferns and that of cycads. In view of this fact, in I899 Potonik (20) named the group $C y c a d o f i l i c e s$, basing it upon anatomical features, its composite character being indicated by the name. The striking anatomical feature of the Cycadofilices is the association of secondary wood with a fernlike vascular system. There was no occasion, on this account, to remove Cycadofilices from pteridophytes, as secondary wood occurs in Sphenophyllum, Lepidodendron, Calamodendron. etc., and also in existing species of Isoetes, Selaginclla, Psilotum, and Equisctum. Nor would this character eren remore the group from ferns, for a cambium occurs in Marattia, Angiopteris, Ophioglossum, and Botrychium (63). In fact, secondary wood eridently originated independently in many groups and at many times (50), and therefore could not be made the basis of an important segregation.

In I903, howerer, Oliver and Scott (39) announced that certain characteristic seeds belonged to the fronds of Lyginodendron Oldhamium, and the association with pteridophytes was at an end. In the same paper the group name Pteridosperms was proposed, to include those Cycadofilices that bear seeds. Since then other seedbearing fronds have been discovered, until now all of the prominent frond genera are involved.

Finally, in 1905 Kinstox (54) announced the discovery of the microsporangia of Lyginodendron Oldhamium, and all of the important 
structures, of this form at least, had been assembled. These micro sporangia at once suggested that the sporangia heretofore thought to demonstrate the occurrence of palcozoic ferns of the Ifaratlia type might be the microsporangia of pteridosperms. In this way the dominant Marattia plexus has disappeared, and the question has been raised as to the evidence of ferns in the Palcozoic. In any event, the pteridosperms have replaced the ferns as a dominant palcozoic group. ScotT $(56)$ has stated that scarcely 20 per cent of the "fern fronds" of the Carboniferous offer any real eridence of being true ferns; and that 30 to 40 per cent of the unassigned remainder may be assumed to fall in the same ratio. In consequence of this, he suggests that since the Carboniferous has been described as the "Reign of the higher cryptogams," remembering that Cordaitales were associated with pteridosperms, it had better be characterized as the "Reign of the primitive seed plants."

It seems impossible at present to recognize a group of pteridosperms as distinct from Cycadofilices, and there is a growing impressiun that the two groups are coextensive. As Scott (82) remarks, the pteridosperms "have proved much more extensive, and also more remote from the ferns, than at first realized." Under the circumstances, it would seem proper to retain for the group the older name. It seems clear, also, that it should take its place as a group of gymnosperms coordinate with Cordaitales, Cycadales, Coniferales, etc., for it is impossible as yet to construct a definition which would exclude it from gymnosperms on the basis of characters of so high an order as those which separate gymnosperms from angiosperms. For this reason, we have appended to the older name the termination that makes it conform to the names of groups of similar rank, and shall refer to it hereafter as the Cycadofilicales $\left(8_{t}\right)$.

\section{The vegetative organs}

The general fernlike aspect of the Cycadofilicales was the conspicuous feature of their habit, an aspect due to their foliage (fig. I). The evidence indicates that there were climbers and trees among them, as well as the more usual habit among modern ferns. In order to understand the combination of fernlike and cycad-like characters exhibited by the regetative structures of the Cycadofilicales, 
it is necessary to present briefly the rascular anatomy of the pteridophytes, and especially that of the ferns. This will serve not

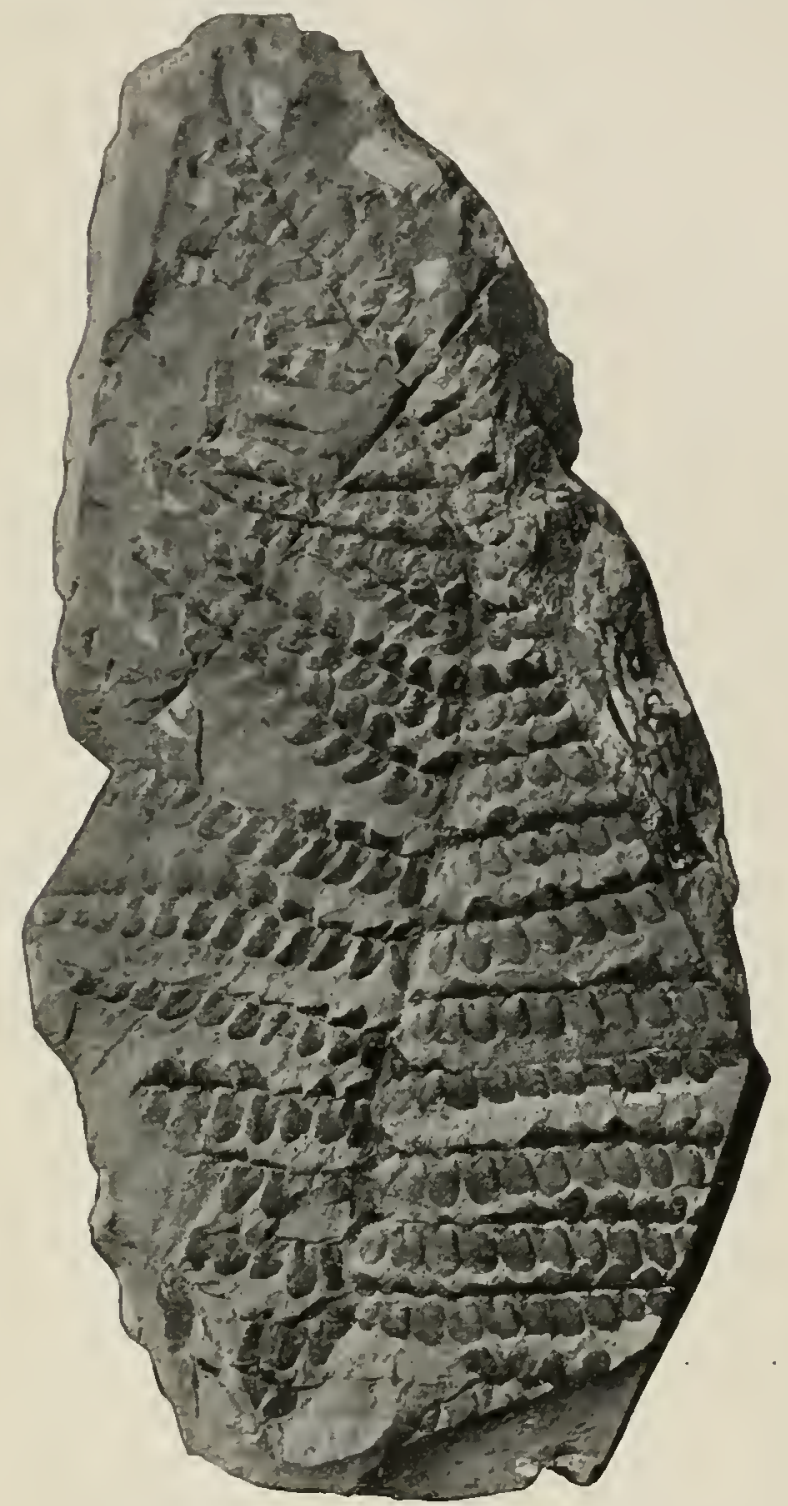

Fig. I.- Neuropteris: impression of frond.From photograph by Kinston. only as an introduction to Cycadofilicales, but also to the vascular anatomy of gymnosperms in general.

\section{VASCULAR ANATOMY OF PTERIDOPHYTES}

The most important recent advance in our knowledge of the rascular groups has been made by the students of rascular anatomy. Morphology had become almost entirely restricted to a study of the structures associated with reproduction, for these structures seemed to offer the only clue to the larger relationships. An enormous mass of facts had been accumulated in reference to the anatomy of the regetative structures, but it was not organized so as to be of service to the morphologist. Now vascular anatomy has emerged as a subject organized upon a morphological basis, and its value in supplementing the older morphology cannot be orerestimated. In fact, it is really the extension of morphology to include the vascular system.

The three conspicuous kinds of rascular axis among pteridophytes are (I) the protostele (fig. 2), which is a single, solid, concentric rascular cylinder; (2) the siphonostele (fig. 3), which is a hollow vascular 
cylinder inclosing pith (medulla); and (3) the polystele (fig. 5), which contains several concentric vascular strands. There are two kinds of siphonostele: one (fig. 3) with internal as well as external phloem (amphiphloic; often called solenostele), the other (fig. 4) with only external phloem (ectophloic). The question as to the phylogenetic

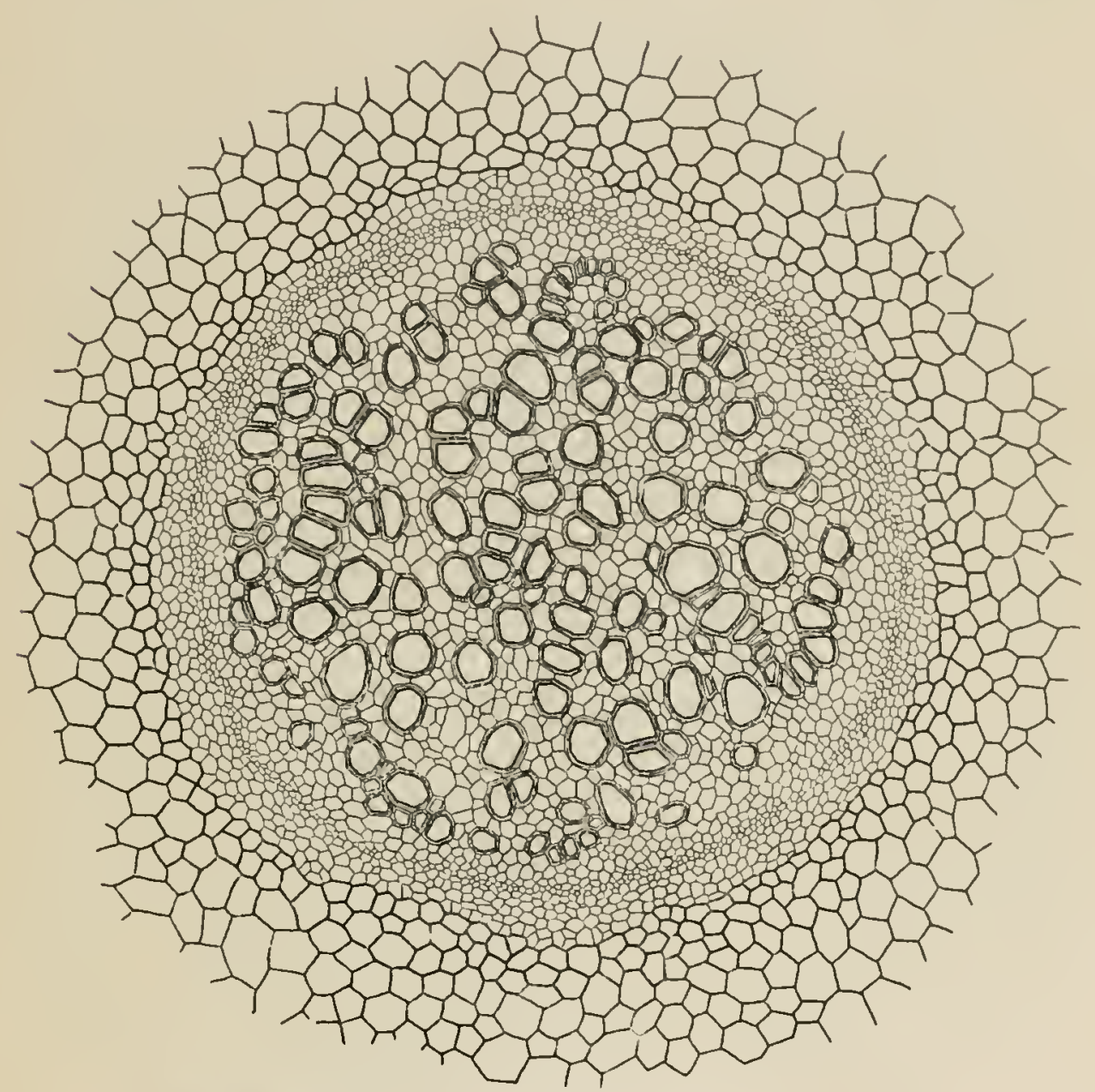

FIG. 2.-Gleichenia pubescens: transverse section of stem, showing the protostele; $\times$ 35.-After Coulter (88).

connection of these types has given rise to considerable diversity of opinion, but for our purpose the general situation seems clear.

The protostele is accepted as the most primitive type of stele. In the study of sporelings it has been shown that the protostele is the first stage in the development of the stele of ferns, whatever may be the adult character $(\mathrm{I} 3,3 \mathrm{I}, 36)$. Among ferns the young protostelic stage usually passes into the siphonostelic, but it persists, for example, 
in the adult stems of species of Gleichenia (fig. 2), Hymenophyllum, Lygodium, and the paleozoic Botryopteris (36).

Which of the two kinds of siphonostele has been derived directly from the protostele is a question under discussion. One view (3I) is that the amphiphloic condition was the first to appear, and that by the gradual reduction of the internal phloem the ectophloic stage

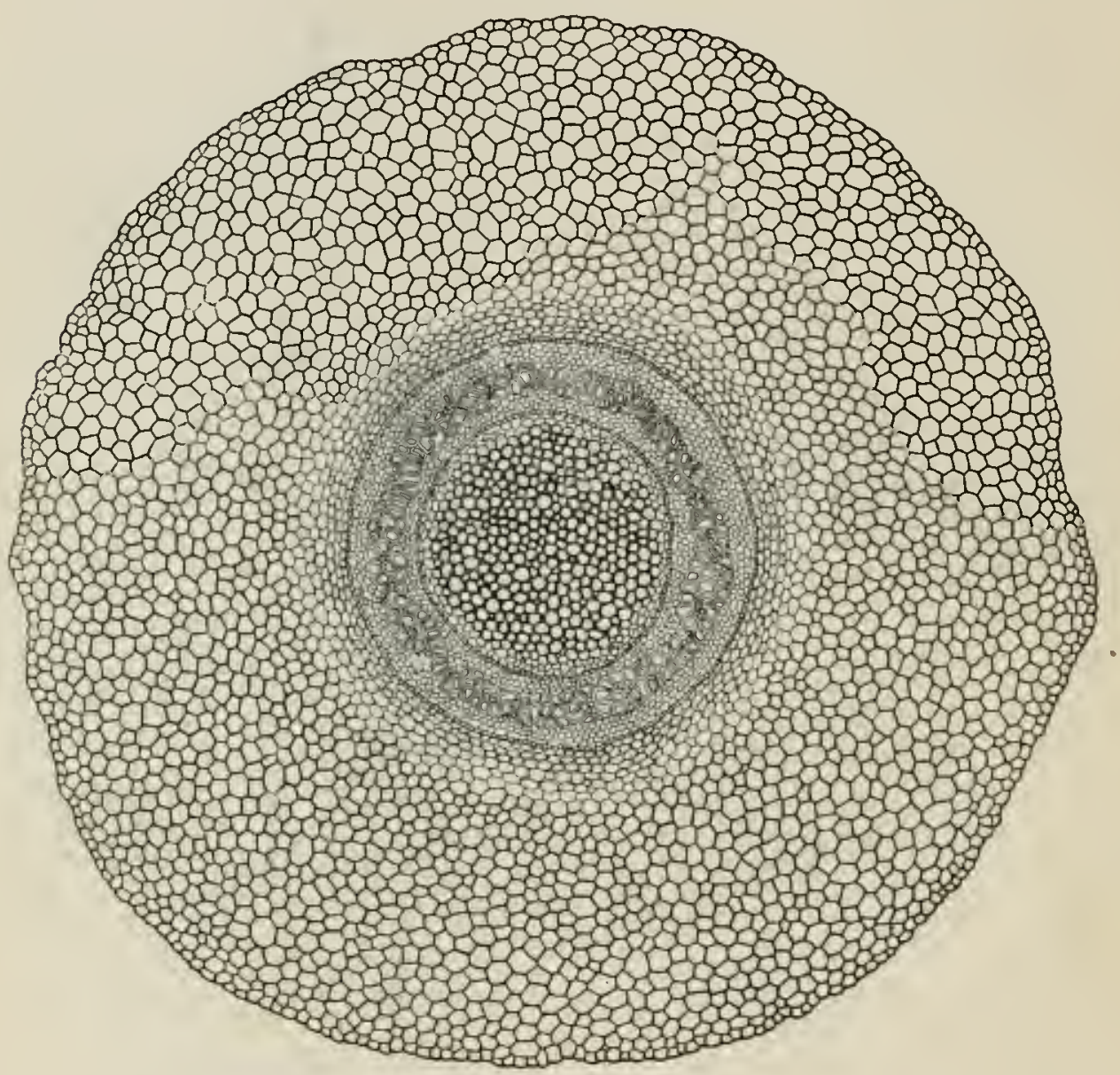

FIG. 3.-Adiantum pedutum: transverse section of stem, showing the amphiphloic siphonostele; $\times 25$-After Coulter (88).

was reached. The other view $\left(3^{6}\right)$ is that pith appeared first in the solid stele (protostele), without any internal phloem, which would make the ectophloic siphonostele more primitive than the amphiphloic. The investigators concerned with these views have arranged such convincing series that it seems reasonable to suppose that both kinds of siphonostele may have arisen directly from the protostele. In any event, the sporeling of such a fern as Adiantum begins with a pro- 
tostelic stem, which merges directly into a siphonostclic condition with internal phloem; while in Osmumila, although there is usually in the adult stem a siphonostele without internal phloem, in (). cimamomea $(27,3 \mathrm{I})$ occasionally internal phloem is found. Neither type of siphonostele is extensively displayed among ferns (36), the

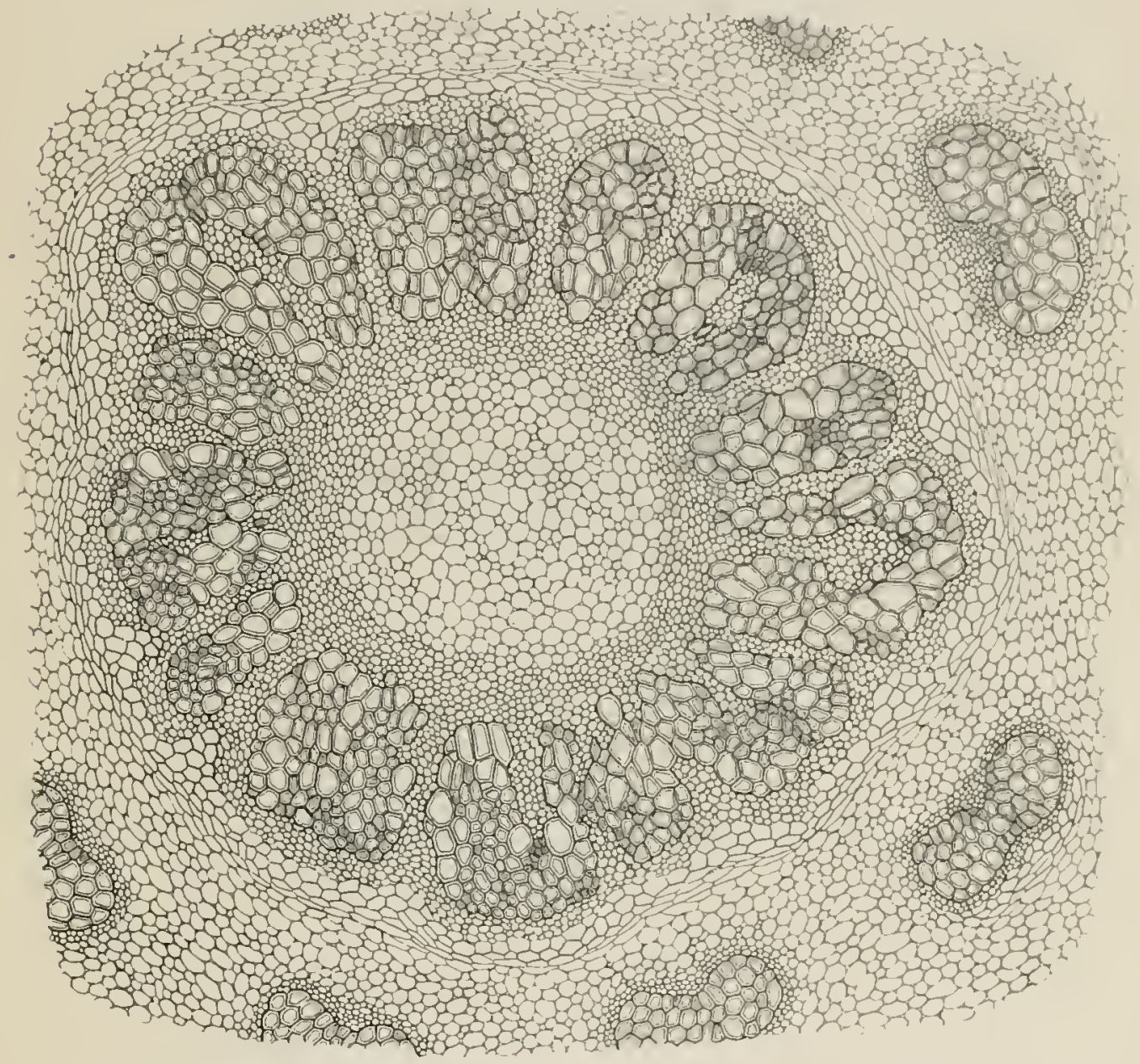

Fig. 4.-Osmunda cinnamomea: transverse section of stem, showing the ectophloie siphonostele; $\times 25$.-.-After Coulter (SS).

amphiphloic type occurring, for example, in Adiantum, Matonia, Lo.rsoma, Aneimia mexicana, etc., and the cctophloic type in Osmunda (fig. 4), Platyzoma, ${ }^{\mathrm{I}}$ Schizaca, etc.

The prevailing type of stele among the ordinary ferns is the polystelic (10), occurring in most Polypodiaceae, Dicksoniaceac, Cyatheaceae, Marattiaceae, etc. (36). The type is well illustrated by Pteris

I A monotypic genus regarded by some taxonomists as a species of Gleichenia. 
aquilina (fig. 5), the ligure referred to showing nine smaller peripheral vascular strands and four much larger central ones. It has been shown (3I) that the young stem of Pleris is not polystelic, but that the vascular cylinder is an amphiphloic siphonostele, like that of Adianlum. In growing to the adult stage it passes gradually into the poly-

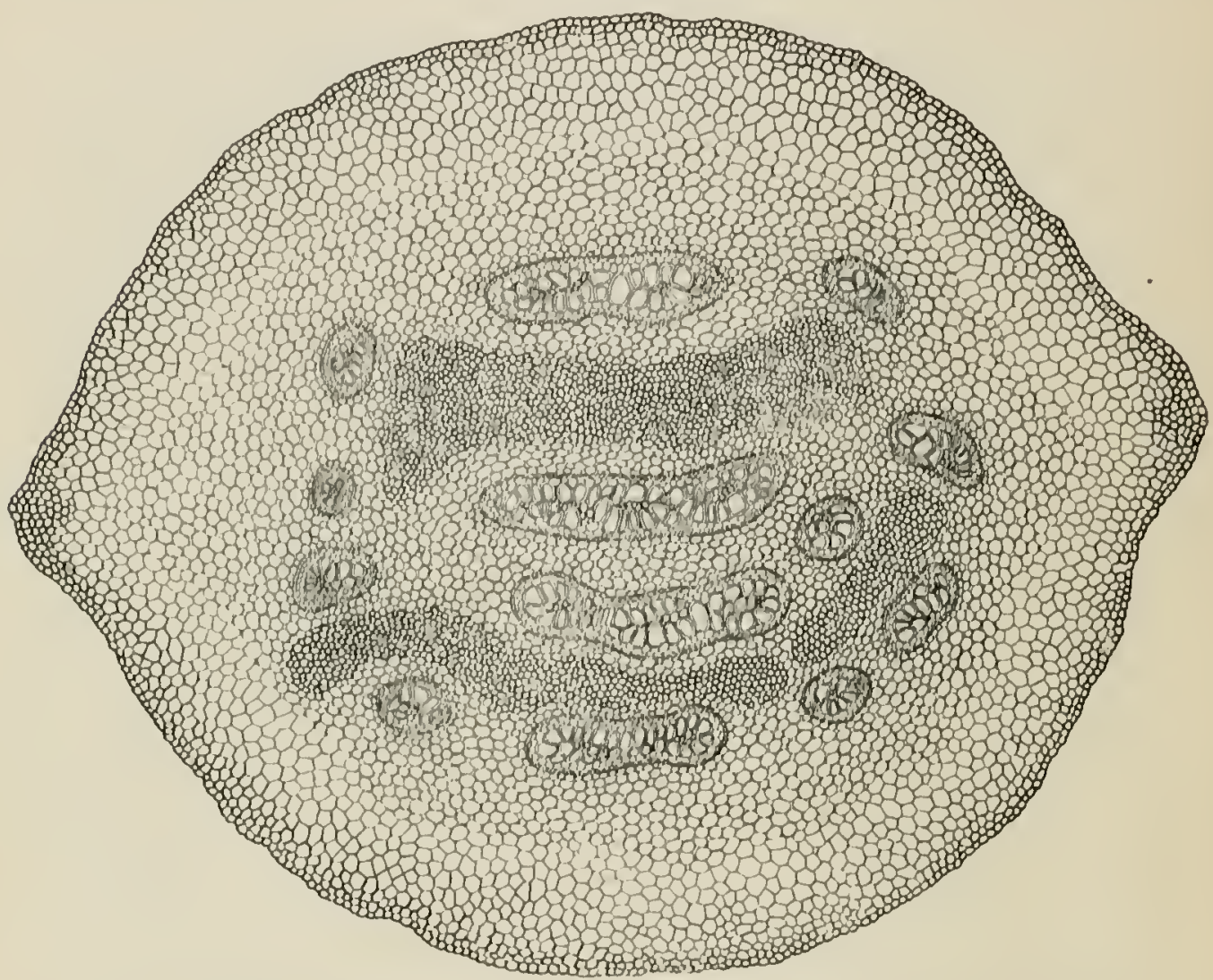

Fin. 5,- I'leris aquilina: Iransverse sertion of stem, showing the polystele; $\times 10$.-After CoulTLR (88).

stelic condition by the overlapping of elongated leaf gaps (see below), and also by the passing of peripheral vascular strands into the pith.

It is evident that the various types of stele are not restricted to different groups of ferns, but may be found as the adult condition at all levels. For example, in existing gymnosperms the ectophloic siphonostele, made up of collateral bundles, is the characteristic type of cylinder. Whether this was attained by way of the polystelic condition, as has been suggested (36), or directly from a siphonostelic condition, may not be clear; in any event, it would seem to be the most advanced type of cylinder, but it is found at various levels among 
pteridophytes, at for cxample in () smmondaceate among ferms. In the ustal sefuence of fern families, the polystelic condition is foumel at both extremes; and the confessedly primitive protostedic condition persists in the midst of the fern series. "The inference is that in varions ways, along various lines, changes in the primitive potostedic con dition have developed. 'To arrange all the yepes of stele in a linear. phylogenctic serics secms to he not omly unnecessaly, hul also contray to all previous experience with phylogenies.

Assuming that the polystele is merely a split ly siphomostele $(31,30)$, there are just wo lypes of central eylinder, the protostele and the siphonostele, the former being the more primitive JelFktir has shomn (31) that siphomosteles are of two fundamental lypes: (r) those wilh hoth leaf and hranch galps (phyllosiphonic), and (2) those with hranch gates alone (cladosiphonic). The phyllosiphonic condition is associated with large lanes, and the chadosiphonic with small ones; and therefore J kifreke recognizes two great primitive stocks of vascular plants: the Lyeopsida, which are cladosiphonic and microphyllows; and the Pleropsida, which are phyllosiphonic and megaphyllous. Fo the latter stock belong the ferms, grymmosperms, and angiosperms. This association of ferms and gymmosperms is a strong conlirmation of the conclusion reached in other ways as to their phylogenctic comnection.

The leaf gap, characteristic of the p'teropsidal, should be under stood clearly. A transverse section of the vascular cylinder of alliunIIIII, passing through a leaf gal], shows lwo crescentic vascular strands facing each other (lig. 6), one heing a section of the leaf tratce, the other a section of the siphonostele which the leaf gap has made incomplete. At the edge of the gatp the extermal and intermal phloems become continuous. Farther up the stem the girl) closes, and the cylinder becomes complete again. 'There is sometimes danger of mistaking a branch galp for a leaf galp), lut the latter should be reconnized by the fact that it occurs immediately above the leaf trace to which it belongs. A truc leaf gat) is always related to a single trace, so that if several traces appeat in relation to at galp in the ratsendar cylinder, and especially if they are related to the sides of the gitp, it is not a true leal gap. It should also be noted that gatps in the vascular cylinder may occur where the vascular tissues are much reduced 
in amount and break up into a loose network, and these hold no necessary relation to the vascular strands of leaves or branches (80).

Vascular bundles have also been characterized by Scotт (24) according to the relation of the protoxylem to subsequent xylem elements. The procambium strand that appears in the plerome does not develop vascular tissue simultaneously throughout its whole

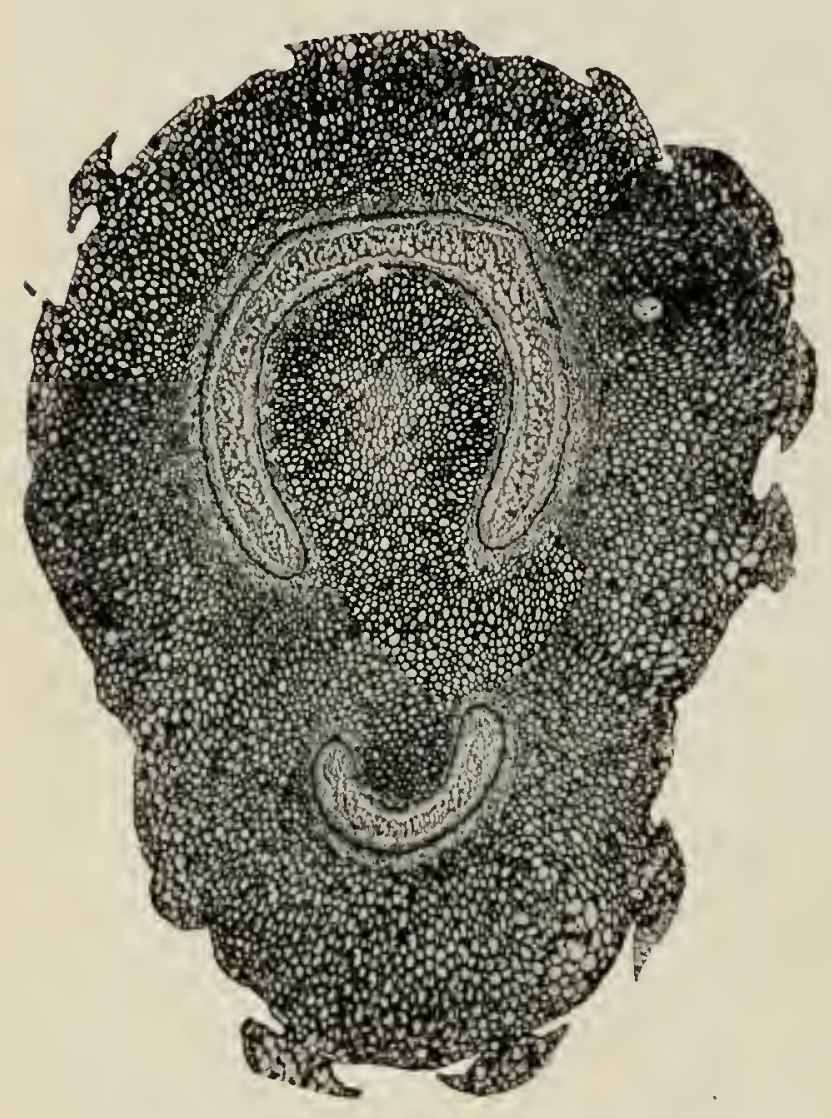

Fig. 6.-Adiantum pedatum: transverse section of stem; the smaller bundle is a leaf trace, opposite the leaf gap in the central cylinder; Xr6.-After JEFFREY (37). transverse section, but begins at one or more definite points, and from each of these points the subsequent xylem extends in one or more directions. This first group of vessels (spiral and annular) constitutes the protoxylem, and the subsequently formed xylem of the primary bundle constitutes the metaxylem. If the protoxylem is in contact with the phloem, the metaxylem thus being all centripetal, the bundle is called exarch (fig. 7); if the protoxylem is surrounded by metaxylem, the bundle is called mesarch (fig. 8); if the protoxylem is in contact with the pith (or at the center of a solid xylem strand), the metaxylem thus being all centrifugal, the bundle is called endarch (fig. 9). These types are not rigidly restricted to different great groups, but they are very serviceable in combination with other characters. In general, exarch wood is considered to be the most primitive type, characteristic of roots, common in the stems of lycopods, and occasional in the stems of ferns. Mesarch wood is very characteristic of ferns, so much so that when it occurs in any part of the vascular system of gymnosperms, it is spoken of 
as a fern character. Among seed plants the prevailing type of wood is endarch, and on this account it may be regarded as the most advanced condition.

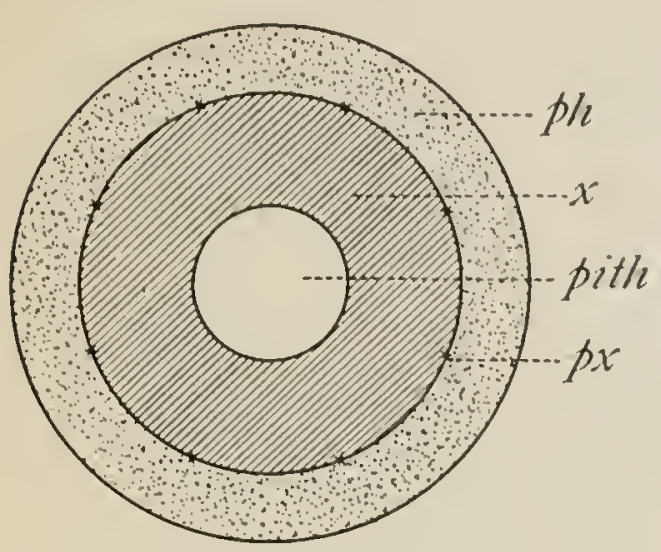

FIG. 7.- Exarch position of protoxylem.-After Worsdell (36).

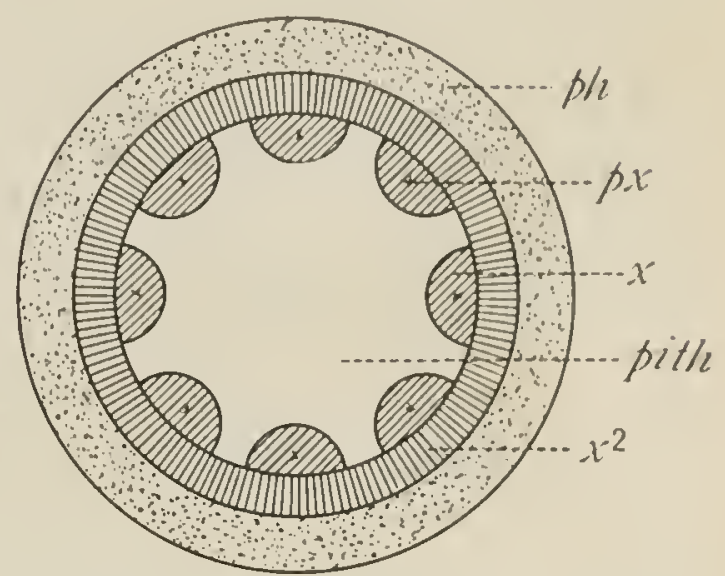

FIG. 8.-Mesarch position of protoxylem.-After IVorsdell (36).

It is important to understand what is meant by the transition from the concentric to the collateral bundle, and from the mesarch to the endarch condition of the xylem. Starting with a siphonostele made up of mesarch concentric bundles, which are thus of distinctly fern type, it is supposed that there has been a gradual reduction of the inner tissues. When the whole of the internal phloem has disappeared, the concentric bundle has become collateral, but it is still mesarch. Later, when the whole of the centripetal metaxylem has disappeared, the mesarch xylem has become endarch. In some cases there may be internal secondary

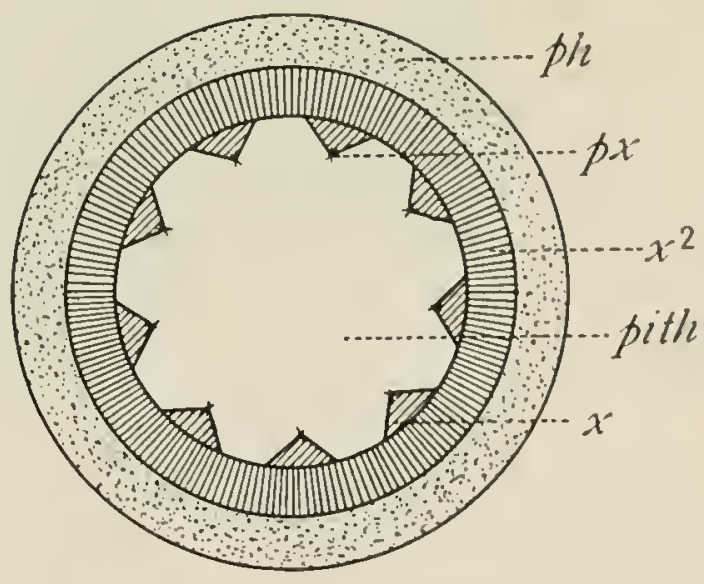

FIG. 9.-Endarch position of protoxylem.-After Irorsdell ( 36$)$. wood, and that disappears after the internal phloem and before the centripetal metaxylem. When the endarch collateral condition is reached, the vascular cylinder is distinctly of the gymnosperm type. Therefore, when mesarch xylem is found among gymnosperms, it is regarded as a primitive feature; but not so primitive as would be the occurrence of concentric bundles. 
Students should be warned that it is not always easy to distinguish metaxylem elements, especially in very young tissue and in the foliar extremities of bundles.

\section{VASCULAR ANATOMY OF CYCADOFILICALES}

The anatomical peculiarity of this group is that it displays the rascular types described abore as characterizing the ordinary ferns, and in each case adds to them the formation of secondary wood. The best known of these stems will be considered briefly.

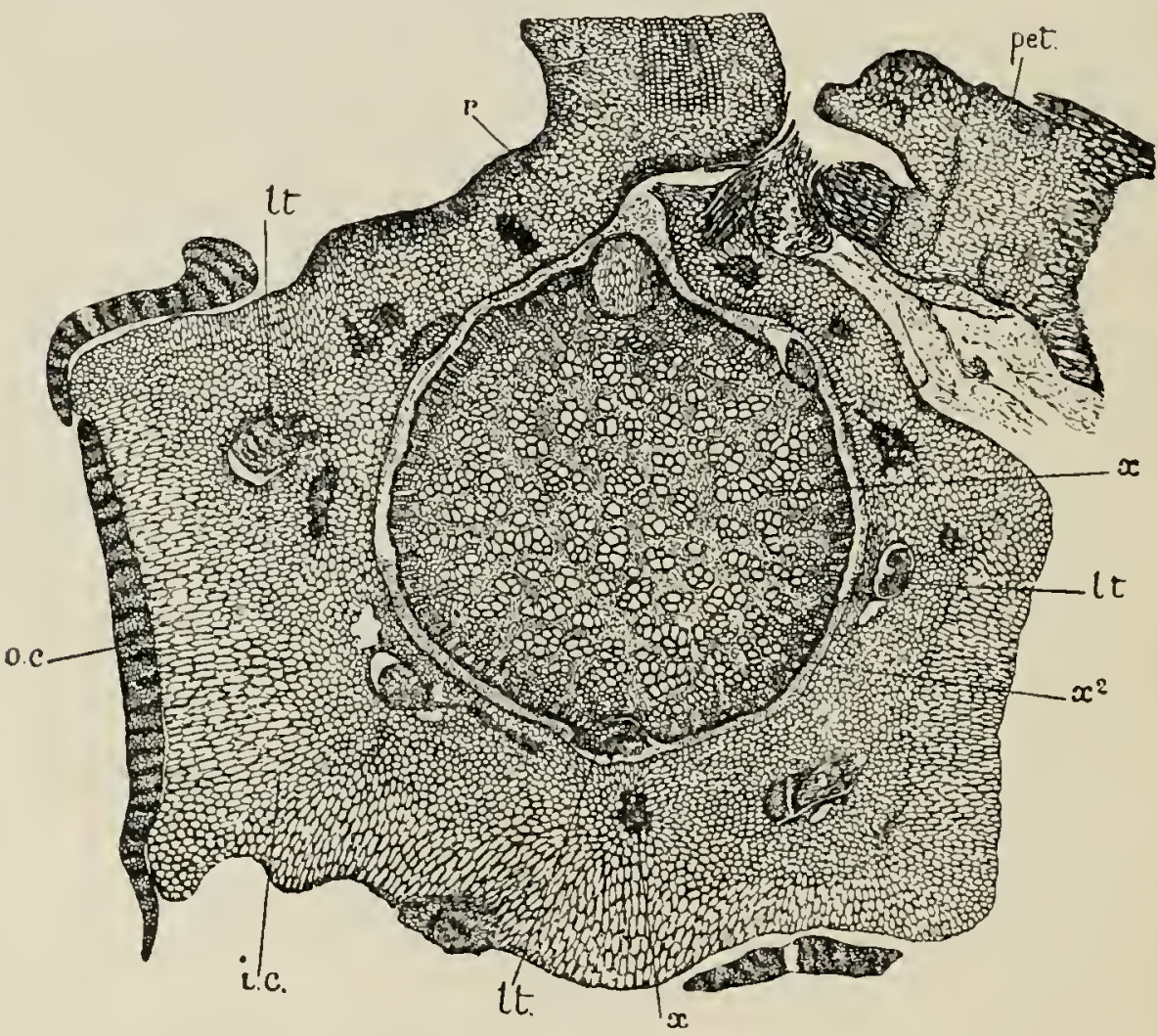

Fig. Io.-Heterangium Grievii: transverse section of stem; $x$, central mass of primary wood; $x^{2}$, secondary wood beginning to form; next the phloem and pericycle; $i c$, inner cortex ( $x$ in this zone is a sclerotic group); $l t$, leaf traces; $r$, base of an adventitious root; $o c$, outer cortex, present only in places; pet, base of petiole; Xabout 5.After ScotT $\left(8_{7}\right)$.

Heterangium.-The stems referred to this genus occur from the base of the Carboniferous into the Permian, one of the oldest and best investigated species being $H$. Grievii (I8). 'The slender stems, not over $1.5 \mathrm{~cm}$. in diameter, are ribbed by the decurrent bases of petioles. The vascular axis is a protostele (fig. Io), very similar to that of Gleichenia pubescens (fig. 2), the single vascular cylinder being 
solid and concentric. Near the periphery of the included xylem there occur small strands of protoxylem, which determine the mesarch character of the bundle. 'Thus far, the structure is distinctly fernlike; but in addition there is a narrow zone of secondary wood about the primary xylem cylinder. 'The elements of this secondary wood are radially arranged, with numerous (multiseriate) bordered pits, and the zone is traversed by pith rays. The large leaf traces are collateral at their junction with the vascular cylinder, but they become concentric before entering the petiole. Although the leaf trace is single in $H$. Grievit, in other species of the genus it becomes double.

LYGINODENDRON. ${ }^{x}$ - One of the most common stems preserved in the British Coal-measures is Lyginodendron Oldhamium, fully described by Williamson and ScotT (I8), and possibly including a group of species. The stems are long, slender $(3 \mathrm{~mm}$. to $4 \mathrm{~cm}$. in diameter), and branching. The vascular axis is a siphonostele, without internal phloem (fig. II), as in Osmunda (fig. 4), the cylinder inclosing a large pith. A variable number $\left(5^{-9}\right)$ of isolated primary xylem strands occur next to the pith, being distinctly mesarch, with the larger part of the metaxylem centripetal (fig. 12). While most of the tracheids of the metaxylem have bordered pits, those next to the spiral elements are usually scalariform $(87)$. The main part of the rascular cylinder, however, consists of a broad zone of secondary wood, whose tracheids, with multiseriate bordered pits, occur in regular radial arrangement, and which is traversed by pith rays. Very evident gaps in the vascular cylinder are associated with the leaf traces, so that the siphonostele is phyllosiphonic and is thus definitely related to the siphonostele of Filicales. The leaf traces near the central cylinder are single and collateral, but soon they fork and gradually become concentric, so that in the petiole (once called Rachiopteris aspera) a pair of concentric bundles occurs. The association of collateral bundles in the stem with concentric bundles in the leaves is a distinct Osmunda character, and is met also among the cycads. Occasionally in L. Oldhamium there is a derelopment of vascular bundles with reversed orientation (xylem next to that of the primary bundle) in the pith. Outside the cambium there is also evident a zone of phloem, broken up by the pith rays (fig. $\mathrm{r}_{3}$ ).

I The generic name sometimes used is Lyginopleris Potonié. 
The roots of L. Oldhamium, long known as Kaloxylon Hookeri, have been preserved so perfectly that their structure has been deter-

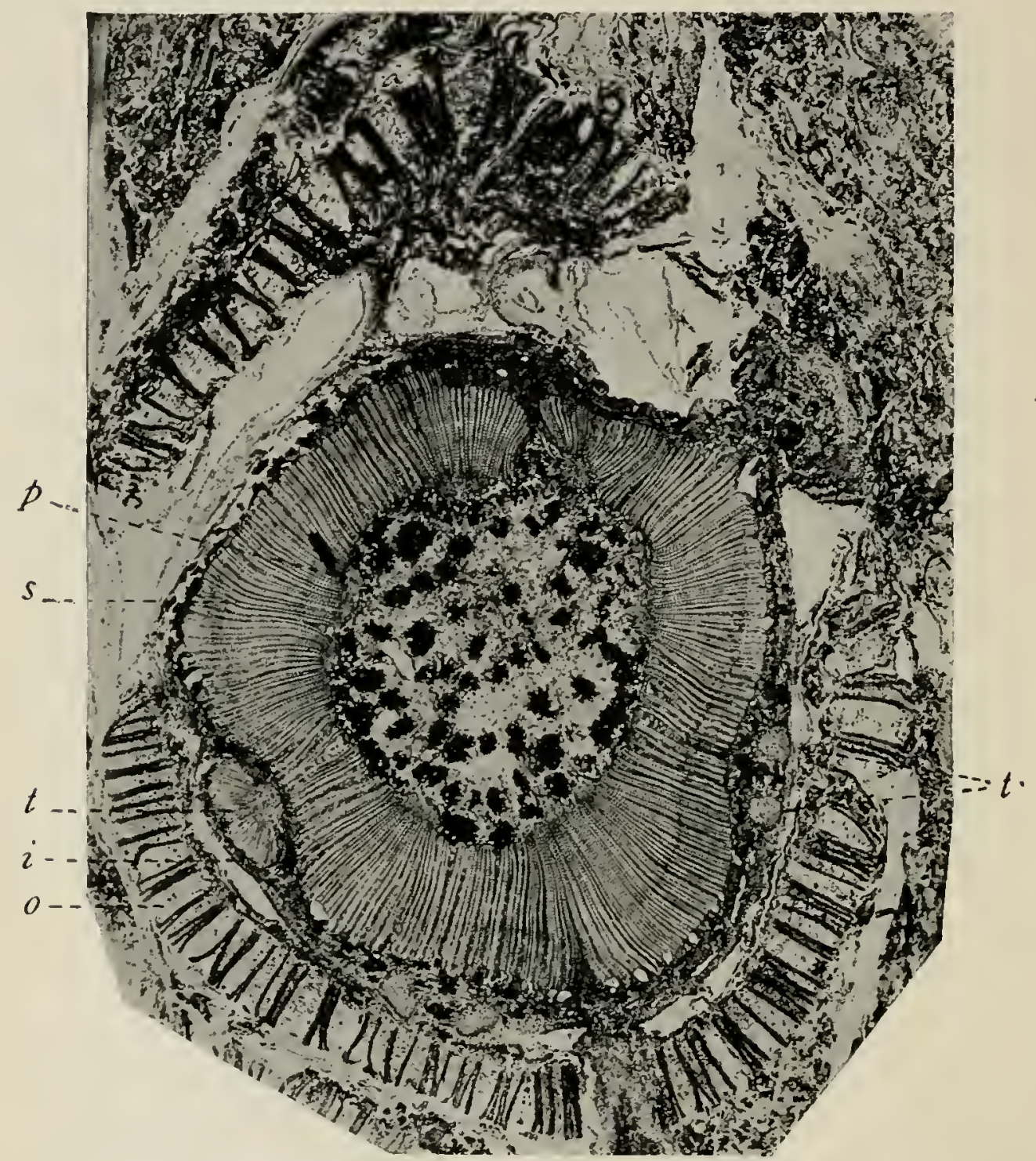

FIG. II.-Lyginodendron Oldhamium: the large pith contains numerous dark masses of sclerotic cells; bordering upon the pith at various places may be seen the primary wood $(p)$, comparatively scanty in amount; next is the secondary wood $(s)$, constituting almost the entire mass of the woody cylinder; a narrow zone of phloem surrounds the secondary wood, and just outside the phloem, in the inner cortex (i), are the leaf traces $(t)$; next is the outer cortex $(o)$, with numerous radially arranged bands of sclerenchyma; $x_{3}$. -From photograph by Kidston.

mined with great completeness. There are usually three to eight alternating xylem and phloem strands, and in the larger roots there is distinct secondary growth, every stage in its development having 
been observed. ScotT (24) remarks that "it is certainly a fact of great interest that the roots of our fossil, which in their primary condition much resemble those of marattiaceous ferns, or of Helminthostachys among Ophioglossaceac, should exhibit a mode of secondary tissue-formation absolutely indistinguishable from that of typical dicotyledons or gymnosperms." At that time it was not realized that $L$. Oldhamium was a gymnosperm. There are cases in which

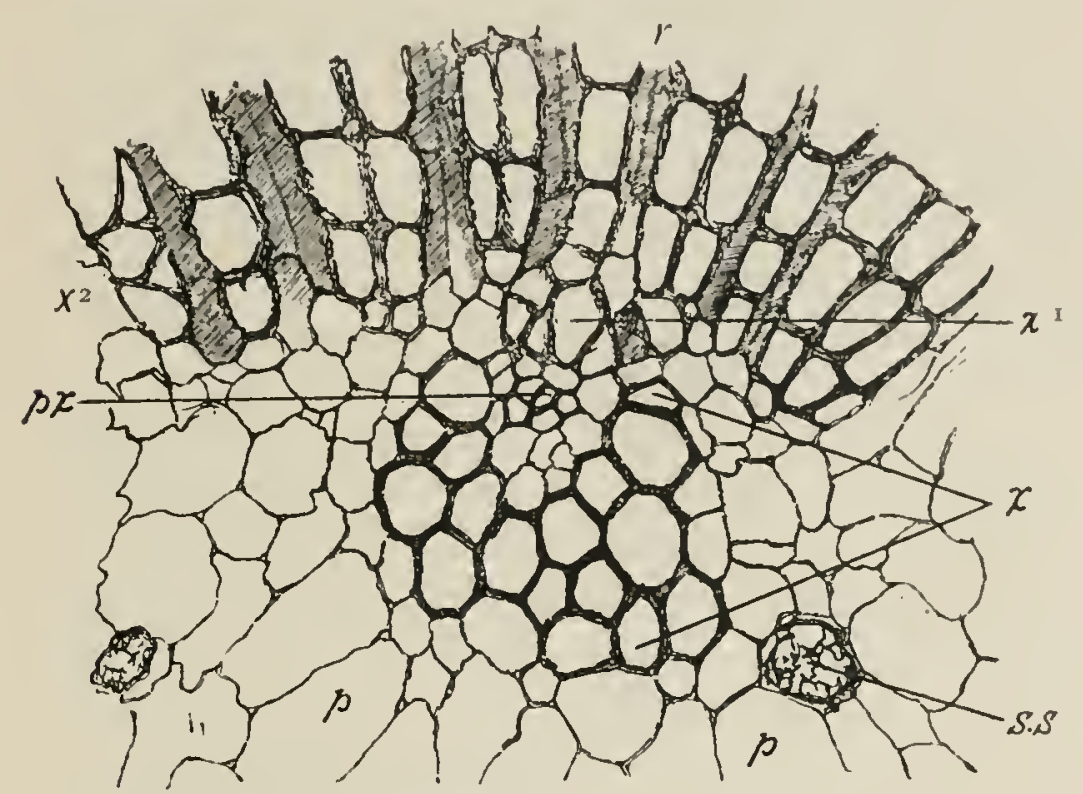

FIG. 12.-Lyginodendron Oldhamium: part of transverse section of stem showing a primary xylem strand and adjacent tissues; $p . x$, protoxylem; $x$, centripetal primary wood; $x^{\mathrm{I}}$, centrifugal primary wood; $x^{2}$, secondary wood; $r$, medullary rays; $p$, pith; ss, secretory sac; X roo.-After Williamison and Scott (is).

the growing point has been preserved so perfectly that it is evident there was no such definite apical cell $(87)$ as characterizes most fern roots.

Megaloxylon. - This stem genus occurs in the British Lower Coal-measures, and has been described by SEWARD (2I). The vascular cylinder only is preserved, being 4 to $5 \mathrm{~cm}$. in diameter, and is a protostele, as in Heterangium; but the secondary wood is more abundant and resembles that of Lyginodendron. The most interesting feature, however, is the exarch structure of the primary wood, in contrast with the mesarch structure of both Heterangium and Lyginodendron. The exarch structure occurs in some ferns, as in Lygodium, and SEWARD remarks that "in anatomical characters the 
two genera Lyginodendron and Heterangium approach most nearly to the Osmundaceae and Gleicheniaceae respectively; in Megaloxylon, on the other hand, the structure of the primary xylem affords evidence that the Lygodium type of stem was also represented in the cycad-fern alliance which played so prominent a part in paleozoic vegetation." Another characteristic feature of Megaloxylon is the structure of the metaxylem, which is usually made up of very short tracheids, often broader than long, interspersed with parenchyma,

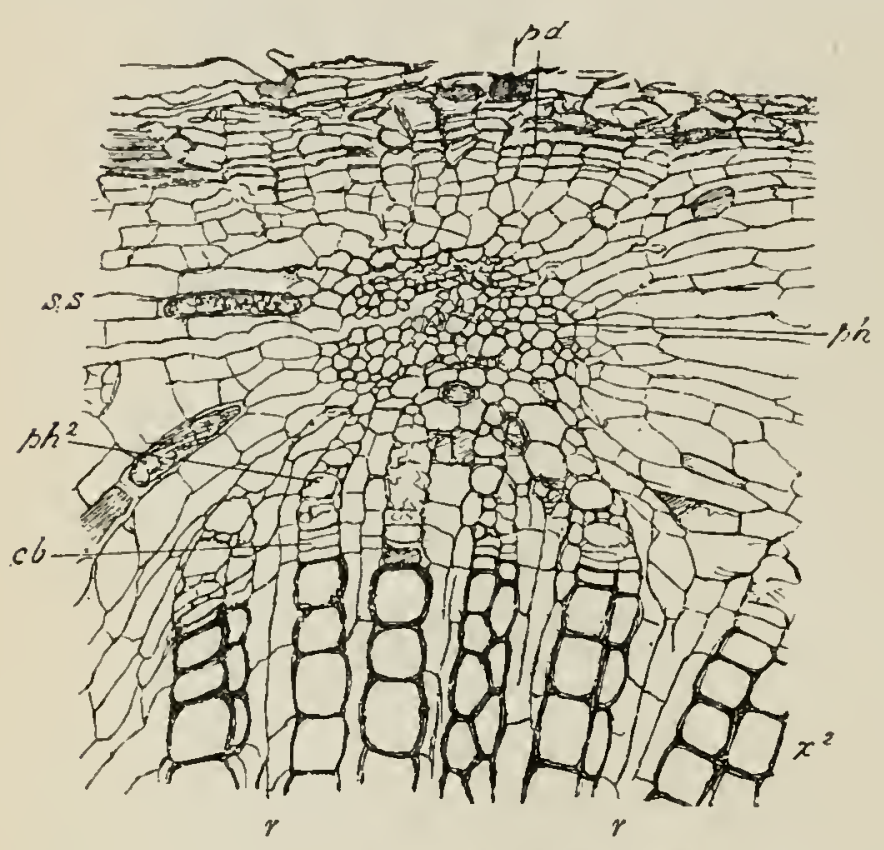

FIG. 13.-Lyginodendron Oldhamium: part of transverse section of outer portion of stele; $x^{2}$, secondary wood; $r$, medullary rays; $c b$, cambium; $p h$, primary phloem; $p h^{2}$, secondary phloem; ss, secretory sac; $p d$, periderm; $\times 5$ 2.-After Williamson and Scott (i 8).

inders are large enough ( $14 \mathrm{~cm}$. in diameter) to suggest stems as large as those of small trees. The anatomy resembles that of Lyginodendron, in fact one of the species was described as $L$. robustum. There is the same siphonostele, with abundant secondary wood traversed by broad pith rays and containing elements of the same character. Two differences, however, are notable. One is the endarch character of the primary vascular strands. This character is not clear in all the forms, and in some a small amount of centripetal xylem is claimed; but in any event, the 
group as a whole shows the complete or nearly comp'ete climination of centripetal xylem in the primary strands. The other notable difference is the development of regular zones of secondary xylem between the primary cylinder and the pith (fig. I4). These centripetally developed zones have reversed orientation, and two or more successive ones may appear. It will be recalled that this feature of

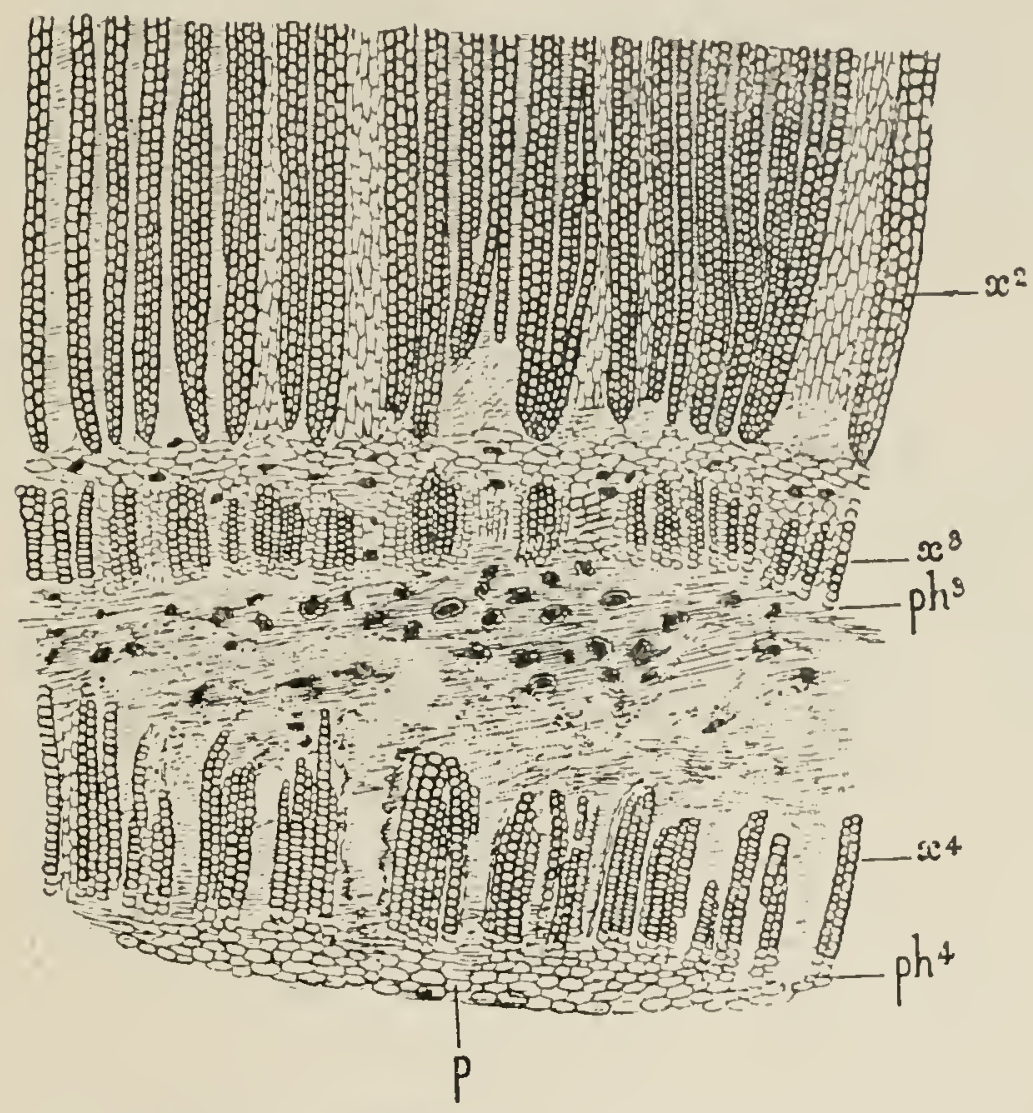

FIG. I4.-Cycadoxylon robustum: part of transverse section of stele showing inner portion of normal wood, with two anomalous zones of wood and bast; $x^{2}$. normal secondary wood; $x 3$, ph3, first inverted band of xylem and phloem; $x^{* 4}, p h 4$, second band; $p$, pith; $X_{12}$.-After Scotr $\left(S_{7}\right)$.

Cycadoxylon appears in certain specimens of Lyginodendron Oldhamium, the two genera evidently being closely related.

Medullosa. - The stems of this important type are found throughout the Carboniferous and Permian deposits, culminating in the latter and then disappearing, and it seems to have been one of the most abundant of the Cycadofilicales. Some of the species were large trees of fernlike habit, and others had long slender stems. In every case the stems were clothed by the sheathing bases of leares. 
The oldest known species of Medullosa, and the simplest in its stem structure, is $M$. anglica, from the Lower Coal-measures of England, and described in detail by ScotT (22). The stems arerage 7 to $8 \mathrm{~cm}$. in diameter, and are distinctly polystelic (fig. I5), resembling Pteris (fig. 5) in this regard. The vascular bundles are usually three in number and are concentric, each one of the xylem strands being surrounded by a zone of secondary wood. This combination of polystely and secondary wood is the chief anatomical feature of the group, and is said to distinguish it from all living plants. The secondary xylem elements resemble

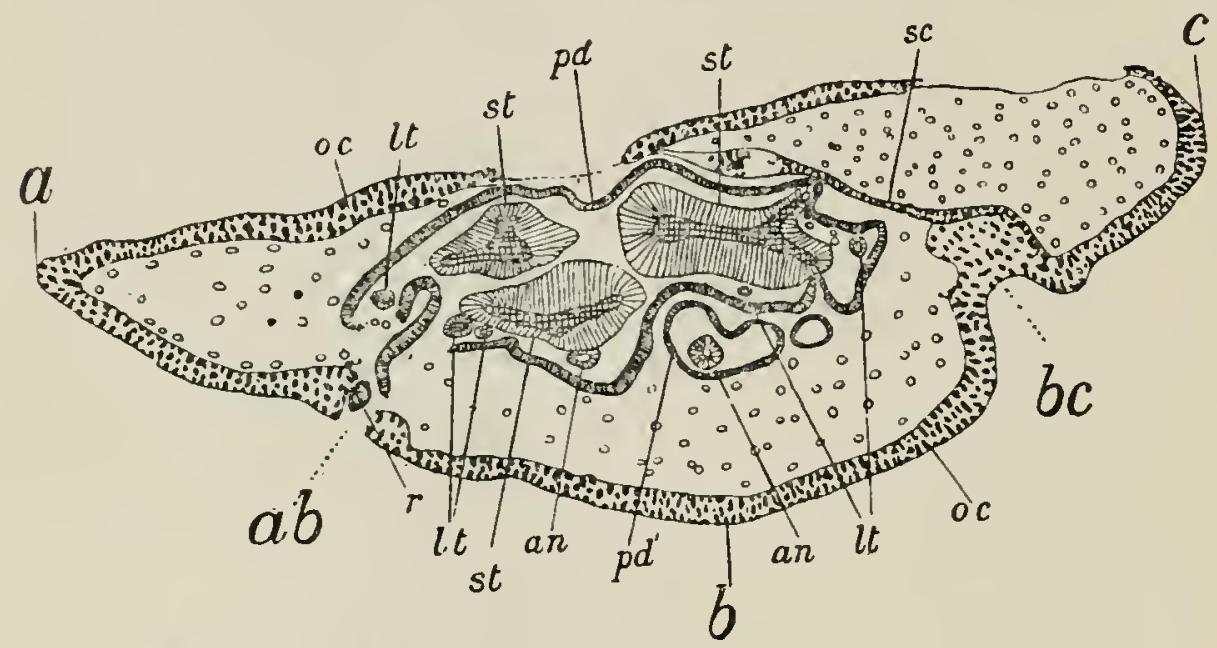

FiG. 15.-Medullosa anglica: transverse section of stem showing three large leaf bases $(a, b, c) ; a b, b c$, position of next leaf bases above; $s l$, the three steles; $l l$, leaf traces; an, accessory rings of wood and bast; $p d$, periderm, forming a ring around the steles; $r$, adventitious root; $a c$, hypodermis; sclerenchyma band between leaf base and stem; slightly reduced.-After Sсотт (22).

those of Heterangium and Lyginodendron, being radially arranged tracheids with bordered pits on the radial walls. In fact, each one of the several steles of Medullosa so closely resembles the single one of Heterangium, that the Medullosa type is believed by some $(36,72)$ to have been derived directly from the Heterangium type; and to have given rise in turn to the Lyginodendron type by the organization of the polystele into a compact cylinder (siphonostele), accompanied by the degeneration of the internal vascular tissues. The opposing view claims that the polystelic condition of Medullosa is derived from the siphonostelic, as in ferns (Pteris, 3I); and that the Medullosa type is to be regarded as a modification of the Lyginodendron type, 
rather than intermediate between the Keterangium and Lyginodendron types. The polystely of Medullosa, however, is said $\left(S_{7}\right)$ to differ from that of the ferns (such as Pteris), in that alpuarently it holds no relation to the presence of leaf gaps. 'The alssence of leaf gaps in Medullosa and its allies has suggested that polystely arose within the family, quite independent of polystely among ferns. Occilsionally vascular strands appear also in the cortex, as among the cycads.

The leaf trace of Medullosa is at first concentric and with secondary wood; but later the secondary tissue disappears, the bundle branches repeatedly, and the branches become collateral and exarch. According to ScotT (24), "each leaf stalk received a large number of vascular bundles, as many as jo to 80 in all, derived from the repeated ramification of several of the principal leaf traces. The supply of bundles did not all enter the leaf base from the stem at the same level; they passed in successirely in groups corresponding to the various principal leaf traces from which they were derived."

The later species of Medullosa, so far as their structure is known,

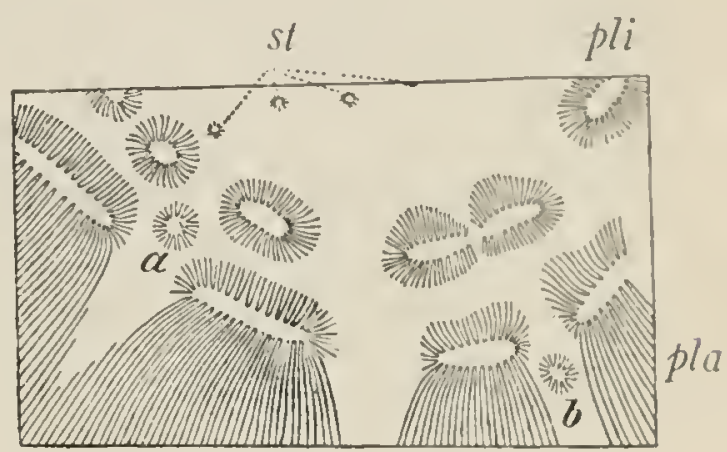

Fig. i6.-Hedullosa. Solmsii: part of transverse section of stele; st, "star rings"; pla, outer zone of bundles; fli. inner zone of bundles; a and b, bunilles which have branched off from the inner zone; $\times 2 .--$ After WEBER and STERzEL (17) in Potonif. (20). are more complex anatomically than $M$. anglica, the vascular bundles being more numerous, and differentiated into an inner group of smaller bundles and a more or less complete peripheral zone of larger ones (fig. I6). All the bundles have the same general structure als those of $M$. anglica. In the older stems of certain forms, howerer. there is an excessive development of sccondary wood on the outer side of the peripheral bundles, so that a section of the stem shows a broad zone of secondary wood surrounding the relatively inconspicuous inner region.

In a specimen of $M$. stellata gigantea, whose vascular region is over $45 \mathrm{~cm}$. in diameter, in addition to the large mass of secondary wood developed on the outer side of the peripheral bundles, there 
are three concentric cortical layers of wood, a succession of cortical cambiums appearing, similar to that found in certain genera of living cycads. In this form numerous bundles also occur in the pith, which is another feature of some of the modern cycads.

Cladoxylon and Colpoxylon are other stem genera with polystelic structure as in Medullosa. In the former genus, a deronian form, the vascular structure is complex, the steles often being elongated and curved in section, and sometimes fusing, but each stele has its own zone of secondary wood, in which the tracheids are scalariform. The latter genus is permian, and is interesting in that the stems are protostelic below and polystelic abore.

Recently ScotT (68) has described a Sutcliffia (S. insignis) from the Lower Coal-measures, which he regards as "a new type of Medulloseae." If so, it is like a Medullosa reduced to the Heterangium condition, for it is protostelic and there is only a slight amount of secondary thickening, but from this main axial stele secondary steles become detached at intervals. Moreover, the xylem is exarch, as contrasted with the mesarch condition in Medullosa. However, the leaf traces are numerous, complexly branching, and anastomosing. Such a complex leaf structure connected with a protostelic stem cylinder is said to be a unique combination, and suggests a reduction of the central cylinder. The Medullosa connection is still further suggested by the mucilage canals and reticulate peripheral bands of sclerenchyma.

Calamopitys is a stem genus of the Devonian and Lower Carboniferous that is very suggestive of Lyginodendron, with small pith, few and comparatively large mesarch primary bundles, a thick. zone of secondary wood, and a leaf trace that forks on leaving the cylinder. The leaf traces are quite distinct, however, in being concentric in the cortex and in dividing on entering the leaf, so that the petiole contains several bundles.

Protopitys is a remarkable isolated form of the Devonian and Lower Carboniferous with an abundant derelopment of secondary wood. The large pith (elliptical in section) is surrounded by a continuous zone of primary wood, of unequal thickness but not broken into bundles.

The preceding stem genera are not all known with certainty to 
belong to Cycadofilicales, but they include forms known to be such (Lyginodendron, Heterangium, Medullosa); others almost certainly such because of their evident relationships (Colpoxylon, Suldiffi, Megalovylon, Calamopitys, Cycadoxylon); and others possibly such because they are Cycadofilices. Each of the genera cited represents a stem family of the same name, except that Heterangium is included in the Lyginodendrineae (Lyginodendreae), and Colpoxylon and Sutcliffia in the Medullosineae (Medulloseae). Cycadofilicales are known to extend beyond the range of these stem genera, for seedbearing fronds have been discovered the structure of whose stems is unknown. The stems already described, however, show a wide anatomical range for the group, being protostelic (Heterangitum and Sutcliffia), siphonostelic (Lyginodendron, Megalorylon, Cycadorylon, etc.), and polystelic (Medullosa, Cladoxylon, Colpoxylon, etc.); while the xylem of the stem ranges from exarch (Sutcliffia), through mesarch (the general condition), to endarch (Cycadoxylon). The leaf traces also range from the usual simple forking to a profuse branching and anastomosing. So far as vascular anatomy is concerned, therefore, the Cycadofilicales exhibit as wide a variation and the same kind of variation as do the existing ferns, and they add to these characteristics those of existing gymnosperms.

\section{THE LEAF OF CYCADOFILICALES}

To distinguish the leaves of Cycadofilicales among the innumerable paleozoic "fronds" that have been preserved is at present impossible. It has been suggested (6o) that the prevailing dichotomy of paleozoic fronds may be indicative of Cycadofilicales rather than of ferns, but such a character cannot be used with any definiteness. In fact, ScotT has said recently $(82)$ that from the frond alone it cannot be told whether a paleozoic plant is a fern or one of the Cycadofilicales. The best that can be done is to select those leaves whose connection with stems or with seeds testifies to their nature. In this way most of the large frond genera have contributed representatives to the Cycadofilicales, but it may be that some of their other members are ferns. At least, so artificial an assemblage as a large frond genus would suggest such a possibility. The certain or probable cases of leares belonging to the Cycadofilicales are as follows: 
The foliage of Heterangium and of Lyginodendrom has been shown to be of the Sphenopteris type, one of the great and heterogeneous

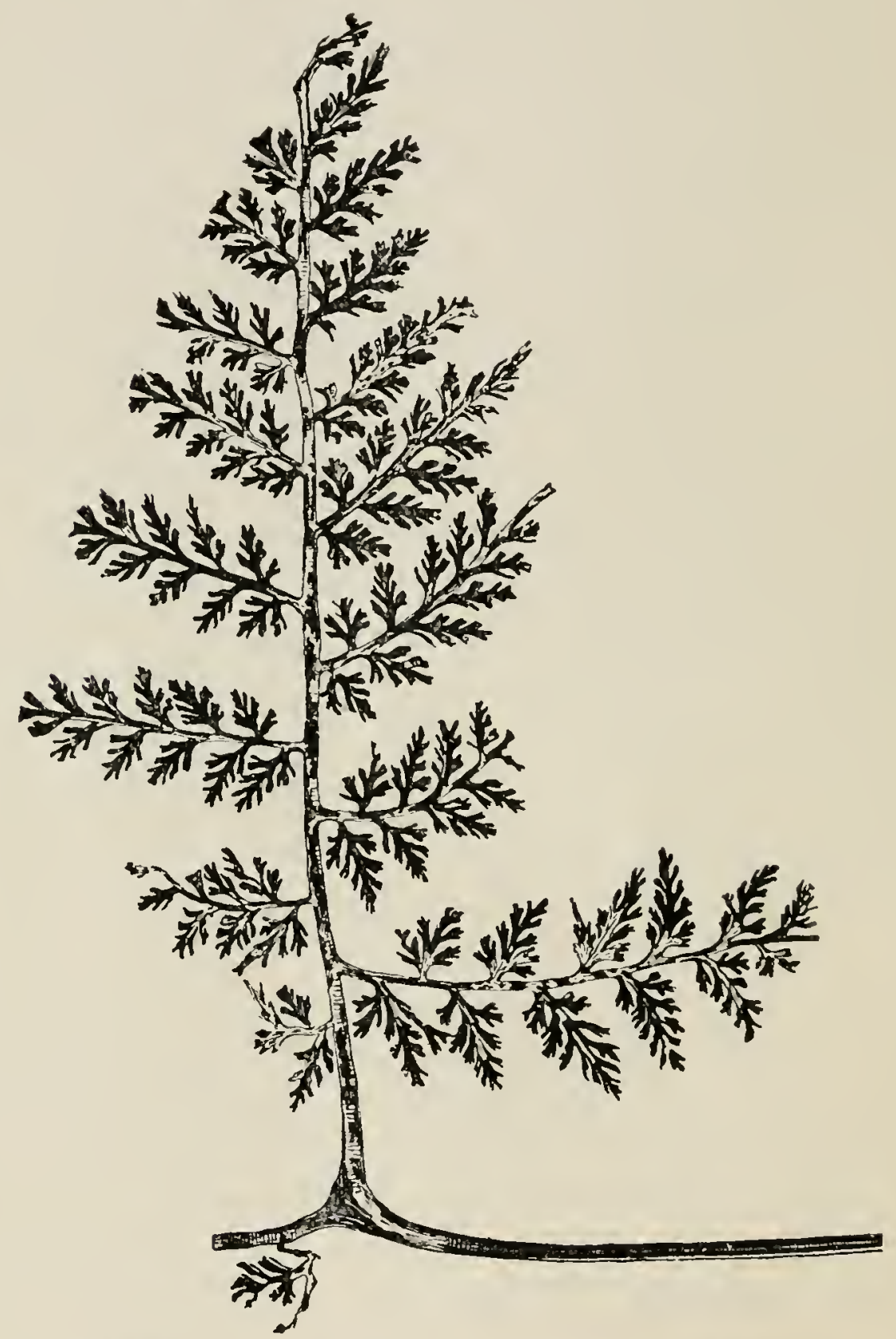

FIG. I7.--Sphenopteris elcgans (probably foliage of Heterangium Grievii): part of frond; $\times \frac{2}{3}$.-After STuR ( 7 ).

frond genera of the Paleozoic, in general habit like Asplenium (82). The foliage of Heterangium Grievii is probably Sphenopteris elegans, the leaf being large and stalked, several times pinnately compound, and with numerous small leaflets (fig. I7). ScotT (24) describes 
H. Grievii as "a fernlike plant, with a long, upright or perhaps trailing, ribbed stem, bearing large and graceful, linely divided fronds, much resembling those of some recent Asplenium." "The foliage of Lyginodendron Oldhamium is Sphenopteris Höninghausii, the leaves being very large and pinnately dissected. The leaflets are describerl (86) as fleshy and incurved, with often dilated rascular endings as though connected with glands, and suggesting plants of the salt water swamps of today. ScotT (24) thinks that it was probably "a climbing plant of the scrambler type, a suggestion which is confirmed by the presence of spines on the stem, and on all parts of the compound leaves." "To this Sphenopteris type of foliage have been referred numerous sporangia, both those supposed to be of ferns and those of Cycadofilicales. It has been suggested $(82)$ that the species with forked rachis are probably Cycadofilicales, and that some of the others are probably ferns.

No leaves have been definitely associated with the stem genus Cycaloxylon, but the associated occurrence of distinctly cycadcan leares, resembling those of Dioon and of Zamia, suggests the possibility that the foliage was of that type.

Among the leaves referred to Medullosa and its associates, the most abundant and conspicuous are those described under the great frond genera Neuropteris (fig. IS) and Alethopteris (A. lonchitica is probably the leaf of $M$. anglica), all of whose species probably belong to Cycadofilicales $\left(8_{2}\right)$. These frond genera, along with Odontopteris and Dictyopteris, are often grouped as the frond family Neuropterideac. and are thought to be generally seed-bearing. The leaves are very arge, several times pinnate, and with ovate or oblong leaflets. Their petioles, often of great length and repeatedly branching, have been described under the form genus Myeloxylon, the structure being very much like that found in cycads.

One of the largest of the frond genera, including many of the most striking of the carboniferous "fronds," is Pecopteris. Through the researches of GRAND 'EURY (52) it is known that one of the species (P. Pluckenetii) is seed-bearing; and the sporangia (as Dacivlotheca. for example) borne by other species are probably the microsporangia

I As many tree ferns are very spiny, the presence of spines in Lyginodendron cannot be used as evidence of a climbing habit. 
of Cycadofilicales. SCOTT (87) concludes that "on present evidence there is every reason to believe that a large proportion of the fernlike paleozoic plants with pecopterid foliage will find their place, like P. Pluckenetii, among seed-bearing plants." There is also good evidence that other species represent the foliage of carboniferous tree ferns, though of course different from our Cyatheaceae; the sporangia of other species suggest the Marattiaceae; and still different

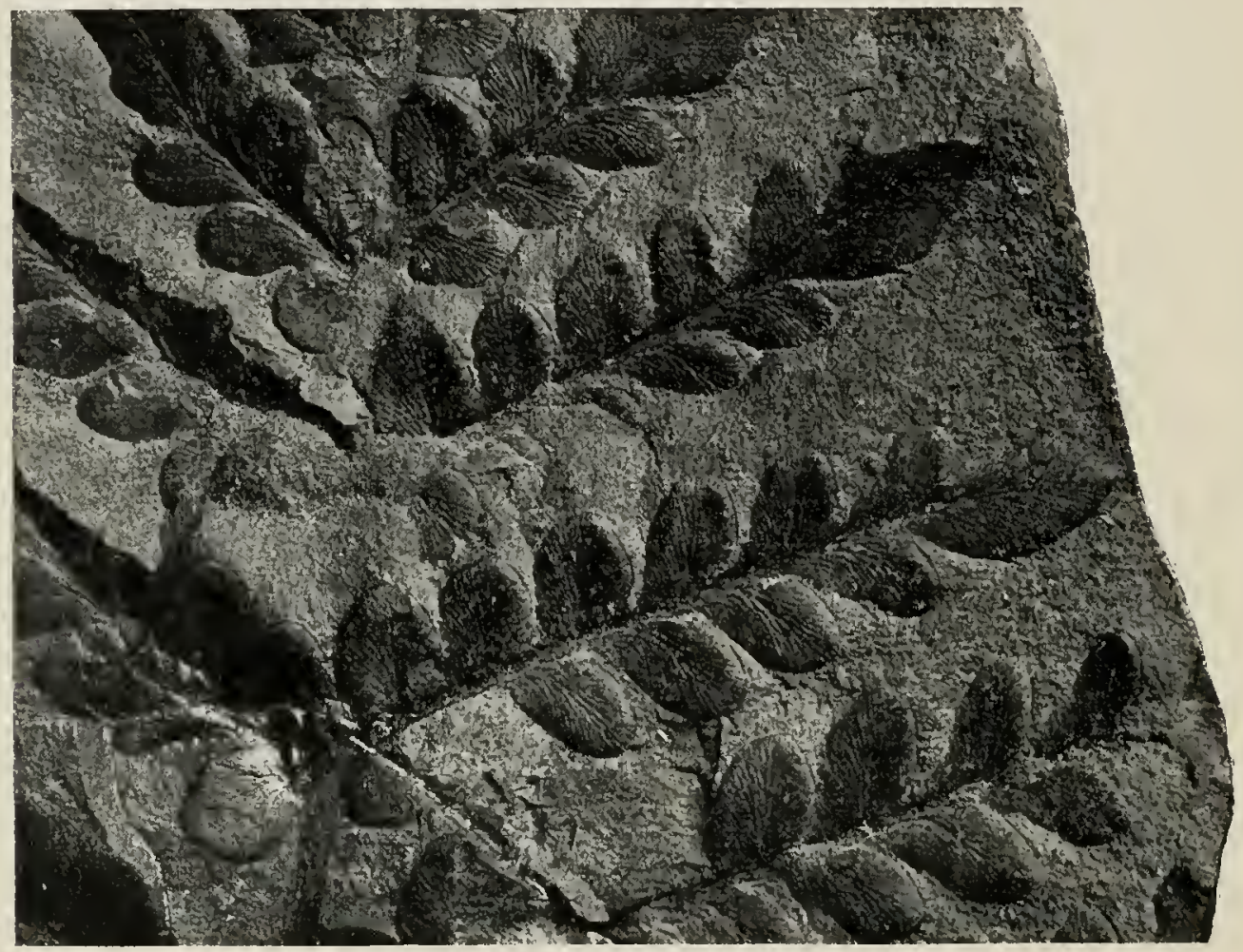

FIG. I 8. - Neuropteris heterophylla: part of frond; slightly enlarged.-From photograph by Kidston (64).

characters of other species join with all the preceding to indicate that Pecopteris is a most heterogeneous assemblage of foliage.

Ancimites (or Adiantites) is a frond genus characteristic of the Lower Coal-measures (Devonian to Middle Coal-measures), whose leaflets resemble those of Adiantum. It has not been found attached to a stem, and there is no knowledge of its vascular anatomy; hence the leaves continued to be regarded as those of ferns until WHITE (49) discovered specimens bearing seeds.

Even the devonian genus Archaeopteris (or Palaeopteris), once referred by some to Hymenophyllaceae and by others to Marattiaceae, 
is now thought by Kinston (64) to belong most probably to the Cycadofilicales.

From the above statement it is evident that all of the so-called "fern fronds" of the Palcozoic may weli be "under suspicion." At the same time, the actual proof of their connection with Cycadofilicales applies to so few species that it is very unsafe to assume that there is no residuum of ferns among them.

\section{The spore-producing members}

THE MICROSPORANGIUM

The microsporangia of Cycadofilicales were naturally regarded at first as the sporangia of ferns, and it was not until rgo5 that a definite connection with one of the Cycadofilicales was announced (54). The microsporangia were those of Lyginodendron Oldhamium. thus completing in a remarkable way our knowledge of that form. The original announcement (54) by KIDston was followed later (64) by his full description and discussion.

The stamen referred to proved to belong to ZeilLER's form genus Crossotheca, to which "fructifications" of a certain type have been referred, and constituted a new form species ( $C$. Höninghausii). The sporangium-bearing frond is dimorphic, but the fertile pinnules are associated in the same frond with the sterile ones. To apply the terms microsporophyll and stamen to this situation may be confus.ng without an explanation. The whole frond is not strictly a microsporophyll, and therefore not a stamen, but it well represents a frond on its way to becoming a microsporophyll. In fact, only certain pinnules bear microsporangia, and for convenience these fertile pinnules may be spoken of as microsporophylls or stamens. Each of these primitive stamens (pinnules) has a very stout pedicel, which is bent at its union with the oral blade, on the under surface of which six or seven bilocular sporangia are developed (fig. I9). The sporangia are fusiform and pointed (about $3 \mathrm{~mm}$. long and $1.5 \mathrm{~mm}$. in maximum breadth), and apparently entirely free from one another. The long axis of the sporangium is attached to the surface of the blade, presumably in connection with a veinlet, and at the margin of the blade the free tip is bent downward. When young, the free ends bend inward, and the group of sporangia resembles a hemispherical 
radiate sorus (fig. 20). At maturity, the tips spread apart, forming a hanging fringe from the under surface of the blade, which then "resembles an epaulet" (fig. 2I). In transverse section each sporangium is seen to be composed of two loculi, circular in section and separated by a thin partition. The accompanying diagrams (figs. 22

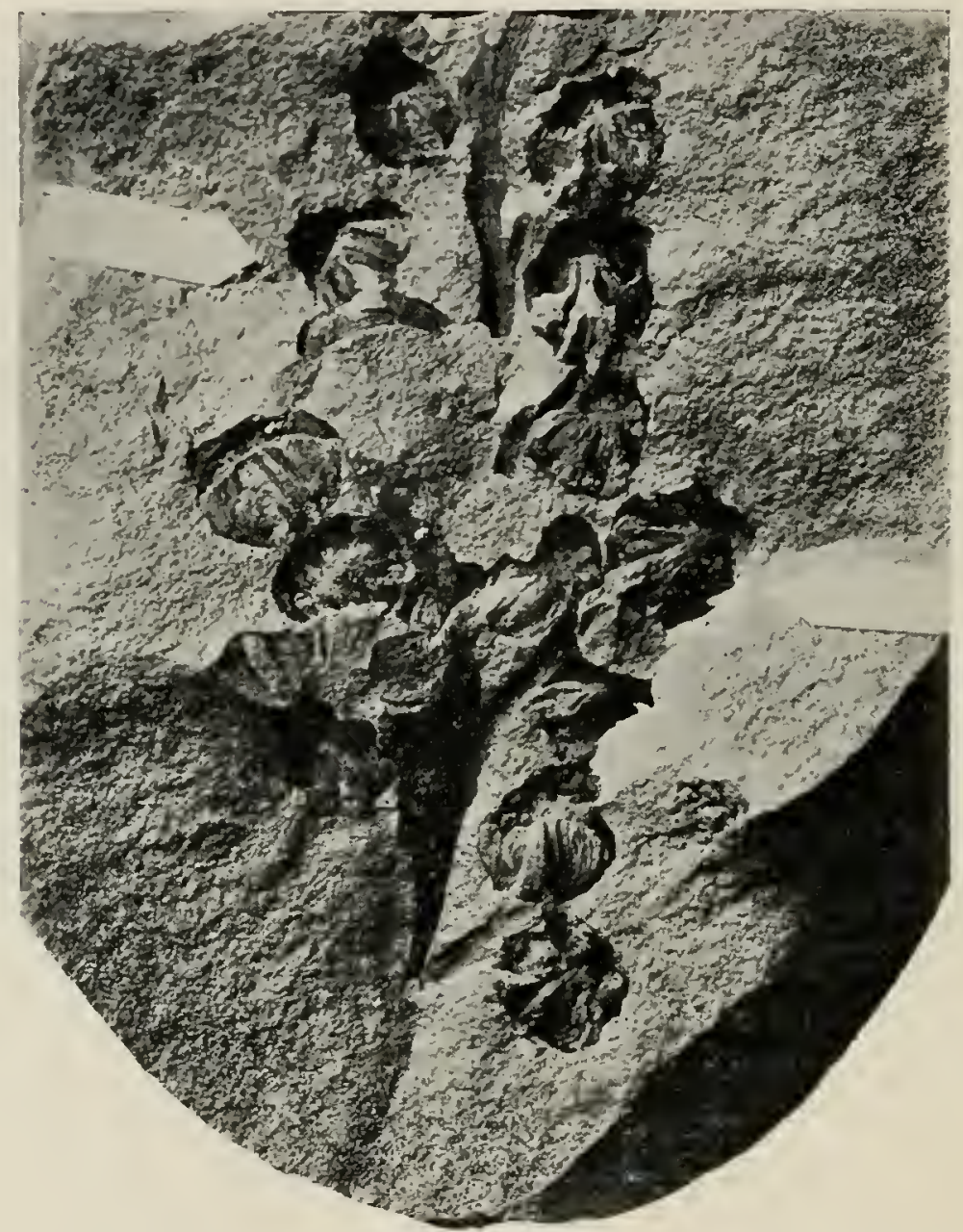

FIG. 19.-Crossotheca Höninghausii: portion of frond with several "stamens," some of which show the individual sporangia; $X_{4}$. - From photograph by Kidston $(64)$.

and 23) show longitudinal and transverse sections of this stamen. Dehiscence takes place by a longitudinal slit along the adaxial face, the spores of both loculi thus being liberated simultaneously. The microspores are 50 to $75 \mu$ in diameter, having a surface rough with blunt points.

The discovery described above raised the question whether all 
the species of Crossotheca are stamens of Cycadofilicales. Recently Miss Brisson has announced $\left(8_{3}\right)$ the discovery of a new species of Crossotheca (C. Grievii), which is described as the stamen of Heterangium Grievii. There are now recognized, therefore, nine species, and all of them have the general "epaulet" character described for C. Höninghausii. 'They differ only in such details as the form of the sporangium-bearing blade (oval, cordate, or lobed), and in the number and form of the sporangia. So similar are these species that it seems safe to infer that they are all stamens of Cycadofilicales. The foliage of all of them is known, except that of C. Hughesiana, and includes species of Pecopteris (as P. exigua) as well as of Sphenopteris (Lyginodendron).

In $\mathrm{ISS}_{7}$ KIDSTON (II) described fronds of Neuropteris heterophylla (Medullosa) in which both the pinnae and axis end in slender, naked, dichotomously divided branchlets, each ultimate division terminated by a fourvalved body. At the time these bodies were regarded simply as the "fructifications" of a fern. Since the seeds of this species have now been

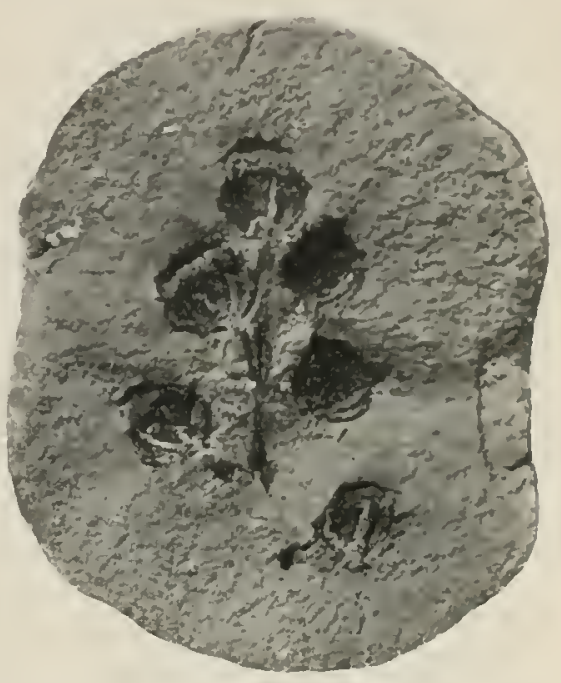

FIG. 20.-Crossothecu Höninghausit: portion of frond with six young stamens; $\quad \times 2.5 .-$ From photograph by Kinsto: (64) discovered, it is apparent that these bodies must represent its microsporangiate structures. "Fructifications" of this kind, terminal on naked, ultimate branchlets of a more or less modified frond, with valves more or less united at base, have been referred to the form genus Calymmatotheca. At least some of them are sporangia more or less united below and free above, and in some cases the dehiscence (internal) and the spores have been found. Of course such a structure is a synangium, ${ }^{\mathrm{I}}$ but its terminal relation to ultimate branches of the frond is quite different from that of the synangia of existing Marattiaceae. There is danger of confusing these structures with the cupule-like investment of such seeds as

I This term is used with no implication of an opinion as to the nature of the structure. 
Lagenostoma (Lyginodendron), and perhaps they may be spoken of as the "cupule" style of stamen, in contrast with the "epaulet" style of Crossotheca. In fact, it is altogether probable that Calymmatotheca Stangeri (STUR in I877), a stellate, six-rayed structure, represents the cupule-like investment of a seed that had dropped. On he other hand, ARBER (77) described from the coal fields of Germany

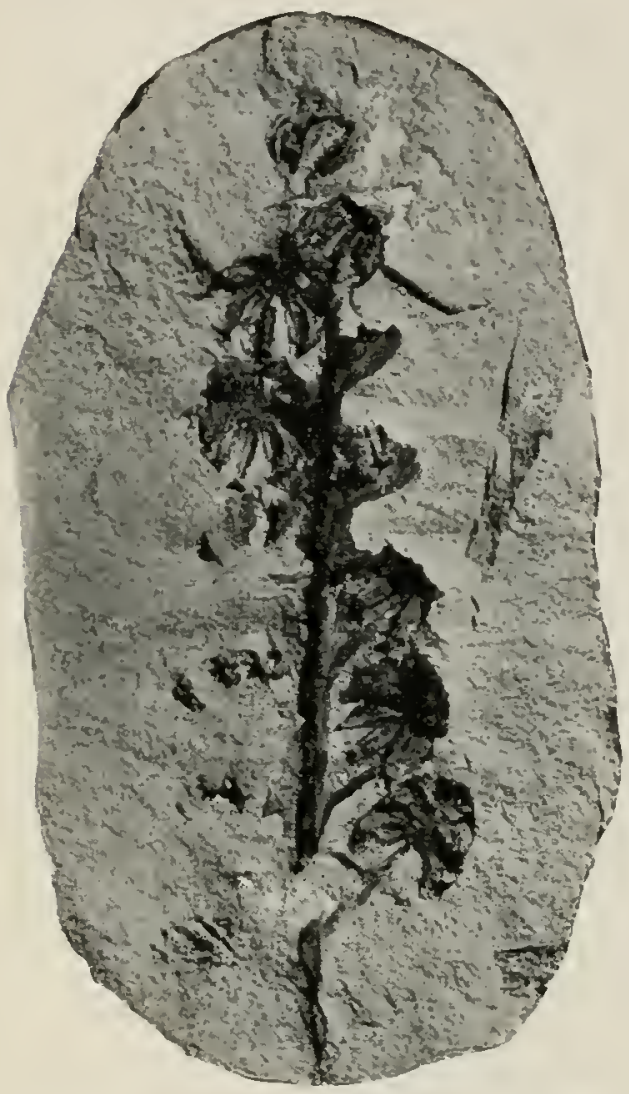

FIg. 21.-Crossolheca Höninghausii: portion of microsporophyll with mature microsporangia; $\quad X_{2} .5 .-$ From photograph by KIDSTON (64). what he regarded as a remarkably small seed (Carpolithus Nathorstii) occurring on the frond of a Sphenopteris; later NATHORST (8I) nvestigated its structure, and found it to be not a seed, but a microsporangiate structure. Miss Bersox (4I) has described a genus (Telangium) of this Calymmatotheca type, to include certain digitate clusters of the Paleozoic, which she referred, from indirect evidence, to Lyginodendron Oldhamium; but since the stamen of that form has now been determined by direct evidence, Telangium remains to be connected, possibly with some other form included under the same name. Telangium was described as term:nal on ultimate branches of the leaf, but ScotT $(87)$ has concluded that the synangial group of long and pointed sporangia was "seated on a flat disk or lamina, quite comparable to the fertile pinnule of Crossotheca. Sellards $(40,74)$, also, has described a spore-bearing structure (Codonotheca) from the Coalmeasures of Illinois, which is a cup-shaped body composed of six bladelike valves united below and free above, and bearing spores liberated on the inside (fig. 24). The association of these structures with the remains of Neuropteris suggests that they are stamens belonging to some species of that frond genus. 'The stamens of Aneimites are unknown, but intimately associated with the seed-bearing fronds there 
occur structures of the Calymmatolleca type. It must be confessed that while the Crossotheca or "epaulet" type of stamen is distinct

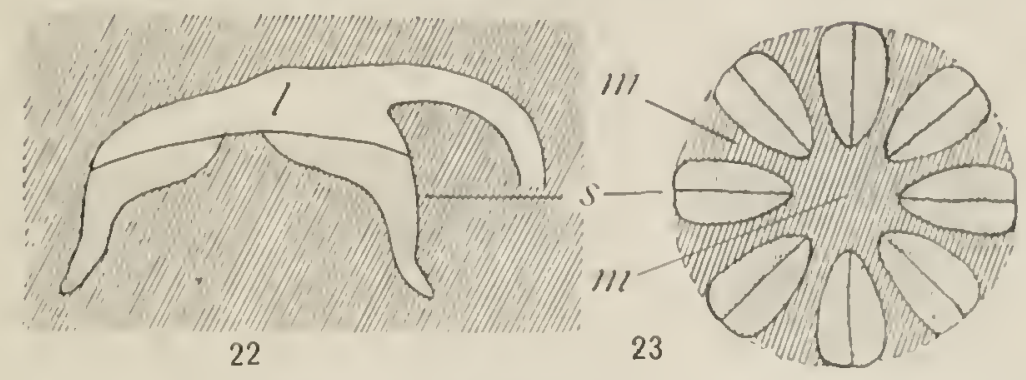

FIgs. 22, 23.-Crossotheca Höninghatesii: fig. 22, diagrammatic longiturlinal section of stamen; fig. 23 , diagrammatic transverse section of stamen; $l$ limb; $s$, sporrangia; $m$, rock matrix.-After Kinston (64).

enough, the so-called Calymmatolheca or "cupule" type is in confusion, and so far as it represents microsporangiate structures at all, they may be referred ultimately to Crossotheca or to ordinary marattiaccous synangia, like those of Kaulfussia.

Although actual organic connection of stamens with plants known to be seed-bearing has been discovered as yet in only two or three forms, it is erident that a much wider range of forms is indicated. All structures of the Crossotheca type may fairly be considered probable stamens of Cycadofilicales, and some of the Calymmatotheca structures, so far as they are distinct from large marattiaceous synangia, are doubtless such also. It must be noted, however, that the frond genera and the sporangium genera cross one another's boundaries. For example, Crossotheca occurs on both Sphenopteris and Pecopteris; while Calymmatotheca (or its equivalents) occurs on Neurop-

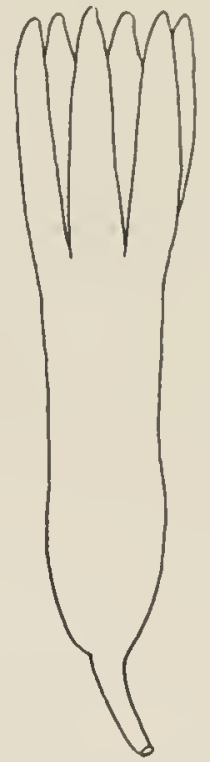

FIG. 24.-Codonutheca; $\times 2 .-$ After SELLARDS (40). teris, Sphenopteris, and probably Aneimites. The dimorphic character of the fronds is quite marked in all these cases, and it suggests the question whether other dimorphic fronds, bearing sporangia of a different type, may not belong to Cycadofilicales. Furthermore, the great frond genus Pecopteris, one of whose species, at least, is known to belong to the Cycadofilicales, possesses all the types of spo- 
rangia once supposed to belong to the palcozoic Marattiaceae. This throws suspicion on all sporangia of paleozoic "fronds."

It is to be expected that among the Cycadofilicales there will be found microsporangiate structures indistinguishable from the sporangia of paleozoic ferns. This statement is emphasized by the fact that eren the stamens of the mesozoic Bennettitales bear synangia closely resembling those of existing Marattiaceae. It would be useless to consider here the numerous "fructifications." mostly those of Pecopteris, which may or may not prove to be microsporangia; this has been done recently by Scotr $\left(8_{2}\right)$. It is well to note, however, that there is every gradation from naked branches bearing abundant free sporangia (as Urnatopteris, whose sporangia have apical pores, and which is strongly suspected of belonging to the Cycadofilicales), to free and often solitary (Dactylotheca, also probably one of the Cycadofilicales) sporangia on ord nary leaves, and finally to synangia of rarious kinds (the radiate or Kaulfussia type prevailing). In Per teris Pluckenetii, whose seeds have been found, GRAND 'Eury reports (62) "stellate groups" of sporangia on the margins of pinnules, a description applicable to the sori or incomplete synangia of marattiaceous ferns.

The danger of too hasty reference of sporangia to Cycadofilicales is illustrated by Stauropteris Oldhamia, investigated by Scott $(57)$. Its very slender and numerous ultimate branchlets occurred "in dense faggot-like groups," and bore terminal sporangia. The fact that the orules of Cycadofilicales are also often terminal on ultimate branchlets, and that some of the Cordaitales bear microsporangia in the same way, made it tempting to infer that Stauropteris belonged to the Cycadofilicales. Later, however, ScotT (70) was fortunate enough to secure preparations of the sporangia of Stauropteris containing germinating spores, which showed distinctly their fernlike character. The great interest of Stauropteris in connection with Cycadofilicales, therefore, is to show that the terminal position of sporangia on ultimate branchlets occurred among ferns.

In any erent, it is evident that the synangial microsporangia of Cycadofilicales and the synangia of marattiaceous ferns were so much alike as to imply common origin $(7 t)$. 
THE MECASPORANGIUM

Numerous detached paleozoic seerls have been discovererl, but it must be remembered that they include the seerls of both Corrlaitales and Cycadofilicales. 'The seeds definitely connected with Cycadofilicales are comparatively very fer, but the structure of at least two of them is known with remarkatble completeness.

LAGENOSTOMA.-In IgOz OLIVER and ScorT (39) announced that a species of this seed genus is the seed of Lyginodendron Oldhamium, and in the following year the full account appeared (48). The seed species was a new one, and was described as Lagen's.'toma Lomaxii (fig. 25). 'The sceds

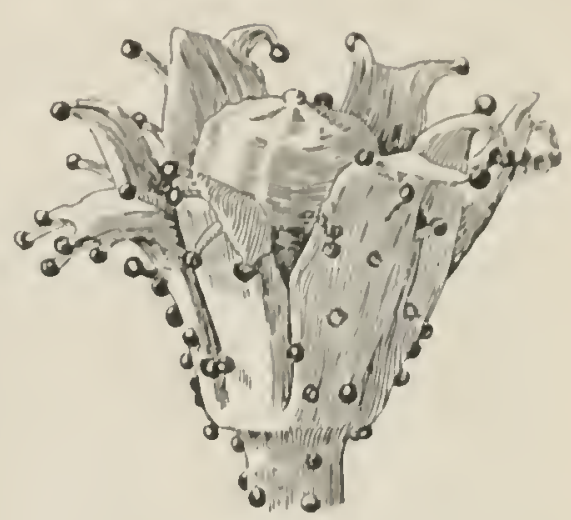

Fig. 25.-Lagenostomu Lamuxii (restored): the secel is surrounderl by a glandular rupule.--Ifter OLINFR and SCOTT $(48)$. were not found in actual organic con-

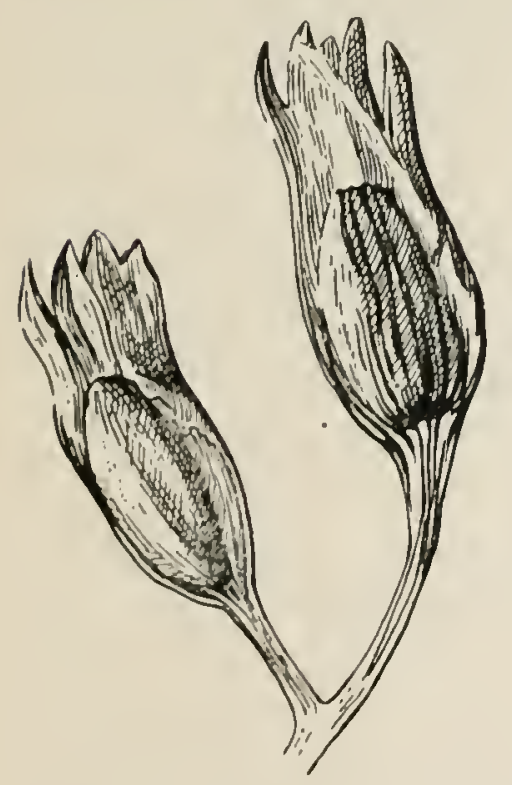

Fig. 26. - Lagenosloma Sincluirii: two seeds on branches of the rachis, each seed surrounded by a cupule.-After ARBER (5I).

nection with the foliage (Sphenopteris) of Lyginodendron, but the numerous and peculiar capitate glands borne on the cupule correspond in crery detail to those on the vegetative organs of the associated Lyginodendron, and represent a character not possessed by any other associated plant. 'There seemed to be no doubt that the reference of the seed to Lyginodendron was fully justified, a conclusion further confirmed by a comparison of the anatomical details. Another species of Lagenostoma (L.ovoides) was known; and later ARBER (5I) described L. Kidslonii and L. Sinclairii from casts. but important in that the seeds were connected with branching axes that represent naked branches of a frond (iig. 26). It is evident, therefore, that the leaves of Lyginodendron were dimorphic, one form being the familiar sterile foliage of the Sphenopteris type, 
the other a form reduced wholly or partly to naked branches, whose ultimate branchlets bore terminal seeds of the Lagenostoma type. There was no more organization of a strobilus than in existing ferns with dimorphic leaves. Additional species have been described also by GRAND 'EURY (53), who found in the Lower Coal-measures a very large number of small Lagenostoma-like seeds associated with species of Sphenopteris under conditions that seem to make it certain that they belonged together.

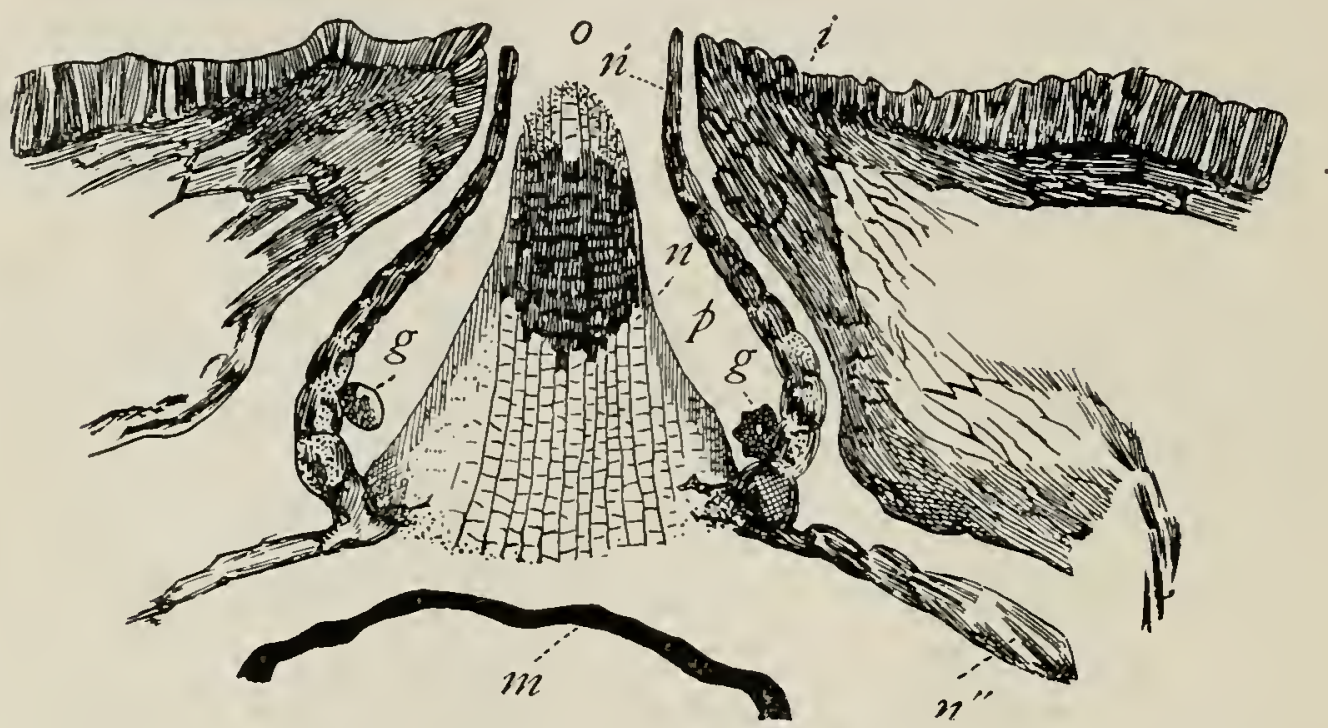

FIs. 27.-Lagenostoma Lomaxii: longitudinal section through apex of seed; $o$, opening at top of pollen chamber; $i$, integument; $n$, central core of nucellus; $n^{\prime}$, outer hard layer of nucellus; $p$, pollen chamber; $g$, pollen grains; $n^{\prime \prime}$, part of nucellus supporting the pollen chamber; $m$, megaspore membrane; Xabout 50.-After OLIV'ER and ScotT (48).

The structure of Lagenostoma Lomaxii has been described in full by Oliver and ScotT $(39,48)$. The seeds occur in the Lower Coal-measures, and each one is invested by a lobed cupule "springing from the pedicel just below the base of the seed and extending above the micropyle, at least in young specimens. The cupule appears to have been ribbed below and deeply lobed above, and in form it may be roughly compared to the husk of a hazelnut, of course on a very small scale" (fig. 25). The integument, which is free only in the region of the pollen chamber, is a remarkably complex structure. A transierse section shows an outer heary zone, and an inner one consisting of several chambers (usually nine) filled with parenchyma, 
each chamber being traversed longitudinally by a single vascular strand, the strands being connected with the main bundle that enters the chalaza. The pollen chamber is peculiar in that it is not the usual open cavity in the beak of the nucellus, but is a cylindrical (bellshaped) crevice between the epidermis of the free tip of the nucellus and its central core of tissue (fig. 27). The archegonia probably occurred in a ring beneath this crevice. Our preparations of $L$. oroides from LoMAx show the method of formation of this peculiar pollen chamber (figs. 28 and 29). The free beak of the nucellus is covered by an epidermal layer whose cells have thick, resistant walls. Within this layer, near the base of the beak, the thinwalled tissue begins to break down; and this breaking down extends upward beneath the epidermis to the apex of the beak, resulting in the characteristic crevice-like

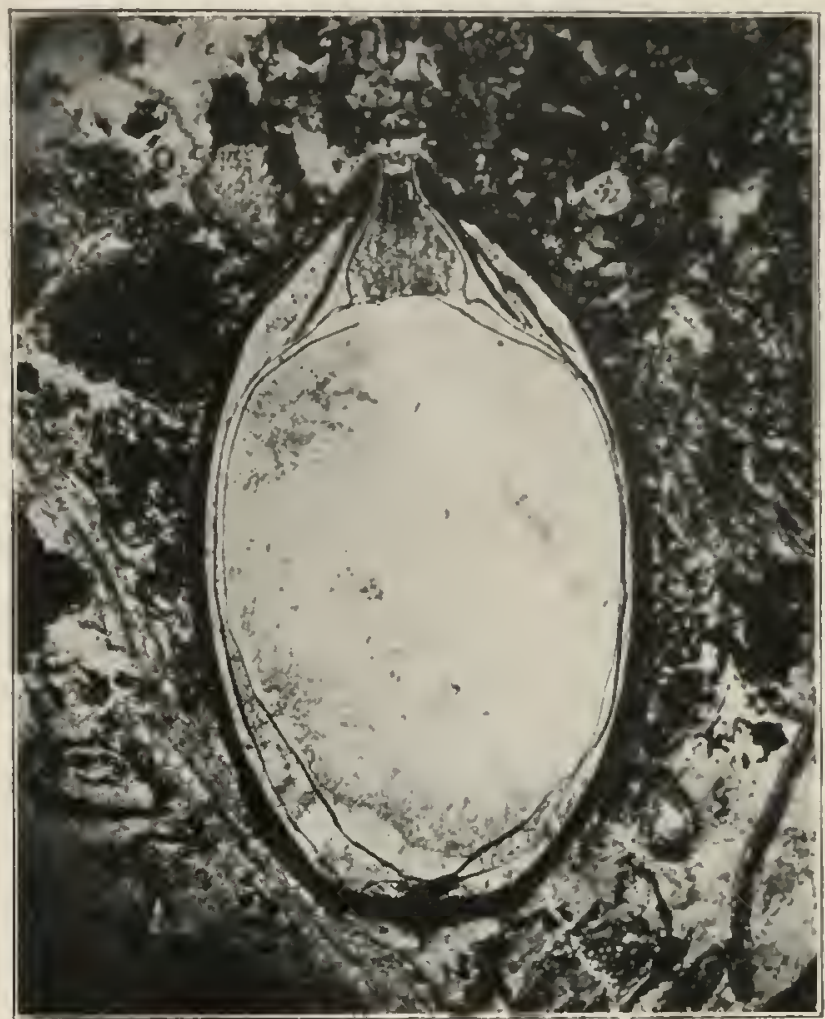

FIG. 28.-Lagenostoma oroides: longiturlinal section of a seed; $\times 12$. - From photomicrograph by LAND. pollen chamber surrounding a central core of tissue. A diagrammatic longitudinal section of the seed is shown in fig. 30; and diagrammatic transwerse sections at various levels through the pollen chamber, in figs. $3 \mathrm{I}-34$. The contrast of this Lagenostoma method of pollen chamber-formation with the ordinary method, such as occurs in the Stephanospermum type of sceds (sce below), in the cycads, etc., is striking. In the latter case the pollen chamber begins to develop at the tip of the nucellus and is central; while in Lagenostoma it begins to develop at the base of the nucellar beak and is peripheral. It must be understood, therefore, that the 
"nucellar beak," which is said to "arise from the floor of the pollen chamber," is in reality a core of tissue left intact in the formation of the pollen chamber. An important feature to note in the seeds of this group is that the open tube of the pollen chamber projects a little through the micropyle, so that the passage for the entrance of the pollen grains is not furnished by the micropyle, but by the protruding nucellar beak $(86,87)$.

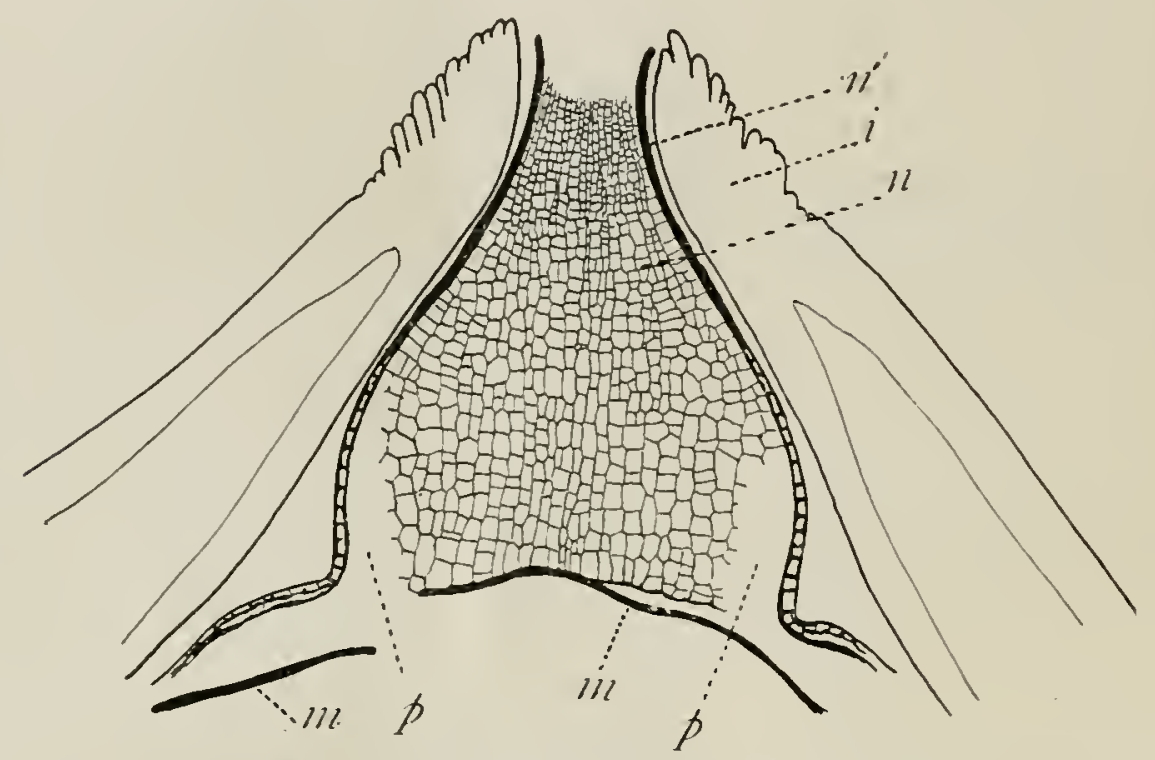

FIG. 29. - Lagenostoma ovoidcs: longitudinal section through apex of seed shown in fig. 28 , illustrating an early stage in the formation of the pollen chamber; $n$, central portion of nucellus which becomes the core shown in fig. $27 ; n^{\prime}$, outer hard part of nucellus; $p$, beginning of pollen chamber; $m$, megaspore membrane; $i$, integument; $\times 3^{6}$.

The impression described as Lagenostoma Sinclairii (5I) shows the same type of seed (fig. 26), so far as external characters are concerned, and furthermore it shows its connection with foliage of the Sphenopteris type.

It is evident that in comparing these seeds with those of living gymnosperms they must be regarded as resembling those of cycads, with decided peculiarities of their own. It is still further evident that such seeds are very far from being primitive in structure, and are no more suggestive of the origin of seeds in general than are the seeds of existing seed plants.

Physostoma.-Recently Oliver (85) has restored this genus, described first by Williamsor (2), but later referred by him (3) to 
his new genus Lagenostoma as J. physoides. This species (OHWR restores as Physostoma elegans, and associates with it ARBBLR's Lagenostoma Kidstonii (51). P. elegans is also the Sporocarpon ornatum of Wildiamson $(4,8)$, as well as his S. anomalum $(8,19)$. It is thought to belong to some one of the Lyginodendrineac (Lyginodendreae) not yet distinguished.

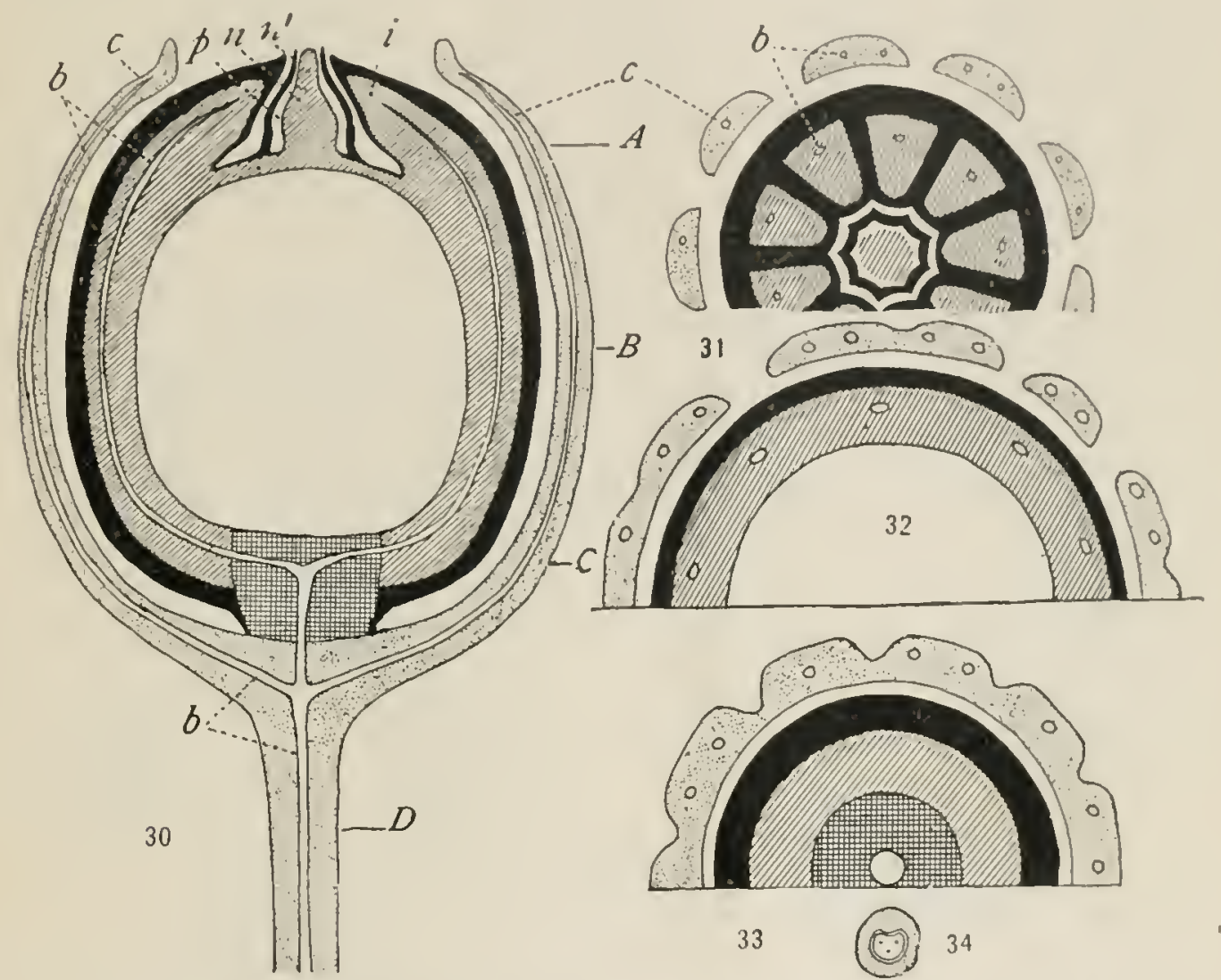

FIGS. 30-34.-Lagenostoma Lomaxii: fig. 30, diagrammatic longitudinal section of ovule with its investing cupule; figs. $3 \mathbf{I}-34$, transverse section at the levels $.1, B$, $C$, $D$, respectively; $n$, central portion of the nucellus, and $n^{\prime}$ the outer hardened portion, with the pollen chamber $(p)$ between; $i$, integument; $c$, cupule; $b$, rascular bundles.-After Otiver $(55 a)$.

The seed is small and oval $(5.5$ to $6 \mathrm{~mm}$. by $2 \mathrm{~mm}$.) with a narrowed base, usually ten-ribbed, and circular in section. 'There is no trace of a cupular sheath as in Lagenostoma. A very remarkable feature, however, is that the integument, free only in the region of the pollen chamber, is broken up into ten "tentacles," the direct prolongations of the ten ribs (figs. 35-39). Ribs and tentacles are corered by long, club-shaped hairs. 'These tentacles of Physostoma 
seem to be the units that make up the chambered integument ("canopy") of Lagenostoma, and this has suggested to Oliver the multiple Torigin of the integument. No stony layer is developed by the testa, and the distribution of the vascular strands is practically as in Lagenostoma, a single strand ascending deep in each rib and
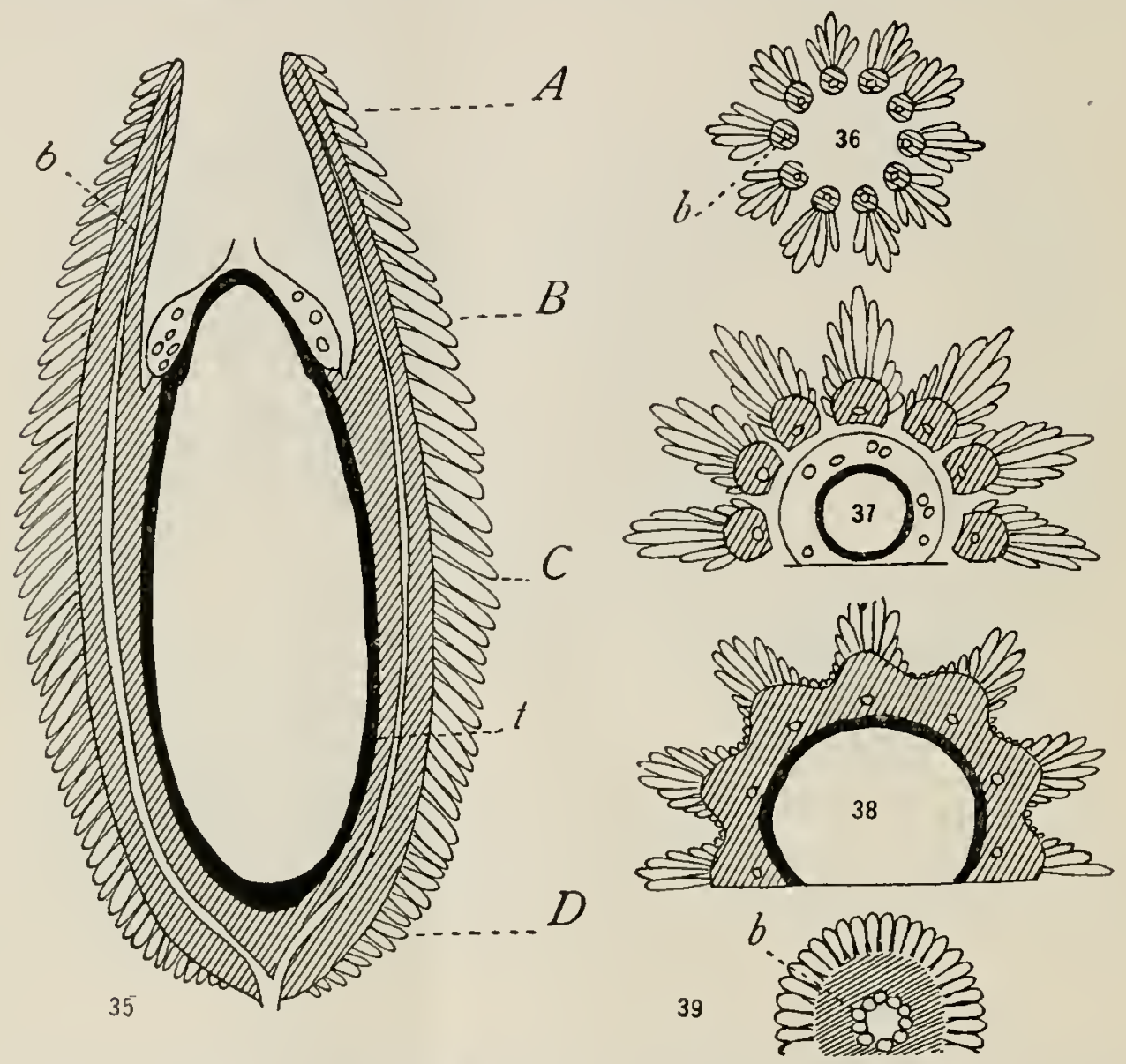

FIGS. 35-39.-Physostoma elegans: fig. 35, diagrammatic median longitudina section; figs. $3^{6-39}$, transverse sections at the levels $A, B, C, D$, respectively; $b$, rascular bundles; $t$, "tapetunı."-After Oliver ( 85 ).

passing on into the corresponding tentacle. The pollen chamber consists of the same circular crevice as in Lagenostoma, but the embryo sac develops into the nucellar projection (fig. 35), so that the pollen chamber really invests the upper end of the sac ("like the incurved bottom of a wine bottle"). The peripheral region of the nucellus, from the chalaza to the top of the embryo sac, is occupied by a remarkable "secretory zone," made up of thin, oblong, tabular cells, and representing what OLIVER regards as the retention of a feature present 
in the vegetative organs. Between the secretory zone and the cmbryo sac, and entering into the cap) of the sac within the pollen chamber, is a region of six or more radially compressed layers of cells. which is regarded as a "tapetum," but which may be only the region of the nucellus compressed by the enlarging embryo sac.

The Lagenostoma group.-Associated with Lagenostoma and Physostoma there is the seed genus Conostoma (3), and also the recently announced genus Sphaerostoma (83), based upon WILlaAsox's Conostoma ovale and the oldest paleozoic orule known structurally. These four genera form what may be regarded as a natural group, belonging to the Iyginodendrineae. Lagenostoma Lomaxii alone, of the petrified seeds of this group, is definitely connected with a species of Lyginodendron (L. Oldhamium); while L. Sinclairii and L. Kidstonii (Plyysostoma Kidstonii) are impressions which are connected with foliage of the Sphenopteris type. Lagenostoma ozoides, Physostoma elegans, and Conostoma all occur as petrifactions, but they have not been referred to definite species of Sphenopteris or of Lyginodendron. It had been inferred from association that one of the species of Conostoma might be the seed of Heterangium, and now Miss Benson $(83)$ has shown it to be probable that the new seed genus Sphaerostoma (Conostoma ovale) belongs to Heterangium Grievii.

In ${ }^{8} 85$ Renault (9) described Gnetopsis elliptica, in which there are four seeds (two often abortive) inclosed in a cupule consisting of two partly fused bracts, each of which becomes five-toothed above. The integument expands around the micropyle and forms a chamber, and bears two long feathery appendages. There is a central core of tissue within the pollen chamber, and the neck of the chamber divides into lobes. The endosperm and two distinct archegonia are preserved. The two fused bracts doubtless suggested to RENALI'T a relationship to Gnetales, but the general structure is much more suggestive of a seed of the Lagenostoma type $(87)$.

The four seed genera referred to agree in the amount of freedom of nucellus and integument, in the peculiar character of the pollen chamber with its projecting beak, in the composition of the free portion of the integument (distinct lobes to lobes "fused"), in the covering of mucilage hairs, in the distribution of the rascular strands, and 
in the character of the pollen grains (described below). Oliver $(85)$ sees in Physostoma elegans, with its "tentacles" and "secretory nucellar zone," the most primitive condition. The following series ${ }^{\mathrm{I}}$ on the basis of freedom or coalescence of the integument lobes is attractive: in Physostoma they are free and the body of the seed is ribbed; in Conostoma the body is ribbed below and smooth abore, and the integument lobes are united, but show a tendency to separate; in Lagenostoma the body is completely smooth and the integument lobes are completely united to form the characteristic chambered "canopy." The numbers of the units of integument structure vary as follows: 10 in Physostoma elegans, 9 in Lagenostoma Lomaxii, 8 in L. ovoides, 7 in Conostoma oblonga, about 6 in L. Kidstonii ( $P$. Kidstonii).

The characters of Lyginodendrineae given in the preceding pages make it possible to outline the probable features of the group. ScotT $\left(8_{7}\right)$ has suggested in effect the following tentative description: leares fernlike (Sphenopteris or Pecopteris); stem monostelic and with xylem mesarch; leaf trace and main leaf bundle single or double, concentric in the petiole; reproductive organs on somewhat modified pinnae; microsporangiate organs of the Crossotheca type; seeds radial, cycadean, with nucellus and integument free only in the region of the nucellar beak and with a singular vascular system, and often inclosed (singly or several together) in a cupule.

Medullosa. - In I904 Kidston $(44,45)$ announced the discovery of three fragments of Neuropteris heterophylla, each of which bore a seed "as large as a hazelnut" on a pedicel terminating a pinna (fig. 40). These seeds are about $3 \mathrm{~cm}$. long, oblong in outline but tapering to a point, and invested by a fibrous envelope. Their internal structure is not known, but they belong to a general type of paleozoic seeds quite different in structure from the Lagenostoma type. The relation of the seeds to the fronds is the same as in Lyginodendron, but there is no evidence of such extreme dimorphism, the seeds being terminal on the naked tip of a pinna which otherwise does not differ from he ordinary pinnae. That this Neuropteris is the foliage of a Medullosa is clear, and there is enough evidence to indicate that all the members of this stem genus were seed-bearing, and that the seeds were borne terminally upon more or less modified pinnae.

I The description of Sphaerostoma is not yet available. 
Aneimites.-In igot l'inte (49) announced the discovery of seeds upon fronds of Aneimites (Adiantites) from West Virginia, the seeds having been used to establish the seed genus Wardia. Aneimites is represented in the Lower Coal-measures, the general habit of the leaf and its cuneate ultimate divisions strongly suggesting

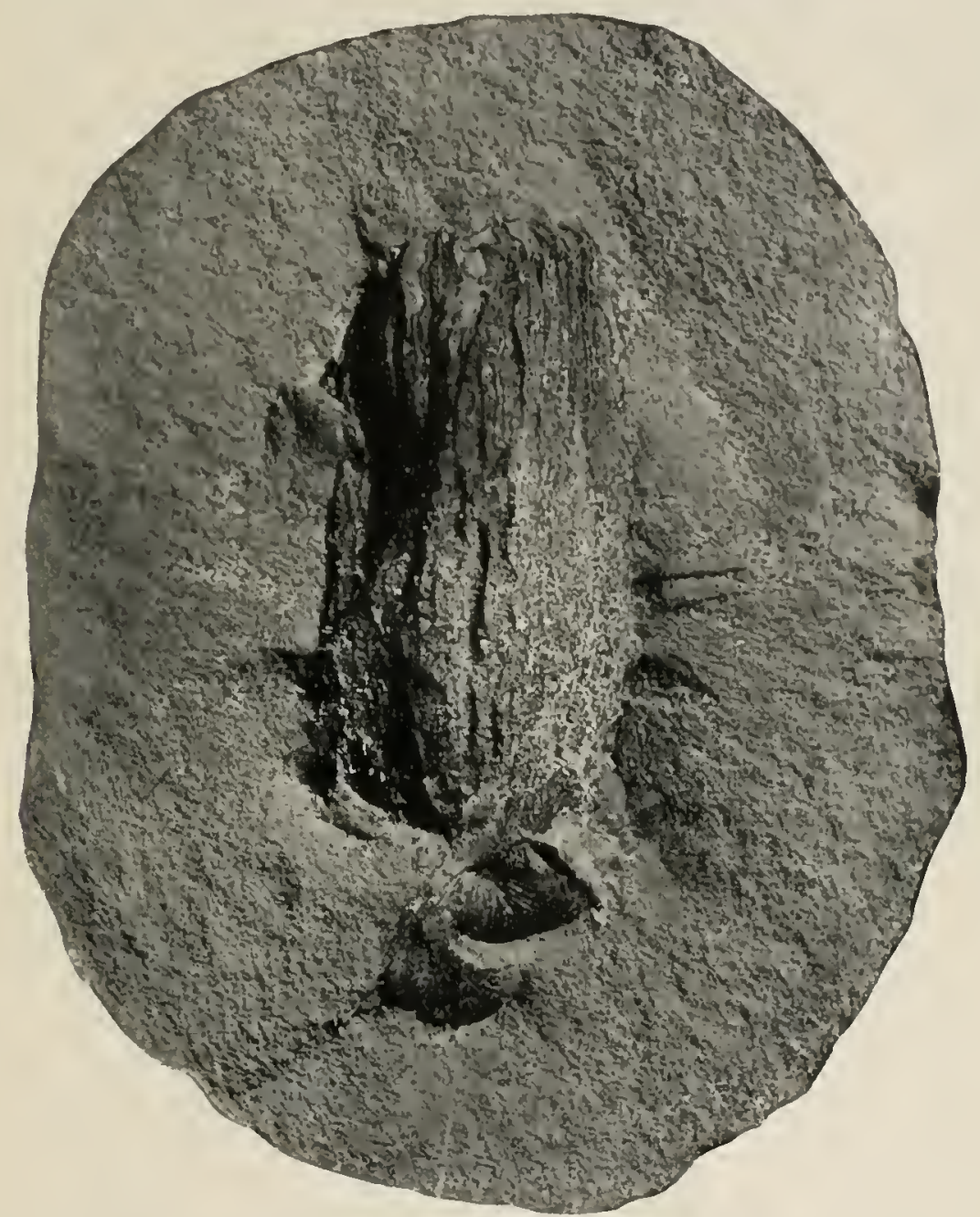

FIG. 40.-Neuropteris heterophylla: seed (Rhabdocarpus) attached to a shore pedicel bearing foliage; $\times$.2.-From photograph by Kidstox ( +4$)$.

Adiantum (figs. 4I and 42). The seeds are borne upon somewhat reduced fronds, occurring singly or in pairs upon pedicels that replace ultimate pinnules. They are rhomboidal in outline and thin lenticular in transverse section, the outer covering (cupule or integument) being latera'ly dilated and winged, especially below the middle (fig. 43), possibly fibrous or slightly fleshy, and inclosing the less rhomboidal and nutlet-like structure within; unfortunately no internal structure is preserved. Such seeds have been found in all stages of 
development, are associated with Aneimites in most of the deposits observed (Lower Pottsville of the Virginia region), and have been found in organic connection with the fronds of two species. They
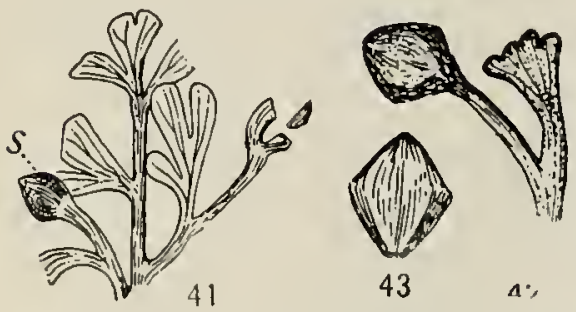

FIGS. 4I-43.-Aneimites fertilis: fig. $4 \mathrm{I}$, fragment of pinna with seed $(s)$; fig. 42, seed on long pedicel connected with foliage; fig. 43 , seed showing wings, the latter somewhat exaggerated; $\times 2$. After IVHite (49). seem to represent a very different type of seed (platysperms) from those found in connection with Lyginodendron and Medullosa.

Pecopteris. - In I905 Grand 'Eury (52) announced the discovery of seeds on P. Pluckenetii. A mass of sterile and fertile pinnules was found, the latter bearing hundreds of seeds. These are not borne at the extremities of naked branchlets, the seed-bearing pinnules being very slightly modified and bearing a seed hanging freely at the extremity of the principal veinlet of each lobe (fig. 44). ScotT (58) speaks of this as "the most striking instance of a "seed-bearing fern' yet brought to light." The seeds are small (about $5 \mathrm{~mm}$. long), oval, and with narrow wings. The winged habit of these seeds and of the seeds of Aneimites suggests the seeds of Cordaitales, and it becomes evident that fossil seeds can no longer be assigned with certainty except on evidence of organic connection. The discovery that a species of Pecopteris was a seed-bearing plant was one of very great interest, for it was the last great frond genus to join the Cycadofilicales, and it is the most conspicuous genus in the variety of sporangia it bears.

Probable seeds of Cycadofilicales.In the preceding cases the evidence of the seed-bearing habit is direct and convincing;

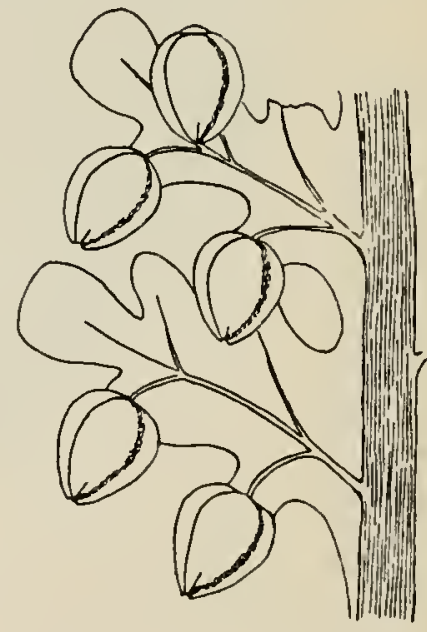

FIG. 44. - Pecopteris Pluckenetii: portion of fertile pinna with seeds attached at ends of lobes of pinnules; $\times_{3}$. - After Grand 'Eury (43). but in addition there is a possible range of inferences that are worth considering. Grand 'Eury (53) has called attention to the great 
number and diversity of "fern seeds." In the assured cases, the relation of seed to frond varies from seeds suspended on the under surface of unmodified leaves (as in Pecopteris), to seeds in rows on a special rachis (as in Neuropteris), and linally to seeds isolated at the ends of ultimate branchlets (as in Sphenopteris). Beyond these few definite cases there lies the vast assemblage of paleozoic seeds which have constituted several times as many seed genera as frond general, which incidentally is another indication of the heterogeneous character of the latter. It is evident, therefore, that there are seeds enough for all the fronds known; and also that the seed habit discovered in one or even several species of a large frond genus need not be imposed upon all the species. At the same time, it is becoming increasingly apparent that large numbers of frond species and of unassigned seeds must belong to Cycadofilicales.

Kidston's discovery of specimens of Neuropteris heterophylla bearing seeds is the only direct evidence that Neuropteris in general was seed-bearing; and yet the investigations of GraND 'EURY (43) on the plants of the Coal-measures of France showed such a constant association of definite types of seeds with definite fronds of Neuropteris that the inference seems justified that the species of Neuropteris in general were seed-bearing plants. Among the better known seeds thus referred are Pachytesta, sometimes reaching the size of a hen's egg, and Trigonocarpum (one of whose species is probably the seed of Medullosa anglica). In this general characterization the frond genera known as Alethopteris, Odontopteris, Linopteris, Lonchopteris, etc., are also included.

Among the Lyginodendron-like forms, the seeds (Lagenostoma Lomavii) of L. Oldhamium stand as the only direct evidence of the seed-bearing habit; and yet Heterangium and other stem genera with Sphenopteris foliage are evidently so nearly related to Lyginodendron that one can hardly doubt that many of the species of Sphenopteris were seed-bearing. In fact, the genus Sphaerostoma (Conostoma ov'ale) is in all probability the seed of Heterangium.

The species of Pecopteris are much more uncertain, and for many reasons no sweeping inference as to the seed-bearing habit of this great frond genus is justified. The single known seed-bearing species (P. Pluckenetii) is said to be an aberrant one in its frond characters. 
PALEOZOIC SEEDS.-Our knowledge of the internal structure of seeds known positively to be those of Cycadofilicales is restricted to the Lagenostoma group; but there is much larger knowledge of detached paleozoic seeds, some of which may well belong to Cycadofilicales. At least it is not out of place to consider the general characters of paleozoic seeds. Numerous detached seeds occur in the Carboniferous, and they have naturally been referred to gymnosperms. Although called seeds, they have been preserved evidently at the stage just preceding or soon after fertilization, and are ovules in the modern sense. Especially in the Permian beds of France are these seeds remarkably well preserved, having been elaborately described by Brongniart (6) and Renault (i6). Seeds from the English beds, usually less well preserved, have been described by Williamson $(2,3)$. The whole subject, however, has lately been reopened by OLIVER (38), in connection with the recent rapid development of our knowledge of gymnosperms.

BRONGNIART for convenience referred all paleozoic seeds to two categories, which OLIVER has named radiosperms and platysperms, the seeds of the former being circular in transverse section or radially symmetrical, those of the latter flattened or bilateral. Some of the platysperms have been referred definitely to the Cordaitales, and the same connection has been inferred for the rest of them; but the seeds of Aneimites and of Pecopteris, described above, suggest that this reference has been too sweeping. The radiosperms have had no such definite assignment, until recently some of them have been found to belong to Cycadofilicales. It is evident that BRongniarT's two types hold no relation to the two paleozoic groups of gymnosperms.

There are certain general features belonging to some of the paleozoic radiosperms that deserve special mention in connection with their possible relation to Cycadofilicales. For this purpose the seed genus Stephanospermum, formerly referred to Cordaitales but now probably to be assigned to the Medullosineae, may be used, both because it is the simplest and because it has been described in great detail by Oliver (47). The seed of S. akenioides (fig. 45) is cylindrical and pointed, the testa being differentiated apparently into an outer stony layer and an inner fleshy layer. ${ }^{\mathrm{I}}$ The nucellus is entirely free from

I An outer fleshy layer might be expected, but either it has not been preserved or has not been recognized. 
the integument or testa, in striking contrast with the ovules of living gymnosperms, in which the integument and nucellus are free only in the region of the pollen chamber or nucellar beak. A long and strong nucellar beak extends into the micropyle, and within it a pollen chamber of great relative size is developed. The vascular strand entering the chalaza expands into a plate, whose margin is continued as a tracheal mantle investing the nucellus beneath the epidermis and extending to the pollen chamber, "the floor of which is pared with tracheids." Oliver sees in this distribution of vascular elements a mechanism for the conduction of water for the use of swimming sperms in the pollen chamber. While the pollen chamber is associated with swimming sperms, there is no evidence that a supply of water is necessary.

Contrasting Stephanospermum with Lagenostoma, it is evident that the latter approaches the structure of cycadean seeds more nearly than does the former, especially in the lack of freedom of nucellus and integument, and in the greater simplicity of the rascular system. On the other hand, the pollen chamber of Stephanospermum is more cycadean, as well as the testa

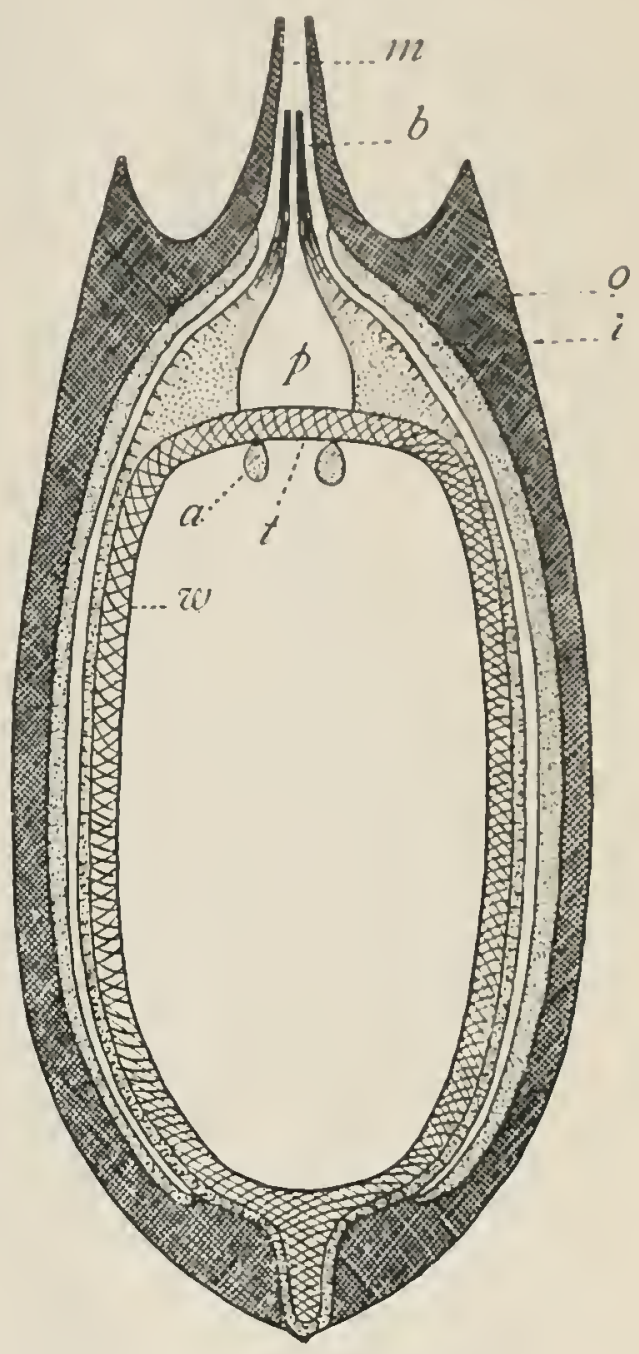

FIG. 45.-Stephanospermum akenioides: partial restoration; $m$, microprle; $b$, heak of nucellus; $p$, pollen chamber; $o$, outer (sclerotic), and $i$, inner laver of integument, which is free from nucellus to base of seed; $t$, tracheal mantle; $a$, archegonia; $\imath$, megaspore nuembrane; Xio.-After Oliver $(4 i)$. in the development of the three characteristic layers. It should be remembered that Lagenostoma is lower carboniferous, while Stephanospermum is permo-carboniferous, so that historically the former is much the older, but its structure shows it to have been far from the simplest type of seed. In living gymno- 
sperms the nucellus and integument are entirely free in the early stages of the ovule; and the later growth of the ovule being in the

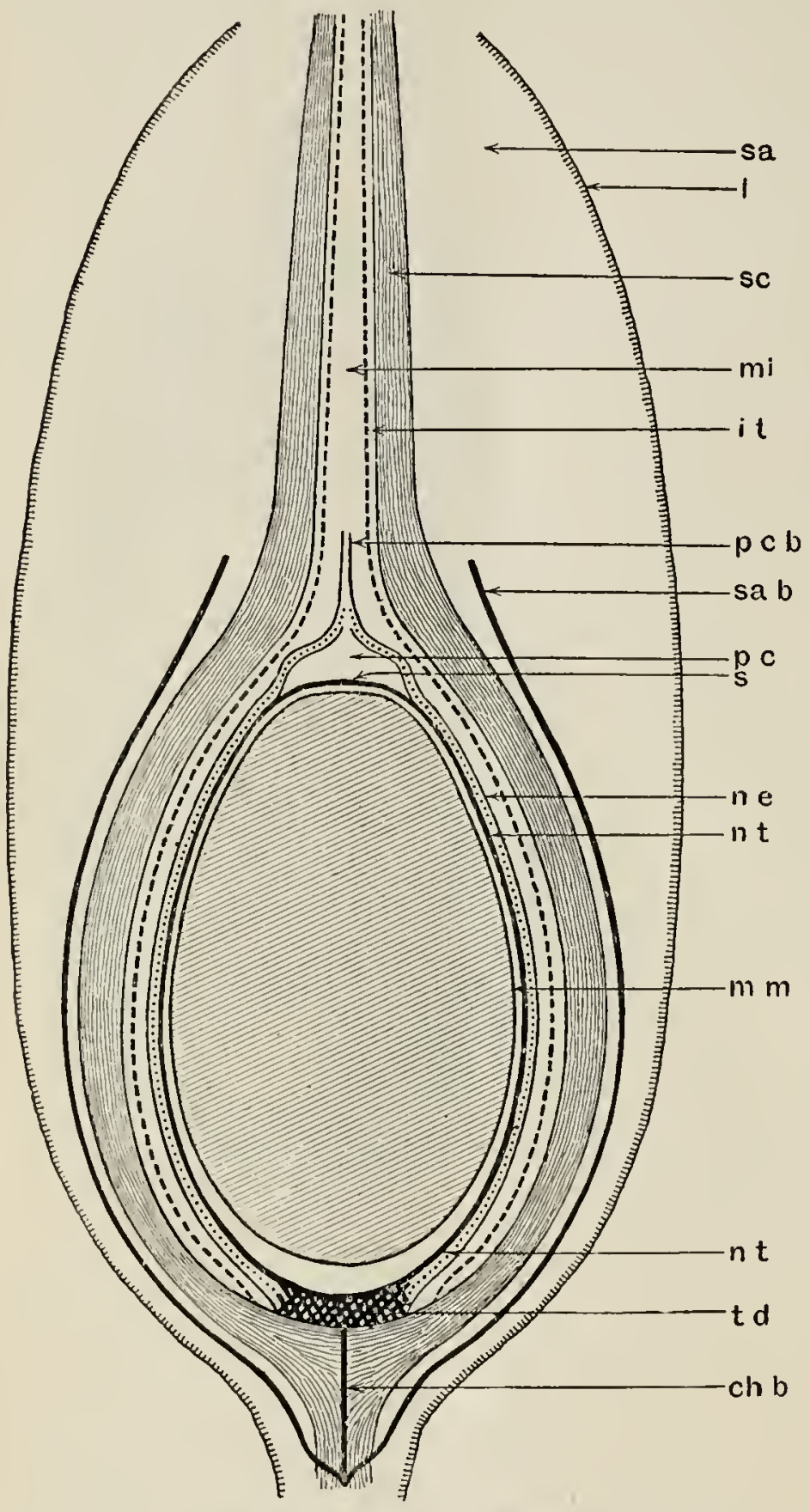

FIG. 46.-Trigonocarpum Parkinsonii: diagrammatic median longitudinal section in the plane of the "wing"; for lettering see fig. $4^{8}$. chalazal region, the free integument and nucellus are carried to the tip. This seems to have taken place in Lagenostoma, and not in Stephanospermum; but whether this latter character represents an ancient feature of orules in general or not can be determined only by a much larger knowledge of the structure of the older paleozoic sceds.

Oliver has shown. (46) also that the permocarboniferous seed genera Trigonocarpum (almost certainly to be referred to the Medullosineae among Cycadofilicales)and Polylophospermum are of the Stcphanospermum type (with broad pollen chambers, nucellar tracheal mantle, and differentiated testa), the former being a three-ridged seed, the latter a hexagonal one. Besides these variations in the form of the seed, other varia- 
tions may occur in the nucellar tracheal mantle, which maty be replaced by a rascular network or by distinct vascular strands. I ater, SCOTT and MASLEN (73) described two species of Trigonocarpum (T. Parkinsonii was probably the seed of Medullosa anglica) from the Coal-measures (figs. 46-48) which conform fully to the Stephanospermum type of structure, in these cases the three layers of the testa being distinguished, and the vascular strands occurring in two sets (an outer system in the outer fleshy layer, and an inner system traversing the periphery of the free nucellus), both distinctly cycadean characters. The inner vascular system forms a "practically continuous sheath " in the lower part of the nucellus, and is traceable through the whole

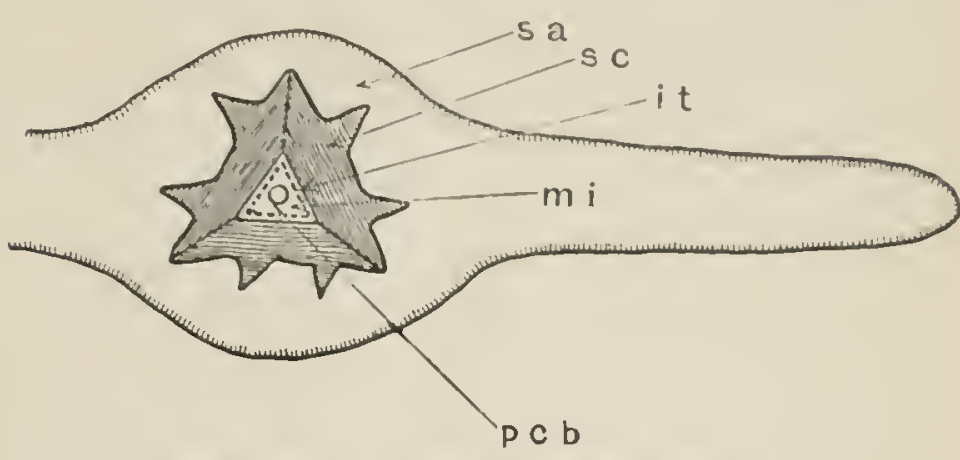

FIG. 47.-Trigonocarpum Parkinsonii: diagrammatic transverse section through the micropyle at about the level of $p c b$ in fig. 4 f; for lettering see fig. 45 .

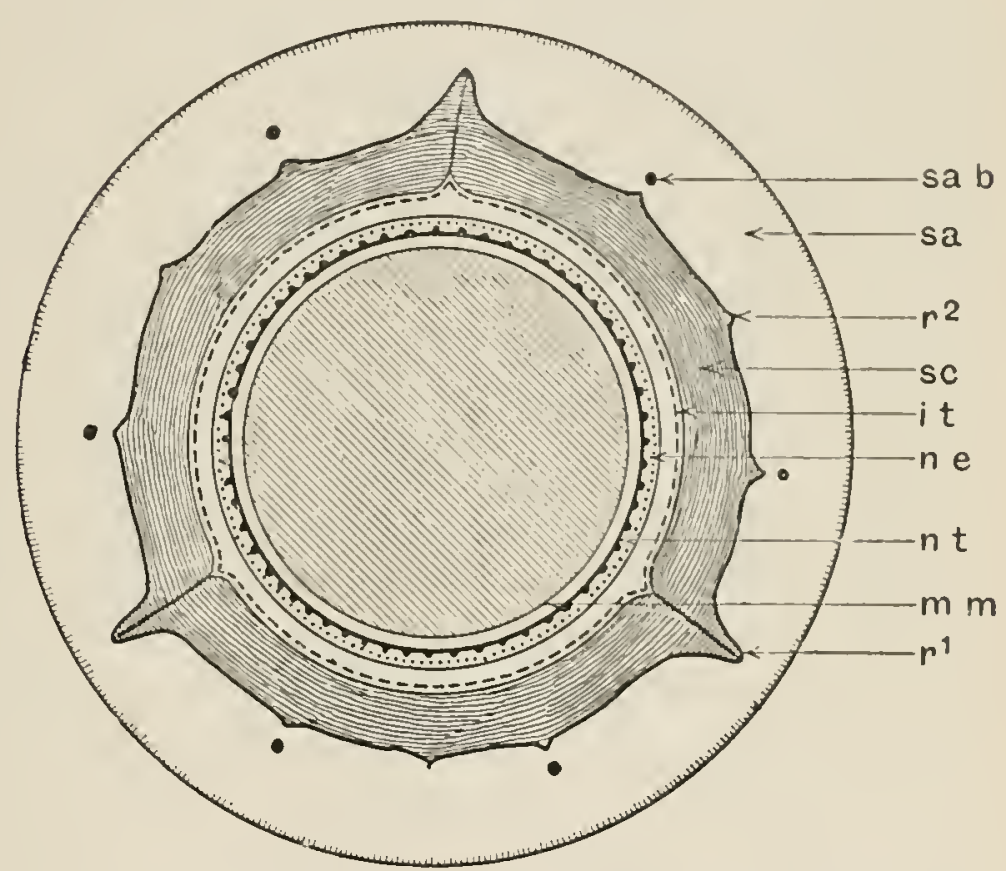

FIg. 4S. - Trigonocarpum Parkinsonii: diagrammatic transverse section at about the level of $m m$ in fig. 46 ; lettering for figs. 46- 48 : $s a$, sarcotesta; $l$, its limiting layers; $s c$, sclerotesta: mi, micropyle; il, remains of "inner flesh"; sal, sarcotestal bundles; $p c$, pollen chamber; $p c b$, its beak; $s$, septum at bottom of pollen chamber; ne, nucellar epidermis; $n$, nucellar tracheal sıstem; $m m$, megaspore membrane; $l d$, tracheal disk at chalaza: $c h b$, chalazal bundle; $r$ and $r^{2}$, principal and secondary ridges; all $\times$ about 3.-MASLFA in SCOTT $\left(S_{7}\right)$.

length of the nucellus, almost to the base of the poilen chamber. A remarkable feature of these winged seeds is the conspicuous micropylar 
beak, which is an extension of the ribbed bony layer often as long as the body of the seed (in some specimens twice as long) and bears two broad wings.

It is evident that at least two types of structure are known among paleozoic seeds, which may be called the Lagenostoma type and the Stephanospermum type, the former known to belong to the Cycadofilicales, the latter very probably including seeds that must be referred to the same group. There are certain features in common, howerer, that should be noted.

A character shared by all paleozoic seeds whose structure is known is the presence of a pollen chamber. Occurring as a circular crevice in Lagenostoma and as a broad chamber in Stephanospermum, it indicates in both the existence of swimming sperms. So far as the evidence goes, therefore, the abandonment of swimming sperms by seed plants did not begin until after the Paleozoic. It is noteworthy that the largest pollen chambers seem to have been attained by the Stephanospermum type as displayed in the Permian, a type which perhaps has no successors.

Perhaps the most puzzling fact discorered in connection with paleozoic seeds is the entire absence of any indication of an embryo. That embryos are preserved in petrifactions is evidenced by their abundant occurrence in the seeds of the mesozoic Bennettitales. OLIVER (38) has suggested that perhaps the long intraseminal period of the embryo of seed plants had not been developed in the Paleozoic; but the abundant endosperm invested by an efficient testa seems to be against this view. Accepting the absence of embryos from paleozoic seeds as a fact, it should be remembered that the proembryo of the more primitive gymnosperms is quite extensive, and that even were it preserved it would hardly be recognized as an embryo. So far as any record to the contrary has shown, all this proembryonic development may have taken place in the preserved paleozoic seeds. It seems possible, therefore, that the paleozoic seeds matured (developing testa) before fertilization, became detached after pollination, and subsequently developed a proembryo which did not invade the endosperm before germination, or invaded it in a very feeble way as compared with the extensive nvasion in modern gymnosperms. Checking the growth of the embryo, if it is related to the organization of a 
testa, may occur at any stage; and if the testa is formed before fertilization (as may have been true in paleozoic seeds), the grow th of the embryo may well have been checked at some stage of the procmbryo, in which case there would be no recognizable embryo. 'That even a well-organized testa does not check the growth of the embryo, howerer, is evidenced by the fact that eren among existing gymnosperms, as cycads, the true embryo (as distinct from an extensive proembryo) may escape from the seed as soon as it is dereloped and grow as continuously as do the embryos of pteridophytes. In such a case, however, the chance of finding preserved a recognizable embryo invested by the testa would be as exceptional as of finding any rery brief stage in the life history. It would seem, therefore, that in paleozoic seeds there was either no resting period between intraseminal and extraseminal development of the very young plant, or it occurred in the proembryonic stages. Sсотт (86) has suggested as "probable that the nursing of the embryo had not yet come to be one of the functions of the seed, and that the whole embryonic development was relegated to the germination stage."

Since belief in the absence of embryos from paleozoic seeds rests as yet upon negative evidence, it should not be forgotten that the sections of suitably preserved seeds are far too few in number to overcome the uncertainty of negative evidence or the possibility of abortive seeds. In fact, comparatively few seeds have been found attached to the shoots that bore them, and seeds that have fallen off at the immature stages suggested by all published figures of sections would be abortive seeds, so far as experience with living seed plants is concerned. Only good seeds remain on the plant, and there is no record of a section of an attached paleozoic seed. Moreover, if the seeds germinated at once, as do those of the cycads, no embryos rould be found except in attached sceds. The seeds of Bennettitales that show conspicuous embryos are all attached seeds, and it is altogether probable that such seeds of Cycadofilicales and of Cordaitales will also show embryos.

Scott (28) has described a seedlike megasporangium (Lepidocarpon) belonging to the lycopods of the Lower Coal-measures, which may well represent a primitive seed condition. These detached megasporangia had already been described as seeds, but their occur- 
rence in an undoubted strobilus of a lycopod made the relationship clear. An integument or testa, growing from the surface of the sporophyll, completely invests the megasporangium except for a slitlike micropyle. To discover an embryo in such a structure, however, would be very unlikely, for it develops continuously into the sporeling. It would seem impossible to avoid the conclusion that a prolonged period of intraseminal rest (as distinct from intraseminal growth) must have been established gradually, and therefore that it may not have been attained by paleozoic seeds in general.

In comparing the majority of known paleozoic seeds with those of angiosperms, it is evident that the latter have advanced in the reception of pollen by the micropyle, and in the nutrition of the embryc (86); but that the general structure of paleozoic seeds is much more complex, with their elaborate vascular system, pollen chamber, and of ten highly differentiated testa. It has been suggested that the seed is "an organ which required to be much more elaborate in the days of spermatozoid fertilization, now only lingering in a few archaic surrivals from the past" (86), as among cycads and in Gingko.

\section{The gametophytes}

THE FEMALE GAMETOPHYTE

The structure of the female gametophyte is largely a matter of inference. In some cases delicate, collapsed tissue has been seen in the embryo sac, but no archegonia, unless Stephanospermum (fig. 45) and RenaulT's Gnetopsis elliptica (p. 37) belong to the Cycadofilicales, of which there can be little doubt. The similarity in the general development of the gametophyte of such heterosporous pteridophytes as Selaginella and Isoetes and of cycads suggests that the endosperm of Cycadofilicales was of the same general nature in development and structure.

The embryo sac enlarges in the usual way, and is remarkable in Physostoma in growing into the nucellar core of tissue which is surrounded by the pollen chamber. In other known gymnosperms with pollen chambers this core is either destroyed, resulting in a large pollen chamber, or remains solid (as in Lagenostoma). If the extension of the embryo sac into the nucellar beak of Physostoma should become filled with permanent endosperm tissue, there would be an 
approximation to the endosperm beak ("tent pole") that occurs among the Cordaitales and in Gingko $\left(8_{5}\right)$.

In the Lagenostoma group the megaspore membrane varies from "robust" in Lagenostoma, to very delicate (only occasionally seen) in Physostoma, and indistinguishable in Conostoma (85); in Trigonocarpum it is distinct (73).

THE MALE GAMETOPHYTE

In the majority of cases the pollen chambers have contained pollen grains in more or less abundance, and these pollen grains, whenever any internal structure is evident, contain a tissuc of numerous cells. In Lagenostoma Lomaxii "multicellular pollen grains" have been observed (38); and in L. ovoides germinating grains have been found in the pollen chamber (fig. 49) associated with bodies interpreted as sperms $(78)$. These sperms are further interesting in agreeing in form and general appearance with those of living cycads and of Gingko rather than with those of ferns. In Physostoma elegans $\left(8_{5}\right)$ the same cell plexus occurs in the much smaller pollen grains (fig. $5^{\mathrm{I}}$ ), recalling that of Stephanospermum (described below); and here also certain associated subreniform bodies are interpreted as sperms. In this species a differentiation of the cells in size was observed

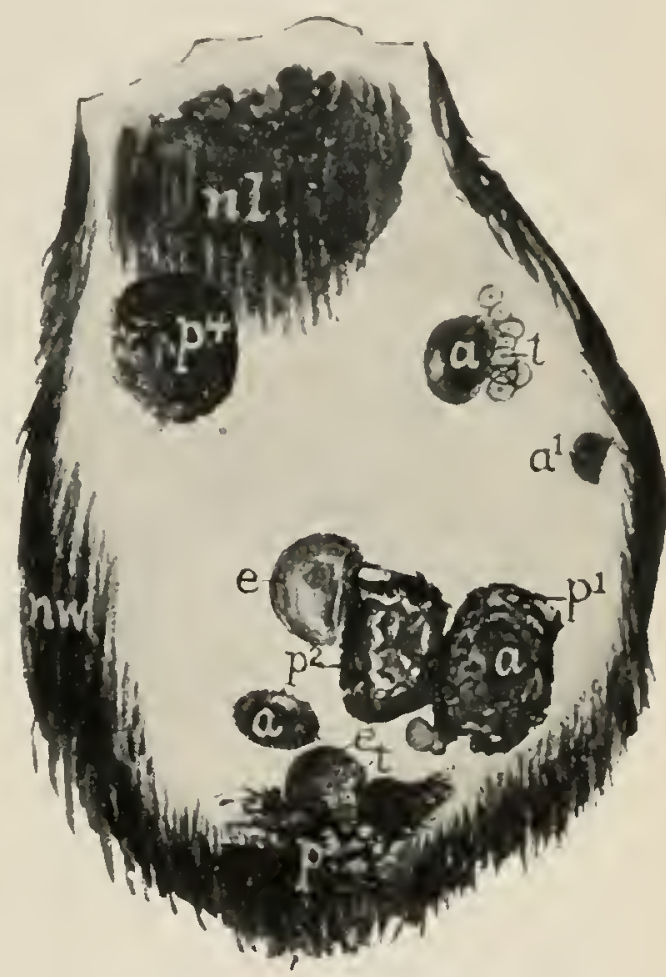

FIG. 49.--Lagenostoma oroides: pollen chamber and contents; $n l$, portion of central core of nucellus; mi, wall of nucellus; $p^{1}, p^{2}, p^{3}, p^{4}$, four pollen grains; $a$, sperm; $a^{\mathrm{I}}$, sperm cut across; $e$, protrusion of endospore; $t$, tissue probably fungal; $\times$ I55.-After Miss Bensox (7S). by Oliver, who suggests that the larger cells, at least, produced sperms, and that the smaller cells might be prothallial.

In Stephanosperum akenioides (47) numerous pollen grains are constantly found within the pollen chambers, and OLIVER succeeded 
in obtaining sections of them, showing the internal structure (fig. 50). The cavity of the grain is completely filled (allowing for shrinkage) with a tissue of about twenty cells, arranged in five rows radially disposed about a central axis. In another species of Stephanospermum the same observer (47) has described pollen grains containing only two cells in addition to the large tube cell, a structure at once suggesting that found in existing gymnosperms.

Since the pollen grains of certain undoubted Cordaitales have long been known to contain a tissue similar to that just described for the Cycadofilicales, the inference is strong that this represents a

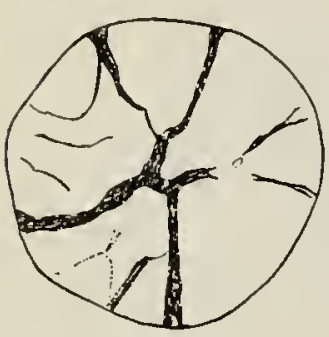

50

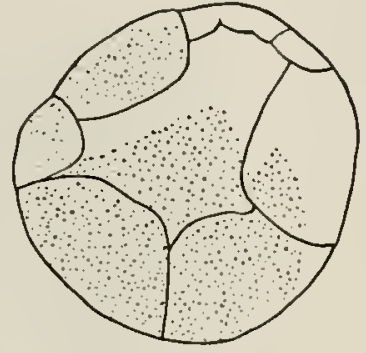

51

FIG. 50.--Stephanospermum akenioides: transverse section of pollen grain showing internal walls; $\times$ iSo.-After OLIVER (47).

FIG. 5I.-Physostoma elegans: section of pollen grain showing internal walls; the dotted area is the exospore where it has not been ground away; $X_{4} 80 .-$ After Oliver $\left(8_{5}\right)$. general condition of the male gametophyteamong paleozoic. gymnosperms. Even among existing gymnosperms there are cases of excessive prothallial tissue (as among the podocarps and araucarians) and of excessive spermatogenous tissue (as in Microcycas); so that the internal tissue of the paleozoic pollen grains may be either mainly prothallial or mainly spermatogenous; or both tissues may occur in more equal proportion. In our specimens of the pollen grains of Physostoma, the internal tissue is not restricted to one pole of the spore, as is true of all male prothallial tissue among living gymnosperms, but is just as conspicuous in the middle region of the spore. We are inclined to the belief, therefore, that most of these internal cells are spermatogenous. However this may be, the chief interest lies in the fact that the male gametophyte of the paleozoic gymnosperms is a more extensive tissue than in most living gymnosperms; and that in all probability it is not restricted to the production of two sperms. That these sperms were discharged into the cavity of the pollen chamber, after its base had broken down to the necks of the archegonia, can scarcely be questioned. There is no evidence of the development of pollen tubes as sperm carriers; and that they did 
not exist even as haustoria is evidenced by the fact that pollen grains with no tubes are found in contact with the megaspore membrane.

ScotT $(87)$ has called attention to the very interesting fact that in I 887 Renault (12), in describing the structure of Actheotesta, a seed allied to Stephanospermum, anticipated through inference the discovery of swimming sperms among gymnosperms. In both of these genera the walls of the pollen grains are perforated, and RENAULT suggested "that these perforations served for the passage of motile bodies analogous to antherozoids." He adds, "we do not regard as impossible the existence in the past of pollen grains which, instead of effecting fertilization by means of a tube, discharged into the pollen chamber of the appropriate seeds antherozoids capable of performing this function."

\section{History and distribution}

That Cycadofilicales were a dominant group during the Carboniferous, and that they were to be found in abundance wherever the regetation of the Coal-measures occurred, are facts that seem to be clearly established. It is scarcely less clear that they existed during the Devonian. Kidston (64) thinks that they are plainly represented in remains of the Upper Devonian; and there are suggestions of still greater age. This means that they can be traced to a time so remote that no other group of vascular plants, or at least fernlike plants, is known to antedate them. The type is distinctly paleozoic, for, although it culminates during the Coal-measures, no trace of it has been discovered in the Mesozoic. From their history, their structure, and their resemblance to ferns, therefore, the Cycadofilicales may be regarded as the most archaic group of spermatophytes known.

\section{Relationship to ferns}

At the first discovery of fernlike seed plants, it was natural to infer that this group must have arisen from the so-called Marattia plexus which was thought to be dominant in the Carboniferous. Subsequent discoveries of seed-bearing plants made serious inroads upon this "plexus," and finally the discovery of the fernlike microsporangiate structures of the Cycadofilicales left the whole question of paleozoic 
ferns in a very uncertain state. It seems certain, at least, that no such dominant Marattia plexus existed during the Paleozoic as has been supposed; for an overwhelming number of the "ferns" constituting it have been placed among the Cycadofilicales, either on direct or on probable evidence. The character of paleozoic ferns, therefore, has become a question bound up with the origin of Cycadofilicales.

\section{PALEOZOIC FERNS}

The present status of knowledge in reference to paleozoic ferns has been presented recently by Arber (60), Kidston. (64), and ScotT (82). For a time, the existence of paleozoic ferns was called in question. The increasing number of known and inferred Cycadofilicales from the Carboniferous, and the fact that the earlier the period the less the evidence of ferns, raised a question as to the presence of ferns in the Lower Carboniferous and Devonian. There is general consent now $(59,61,82)$ that ferns existed during the Paleozoic, but not as a dominant group and many of them not to be referred to existing groups of ferns. In fact, ScotT (82) states that the evidence is decidedly in favor of the view that a considerable group of Marattialike ferns existed during the Upper Coal-measures and Permian, side by side with Cycadofilicales of similar habit, but not known to extend to the Lower Carboniferous. When representatives of the living eusporangiate and leptosporangiate ferns are sought among paleozoic plants, they are not recognizable. There is an abundance of annulate and exannulate sporangia; and in general the former have been regarded as standing for leptosporangiate ferns, and the latter for eusporangiate ferns. But some of the exannulate sporangia have been discovered to be the microsporangia of Cycadofilicales; and the annulate sporang:a are very different, both in the character of the annulus and in the structure of the sporangium wall, from those of the modern leptosporangiate ferns. Scotr $(69,82)$ has established the sporangium genus Pteridotheca to receive the unassigned, petrified, paleozoic sporangia bearing an annulus or with other characters indicating their affinity with ferns; and he thinks that doubtless some of the species belong to true ferns. The paleozoic ferns in general, which were neither leptosporangiate nor eusporangiate ferns in the modern sense, have been called Primofilices by ARBER 
(6o), an ancestral race which combined the characters of the modern groups. In fact, the existence of leptosporangiate ferns. in the modern sense, has not been recognized until the Permian, and during the Mesozoic the group was a dominant one and its modern families became differentiated; while eridence of the existence of eusporangiate ferns, in the modern sense, is not satisfactory until the Tertiary $(60,6 \mathrm{I})$.

Paleozoic Maratiaceae (82).--The very large proportion of synangia belonging to the carboniferous flora led to the inference that the Marattiaceae were conspicuously represented. All types of sporangia, from free to united (synangia), occur on leaves referred to Pecopteris, and one Pecopteris (P. Pluckenetii) has been found to be seed-bearing. It was natural to raise the question whether all of the sporangia referred to Marattiaceae are not microsporangia. But Pecopteris is a very large frond genus, and such sporangium genera as Ptychocarpus, Asterotheca, Scolecopteris, and Dancites, which are synangia borne on the ordinary foliage, have every right to be regarded as belonging to the Marattiaceae until there is absolute proof to the contrary. Such forms are characteristic of the Permian and Upper Coal-measures, and are not known to occur in the Lower Carboniferous.

In addition to this evidence of the existence of paleozoic Marattiaceae, which may be regarded as negative, there is positive eridence from the anatomy of Psaronius, a stem genus occurring at the same horizons. The fronds borne by this stem were of the Pecopteris type (42), as shown by constant association, and are identical with those bearing such sporangia as Asterotheca and Scolecopteris. Repeated investigation of the anatomy of these stems and leares has strongly confirmed the belief that the species of Psaronius were stems of arborescent members of the Marattiaceae. Some of these permo-carboniferous trees were of great size, reaching a height of I 8 to $20 \mathrm{~m}$. The stems were complex polystelic and the roots polyarch, the whole structure more nearly resembling the vascular structure of the Marattiaceae than of any other known stems. A species (P. Renaultii) from the Lower Coal-measures is of exceptional antiquity and simplicity, being monostelic, a single endarch vascular cylinder inclosing pith. 
The general conclusion is that "ferns with marattiaceous affinities formed an important constituent of the permo-carboniferous flora, especially toward the close of that period" $\left(8_{2}\right)$.

Primofilices.-Only one family of Primofilices has been distinguished clearly, and that is the peculiar group Botryopterideae, brought to light by Scort (24), and probably extensively displayed during the Paleozoic. The structure of all the important organs of two of the genera (Zygopteris and Botryopteris) is fairly well known. The stems are monostelic; those of Botryopteris being endarch protostelic and the vascular cylinder circular in section; while those of Zygopteris are exarch protostelic and the vascular cylinder has a lobed (five-rayed) section. In the latter genus the stele is differentiated into a peripheral region of large tracheids, and a central region (once thought to be pith) of small tracheids; and there is both internal and external protoxylem. Among Botryopterideae, therefore, there is both exarch and endarch protostely (79), and these conditions vary in a single group. For example, one of the two groups of the family contains Botryopteris, which is endarch; Tubicaulis, all or nearly all of whose xylem is centripetal; and Grammatopteris, which is exarch. The exarch protostele of Tubicaulis and Grammatopteris has been regarded as the most primitive type of vascular strand found in the axis of a vascular plant $(75)$. The range of vascular structure displayed by the Botryopterideae is said $(65,75)$ to be sufficient to serve as a starting point for the modern groups of ferns and for Cycadofilicales.

The sporangia of Zygopteris and Botryopteris are elongated sacs, with walls at least two layers of cells thick, each with a short pedicel, and borne in terminal tufts $\left(3^{-8}\right)$ on a common peduncle (fig. 52 ) from a branching rachis of a dimorphic leaf ( $\mathrm{I} a$ ). In Zygopteris there is a vertical annulus band, several cells wide (multiseriate), on each side of the sporangium (figs. 53 and 54); while in Botryopteris there is such a band only on one side. That these sporangia are those of ferns is further indicated by the fact that in Stauropteris, whose affinities are probably with the Botryopterideae, germinating spores of undoubted fern character have been found ( 70 ).

The conclusion is $\left(8_{2}\right)$ that in habit, anatomy, and sporangia, the Botryopterideae show that they are ferns, which in all probability 
have given rise at least to the more modern leptosporangiate and eusporangiate ferns. It is a type older than the paleozoic Marattiaceae described above, and it is interesting to note that the sporangia were free, rather than in synangia; the conclusion having been drawn (82) that "the fossil evidence, on the whole, supports the view that free sporangia represent the original form of filicinean fructification,

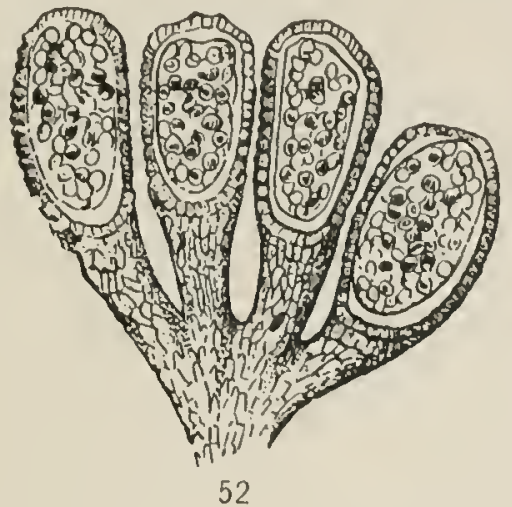

52

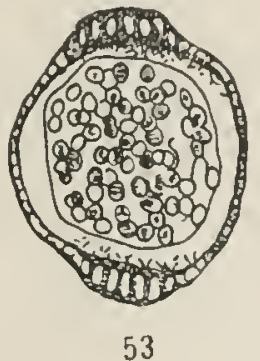

54

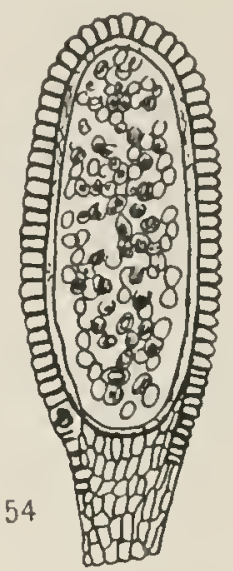

FIGs. 52-54.-Zygopleris sp.: fig. 52, four sporangia on a common pedicel; $X_{10}$; fig. 53, transverse section through the middle of a single sporangium, showing sections of the multiseriate vertical annulus; $X 20$; fig. 54 , longitudinal section of single s[orangium cul in plane of vertical annulus; $\times 20$.- After RENAUl.T ( $\mathrm{I} a$ ).

and that their cohesion to form synangia was a secondary modificition, though one which took place in certain groups at a very early period." It must be remembered that Filicales are probably so ancient that all of our evidence is relatively morlern.

Two main anatomical types of ferns, therefore, probably existed during the Paleozoic: (I) the complex-polystelic, Marattia-like tree ferns represented by the Psaronius stems, which ScotT calls the PaleoMarattiaceae; and (2) the low, much simpler, monostelic forms, represented by Botryopterideae, and constituting the very ancient synthetic group Primofilices.

\section{ORIGIN OF CYCADOFILICALES}

Just as it was tempting at first to derive the Cycadofilicales from the Marattia plexus of the Carboniferous, so it was tempting later to derive them, along with modern ferns, from the Botryopterideae (64). To search for the actual ancestral forms of the Cycadofilicales seems to be futile (50), for remains of the group have been traced 
as far back as any of the Primofilices. That the group arose from fernlike ancestors seems evident from their foliage, anatomy, and microsporangiate structures (6I). We are confronted by two alternatives: either the Cycadofilicales were derived from the Primofilices, or the two groups had a common origin far back in the Paleozoic. It would seem to make very little difference which alternative is selected, for either would explain the similarities, and neither can be proved.

Microsporangiate STRUCtURes. - The resemblance of the microsporangiate structures of all the cycadophytes (see below) to the sori and synangia of ferns is so evident that further statement seems hardly necessary. Kinston $(64)$ has called attention to the resemblance between the sorus known as Dactylotheca and the microsporangiate sorus known as Crossotheca. There is the same relation to the pinnules, the same radiate arrangement of the sporangia; and if the sporangia of Dactylotheca were extended beyond the margin of the pinnule into a free tip which bent downward, the Crossotheca type would be reached. Of course, Dactylotheca may prove to belong to the Cycadofilicales, but it represents a soral structure that belongs to undoubted ferns. The terminal sporangial tufts of Botryopteris and of Zygopteris are easily related to the Calymmatotheca type of terminal synangium; while ordinary synangia borne upon the comparatively unmodified foliage leares of Cycadofilicales (and even Bennettitales) are exact duplicates of the synangia of Paleo-Marattiaceae and modern Marattiaceae. In microsporangiate structures, therefore, the Cycadofilicales, and even the cycadophytes, can hardly be regarded as above the level of ferns.

MEgasporangiate structures. - While the vascular anatomy and microsporangiate structures of the Cycadofilicales may be shown to be so closely related to the corresponding structures of the Primofilices and Marattiaceae that a phylogenetic connection seems clear, no such claim can be made for the seeds. As Scotr has said $\left(6_{7}\right)$, "the discovery of seeds [of Cycadofilicales] hardly touches the problem of the origin of gymnosperms, for the discorered seeds are well developed, on the cycad level; therefore they are too much advanced to throw light on the origin of a seed, and the question of the origin of gymnosperms remains practically as it was before the discovery 
of pteridosperms." 'Theoretically, there remains a stage of progress entirely lacking in our records, and that is the heterosporous fernlike forms that preceded the evolution of sceds. 'The gap between the homosporous Primofilices (or their unknown ancestors) and the seedbearing Cycadofilicales is an enormous one, including the evolution of both heterospory and the seed.

Proceeding on purely hypothetical grounds, the most natural inference is that homosporous sporangia began to differentiate into the heterosporous condition; that the microsporangia continued with relatively little change throughout the cycadophyte phylum; and that the megasporangia developed with comparative rapidity into orules. Miss Bensor (4I) has suggested that the orule is a transformed sorus, explaining the peculiar integument of Lagenostoma by regarding the tissue-filled chambers as the sterilized peripheral sporangia of a radiate sorus or synangium. OLIVER (85) infers from the free integument lobes of Physostoma that the integument of the Lagenostoma group originated as a multiple structure, the nature of the units (free lobes in Physostoma, coalescent chambers in Lagenostoma) being an open question. His suggestion is that they have arisen as new formations, without any phylogenetic connection, being related to the encasement of reproductive structures that so frequently precedes or follows fertilization. This view would mean that the origin of the integument was contemporaneous with the origin of the seed itself; and that the cupule (as in Lagenostoma) is a second such encasement. However true either of these suggestions may be with reference to Lagenostoma, the relation of the seeds to the fronds and a comparison of the position of seeds with that of microsporangiate sori compel the belief that orules often may have arisen by the transformation of sori, a transformation probably introduced by restricting a sorus to a single sporangium. If, as seems possible, a sorus of free sporangia is a more primitive condition of ferns than a synangium. it may be that free sporangia not grouped in a sorus represent a still more primitive condition, and that neither synangium nor sorus holds any relation to the origin of the ov'ule. After all, the important and obvious fact is that an orule is a transformed sporangium, and that the phylogenetic stages in this transformation are absolutely lacking. 


\section{Relationship to other gymnosperms}

When Oliver and ScotT $(39,48)$ proposed the name Pteridospermae, "to embrace those paleozoic plants with the habit and much of the internal organization of ferns, which were reproduced by means of seeds," it was with the claim, implied in the name, that it represented a third great group of seed plants, coordinate with gymnosperms and angiosperms. Fuller knowledge and a stricter definition of the group was awaited with interest. Later, ScotT $\left(5^{8}\right)$ said that a strict definition was not possible as yet, but that the following provisional one was suggested: "Plants with the habit and certain of the anatomical characters of ferns, bearing on fronds only slightly differentiated from the regetative foliage seeds of a cycadean type of structure:" There seemed to be no sufficient reason for establishing a group coordinate with gymnosperms upon such comparative features; for it certainly possessed the important character of gymnospermy. Still later, ScotT (69) formulated his reasons for regarding pteridosperms as worthy of separation from gymnosperms, under two categories: (I) megasporophylls and microsporophylis little modified from ordinary vegetative fronds; (2) anatomical structure more fernlike than in gymnosperms. The cycadophytes as a whole have equally fernlike foliage and sporophylls, and the anatomical peculiarities can nearly all be duplicated among the more primitive gymnosperms. The group is then defined as follow's: "Male and female sporophylls little differentiated from the vegetative foliage; no cones formed; anatomy of either stem, or leaf, or both, of a filicinean type, as was also the habit." It is hard to see that such characters are more impo-tant than those which distinguish the acknowledged groups of gymnosperms, and of equal importance with those that distinguish gymnosperms from angiosperms. We are compelled to regard pteridosperms as the most primitive known group of gymnosperms, and our reasons for calling them Cycadofilicales have been given above (p. 3).

There is no more suggestion of the organization of a strobilus, and no more extreme differentiation of a sporophyll, than among ferns; so that in these respects the group has remained at the fern level. Among living cycadophytes, the megasporophylls of cycads do not always form a compact strobilus, and every gradation is found 
from loosely arranged sporophylls that have retained features of the foliage, to the very compactly arranged and much modified sporophylls of such a strobilus as that of Zamia. It is this tendency among the cycads that may be added to the burden of testimony indicating the origin of all cycads from a group in which no strobili were organized and no sporophylls differentiated.

It may be said that in microsporangiate structures the Cycadofilicales made very little progress; but these are also fernlike in both Bennettitales and Cycadales. In megasporangiate structures, the Cycadofilicales are far advanced, for the seeds are distinctly of the so-called cycadean type, and so far removed from the fern level that we seem to be no nearer the origin of seeds than before the discovery of the group.

The relationship of Cycadofilicales to Bennettitales and Cycadales seems so erident, the historical sequence being as definite as the morphological, that Nathorst and Worsdell (72) have adopted the name Cycadophyta for the phylum including these three groups. It would seem as if this gymnosperm phylum, extending from carly Paleozoic to the present time, is thoroughly well established.

The relationship of Cycadofilicales to the other gymnosperm groups is by no means so clear, but their intimate association with the Cordaitales, as well as the morphological resemblances of the two groups, suggests that Cordaitales may be the beginning of another gymnosperm phylum which diverged from Cycadofilicales much earlier than did the cycad phylum. The presentation of this testimony will be given under Cordaitales.

In any event, there seem to have been two great phyla of gymnosperms, both differentiating from the Cycadofilicales, or each arising independently from the progenitors of the Cycadofilicales. One of these phyla has already been called the Cycadophytes, and includes the Cycadofilicales, Bennettitales, and Cycadales; the other. which arose either from the more ancient Cycadofilicales or their immediate ancestors, and includes Cordaitales, Ginkgoales, and Coniferales, may be called the Coniferophytes. The reasons for excluding Gnetales from these connections will appear in the discussion of that group; but as between the two phyla proposed, the Gnetales would certainly be related to the second. 


\section{LITERATURE CITED}

I. Williamson, $\mathbf{W}$. C., On the organization of the fossil plants of the Coalmeasures. IV. Dictyoxylon, Lyginodendron, and Heterangium. Phil. Trans. Roy. Soc. London B I63:377-408. pls. 22-3I. I873.

I $a$. Renault, B., Recherches sur la fructification de quelques régétaux provenant des gisements silicifiés d'Autun et de Saint Etienne. Ann. Sci. Nat. Bot. VI. 3:5-29. pls. I-4. I876.

2. Williamson, W. C., On some fossil seeds from the Lower Carboniferous beds of Lancashire. Rep. 45th Meeting British Assoc. (I875): 159-160. I 876 .

3. spermous stems and seeds. Ann. Mag. Nat. Hist. 18:268-273. I876 (preliminary notice); Proc. Roy. Soc. London 25:68-73. I877 (abstract); Phil. Trans. Roy. Soc. London B I67:2I3-270. pls. 5-16. I878 (full paper).

4. - On the organization, etc. X. Phil. Trans. Roy. Soc. London B I 7 I : 493-539. pls. I4-21. I880.

5. - , On the organization, etc. XIII. Phil. Trans. Roy. Soc. London B I78:289-304. pls. 2I-24. I887 (p. 299).

6. Brongniart, A., Recherches sur les graines fossiles silicifiés. Paris. i88 I.

7. Stur, D., Zur Morphologie und Systematik der Kulm- und Karbonfarne. Sitzungsb. Akad. Wiss. Wien 88: pp. 2 I4. figs. 4. I883.

8. Williamson, W. C., On the organization, etc. XII. Phil. Trans. Roy. Soc. London B I 74:459-475. pls. 27-34. I 883 .

9. Renault, B., Cours de botanique fossile. Paris. I880-I884.

io. Van Tieghem, Ph., et Douliot, H., Sur la polystelie. Ann. Sci. Nat. Bot. VII. 3:275-322. pls. I3, I4. I 886 .

II. Kinston, R., On the fructifications of some ferns from the Carboniferous formation. Trans. Roy. Soc. Edinburgh $33^{1}: 137^{-156}$. pls. S. figs. 7. r887.

12. Renault, B., Note sur le genre Aetheotesta. Mém. Soc. Hist. Nat. Saôneet-Loire, pp. I56, I58. I 887 .

I3. Sablon, Leclerc du, Recherches sur la tige des fougères. Ann. Sci. Nat. Bot. VII. I I : I-I6. pls. I, 2. I 890 .

I4. Williamson, W. C., On the organization, etc. XVII. Phil. Trans. Roy. Soc. London B I 8I:89-106. pls. I2-15. I890.

I5. Kinston, R., On the various divisions of British Carboniferous rocks, as determined by their fossil floras. Proc. Roy. Soc. Edinburgh I $2: 183^{-257}$. I893-IS94.

I6. Renault, B., Bassin houiller et Permien d'Autun et d'Épinac. IV. Flore fossile. Part II. pp. 578. pls. 62. Paris. I896.

7. Weber, O., und Sterzel, J. T., Beiträge zur Kenntnis der Medulloseae. XIII. Ber. Naturwiss. Gesell. Chemnitz. pp. I02. pls. 9. figs. 33. I 896.

I8. Williamson, W. C., and Scott, D. H., Further observations on the organization of the fossil plants from the Coal-measures. III. Lyginodendron and 
Heterangium. Phil. Trans. Roy. Soc. London 13 I86:703-779. pls, I\&-2I. I 896 .

I9. BUTTERWORT1, J., Some further investigation of fossil seeds of the genus Lagenostoma (WhLauson) from the Lower Coal-measures. Iem. and Proc. Manchester lit. and Phil. Soc, 4 I : I-4. I897.

20. Potonjé, H., Lehrbuch der Pflanzenpalacontologie. Berlin. I899.

21. Seward, A. C., Notes on the Binney collection of Coal-measure plants. II. Megaloxylon, gen. nov. I'roc. Cambridge Phil. Soc. 10:158-174. pls. 5-7. I899.

22. Sсотт, D. H., On the structure and affinities of fossil plants from the paleozoic rocks. III. Medullosu anglica, a new representative of the Cycarlofilices. Proc. Roy. Soc. London 64:249-253. 1899 (abstract); Phil. Trans. Roy. Soc. London B I9I:8I-126. pls. 5-I3. IS99 (full pajer).

23. - Note on the occurrence of a seedlike fructification in certain paleozoic lycopods. Proc. Roy. Soc. London 67:306-309. I900.

24. - Studies in fossil botany. London. 1900.

25. Wild, G., On Trigonocarpum olizacforme. Trans. Manchester Geol. Soc. 26: pp. 16. pls. 2. I900.

26. Ze.iller, R., Éléments de palacobotanique. 1900.

27. Faull, J. H., The anatomy of the Osmundaceae. Bot. Gazette $32:{ }_{3} S_{1}-420$. pls. If -17 . I901.

28. Scotr, D. H., On the structure and affinities of fossil plants from the paleozoic rocks. IV. The seedlike fructification of Lepidocarpon, a genus of lycopodiaceous cones from the Carboniferous formation. Phil. Trans. Roy. Soc. London B I94:291-333. pls. 38-43. I901.

29. Benson, Margaret, On a new lycopodiaceous seedlike organ. New Phytologist I: 58 , 59. fig. 3. 1902.

30. - The fructification of Lyginodendron Oldhamium. Annals of Botany I6:575, 576. figs. 3I. I902.

3I. Jeffrey, E. C., The structure and development of the stem in the Pteridophyta and Gymnosperms. Phil. Trans. Roy. Soc. London B I95: I I9-I 46. pls. $I-6.1902$.

32. Lomax, J., Some new features in relation to Lyginodendron Oldhaminm. Annals of Botany 16:601, 602. 1902.

33. Nathorst, A. G., Beiträge zur Kenntnis einiger mesozoischen Cycadophyten. Handl. Kgl. Svensk. Vetensk.-Akad. 36: I-2S. pls. I-3. 1902.

34. Olfver, F. IT., On some points of apparent resemblance in certain fossil and recent gymnospermous seeds. New Phytologist I: I45-15t. figs. f $^{-6}$. 1902.

35. Potonié, H., Cycadofilices in Engler und Prantl's Natürlichen Pflanzenfamilien $I^{\mathrm{I}}: 780-798$. I902.

36. Worsdell, W. C., The evolution of the rascular tissue of plants. Bot. Gazette 34:216-223. figs. 7. 1902. 
37. Jeffrey, E. C., Vascular anatomy in Covlter and Chamberlain's Morphology of angiosperms. New York. I903.

38. Oliver, F. W., The ovules of the older gymnosperms. Annals of Botany I 7: 45I-476. pl. 24. figs. 20. I903.

39. - - a a - ScotT, D. H., On Lagenostoma Lomaxii, the seed of Lyginodendron. Proc. Roy. Soc. London 71:477-481. 1903; reprint in Annals of Botany I 7:625-629. I903.

40. Sellards, E. H., Codonotheca, a new type of spore-bearing organ from the Coal-measures. Amer. Jour. Sci. IV. I6:87-95. pl. 8. I903.

4I. Benson, Margaret, Telangium Scottii, a new species of Telangium (Calymmatotheca) showing structure. Annals of Botany I8: I6I-I77. pl. II. I904.

42. Grand 'Eury, C., Sur les rhizomes et les racines des fougères fossiles et des Cycadofilices. Compt. Rend. Acad. Sci. Paris I 38:607-610. I904. .

43. - Sur les graines des Neuropteridées. Compt. Rend. Acad. Sci. Paris I 39: $23^{-27}, 782-786$. I904.

44. Kinston, R., On the fructification of Neuropteris heterophylla Brongniart. Proc. Roy. Soc. London 72:487. I904 (abstract); Phil. Trans. Roy. Soc. London B I97:I-5. pl. I. I904 (full paper).

45. Oliver, F. W., A new pteridosperm. New Phytologist 3:32. Igo4.

46. - Notes on Trigonocarpum Brongn. and Polylophospermum Brongn., two genera of paleozoic seeds. New Phytologist 3:96-104. pl. 2. I904.

47. - On the structure and affinities of Stephanospermum Brongniart, a genus of fossil gymnosperm seeds. Trans. Linn. Soc. London Bot. II. 6:36I-400. pls. 4I-44. I904.

48. — - - and Scotт, D. H., On the structure of the paleozoic seed Lagenostoma Lomaxii, with a statement of the evidence upon which it is referred to Lyginodendron. Proc. Roy. Soc. London, Jan. 2 I, I904 (abstract preprint); Phil. Trans. Roy. Soc. London B I97: I93-247. pls. 4-10. I904 (full paper).

49. White, David, The seeds of Aneimites. Smithson. Miscell. Coll. 47:32233т. pls. $47,48.1904$.

50. $\longrightarrow$, Fossil plants of the group Cycadofilices. Smithson. Miscell. Coll. 47:377-390. pls. 53-55. I904.

5I. Arber, E. A. Newell, On some new species of Lagenostoma, a type of pteridospermous seed from the Coal-measures. Annals of Botany I9:326328. igo5 (abstract).

52. Grand 'Eury, C., Sur les graines trouvées attachées au Pecopteris Pluckenetii Schlot. Compt. Rend. Acad. Sci. Paris 140:920 923. figs. 2. 1905.

53. — Sur les graines de Sphenopteris, sur l'attribution des Codonospermum, et sur l'extrême variété des graines des fougères. Compt. Rend. Acad. Sci. Paris I4I : 8 I $2-8$ I5. I905.

54. Kinston, R., Preliminary note on the occurrence of microsporangia in organic connection with the foliage of Lyginodendron. Proc. Roy. Soc. London $76: 35^{8-360 . ~ p l .6 . ~} 1905$. 
55. Kunston R., The early history of seed-bearing plants as recorded in the carboniferous flora. Wilde Lecture. Mem. and P'roc. Manchester Lit. and Phil. Soc. 49:no. 12. pp. 32. pls. 3. 1905.

554. Otrver, F. W., Ueber die neuenteckten Samen der Steintohlenfarne. Biol. Centralbl. 25:40I-418. figs. 6. I905.

56. Scort, D. H., What were the carboniferous ferns? Jour. Roy. Micr. Soc. I $905^{2}: 137-149$. pls. I-3. figs. 32, 33.

57. - The sporangia of Stauropteris Oldhamia Binney. New Phytologist 4:114-120. figs. 2. 1905 .

58. - The fernlike seed plants of the carboniferous flora. Sci. papers Internat. Bot. Congress Vienna. I905.

59. Zeiller, R., Une nouvelle classe de Gymnospermes: les Pteridospermées. Rev. Gén. Sci. 16:718-727. figs. 7. 1905.

6o. Arber, E. A. Neweld, On the past history of ferns. Annals of Botany $20: 2$ I $5^{-232 .} 1906$.

6r. - - "The origin of gymnosperms"; a discussion at the Linnean Society. New Phytologist 5:68-76, I4I-I48. I 906.

62. Grand 'Eury, C., Sur les inflorescences des fougères avec graines, etc. Compt. Rend. Acad. Sci. Paris I43:764. I go6.

63. Hill, T. G., On secondary thickening in recent Pteridophyta. New Phytologist 5:208-2 I 4. 1906.

64. Kinston, R., On the microsporangia of the Pteridospermae, with remarks on their relationships to existing groups. Phil. Trans. Roy. Soc. London B I 98: 4 I 3-445. pls. 25-2S. I go6.

65. Oliver, F. IV., "The origin of gymnosperms"; a discussion at the Linnean Society. New Phytologist 5:68-76, I4I-I48. 1906.

66. - Pteridosperms and angiosperms. New Phytologist 5:232-242 I906.

67. Sсотт, D. H., "The origin of gymnosperms"; a discussion at the Linnean Society. New Phytologist 5:68-76, 141-148. 1906.

68. - On Sutcliffia insignis, a new type of Medulloseae from the Lower Coal-measures. Trans. Linn. Soc. London II. 7:45-68. pl. 4. 1906.

69. - The present position of paleozoic botany. Progressus rei botanicae (J. P. LotsY) I ${ }^{\mathrm{I}}$ I39-2I7. figs. 37. I906.

70. - The occurrence of germinating spores in Stauropteris Oldhamia. New Phytologist 5: 170-172. igo6.

7I. Stopes, M. C., A new ferm from the Coal-measures: Tubicaulis Sutdifii, spec. nov. Mem. and Proc. Manchester Lit. and Phil. Soc. 50: 1-30. pls. I-3. 1906.

72. Worsdell, W. C., The structure and origin of the Cycadaceae. Amals of Botany 20:129-159. figs. 17. 1906.

73. Scott, D. H., and Maslen, Arthur J., The structure of the paleozoic seeds Trigonocarpus Parkinsonii Brongniart and Trigonocarpus Oliveri, sp. nov. I. Annals of Botany 21:89-134. pls. II-I4. I907. 
74. Sellards, E. H., Notes on the spore-bearing organ Codonotheca and its relationship with the Cycadofilices. New Phytologist 6: I75-I78. I907.

75. TAnsley, A. G., Lectures on the evolution of the filicinean vascular system. II. The Botryopterideae. New Phytologist 6:53-68. figs. 22. 1907.

76. Thomas, Ether N., A theory of the double leaf trace founded on seedling structure. New Phytologist 6:77-9I. figs. 4. 1907.

77. Arber, E. A. Newell, On a new pteridosperm possessing the Sphenopteris type of foliage. Annals of Botany $22: 57-62$. pl. 6. I908.

78. Benson, Margaret, On the contents of the pollen chamber of a specimen of Lagenostoma ovoides. Bot. Gazette 45:409-412. figs. 2. I 908 .

79. Browne, Lady ISABer, The phylogeny and interrelationships of the Pteridophyta. V. Filicales. New Phytologist 7:230-253. Igo8.

8o. Jefreey, E. C., Are there foliar gaps in the Lycopsida? Bot. Gazette 46:24I-258. pls. 17 , I8. I908.

81. Nathorst, A. G., Palaeobotanische Mitteilungen. IV. Ueber die Untersuchung kutinisierter fossiler Pflanzenteile. Handl. Kgl. Svensk. Vetensk.Akad. 43:I-I3. pls. I, 2. Igo8.

82. Scott, D. H., Studies in fossil botany. Second edition. Vol. I. London. I 908 .

83. Benson, Margaret, Report of Proc. Roy. Soc. London in Nature 80:239. I909.

84. Coulter, John M., Evolutionary tendencies among gymnosperms. Bot. Gazette 48:8I-97. I909.

85. Oliver, F. W., On Physostoma elegans Williamson, an archaic type of seed from the paleozoic rocks. Annals of Botany 23:73-1 I6. pls. 5-7. figs. Io. Ig09.

86. Scotr, D. H., The paleontological record. II. Plants. Darwin and moderr science, pp. 200-222. Cambridge University Press. I909.

87. — Studies in fossil botany. Second edition. Vol. II. London. I909.

88. Coulter, J. M., Barnes, C. R., and Cowles, H. C., A textbook of botany. New York. I9io. 


\section{CHAPTER II}

\section{BENNETTITALISS}

Bennettitales are as characteristic of the mesozoic flora, from the Trias to the Lower Cretaceous, as are the Cycadofilicales of the paleozoic. The historical and morphological succession is so distinct that there seems to be no reasonable doubt of the phylogenetic connection of the two groups. The Mesozoic has long been called "the age of cycads," but it was recognized that the mesozoic forms differ so much from the modern ones as to justify speaking of them as "anomalous" or "aberrant" cycads. The type genus, Bennettites, was described by CARruthers (2) in I 867 , and in I 870 he established (4) the group Bennettiteae as an assemblage of aberrant Cycadales.

The best known foreign localities for the remains of Bennettitales are in Western Europe and India; but by far the richest display of these forms has been found in the United States and Mexico. These North American forms have been described chiefly by ITARD (II, I2), and their structure has been skilfully investigated and set forth in great detail by Wieland (22). The three prominent American localities that have yielded material are in Maryland, in the Black Hills of South Dakota and Wyoming, and in the Freezeout Hills of Wyoming; while the recently discovered Mexican locality is in the mountains of western Oaxaca (30). The remarkable Mexican deposits were discovered by WIELAND (30) in I909, and they bid fair to surpass in abundance of remains and in interest even those of the United States. The region is a great plateau of Oaxaca on the southern edge of the Cordilleras facing the Pacific, and known locally as "Mixteca Alta." A section through 2,000 feet of "Rhät-Liassic" is full of the remains of cycadophytes, and among them there is a profusion of the strobili of Williamsonia, a most interesting addition to the cycadophyte flora of America. Unfortunately, silicified remains have not yet been found.

The best known and largest genera of the group are Bennettites, Cycadeoidea, and Cycadella; other genera (not American) are Bucklandia, Williamsonia (also Mexican), Cycadocephalus, Iatesia, 
Ptolophyllum (from India), etc. There is more or less confusion as to generic limitations, and the names cited are not applied uniformly by all writers. For example, the Cycadeoidea Buckland of American authors is a synonym of Bennettites Carruthers of European authors, but it is convenient to use the two names at present to distinguish American and European material of the genus. To the morphologist the group is a very consistent one, and at this stage of knowledge the differences among genera and their nomenclature are of minor importance.

\section{The vegetative organs}

The habit of Bennettitales was much more diversified than that of existing Cycadales. The tuberous type of trunk (fig. 55) prevails among the known forms, and short columnar trunks also occur, both of which types of body are familiar among cycads; but there are also tall and slender forms, as Williamsonia gigas (fig. 56); and branching forms occur, commonly resulting in multiple crowns (as in Dioon and Zamia), and in the case of Williamsonia angustifolia (Anomszamites, I7), a form which flourished in the early Triassic of southern Sweden, and probably represented in Mexico (30), the body was slender and widely branching (fig. 57). The recently described (3I) Wielandiclla, from the Jurassic beds of England, is also slender and widely branching. The largest specimens are from the Black Hills region, huge tuberous bodies of Cycadeoidea occurring over a meter in height and more than half that in diameter; while the species of Cycadella from the Freezeout Hills are said to average only $35 \mathrm{~cm}$. in height and $20 \mathrm{~cm}$. in diameter. The columnar trunks from the United States are over a meter in height, and in the case of Cycadeoidea Jemneyana such trunks reach a height of three to four meters.

The compact forms are covered by an armor of closely imbricated persistent leaf bases, and a crown of cycad-like leaves. Among these leaf bases numerous short, axillary branches are wedged, each bearing a terminal strobilus that projects more or less beyond the armor (fig. 55). These numerous axillary, cone-bearing dwarf shoots, borne on a monopodial trunk, are in sharp contrast with the habit of Cycadales, whose sympodial trunks bear a succession of terminal 
strobili. A possible relation between the two is evident when it is remembered that in reality the apparently terminal strobili of Cycadales are borne on a succession of branches which build up the sympodial trunk. If the cone-bearing branches of Bennettitales were restricted more and more to the tip of the axis, the cycad condition

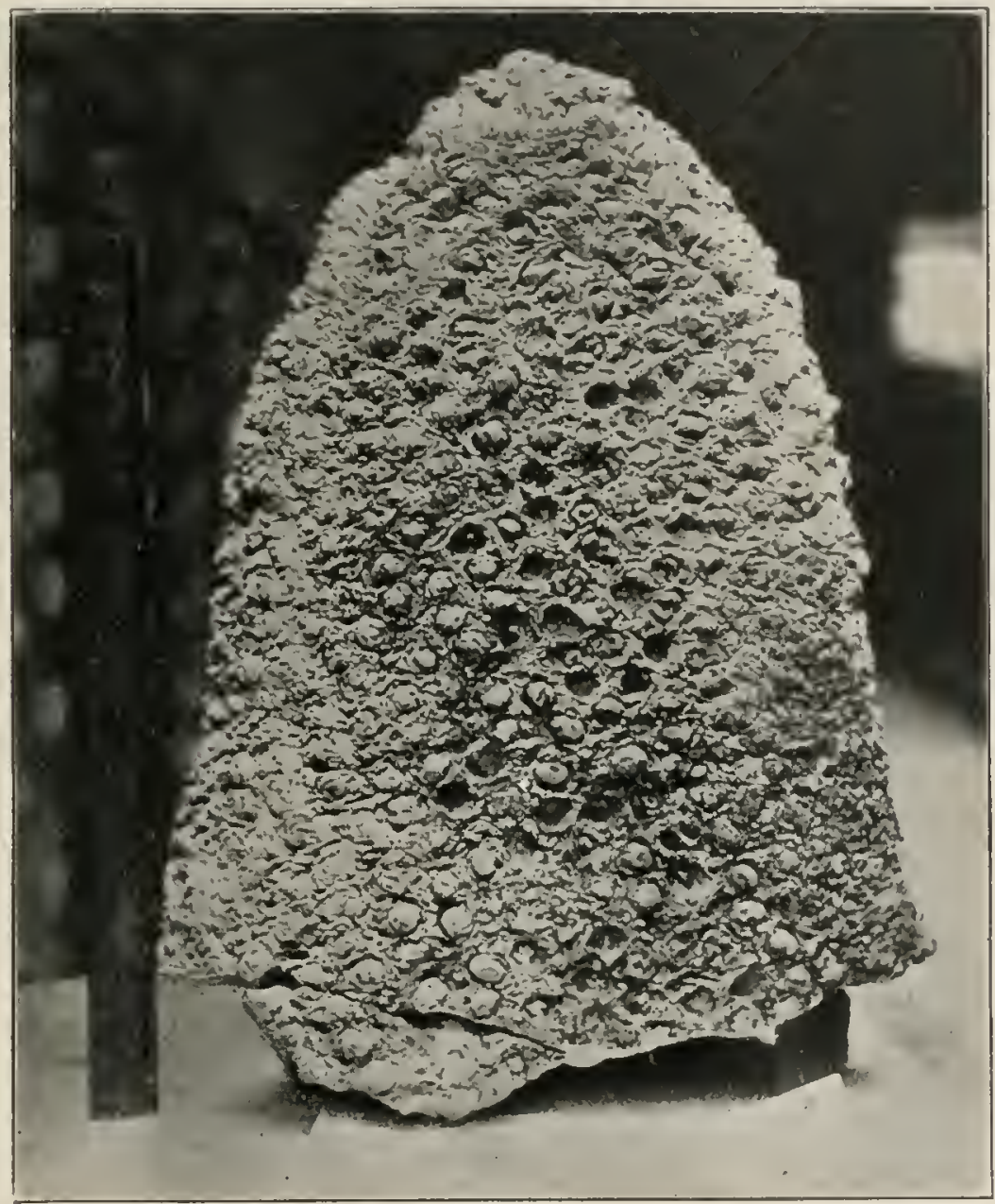

FIG. 55.-Cycadeoidea Wiclandii: upper part of a large trunk found near Hermosa, South Dakota; numerous strobili project more or less through the armor; the dark circular holes are cavities from which strobili have fallen; height of specimen, $5+\mathrm{cm}$. From photograph by Thiessen.

might follow. In fact, there are cases which may be interpreted as showing this tendency among the Bennettitales, and occasionally cycads develop lateral groups of strobili, as in Encephalartos (p. I 2 I).

The restoration of Williamsonia gigas (4), from the Lower Oolite of the Yorkshire coast, long known as Zamia gigas ( 1,3$)$, shows (fig. 56) a slender columnar shaft bearing a crown of large leaves, the 
whole habit suggesting that of one of the taller species of Cycas. The stem was covered with rhomboidal scars, and the strobili were borne on long $(20-30 \mathrm{~cm}$.) stalks covered with spirally arranged scale

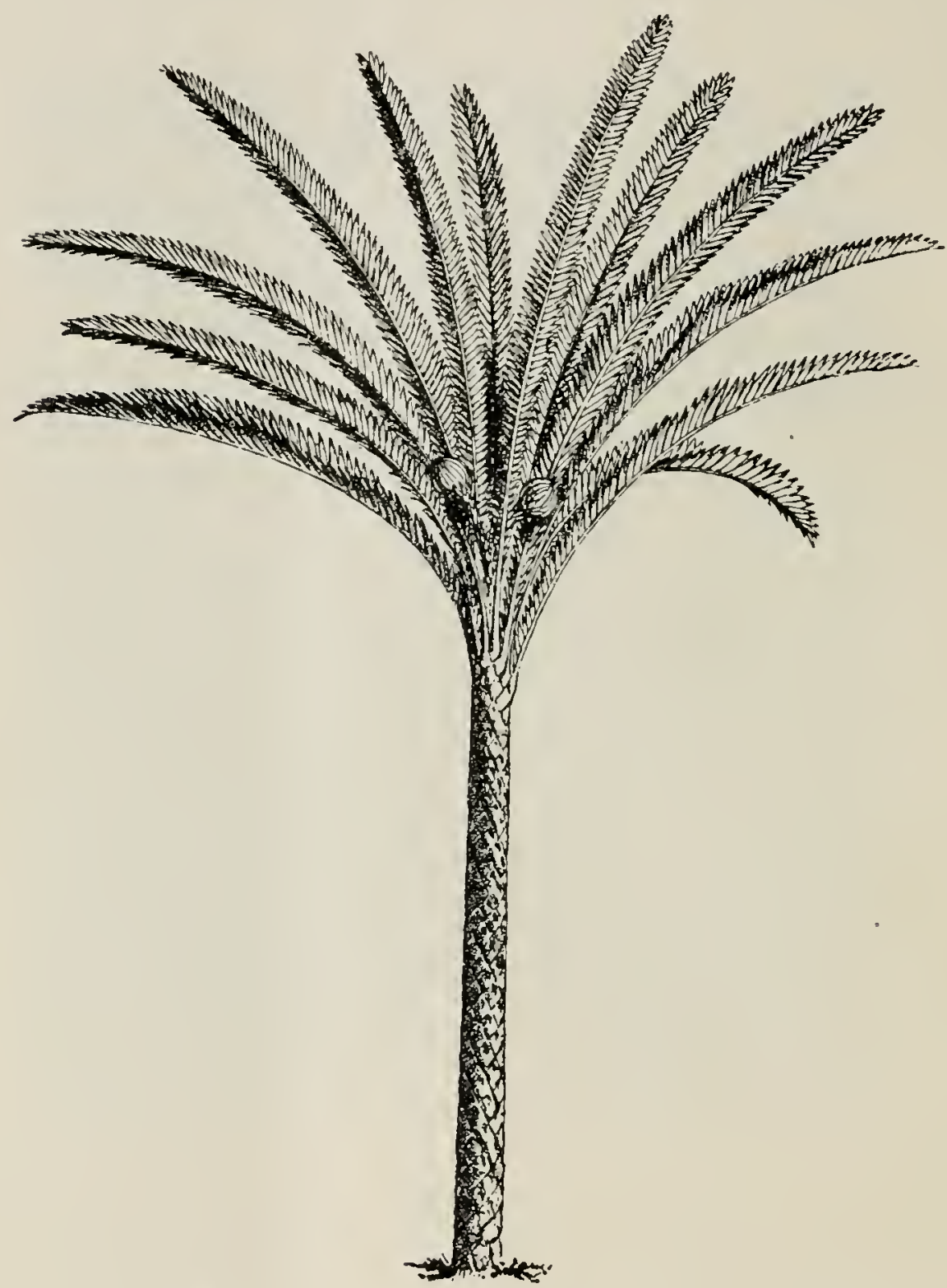

FIG. 56. -Williamsonia gigas: restoration showing stem with leaf scars, crown of leaves, and two spherical and peduncled strobili.-After WILliamson (3).

leaves, and arising within the crown of leaves. This species of Williamsonia differs from the other Bennettitales chiefly in these long peduncles. In Williamsonia angustifolia (fig. 57), whose leaves have been called Anomozamites minor, the small strobili occur singly in 
forks of the widely spreading branches (also in Wielandiella), cvidently being terminal structures, and the narrow pinnate leaves, only $7^{-S \mathrm{~cm}}$. long, form rosettes about the forks. In general habit, therefore, the Bennettitales show a range that may well connect the more open, branching forms of the Cycadofilicales with the very compact and usually simple body of the Cycadales. It has been suggested (29) that Bennettites (Cycadeoidea) and Williamsoniu may be regarded as representatives of two groups of Bennettitales.

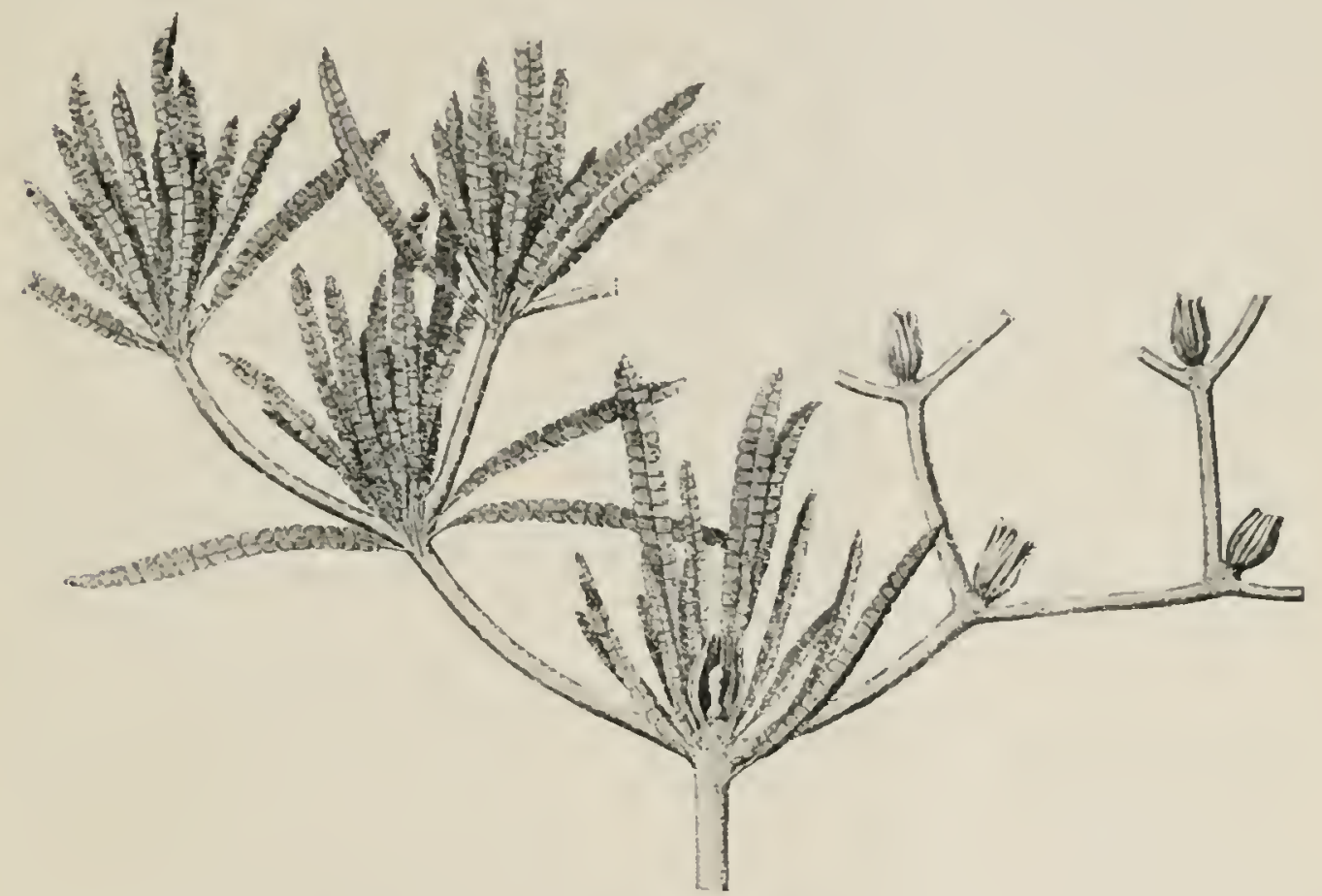

FIG. 57.-Williamsonia (Anomozamites) angustifolia: branching trunk, with rosettes of leaves and strobili at the forks; ahout $\frac{1}{6}$ natural size.-After NatHorst ( 17 ).

A second striking external feature of the Bennettitales is the occurrence of scales densely packed between the leaf bases and about the strobili, and also covering the crown. This is distinctly the so-called ramentum of ferns, the scales being one layer of cells thick, except in the central region, the cells becoming much elongated (fig. $5^{S}$ ). In certain species of $C y c a d c l l a$, a dwarf genus distinguished by its abundant ramental covering, WARD and WIELAND describe the ramentum and armor of leaf bases as making up half the bulk of many trunks. While ramentum is not lacking in any of the Bennettitales, so far as known, there is every gradation in its abundance, 
some trunks bearing but little. Among the cycads, certain genera, as Dioon, Encephalartos, etc., produce long one-celled or two-celled hairs which may be regarded as re-

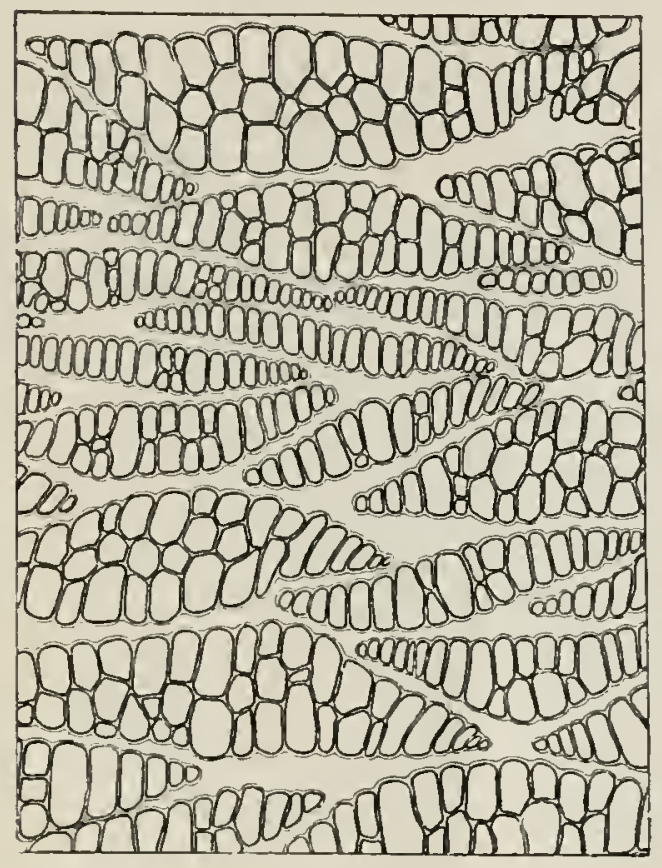

FIG. 5S. - Cycadella ramentosa: transverse section of the ramentum of the leaves; $\times 66$.-After WIELAND (22). placing in a general way the ramentum of ferns and of Bennettitales, but they are so different from the scales that make up the ramentum that the latter must be regarded as a rery distinct feature of the Bennettitales.

\section{YASCULAR ANATOMY}

The anatomy of the stem is very much like that of the stem of Cycadales. A transverse section shows a very thick cortex, usually a comparatively thin vascular cylinder, and a large pith with mucilage or gum canals or reservoirs. The vascular cylinder is made up of collateral endarch bundles, so that the most advanced type of gymnosperm cylinder had been attained; in fact, it had been attained by some of the Cycadofilicales. In Cycadeoidea Jenneyana and C. ingens the vascular cylinder is so massive (22) as to suggest the cylinder of Cordaitales, being made up of successive woody zones. Among the cycads there is sometimes a succession of rascular zones which arise from a succession of cortical cambiums; but in these species of Cycaleoidea the cylinder is so compact that it suggests a persistent primary cambium.

The vascular cylinder of Bennettitales and of Cycadales is regarded by WORSDELL (23) as giving clear evidence of its derivation from the Medullosa type of cylinder among the Cycadofilicales. His proofs are largely obtained from investigations of the cotyledonary node and strobilar axis of certain cycads, polystely having been found in the cotyledonary node of a species of Encephalartos, and a very irregular orientation of bundles in the peduncle of Stangeria. According to this view, the cycadean cylinder has been built up by the regular 
arrangement of the separate steles of Medullosa, accompanied by the elimination of internal vascular tissues out to the protoxylem. In any event, the type of cylinder displayed by Lyginodendron, which according to this view was formed in the same way, would be the immediate progenitor of the cycadean cylinder, the only change necessary being a transition from the mesarch to the endarch condition, a transition completely or at least very nearly attained by $C y c a-$ doxylon, and seen in the seedling of Ceratozamia. It was in this connection that WorsDel. (23) extended the very useful group named Cycadophyta, suggested by NATHorst, to include the Cycadofilicales, Bennettitales, and Cycadales, NATHorst's "cycadophytes" including the mesozoic plexus of cycadean forms and the living cycads.

The leaf traces, at first endarch near the vascular cylinder, soon become mesarch, as in cycads, and this structure characterizes the foliar bundles. It is altogether probable that the mesarch condition passes into the exarch in the ultimate foliar branches of the vascular system, for this is evident among cycads as the bundles become simpler; but the prevailing mesarch type of leaf trace and leaf bundle is an important reminder of fern connections. It is in connection with the leaf traces, however, that a striking contrast between Bennettitales and Cycadales appears. In the latter group, several vascular strands leave the cylinder and enter a single leaf, two of them following a more or less devious route through the cortex, resulting in the so-called "girdles." Among Bennettitales a single bundle leaves the vascular cylinder, and in passing directly through the cortex toward its leaf breaks up into numerous smaller bundles that enter the leaf. The "girdle" habit will be discussed under Cycadales, but at this point it is important to note that the direct course of the leaf trace, characteristic of the mature stems of Bennettitales, is found in the vascular connections of the sporophylls and cotyledons of Cycadales.

\section{THE LEAF}

The leaves, arising in a crown from the top of the tuberous or columnar trunks, closely resemble those of Dioon, Zamia, etc., both in form and in structure. In fact, the abundant detached leaves found in certain mesozoic deposits have suggested the establishment of such leaf gencra as Zamites, Dioonites, and Cycadites; while Otozamites and 
Anomozamites are leaves differing from those of any living cycads. The mature fronds of Cycadeoidea ingens are estimated (22) to have attained a length of three meters. The leaves of the slender and widely branching Williamsonia angustifolia (Anomozamites) seem to have occurred in clusters at the ends of branches and at the forks, each cluster surrounding a small terminal strobilus (fig. 57), and composed of leaves which were linear in general outline and pinnate with short, broad lobes.

The absence of scale leaves from the crown of the tuberous and columnar forms, alternating with the foliage leaves, has been remarked; but scale leaves are related to strobili. Among Cycadales the terminal strobili necessarily involve the association of their enveloping scales or bracts with the crown of foliage leaves; among Bennettitales the lateral position of the strobili prevents any association of their scale leaves with the foliage of the crown, and such leaves or bracts form the characteristic husklike covering of the strobili. Among Cycadales the enveloping bracts are much more open, but they are as definitely related to individual strobili as among the Bennettitales.

\section{The spore-producing members}

THE STROBILUS

Perhaps the most important result of WIELAND's investigations $(7,8,9,16,22)$ was the discovery of the bisporangiate character of the strobilus. At first it was supposed that this might be an exceptional condition in the group, but it has now been found in so many genera and species that it is known to represent the general condition. In a recent examination of certain species of Bennettittales from the Jurassic beds of England, NATHORST (3I) concludes that two species of Williamsonia and Cycadocephalus Sewardii bore monosporangiate strobili, but the general occurrence of bisporangiate strobili seems assured. WIELAND found bisporangiate strobili not only in numerous sections of American material, but examined the best known European forms (Cycadeoidea etrusca, C. Reichenbachiana, Williamsonia gigas, and $W$. angustifolia) and found bisporangiate strobili in all of them (26). The microsporophylls (stamens) have disappeared when the sceds are mature, but in seed-bearing strobili the former position of the 
stamens is always shown by a distinct "shoulder" or "hypogynous disk" on the receptacle between the enveloping sterile bracts and the seed-bearing structures. This interpretation is confirmed by the fact that in strobili containing mature stamens the orulate structures are always present in a very young stage. It may be presumed that when the stamens were mature, the orules were ready for pollination. The period between pollination and the appearance of a fully formed embryo is usually long enough among gymnosperms to account for the absence of stamens from the strobili of Bennettitales bearing mature seeds. It may be unsafe to assume, as yet, that there were few Bennettitales with monosporangiate strobili, but at present the bisporangiate strobilus is one of the outstanding features of the group.

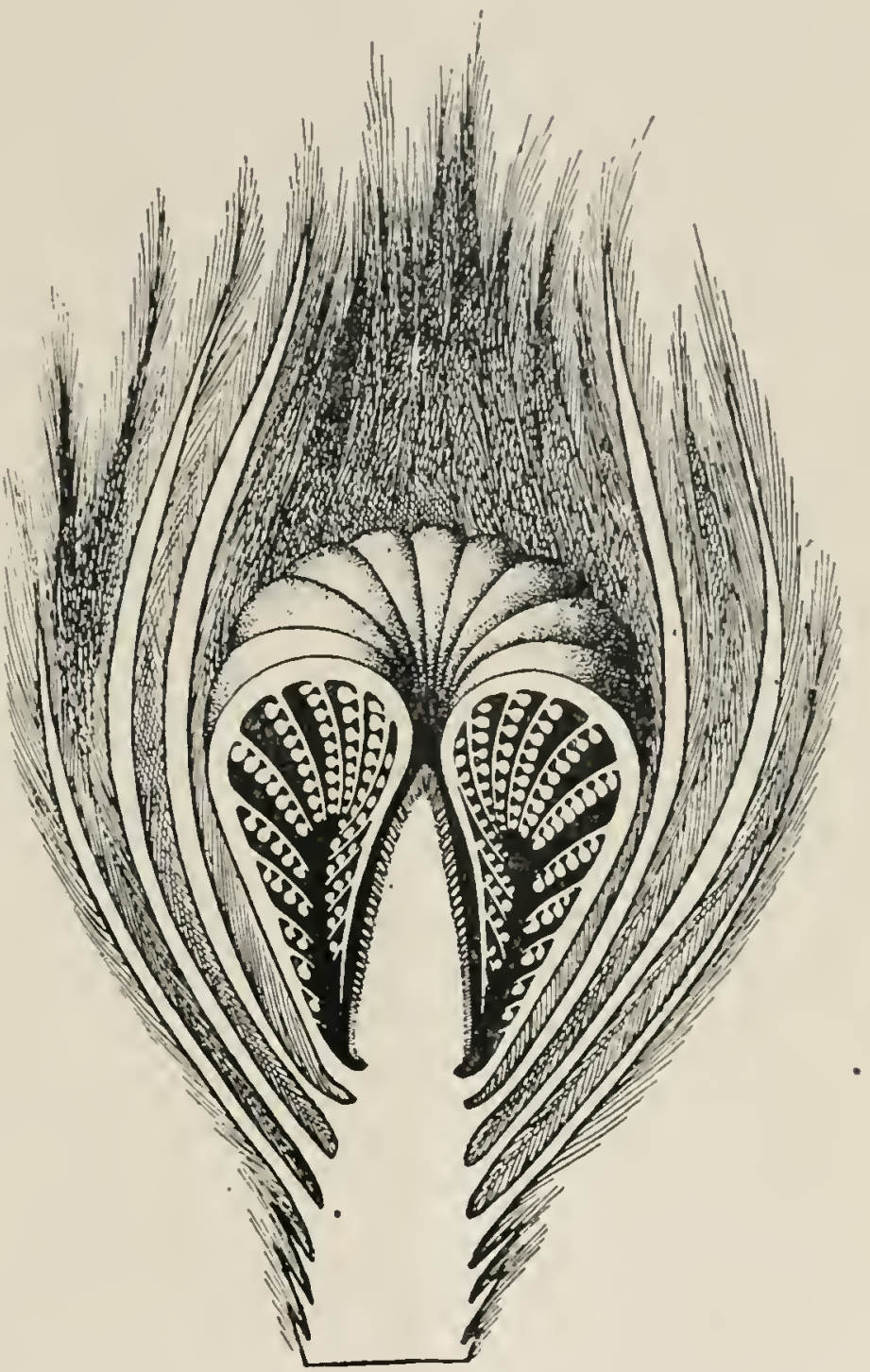

FIr. 59.-Cycadeoidea: restoration of an unexpanded strobilus, with part of the enveloping hairy bracts removed; is folded fronds are shown as in C. ducotensis; about natural size, or not nearly so large as various examples.-Figure and description after WIEL.ND (22).

The general structure of the strobilus is as follows: The tip of the axillary dwarf branch or peduncle is expanded into a hemispherical receptacle or is continued more or less as a thick axial receptacle. Upon this receptacle three sets of members are developed in spiral 
succession (fig. 59): (I) the outermost (lowest), a series of heavy, imbricated bracts completely inclosing the structures within; (2) next a series of the characteristic leaflike microsporophylls (IO-20 in number); (3) on the top of the hemispherical receptacle, or on the conelike tip of the axial one, a large number of remarkable orulate sporophylls intermixed with still more numerous sterile ones ("interseminal scales"). The recorded length of the larger ovoid strobili is 4 to $7 \mathrm{~cm}$.; while smaller ones (as those of Cycadella) range down to $\mathrm{I} \mathrm{cm}$.

A strobilus of this type, characterizing an extensively displayed group of mesozoic gymnosperms, has tempted to much speculation as to its relation to the flowers of angiosperms, which seem to have begun to emerge into notice during the same time. Following Wieland's original suggestion (22), Oliver (2I), and Arber and PARKIN (24) have further elaborated the same thesis, and SCOTT (28) has expressed the opinion that "the affinities between mesozoic Cycadophyta and the angiosperms appear extremely significant," and that it is "difficult to resist the conviction that the ancestry of the angiosperms, so long shrouded in complete obscurity, is to be sought among the great plexus of cycad-like plants which dominated the flora of the world in mesozoic times." Oliver has suggested angiocycads as the phyletic name of Bennettitales (or some allied stock) as possible ancestors of angiosperms. Arber and PARkin have analyzed the strobilus situation and given it a terminology. An anthostrobilus is a bisporangiate strobilus in which the megasporophylls are above the microsporophylls, as in Bennettitales and all angiosperms. The earlier form of this strobilus is called the proanthostrobilus, in which there is gymnospermy and the microsporophylls have not reached the real stamen form; a definition eridently constructed to describe the strobilus of Bennettitales. The later form of anthostrobilus is the euanthostrobilus (or "flower"), in which angiospermy has been attained and a well-marked perianth has been developed. This phylogenetic suggestion further supposes a hypothetical group of plants to intermediate between the Bennettitales (or their equivalents) and the angiosperms, to which the name hemiangiosperms is given. Lignier (25) has dissented from this view of the origin of angiosperms, for he regards the strobilus of 
Bennettitales as an "inflorescence" rather than "flower"; and he has enriched the terminology of the strobilus further by adding pteridostrobilus as a stage before the proanthostrobilus, to include the grouping of fernlike microsporophylls and megasporophylls in monosporangiate strobili. WIELAND (30) has also dissented from the substitution of the new term hemiangiosperms for the long-used proangiosperms of SAPORTA. 'The possible relationship of gymnosperms to angiosperms does not come within the province of this volume, but in connection with the structure of the strobilus of Bennettitales its responsibility for speculation in reference to the origin of the angiosperms should be known.

In any event, it is safe to conclude that if the Cycadofilicales gave rise to the strobilus-bearing cycadophytes, there were at least two lines of development: one leading to forms with bisporangiate strobili (Bennettitales), and the other to forms with monosporangiate strobili (Cycadales).

\section{THE MICROSPORANGIUM}

WIELAND's investigations (22) of Cycadeoidea indicate that the microsporophylls (stamens) are remarkably uniform in character. In number they range from ten (C. Jenneyana) to twenty $(C$. dacotensis). In form they are elongated, pinnate, fernlike leaves, with about twenty slender pinnae, beneath which there are borne two lateral rows of close-set synangia (fig. 60). It has been suggested that these sporophylls should be called bipinnate, on the ground that the synangia represent ultimate pinnules. The only advantage to be gained from this somewhat doubtful interpretation is that it serves to distinguish the microsporophylls of Cycadeoidea (so far as studied) from the simpler ones of Williamsonia. The sporophylls are united at base into a "disk" and become free and pinnate above the ovuliferous apex of the receptacle. The condition might be described as that of monadelphous stamens, and it suggests the monadelphous stamens of Welwitschia (Tumboa), in which the strobilus is also bisporangiate. All the microsporophylls are inflexed, so that the upper third lies with its back against the ovuliferous apex of the receptacle, and its synangia against those of the rest of the sporophyll (figs. 59 and 60). We must imagine the straightening and possible 
spreading of these remarkable stamens during the shedding of pollen (fig. 60). The strobili of Williamsonia gigas, regarded by WILliamsON as "male flowers," have been reinvestigated by Lignier (I8), who has discorered them to contain a stout pyriform axis from which the seeds had probably become detached after maturity, and also

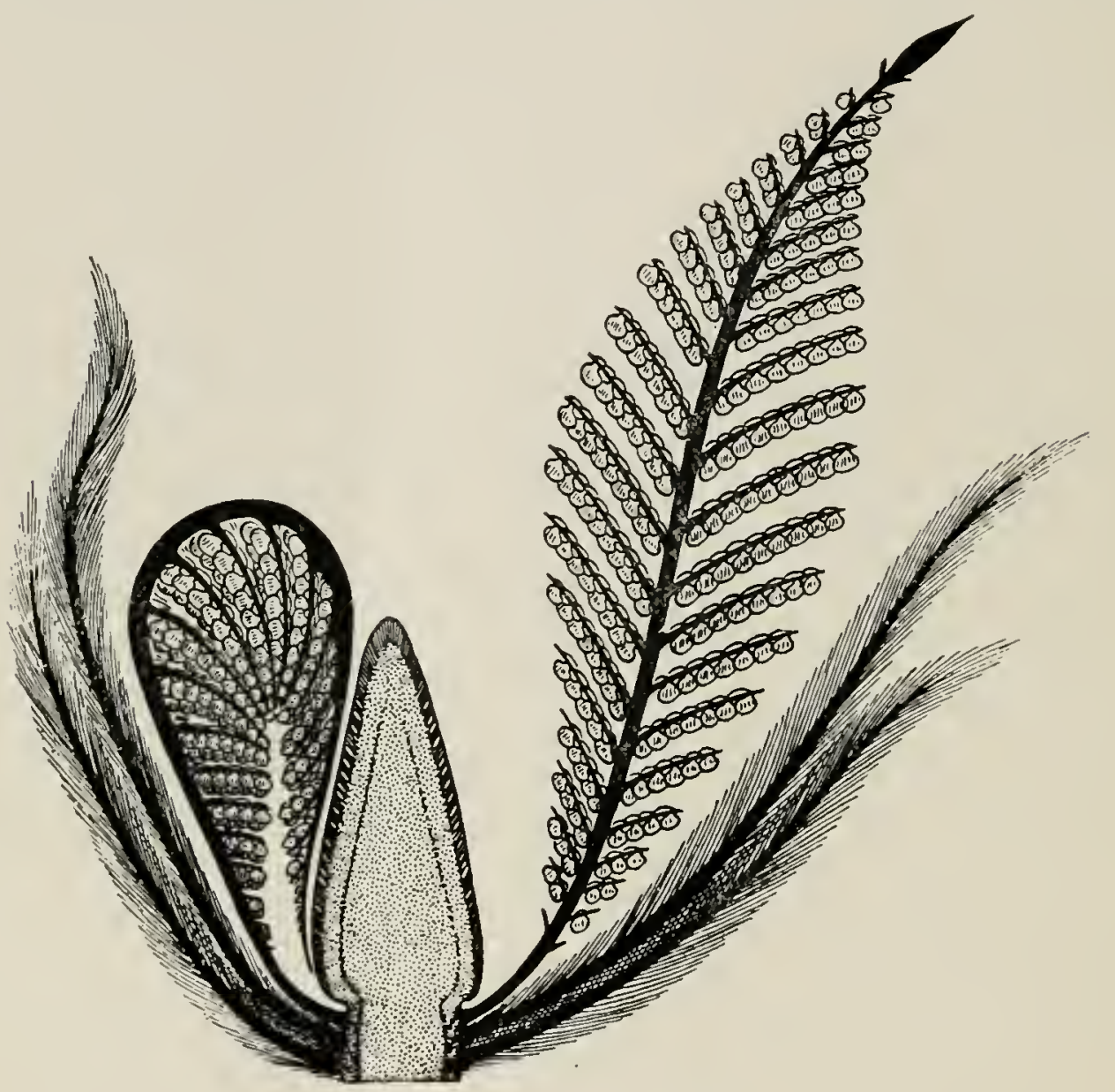

FIg. 60--Cycadeoidea dacotensis: semi-diagranımatic sketch of strobilus; the ovulate cone in the center is covered by short-stalked ovules and interseminal scales; one staminate sporophyll expanded, and one still folded; outside the staminate sporophylls are hairy bracts; a little less than natural size.-After VIELAND (22).

traces of the stamen set. Recently Nathorst (3r) has found additional "male flowers" of Williamsonia on the Yorkshire coast, and confirms the view that they are bisporangiate strobili of the cycadeoidean type. About the same time Wieland (30) discorered a well-preserved staminate disk of Williamsonia in the Mexican deposits, which he describes as being a "reduced campanulate form," comprising eight to ten small and strictly once-pinnate sporophylls, 
which project only I. $5 \mathrm{~cm}$. beyond the disk, each bearing two lateral rows of synangia along the rachis. This remarkable "reduction" of the stamen set, as compared with that in Cycudeoidea, has intensified the suggestion of an angiosperm connection.

That the stamens of Bennettitales bore synangia of the ordinary Marattia type (fig. 6r) has been shown to be true of all the forms

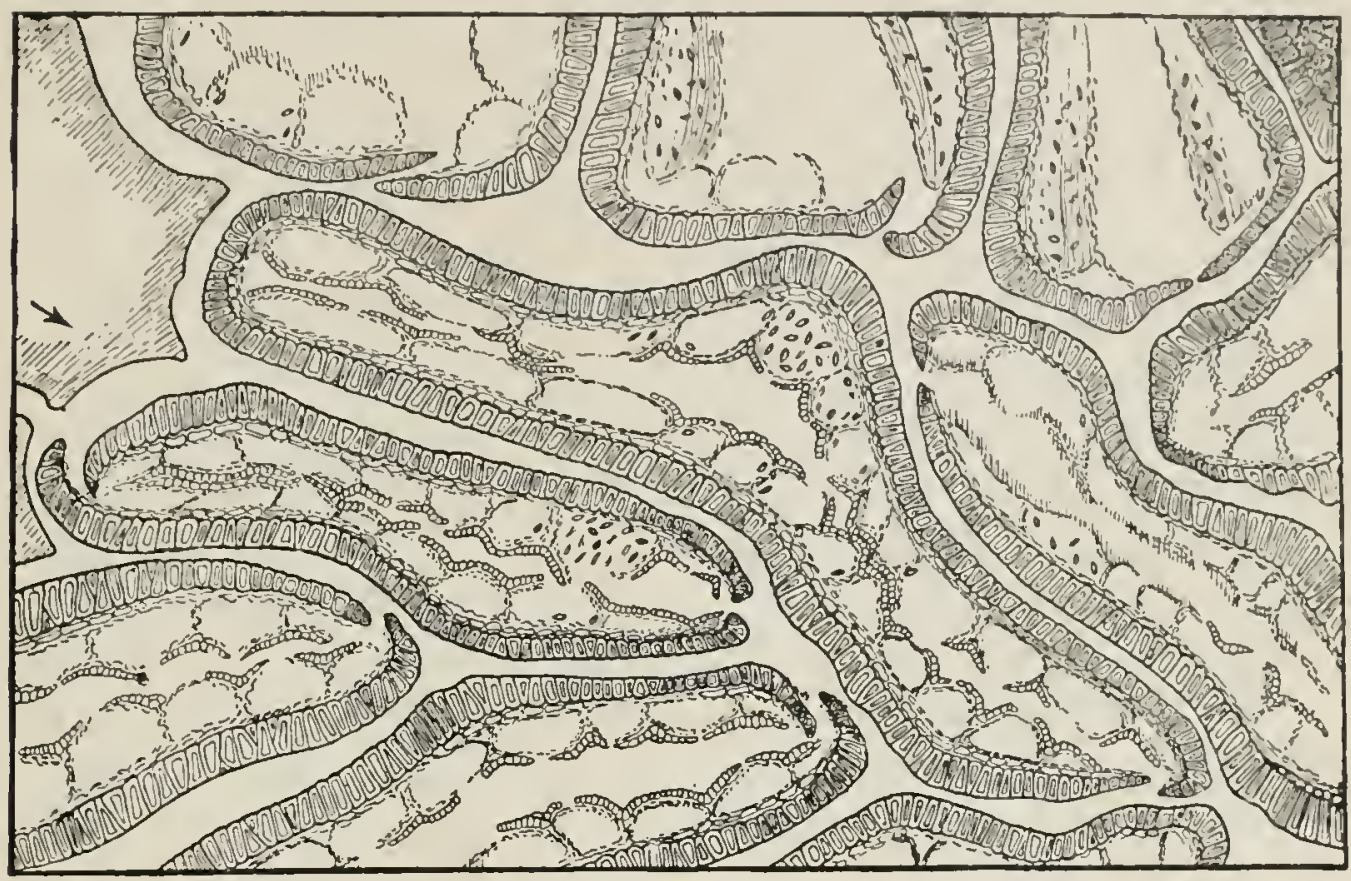

FIG. 6I.-Cycadeoidea dacotensis: part of transverse section through unexpanded microsporophyll, showing synangia with loculi arranged in (wo rows; some of the loculi contain pollen grains; $X_{25}$. - After WIELAND (22).

examined, including the older known European species. The structure of the synangia seems to be almost identical with those of Marattia or of Danaca (fig. 62). Superficially there is a wall of heary cells. and between it and the sporangial chambers there is a more delicate tissue. The sporangial chambers are separated from one another by partitions consisting each of a single plate of cells, and form two rows, between which the synangium dehisces in two valves. It is evident that this structure has advanced little beyond the fern level, and might well belong to Cycadofilicales or to Filicales. In fact. the free portion of a microsporophyll, if detached, would certainly be mistaken for a Marattia-like fern. This relatively stationary character of the microsporangiate structures appears throughout the 
whole cycadophyte phylum, including even the Cycadales, and is one of its striking features.

\section{THE MEGASPORANGIUM}

If the microsporangiate structures of Bennettitales have advanced little beyond the fern level, no such claim can be made for the mega-

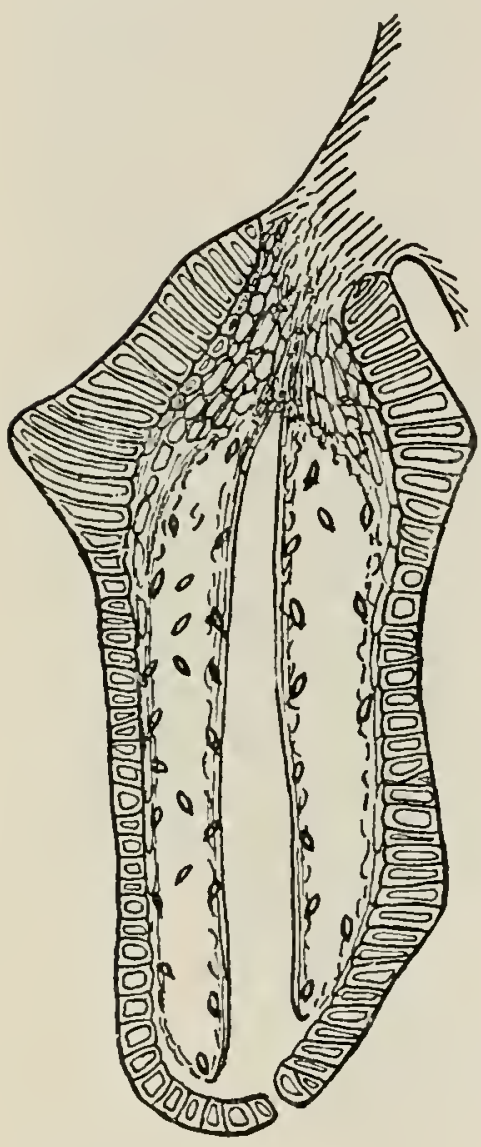

FIG. 62.-Cycadeoidea dacotensis: longitudinal section of synangium, showing stalk, hard outer layer of cells, portions of wall layers of cells, and two chambers containing pollen grains; $\times 40 .-$ After IIIELAND (22). sporangiate structures. They are not only remarkably different from the corresponding structures among Cycadofilicales, but they are even more different from those of the Cycadales.

The description of Bennettites Gibsonianus, as given by CARruthers (2), Solms-Laubach $(5,6)$, and Scott (Io), may be used as an introduction to the situation (fig. 63). From the convex surface of the hemispherical receptacle a great number of slender stalks arise, which pass vertically upward, or diverge slightly toward the curved surface of the "fruit." The central stalks are the longest, the outer ones gradually diminishing in length, so that the general outline is oblong or oborate. Each of these stalks bears at its tip a single erect seed, with the micropyle directed outward. The seeds are so placed that the long axis meets the surface approximately at right angles. The spaces among the stallss are packed with scales, which are dilated at tip, between the seeds, so as to form a continuous envelope, interrupted only by the small pits through which the micropylar tubes project.

The corresponding structures of the beautifully preserved Cycadeoidea Wielandii (fig. 64) have been more fully described by WIELAND (22). They conform to the description of Bennettites given above, but many additional details are given. In the lower part of the orulif- 
erous region only interseminal scales occur; above this there are usually five or six scales packed around each seed pedicel (fig. 65). The scales are slender (filiform) at base and gradually thicken upward in prismatic form to the seeds, where the faces are hollowed to receive them. Above the seeds the scales enlarge again and their tips form a complete mosaic, perforated only by the micropylar tubes.

In the group of species with more or less elongated receptacles, as Cycadeoidea dacotensis (fig. 66), the numerous scales and pedicels are relatively short and of uniform length, so that in a young stage the conical tip of the axis, as WiELAND suggests, appears like a brush.

There are two interpretations of these scales and pedicels. Lignier (25) maintains that the scales are bracts in whose axils the pedicels appear; and that therefore the pedicel is an axial structure bearing an ovulate "flower" reduced to its lowest terms. This view necessarily regards the strobilus of Bennettitales as an "inflorescence," which, in so far as

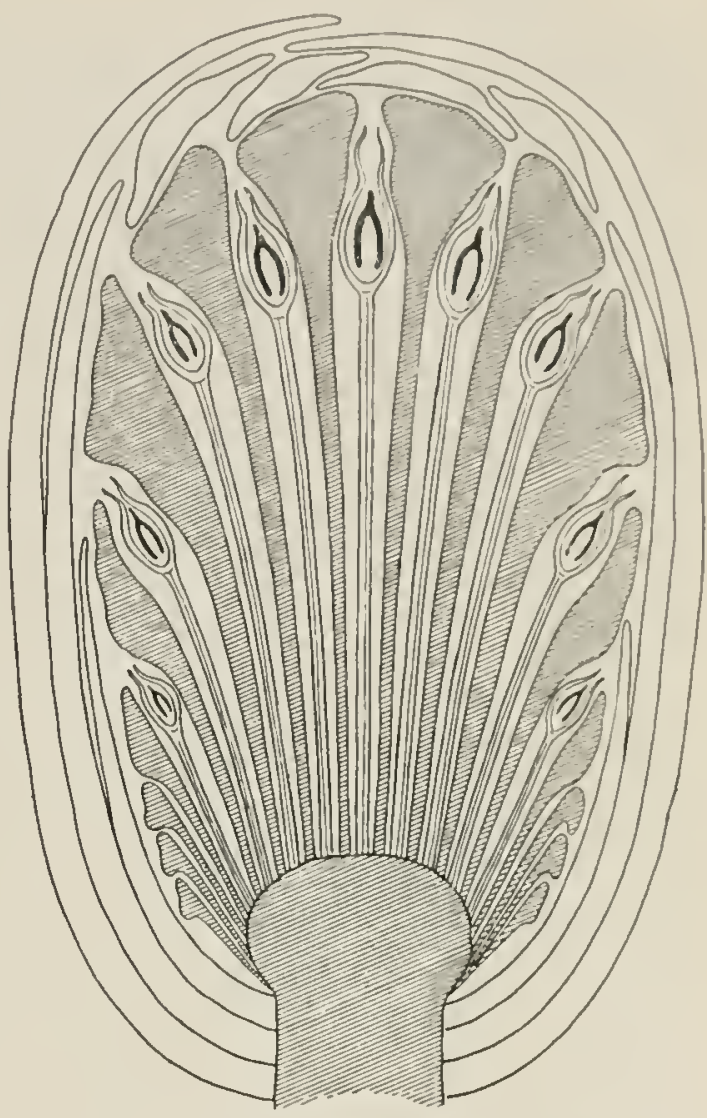

Fig. 63.-Bennettites Gibsonianus: diagram of seed-bearing strobilus; the seerts, each containing a dicotyledonous embryo, are borne on long pedicels; between the seeds are the interseminal scales with dilated ends; surrounding seeds and scales are overlapping bracts.-Modified by ScotT (IC) after Solms-LaUbach (5) and Potoví́ $(6 a)$.

it means a compound (branching) strobilus, is represented among gymnosperms by the orulate strobili of certain of the Pinaceac and by both strobili of the Gnetales. The same investigator (I9) has also satisfied himself, by an examination of Bennettites Morieri, that in all the scales which enter into the composition of the strobilus the terminal enlargement is due to hypertrophy and is not a reduction stage. 
The general and apparently inevitable interpretation has become more assured since the discovery of Cycadofilicales. In that group many

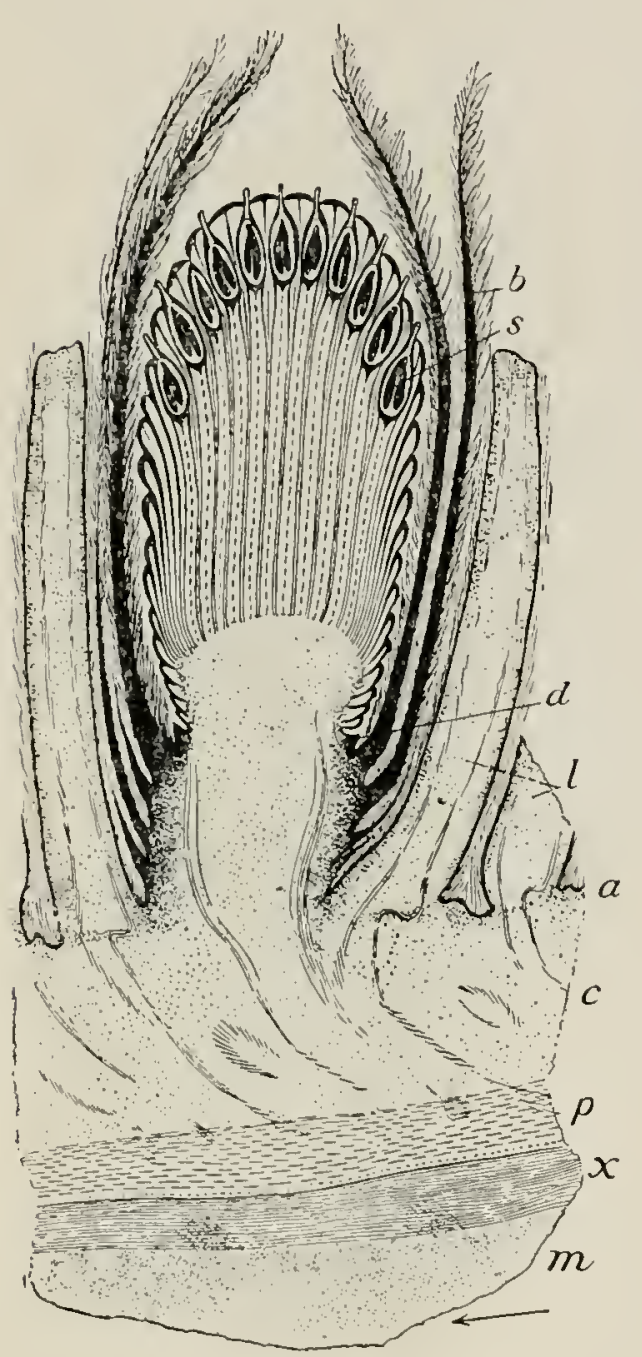

FIG. 64.--Cycadeoidea Wielandii: radial longitudinal section of seed-bearing strobilus, with partially restored bract tips; the arrow indicates direction vertical to the trunk, the section passing through the exact median and vertical plane of the axis of fructification; $m, x, p$, and $c$, respectively the medulla, xylem, phloem, and cortex of the trunk as seen in radial longitudinal section; $a$, insertion of armor on cortex; $l$. old leaf bases; $d$, insertion of dehiscent hypogynous disk; $s$, erect seed; $h$, hair-corered bract.-Figure and description after WIELAND (22). of the seeds are borne terminally upon reduced filiform branches of a modified frond; and it is natural to infer that the seed pedicel of Bennettitales represents such a frond reduced to its lowest terms, that is to a single seed-bearing stalk. This means that the seed pedicel is a foliar rather than an axial structure, and that it is a case of excessive reduction, which has resulted in a simple, one-seeded megasporophyll (carpel). There seems to be no better way of disposing of the interseminal scales than to regard them as sterile and specialized megasporophylls. One of the most striking features of Bennettitales, as constrasted with Cycadofilicales, is the relatively slight reduction of the microsporophylls, associated with the very great reduction of the megasporophylls.

The structure of the seed is what has come to be spoken of as the cycadean type (figs. 67-69). There is a distinctly three-layered testa (outer and inner fleshy layers and a middle stony layer), which is evident chiefly in the region of the integument free from the nucellus (29). The inner layer of the testa is said to form the lining of the long micropylar tube, which reaches to the surface of the ovulate 
structure. A most interesting feature is the occurrence of a batsal cupule, for it suggests a remnant of the completely investing cupules of certain seeds (Lagenostoma) of Cycadofilicales. The usual nuce!lar beak and large pollen chamber, characteristic of this type of ovule,

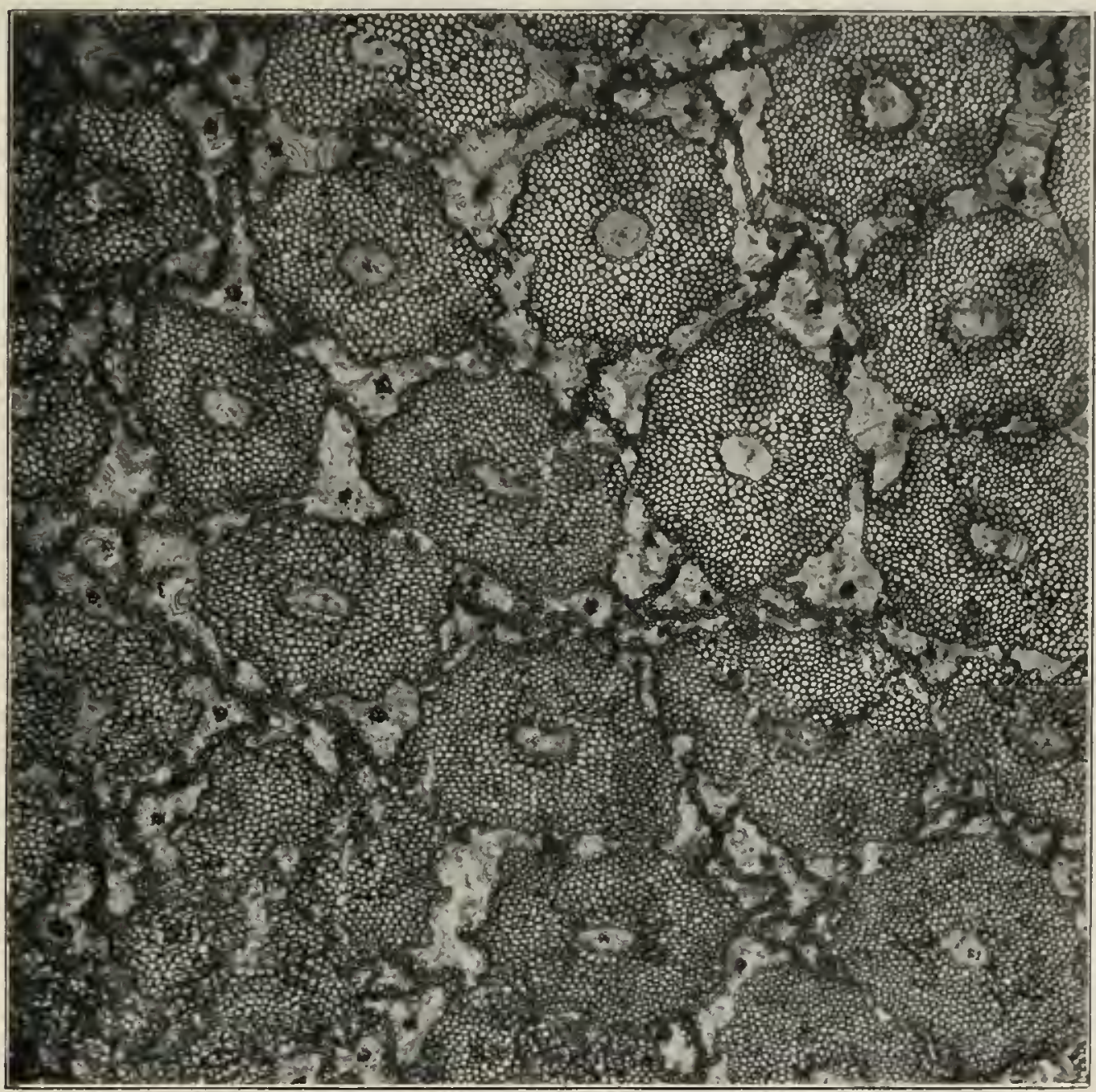

FIG. 65.-Cycadeoidea II'ielandii: transverse section of a portion of the seedbearing strobilus, showing seed-stalks with their central bundles, and interseminal scales packed between.-From photograph by BEEcHER of section made by. WIELAND.

are evident, and also a heary megaspore membrane. It must be recognized that the structure of the seeds of Bennettitales is not linown with such completeness as is that of Lagenostoma, so that a definite comparative statement is impossible at present. The conjectural situation is possibly the true one, which the abundance of material should soon establish. 


\section{The gametophytes}

In his examination of pollen grains, WIELAND (22) discovered appearances of cell structure, but it was not determined whether these appearances belonged to the wall or not. If they are internal cells, a series was obtained from the cutting off of one lenticular cell up to five cells. Since the pollen grains of Cycadofilicales and Cor-

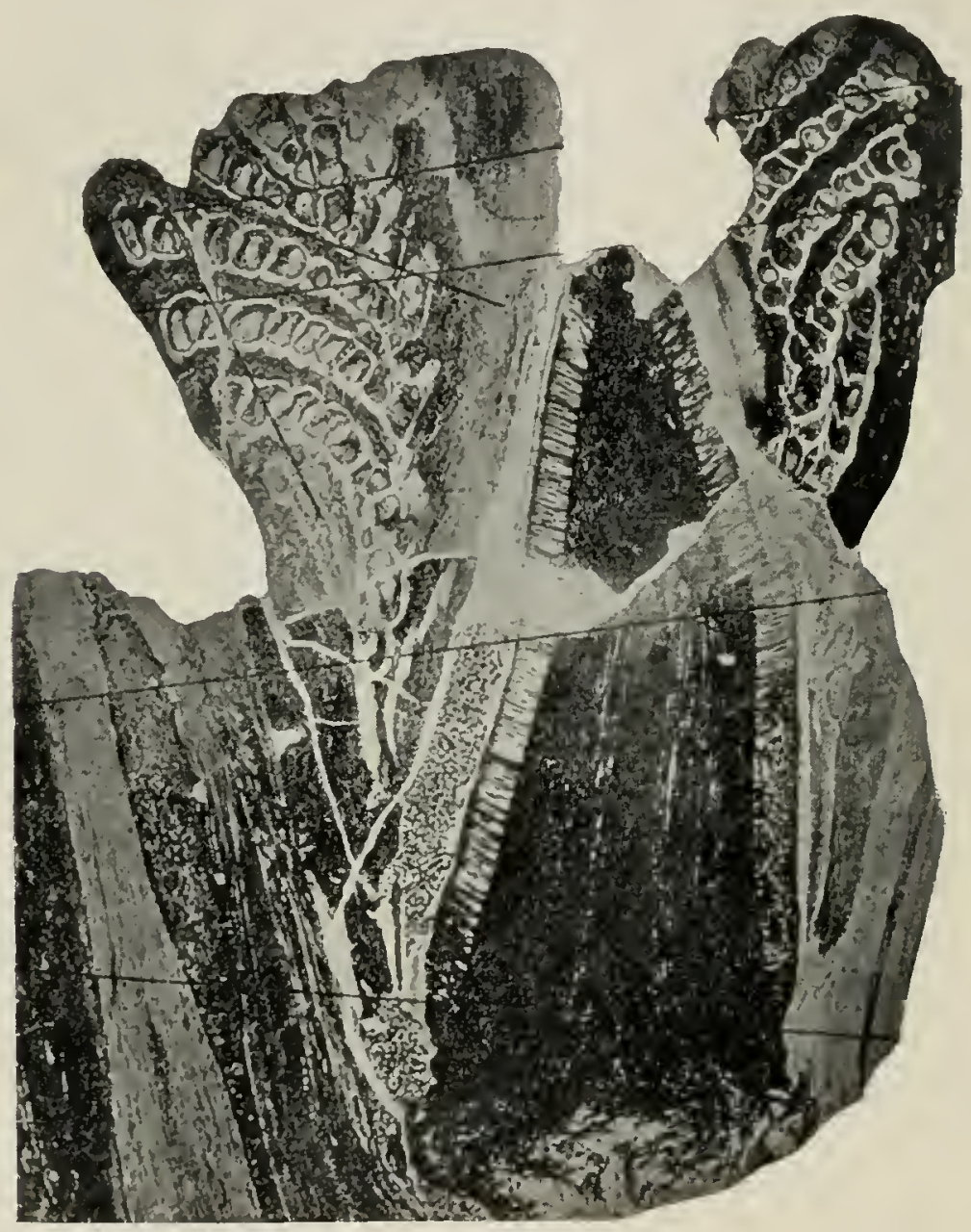

FIG. 66.-Cycadeoidea dacotensis: longitudinal section through strobilus, from a photograph; X2.-After WIELAND (22).

daitales are known to have become multicellular, it would not be surprising to find in the pollen grains of Bennettitales a more extensive tissue than is developed in the pollen grains of Cycadales. The formation of swimming sperms cannot be doubted, on account of the structure of the orule and the relationship of the group. 
No recognizable trace of a female gametophyte has been observed, for all of the sections of strobili have shown either very young and structureless orules or mature seeds with fully developerl embryos.

\section{The embryo}

One of the characteristic features of Bennettitales is the large dicotyledonous embryo completely filling the embryo sac, in fact filling the whole seed to the testa, with the exception of the nucellar beak (figs. 67-69). The numerous sections of strobili that have been made show that this remarkable embryo, much the larger part of whose bulk consists of two cotyledons, was quite uniform in appearance and was very favorable for preservation. Unlike the embryo of any other known gymnosperm, it destroyed practically all of the endosperm during its intraseminal development. Unusual as this is, however, it is merely a difference of degree, since the embryos of all gymnosperms encroach more or less upon the endosperm. The contrast in this feature between Bennettitales and Cycadofilicales is all the more remarkable from the fact that the former group is believed to have been derived from the latter. If this view is a true one, a remarkable change in the intraseminal derelopment of the embryo has been supposed to have taken place during the passage of cycadophytes from the Paleozoic into the Mesozoic; but it should be remembered that probably the embryos of Bennettitales are

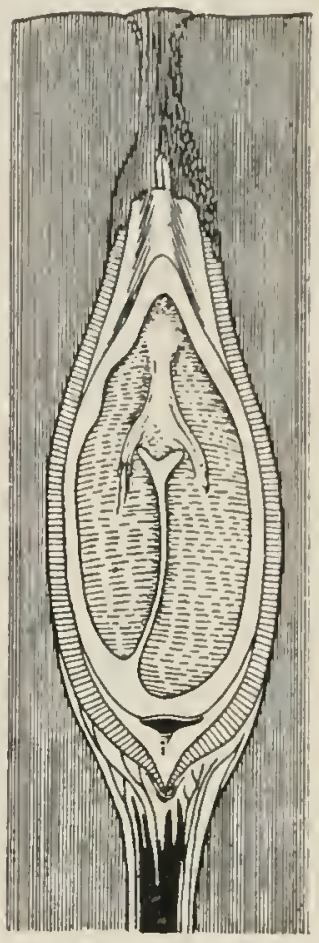

FIG. 67. - Bennettites Gibsonianus: mature seed showing embryo with two somewhat unequal cotyledons; the testa shaded with parallel radial lines; at the base of the seed and in the pedicel the vascular supply is shown. - After Solms-Laubach ( $(5)$. in evidence because the strobili remained attached to the plant $(p, 4 i)$.

It has also attracted attention that this bulky, dicotyledonous embryo gives no evidence of the long, slender, and tortuous suspensor characteristic of all living gymnosperms except Ginkgo. Those who are familiar with sections of the seeds of Cycadales and Coniferales, 
however, will recognize the fact that this is negative testimony. In a fully developed embryo the suspensor may have become scarcely

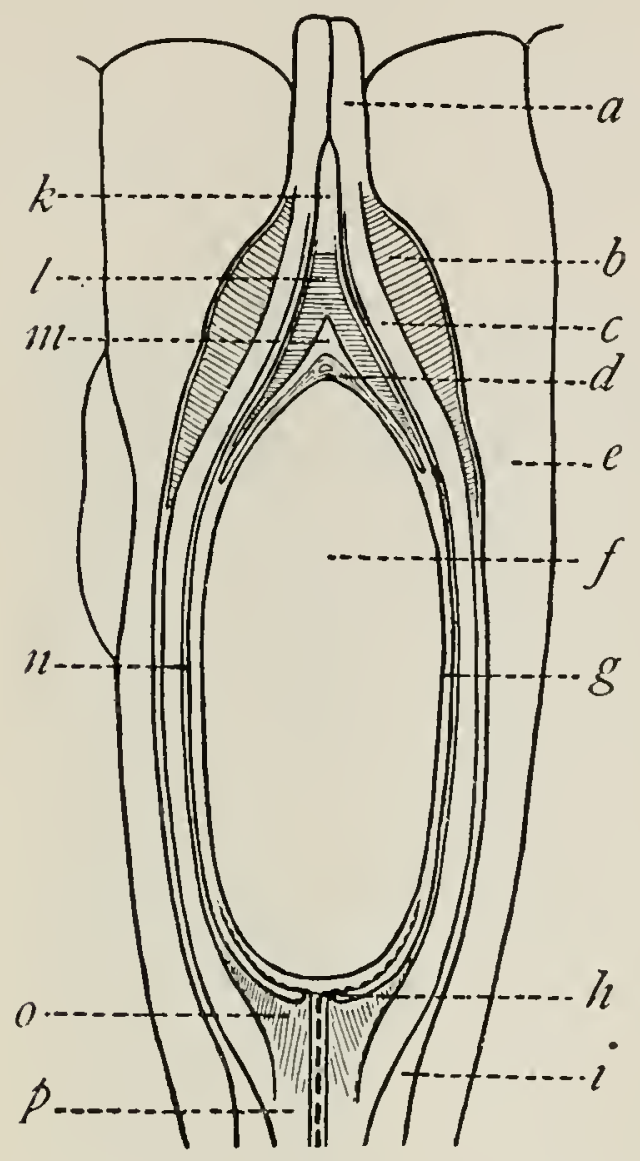

FIG. 68

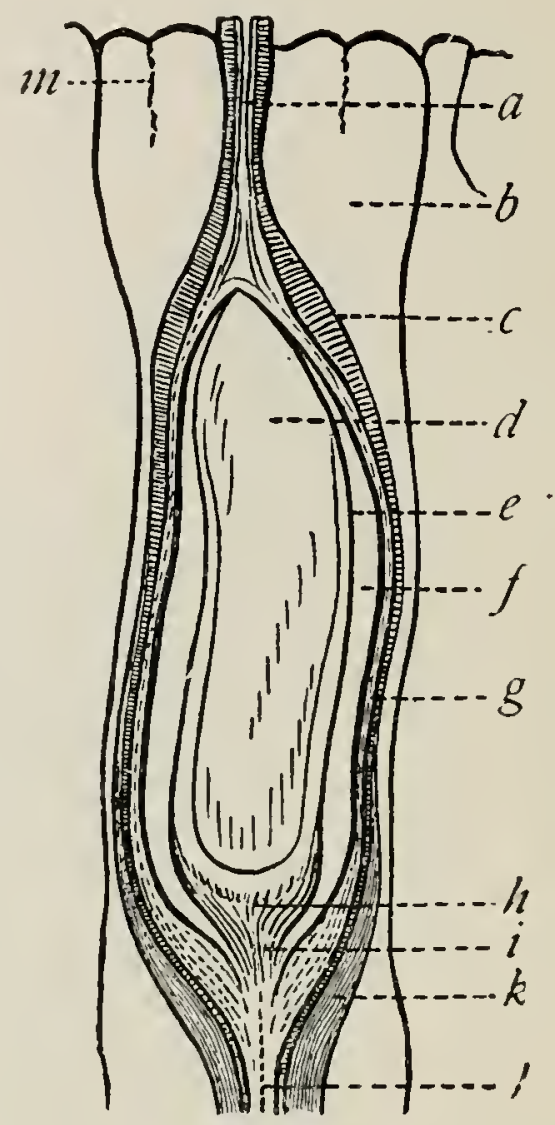

FIG. 69

FIG. 68.-Bennettites Morieri: longitudinal section of seed; $a$, micropylar tube; $b$, prismatic layer; $c$, pulpy tissue; $d$, "corpuscular" mass; $e$, interseminal scale; $f$, embryo space; $g$, remains of nucellus; $h$, chalaza; $i$, tubular envelope; $k$, micropylar canal; $l$, nucellar beak; $m$, pollen chamber; $n$, fibrous stratum; $o$, basal expansion of $n$; $p$, pedicel bundle.-After W'IELAND's reproduction (22) of LIGNIER's figure (I8).

FIG. 69.-Cycadeoidea Wielandii: longitudinal section of seed; a, micropylar tube; $b$, expanded summit of interseninal scale; $c$, slightly palisaded layer of heavywalled cells, which forms the true external coat of the seed, but is covered in all the basal region of the seed by the woody and tubular cells of the cuplike extension ( $k$ ) of the cortex of the seed pedicels; $e$, wall of nucellus ending below the chalaza in an expanded cup-shaped base; $f$, a structureless zone or simply a space between $e$ and $g ; g$, stringy remains of cells expanding into a cup below; $h$, chalaza; $i$, woody scalariform tissue; $k$, continuation of the heavy-walled tubular cells forming the outer layer of the seed pedicels, which overlaps the outer layer of the seed $(c)$ and forms the cuplike seed support or husl;; $l$, central bundle of pedicel; $m$, remnant of aborted seed and

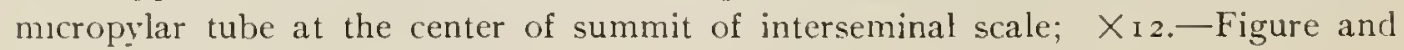
description after WiELand (22). 
recognizable, except to one very familiar with the situation; and there may be many sections that would not show any trace of it. The obliteration of the suspensor would be even more extreme in the case of an embryo that has completely or approximately obliterated all the tissues within the testa. At the same time, the embryo of Ginkgo suggests the possibility that the embryo of Bennettitales may have lacked an elongated and slender suspensor, and that there was simply a suspensor-like elongation of the massive proembryo. In certain sections Wiecand (20) has discovered the seed filled with a tissue which suggested to him proembryonic tissue. It is altogether unlikely that the embryo in its proembryonic stage would have destroyed all the endosperm. 'The tissue in question is probably that of the embryo, through which both transverse and longitudinal sections are possible that would not show the dicotyledonous character, or the figure published might indicate three cotyledons.

It is tempting to cite the embryo of Bennettitales as eridence that the primitive embryo of gymnosperms was dicotyledonous. Recent investigations, however, have shown that Bennettitales cannot be used for or against this view until the anatomical structure of its cotyledons has been determined. The embryo of this group, as we know it, is probably far from representing even the most primitive embryo of mesozoic gymnosperms; and behind the Mesozoic there stretches the long series of paleozoic Cycadofilicales, whose embryos are unknown.

\section{History and distribution}

This characteristic mesozoic type ranges from the early Triassic into the Lower Cretaceous, being extraordinarily abundant during the Jurassic. In the United States the remains of Bennettitales are known from the Triassic of Pennsylvania and North Carolina, through the Jurassic of Colorado and the Potomac formation of Maryland, to the Upper Jurassic and Lower Cretaceous of the Black Hills of South Dakota and Wyoming. The recently discovered Mexican remains of the group occur in the Lower Jurassic (Lias) of the mountains of western Oaxaca (30). The known historical range of the group in Europe is even greater, beginning with the early 'Triassic (Williamsonia angustifolia) of southern Sweden.

The remains have been found in abundance wherever favorable 
mesozoic deposits occur, ranging through North America, Europe, and Asia, and extending into the arctic regions; so that Bennettitales were evidently a world-wide type of great prominence. It is to be expected that investigations in the southern hemisphere, and especially in the mountainous region of western China, may much extend our knowledge of the group.

\section{Relationship to other gymnosperms}

The question of the gymnosperm relationship of Bennettitales is concerned with the relation to Cycadofilicales and Cycadales, the two other members of the cycadophyte phylum. It is hardly worth while at present to consider the vague suggestions of relationship to the Cordaitales, to the Ginkgoales, and even to the Gnetales. The present evidence for such connections is too slight to merit serious discussion.

There seems to be no good reason for doubting that the mesozoic Bennettitales were derived from the paleozoic Cycadofilicales. This view has been expressed by including both groups in the cycadophyte phylum, and this view seems to be justified by both history and structure. The Bennettitales began to rise into prominence as the Cycadofilicales declined, and undoubtedly lingering members of the latter group continued into the early Mesozoic, and early members of the former group existed during late Paleozoic; so that Bennettitales may be said to have carried forward into the Mesozoic many of the primitive features of the Cycadofilicales, associating with these features others of more advanced type in the phylum.

A summary of these primitive features will serve to emphasize the connection with Cycadofilicales. The ramentum is a character that indicates the general connection of both groups with ferns. The vascular anatomy and the direct leaf traces of the Bennettitales agree so closely with those of the siphonostelic Cycadofilicales that the relationship seems obvious. The lateral branching of a monopodial axis is a feature of both groups, the more open and widely branching bodies of Cycadofilicales being carried forward into the Bennettitales in such forms as Williamsonia angustifolia (Anomozamites) and Wielandiella, but becoming much compacted in the later members of the group. This more compact body arose in connection with the organization of 
strobili and a restriction of the function of the branches. Instead of remaining elongated, foliage-bearing branches, with sporangia borne on more or less modified leaves, they became short branches, without foliage, but with bracts and sporoplyylls arranged in a strobilus by the shortening of the axis. 'That the short, lateral, strobilusbearing branches of Bennettitales have been derived from elongated branches with foliage more or less modified to bear sporangia appears to be a safe conclusion. The bisporangiate character of the strobilus is probably to be explained by the bisporangiate character of the fronds of those Cycadofilicales which gave rise to Bennettitales.

In addition to ramentum, vascular anatomy, direct leaf trace, and lateral branching, a conspicuous feature which the Bennettitales have carried forward from the Cycadofilicales is the microsporophyll, both in form and in the structure of its sporangia. In fact, the modification of the ordinary Marattia-like frond is much more extreme among certain of the Cycadofilicales. So clear is the resemblance of these microsporophylls to "fertile fronds" of ferns and of Cycadofilicales, that it is not disguised by their monadelphous character, which is probably related to the development of such large organs upon a shortened axis. The so-called "disk" or "basal union" of the stamens, it must be remembered, is due to a final simultaneous growth of the whole zone of tissue from which the stamens began to arise as separate members.

The change in the megasporophylls was more extreme, but it does not differ in kind from that observed in the microsporophylls. It is simply a still greater reduction, which in this case is carried to an extreme; a naked branching rachis bearing terminal orules upon its ultimate branches, common among the Cycadofilicales, has become a single ovule-bearing stalk. The connection is still more evident when it is noted that the cupule investing the seeds of certain Cycadofilicales has become a basal cupule in the well-protected seeds of Bennettitales. The extreme modification has been attained in the differentiation of sterile and fertile megasporophylls, and their organization into a single fruitlike body.

The most inexplicable feature in this supposed connection of the two groups is the transition from a seed with no evident embryo to one containing relatively the largest embryo among gymnosperms. 
Howerer, even if this is really a difference (pp. 46,47 ), it deals with the common condition of seed plants during the Paleozoic, and would belong to the development of seed plants in general.

The resemblance of Bennettitales to Cycadales is so evident that reasons for keeping the two groups separate are more necessary than reasons for claiming that they are genetically related. The regetative body in external appearance, and in the anatomical structure of both stem and leaf, seems to be so exact a reproduction of that of Cycadales that an intimate relationship of the two groups is an unaroidable conclusion. If this were the only testimony, no one would suggest a separation of Bennettitales and Cycadales; and, as it is, this testimony justifies the belief that the two groups are more intimately related to one another than to any other gymnosperm group.

The divergent characters of Bennettitales, however, are very striking, and force the conclusion that the two groups, although undoubtedly of common origin, are divergent groups, and that "transitions" from the Bennettitales to the Cycadales, in the important differences between the two groups, need not be expected. In such a feature as its fernlike ramentum, the Bennettitales might be regarded as on the way to Cycadales. The direct leaf traces, also, may be associated with the monopodial habit, and this might be conceived of as passing into the slow-growing sympodial habit of Cycadales, which may hold some causal relation to the formation of "girdles." Even the lateral branching, represented by numerous dwarf fertile shoots, may be conceived of as being more and more restricted to the apical region until the condition in Cycadales is attained. In fact, this restriction has apparently reached the cycad level in Williamsonia gigas, whose strobili are borne on "peduncles" arising from within the crown of Zamia-like leaves.

In the strobili, however, extreme specialization is met in almost every feature. The bisporangiate character, the closely enveloping bracts, the monadelphous and pinnate microsporophylls bearing synangia, the admixture of sterile and fertile megasporophylls, the reduction of the fertile megasporophyll to a single pedicel bearing a terminal erect orule, the organization of both kinds of megasporophylls into a compact fruiting body, the development of an embryo which destroys completely the endosperm during its intraseminal develop- 
ment, all taken together present a combination of characters that serves to set the group very distinctly apart from other gymnosperms, and suggests that it represents the end of a gymnosperm phylum.

The testimony, on the whole, indicates that the Cycadofilicales gave rise to at least two mesozoic phyla: one with monosporangiate strobili, represented in the present flora by Cycadales; the other with bisporangiate strobili, which culminated in the Bennettitales and is probably not represented in the present flora. Whether there was first a common stock from the Cycadofilicales, which later differentiated into the two groups, or the two groups emerged from the Cycadofilicales independently, is a question that can be discussed rather than decided $(27)$.

\section{LITERATURE CITED}

I. Lindley, J., and Hutton, J., Fossil flora of Great Britain. I830.

2. Carruthers, W., On gymnospermatous fruits from the secondary rocks of Britain. Journal of Botany 5: I-2 I. I 867 .

3. Willianson, W. C., Contributions towards the history of Zamia gigas. Trans. Linn. Soc. Bot. 26:663-674. pls. 52, 53. 1870.

4. Carruthers, W., On fossil cycadean stems from the secondary rocks of Great Britain. Trans. Linn. Soc. Bot. 26:675-708. pls. 54-63. 1870 .

5. Solurs-Laubach, H., Ueber die Fructification von Bennettites Gibsonianus Carr. Bot. Zeit. 48: $789-798,805-8$ I5, 82 I-833, 843-847. pls.9, Io. I890.

6. — Fossil botany. English translation. Oxford. I89r.

6a. Potoní, H., Lehrbuch der Pflanzenpalaeontologie. Berlin. I899.

7. Wieland, G. R., A study of some American fossil cycads. I. The male flower of Cycadeoidea. Amer. Jour. Sci. IV. 7:223-226. pls. 2-4. I899.

8. - - A study of some American fossil cycads. II. The leaf structure of Cycadeoidea. Amer. Jour. Sci. IV. 7:305-308. pl. 7. I899.

9. - - A study of some American fossil cycads. III. The female fructification of Cycadeoidea. Amer. Jour. Sci. IV. 7:383-39r. pls. 8-10. I899.

го. Scott, D. H., Studies in fossil botany. London. Igoo.

Ir. WARD, Lester F., The Cretaceous formation of the Black Hills as indicated by the fossil plants. I Ith Annual Report U.S. Geol. Survey. Igoo.

I2. - Description of a new genus and twenty new species of fossil cycadean trunks from the Jurassic of Wyoming. Proc. Wash. Acad. Sci. I:253300. pls. I4-2I. 1900 .

I3. - Elaboration of the fossil cycads in the Yale Museum. Amer. Jour. Sci. IV. 10:327-345. pls. 2-t. I900.

r4. Wieland, G. R., The Yale collection of fossil cycads. Yale Sci. MIonthly 6: $\mathrm{x}-\mathrm{xI}$. pl. I. I 900 . 
15. Worsdell, IV. C., The affinities of the mesozoic fossil Bennettites Gibsoniamus. Annals of Botany 14:717-72I. I900.

I6. Wieland, G. R., A study of some American fossil cycads. IV. On the microsporangiate fructification of Cycadeoidea. Amer. Jour. Sci. IV. I I : 423-436. I 90 I.

I7. Nathorst, A. G., Beiträge zur Kenntnis einiger mesozoischen Cycadophyten. Handl. Kgl. Srensk. Vetensk.-Akad. 36+: pp. 28. pls. 3. 1902.

I8. Lignier, O., Le fruit du Whlliamsonia gigas Carr. et les Bennettitales, documents nouveaux et notes critiques. Mém. Soc. Linn. Normandie $21: 19^{-56}$. figs. 9. 1903 .

19. - Notes complémentaires sur la structure du Bennettites Morieri. Bull. Soc. Linn. Normandie V. 8:3-7. figs. 3. 1905.

20. Wieland, G. R., The proembryo of the Bennettiteae. Amer. Jour. Sci. IV. I 8:445-447. pl. 20. I904.

21. Oliver, F. W., Pteridosperms and angiosperms. New Phytologist 5:232242. Ig06.

22. Wreland, G. R., American fossil cycads. Publ. No. 34, Carnegie Institution of Washington. pp. 296. pls. 5o. figs. I38. 1906.

23. Worsdell, W. C., The structure and origin of the Cycadaceae. Annals of Botany 20:129-I59. figs. 17. I906.

24. Arber, E. A. Newell, and Parkin, John, On the origin of angiosperms. Jour. Linn. Soc. London Bot. 38:29-80. 1907 .

25. Lignier, O., Le fruit des Bennettitées et l'ascendance des Angiospermes. Bull. Soc. Bot. France IV. 8: I-I7. I908.

26. Wieland, G. R., Historic fossil cycads. Amer. Jour. Sci. IV. 25:93-IoI. Igo8.

27. Coulter, John M., Evolutionary tendencies among gymnosperms. Bot. Gazette 48:8I-97. I909.

28. Sсотт, D. H., The paleontological record. II. Plants. Darwin and modern science, pp. 200-222. Cambridge University Press. I9o9.

29. - - Studies in fossil botany. Second edition. Vol. II. London. Igog.

3o. Wieland, G. R., 'The Williamsonias of the "Mixteca Alta." Bot. Gazette 48:427-441. figs. IO. I909.

3I. Nathorst, A. G., Palaeobotanische Mitteilungen. VIII. Handl. Kgl. Svensk. Vetensk.-Akad. 45: no. 4. I9Io. 


\section{CHAP'TER III}

\section{CYCADALES}

The living cycads form a small natural group containing only nine genera and less than one hundred species, all of which are tropical or subtropical. Four of the genera belong exclusively to the western hemisphere and the other five to the eastern.

Of the western genera, Zamia contains about thirty species and ranges from southern Florida to Chili. The three other genera are very limited both in number of species and in distribution: Microcycas is monotypic and confined to western Cuba; Dioon, with three species, is found only in southern Mexico; and Ceratozamia, with two or perhaps more species, has about the same range as Dioon, with which it is associated in some localities.

Of the five eastern genera, Cycas is the most prominent, both in number of species and in distribution, its sixteen species ranging from Japan to Australia. The four other genera are very restricted: Macrozamia, with fourteen species, and the monotypic Bowenia belong to Australia; while Encephalartos, with twelve species, and Stangeria, with two or more species, belong to southeastern Africa.

The genera are sharply defined, but such species as are based only upon leaf characters are open to suspicion, because the leaves vary greatly with the age of the plant. In Igor, when the first edition of this book was written, little was known of the morphology of any of the cycads except the widely ranging and consequently easily accessible Cycas and Zamia. Since then, Dioon, Ceratozamia, and Microcycas have been studied, so that the life histories of all the occidental genera are quite well known. Some additional information in regard to the oriental genera is also available, but many important features in the life histories of the Australian and African forms are still unknown. This increased knowledge of the cycads thenselves, together with extensive studies of the Cycadofilicales and Bennettitales, allows a more satisfactory presentation of the group than was possible a few years ago.

The cycads are distinguished from the other living gymnosperms 
and from the Cordaitales by the unbranched stem, with a terminal rosette of comparatively few, large, branched leaves, which gives the

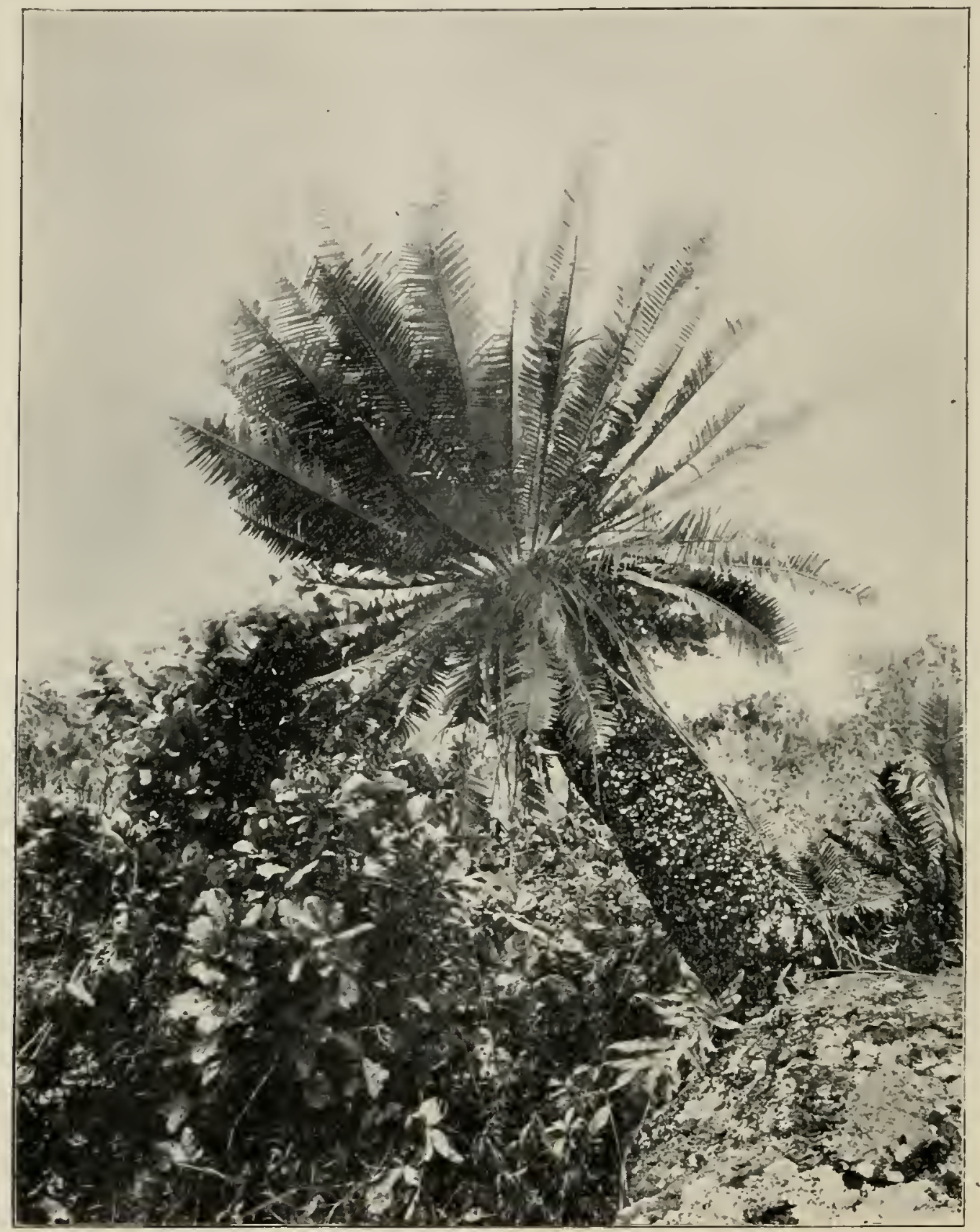

Fig. 7o.-Dioon edule: ovulate plant on rocky hillside at Chavarrillo, Mexico; the trunk is $1.5 \mathrm{~m}$. high, and shows the armor of leaf bases throughout its entire length.--After ChaMiBerLain (46).

1 columnar forms the habit of the tree ferns or palms (fig. 70 ). The definitely organized strobili readily separate the cycads from the 
Cycadofilicales, and the monosporangiate strobilus separates them from the Bennettitales. The multiciliate sperm, now demonstrated for all the genera except Macrozamia, Bowenia, and Encephalartos, and certainly present in these three also, is a character shared by Ginkgo, and doubtless by all of the extinct orders.

\section{The vegetative organs}

The stems are columnar or tuberous, the former kind prevailing and often becoming quite tall. The Australian Cycas media reaches a height of more than twenty meters; the Mexican Dioon spinulosum (fig. 7I) becomes twelve meters high; the Cuban Microcycas is nearly as tall; while Encephalartos, Ceratozamia, and some species of Macrozamia form trunks of considerable size. In the tuberous forms the stem is either entirely subterranean or appears more or less above the surface. All stems are typically unbranched, but branched individuals are not rare in cultivation and are readily found in the field (fig. 72). Doubtless all the genera have their branching individuals, but most of the branching is due probably to injuries or to the germination of seeds in the nest formed by the crown of leares.

A striking feature of the cycad trunk, especially in the columnar forms, is the investing armor of leaf bases, recalling the large persistent leaf bases of the marattiaceous ferns. In some forms, as in Dioon edule, the armor is so persistent that even in an old plant the number of leaves which it has produced can be determined with reasonable accuracy. From the number of leaf bases, the average number of leaves in a crown, and the duration of the crown, the age of a plant can be estimated. The plant shown in fig. 70, with a trunk less than two meters high, is probably about $\mathrm{x}, 000$ years old. In the smaller tuberous forms and in some species of Cycas, the armor is not so persistent, and may be visible for only a short distance below the crown, the lower portion of the stem becoming quite smooth and free from leaf bases.

\section{VASCULAR ANATOMY}

A transverse section of the stem of a cycad (fig. 73) shows a large pith, a relatively thin vascular cylinder of collateral endarch bundles, and a very thick cortex containing the numerous conspicuous "girdles" 
(leaf traces). The contrast with stems of Ginkgoales and Coniferales is striking, these groups having relatively small pith, very thick

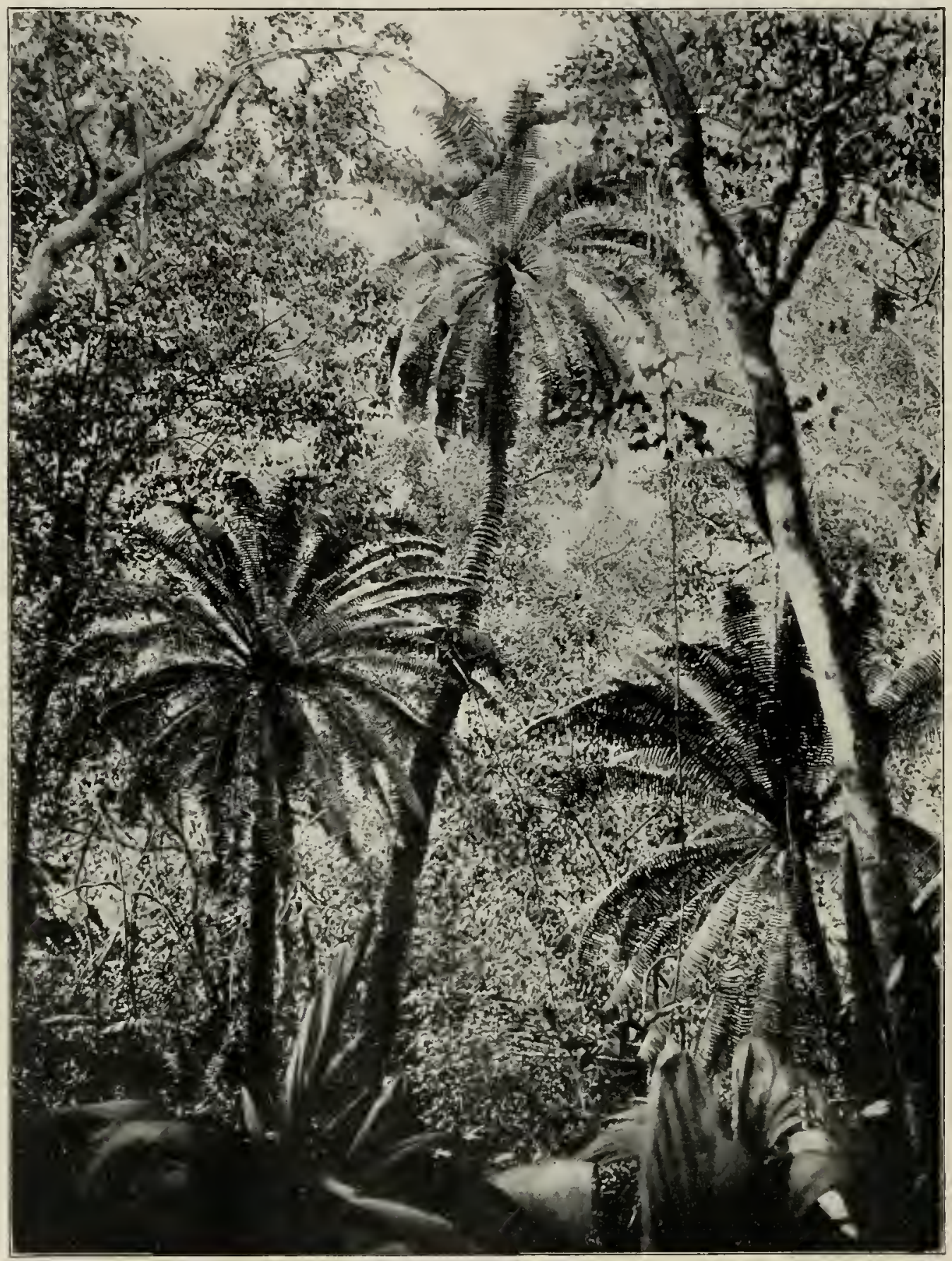

Fig. 71.-Dioon spinulosum: on the Hacienda de Joliet near Tierra Blanca (Mexico), March I908; the tallest plant is about $10 \mathrm{~m}$. in height.-After CHAMBERLAIN (64).

vascular cylinders, and a comparatively thin cortex. Systems of mucilage canals occur in the cortex and in the pith, connecting with 


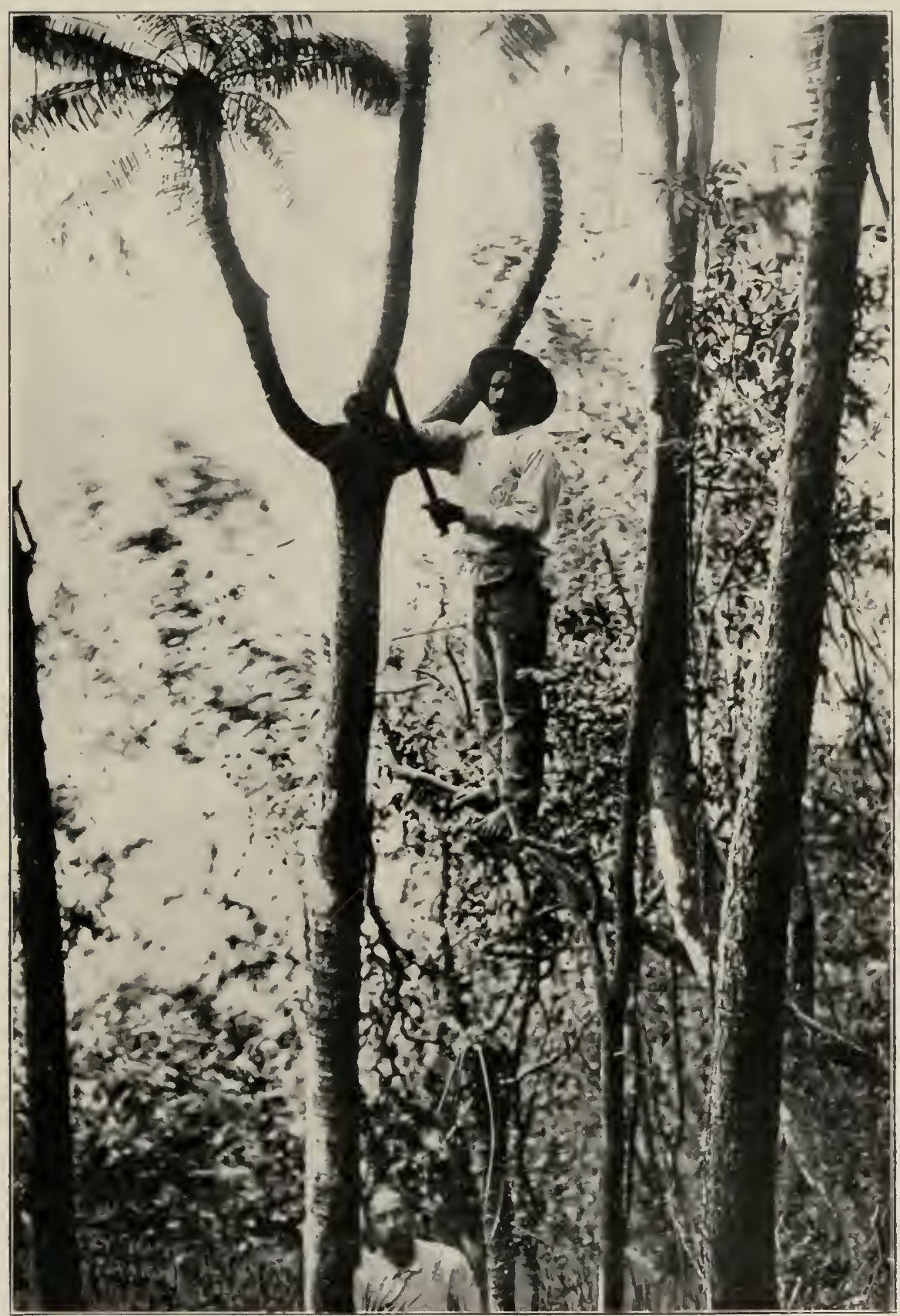

F1c. 72.-Microcycas calocoma: three plants; the one at the right $(0.5 \mathrm{~m}$. high $)$ shows neither crown nor base; the height of the middle branching specimen is suggested by the two men, one of whom is standing on the ground. - After C.MLWELL (52). 
one another through the foliar gaps. The presence of foliar gaps is an evidence of fern connection, and this is confirmed by the usual occurrence of mesarch bundles and sometimes of concentric bundles in all regions of the vascular system outside of the primary cylinder. If such bundles as occur in leaf traces, leaves, peduncles, and cotyledons, were present in the primary cylinder, it would correspond to that of Lyginodendron, which is that of Filicales except for the secondary wood.

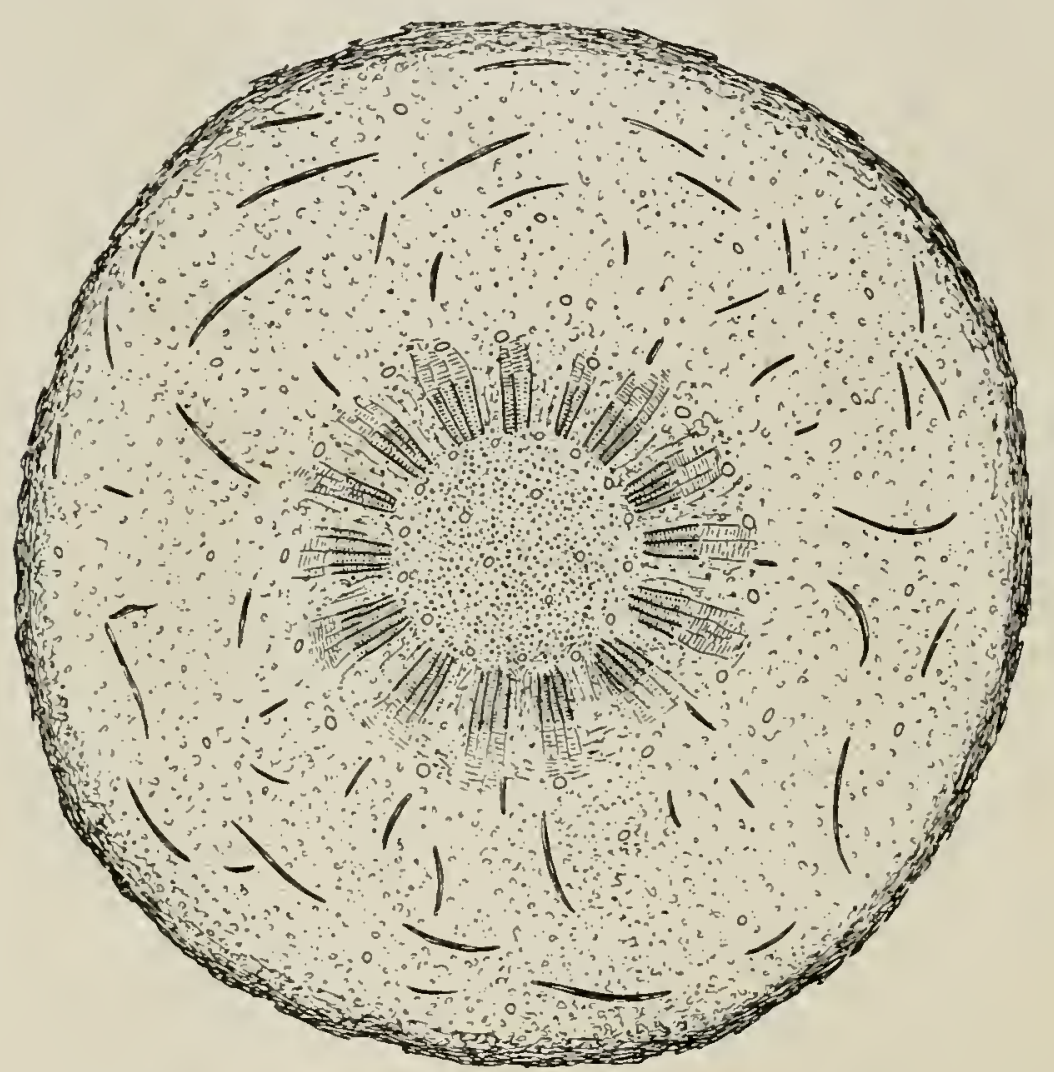

FIG. 73.-Zamia floridana: transverse section of stem, showing the large pith, rather narrow zone of xylem and phloem, and the thick cortex traversed in various directions by oblique sections of the leaf traces (girdles); about natural size.-After COUlter (75).

A historical résumé of the development of knowledge in reference to the vascular anatomy of the stem of Cycadales has been published by WORSDELL (20), from which the following facts are obtained. In I829 Brongniart (I) described the stem of Cycas revoluta, refuting the idea that cycadean stems are similar to those of monocotyledons. In I832 Vox MoHL (2) investigated Cycas and Encephalartos, discovering in a species of the latter genus the meshwork of vascular 
bundles in the pith. In I 84 I Miquel (3) published his monograph of the group, and included the anatomy of sereral genera. In I86I Mettenius (4) published the account of cycadean stems which long remained the chief source of information concerning them, including Cycas, Encephalartos, Dioon, and Zamia, and discovering in the last two genera none of the secondary cortical bundles characteristic of the first two. In I885 Constantin and MOROT (I 4 ) investigated Cycas siamensis, and stated that the cortical cambium has its origin in the pericycle. In I89o Solms-Laubacir (I6) traced the rascular bundles of Stangeria from the peduncles to the stem cylinder, and

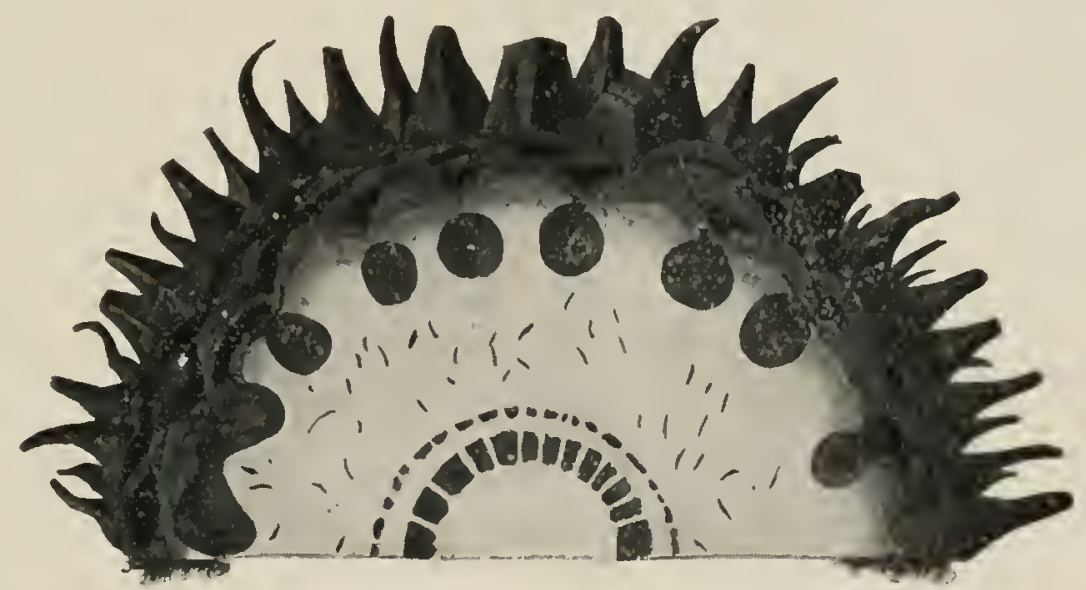

Fig. 74.-Cycas rezoluta: transverse section of stem, showing pith, two concentric zones of xylem, cortex, and armor of leaf bases; one-half natural size.-After Broxg$\operatorname{NIART}(\mathrm{I})$.

found no evidence of cortical bundles. In i89i Strasburger (I 7 ) brought together the knowledge of stem anatomy with reference to Cycas, but did not include other genera. Then came the work of Worsdell on Macrozamia (20) and Bowenia (30), and that of ScotT (23) on the peduncles of cycads. Since igoo the vascular anatomy of cycads has been investigated with increased intensity, including every region of the body, and especially the seedling.

The primary cambium may be short-lived, as in Cycas; or it may be persistent, as in Zamia, Dioon, and Stangeria. Even when it is persistent, the accumulation of secondary xylem is very slow, and there are no growth rings even when the stem is several years old. In case the cambium is short-lived, a succession of secondary cambiums in the cortex produce cortical cylinders (fig. 74). The first cortical 
cambium produces a vascular cylinder as prominent as the primary one; the second derelops much smaller and more widely separated bundles; and this continues with diminishing constructive power until the outermost cylinder is recognized only by the appearance of a small bundle here and there. These cortical bundles are produced in Cycas, Encephalartos, Macrozamia, and Bowenia; and in Cycas they are concentric. In Macrozamia and Bowenia Worsdell $(20,30)$ discorered a tertiary cambium, appearing between the successive secondary cambiums, and giving rise to small intermediate bundles with reversed orientation, the xylem being directed toward the xylem of the next outer bundles. This suggested that the original structure of all the cortical bundles of these genera was concentric, and that in the layers of concentric bundles the meristem of the inner portion of each bundle became gradually less functional, until in most cases the concentric bundles have become collateral. The cortical concentric bundles of Cycas, the concentric bundles in the peduncles and leares of sereral genera, the evidence of incomplete concentric bundles in the cortical cylinders of Macrozamia and Bowenia, all indicate derivation from an ancient stem type in which layers of concentric bundles were developed, such a type as exists among the Cycadofilicales (23).

In Encephalartos and Macrozamia a system of bundles is also developed in the pith, forming a dense network, each bundle being accompanied by a mucilage canal in contact with the phloem. Some of the smaller bundles pass out through the leaf gaps, the xylem and phloem strands joining the corresponding elements of the primary cylinder, and the mucilage canals passing on to join the cortical canal system.

An account of the anatomy of the seedlings of Ceratozamia, Dioon, Microcycas, and Zamia will furnish a basis of comparison. Ceratozamia is peculiar in the fact that one of the cotyledons is abortive, but it has been made to develop by eliminating the influence of gravity (58). The seedling has been investigated by Sister Helen Axgela (59), the outline of whose results is as follows. The vascular plate of the transition region is irregularly four-cornered, all of the xylem being in the center, sometimes in a solid mass, sometimes interspersed with pith cells (fig. 75). This protostelic condition may 
persist above the plate more or less, in one case for a distance of I. $6 \mathrm{~mm}$., alsove which a siphonostele is established. The derelopment of the tetrarch root is delayed, its four protoxylem poles being inserted upon the cotyledonary bundles, and the entire xylem system of the root being bordered peripherally by cambium. The single cotyledon, which is often lobed at tip, is multifascicular, usually with alternating mucilage ducts, but all the vascular strands are derived from three bundles that connect with the vascular plate (figs. 76, 77).

These three strands are not of the same rank, and their relation to the vascular plate of the transition region should be understood. Two of the angles of this plate are directed toward the center of the two cotyledons (the

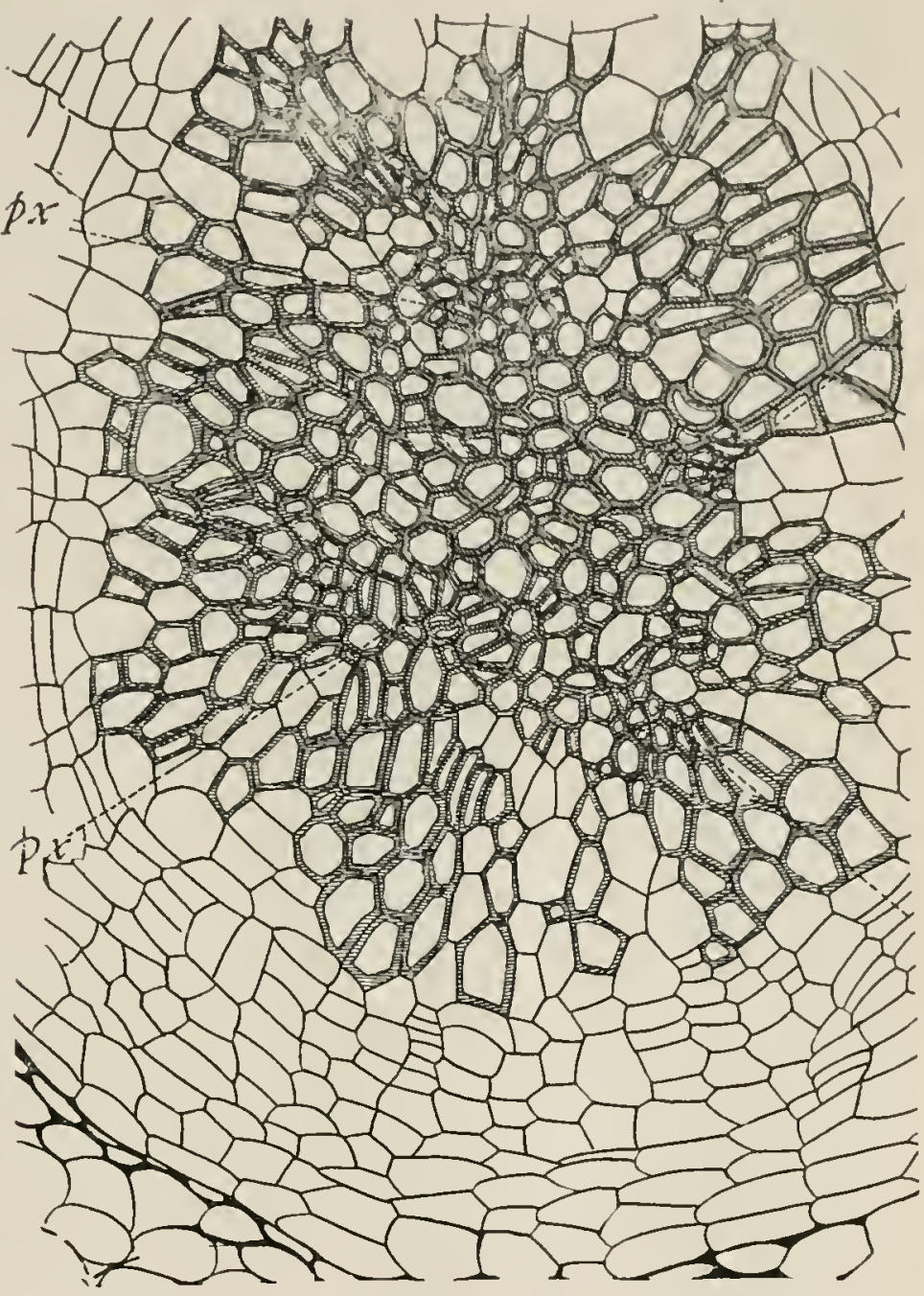

FIG. 75.-Ceratozamia mexicana: transverse section of vascular plate of seedling, showing the protostelic condition; $p x$, protoxylem; $\times 225$. - After Sistek HELEN ANGELA (59).

usual abortion of one cotyledon in Ceratozamia does not affect this orientation), and therefore may be called cotyledonary; and the other two are in the plane between the two cotyledons, and therefore may be called intercotyledonary. The median rascular strand that enters a cotyledon is connected directly with the adjacent cotyledonary angle or pole of the vascular plate, and therefore is a 
primary strand. The two lateral strands that enter a cotyledon are branches of the two primary strands that are connected with the two intercotyledonary angles or poles, and therefore are secondary strands. The primary strand from an intercotyledonary angle follows a very short radial course and then forks, the branches taking a tangential course in opposite directions and passing into opposite cotyledons. Each primary intercotyledonary strand, therefore, sends a branch

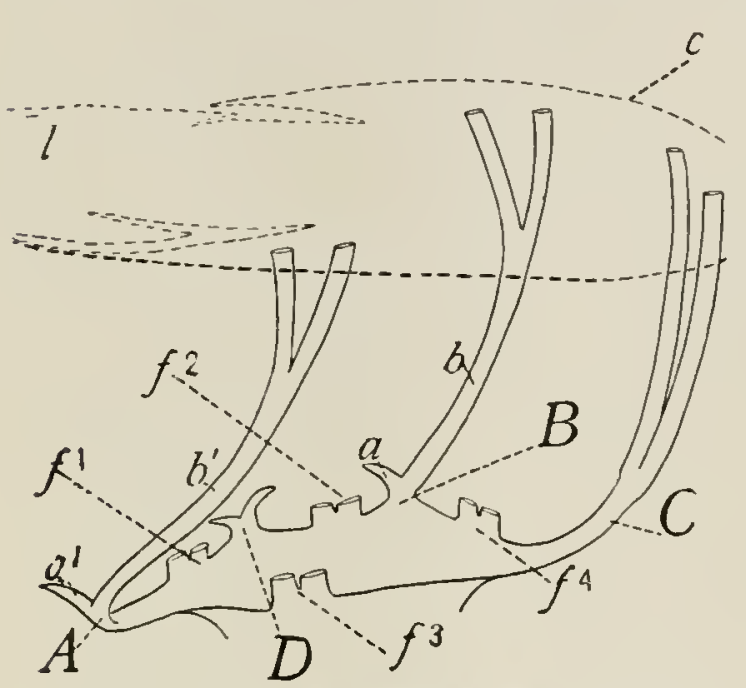

FIG. 76.-Ceratozamia mexicana: diagram representing connection of cotyledonary bundles with the vascular plate; $A, B, C, D$, the four main cotyledonary bundles; $C$, median bundle of developed cotyledon; $D$, median bundle of aborted cotyledon; $a, a^{\text {I }}$, lateral bundles of aborted cotyledon; $b, b^{\mathrm{r}}$, lateral bundles of developed cotyledon; $f^{2}, f^{2}, f_{3}, f_{4}$, the four principal groups of foliar bundles; $c$, cotyledon; l, leaf.-After Sister Helen Angela (59). into each cotyledon; while each primary cotyledonary strand is connected with a single cotyledon as its median strand. This median strand usually does not fork until well within the cotyledon of Ceratozamia; in some other cycads it forks sooner; and in others it is said to be double from the beginning. This rariation in the forking of the median strand accounts for the reports of three or four vascular bundles occurring at the base of each cotyledon. In Ceratozamia the lateral strands and also the bifurcated median strand branch, so that the cotyledon becomes multifascicular. The xylem of the cotyledonary strands is mesarch at the base of the cotyledon, but becomes exarch in the upper part.

In the early stages of the seedling several groups of extrafascicular cambium appear (fig. 78 ), but in seedlings two years old only the slightest trace of them can be found. The stem develops as a sympodium, and the number of vascular strands entering successive leaves increases, sometimes with great regularity, as from three in the cotyledon to seren in the fourth leaf. The origin of these leaf strands is exceedingly complex, as they represent a few of the ultimate branches from four (or three by the fusion of two) original foliar bundles con- 
nected with the central cylinder (fig. 79). 'There is no girdling of leaf traces in the younger stages, the traces being at first icrtical; but with the radial increase of the inclosed leares and stem tip girdling becomes apparent. 'The xylem of the leaf traces is endarch, but it becomes mesarch in the base of the leaf and remains so to the tips of the pinnac. In a later study (66) the extrafascicular cambium of the secdling of Ceratozamia was investigated. In over eighty seedlings, ranging in age from a few months to over two years, only one small extrafascicular bundle was found, although the central cylinder was surrounded by screral groups of cambium cells. If these groups should function in the production of vascular bundles, the result would be strongly suggestive of polystely. The innermost extrafascicular cambium groups arise in the pericycle, near the transition region, but the others appear later.

The vascular anatomy of the seedling of Dioon edule has been investigated by Thiessen (62), and illustrates the origin and course of the leaf traces of cycads, concerning which there has been much misapprehension. The vascular plate of the transition region is four-cornered in section, with a protoxylem group at each corner, and, as in Ceratozamia, it is protostelic and soon

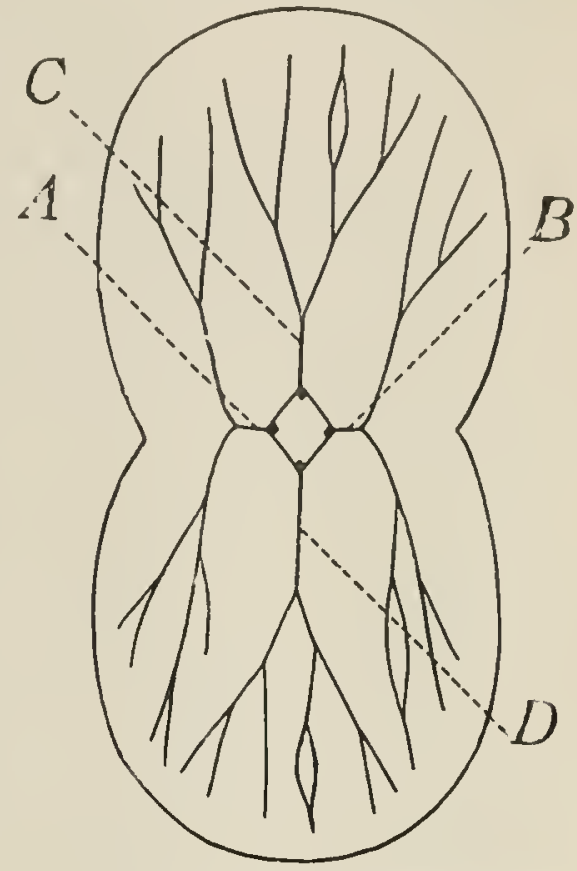

FIG. 77-Ceralozamia mexicana: diagram of vertical view of vascular supply of cotyledons, where the usually aborting cotyledon has been made to develop; $A, B, C, D$, the four main cotyledonary bundles. -Made for this work by Sister HELEN ANGELA. passes into the siphonostelic condition in the seedling stem. The four protoxylem groups of the vascular plate are continuous with those of the root, which is therefore tetrarch. The primary strands from the intercotyledonary angles of the transition plate are related to the cotyledons exactly as described above for Ceratozamia, but the primary strand from each cotyledonary angle forks, so that four strands enter the base of each cotyledon (fig. 8o).

The connections of the leaf traces of Dioon are simpler. 'The 

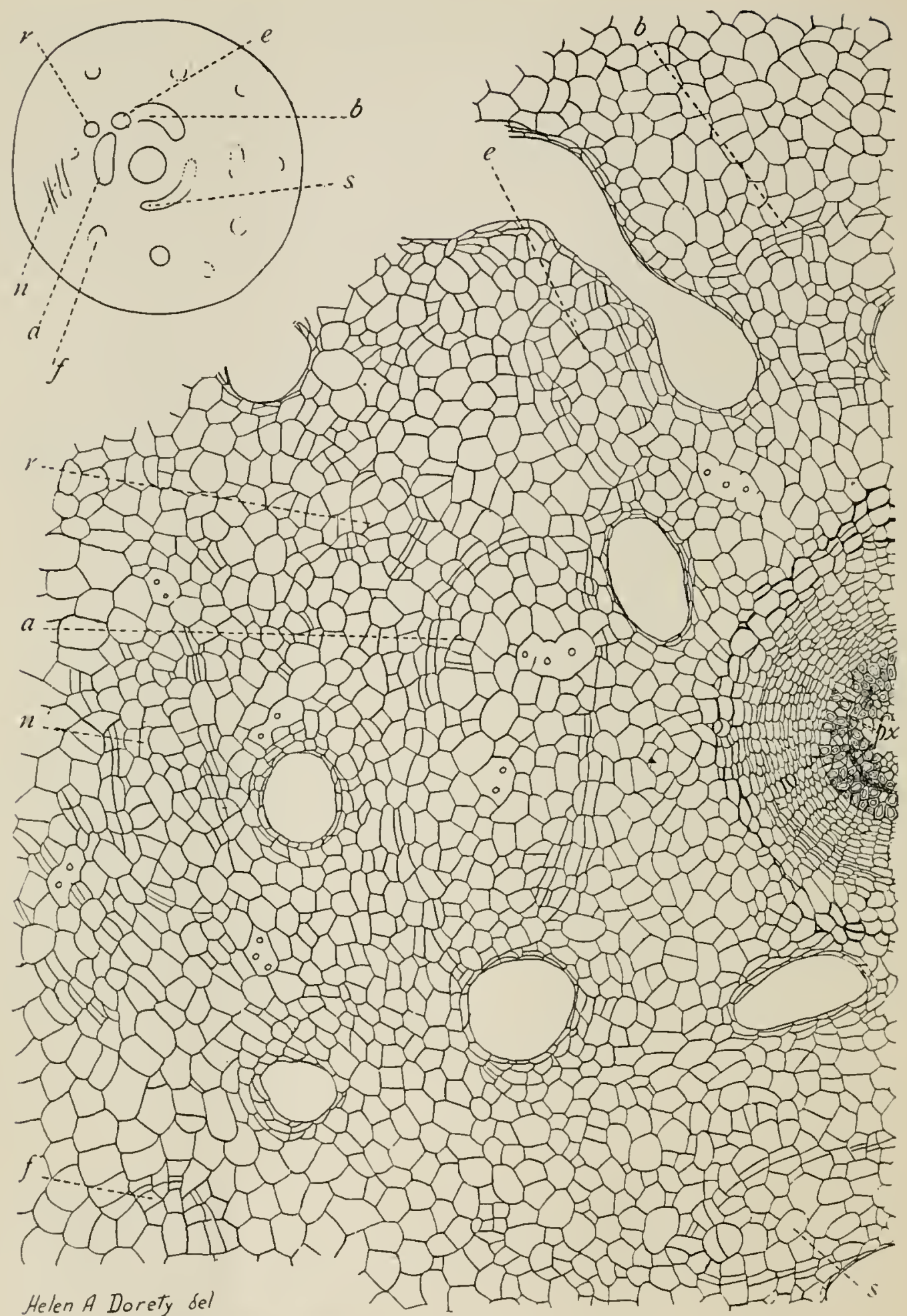

FIG. 78.-Ceratozamia mexicana: transverse section of hypocotyl slightly below exit of cotyledonary traces; the diagram shows the position of the stele, surrounded by three large groups of extrafascicular cambium $(a, b, s)$, and some smaller groups like $e$ and- $r$; the drawing shows a portion of the section indicated in the diagram, including one of the groups of extrafascicular cambium ( $a$ ), parts of $b$ and $s$, and also. the smaller groups ( $e$ and $r$ ); the bundles of the stele are mesarch, with considerable centripetal xylem.-After Sister Helex Axgela (66). 
current statement has been that two leaf traces leare the vascular cylinder on the side away from the leaf they are to enter, swing around to left and right in wide curves through the cortex, forming the characteristic girdles, and so pass to the leaf. This needs amendment as follows. As usual in cycads, a variable number of scales succeed the cotyledons before true foliage leares are dereloped, but the traces of scales and leares are the same. In Dioon four strands leave the central cylinder for cach scale or leaf, at indefinite but well-distributed points. Two of them leave approximately on the side of the cylinder toward the leaf, and without branching pass more or less directly through the cortex to the petiole. The two other strands leave the central cylinder approximately on the opposite side, describe wide right and left curves about it through the cortex, and so enter the petiole, where they begin to branch freely (fig. 8I). The leaf traces of the cycads, therefore, include not only "girdles," but also direct traces. The vascular

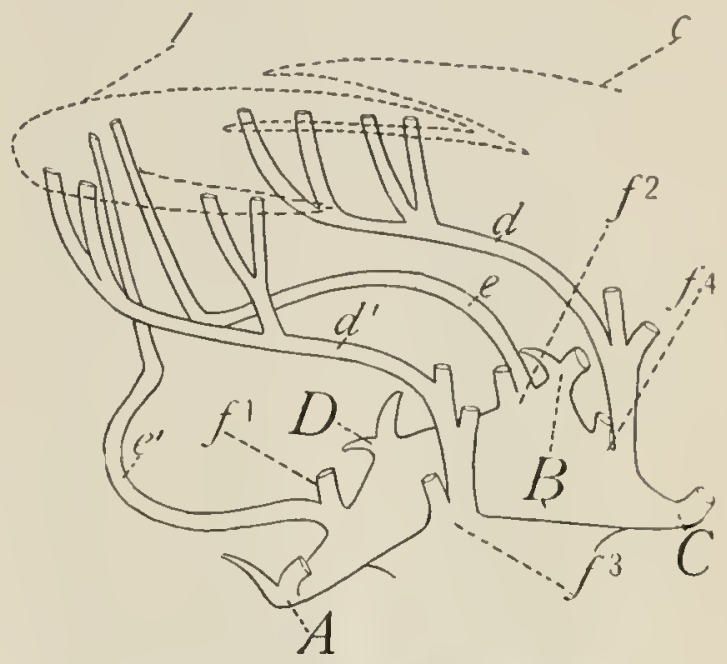

FIG. 79.-Ceratozamia mexicana: diagram of vascular plate of seedling, showing origin of leaf bundles; $d, d r$, lateral traces of first leaf; $e, e^{\mathrm{I}}$, middle traces of same; rest of lettering as in fig. 76 .-After SisteR HELEN ANGELA (.59).

strands of both leaves and cotyledons are endarch at their junction with the cylinder, but gradually become mesarch, and in the upper stretches of leaf or cotyledon the exarch condition is approached more or less completely. This transition from endarch to mesarch and perhaps exarch secms to be a common feature of the foliar strands of cycads.

The origin of the "girdle" is a very obscure problem. In connection with Ceratozamia it was stated that the girdling became erident in connection with the diameter increase of the inclosed group of leaves and stem. It would be a natural inference that the curve of the girdle is produced by the growth of the group of organs within; but in Dioon it is evident that the girdle is established in the procam- 


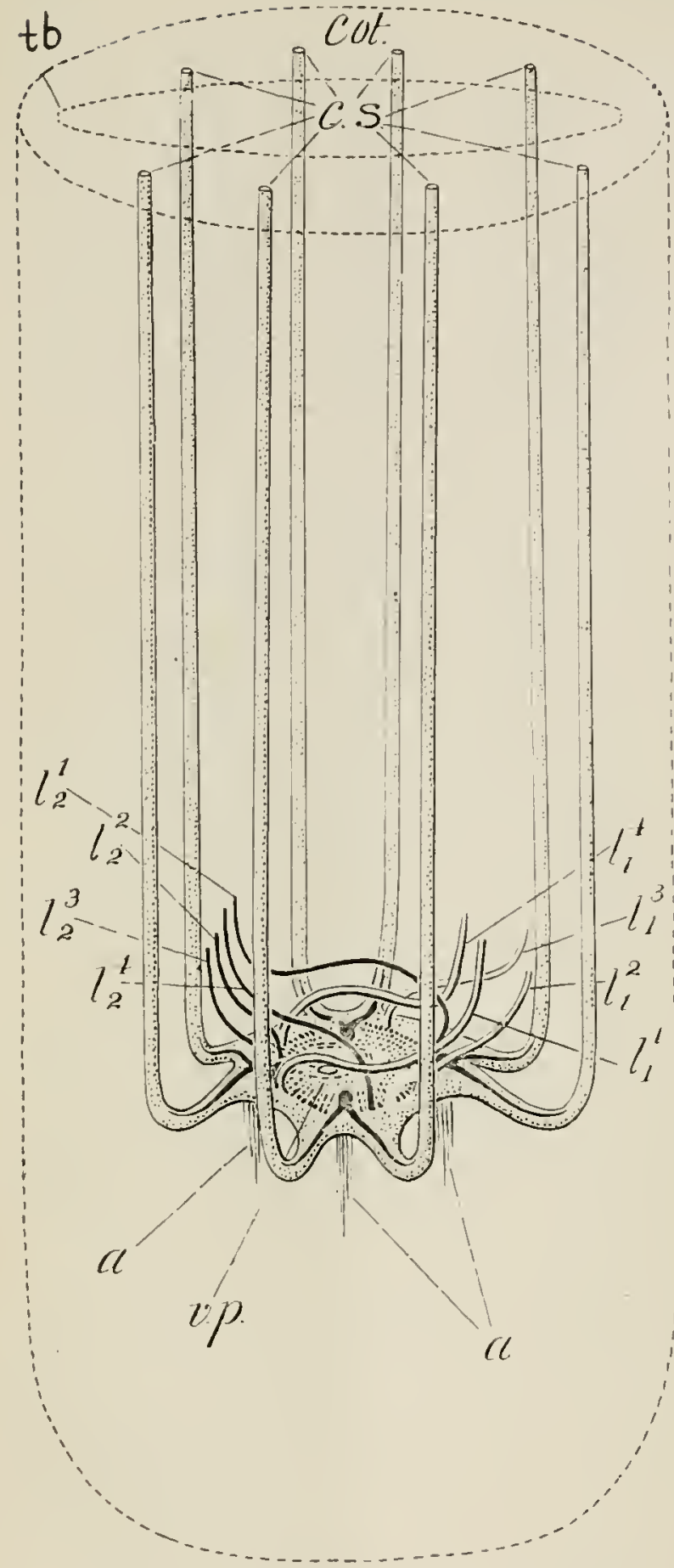

Fig. So.-Dioon edule: semi-diagrammatic reconstruction of part of vascular svstem of embryo; col, cotyledon; $t b$, tubular part of cotyledons; $c s$, cotyledonary strands; li-li, foliar strands of first leaf; $l \frac{1}{2}-l \pm$, foliar strands of second leaf; $2 \cdot p$, vascular plate; $a$, protoxylem elements continuing downward into the hypocoty.-After ThIESSEN (62). bial stage of the strand, and that its final course is laid down from the beginning.

The seedlings of Zamia (Z. floridana and Z. integrijolia) have been studied recently by MatTe (68) and are found to confirm the results obtained from the preceding genera. The vascular plate of the cotyledonary node is a protostele, and each cotyledon receives three vascular strands, as described for Ceratozamia. At the base of the cotyledon the strands are mesarch or even concentric, but in the middle region they become exarch and remain so to the tip, where transfusion tissue occurs and probably has replaced the centripetal xylem. The tap root is of the usual tetrarch type, becoming reduced to triarch or even diarch toward the tip.

The study of the seedlings of Microcycas by SisTeR Helen Angela (65) confirms the general situation described for Ceratozamia, Dioon, and Zamia, and shows some interesting variations. Microcycas is peculiar in the extensive 
fusion of its cotyledons. 'They arise as two distinct organs, but in the older embryos the fusion is so complete that serial sections from the apex downward almost to the apex of the plumule do not reveal the characteristic "seam," in many" cases the abutting epidermal layers having disappeared. As in Ceratozamia, there is no "resting stage" of the embryo, which emerges from the testa as soon as it is formed. In Ceratozamia, Dioon, Microcycas, and Zamia, and presumably in other cycads, the root is much delayed in its derelopment, not being formed when the base of the embryo ruptures the testa and exposes a small brown disk of disorganized tissue, which represents the remains of the once extensive coleorhiza, and through which the root may not penetrate until the soil is reached or even until after the exit of the plumule.

An interesting deviation is shown in Microcycas by the vascular cylinder of the transition region, which is not a protostelic plate, as in the preceding cases, but is siphonostelic from the beginning (fig. 82). The four cotyledonary strands remain distinct, and

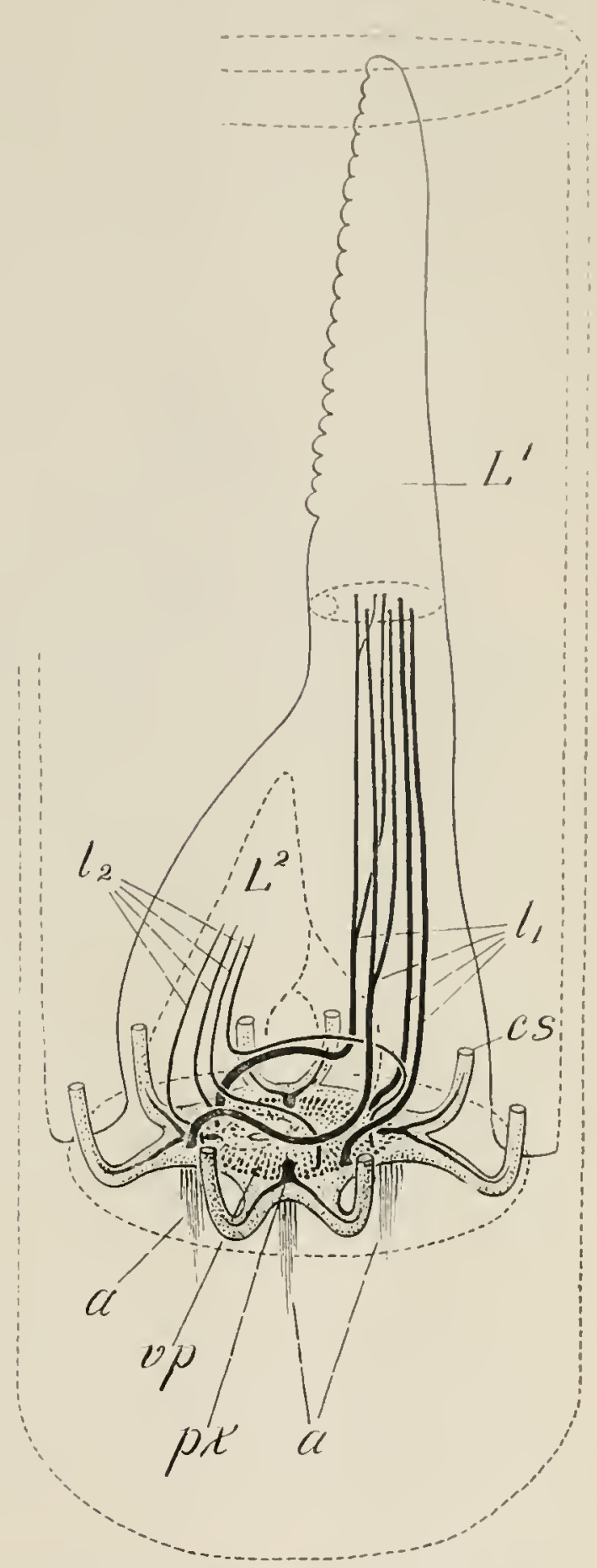

Fig. 81.-Dioon edule: semi-cliagrammatic reconstruction of part of vascular system of embryo, to show especially the girdling; $l_{\mathrm{I}}, l_{2}$, traces of first and second leaves $\left(L^{\mathrm{I}}, L^{2}\right)$; ¿'p, vascular plate; $p x$, protoxylem groups; $a$, xylem elements continuing from protoxylem groups of plate to form the protoxylem of the primary' root.-After 'THiessex" (62). 
their elements become continuous with those of the four poles of the root, which is at first tetrarch, but may become triarch toward the tip. Each cotyledon contains eight or ten rascular strands, with alternating mucilage ducts, the strands being all derived from the branching of three main bundles that join the central cylinder. In the young stem four large groups of leaf traces alternate with the four cotyledonary groups, and just abore the cotyledonary node they close together

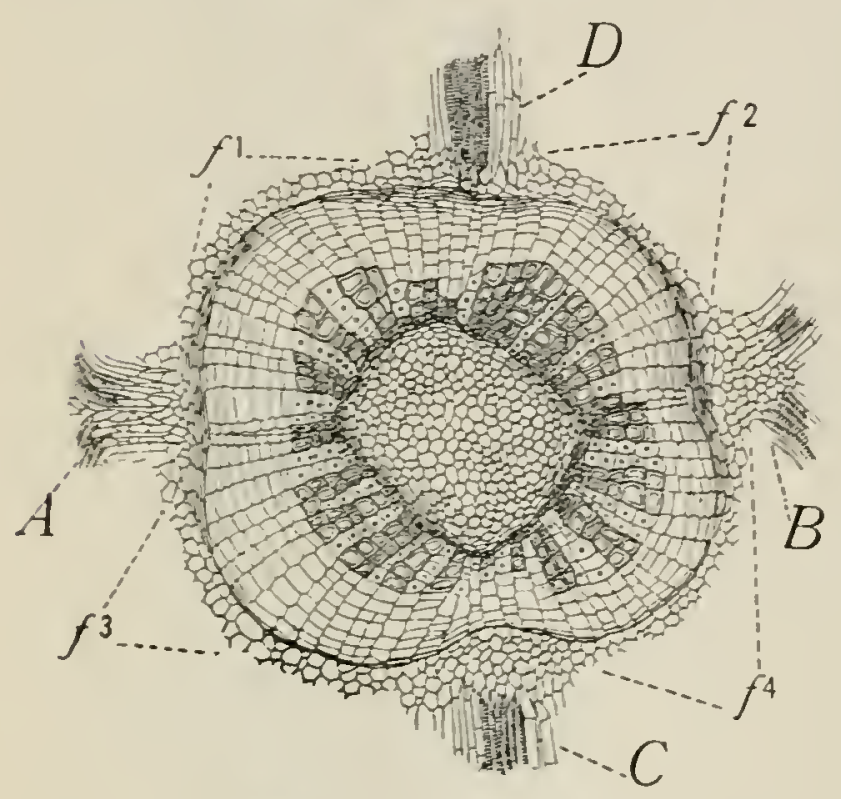

FIG. 82.-Microcycas calocoma: semi-diagrammatic transverse section of the central vascular system of the seedling above the cotyledonary node, composed of four groups of leaf traces $\left(j^{1}, j^{2}, j^{3}, j^{4}\right)$; $A, B, C, D$, main cotyledonary traces.-After Sister Helex Aligela (65).

cortex of the young stem, not so distinct as in Ceratozamia and never forming an extrafascicular bundle.

The seedlings of these four genera may be regarded as representative of the seedlings of cycads in general, and the situation may be summarized as follows: At the cotyledonary node there appears a quadrangular protostelic plate or a siphonostelic grouping of four sets of cotyledonary strands (Microcycas), in both cases connecting with the four poles of the tetrarch root, which later may become triarch or even diarch. At the base of the cotyledon three or four vascular strands occur. connected with three of the poles of the quadrangular vascular plate. In Zamia and Dioon edule these strands seldom 
branch, so that the cotyledons contain only four vascular strands. and this seems to be true also of some species of Cycas, of Macrozamia, and of Stangeria; but in Ceratozamia the branching may reach twelve cotyledonary strands; and in Dioon spinulosum. Microcycas. and Bowienia the branching is even more extensive. When the root is diarch, as in some species of Cycas, it is the intercotyledonary poles that are suppressed, and although the corresponding strands are represented in each cotyledon, their basal endings are free in the cortex. The leaf traces are usually four in number; the two inner ones arising from the proximal side of the central cylinder and being more or less direct; the two outer ones arising from the distal side of the central cylinder and forming the characteristic girdles of the cortex in their course to the leaf.

In a general review of seedling anatomy Miss Thous (57) concludes that in all cycads four or six vascular strands enter the cotrledon, and that the primary root is prevailingly tetrarch, with a strong tendency to become reduced toward the apex to the triarch or diarch condition. For example, in Cycas siamensis there are four cotyledonary strands. but in connecting with the root two of the strands (the intercotyledonary ones) die out and the root is diarch.

In a similar review of the seedling anatomy HILL and DE FRAINE $(67)$ conclude that the number of rascular bundles at the base of each cotyledon ranges from two to eight; that these bundles in general are mesarch and become exarch; that the transition phenomena occur so rapidly that most of the hypocotyl shorrs root structure; that the cotyledonary strands are not of equal value in the production of root structure; and that after the initial root structure is attained the number of poles may be increased at lower levels.

Certain occasional situations have been recorded, which are interesting not only in what they imply, but also in suggesting a search for their wider occurrence. For example, the concentric bundles at the base of the cotyledons in Stangeria, the polystelic condition in the earlier stages of the peduncle of Encephalartos, the cortical strands in the base of the peduncle of Dioon (6I), and the mucilage canals in the root of Dioon are all features that fit into the general anatomical condition of the cycads, as described above.

In his conclusions from an inrestigation of the vascular anatomy 
of cycads MatTe (40) lays special stress on foliar strands, which he regards as of more phylogenetic importance than the vascular axis of the stem, his unit of structure being the "meriphyte." In this work the leaves and sporophylls of representative species of all the genera were examined, and the seedlings of Cycas, Dioon, and Encephalartos. The well-known omega $(\Omega)$ outline of the foliar arc was found to hold for the whole group, even the complex arrangement of the strands of Bowenia (43) being referable to it. He also discovered in the ovulate sporophyll of Ceratozamia (35) three or more accessory vascular strands near the abaxial surface, in addition to the usual transverse row of strands; and inferred from their inverse orientation (xylem abaxial) that the sporophyll is really a union of two sporophylls.

\section{THE LEAF}

The crown of large leares at the apex of the stem gives the cycad its palmlike or fernlike aspect. In Dioon edule, as it grows in the field, a new crown of foliage leaves is produced every other year. When just unfolding, the new crown is easily distinguished from the previous one (fig. 83), but a few months later, after the new crown has fully expanded, the presence of two crowns can scarcely be noticed. In fig. 70 the leaves of the new crown are obliquely erect, while those of the previous crown are horizontal or somewhat reflexed. Below this older crown may be seen some midribs of leaves of a still older crown, the leaflets having fallen off. Below these naked ribs may be found all stages down to the typical crown of persistent leaf bases. It is certain that in greenhouses a crown of Dioon edule may persist much longer than two years. In Cycas revoluta it is said that a crown is formed every other year, but information in regard to the duration of crowns, as they occur in the field, is scanty and uncertain. In seedlings there is only one leaf, or occasionally two, and for a considerable period the leaves appear singly at irregular intervals, the production of a whole crown of leaves at one time being a feature of the later history of the individual.

The leaves are once-pinnate in all the genera except Bowenia, in which they are twice-pinnate. They vary in length from $10 \mathrm{~cm}$. in Zamia pygmaea to more than $3 \mathrm{~m}$. in some species of Cycas. The number of leaflets varies greatly eren in adult leaves, which in Dioon 
edule often have more than roo leaflets on each side of the rachis. The number increases gradually with the age of the plant, the first

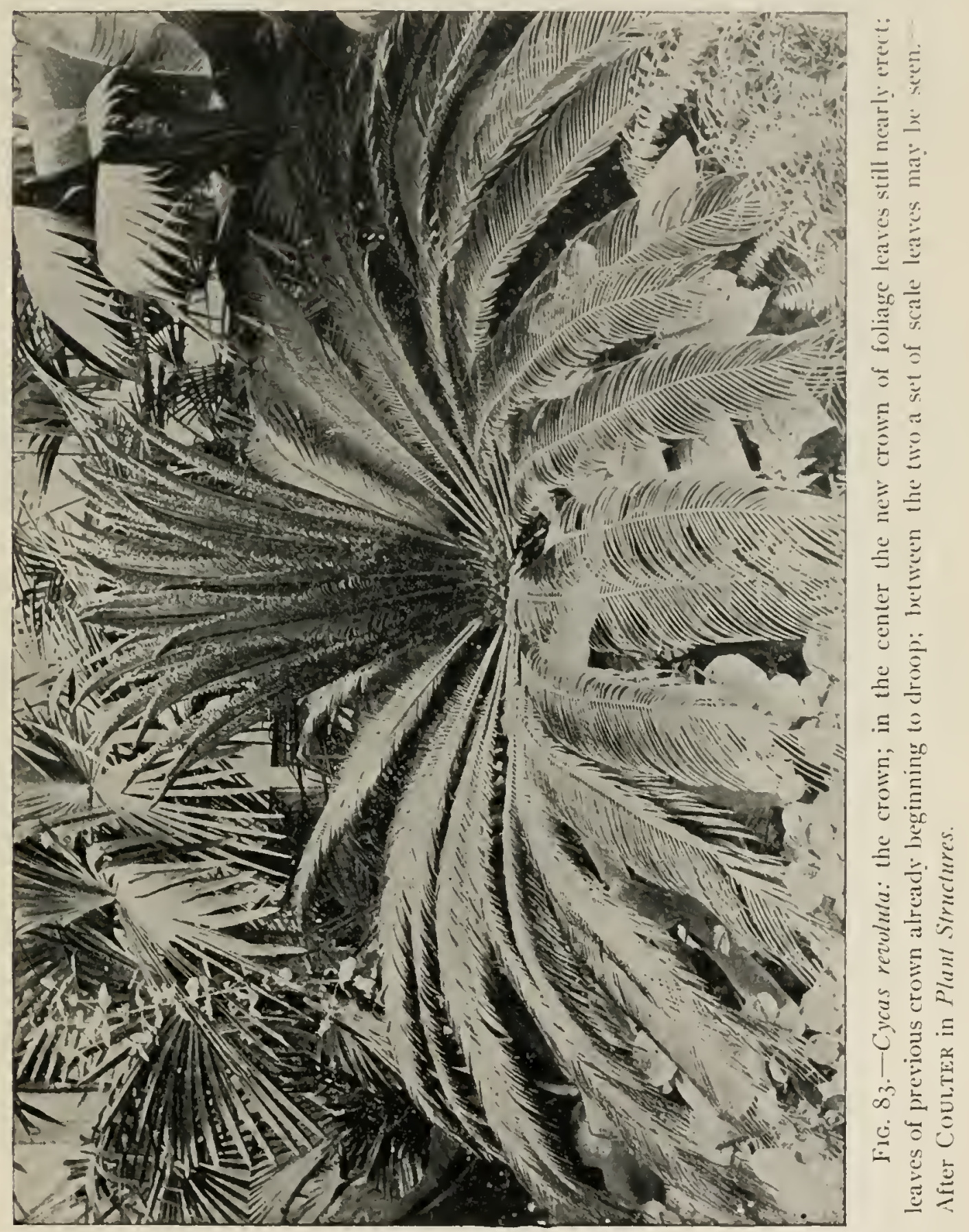

leaf of Ceratozamia having two or four leaflets, while the leaf of a fully grown plant has as many as roo. The margins of the leaflets are entire or variously serrate (figs. $84-89$ ), while in Macrozamia heteromera they are dichotomously branched. In Dioon edule the 
leaflets of the seedling are conspicuously spinulose, like the adult leaflets of $D$. spinulosum, but in older plants the margins are perfectly smooth, the spinulose condition of the seedling of $D$, edule being a jurenile character indicating an ancestry with spinulose leaves (figs. 84-87). The renation is various; for example, the leaflets of $C y c a s$ have only a midrib without any branches; those of
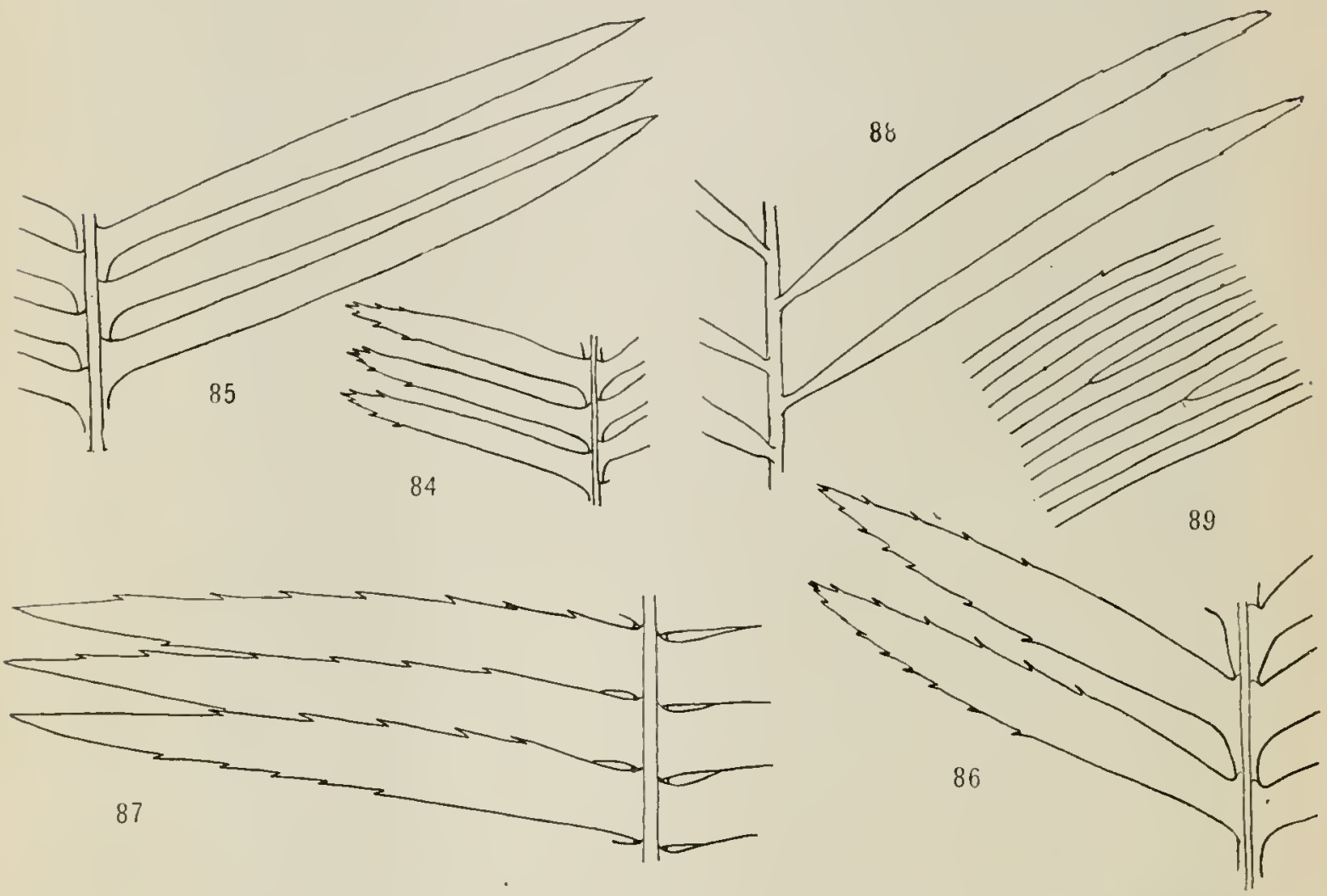

FIGS. $S_{4}-89$.-Pinnules of cycads: fig. $S_{4}$, part of leaf of seedling of Dioon edule; fig. 85 , part of adult leaf of same; fig. 86, part of leaflet of seedling of Dioon spinulosum; fig. 87, part of adult leaf of same; fig. 88 , part of adult leaf of Zamiu floridana; fig. 89 , detail of venation of leaf of Zamia floridana; figs. $S_{4}-88$, one-half natural size; fig. $S_{9}$, $x_{4}$.

Stangeria have a midrib with numerous veinlets; those of other genera have no midrib, but form more or less parallel veins, some of which run the entire length of the leaflet without branching, while others branch dichotomously and often anastomose (fig. 89). Circinate vernation, characteristic of ferns, appears in the midrib and pinnules of Cycas and in the midrib of Stangeria, Ceratozamia, and Zamia, but otherwise it does not occur.

The leaflets are tough and leathery, a texture due to thick-walled 
hypodermal cells. The epidermis is strongly cutinized, as in conifers, and the stomata, which in all the genera except Bowenia occur only on the under surface, are deeply sunken. In most forms the mesophyll is differentiated into palisade and spongy parenchyma, both rich in chlorophyll, but in addition to this some leaves, as in Cycas, have colorless cells, elongated parallel with the leaf surface, lying between the palisade and the spongy parenchyma. A general view of the structure of a leaflet is shown in figs. 90, $9 \mathrm{I}$.

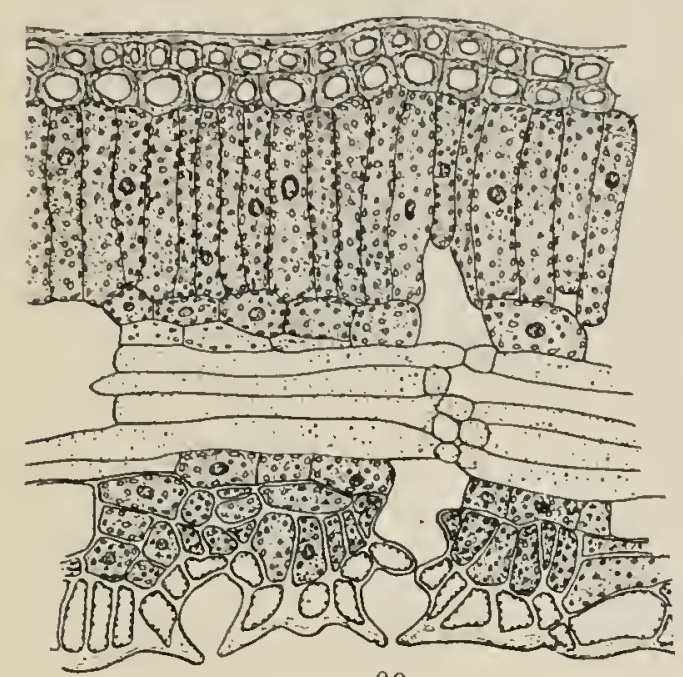

90

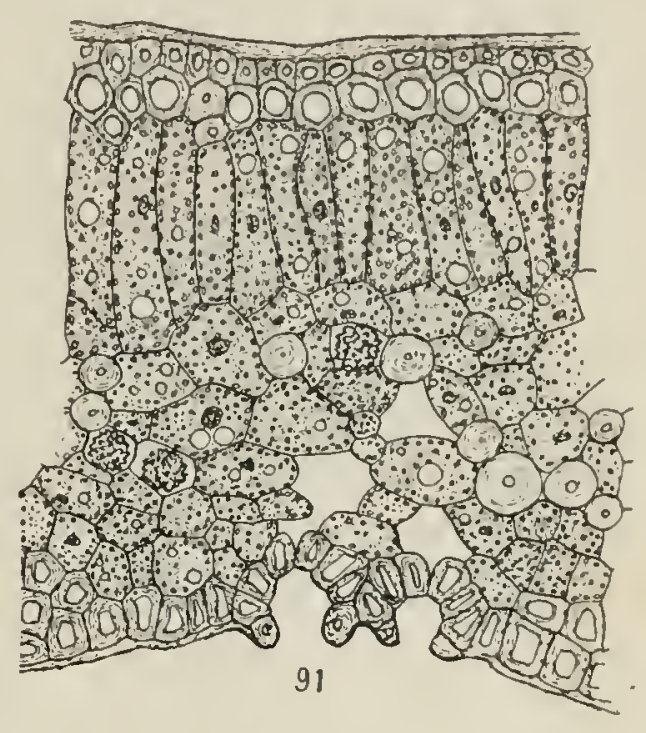

91

Fig. 90.-Cycas revolula: part of transverse section of pinnule, showing the cholorophyll-bearing palisade layer, the elongated colorless cells in the middle region, beneath this a few layers of mesophyll, and the lower epidermis with two stomata.

Fig. 9I.-Dioon edule: part of transverse section of pinnule, showing palisade layer, lower mesophyll region without elongated colorless cells, and lower epidermis with two stomata.

The first leaves of the seedling are almost always scale leares, one or more of which form a protection for the first foliage leaf. Succeeding leaves are similarly protected, and when crowns begin to be produced each young crown is covered by a large number of thick, brownish, hairy scale leaves. Young cones are similarly protected, the scale leaves covering the young staminate cone of Dioon edule being as thick, fleshy, and hairy as the ovulate sporophylls, and in such cases they form an appreciable part of the armor. In some species of Macrozamia there are no scale leaves at all. 


\section{THE ROOT}

The primary root continues as a strong tap root, with a scanty display of branches (fig. 92), but with numerous small secondary roots. Although dichotomous branching has been thought to be restricted to the secondary roots, under conditions described below, Hill and DE FraINe (67) state that in Stangeria the primary root may branch dichotomously. The soil about the roots is full of low algal

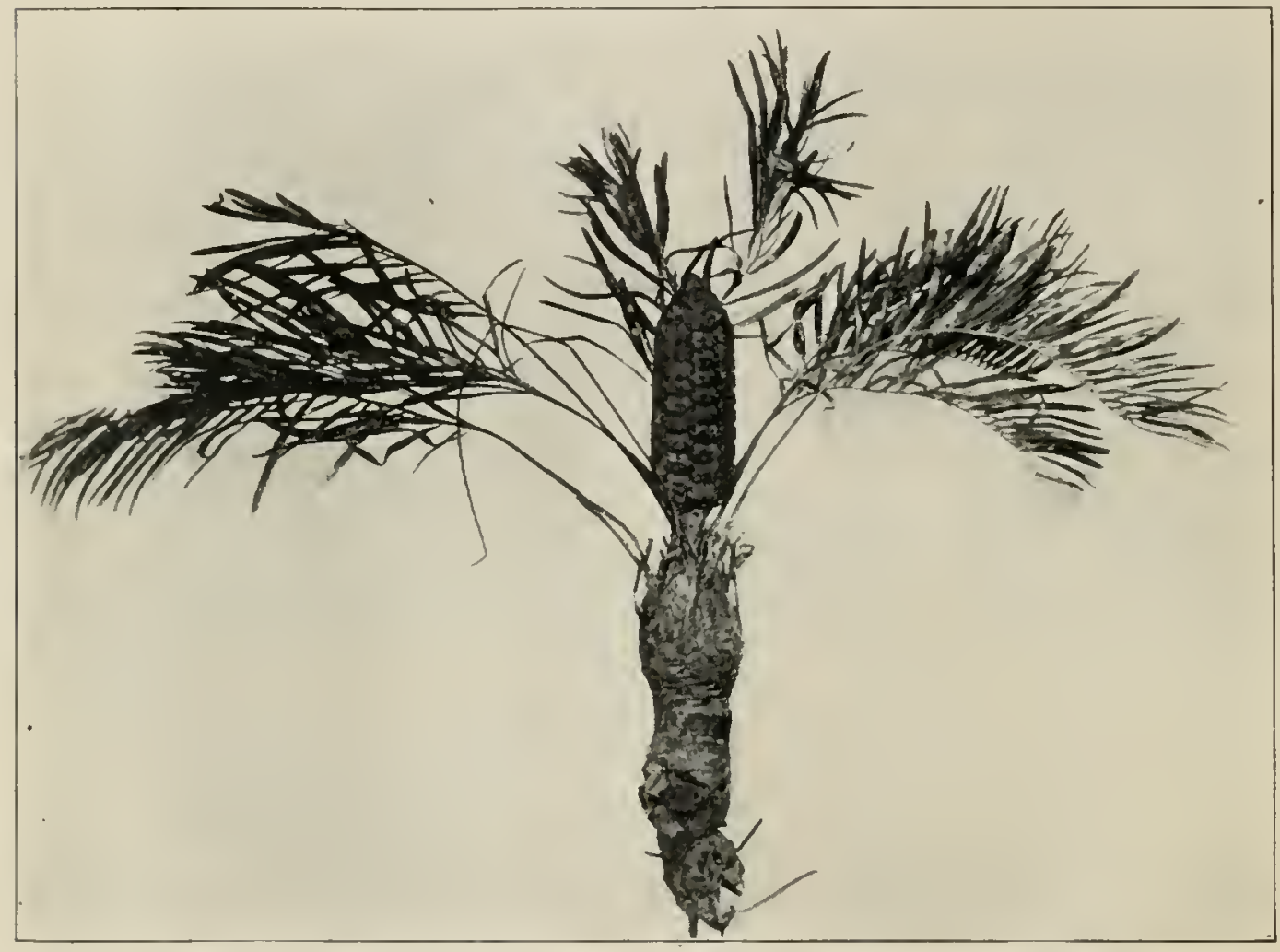

FIG. 92.-Zamia floridana: entire plant, showing strong tap root.

and fungal forms, and in many, perhaps all, of the genera, some of the secondary roots become infected, in which case they become negatively geotropic. Near the surface of the ground they branch profusely and dichotomously, forming the so-called "root tubercles" which occur in coralloid masses just above or a little below the surface (fig. 93). A study of sections shows that the dichotomy so conspicuous to the naked eye is only apparent, the root apex remaining between the two branches. Reinke (6), SchneIder (i8), and LIFE (3I) have contributed mostly to our knowledge of these peculiar 
roots. LIFE found that at the very inception of a branch, bacteroid forms effect an entrance and multiply rapidly in the cells of the apical

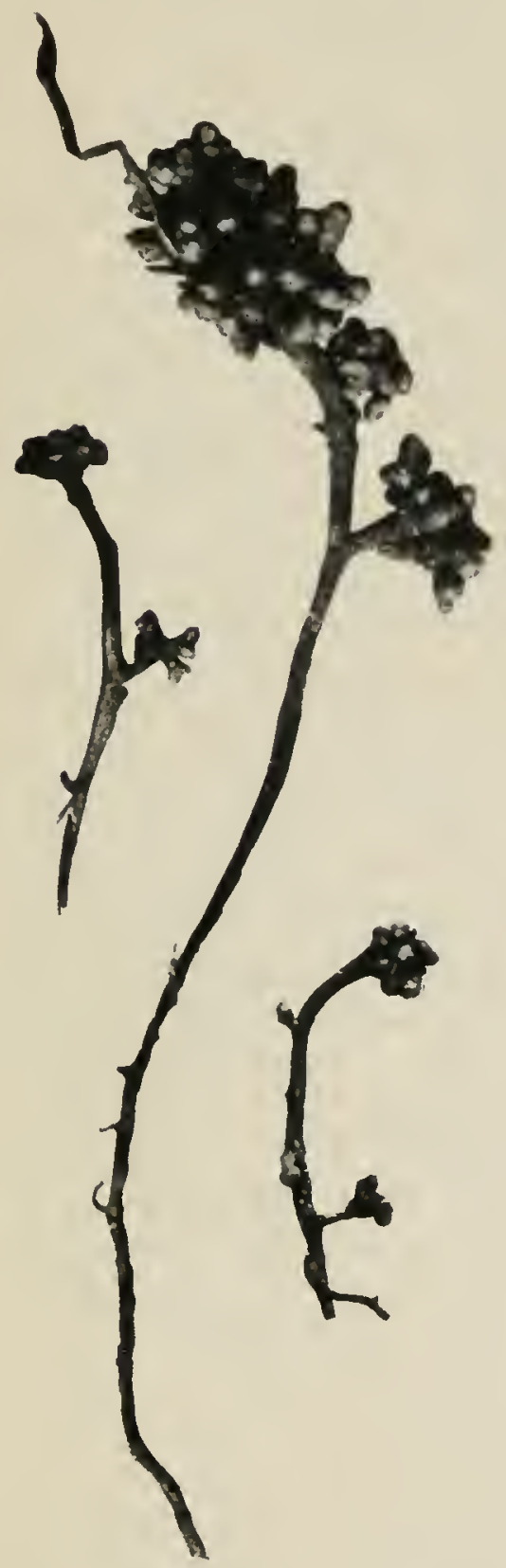

Fis. 93-Cycas revoluta: negatively geotropic roots in coralloid masses, as they appear just above the surface of the soil; about natural size. region. 'The presence of the bacteroids causes a considerable enlargement of the intercellular spaces and a disorganization of some of the cells. Algae soon appear in the intercellular spaces and their multiplication still further enlarges them. In its fully dereloped condition the algal zone, in transverse

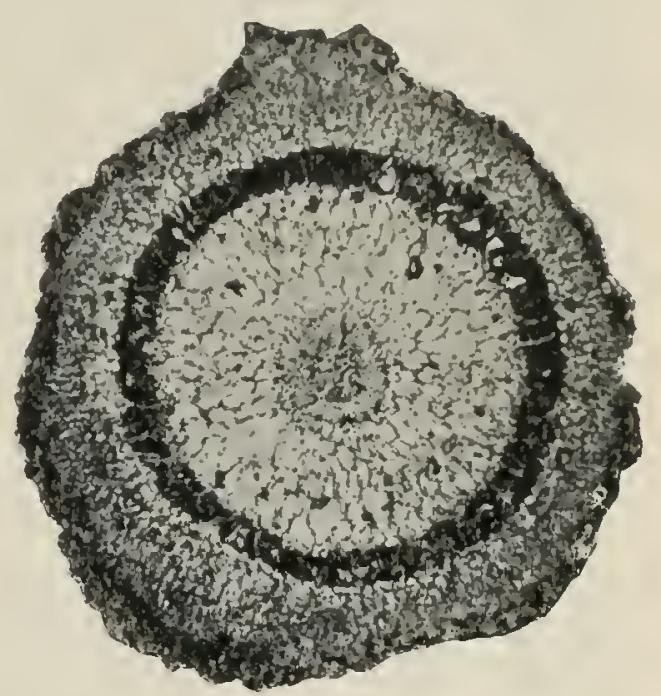

FIG. 94-Cycas reioluta: transverse section of a "root tubercle," showing the conspicuous algal zone; $\times 20$.After Life (3I).

section, appears as a conspicuous ring about midway between the stele and the periphery (fig. 94). The alga has been described as an Anabaena, but looks more like a Nostoc, although it is possible that there may be more than one alga. Life believes that the tubercles serve both in aerating and in assisting in nitrogen assimilation. From a recent study $\mathrm{Z}_{\mathrm{ACH}}(73)^{\text {: }}$ has concluded that a fungus is not the cause of the tubercles, although a mycelium is abundant in them; 
and that it is not a symbiont, but rather a parasite against which the cell reacts as a phagocyte.

\section{The spore-producing members}

THE MICROSPORANGIUM

All the living cycads are strictly dioecious. The staminate strobili

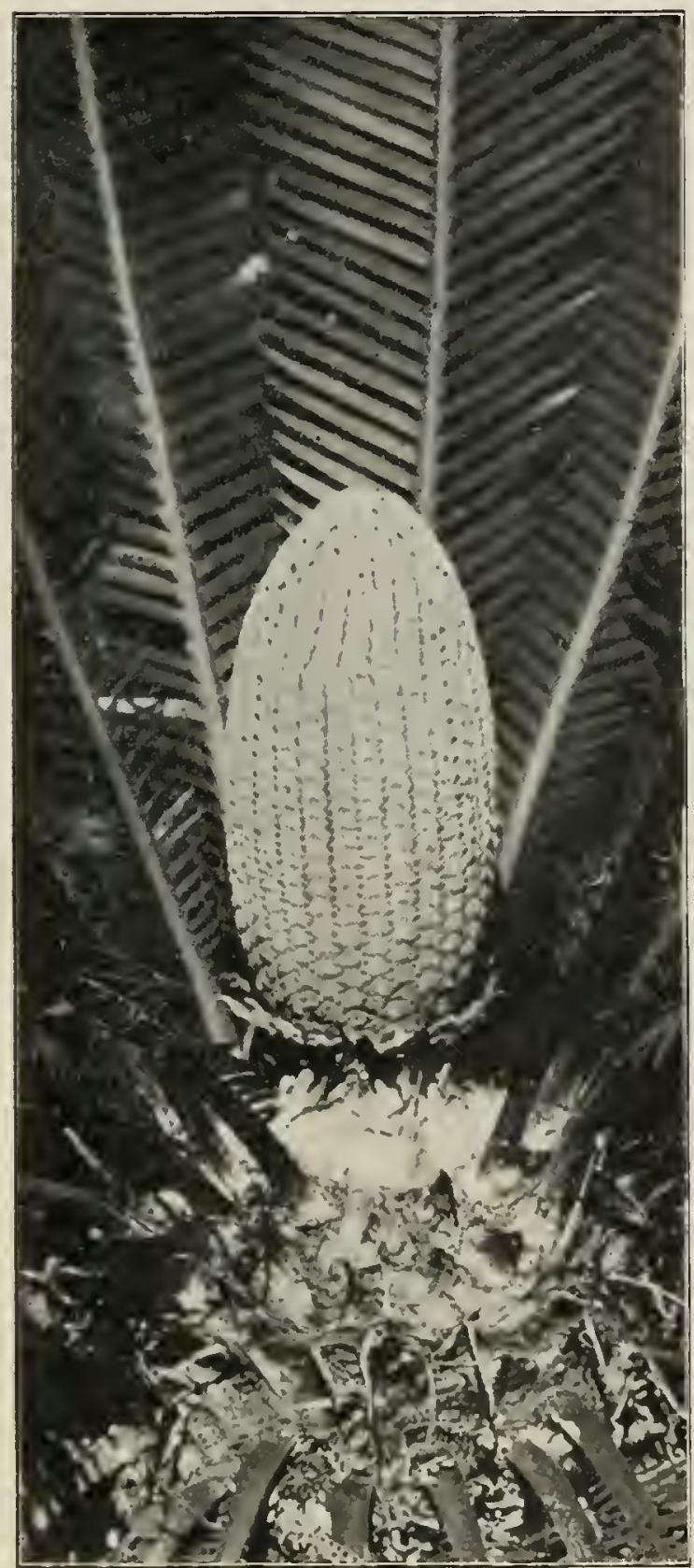

Fig. 95.-Dioon edule: upper portion of plant with staminate cone; photographed at Chavarrillo, Mexico, September I906; onethird natural size.-After ChamberLaIN (63). usually occur singly in the center of the crown (fig. 95), but several may appear at once, as is frequently the case in Zamia and Encephalartos. The first cone produced by a plant is always terminal, but all subsequent ones are lateral. Growth from an apical meristem is continuous until a cone is produced, in which case the meristem is used up in the production of the cone, and a new meristem appearing at the base continues the growth, pushing aside the cone and assuming the erect position. Miss F. Grace Smith (56) has shown that the trunk of Zamia is really a sympodium, the production of a cone being followed by the development of a branch which quickly becomes erect, so that the trunk does not appear to be branched (figs. 96-98). In Encephalartos Friderici-Guilielmi and in E. Altensteinii PEARson (47) has described a group of three to six cones arranged symmetrically about the apex, so that in these cases there is 
no sympodium, the summit of the regetative axis continuing the growth of the stem. Such a condition among the cycads connects with the branching habit among Bennettitales.

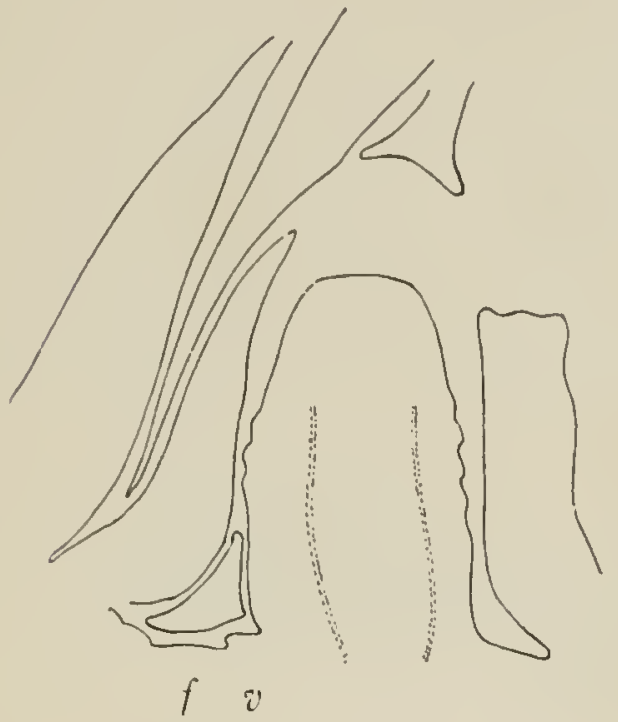

996

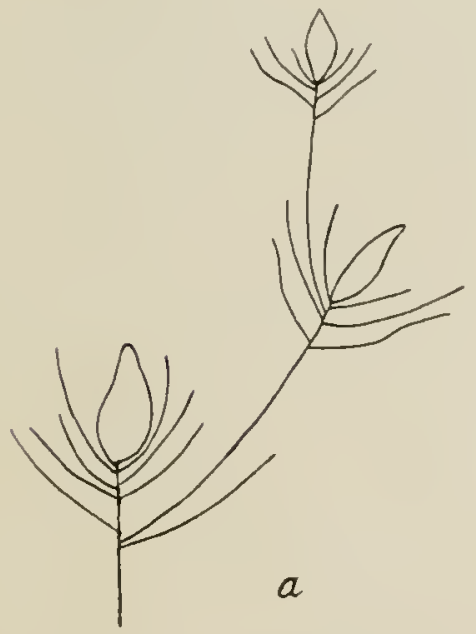

98
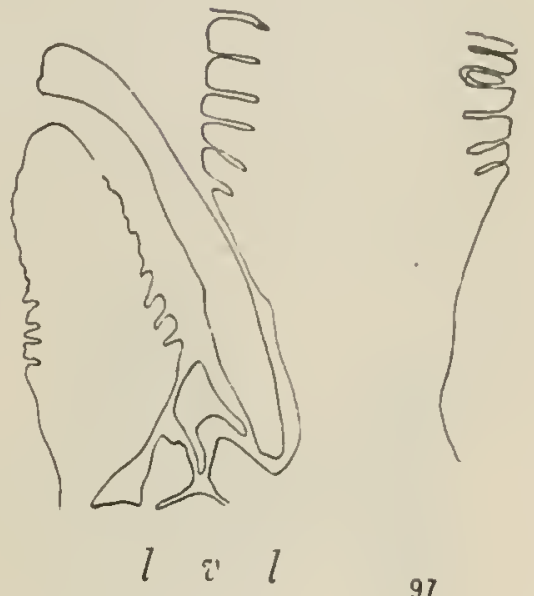

97

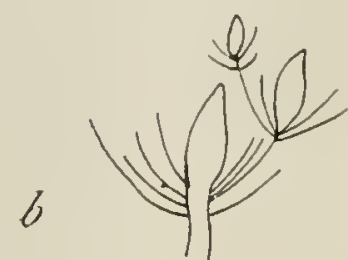

$C$

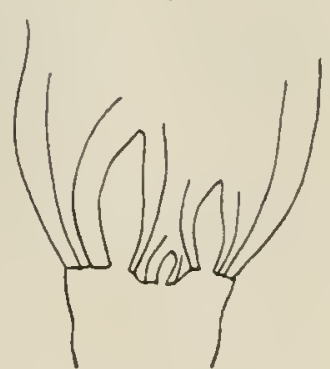

FIGS. 96-98.-Zamia floridana: fig. 96, longitudinal section of apex of stem, showing a young staminate cone; 2 , litteral stem tip; $f$, very young leaf; fig. 97 , longitudinal section of ape $x$ of stem, showing two young staminate cones; $v$, stem tip; l, young leaves; fig. 98 , diagrams based upon preparations like those shown in figs. 96 and 97 ; a, sympodium, showing relations of strobili, crowns, and trunk; $b$, the same with internodes shortened; $c$, internodes shortened until the cones are on a level, as in Zamia.-After F. GRACE Smith (56).

The length of the staminate cones varies from $2 \mathrm{~cm}$. in some species of Zamia to more than $50 \mathrm{~cm}$. in species of Encephalartos and Cycas. 
The sporophylls are spirally arranged in a compact strobilus, and show only slight traces of the pinnate character of the regetative leaves. At the apex and base of the cone the sporophylls are sterile, and the remaining sporophylls bear abaxial sporangia in two more or less distinct groups separated by a median sterile line (fig. 99). In the median region of the cone the sporangia cover the entire abaxial surface of the sporophylls and sometimes even their margins. In all the genera the sporangia occur in soral groups of five, four, or three;

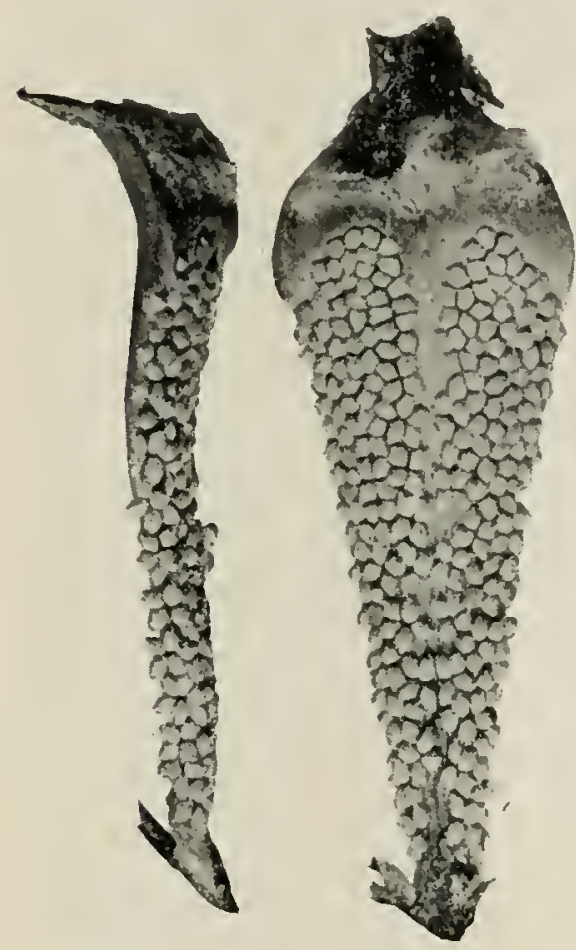

FIG. 99-Dioon edule: photograph of two microsporophylls; $\times \frac{4}{3}$.-After Chamberlain (63).

but some sori may contain only two sporangia, and in the more highly specialized forms some of the sporangia may occur singly. The sori are surrounded by one-celled or two-celled hairs, and such hairs appear eren on the lower portion of the sporangia (fig., IOO, II I).

The number of sporangia on a sporophyll corresponds roughly to the size of the sporophyll. The following estimates have been made by Miss $\mathrm{F}$. Grace SMith (56) and by ChamBERLAIN $\left(6_{3}\right)$ : Dioon spinulosum 750 , Cycas circinalis 700, Encephalartos Caffer 700, Macrozamia Miquelii 600, Encephalartos villosus 500, Dioon edule 300, Ceratozamia mexicana 250-300, Stangeria paradoxa 260, Microcycas calocoma about $\mathrm{I} 20$, Bowenia spectabilis

67. A large number of sporangia on a sporophyll, and also the larger number in a sorus, may be regarded as primitive features, while fewer sporangia on a sporophyll and fewer in a sorus are probably due to reduction.

The first full account of the development of the microsporangium was published by TREuB (II) in I88I, who investigated especially Zamia muricata. LANG's (22) work on Stangeria paradoxa confirmed TREub's results in a general way and cleared up some doubtful points. Later, Miss F. Grace Smith (56) studied abundant material of very 
young staminate cones of Zamia floridana and CimamberLaIx (63) described spermatogenesis in Dioon edule.

The sporophylls first appear as minute papillae, giving the young cone a wavy contour as seen in longitudinal sections (figs. 96, 97). According to Miss Smitr, there is in Zamia a single archesporial cell, the first division of which may be either periclinal or anticlinal, but in any case primary wall cells and primary sporogenous cells are soon formed (figs. IOI-IO4). In Stangeria LANG (22) first recognized the archesporium as a hypodermal plate of four cells (figs. IO5-IO9). By comparing these figures with those of Miss Smith, it is erident

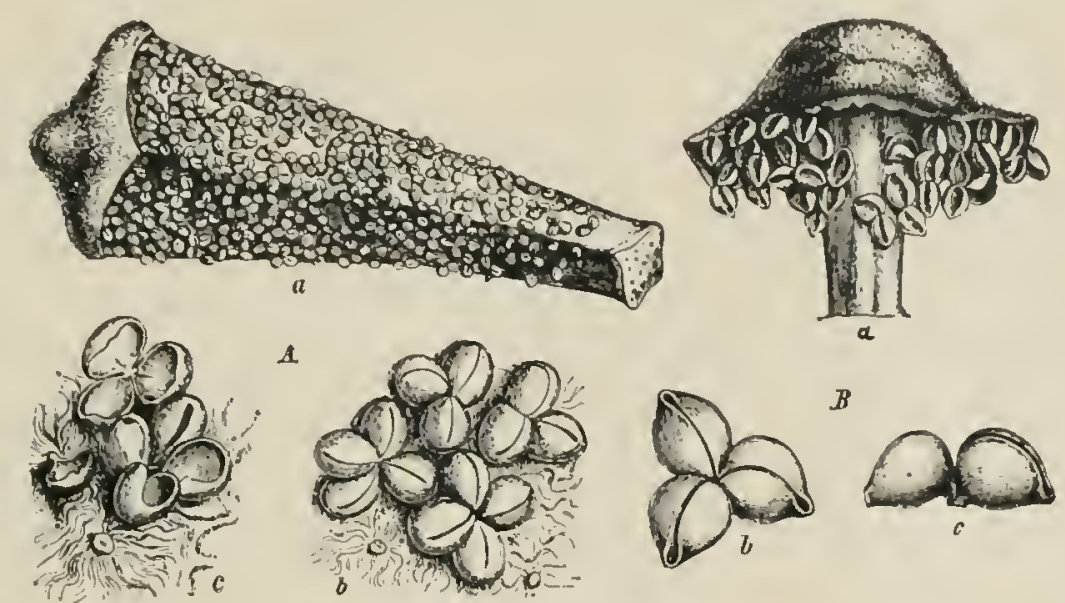

FIG. I0o.-Microsporophylls of cycads: A, Cycas circinalis (u, entire sporophy-ll, showing sporangia on under surface; $b$, four groups of sporangia; $c$, same as $b$ after the pollen has been shed); $B$, Zamia integrifolia ( $a$, entire sporophyll; $b, c$, clusters of sporangici).- $A b, A c$, after BuUne; the rest after RICHARD; the whole figure taken from Exgler and Prantl's Natürlichen Pflanzenfumilien.

that Stangeria develops like Zamia, the hypodermal plate having come from a single cell. The later stages are essentially the same in both accounts. A sporangium wall several cells in thickness is developed, and also a large mass of sporogenous tissue, from the periphery of which the tapetum is differentiated. While the origin of the tapetum was not studied in Dioon, fig. I Io would indicate that it is more probably derived from the wall cells. The resemblance of the cycadean sporangia to those of the marattiaceous fern Angiopteris is quite striking, the principal difference being the comparatively scanty development of the tapetum in the cycad (fig. II $x$ ). As the spores mature, the epidermal layer of the sporangium becomes thick- 
ened, and the layers between the epidermis and the spores disorganize, as in the sporangia of ferns. Two rows of elongated thin-walled

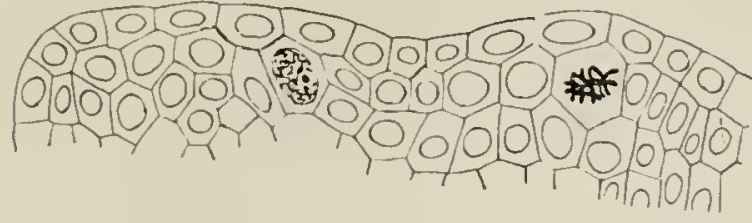

101

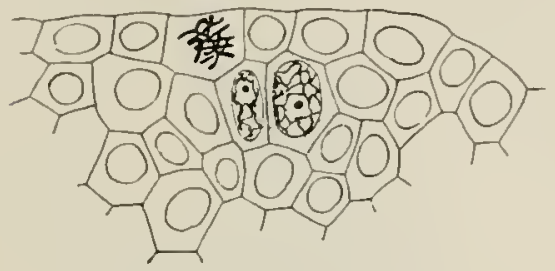

102

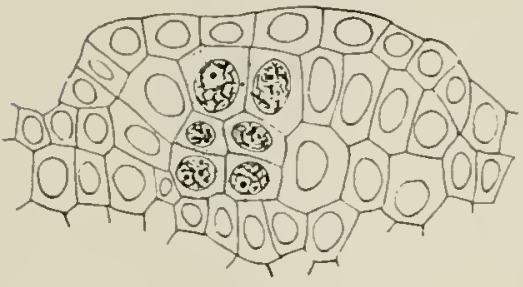

103

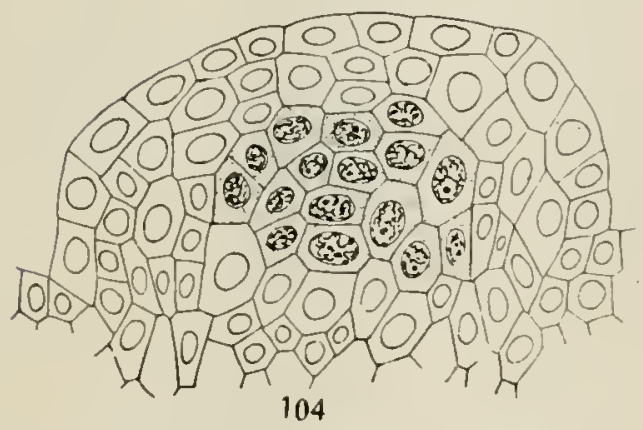

Figs. IOI-I04.-Zumia floridana: early stages in the development of the microsporangium; fig. I01, single hypodermal archesporial cell; fig. I O2, first periclinal division; fig. I 3 , usual divisions following stage shown in previous figure; fig. I04, longitudinal section of a sporangium in a more advanced stage; all figures $\times 920 .-$ After F. GRACE SuItH $(56)$.

demands of such difficult nuclei. Miss F. Grace Smith counted 50 cases in Ceratozamia, and in forty-six found I 2 chromosomes, in three cells bordered by cells with thick walls give the dehiscence much the appearance of that of Angiopteris.

The formation of microspores from the mother cell has been described by Juranyi (5) and by Miss F. Grace Smith $\left(5^{6}\right)$ for Ceratozamia, and by Treub (II) for Zamia muricata. With the appearance of the cell plate in the first division, a ringlike thickening of cellulose appears on the wall of the mother cell, and proceeding from this ring a thick wall develops between the two daughter cells. Each of these two cells divides and heary walls are formed again, and within this heary four-celled and often lobed case the microspores are organized. The number of chromosomes in the pollen mother cells of Ceratozamia and Zamia is I 2 ; other numbers $(7,17)$ have been reported for Ceratozamia, but technic at that time was hardly adequate to meet the trying 
I I chromosomes, and in one case I 3 chromosomes; in Zamia 25 nuclei were examined and all showed 2 chromosomes. CHAMBrirLAIN $(46,63)$ found 12 chromosomes in the pollen mother cells of Dioon edule, I 2 at the mitosis which gives rise to the rentral canal and egg nuclei, and $\mathrm{i} 2$ in cells of the endosperm.

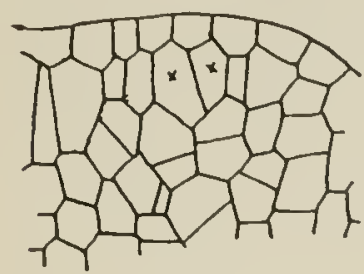

105

107

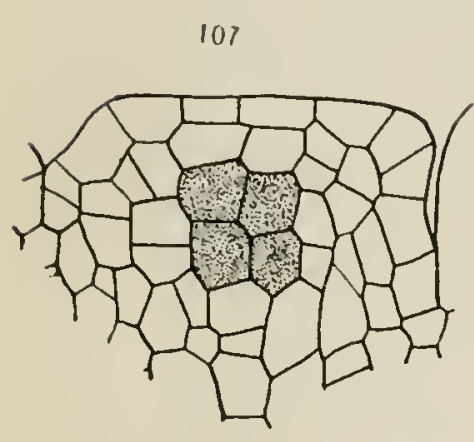

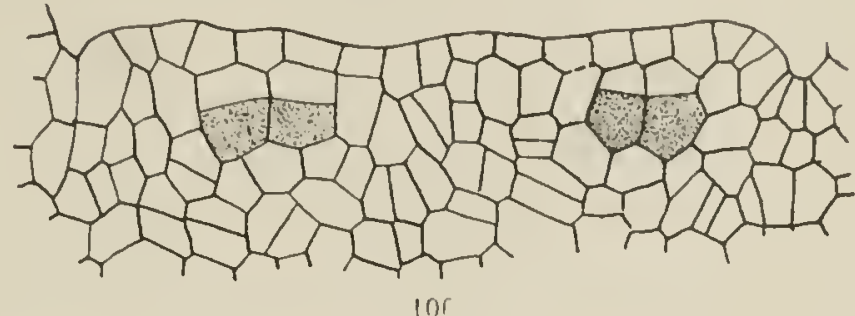

ins
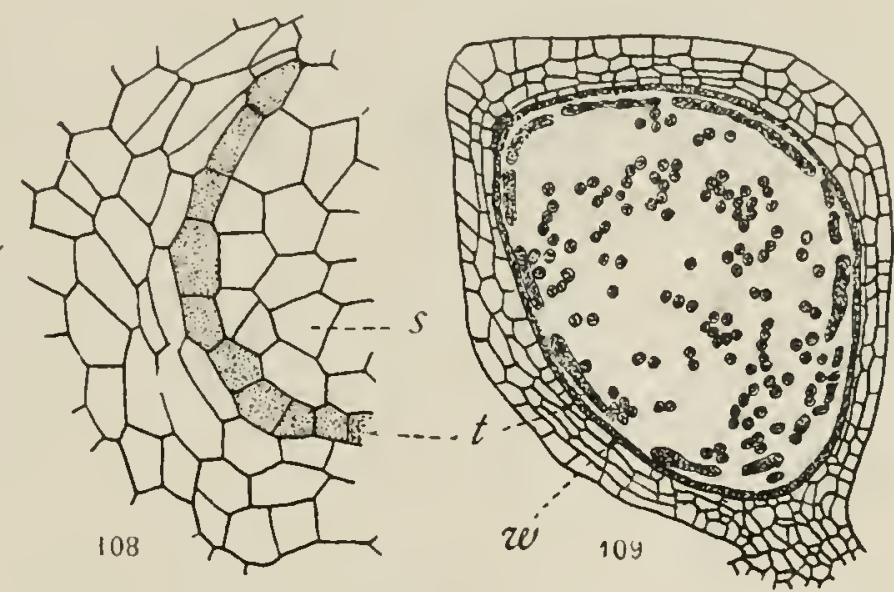

Figs. 105-107.-Stangeria paradoxa: developnent of microsporangium; fig. 105, section showing two of the four cells forming the archesporial plate; fig. ro6, each cell of the plate divided into an inner primary sporogenous cell (shaded) and an outer primary wall cell; fig. 107 , a more advanced stage; fig. I 08 , still more advanced stage, showing tapetum (shaded) and sporogenous cells (s); fig. ro7, mature microsporangium; $t$, tapetuni; $z$, crushed rells of the wall; figs. 105-108, $\times 266$; fig. 107, $\times 66$ After LANG (22).

The output of spores has been estimated by Miss F. Grace Smith $(56)$ and by Chamberlain $\left(6_{3}\right)$. When spores are very small and closely packed together, and the spore mass is nearly spherical, the number in a sporangium may be estimated by the formula ${ }_{3}^{4} \pi R^{3}$. To apply the formula it is necessary only to count the number of spores in a radius from the center of the sporangium to the tapetum, substitute this number for $R$ in the formula, and make the calculation. There is some error because the spore mass may not be exactly 
spherical, and because the formula does not regard the small spaces between spores, but the error is far less than the variation in the out-

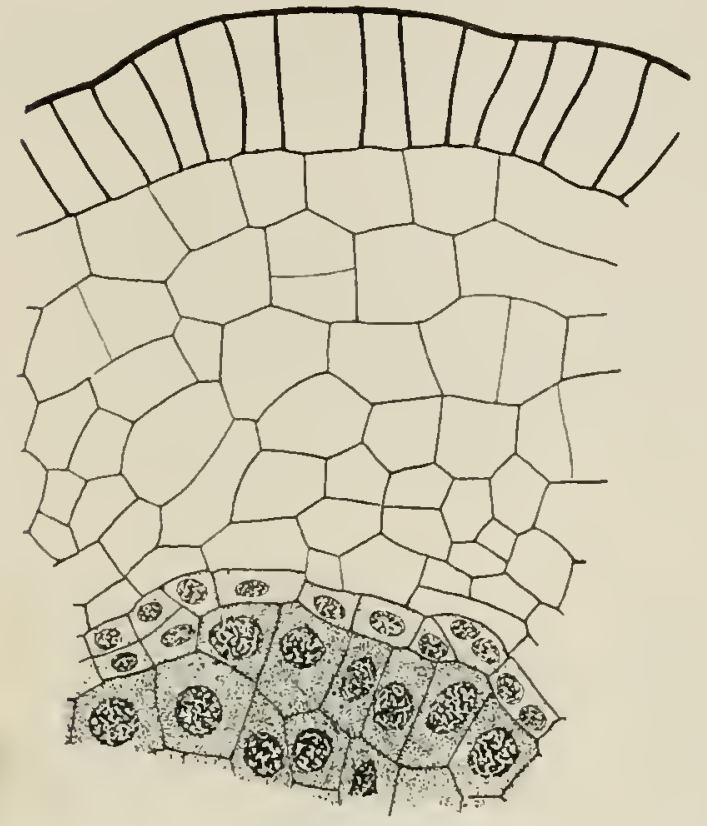

FIG. IIo.-Dioon edule: microsporangium; detail showing thickened epidermis, wall cells, tapetum, and sporogenous tissue; $\times 250 .-$ After Chamberlain (63). put of individual sporangia of average size. It is recognized that this formula could be used only when spores are very small and sporangia very large. Estimating in this way, ChamberLAIN (63) found the output of spores in Dioon edule to be 30,000 ; Miss F. Grace Smith found it to be 26,000 in $\mathrm{En}$ cephalartos villosus, 8,000 in Ceratozamia, and 500-600 in Zamia floridana. In general the results favor the view that the output is larger in the more primitive forms and decreases toward the more highly specialized forms.

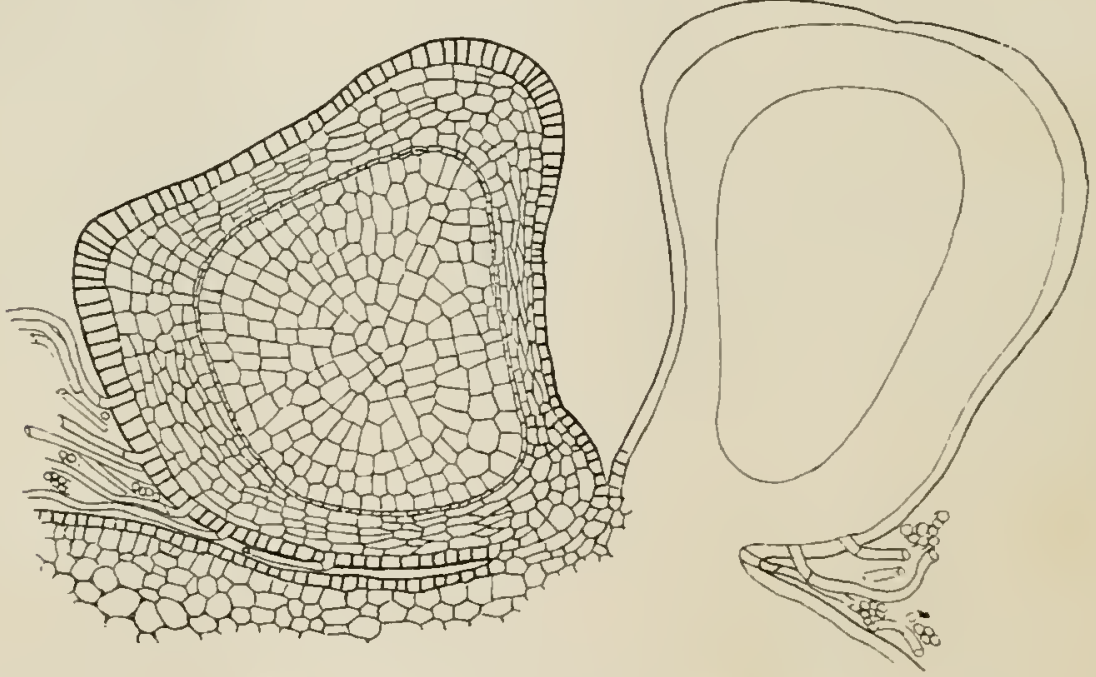

FIG. III.-Dioon edule: microsporangium; two of the sporangia of a sorus, showing extensive sporogenous tissue and scanty tapetum; two-celled hairs growing on the base of the sporangium; $\times 55$ - After CHAMBERLAIN $\left(6_{3}\right)$.

Since the spore is regarded as the first cell of the gametophyte generation, it will be considered in the section on the male gametophyte. 


\section{THE. MEGASPORANGIUM}

The orulate strobili usually occur singly in the center of the crown (fig. II2), but sometimes, especially in Encephalartos, two or more may be produced. The ovulate strobili of cycads are the largest known, those of Dioon spinulosum reaching a diameter of $23 \mathrm{~cm}$., with a length of $50 \mathrm{~cm}$. and a weight of $14 \mathrm{~kg}$. The long and comparatively slender strobilus of Microcycas sometimes reaches a length of $94 \mathrm{~cm}$., but is not so heary; the weight of $9.5 \mathrm{~kg}$. as well as the length of $94 \mathrm{~cm}$. reported by CALDwell (52) is exceptional. The strobili of Encephalartos and Macrozamia are not quite so large, and in Ceratozamia they are seldom more than $26 \mathrm{~cm}$. in length; in the remaining genera they are comparatively small, perhaps the smallest being that of Zamia pygmaea, in which they may be less than $3 \mathrm{~cm}$. in length. If the group of ovulate sporophylls of Cycas be regarded as a strobilus, it may be the largest and heaviest of all; but we have not had an opportunity to weigh it or to measure a fully grown specimen.

In all the genera except $C y c a s$ the megasporophylls are in compact strobili, the first strobilus being terminal on the primary axis of the plant, while all the others terminate secondary axes. PEArson (47) states that in Encephalartos Friderici-Guilielmi and in E. Altensteinii there are three to six cones symmetrically arranged around the apex, so that there is no sympodium, but the vegetative apex continues the growth of the stem, as already noted in the staminate plants of these species. In Cycas the sporophylls bear considerable resemblance to the foliage leaves, and are arranged like an ordinary crown of foliage leaves, with the bud for the next crown in the center (fig. II3); hence the trunk of the ovulate plant of $C y c a s$ is always a continuation of the primary axis, and never a sympodium as in all other cycads, including the staminate plant of $C y c a s$ itself, and also excepting cases in which several cones may be arranged around a persistent regetative apex. It can hardly be doubted that the compact strobili are a later development from the Cycas type. Occasionally, even in compact strobili, the meristem, instead of producing the stunted sporophylls which usually terminate the strobilus, produces sporophylls resembling foliage leares; and in Encephalartos Wreland (5I) figures a strobilus with transitions between the sporophylls and the 
ordinary pinnate leaves. The Cycas condition resembles that of the Cycadofilicales, and not at all that of the Bennettitales. How-

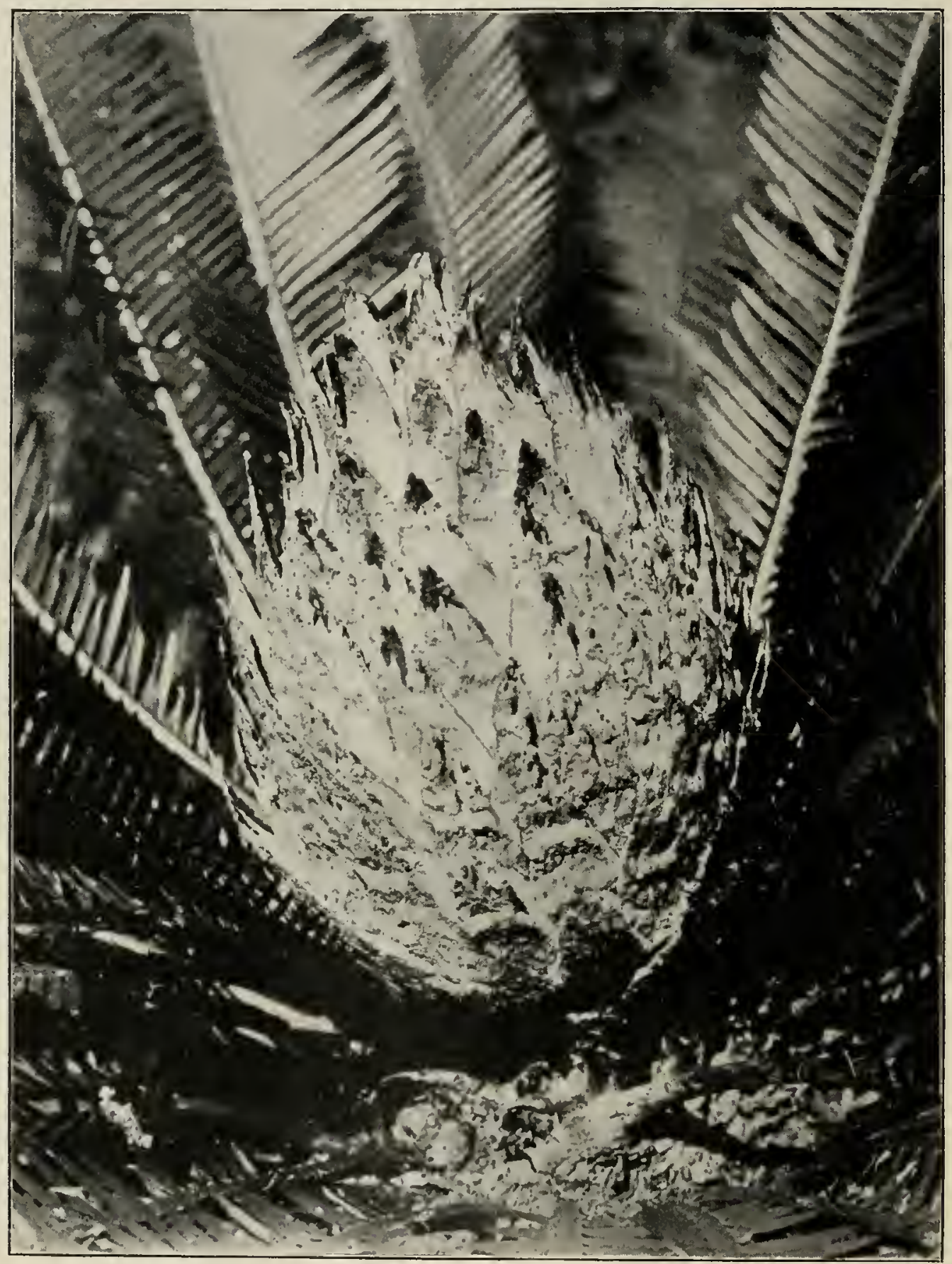

Fig. II 2.-Dioon edule: ovulate cone $(30 \mathrm{~cm}$. in length) in the center of the crown; some of the leaves have been trimmed away.-After Chamberlain (46).

ever, the staminate sporophylls of the Bennettitales are borne like the ovulate sporophylls of Cycas, the principal difference being that 
in the Bennettitales the meristem, after producing the staminate sporophylls, produces an ovulate strobilus which terminates that axis; while in Cycas the meristem, after producing orulate sporophylls, produces vegetative leaves.

In Cycas revoluta the megasporophylls are more nearly like the

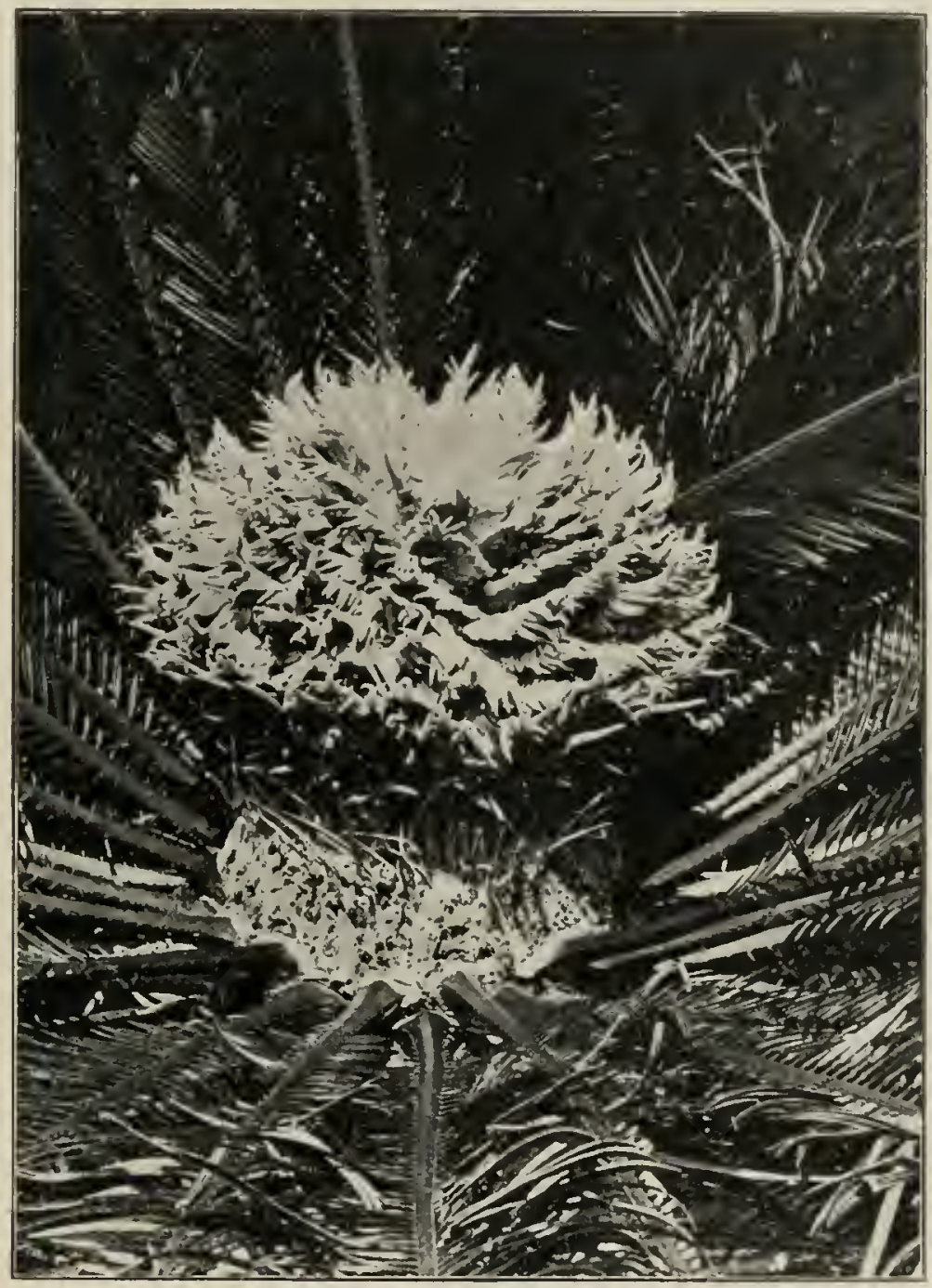

FIG. I 3.-Cycas revoluta: loose orulate strobilus, Kochi, Fosa, Japan, August 4 , I909.-From photograph by MiYake.

vegetative leaves than in any other cycad (fig. II4). C. circinalis and $C$. Normanbyana show more reduction, but the pinnate character of the vegetative leaf is still conspicuous. In Dioon edule the pinnate character is not conspicuous, but the blade is still leaflike, and the strobilus has to some extent the loose arrangement of sporo- 
phylls characteristic of Cycas (figs. II2, II4). In D. spinulosum and in Stangeria the sporophylls are still less leaflike, and the strobilus
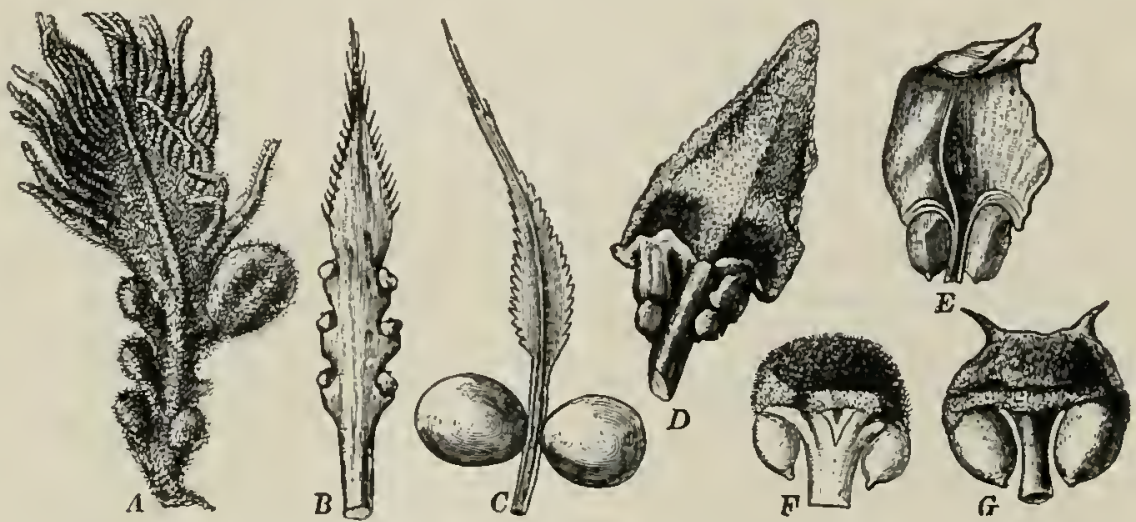

FIG. Ir 4.-Megasporophylls of cycads: A, Cycas revoluta; $B, C y c a s$ circinatis; $C$, Cycas Normanbyana; D, Dioon edule; E, Encephalartos Preissii; F, Zamia integrifolia; $G$, Ceratozamia mexicana.- $A$, after SACHS; $C$ and $F$, after Von Muller; $E$, after Miquel; $F$, after Richard; $B, D$, and $G$, drawn for ENgler and Pranth's Nat. Pfanzenf., from which the entire plate is taken.

is much more compact; while in the remaining genera the sporophylls show very little of the leaflike character and are organized into hard compact strobili (fig. 92).

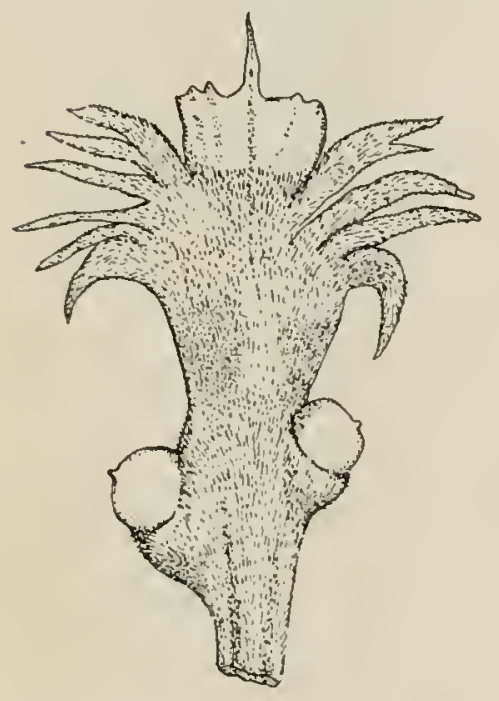

FIG. II5.-Cycas siamensis: sporophyll with two ovules; in the upper part of the sporophyll the pinnules are united into a solid mass, but the lower pinnules are still free; one-half natural size. - After Miss STOPES (42).

In Cycas revoluta several ovules are borne on the margins of the sporophyll (fig. II4), as is also the case in C. circinalis, in which the leafy portion is more reduced; but even in the genus Cycas the number of ovules becomes reduced to two, as in $C$. Normanbyana and $C$. siamensis (fig. II5). Two ovules are characteristic of all the other genera, with only occasional exceptions. The two ovules are really borne on the margins, but the sporophylls are so reduced that they seem to be borne on the under surface of a peltate structure (fig. I $4, F, G$ ). In all the genera the ovules are sessile, but in Dioon the crowding of the orules in the strobilus results in a stretching of the tissue of the sporophyll so that it resembles a stalk (fig. $x$ r6). 
The size, color, and surface of the orules differ in the various genera and even in the species of a genus. The largest ovules are

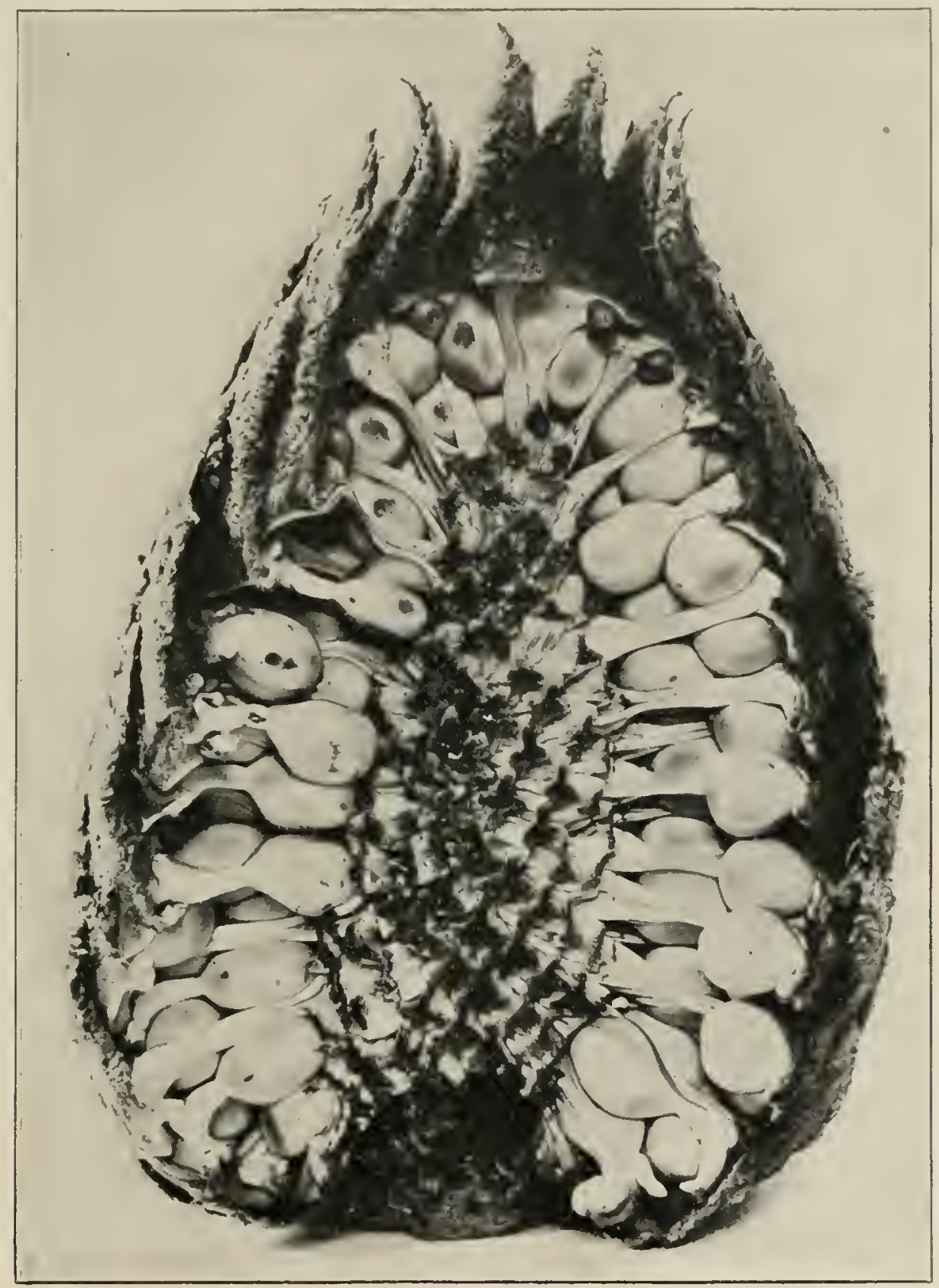

FIG. Ir6.-Dioon edule: longitudinal section of strobilus, showing crowding of ovules and consequent development of false stalls; this strobilus is $33 \mathrm{~cm}$. in length.After Chamberlain (46).

formed in Cycas circinalis, in which they become $6 \mathrm{~cm}$. long and $4 \mathrm{~cm}$. wide. The ovules of Dioon spinulosum are almost as large, and from these dimensions all sizes are found down to the tiny orules of species 
of Zamia, which are less than $3 \mathrm{~mm}$. in length. The color is as various as the size, white, creamy, pink, and various shades of red predominating. Within the same species there is not nearly so much

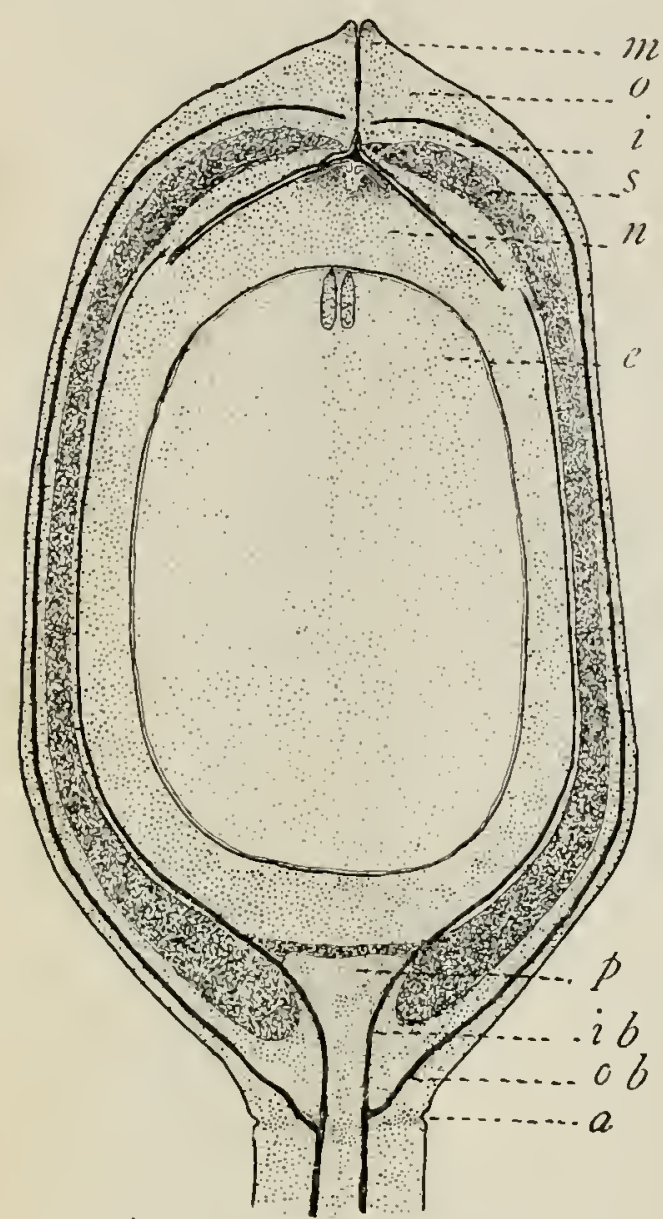

Fig. I 7 .-Dioon edule: longitudinal section of ovule after pollination, but about three months before fertilization: $a$, abscission layer; $e$, endosperm; $i$, inner fleshy layer (between $s$ and $n$ ); $i b$, bundle of inner vascular system; $m$, micropyle; $n$, free portion of nucellus; $o$, outer fleshy layer of integument; $a b$, bundle of outer fleshy layer; $p$, basal papilla; $s$, stony layer of integument; $\times 2$. - After Chamberi.ain (46). variation in color of ovules as in size. Some ovules are densely hairy, as those of Cycas revoluta; while others, as those of Dioon, are perfectly smooth. The general topography of the ovule, which is fairly well known in all the genera, is shown in fig. II 7 .

Important among the earlier contributions are those of IVARMing $(8,9)$ on Cycas in 1877 and I879, and of 'Treub (I I, I3) on Ceratozamia and Zamia in I88I and I884. Later, WorsDELL (27a) paid particular attention to the anatomy of the sporophylls of most of the genera. LANG (22) studied several stages in the development of the orule of Stangeria, and Oliver (36) made a comparative study of the ovules of the older gymnosperms. In I904 MatTe (40) and Miss Stopes (42) published independently and almost simultaneousiy very comprehensive accounts of the vascular anatomy of the sporophylls and orules of all the genera. MatTe's account treats of the entire vascular structure of the Cycadales, while Miss STopes deals particularly with the ovules, and includes a discussion of the integument as well as of the vascular system. In I906 Chamberlain (46) described the ovule of Dioon edule, paying particular attention to the structure of the integument and nucellus. 
The earliest stages in the development of the strobilus, sporophylls, and orules have not been studied in any of the genera, even so late a stage as the row of megaspores having been noted only in Stangeria, Ceratozamia, and Zamia. In these genera the megaspore mother cell when first recognized was deepseated in the nucellus and surrounded by a mass of cells doubtless homologous with the "spongy tissue" of conifers. In Stangeria (29) and Ceratozamia (II) the mother cell gives rise to a row of three cells, and in Zamia (74) to a row of four cells, the innermost of which becomes the functioning megaspore (figs. II $8-120$ ), the first cell of a new gametophyte.

There is a single massive integument, and the nucellus is free only for a short distance.

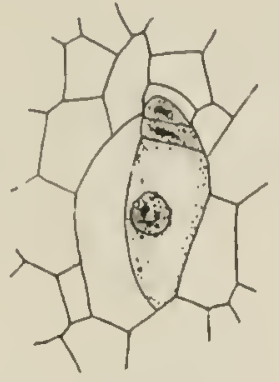

118

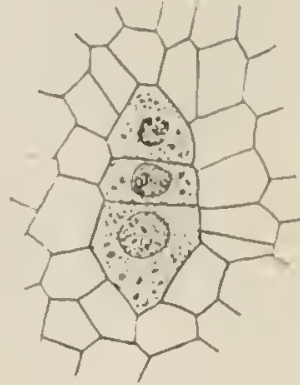

119

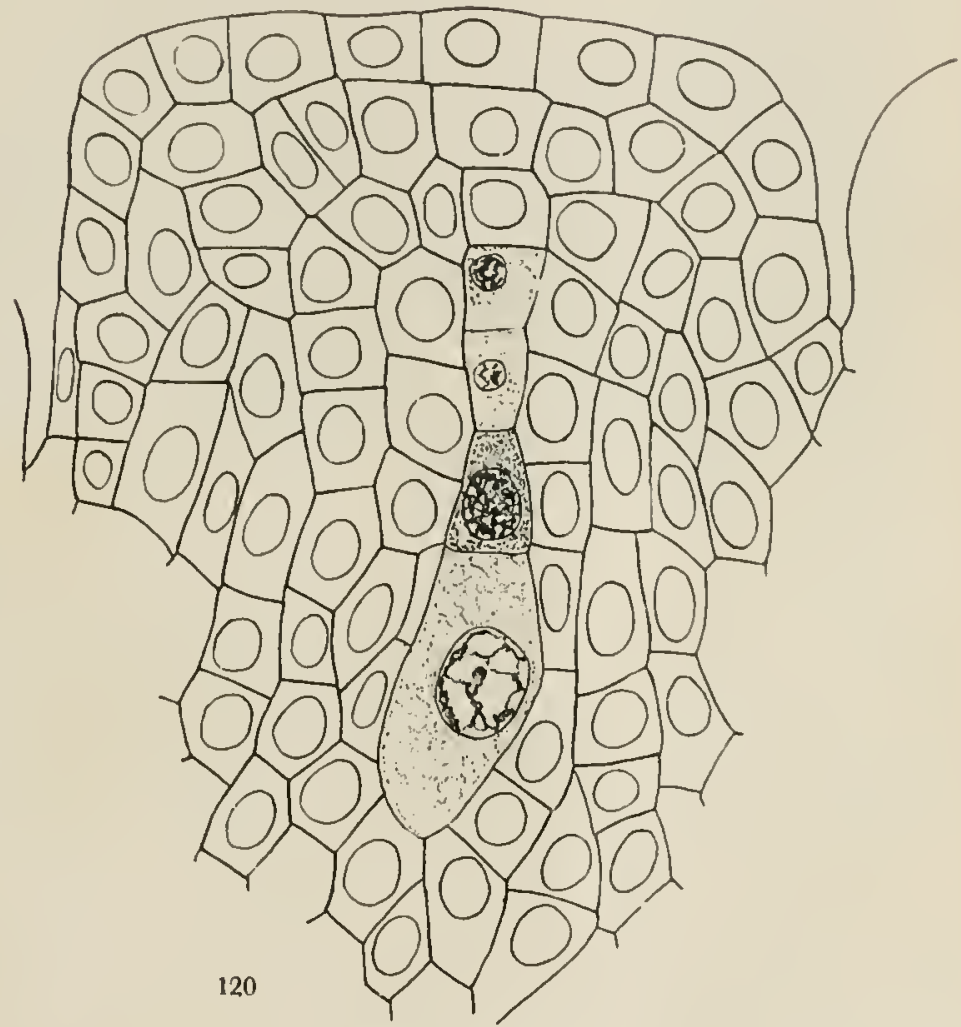

Figs. 118-I20--Megaspores of cycarls: fig. IIS, Stangeria paradoxa, showing the functional megaspore enlarging at the expense of two functionless cells of the megaspore row; $\times 250$; fig. I I9, Ceratozamia longifolia, showing row of three cells, the lowest (functional megaspore) beginning to enlarge: $X_{2} 66$; fig. $\mathrm{r}_{20}$, Zamia floridana, the row of four megaspores.-FIG. ins, after LANG (29); fig. II9, after Treub (1 I); fig. I20, after F. (iR.ICE. Sм1тн (74).

At the apex of the nucellus, some time before the shedding of pollen, a vigorous growth results in the formation of the character- 
istic beak, which is forced up into the micropyle; while in the center of the beak and below it cells break down and form the beginning of the pollen chamber. After the reception of the pollen the beak closes and hardens, effectively shutting in the pollen grains; while the pollen chamber continues to enlarge for several months by the

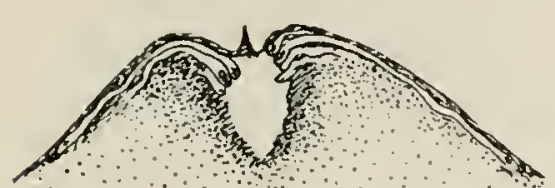

121

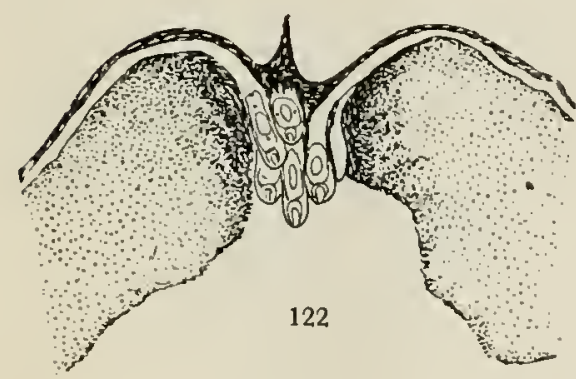

FIGS. I2 I, I22.-Dioon edule: general view of the nucellus with pollen tubes; fig. I 2I, pollen chamber and pollen tubes (November 20) about two months after pollination; $X_{40}$; fig. I22, pollen tubes (in May) after the pollen chamber has extended entirely through the nucellus; $X$ io.- - After ChamberLain $(63)$.

while the single fleshy layer of the integument, within the stony layer, contained the inner bundles. The structure of the stony layer, however, is very different, being simply a modified epidermis in Lagenostoma, while it is an extremely complex tissue sereral cells thick in cycads.

If there is a boundary between the inner fleshy layer and the nucellus, it is not conspicuous, but the innermost layer of cells next the breaking-down of adjacent tissue, until it finally extends entirely through the nucellus, leaving no obstruction between the pollen tubes and the female gametophyte (figs. I2I, I22).

The integument consists of three easily recognized layers: an outer and an inner fleshy layer of rather simple structure, and a very complex stony layer between them. Many of the cells of the stony layer are elongated in various directions and are often curved, thus making not only a very hard but also a very tenacious tissue. The two sets of vascular bundles are found in the fleshy layers. Whether the single integument has always been single or has arisen from the fusion of two structures, as if the cupule of a Lagenostoma had fused with the integument, is an open question. The cupule of Lagenostoma was doubtless fleshy, and contained vascular bundles which might correspond to the outer vascular bundles of the cycadean ovule; 
endosperm is differentiated into an endosperm jacket or tapetum as conspicuous as the tapetum of any fern or angiosperm microsporangium. In the mature sced the outer fleshy layer remains fresh for a while, and then either dries or decays. All the sporophytic tissue within the stony layer, including the inner fleshy layer, the nucellus, and the base of the orule, becomes reduced to a thin dry membrane in which the bundles of the inner vascular system are the most noticeable feature.

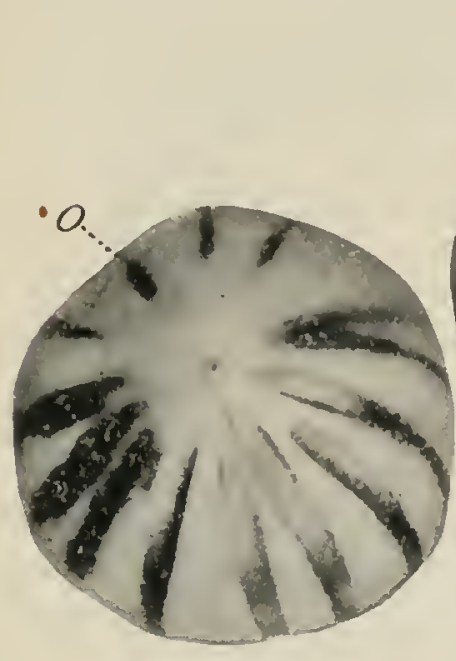

123

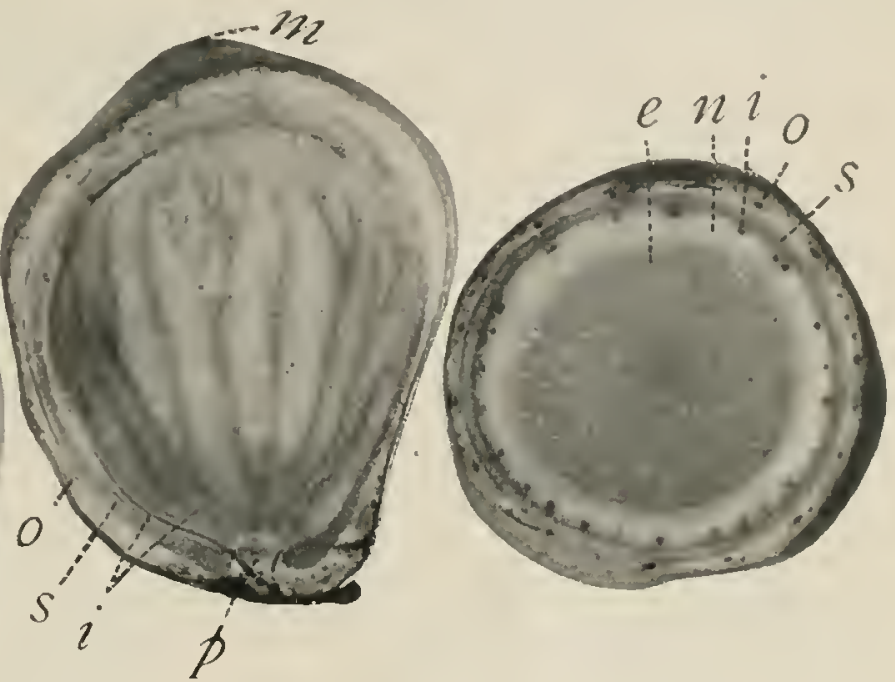

125

FIGS. 1 23-125.- Dioon edule: photographs of ovules after allowing eosin to enter the bundles; fig. I 23 , vertical view showing I 4 bundles; the eosin has spread and exaggerated the size of the outer bundles; fig. 124, photographed after the endosperm and part of the inner fleshy layer had been remover; fig. I 25 , transierse section; $s$, stony layer; o, outer fleshy layer, showing cut ends of bundles of outer vascular system; $i$, inner fleshy layer with bundles; $n$, inner fleshy layer and fused portion of nucellus; $e$, endosperm; all X2.-After CHAMBERLAIN (46).

The vascular anatomy of the ovule in its broader features is quite uniform throughout the group. There is an outer set of vascular strands, consisting of a few bundles, that traverses the outer fleshy layer of the integument and extends with little or no branching from the base of the orule to the micropyle; and an inner set traversing the fleshy layer just within the stony coat, extending to the free portion of the nucellus, branching dichotomously, and often anastomosing. A general view of the two systems of bundles is shown in figs. I23I25. After investigating all the genera except Microcycas and Ceratozamia, Worsdell $(27 a)$ states that two bundles leave the rascular 
cylinder of the cone axis and branch, so that usually there are found in the stalk of the sporophyll four bundles, the two outer ones of which supply the two orules (fig. I26). The bundle passing to the ovule divides twice before the outer and inner vascular systems of the orule are established. Miss Stopes (44) finds that the inner system belongs to the inner fleshy layer of the integument rather than to the nucellus, because the bundles, especially in Cycas, continue in the inner fleshy layer beyond the free portion of the nucellus

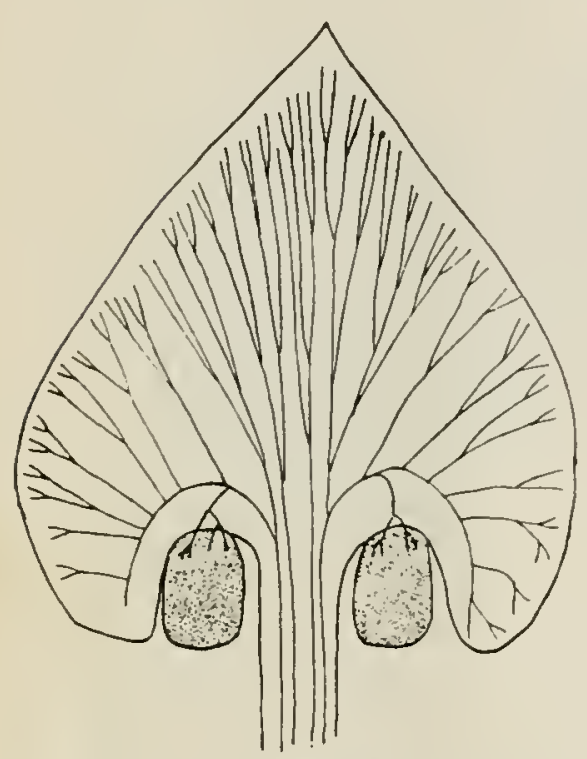

Fig. I 26.--Stangeria paradoxa: diagram of the vascular system of the megasporophyll.-After Wors$\operatorname{DELL}(27 a)$.

and extend into the free portion itself. She concludes

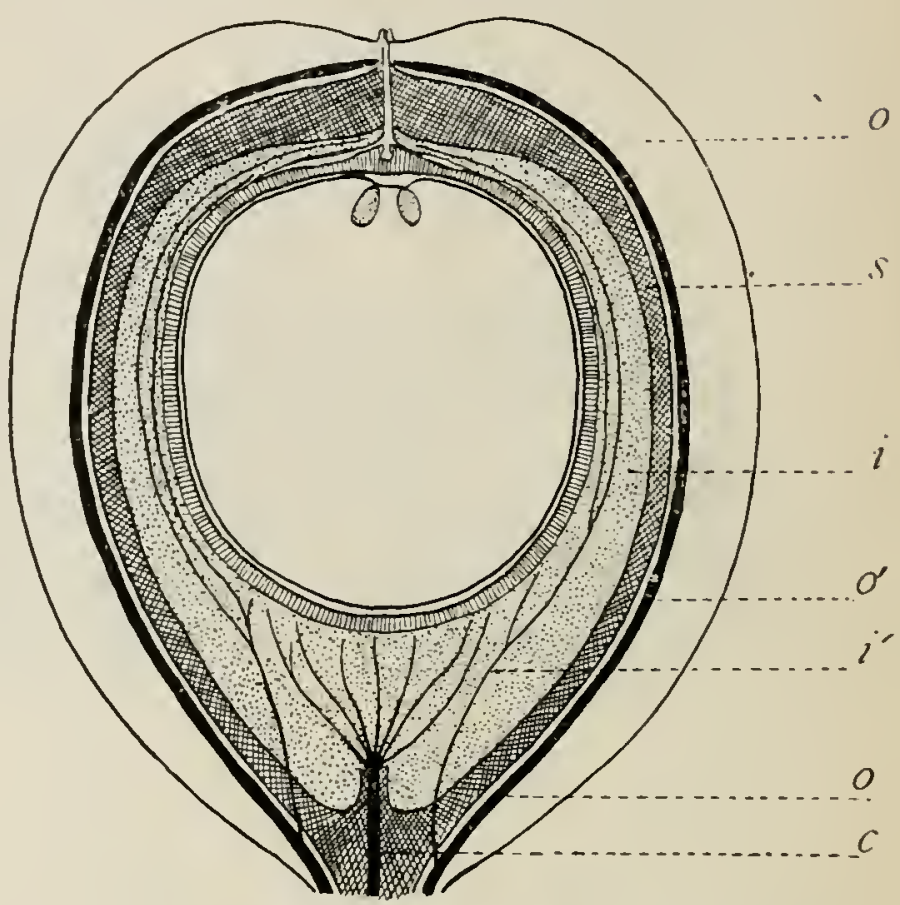

FIG. I 27.-Cycas circinalis: diagrammatic longitudinal section of nearly mature seed; 0 , outer fleshy layer, with a bundle $\left(o^{\prime}\right)$ of the outer vascular ș̣stem; $s$, stony layer; $i$, inner fleshy. layer, with a bundle $\left(i^{\prime}\right)$ of the inner vascular system; $c$, central vascular strand.-After Miss Stopes (42).

also that these bundles, in the simplest cases, are the branches of a single central strand, only a few branches coming from the side bundles (fig. 127). The relation of the inner and outer sets of vascular strands to the bundles of the sporophyll may be seen by studying figs. I28-I3I, taken from MATTE's monograph on the rascular anatomy of cycads (40).

The vascular bundles of the sterile portion of the sporophyll above the orules are generally mesarch, as in the foliage leares; and in the bundles of the outer fleshy layer of the integument the mesarch 
character prevails; but in the rather feebly developed bundles of the inner set of strands of the orule it is not always easy to distinguish the protoxylem. These weaker bundles are collateral, with but

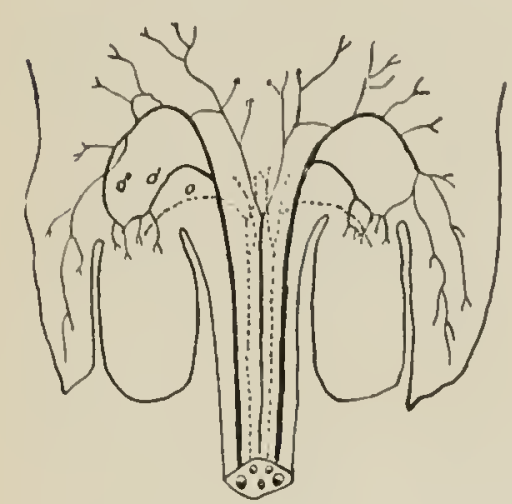

128

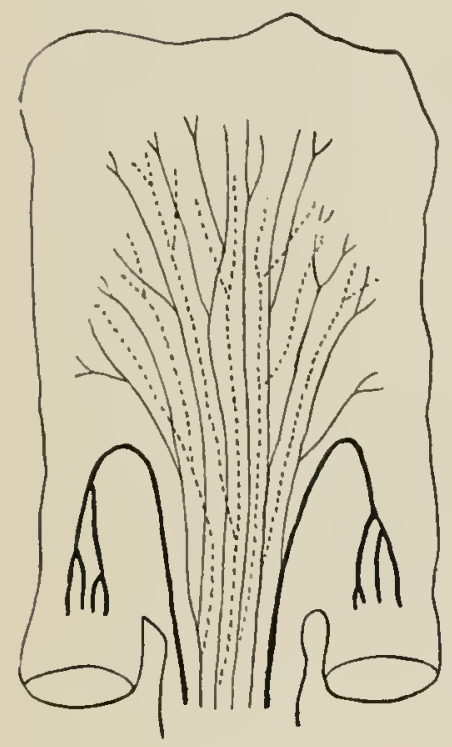

130

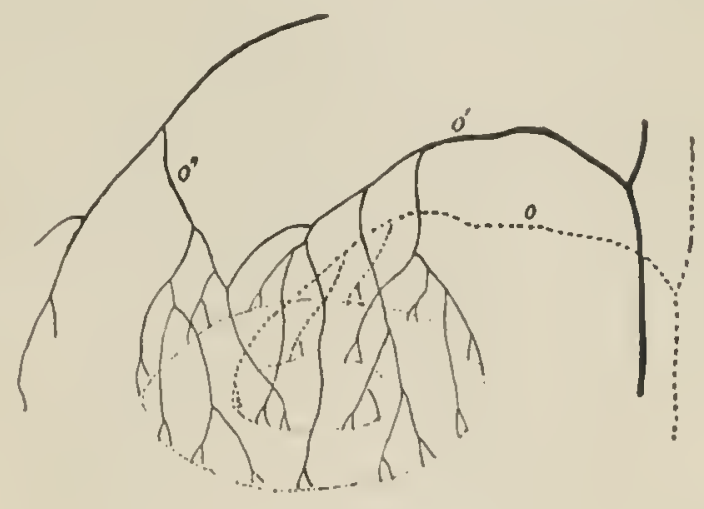

129

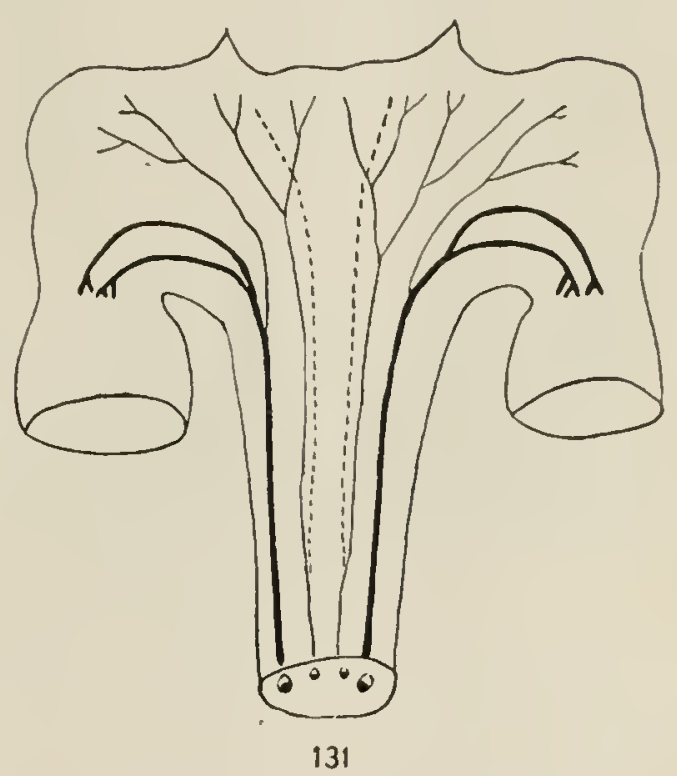

Figs. I 2S-I,3r-Diagrams of course of vascular bundles in sporophyll and ovule: fig. I $2 S$, Encephalartos villosus, course of bundles in megasporophyll; $o, o^{\prime}, o^{\prime \prime}$, three bundles passing to the ovule; fig. I 20 , small portion of the upper part of the orule on a larger scale; fig. I 30 , Microcycas calocoma, vascular supply of orule and sporophyll; fig. I3I, Ceratozamia mexicana, vascular supply of orule and sporophyll.After MATTE (40).

little phloem, and when mesarch the development of centripetal xylem is very slight. The large central bundle, which in Cycas and some other genera gives rise to most of the inner set of vascular strands, is concentric or nearly so. 


\section{The gametophytes}

THE FEMALE GAMETOPHYTE

Fi. The megaspore is the first cell of the female gametophyte. It germinates immediately, a prolonged period of free nuclear division
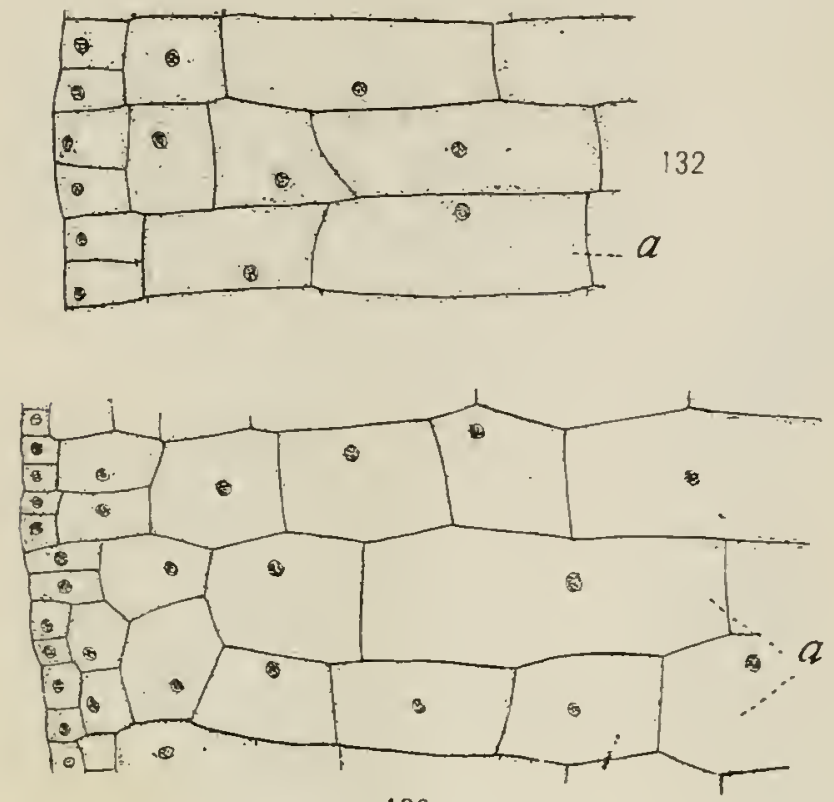

133

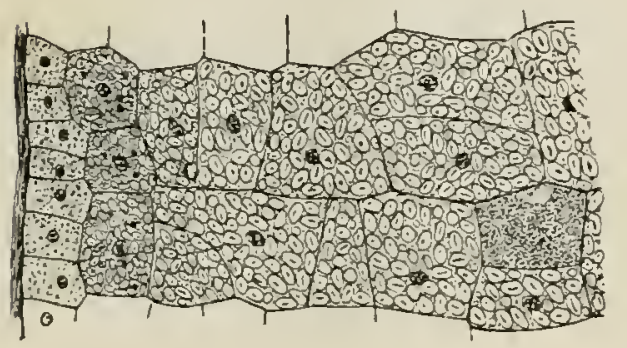

134

Figs. I32-I34.-Dioon edule: stages in the development of the endosperm; fig. I32, small portion of periphery of endosperm some time after it has become cellular throughout; fig. I 33 , still later; the two rows ( $a$ ) have come from a single roy (like a) of the preceding figure; fig. I 34 , mature endosperm, showing thick megaspore membrane at the left, the outer row of rells with little or no starch, the next row with small starch grains, and the rest with large starch grains; the evenly shaded cell contains tannin; all XSS. - After ChamberLaIN (46).

ingly abundant, and in the mature seed it occupies almost the entire cell. The cells of the outermost layer are sharply differentiated from the rest, not only by their smaller size, but also by their almost much greater increase in the size of the embryo sac than in the quantity of cytoplasm, resulting in the formation of a large central vacuole which presses the cytoplasm with its nuclei against the megaspore membrane. Although cellformation has not been studied among cycads, it is erident that it begins at the periphery of the embryo sac and advances toward the center, as has been described for other gymnosperms (figs. I32I34). From the figure it will be seen that cell-division is more vigorous at the periphery. Even after the gametophyte has become cellular throughout, sugar is the principal food content of the cell; but as the orule approaches its full size, starch becomes increas-

being accompanied by a 
entire lack of starch. The layer next within is also somewhat differentiated, its cells being much larger than those of the outer layer, but much smaller than those of the ordinary endosperm cells of the remaining regetative portion of the gametophyte. Many cells, like the evenly shaded one in fig. I34, contain tannin.

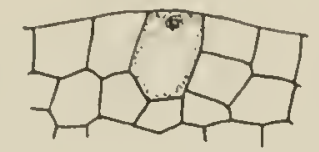

135

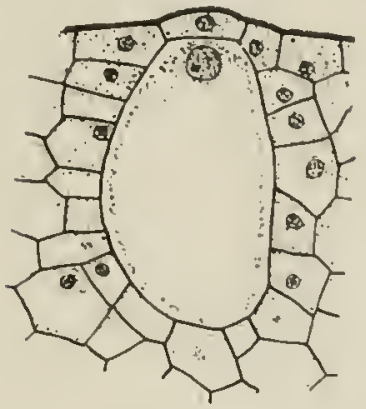

136

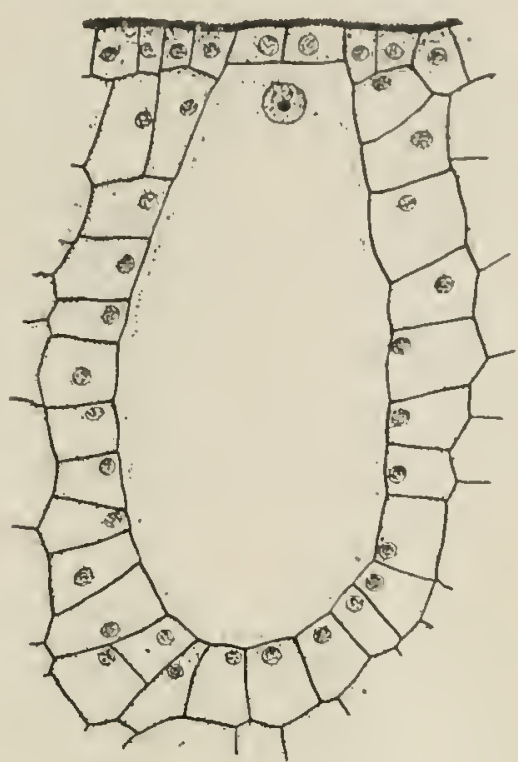

137

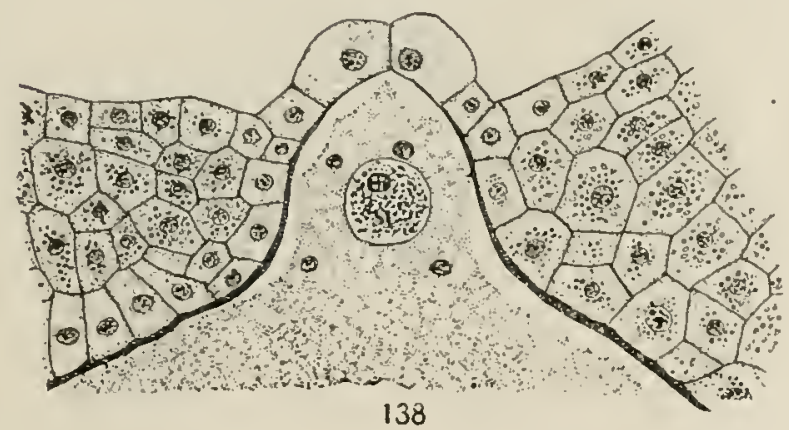

Figs. I35-138.-Dioon edule: development of the archegonium; fig. I $355^{-}$the archegonium initial (November); fig. i 36 , central cell and neck cell (December); fig. I37, archegonium in January; fig. I 38 , upper portion of archegonium in March: all XSS.-After ChAMBERLAin $(46)$.

The development of the archegonium has been described for Cycas revoluta by Ineno (27) and for Dioon edule by ChamberLain (46); isolated stages are known in other forms. In Dioon edule the archegonium initials, usually four or five in number, may be seen early in November, more than five months before fertilization. The initial soon divides, giving rise to a primary neck cell and a central 
cell. The central cell is all that remains of the "axial row" of bryophytes and pteridophytes, true neck canal cells having been eliminated from the history of the archegonium. The primary neck cell divides almost immediately, forming the two neck cells which are characteristic of the whole group. After remaining for about three months with little change, the neck cells grow rapidly and project prominently above the general level of the surrounding tissue (figs. $135^{-1} 3^{8}$ ).

For some time the central cell increases in size much faster than in cytoplasmic content, so that a large vacuole presses the scanty cytoplasm into a thin layer against the cell wall. As the central cell approaches full size, its cytoplasmic content increases and it receives various food substances from the surrounding tissue. This accumulation of food substances by the central cell may be spoken of as the nutrition of the egg, although in a strict sense the term egg cannot be used before the mitosis which gives rise to the egg nucleus and the ventral canal nucleus. During the enlargement of the central cell its wall becomes greatly thickened and chemically modified, containing besides the original cellulose both pectin and amyloid substances. The wall also becomes conspicuously pitted, and this thick pitted wall is called the egg membrane. Through the pits in this membrane food materials from the surrounding tissue enter the central cell, although during its earlier developmental stages it receives material by the ordinary methods of transferring substances from one cell to another. Goroschankin (I2) described pits with fine strands of protoplasm connecting the jacket cells and the egg, and a year later Treub (I3) saw the pits in Cycas circinalis. In his work upon Cycas revoluta Ineno (27) investigated this subject and found that large quantities of food material pass through the pits into the central cell. He likens this process to the passage of food materials from the follicle cells into the eggs in many animals. In the Abietineae Arnoldi (28) describes even the passage of entire nuclei through the pits. Miss Isabel Smith (4I) investigated the egg membrane of Zamia floridana and found that the cytoplasm of the egg protrudes through the pits into the jacket cells and forms processes which she called haustoria, and showed that the structures described as nuclei by ARNOLDI might have been tangential sections of the enlarged ends of haustoria. Stopes and Fujir (5o) found that a delicate membrane 
closes the pit and that communication between the jacket cells and the central cell is only through fine strands of protoplasm (Plasmodes$m e n)$ traversing the pit-closing membrane, and claim that it would be absurd to suggest that protein granules travel from the jacket cells to the central cell. In Dioon edule, according to ChamberLan (46),

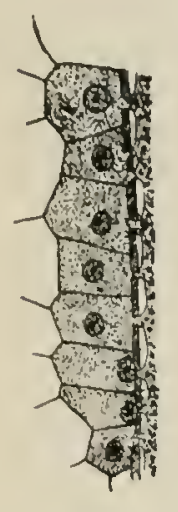

139

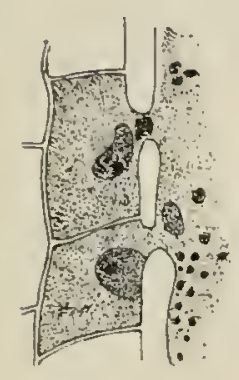

140

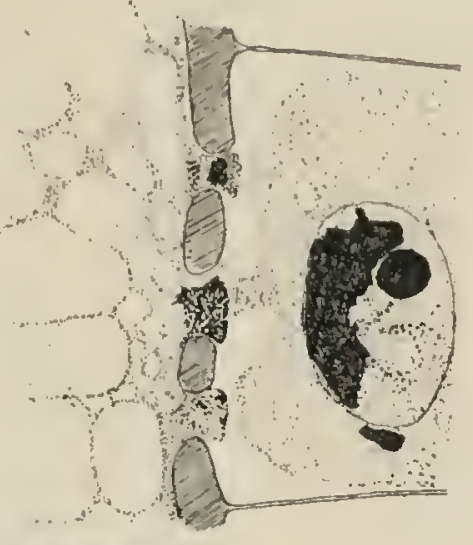

141
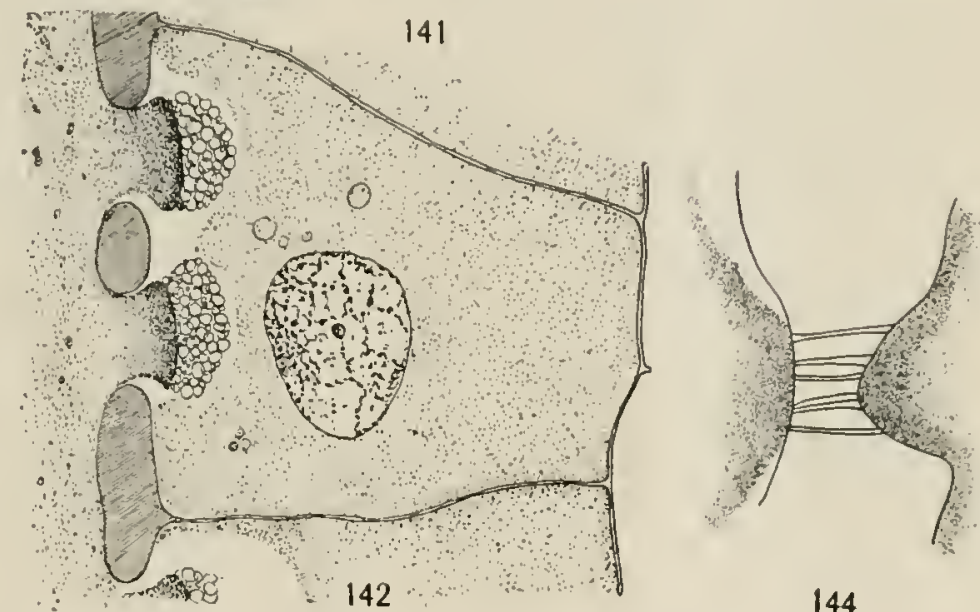

144

Figs. I30-I 4 4.-Haustoria of cycads: fig. I39, Cycas revoluta; $X$ I50; fig. I 40 , the same $\times 375$; figs. I 4 I-I 43 , Dioon edule; $\times 800 ;$ fig. I 44 , Encephalartos Lehmanii, showing the Plismodesmen; from a free-hand section which had been treated with sulphuric acid; XI,100.-Figs. I39, I 40 , after IKENO (27); figs. I 4 I-I 43 , after Chamberlaix (46); fig. I 4 , after Stopes and FujiI (.50).

substances pass from the jacket cells into the haustoria as readily as from one part of the cell into another. Doubtless a pit-closing membrane exists here, as elsewhere, during the earlier development of the central cell, but as the haustoria grow larger and project into the cells of the jacket, the closing membrane is ruptured. 'The situation may be better understood from a series of figures by the various investigators (figs. I39-I44). 
A ventral canal cell in cycads was first described by STRASBURGER (7) in I876 for Cycas sphaerica, and the next year WARMING (8) described one in Ceratozamia robusta, but soon concluded that he had been mistaken. Treub (I 3 ) in I 884 failed to find any ventral canal cell in Cycas circinalis, and from that time it was generally believed that the cycads have no ventral canal cell. In i 898, however, IkENo (27) made an unmistakable demonstration of the critical
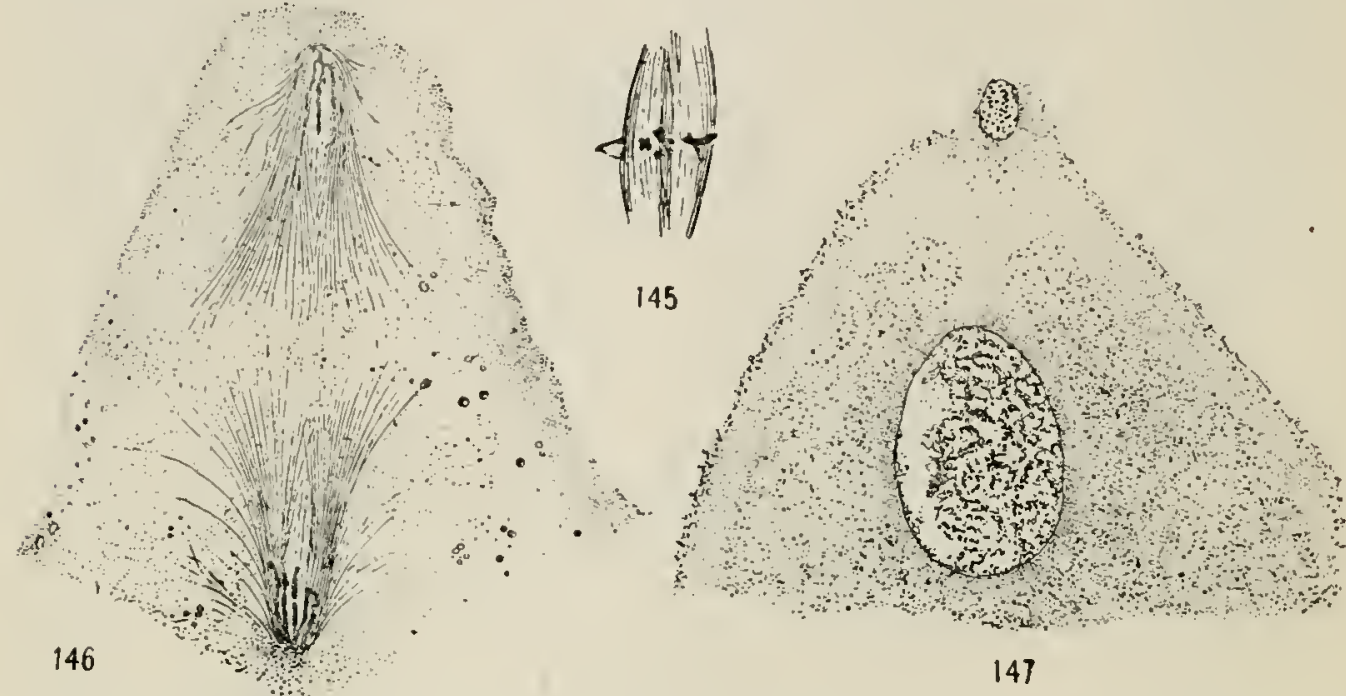

147

Figs. I 4.5-1 47.-The ventral nucleus in cycads: fig. I +5, Cycas revoluta; mitosis which produces ventral canal nucleus and egg nucleus; $\times_{375}$; fig. 146 , Dioon edule; later stage, showing that no cell plate is appearing in connection with the spindle; $\times 35^{\circ}$; fig. I 47 , Dioon edule; the ventral canal nucleus disorganizing, while the egg nucleus is increasing in size (no wall has been formed between the nuclei); $X_{+} I$. Fig. I 45 , after I kexo (27); figs. I 46 , I 47 , after CHAMBERLAin (46).

mitosis in Cycas revoluta (fig. I45), his figures showing that no wall is formed between the ventral canal nucleus and the egg. WEBBER (26) in 1897 reported a small cell cut off from the apex of the archegonium in Zamia, but in Igo3 Coulter and Chamberlain (33) showed that here too there is only a nuclear division. More recently, Chamberlain (46) has shown that there is a ventral canal nucleus in Dioon and in Encephalartos (figs. I46, I47). The figure of Dioon shows not only that there is a nuclear division that gives rise to the ventral canal nucleus and egg nucleus, but also that wall-formation between the two nuclei has been so completely suppressed that no trace of its initiation is seen in the spindle. 
It is probable that this condition is characteristic of the $\mathrm{cy}$ cads, with the possible exception of Microcycas. Doubtless this free nuclear condition is less primitive than that shown by Pinus and some other gymnosperms, in which a wall is formed between the ventral canal nucleus and that of the egg. Caldwell (52) states that in Microcycas there are often two or three free nuclei in the archegonium, and suggests that the extra nuclei may have arisen from the division of the free ventral canal nucleus, but more probably from the fusion of two or more archegonia. From a study of CALDWELL's figures, LAND (5t) suggests that these archegonia are not primitive, but are homologous with the multinucleate "archegonial tubes" of Welwitschia, so that the condition would be intermediate between that which prevails in gymnosperms and that which characterizes angiosperms. The fact that the neck of the archegonium in Microcycas is only feebly developed seems to favor this view. The archegonium situation in Microcycas is shown in figs. $148-150$.

During the early stages in the development of the archegonia there is not only no archegonial chamber, but the archegonial region of the gametophyte is slightly elevated.

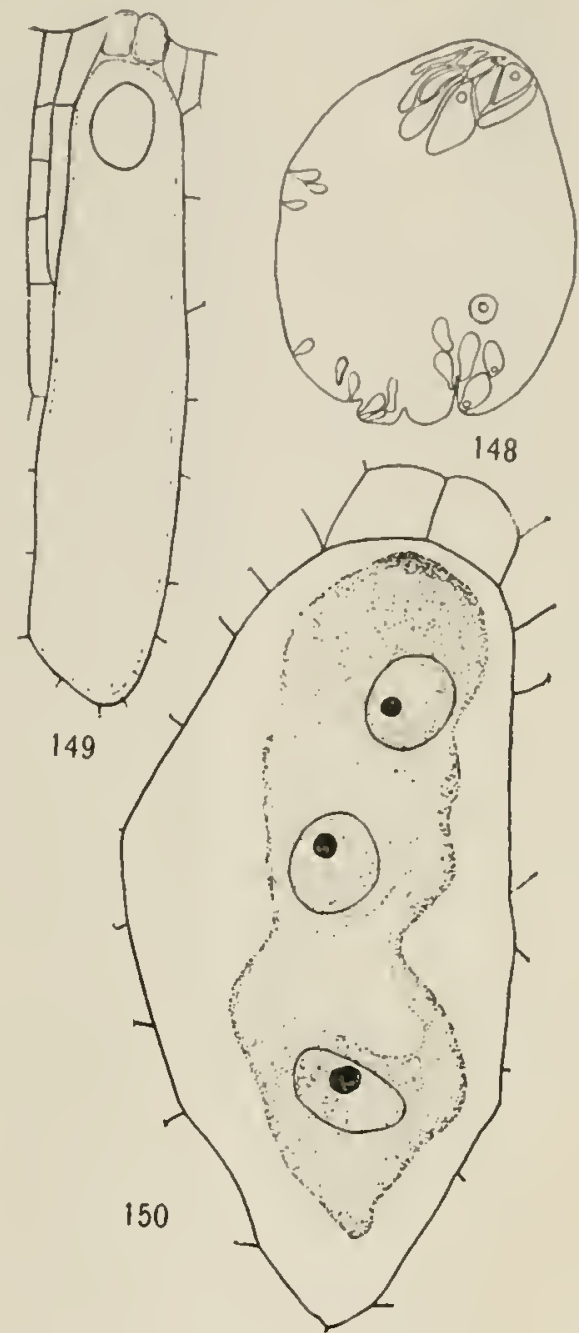

Figs. I48-150.-Microcycas calocoma: fig. 148 , general view of transverse section of endosperm, showing numerous scattered archegonia; $\times_{3}$; fig. I 49, archegonium with one nucleus; $\times 75$; fig. 150 , archegonia with three nuclei, "probably resulting from the fusion of three archegonia"; $\times 270$. After Caldwell $(52)$.

Later, the rim of the elevation grows rapidly, while the growth of the elevation itself is checked, so that what was at first the most elevated portion becomes the bottom of the archegonial chamber 
(fig. ${ }_{5} \mathrm{I}$ ). The number of archegonia varies considerably: in Cycas revoluta there are two to eight, with three the most frequent number; and in Dioon edule, one

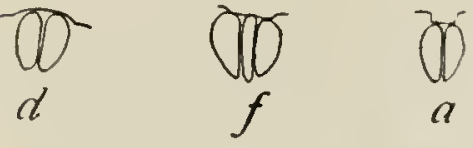

FIG. I.5.-Dioon edule: development of the archegonial chamber; $d$, the condition in December, the endosperm somewhat elevated over the archegonia; $f$, in February, the chamber appearing as a slight depression; $a$, in April, shortly before fertilization; all natural size. - After CHAMBERLAIN $(46)$. to ten, with four the most frequent. All the cycads that have been examined fall within these limits, with the single exception of Microcycas. In this genus Caldwell (52) reports more than 200 archegonia scattered over the entire surface of the gametophyte, and some of them may even open into the median cleft where the centripetal growth of the gametophyte has not completely replaced the large central vacuole. Usually the archegonia are grouped at the micropylar end of the gametophyte.

In the heterosporous pteridophytes the megaspore wall is thick and highly differentiated, and it has long been known that the endosperm of $C y c a s$ is surrounded by a membrane which is the homologue of the spore coat of the pteridophytes. With the retention of the megaspore in the sporangium, the spore coat would naturally become reduced as the retention became more and more pronounced, so that the thickness of the megaspore coat, or megaspore membrane as it is more usually called, is one of the factors to be considered in estimating the relative antiquity of the different forms. At present, however, little dependence can be placed upon this factor, because the thickness of the membrane differs decidedly at different stages in the development of the ovule. In Dioon edule (46) the thickness of the membrane during free nuclear division in the endosperm is about $3 \mu$, just before the beginning of the archegonial chamber about $5 \mu$, while in the germinating seed it has increased to 9-1o $\mu$. Not enough stages have been measured in any other form to make comparisons reliable.

The most extended investigation of this subject is that of THomson (45), who studied not only cycads, but also the other living groups of gymnosperms. He finds that the membrane is differentiated into two layers, an exospore, which is suberized, and an endospore of complex composition. The inner region of the endospore, next 
to the endosperm, contains a substance related to pectin, toward the middle the pectin is replaced by cellulose, and the cellulose is replaced in turn by suberin in the outer part of the endospore, where it borders upon the suberized exospore. In structure the endospore is rather homogeneous, while the exospore is formed of little columns or fibrillae, which give it a distinctly striated appearance (fig. I 52). The outer walls of the endosperm cells bordering upon the endospore become suberized, and might sometimes be mistaken for a part of the endospore itself. The membrane in Dioon edule is shown in figs. I $36, \mathrm{I}_{37}$, where it is in contact with the endosperm above the archegonia; and in fig. 153 , which shows the comparatively homogeneous endospore and the exospore consisting of club-shaped bodies with an ovoidal outer portion connected with the endospore by a stalk. In sections more than I or $2 \mu$ in thickness, the region of the stalks appears as a nearly black line, so that there seem to be three layers,

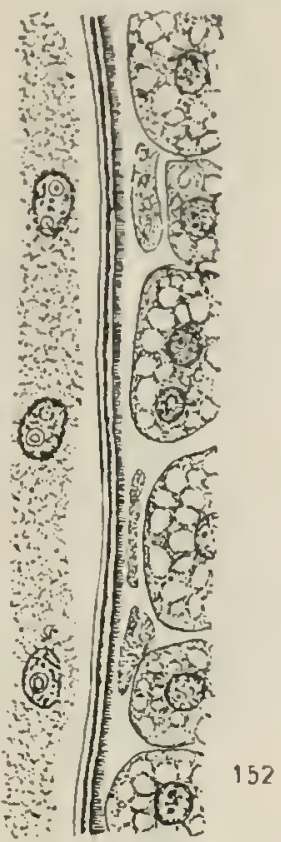

FIGS. 152, I 53 - The megaspore membrane of the cycads: fig. 152 , Cycas revoluta; three free nuclei of the endosperm at the left, cells of the endosperm jacket at the right, and the megaspore membrane $(4.5 \mu$ thick) between them; fig. 153, Dioon edule; section of megaspore membrane showing inner homogeneous layer and outer layer of cluts-shaped bodies; $X_{1,200}-$ Fig. 152, after Thomson (45); fig. I53, after Chamberlain (46). the extra layer being only an optical effect due to the stalk region.

\section{THE MALE GAMETOPHYTE}

The microspore is the first cell of the male gametophyte. The peculiar thickening of the wall of the microspore mother cell, making it resemble a heary, four-celled case containing the four spores, has been described by Juranyi (5) for Ceratozamia longifolia, and by Treub (I I) for Zamia muricata (fig. I 54). JURANYi (5) gare also a fairly full account of the germination of the microspore of Cera- 
tozamia longifolia. His material, which was secured by growing the spores upon juicy pears, showed four cells in the spore, and no further divisions seem to have occurred during such early stages in the formation of the pollen tube as could be obtained in this way. In 1896 , in a preliminary paper ( 19 ), followed by the full paper (27) in I898, IkENo presented a detailed account for Cycas revoluta;
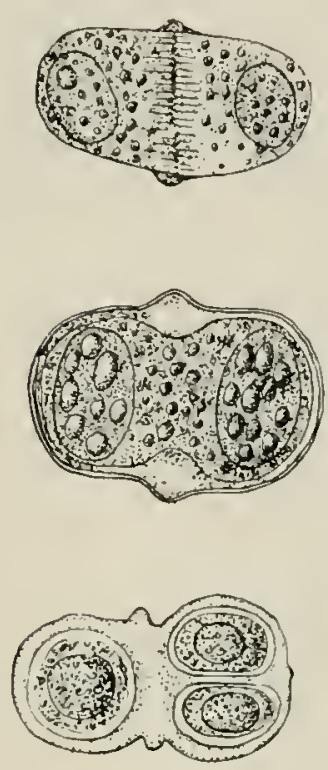

FIG. I54.-Zamia muricata: three stages in the development of microspores from the mother cell, the lowest figure showing the four microspores within the thick-walled structure; lowest figure, $X_{4} 66$; other two, $\times 596 .-$ After TREUB (I I). while in 1897 (26) and IgOI (32) WEBBER published his results for Zamia integrifolia. More recently CALDWELL ( 52 ) has described the male gametophyte of Microcycas calocoma, and Chamberlain $(63,70)$ that of Dioon edule.

The microspore has two sharply differentiated coats, the exine and the intine. The exine is thickest in the basal region of the spore, and becomes very thin toward the apex, where the pollen tube is to emerge; while the intine is thinnest in the basal region, where it is in contact with the thickest portion of the exine, and thickest along the sides of the spore (figs. I $55^{-1} 59$ ).

'The microspore germinates while still in the microsporangium, the nuclear division forming two unequal cells, a small persistent prothallial cell, and a larger cell, the antheridium initial. Immediately afterward the nucleus of the larger cell divides, forming two unequal cells, one a small cell so closely applied to the prothallial cell that it looks as if it had arisen by the division of the prothallial cell itself, and the other the tube cell. This second small cell has been called the generative cell, although it is probable that it cannot be regarded as the primary spermatogenous cell, since one of its daughter cells (the stalk cell) has proved to be persistently sterile throughout gymnosperms. In Cycas revoluta, Zamia floridana, Encephalartos villosus, and Dioon edule the pollen is shed in this three-celled condition (fig. I56); the other genera have not been studied with sufficient thoroughness to warrant any statement as to the shedding condition. 
It is generally accepted that the cycads are wind-pollinated. PEARSON (47), however, observed insects dusted with the pollen of Encephalartos iillosus, and believes it is probable that they effect

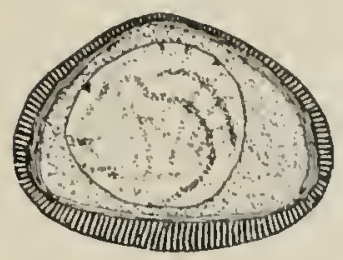

155

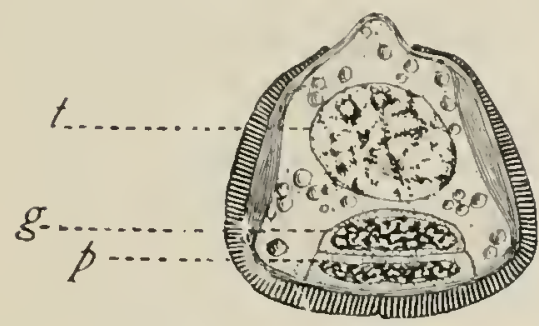

157

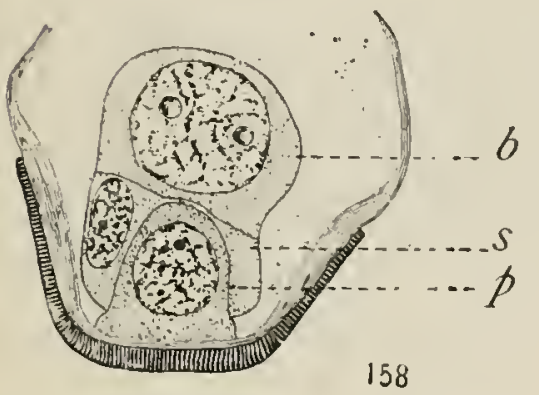

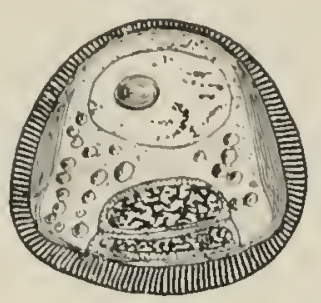

150
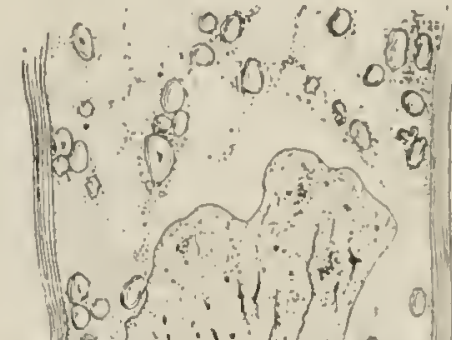

b pro

FIGS. I55-159.-Dioon edule; the germination of the microspore: fig. I55, the nucleus in early prophase of the first mitosis, exine and intine sharply differentiated (August I4, 1905); fig. ${ }_{5} 5$, the shedeling stage (September 1906); fig. 15.7 beginning of the pollen tube; $t$, tube nucleus; $g$, generative cell; $p$, prothallial cell; fig. ${ }_{5} \delta$, the generative cell divided (October 2I, I907), giving rise to stalk cell $(s)$ and body cell (b), no blepharoplasts visible; fig. 159, later stage (November 20, I906), the body cell much elongated and the blepharoplasts with very conspicuous radiations; figs. I55-157, XI,260; fig. I58, XI,000; fig. I59, X630.-After Chamberlain (63).

pollination. In Dioon edule (63), when the pollen is shed, a large pollination drop oozes from the micropyle, just as in gymnosperms which are known to be wind-pollinated, and in this case, also, insects dusted with pollen were found in the staminate cones, but there was nothing further to indicate that pollination was being effected through 
their agency. Until insect pollination is proved, it is safer to assume that the pollen is carried by the wind, as is generally supposed.

Whether in artificial culture or in the pollen chamber, the pollen tube begins to grow at once, but in cultures the growth is very limited, neither Juranil (5) nor Strasburger (7) having been able to get the division of the generative cell. Under natural conditions the development continues without interruption from pollination to fertilization, a period of about four months in Cycas revoluta, about five months in Zamia floridana, and about six months in Dioon edule. The pollen grain end is pushed into the open cavity of the pollen chamber, while the haustorial end penetrates the nucellus, branching occasionally and running so near the surface that the brown lines due to the tubes are easily visible to the naked eye. Starch is abundant in the pollen grain and during all stages in the derelopment of the pollen tube.

The generative cell soon divides, forming two cells which have been called the stalk and body cells on account of their usual relations to each other in most gymnosperms. In IkENo's figures of Cycas revoluta (27) these two cells lie side by side, and it would seem that either might function further; while in Zamia, Dioon, Microcycas, and Ceratozamia they have the more usual fore and aft position (fig. I 59). The stalk cell does not divide again, but increases greatly in size and becomes filled with large starch grains; and since it has been found to be sterile in all gymnosperms, it may be regarded as representing the actual stalk cell of an antheridium. In that case, the body cell is the real primary spermatogenous cell. The body cell increases both in size and cytoplasmic content, but contains little or no starch. As these two cells enlarge, the prothallial cell behaves in a peculiar way, pushing into the stalk cell until it often presses against the wall between the stalk and body cells (figs. 158, I59).

The most interesting feature in the development of the male gametophyte is the fact that motile sperms are produced. The cilia by which the sperms swim are the culmination of the development of a small body called the blepharoplast, which appears in the body cell several months before the latter divides. When first unmistakably distinguishable, there are two blepharoplasts, one at each pole of the nucleus of the body cell, but occasionally they may be nearer together 
(fig. I66). The blepharoplast is surrounded by a beautiful system of radiations, so that the whole structure has exactly the appearance of a centrosome with its aster. In Dioon edule, during early stages, the rays appear very coarse on account of globules which become

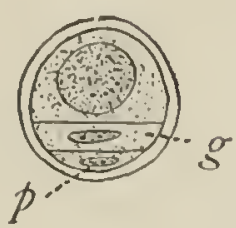

160
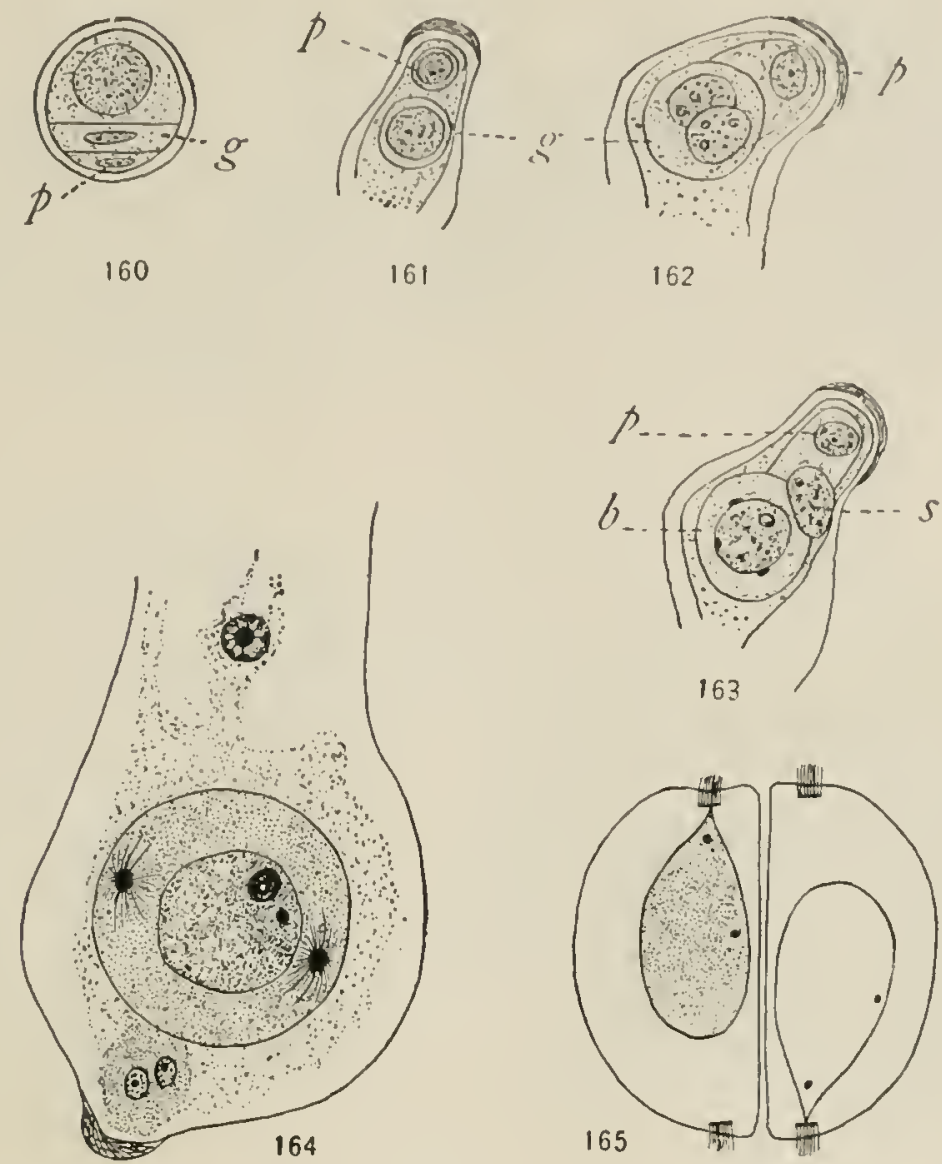

FIGs. I60-I65.-Cycas revoluta: fig. I 60, pollen grains at shedding stage; $\times 500$, fig. 16I, later stage, showing prothallial cell $(p)$ and generative cell $(g)$, the tube nucleus not shown; $\times 200$; fig. I 62 , generative cell divided, giving rise to stalk and body cells; $\times_{500}$; fig. $6_{3}$, the stalk nucleus $(s)$ being crowded out, and blepharoplasts appearing in the body cell $(b) ; X_{500}$; fig. $16_{4}$, the body cell shortly before division, sliowing two well-developed blepharoplasts; $\times 750$; fig. 165 , the two male cells resulting from the division of the body cell; the beaks of the nuclei are attached to the cilia-bearing bands; X200.-After IKExo (27).

attached and spread along them (fig. I 59); later they become smooth and even. During the earlier stages in the development of the body cell, when it is more or less elongated in the direction of the long axis of the pollen tube, the blepharoplasts lie in the plane of the long axis; but as the pollen tube enlarges, the body cell gradually becomes nearly 
spherical and the blepharoplasts rotate through $90^{\circ}$, so that they become transverse to the long axis of the tube (figs. I59-I69). The body cell divides in the plane of the long axis of the tube, giving rise to two sperm mother cells. As division of the body cell approaches,

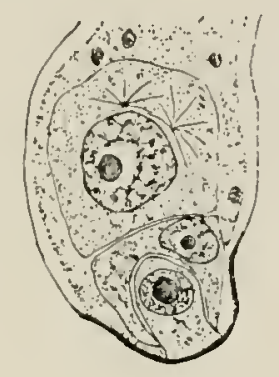

166

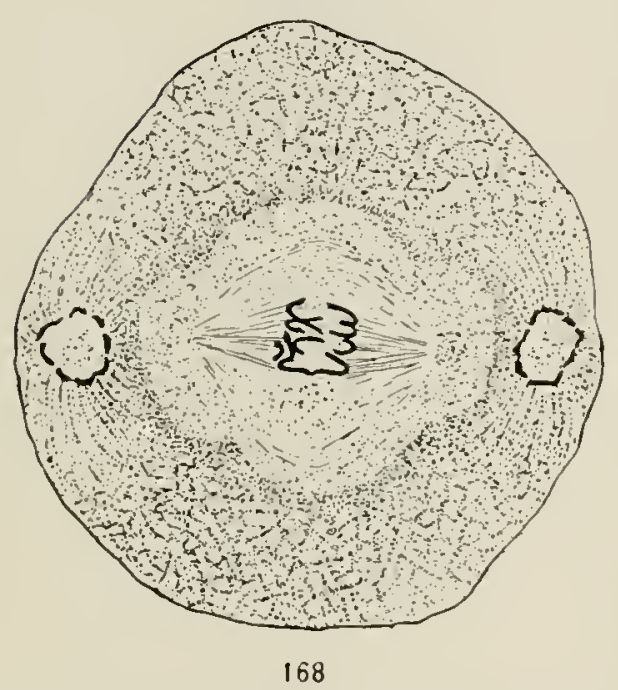

Figs. I66-I6).-Zamia floridana: fig. I66, end of pollen tube with prothallial and stalk cells, and the body cell with young blepharoplasts; fig. I67, later stage, showing blepharoplasts in fore and aft position; fig. I6S, division of body cell; in section the blepharoplasts appear as broken circles; fig. I 69 , the two cells resulting from the division of the body cell; the blepharoplast elongating into a band.-After IVEBBER (32).

the blepharoplast becomes very much vacuolated, and during the division it breaks up into a large number of granules which fuse together and thus initiate the formation of a spiral band (figs. I68, I69). While the band is being formed, it is intimately connected with the nucleus (fig. I65), and when completed it is a spiral of five or six turns, lying just below the surface and giving rise to numerous 
cilia that pass through the outer border of the sperm and project for some distance.

It has been claimed that the two cells formed by the division of the body cell become ciliated and are themselves the sperms. InExo
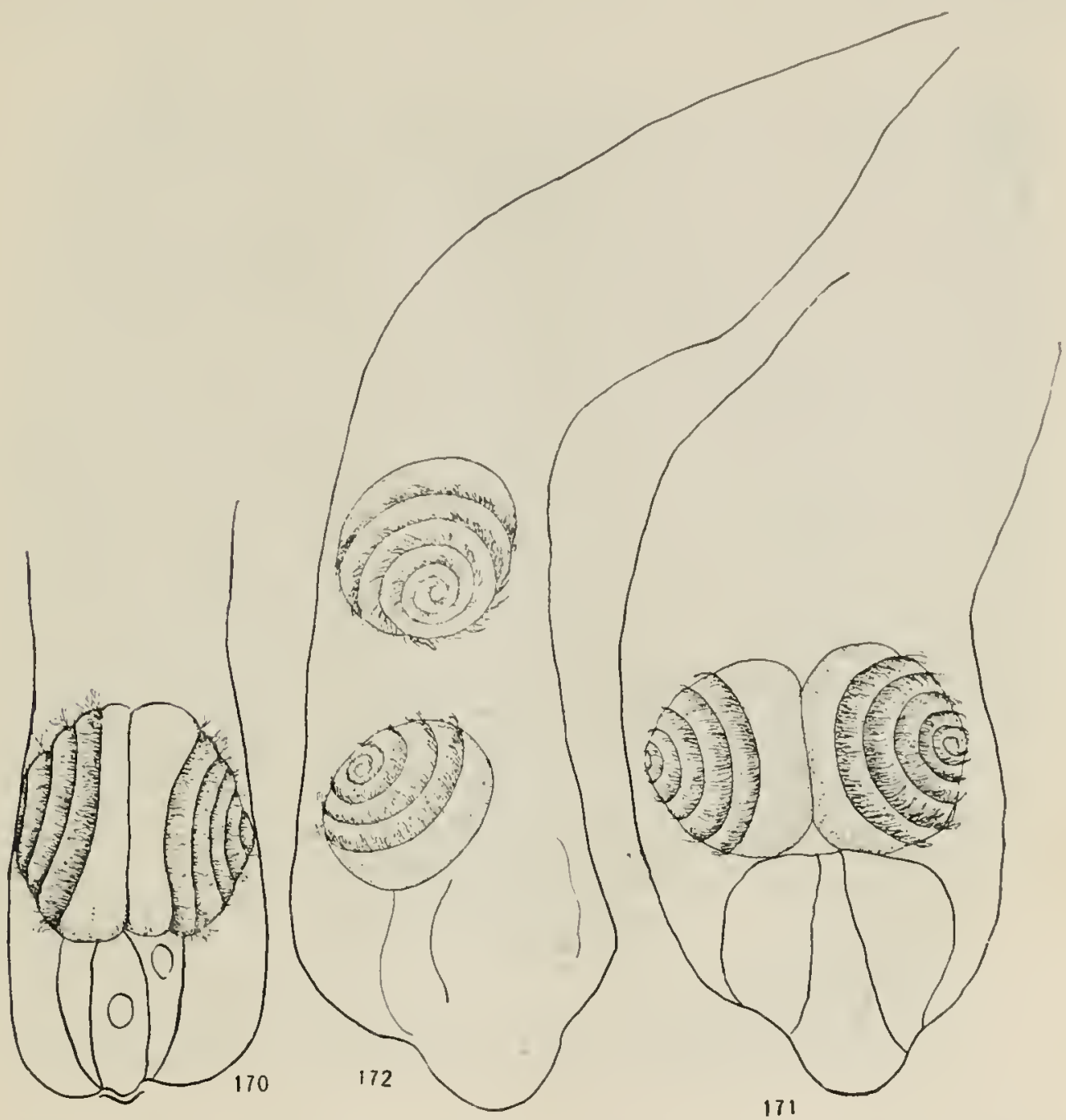

FIGs. 170-172.-Sperms of cycads, represented as not formed within mother cells, but as consisting of the entire transformed halves of body cells: fig. I 7o, Zamia; pollen tube with sperms just before they begin to swim; $X_{90}$; fig. I 71, Cycas rezoluta; the sperms at the beginning of movement; fig. I 72, Cycas revoluta: the sperms swimming freely in the tube; $\times 8 S$. - Fig. I 70 , after $W^{7}$ FBBER (32); figs. I 71,172 , after MIYAKE (48).

(27) described the sperms of Cycas as perfectly naked, and WebBeR (32) found the same condition in Zamia, where he was unable to find any inclosing mother cell, although he looked for it. Mrrake (48) also looked for an inclosing cell in Cycas and saw a thin mem- 
brane, but could not determine whether it belonged to the sperms or might be only the Hautschicht of the cytoplasm of the pollen tube. In such a case the two sperms would simply become loosened from the stalk cell and swim away (figs. I 7o-I72). In Dioon edule, according to Chamberlain $\left(6_{3}\right)$, the division of the body cell gives rise to

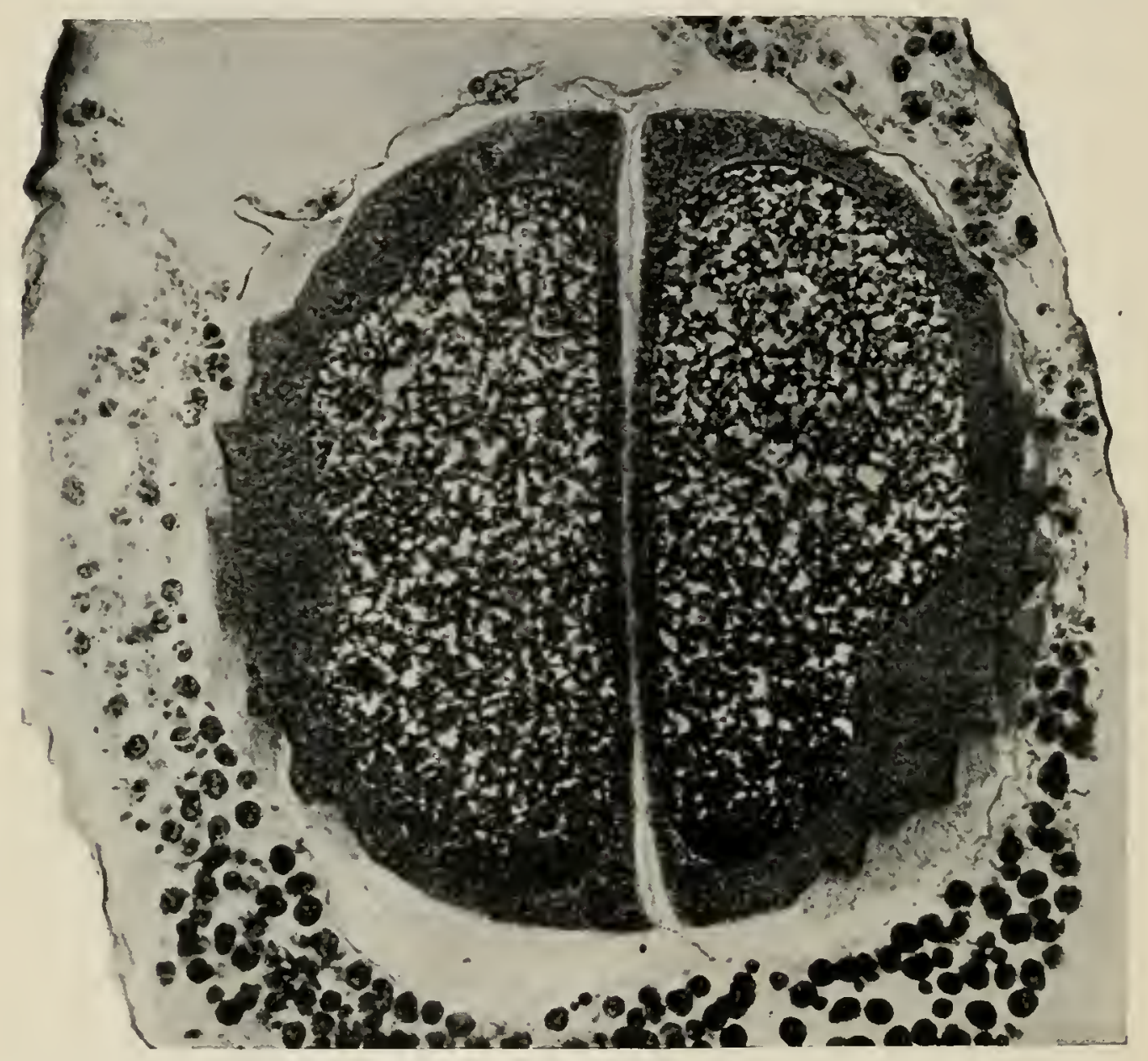

FIG. I73.-Dioon edule: photomicrograph of end of pollen tube, showing that the two sperms are formed within sperm mother cells; the walls of the mother cells can be seen between the sperms and surrounding them; $X_{720}$.-After CHAMBERLAIN $(63)$.

two sperm mother cells, inside of which the sperms are organized and from which they are discharged. This conclusion is based upon an examination of both living material and sections. The photomicrograph reproduced in fig. I 73 shows the two sperms within their mother cells.

In Cycas, Zamia, and Dioon two sperms are formed in the pollen 
tube; but in Microcycas CaLDWELL (52) describes and figures sixteen to twenty sperms (figs. I 74,175 ), and four sperms are found occasionally in Ceratozamia (53). It is evident that in Microcycas the body cell has given rise to cight or ten spermatogenous cells, each of which has produced two sperms. Cupressus Gozeniana, described
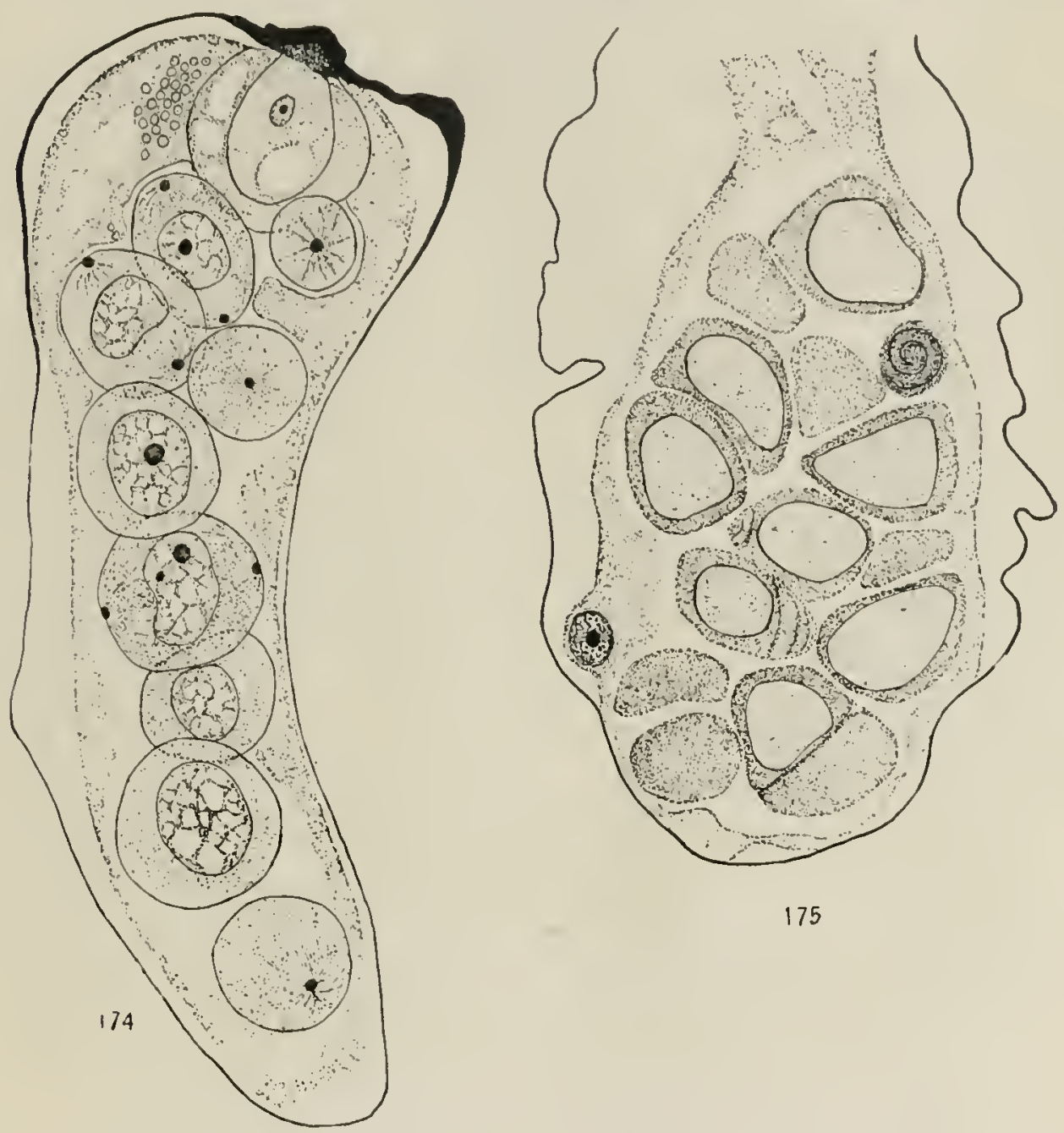

175

Figs. I74, I 75.-Microcycas calocoma: fig. I 74 , pollen tube showing nine spermatogenous cells, in most of which the blepharoplasts are seen; $X_{1} 60$; fig. 175 , later stage showing sections of ${ }_{5} 5$ sperms; $X_{450}$.-After Caldwell ( 52 ).

by JUeL (39), has four to twenty sperms, all derived from the body cell. The large number of sperms is doubtless a primitive character, as both investigators suggest, but the cases seem somewhat different, since in Microcycas the condition may have persisted from earlier forms, while in Cupressus Goveniana it is more likely to be a reversion.

The sperms of cycads are remarkably large, in fact larger than any 
known in other plants or in animals. They are usually slightly longer than broad, in Zamia floridana being $222-332 \mu$ in length and $222-306 \mu$ in width; in Dioon edule $300 \mu$ in length and $230 \mu$ in width; in Cycas revoluta $180-210 \mu$ in width; and in Microcycas calocoma about $60 \mu$ in width. As shown in fig. 173 , the nucleus is very large, with only a thin sheath of cytoplasm. Such large bodies, of course, are easily visible to the naked eye, and since the pollen tubes are transparent, it is easy to observe the movements of the sperms.

The cilia begin to move while the sperms are still within the mother cells, and their movement is accompanied by pulsating and amoeboid movements of the cytoplasm and nucleus. The peripheral portion of the partition between the sperms soon breaks down, and the two sperms, still attached to one another, often begin to swim in the old body cell before they escape into the general cavity of the tube. When free from one another, the principal movement is straight ahead, with a rotation on the long axis. The movements may continue for several hours before the sperms are discharged from the tube. For some time before the sperms are discharged, the portion of the pollen tube which projects into the pollen chamber becomes more and more turgid, until finally a rupture occurs at or near the wall of the pollen grain which still caps the end of the tube. One sperm escapes in two or three seconds, but the other may be half a minute in getting out. Experiments have been made to determine whether the sperms are chemotactic or not, but so far with only negative results.

\section{FERTILIZATION}

When the pollen chamber. breaks through the base of the nucellar cap, the portion of the megaspore membrane covering the archegonial chamber is ruptured, so that the two chambers form one continuous cavity. The archegonial chamber is moist, but contains no liquid until the turgid pollen tubes begin to discharge. The sperms swim in the liquid discharged from the pollen tubes and enter the necks of the archegonia (fig. I 76 ).

Fertilization has been described in three cases: in Cycas revoluta by Ikeno (27), in Zamia floridana by Webber (32), and in Dioon edule by Chamberlain (70), who has also observed it in Ceratozamia 
mevicana. In these four forms the entire sperm enters the egg, -but the nucleus soon slips out from the cytoplasmic sheath, and leaving it with its ciliated band in the upper part of the egg moves toward

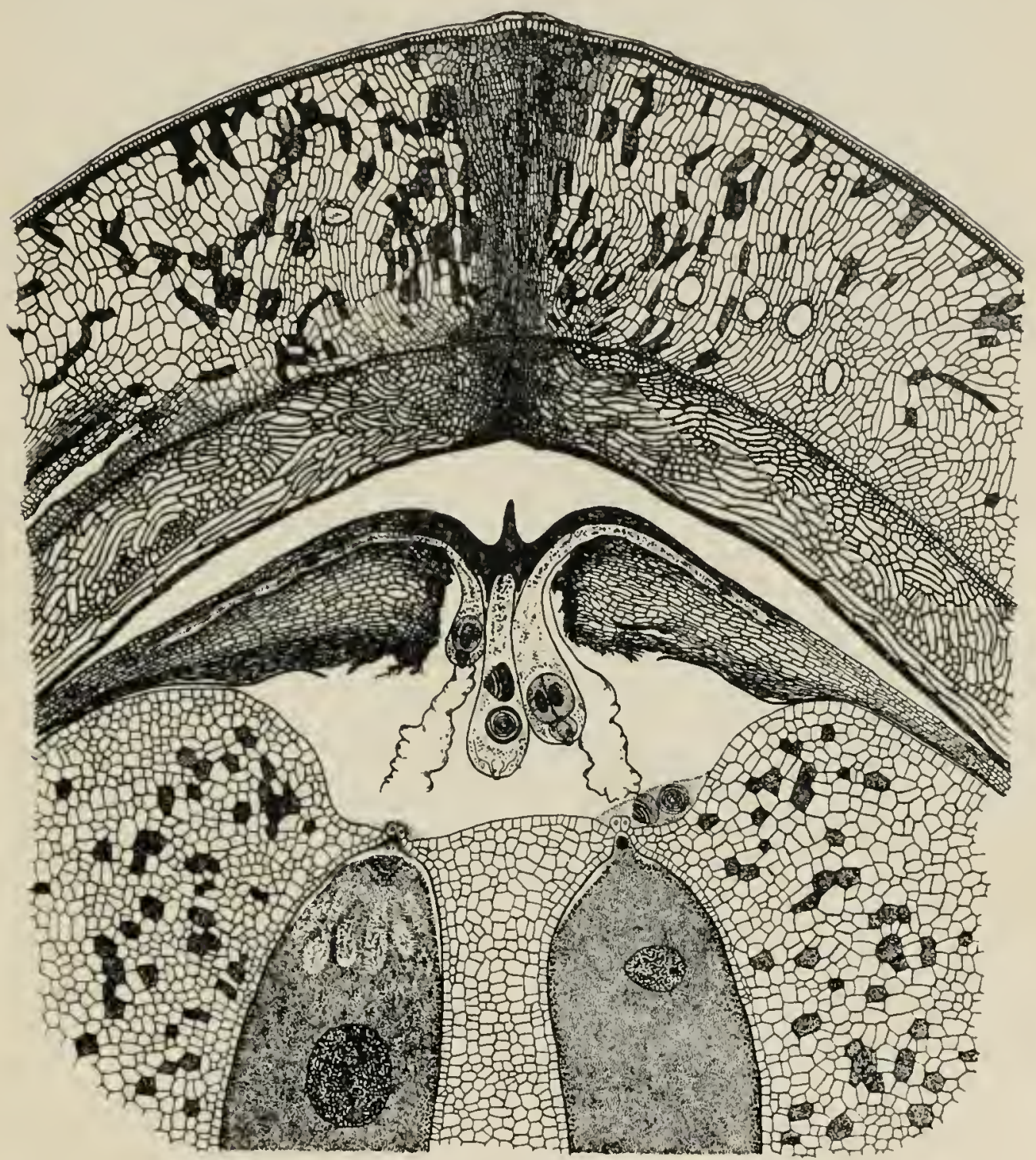

Fig. I 76. -Dioon edule: upper part of ovule at time of fertilization, showing integument, nucellus, and both male and female gametophytes; reconstructed from sections of several ovules.-After ChamberLain (73).

the egg nucleus. The ciliated band was observed by LANG (29) in the upper part of the egg of Stangeria, so that in this form also it is evident that the sperms are motile and that the whole sperm enters the egg. The sperm nucleus is much smaller than that of the egg, and it penetrates some distance into the egg nucleus before the bound- 
ary between the two becomes indistinct (fig. I77). Nothing is known of the behavior of chromatin during fertilization.

The prominent development of the pollen tube as an absorbing

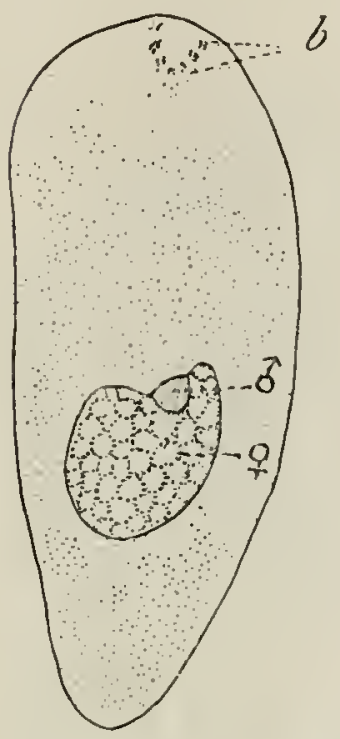

FIG. I 77.-Zamia flor:dana: fertilization; the smaller sperm nucleus has pressed into the egg nucleus, but still retains its contour; the ciliated band is still visible at the top of the egg; $\times 20 .-$ After WEBBER.(26). organ suggests a question as to its original significance. In the Cycadofilicales the pollen grains are in close proximity to the egg, and there is nothing to indicate that any pollen tube was formed. In the cycads and in Ginkgo the pollen tube in the earlier stages of its development functions only as a haustorium. The pollen grain end, with its cell complex, projects into the pollen chamber and gradually approaches the egg, not by actively invading any tissue, but merely by elongating into the enlarging pollen chamber. The portion which actively invades the nucellus is somewhat longer than the part in the pollen chamber, but has a much smaller diameter and never carries the sperms. In all other living seed plants, the pollen grain remains just where it falls, and the pollen tube acts both as a haustorium, actively invading the tissue, and as a sperm carrier. - It seems safe to assume that the pollen tube was originally a haustorium," and that its function as a sperm carrier was developed later.

\section{The embryo}

In 1877 WARMING (8) described some of the later stages in the development of the embryo of Ceratozamia, but in all cases the embryo had already passed through the base of the egg and invaded the endosperm. In I 884 TREUB (I 3 ) gave a comparatively full account of the embryogeny of Cycas circinalis, and this account was to some extent confirmed and supplemented by IkENo's (27) study of Cycas revoluta. Later, Coulter and Chamberlain (33) investigated Zamia floridana (figs. I78-I8I), and more recently CHAMBERLAIN (70) has described the embryogeny of Dioon edule (figs. I83-I 85 ). 


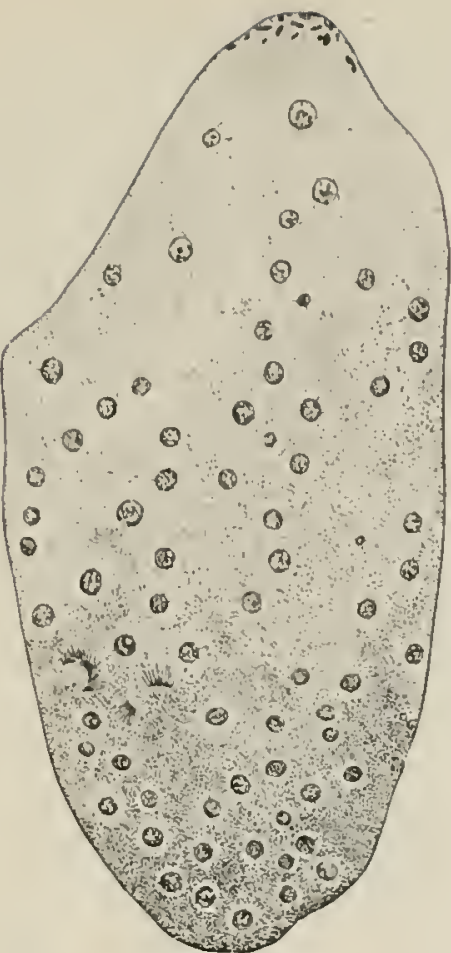

178

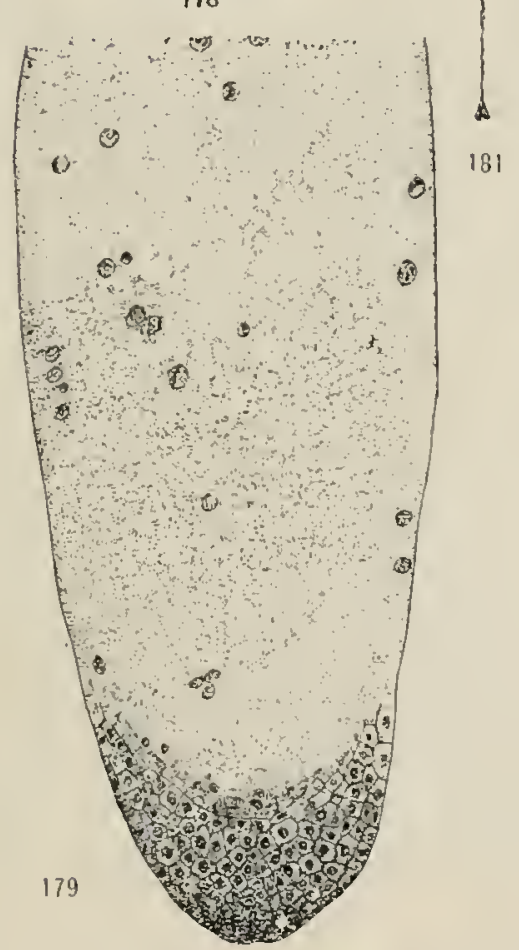

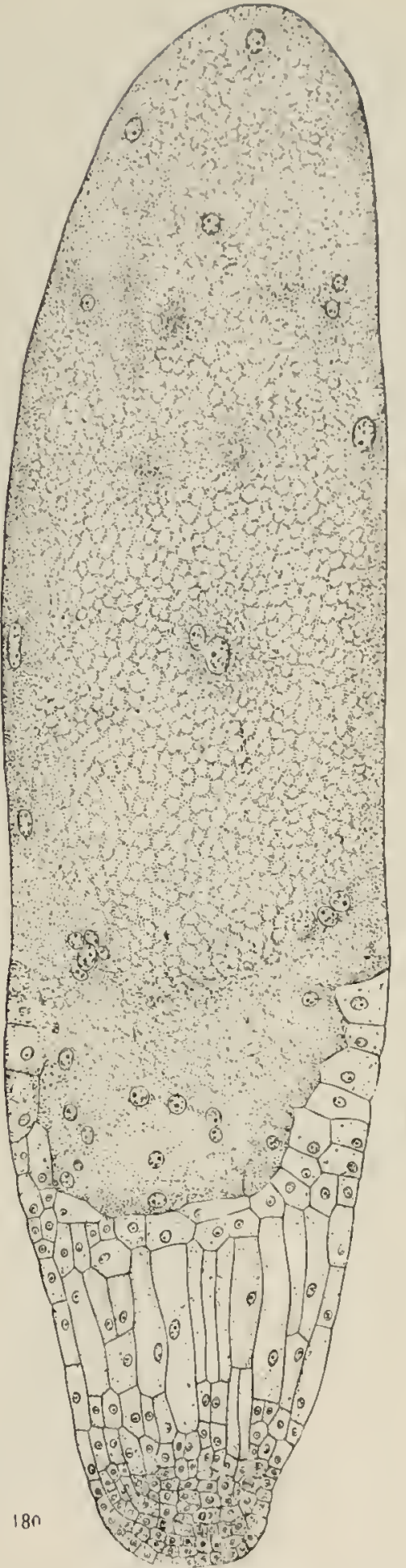

FIgS. I 7 S-i $S_{1}$-Z Zamia floridana: fig. I 7 , free nuclei of proembryo; $x_{1} 6$; fig. I 79 , tissue at base of proembryo; $\times 24$; fig. ISo, differentiation into suspensor and embrvo; $\times 29$; fig. I 8 I, young embryo showing long suspensor, natural size.-After Coultek and Chamberlain (33). 
After fertilization there is a prolonged period of free nuclear division, in which the mitotic figures are intranuclear and the spindles very conspicuous (fig. I78). Since some have regarded the blepharoplast as a centrosome, these figures have been examined with great care, and it can be stated confidently that no centrosomes are concerned in their formation. The free nuclear divisions are simultaneous, just as in the germination of the megaspore or in the

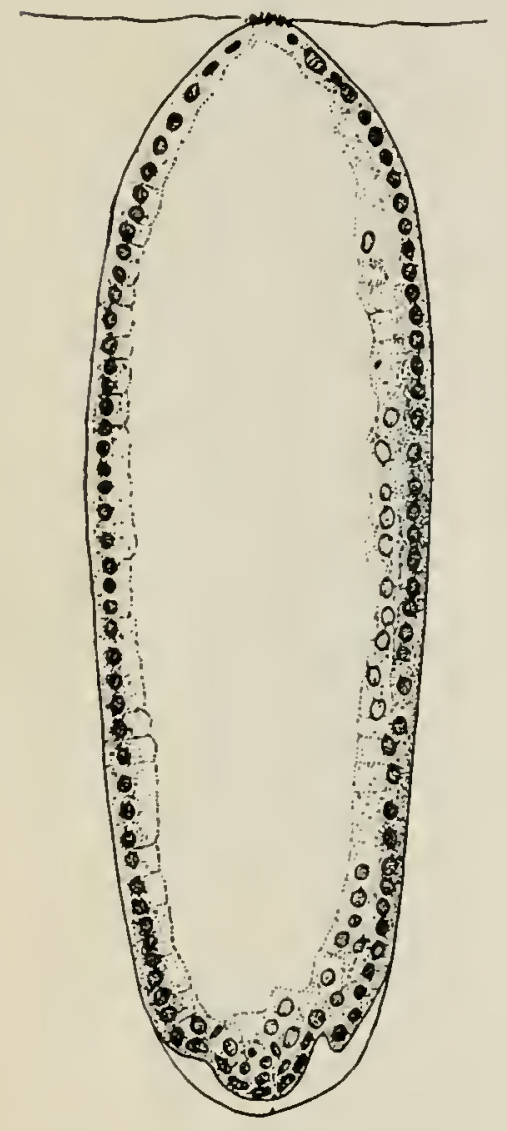

FIG. I 82.--Cyeas circinalis: beginning of wallformation in proembryo; $\times 25$.-After TREUB (I3). early development of endosperm in most angiosperms. The number of successive free nuclear divisions in Zamia floridana (33) was estimated as eight, giving 256 free nuclei before any walls begin to appear. In Cycas revoluta no estimate was made, but there are certainly as many as 256 nuclei and very probably more. In Dioon edule $(70)$ there are at least nine successive divisions, giving $5^{\mathrm{I} 2}$ nuclei, but the divisions become irregular and not perfectly simultaneous; hence one cannot assume that if the number is over $5^{\text {I } 2}$ it will be 1024 .

In Cycas circinalis, according to Treub (I3), a large central vacuole appears and crowds all the nuclei to the periphery, so that they form a parietal. layer (fig. I 82). In Cycas revoluta IkENo (27) gives a different account of the formation of the central vacuole, stating that a large number of small vacuoles are formed, and that the cytoplasm of the central portion of the proembryo with its contained nuclei then disorganizes, leaving a parietal layer of cytoplasm and nuclei, while a single large vacuole occupies the center. Ikeno's account is doubtless true for Cycas revoluta, and probably holds for $C$. circinalis also. It is evident that the proembryo becomes a sac, somewhat thickened at the base, but with the wall composed of one or two layers. In Cycas reioluta, after this stage has been reached, there are a few 


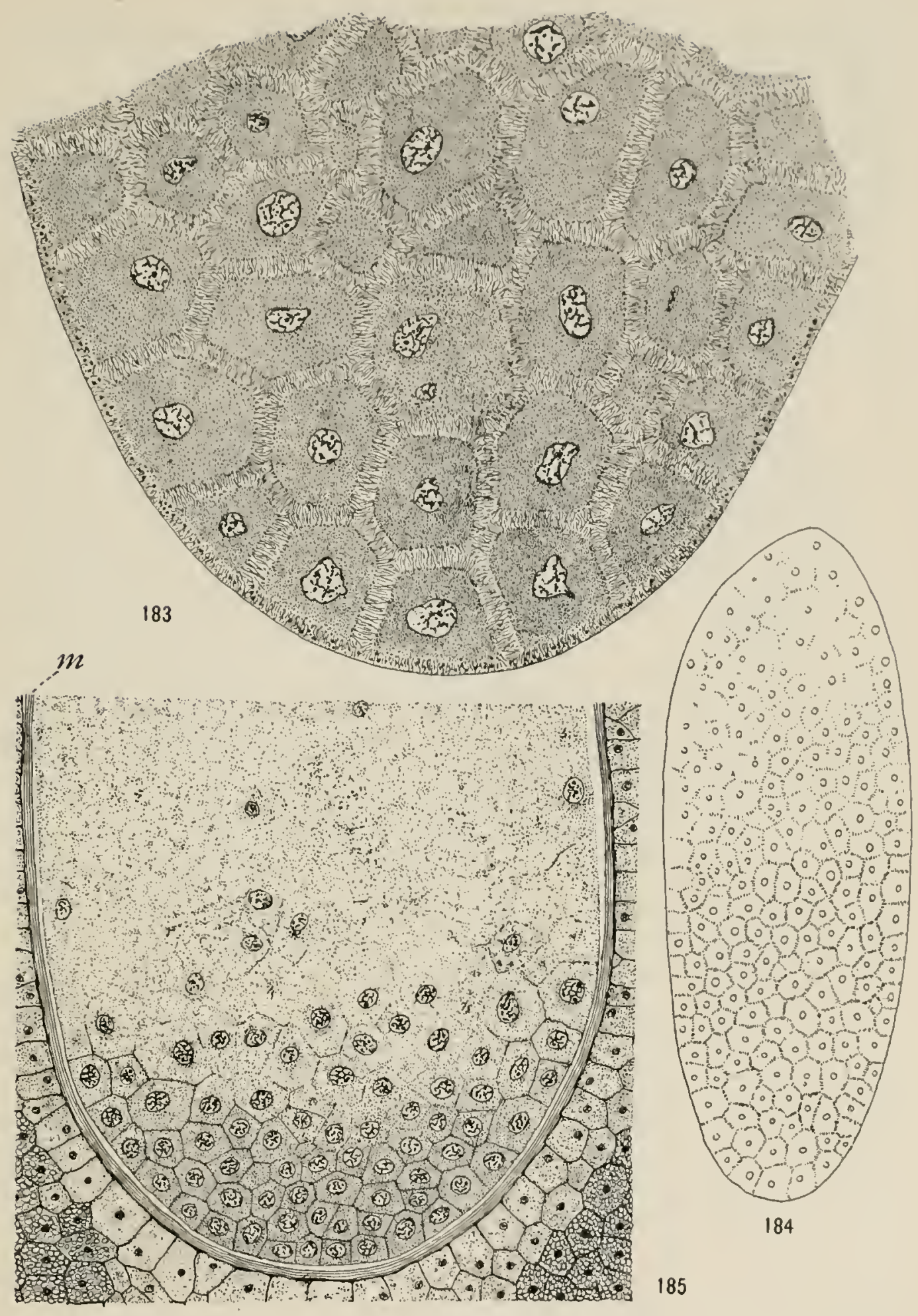

Figs. I $8_{3}-18_{5}$-Dioon edule: development of proembryo; tig. $18_{3}$, base of proembryo, showing character of segmentation at a stage when the entire egg is segmented; XIoS; fig. I $S_{4}$, diagram of entire proembryo at the stage shown in fig. I $S_{3}$ : the segmentation is disappearing in the upper region; $X_{20}$; fig. I $S_{5}$, permanent walls at the base, but as yet no differentiation into regions; free nuclei above; membrane $(m)$

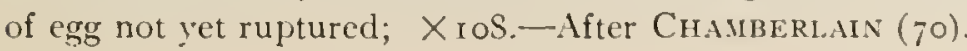


simultaneous free nuclear divisions at the base of the proembryo before walls begin to appear, and at the same time amitotic divisions may take place in the upper portion. 'The peripheral walls of the proembryo are a new formation, entirely independent of the wall of the egg. At this point the work of IkENo stops, and beyond it WARMing and Treub give very little detail.

In Zamia floridana Coulter and Chamberlain (33) found a different condition, no central vacuole being present even at a rather late period, when the suspensor has begun to elongate (fig. I80). Walls begin to appear at the base of the

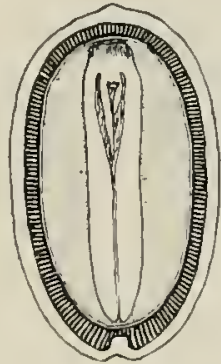

FIG. IS6.-Dioon edule: longitudinal section of mature seed, showing embryo with two cotyledons and plumule, endosperm, inner fleshy layer represented only by a line, stony layer shaded, and outer fleshy layer; natural size.Aftet ChamberLain (70). proembryo, just as in the beginning of wall-formation in the endosperm of most angiosperms.

In Dioon edule (70), at the close of the free nuclear period, walls appear simultaneously throughout the whole egg, but the walls are weak and evanescent, except at the base of the proembryo, where they become permanent (figs. $188_{3}-185$ ). Dioon resembles Zamia in having no central vacuole during the proembryo stages, but at a very late stage, like that shown in fig. I82, the egg becomes empty and preserves its contour only on account of its very thick membrane.

After wall-formation has become established at the base of the proembryo, the sequence seems to be about the same in all the forms which have been studied. The cells bordering upon the large central vacuole, as in Cycas, or upon the free nuclear area, as in Zamia and Dioon, undergo little or no change in form, while the cells immediately below them become greatly elongated, constituting the suspensor (fig. I 80). The cells at the tip remain meristematic, and from this apical region the embryo proper is organized.

The suspensor is massive and tortuous and is remarkably long (fig. I8I), that of Dioon edule, when straightened out, frequently reaching a length of $70 \mathrm{~mm}$., but it has never been observed to branch or to bear more than one embryo. The suspensors start separately from the 
sereral archegonia, but soon become twisted together, so that what appears to be a single suspensor is composed of two or three or more suspensors in its upper portion, each terminated by an abortive embryo, while beyond the region of abortive embryos stretches the single successful suspensor with its embryo. It is this twisting together in the upper part that makes the whole structure look like one suspensor with several eggs at one end and a single embryo at the other. During these stages the tissue in the archegonial region disorganizes, so that there is formed a large cavity which later becomes packed with the tortuous suspensor.

The single successful embryo rapidly invades the endosperm, and for a time increases in size with little internal differentiation. At the base of the embryo there develops a conspicuous and peculiar structure, the coleorhiza, and at the opposite end the stem tip and two cotyledons, while the root appears rather late (fig. I86).

The usual number of

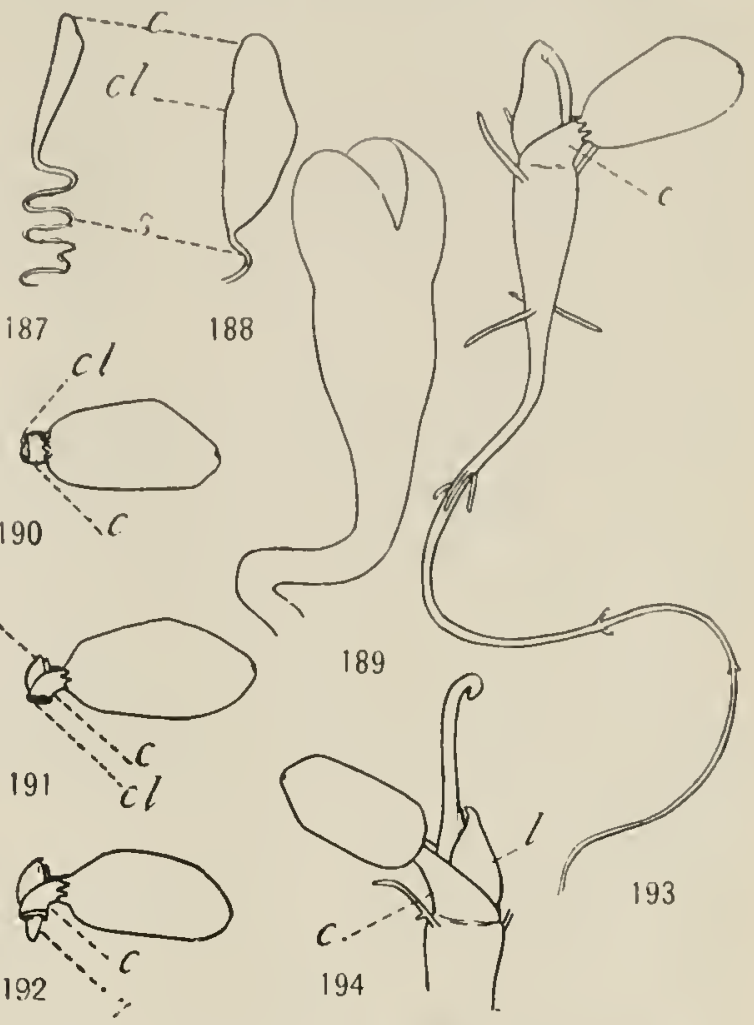

FIGS. I $S_{7}$-I94-Ceratozamia mexicana: embryo and germination of the seed; figs. 187 , I 88 , normal embryos with a single lateral cotyledon; $\times_{5}$; fig. I $S_{9}$, embryo with two cotyledons, from seed which had been on a clinostat during the entire period of cotyledon development; $\times 8$; figs. I90-19.4, successive stages in germination; $\times \frac{1}{2}$; in all figures, $c$, cotyledon; $c l$, coleorhiza; $l$, scale leaf; $f$, first foliage leaf; $r$, root; $s$, suspensor-After Sister Helen ANgela $(58,59)$. cotyledons is two, but three united throughout their entire length have been found in Encephalartos (7I). In I879 WARMING (9) described the single peculiar cotyledon of Ceratozamia, and an examination of abundant material from the field confirms the description, but Sister Helen Angela (58) noticed that the strobilus disintegrates and frees the seeds before the cotyledon has 
begun to develop. Suspecting that gravity might be concerned in the suppression of one of the cotyledons, she placed seeds upon a clinostat during the entire period of cotyledon development, and these seeds developed regularly two cotyledons (figs. I87-I94).

The mature seed has a fleshy and variously colored outer coat, developed from the outer portion of the integument, and an inner stony coat, extremely hard and tough, derived mostly from the middle region of the integument. Within the stony layer is a thin, dry membranous layer derived partly from the nucellus and partly from the inner fleshy layer of the integument and containing the inner vascular system of the ovule. In Encephalartos, Cycas, Ceratozamia, and perhaps other genera, the ovule often reaches its full size and seedlike appearance whether pollination has taken place or not. In Dioon, ovules which have not been pollinated usually abort, and consequently greenhouse material, and even cones in the field, if widely separated from staminate plants, are likely to have only abortive orules.

Seeds germinate readily if simply placed on the surface of moist soil. If corered by the soil, they are raised to the surface, but not much above it, by the cotyledons, which always remain within the seed coats.

In Dioon, Zamia, Ceratozamia, Microcycas, and probably in all the other genera, the intraseminal development may be followed immediately by the germination of the seed, no resting period being necessary. The coleorhiza, which in early stages constitutes a considerable portion of the embryo, becomes reduced to a thin, hard, brown cap which protects the more delicate structures while the micropylar portion of the stony coat is being ruptured and the young seedling is emerging. After the coleorhiza has broken through the seed coat, the tardy root pierces it and soon thickens into a stout tap root.

\section{History and distribution}

That representatives of the Cycadales existed during the Mesozoic, side by side with the predominant Bennettitales, is a safe inference, but the evidence is extremely meager. Strobili thought to be staminate cones of cycads have been used as the basis of the form genus Androstrobus. The structure of a few of these species suggests a possible connection with cycads, but Nathorst (60) has shown that 
one of them is the strobilus of a heterosporous lycopod, which he has named Lycostrobus. ScotT (69) regards the eridence of the existence of mesozoic cycads on the basis of staminate strobili as not convincing.

The testimony from ovulate strobili is more definite. The evidence of Zamia-like forms is unsatisfactory, but megasporophylls like those of Cycas are recorded from various strata of the Mesozoic, in one case with a seed attached. While the occurrence of Cycas-like forms seems to be established, NATHORST (55) has found that the pinnae of several of them contain double vascular bundles, rather than the single one of the living Cycas, and for these he has proposed the genus Pseudocycas.

Fragments of the regetative structures cannot be used to differentiate Cycadales and Bennettitales, so that strobili are essential and these must be well preserved. In summing up the evidence for the existence of mesozoic cycads, therefore, ScotT (69) says that the whole question "is in an unsatisfactory condition and the evidence is singularly meager."

In view of the above statements, it is evident that there are no facts as to the distribution of mesozoic cycads. That they were widely distributed may be inferred from their relationship to the Bennettitales, from the increasing abundance of cycads in more recent deposits, and from the present distribution of the group. The distribution of the living cycads has been stated at the first of the chapter.

\section{Relationship to other gymnosperms}

The relationship of Cycadales to Bennettitales and Cycadofilicales is the only one that needs consideration, since the other gymnosperm groups can be connected with it only by way of the Cycadofilicales. Under Bennettitales (p. 86) this subject was discussed somewhat in detail, and little need be added here.

That Cycadales are connected with the Bennettitales in origin seems clear; in fact, no two great gymnosperm groups have so many features in common. The transition from the trunks of $C y c a d e o i d e a$, with their numerous lateral strobili, through such a form as Williamsonia gigas, with its several strobili appearing from the center of a crown of leaves, to the cycads, with a usually solitary and terminal strobilus, seems natural, and suggests that the Cycadales are 
an offshoot from the Bennettitales. And yet, the striking differences in the strobili of the two groups seem to contradict such an easy disposition of the question, and suggest independent origin from the Cycadofilicales.

The bisporangiate strobilus of Bennettitales, with its pinnate stamens and stalked ovules, suggests an origin from the groups of Cycadofilicales with stalked ovules and marattiaceous microsporophylls. The Cycadales, on the other hand, taking Cycas and Pseudocycas as its oldest known representatives, suggest an origin from groups of Cycadofilicales bearing ovules as did Pecopteris Pluckenetii. This separate origin is further emphasized by the fact that in the one case bisporangiate strobili are developed, with a characteristic relation of microsporophylls and megasporophylls; and in the other monosporangiate strobili are produced, with the dioecious habit; and still further by the fact that in the one case a monopodial stem with direct leaf traces is maintained; and in the other a sympodial stem with its characteristic "girdles" is established. It is recognized that such differentiations from Bennettitales are conceivable, but it is easier to conceive of them as having arisen from such a synthetic group as the Cycadofilicales than from such an extremely specialized group as the Bennettitales. The historical testimony that will answer this question will be forthcoming only when the actual connections with Cycadofilicales are discovered.

The Cycadales are remarkable in the retention of more primitive characters than are possessed by any living group of gymnosperms. The swimming sperms are shared by Ginkgoales, and the structure of the ovule that goes with them, but the vegetative structures are more fernlike than in any other living group. In this sense it is proper to speak of Cycadales as the most primitive of living gymnosperms; but it must be remembered that they are probably not so old as either the Ginkgoales or the Coniferales.

\section{LITERATURE CITED}

I. Brongniart, A., Recherches sur l'organisation des tiges des Cycadées. Ann. Sci. Nat. I. I6:389-402. pls. 20-22. 1829.

2. Von Mohl, Hugo, Ueber den Bau des Cycadeen-Stammes. Abh. K. Acad. München I:397-442. I832; republished and revised in Vermischte Schriften, pp. 195-2II. 1845. 
3. Miquel, F. A. W., Monographia Cycadearum. I84I.

4. Mertenius, G. H., Beitrige zur Anatomie der Cycadeen. Mlh. K. Saths. Gesell. Wiss. 7:565-608. pls. 1-5. I861.

5. Jurania, L., Bau und Entwickelung des J'ollens bei Ceralozamia longifolia Miq. Jahrb. Wiss. Bot. 8:382-400. pls. $31-37.1872$.

6. Rrrve, J., Parasitische Anabaena in Wurzelen der Crcadeen. Gött. Nachr. I07. I872.

7. Strasburger, E., Ueber Zellbildung und Zelltheilung. I876.

8. Warming, E., Recherches et remarques sur les Cycadées. Oversigter Vidensk. Selsk. Forh. I 877.

9. ——, Contributions à l'histoire naturelle des Cycadées. Orersigter Vidensk. Selsk. Forh. I879.

ro. Sokolowa, Mlte C., Naissance de l'endosperme dans le sac embryonnaire de quelques gymnospermes. Moscou. I880.

I I. Trfub, M., Recherches sur les Cycadées. Ann. Jard. Bot. Buitenzorg $2: 3^{2-53}$. pls. I-7. ISS I (date of reprint, volume date being I885).

i2. Goroschankin, J., Zur Kenntniss der Corpuscula bei den Gymnospermen. Bot. Zeit. 4r:825-83I. pl. 7 A. I883.

I3. Treub, M., Recherches sur les Cycadées. 3. Embryogenie du Cycas circinalis. Ann. Jard. Bot. Buitenzorg 4:I-II. pls. I-3. I884.

I4. Constantin, J., et Morot, L., Sur l'origine des faisceaux libéro-ligneux supernuméraires dans la tige des Cycadées. Bull. Soc. Bot. France $32:$ I 73. I 885 .

15. Goeber, K., Outlines of classification and special morphology. English translation, p. 3 I6. I 887 .

i6. Solms-Laubach, H., Die Sprossfolge der Stangeria und der übrigen Cycadeen. Bot. Zeit. 48: 177-187, 193-199, 209-215, 225-230. I 890.

17. Strasburger, E., Histologische Beiträge 3:151. 1891.

I8. Schneider, A., Mutualistic symbiosis of algae and bacteria with Cycas revolula. Bot. Gazette I9:25-32. pl. 3. I894.

19. Ikeno, S., Das Spermatozoid von Cycas revolula. Bot. Mag. Tokyo Io: 367 , 368. I 896.

20. Worsdeli, W. C., Anatomy of stem of Macrozamia compared with that of other genera of Cycadeae. Annals of Botany I0:60I-620. pls. 27, 28. I896.

21. Ikeno, S., Vorläufige Mittheilung über die Spermatozoiden bei Cycas revoluta. Bot. Centralbl. 69: I-3. I897.

22. LANG, W. H., Studies in the development and morphology of cycadean sporangia. I. The microsporangia of Stangeria paradoxa. Annals of Botany I I : 42 I-438. pl. 22. I 897 .

2.3. ScotT, D. H., The anatomical characters presented by the peduncles of Cycadaceae. Annals of Botany II:399-4I9. pls. 20, 21 . I897.

24. Webber, H. J., Peculiar structures occurring in the pollen tube of Zamia. Bot. Gazette 23:453-459. pl. 40. 1897 . 
25. Webber, H. J., The development of the antherozoids of Zamia. Bot. Gazette 24: I6-22. I897.

26. - Notes on the fecundation of Zamia and the pollen tube apparatus of Ginkgo. Bot. Gazette 24:225-235. pl. Io. 1897 .

27. IkENo, S., Untersuchungen über die Entwickelung der Geschlechtsorgane und der Vorgang der Befruchtung bei Cycas revoluta. Jahrb. Wiss. Bot. $32: 557-602$. pls. S-IO. I898.

$27 a$. Worsdelt, W. C., The vascular structure of the sporophylls of the Cycadaceae. Annals of Botany I 2:203-24I. pls. I7, I8. I898.

28. ARxold, W., Beiträge zur Morphologie der Gymnospermen. IV. Was sind die "Keimbläschen" oder "Hofmeister's-Körperchen" in der Eizelle der Abietineen? Flora 87:194-204. pls. 6, 7. I900.

29. LANG, W. H., Studies in the development and morphology of cycadean sporangia. II. The ovule of Stangeria paradoxa. Annals of Botany 14:28I306. pls. 17, I8. I900.

30. Worsdell, W. C., The anatomical structure of Bowenia spectabilis. Annals of Botany I4:159, I60. I900.

3I. Life, A. C., The tubercle-like roots of Cycas revoluta. Bot. Gazette 3I: 265-27I. figs. IO. I9วг.

32. Webber, H. J., Spermatogenesis and fecundation of Zamia. U.S. Dept. Agric., Bur. Pl. Ind., Bull. 2. pp. I00. pls. 7. 1901.

33. Coulter, Johx M., and Chamberlain, C. J., The embryogeny of Zamia. Bot. Gazette 35:184-I94. pls. 6-8. I903.

34. Enrico, C. V., Contribuzione alla conoscenza della morphologia e dello sviluppo del fascio vascolare delle foglie delle Cicadacee. Annales di Bot. I : Iog-I2I. pls. 8, 9. I903.

35. Matte, H., Une anomalie de structure dans l'écaille ovulifère de Ceratozamia mexicana. Bull. Soc. Linn. Normandie V. 7:52-54. I903.

36. Oliver, F. W., The orules of the older gymnosperms. Annals of Botany I 7:45I-476. pl. 24. figs. 20. I903.

37. Coker, IV. C., On the spores of certain Coniferae. Bot. Gazette 38:2062I3. figs. 24. I904.

38. Coulter, John M., and Chrysler, M. A., Regeneration in Zamia. Bot. Gazette 38:452-458. figs. 8. I904.

39. Juel, H. O., Ueber den Pollenschlauch von Cupressus. Flora 93:56-62. pl. 3. I904.

40. Матте, H., Recherches sur l'appareil libéro-ligneux des Cycadées. pp. 233. pls. I6. figs. 264. I904.

4I. Simth, Isabel S., The nutrition of the egg in Zamia. Bot. Gazette 37:346352. figs. 6. I904.

42. Stopes, Marie C., Beiträge zur Kenntniss der Fortpflanzungsorgane der Cycadeen. Flora 93:435-482. figs. 37. I904.

43. Matte, H., Compléments à la structure mériphytaire du Bowenia spectabilis Hord. Compt. Rend. Assoc. Fr. Adv. Sci. I905:409-4 I6. 
44. Stopes, Marie C., On the double nature of the cycadean integument. Annals of Botany $19: 561-566$. I905.

45. Thomson, R. B., The megaspore membrane of the gymnosperms. Univ. 'Toronto Biol. Series no. 4. pp. 64. pls. 5. 1905.

46. Chamberlain, Cifarles J., The ovule and female gametophyte of Dioon. Bot. Gazette $42: 32$ I-358. pls. 13-15. figs. 9. 1906.

47. Pearson, H. H. IV., Notes on the South African cycads. I. Trans. S. African Phil. Soc. I6:34I-354. pls. 6-8. 1906.

48. Mirake, K., Ueber die Spermatozoiden von Cycas rczoluta. Ber. Deutsch. Bot. Gesell. 24:78-83. pl. 6. I906.

49. Seward, A. C., Notes on cycads. Proc. Cambridge Phil. Soc. 13:293-302. I 906.

50. Stopes, M. C., and Fujir, K., The nutritive relations of the surrounding tissues to the archegonia in gymnosperms. Beih. Bot. Centralbl. 20: $1-24$. pl. I. 1906 .

5 I. Wieland, G. R., American fossil cycads. Publ. No. 34, Carnegie Institution of Washington. pp. 296. pls. 50. figs. 138. I906.

52. Caldwell, Otis IV., Microcycas calocoma. Bot. Gazette 44: i I8-i4I. pls. IO-I3. figs. I4. 1907.

53. Chamberlain, Charles J., Preliminary note on Ceralozamia. Bot. Gazette 43: 137.1907 .

54. Land, IV. J. G., Fertilization and embryogeny in Ephedra trifurca. Bot. Gazette 44:273-292. pls. 20-22. I907.

55. Nathorst, A. G., Palaeobotanische Mitteilungen. I. Pseudocycas, eine neue Cycadophytengattung aus den cenomanen Kreideablagerungen Grönlands. Handl. Kgl. Svensk. Vetensk.-Akad. 42: I-I I. pls. I-3. I907.

56. Sirth, Frances Grace, Morphology of the trunk and development of the microsporangium of cycads. Bot. Gazette 43:187-204. pl. IO. I907.

57. Thonas, Ethel N., A theory of the double leaf trace founded on seedling structure. New Phytologist 6:77-91. figs. 4. I907.

58. Dorety, Helen A. (Sister Helen Angela), The embryo of Ceratozamia; a physiological study. Bot. Gazette 45:4 I2-4I6. figs. 7. I908.

59. - The seedling of Ceratosamia. Bot. Gazette 46:203-220. pls. I2-I6. 1908 .

6o. Nathorst, A. G., Palaeobotanische Mitteilungen. III. Lycostrobus Scottii, eine grosse Sporophyllähre aus den rätischen Ablagerungen Schonens. Handl. Kgl. Svensk. Vetensk.-Akad. 43: I-I2. pls. I, 2. I 908.

6r. South, F. W., and Compton, R. H., On the anatomy of Dioon edule Lindl. New Phytologist 7:222-229. 1908.

62. Thiessen, Reinhardt, The vascular anatomy of the seedling of Dioon edule. Bot. Gazette 46:357-380. pls. 23-29. I 9o8.

63. Chamberlain, Charles J., Spermatogenesis in Dioon edule. Bot. Gazette 47:2 I 5-236. pls. I 5-IS. figs. 3. I909.

64. - Dioon spinulosum. Bot. Gazette 48:40I-4I3. figs. 7. I乌̧c9. 
65. Dorety, Helex A. (Sister Helen Angela), Vascular anatomy of the seedling of Microcycas calocoma. Bot. Gazette 47: I39-147. pls. 5, 6. I909.

66. ㄴ.. The extrafascicular cambium of Ceratozamia. Bot. Gazette 47: $55^{-}$ I52. pl. 7. I909.

67. Hitl, 'T. G., and De Fraine, E., On the seedling structure of gymnosperms. III. Annals of Botany 23:433-458. pl. 30. Igog.

68. Matte, H., Sur la structure de l'embryon et des germinations du genre Zamia L. Bull. Soc. Sci. et Med. de l'Ouest I8: nos. 2 and 3. I909.

69. Scott, D. H., Studies in fossil botany. Second edition. London. I909.

70. Chamberlain, Charles J., Fertilization and embryogeny of Dioon edule. Bot. Gazette 50:December I9I0.

7 I. Saxton, IW. T., The development of the embryo of Encephalartos. Bot. Gazette 49: I3-I8. pl. 2. I9I0.

72. PAlolint, A. F., La Stangeria paradoxa Th. Moore. Nuovo Giorn. Bot. Ital. I6:335-35I. I909.

73. ZACH, Franz, Studie über Phagocytose in den Wurzalknöllchen der Cycadeen. Oesterreich. Bot. Zeitschr. 60:49-55. pl. 2. I9I0.

74. Simth, Frances Grace, Development of the ovulate strobilus and young ovule of Zamia floridana. Bot. Gazette 50:I28-I4I. figs. 22. I9Io.

75. Coulter, J. M., Barnes, C. R., and Cowles, H. C., A textbook of botany. New York. I9Io. 


\section{CHAP'TER IV}

\section{CORDAITALES}

The Cordaitales were brought into recognition as a great group of paleozoic gymnosperms by Grand 'Eury (2) and Renault (3). For a long time they were regarded as the dominant gymnosperm group of the Paleozoic, but since the discovery of Cycadofilicales it has become evident that these two gymnosperm groups were equally prominent in Paleozoic times, although the Cordaitales may still be regarded as the prevailing gymnosperm forest type. Side by side the two groups appear in our earliest records, culminated in a great diversity of forms and in an astonishing display of individuals during the Carboniferous, and then disappeared.

The detached parts of Cordaitales were long known from Carboniferous and Devonian deposits, and had received various generic names. For example, the petrified wood was called Araucarioxylon (showing a structure resembling that of Aracaria) and Dadoxylon; casts of the pith cavity were called Artisia or Sternbergia; the roots were known as Amyeloin, etc.; shoots bearing the large, parallelreined leaves were called Cordaites, and other similar generic names with various prefixes; the catkin-like clusters of strobili formed the genus Antholithus; the individual strobili ("flowers") were called Cordaianthus, etc.; and a multitude of seeds constituted such genera as Cordaicarpus (Cardiocarpus), Cycadinocarpus, etc. The assembling of these fragments was begun when WiLLIAMson (I) found Sternbergia casts inclosed in Araucarioxylon wood; and it was continued when Grand 'EURY found the Antholithus "inflorescence" in connection with the leaf-bearing shoots of Cordaites. Finally stems, roots, leaves, strobili, and seeds were brought together and Cordaitales became permanently established through the extended researches of Grand 'Euri' (2) and Renault (3). Unfortunately, during the last thirty years little additional information concerning the structure of the group has been obtained. The details of regetative structure are as clear as those of any group of fossil plants; but the record of 
the details of the reproductive structures is a very scanty one for so great a group, and leaves very much to be desired.

\section{The vegetative organs}

The Cordaitales were tall and slender trees, the trunks often reaching a height of 10 to $30 \mathrm{~m}$. before branching (fig. I95). This long

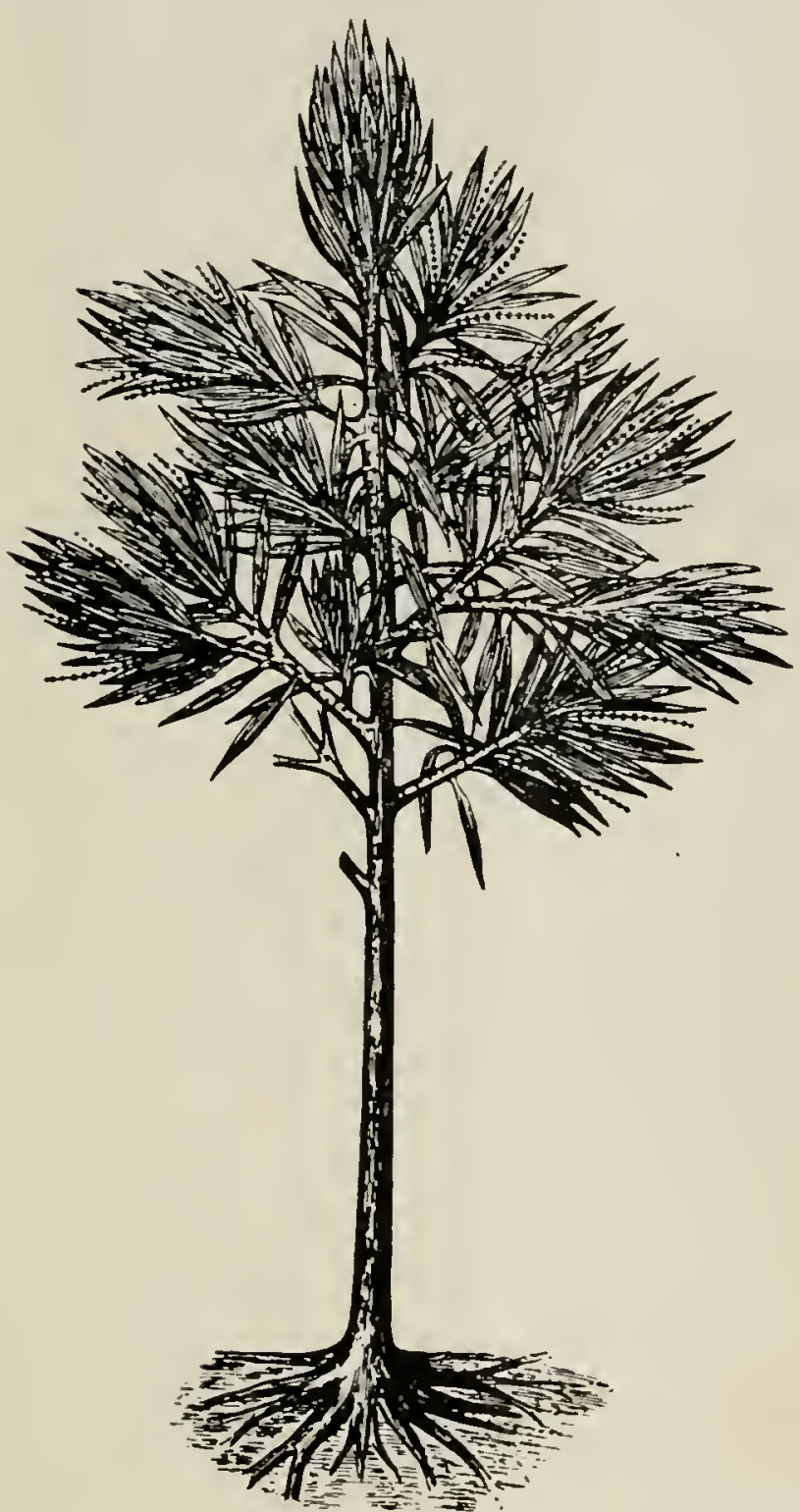

FJG. I95.-Dorycordaites sp.: restoration, showing roots, trunk, and crown, the latter conposed of branches bearing large lanceolate leaves and clusters of strobili.-From ScotT's (25) modification of GRAND 'EURY's figure; the modification consists principally in shortening the trunk, which is many times longer than represented here. slender shaft $(60 \mathrm{~cm}$. or more in diameter) bore a dense crown of branches, on which were produced a great abundance of large and simple leaves. No such habit is known among existing gymnosperms. Scott says (8) that the short-leaved species might suggest Agathis or some forms of Podocarpus, both coniferous genera of the southern hemisphere; "but the large-leaved species must have had a habit very different from anything which we are accustomed to associate with gymnosperms at the present day." The branching habit, at least, suggests Coniferales rather than any of the cycadophytes; and the same may be said of the simple leaves, but their size is far beyond that attained by the leaves of conifers. 


\section{VASCULAR ANATOMY}

A transverse section of the stem of Cordaitales show's a combination of cycad and conifer characters (figs. 196, I97). The relatively large pith, sometimes reaching nearly $10 \mathrm{~cm}$. in diameter, is a cycadean feature, and is peculiar in being discoid; while the thick rascular cylinder is as distinctly coniferous. The cylinder is collateral endarch in the forms originally described, in contrast with the mesarch condition of such a type as Lyginodendron (Cycadofilicales); but ScotT (25) has found occasional centripetal xylem in certain stems. There is no distinction evident in transverse section between primary and secondary wood, but radial sections show a more extensive transition region than usual, from the narrow spiral ressels of the protoxylem to the pitted tracheids that form the bulk of the second-

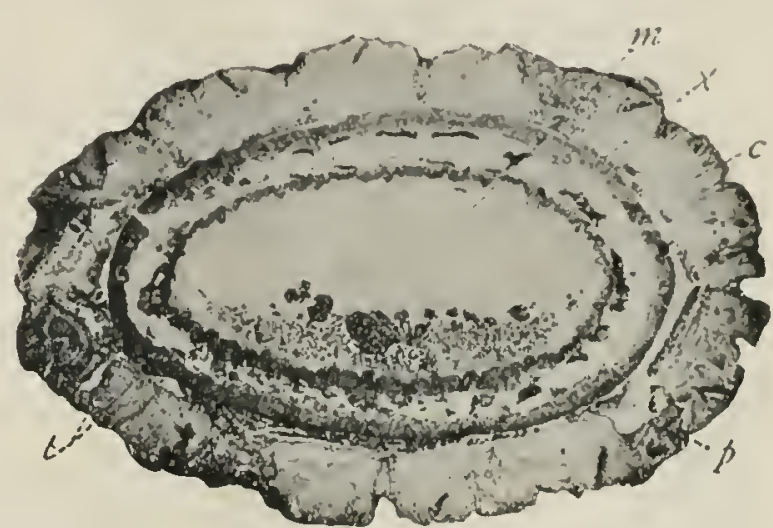

Fig. I06.-Cordaites Sutcliffii: transverse section of stem; $m$, pith; $x$, xylem; $p$, phloem; $t$, double leaf traces; $c$, cortex; natural size.From photograph of section made by I ondx. ary wood.

The secondary wood is really indistinguishable from that of Araucaria $(20,2 \mathrm{I})$, the large proportion of paleozoic wood referred to Araucarioxylon and Dadoxylon having been found to be that of Cordaitales. Such wood is recognized by the fact that the bordered pits, restricted to the radial walls, are densely crowded in two or more rows (multiseriate), becoming hexagonal in outline. While in general "annual rings" may not be recognizable, in certain specimens the occurrence of such rings is strongly suggested (fig. 197). The medullary rays are narrow, usually one or two cells thick, or the principal rays may become three cells thick.

The leaf traces are usually, perhaps always, double, a feature characteristic of the Cycadofilicales, and plainly seen in Lyginodendron, in which form, however, the two strands unite before joining the central cylinder (fig. Ig8). The collateral endarch leaf trace becomes collateral mesarch in the leaves, a well-known cycadean 
combination; and as the bundles approach their terminations in the leaf the centrifugal xylem may "die out" (8), resulting in an exarch bundle. In fact, Miss Stopes (I3) states that the exarch bundle is apparently characteristic of the majority of cordaitean leaves. In modern cycads this dying out of centrifugal xylem may occur at

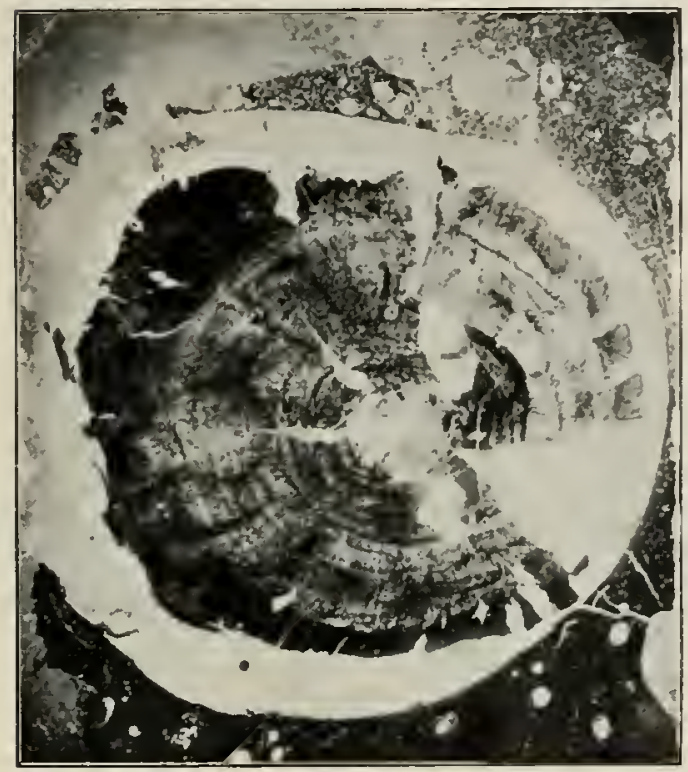

FIG. I97-Cordaites sp. (?): transverse section of stem; the pith is small and the extensive wood shows rings that resemble growth rings; the structures outside the secondary xylem have not been preserved; natural size.-From photograph of section made by Lomax. any level in the leaf, so that exarch bundles are not necessarily restricted to vascular terminations.

The vascular anatomy of Cordaitales evidently connects the group, by descent or common origin, with such Cycadofilicales as the Lyginodendrineae; but this connection is made still more evident by the occurrence of whole series of anastomosing forms (24). One of the most notable of these is Poroxylon, whose beautifully preserved anatomical structure has been described in detail by ReNault and BERTRAND $(3,4)$. It was originally found in the Permo-Carboniferous of France, a period much too recent to be regarded as containing members of the phylogenetic series leading to Cordaitales.

The stems of Poroxylon are slender (approximately $1.5 \mathrm{~cm}$. in diameter), with a complex branch system, and bear spirally arranged and simple leaves separated by rather long internodes. The pith is relatively large and continuous, and the vascular cylinder is collateral exarch according to BERnARD and Renault. Furthermore, the leaf trace is double, the two strands being separate and mesarch to the central cylinder; and they remain collateral mesarch in both cortex and leaf. In Lyginodendron, it will be remembered, the colateral strands of the leaf trace become concentric when they enter the 
petiole. If the cordaitean leares of Poroxylon (see below) are added to this combination of the vascular anatomy of Lyginodendron and Corlaites, there seems to be good ground for regarding Poroxylon as one of the Cordaitales with strong Lyginodendron affinities; the foliage will hardly permit the converse alternative. Certain stems recently discovered in the Lower Coal-measures of England were referred at first to Poroxylon (25), but these, together with certain other stems referred to Corlaites, have been made by ScotT and Masien (27) the basis of the new genus Mesoxylon, whose name

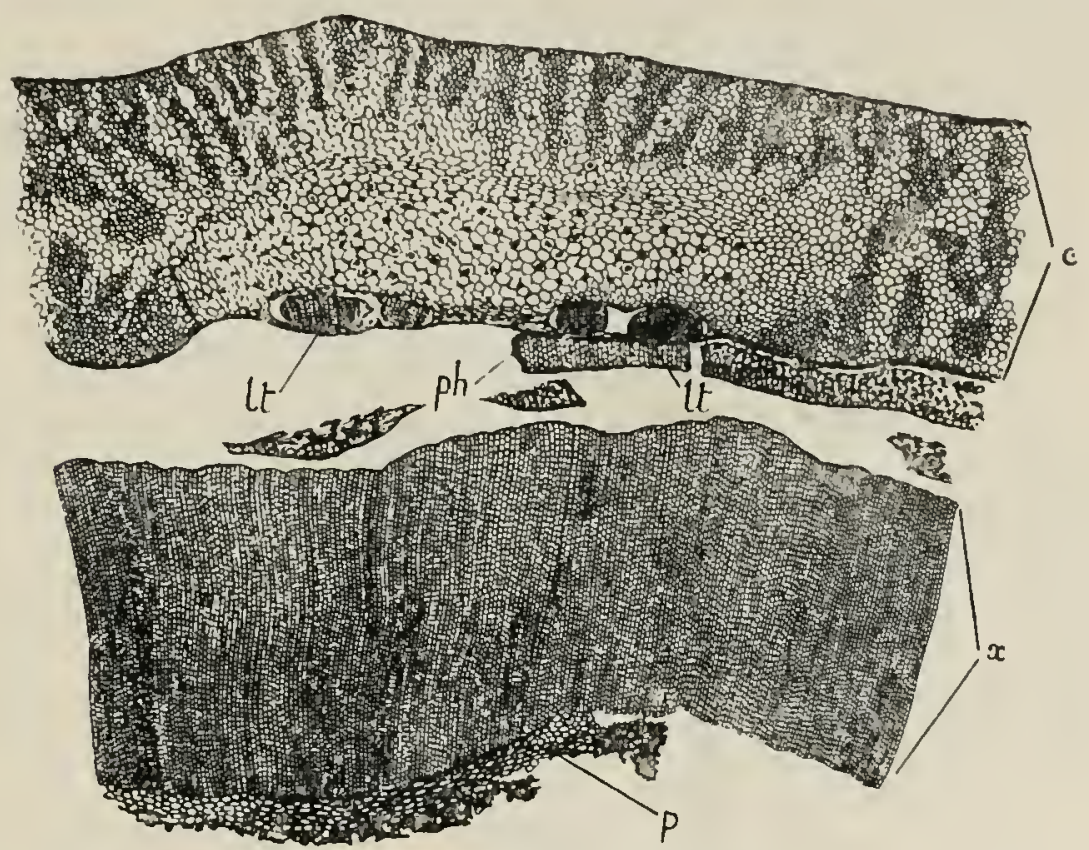

FIG. I9S.-Cordaites sp.: part of transverse section of stem; $p$, pith; $x$, xylem; ph, phloem; $l l$, leaf trace; $c$, cortex; $\times 6$ - -After Scotr (25).

suggests its intermediate character. The pith is relatively large and discoid (as in Cordaites); the leaf traces are double at first, but divide further before entering the leaf; and the leaf traces are mesarch from the first (as in Poroxylon). The genus is regarded by its authors "to completely bridge the gap, so far as anatomy is concerned, between the Poroxyleae and the Cordaiteae."

From the Lower Carboniferous of Scotland, ScotT (9) has obtained evidence of stems that show a connection between Cycadofilicales and Cordaitales even more clearly than does Poroxylon, and they have the advantage of being in a far better historical position to play the rôle of actual connecting forms. The group of stems considered 
is usually referred to Cordaitales, but they differ from other known stems of Cordaitales in certain important features. Pitys is known as yet only from its pith and wood, the latter being araucarian (and therefore cordaitean) in type, but with remarkably broad medullary rays. The principal feature, however, is the occurrence of numerous small mesarch strands which are imbedded in the pith at some distance from the cylinder of wood, and which must represent the primary xylem. The araucarian cylinder of secondary wood and the mesarch primary cylinder is a combination of features belonging to Cordaitales and Lyginodendron. Dadoxylon Spenceri, probably from the Upper Carboniferous, also has mesarch primary wood, cordaitean secondary wood, and double leaf traces. Scotт (9) says that this stem "suggests, perhaps more strongly than any of the other species described, a truly gymnospermous stem, which may well have belonged to one of the Cordaiteae, but which still retains the last relics of the primary wood structure characteristic of the Poroxyleae and Lyginodendreae." He is of the opinion (25) that Pitys and Dadoxylon probably belong to a plexus of forms connecting Cycadofilicales of the Lyginodendron type with Cordaites, but nearer to the latter. Therefore, he proposes to recognize Cordaitales as including the three groups Poroxyleae, Pityeae, and Cordaiteae, in which there are all gradations from primary wood that is distinctly mesarch to that which is completely endarch. In our terminology these three names would be Poroxylineae, Pityneae, and Cordaitineae.

\section{THE LEAF}

The leaves are borne in spiral succession on ultimate branches. They are usually simple, elongated, with parallel and repeatedly dichotomous venation (except in the grasslike forms). Naturally they were first thought to be the leaves of monocotyledons. They occur sometimes in dense masses, packed together in layers "like damp beech leaves on the ground of our forests" (5).

There is considerable diversity of form, which has been made the basis for generic distinctions. For example, the leaves of Cordaites are spatulate with blunt ends (fig. 199), reaching a meter in length and about $15 \mathrm{~cm}$. in width; those of Dorycordaites are lanceolate and sharp pointed (fig. 195), and little inferior in length; those of Poacor- 
daites are" gratsslike, not over half a meter long and about a centimeter wide. In still

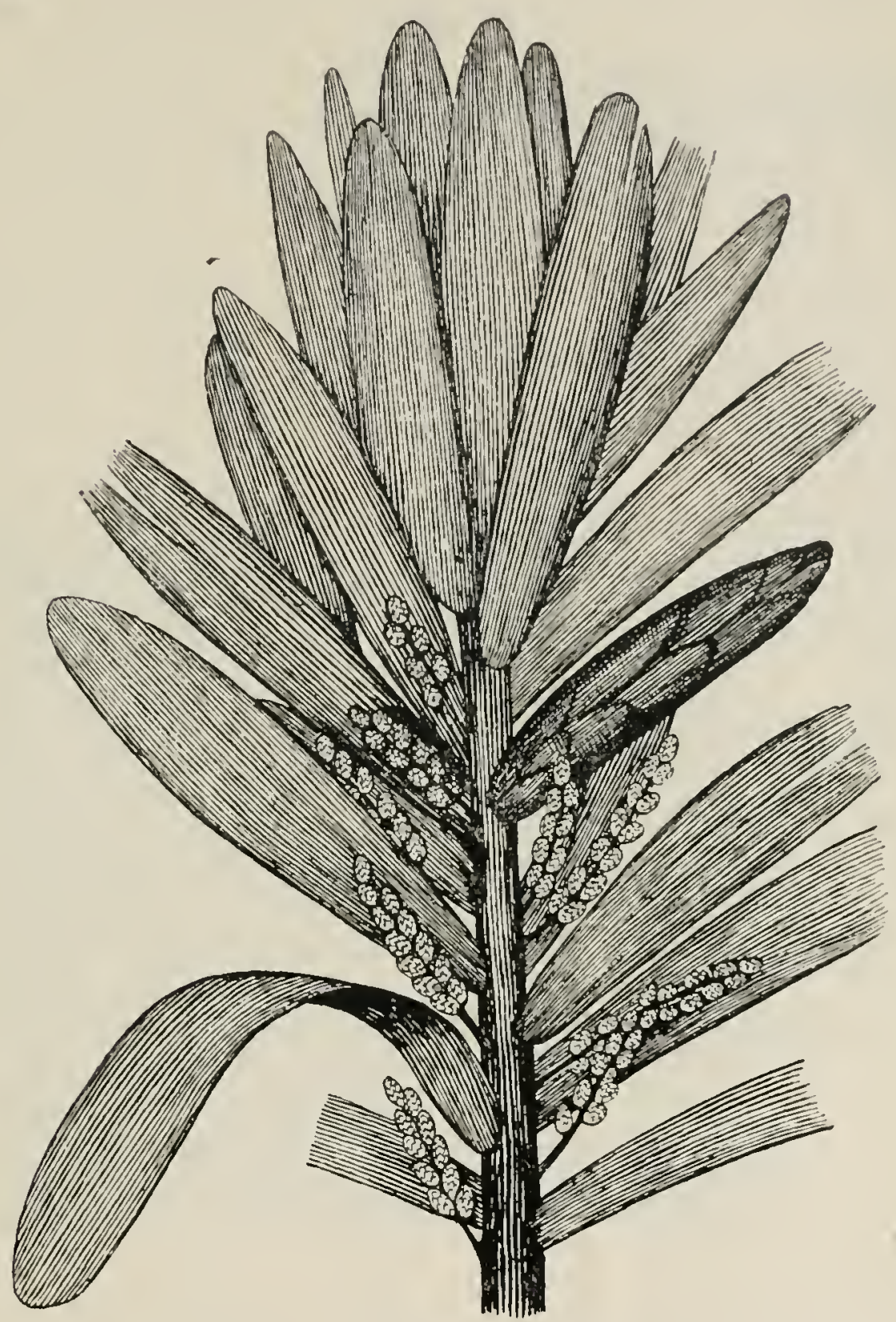

FIG. 199.-Curdaites laevis: restoration of branch with spatulate leares and branches bearing numerous strobili; a large bud is shown at the right.-After GRAND 'EURY (2).

short and obovate, even branching dichotomously, a type suggestive of the leaves of Ginkgo.

The recorded anatomy of the leaves has all been obtained from Cordaites, and is very characteristic (figs. 200-202). Each of the 
conspicuous parallel vascular bundles is invested by a strong sheath which abuts above and below on a hypodermal strand of fibers. These bundle sheaths connect laterally by transverse "bridles"
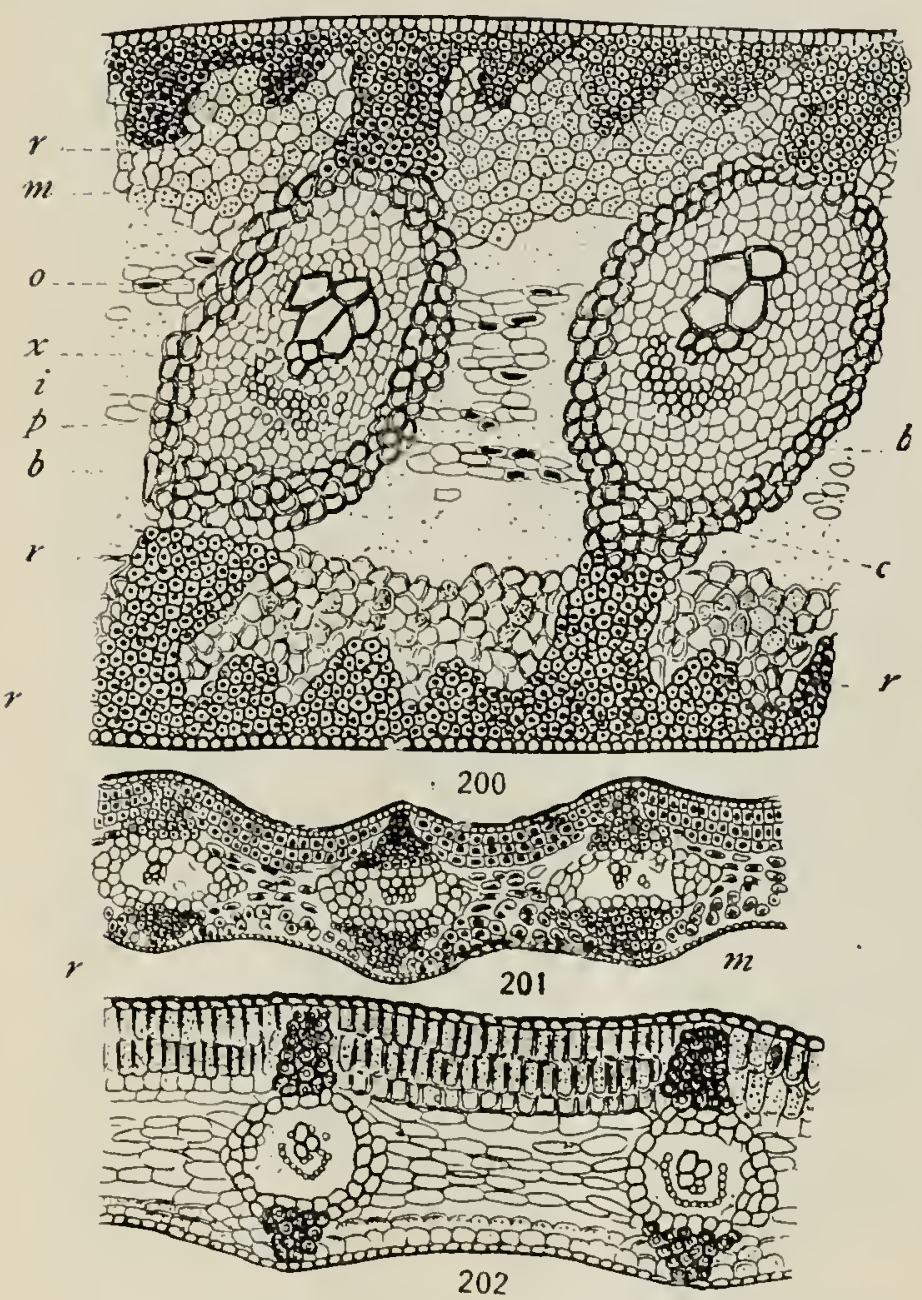

FIGS. 200-202.-Cordaites: transverse sections of leaves; fig. 200, C. angulostriatus (?); $r$, ribs of sclerenchyma; $m$, mesophyll; $o$, centrifugal xylem; $i$, centripetal xylem; $x$, protorylem; $p$, pliloem; $b$, bundle sheath; $c$, elongated cells connecting bundles; $\times 60$; fig. 2or, C. rhombinervis, showing sclerenchyma ribs only in connection with bundles; $X_{50}$; fig: 202 , C. lingulatus, showing well-developed palisade tissue; $\times$ 50.-After RENAULT (3).

The leaves of Porowylon are of the same general type. They are spirally borne on rather widely separated nodes of a slender stem, and are simple, broad, thick, and petioled, with parallel veins repeatedly dichotomous. The blade is stiffened by hypodermal strands of thickened cells, which may represent a "transfusion tissue." In some cases the hypodermal ribs occur only in connection with the bundles; while in other cases they are developed between the bundles. The mesophyll in some leaves is differentiated into palisade and spongy regions, and in others it is very little differentiated.

There is really the leaves of Cordaitales than is usually appreciated ( 16 ), and, as in the case of the anatomy of the stem, they suggest possible connections in various directions, namely, with Cycadofilicales on the one hand, and Coniferales and Ginkgoales on the other. greater variation in 
of fibers on both sides; the large bundles are connected by transverse bridges of thick-walled cells; and the mesophyll is compact. Such a form and structure is entirely unlike anything known among ferns or Cycadofilicales, and certainly approximates that of the leaves of Cordaites. ScotT (8) says that such a leaf organization is comparable to a single leaflet of such a cycad as Bowenia.

\section{THE ROOT}

Amyelon radicans is a root of the Coal-measures known to belong to Cordaites, and often preserved in remarkable detail (fig. 203). It bears irregularly arranged bunches of lateral roots, which have been examined recently by OSBORN (26). The thick cortex is

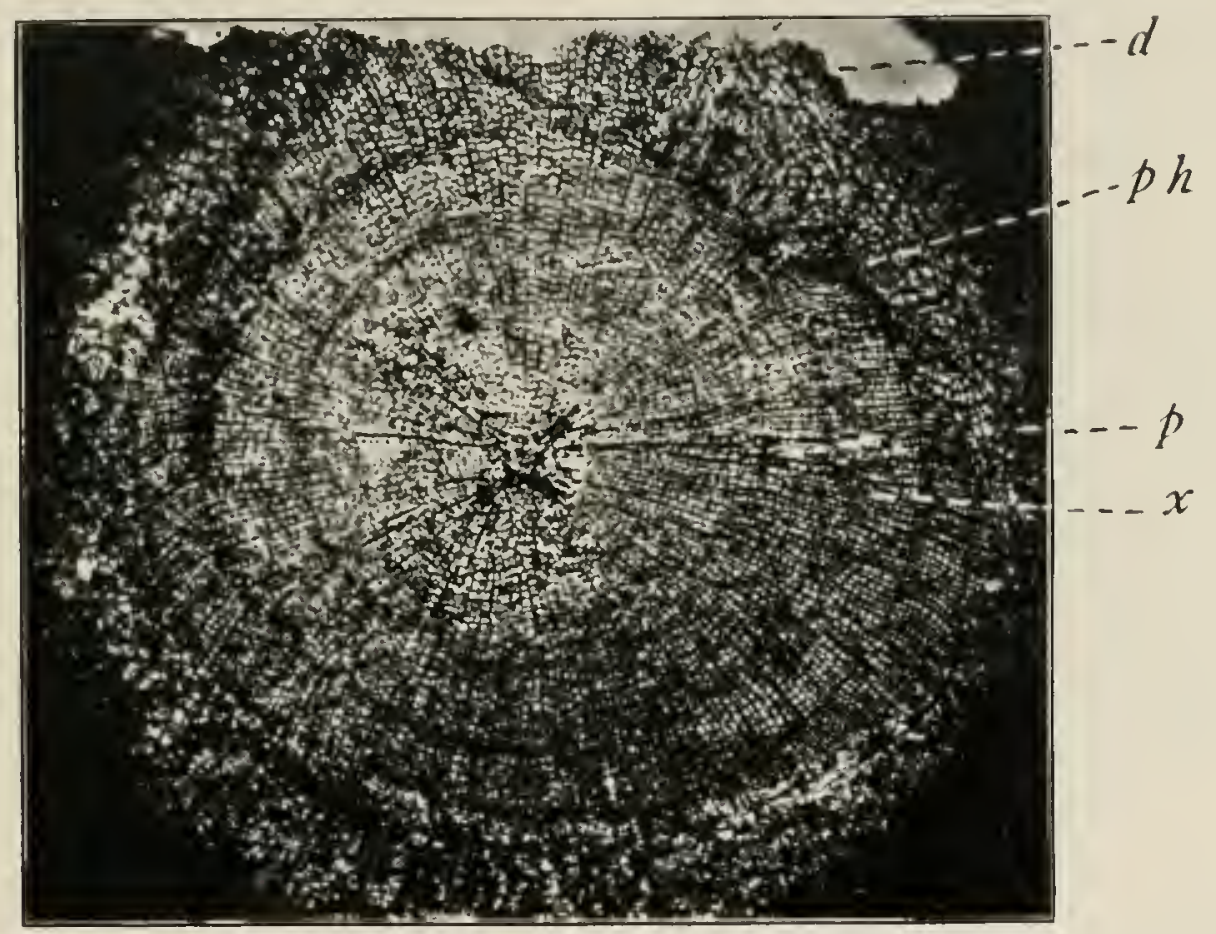

FIG. 203. - 4 myelon, the root of Cordaites: $p$, tetrarch primary xylem;.$x$, secondary xylem showing growth rings; $p h$, phloem; $d$, periderm; $X_{9}$.-Fron 1 photomicrograph of section made by Lowsx.

divisible into two regions, the inner of which contains dark cells that show fungal hyphac. The conclusion is reached that "Cordaites was probably a tree inhabiting saline swamps, and having bunches of coralline rootlets on its roots, such as are known to occur in many recent plants growing under similar conditions." As only one case 
of mycorhiza had been reported previously from the Coal-measures, this observation is one of special interest.

\section{The spore-producing members}

THE STROBILI

The small strobili, not often more than a centimeter in length, are borne laterally upon short, simple or branched, lateral shoots

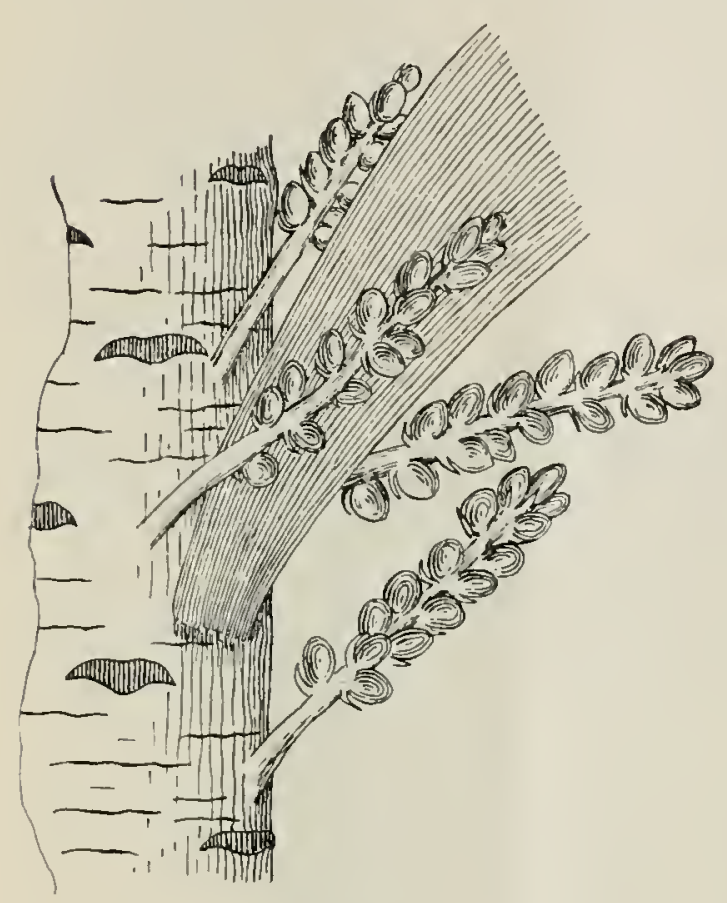

FIG. 204.-Cordaites: portion of stem showing one leaf and four branches, each branch bearing numerous strobili; $\times \frac{2}{3}$. After Grand 'Eury (2). (fig. 204). These strobilusbearing branches suggest inflorescences; and although occurring among the leaves, they do not always seem to be axillary. These structures were recorded under the general name Antholithus until Grand 'Eury found Antholithus in connection with the leaf-bearing shoots of Cordaites. Since many of the strobili cannot be referred with certainty as yet to the definite species of Cordaitales, the form genus Cordaianthus has been used to record most of them. Our knowledge of the internal structure of Cordaianthus has come chiefly from the few sections made by Renault (3). Both kinds of strobili are sheathed by bracts, so that it is not always possible to distinguish them externally.

\section{THE MICROSPORANGIUM}

In Cordaianthus Penjonii (fig. 205) the staminate strobilus ( $1 \mathrm{~cm}$. long) consists of a thick axis bearing spirally arranged bracts, among which stamens are inserted. The stamens are either solitary or are grouped near the apex of the axis. Each stamen consists of a more or less elongated stalk bearing at its tip a cluster of three to six erect sporangia (fig. 206). The wall of the sporangium is a single layer 
of cells, and the dehiscence is longitudinal. The stalk is traversed by a single vascular strand which sends a branch to the base of each sporangium. There is no evidence that the stamens arise from the axils of bracts, but the two structures seem to replace each other; in fact, the stamen stalk is very little modified from the bract form. In Cordaianthus Saportanus the stamens are fewer in number, being restricted to the apical region of the strobilus, and the stalks are shorter.

It is evident that this strobilus is to be interpreted as a mixture of sterile and fertile microsporophylls. If the sterile sporophylls were suppressed, the general condition of the staminate strobilus of Ginkgo would be attained, but the sporangia of that form are borne differently. This interpretation implies that the staminate strobilus of Cordaitales is a simple one, and that the stamen stalk is a filament. The suggestion that each stamen is a "flower," and that therefore the stamen

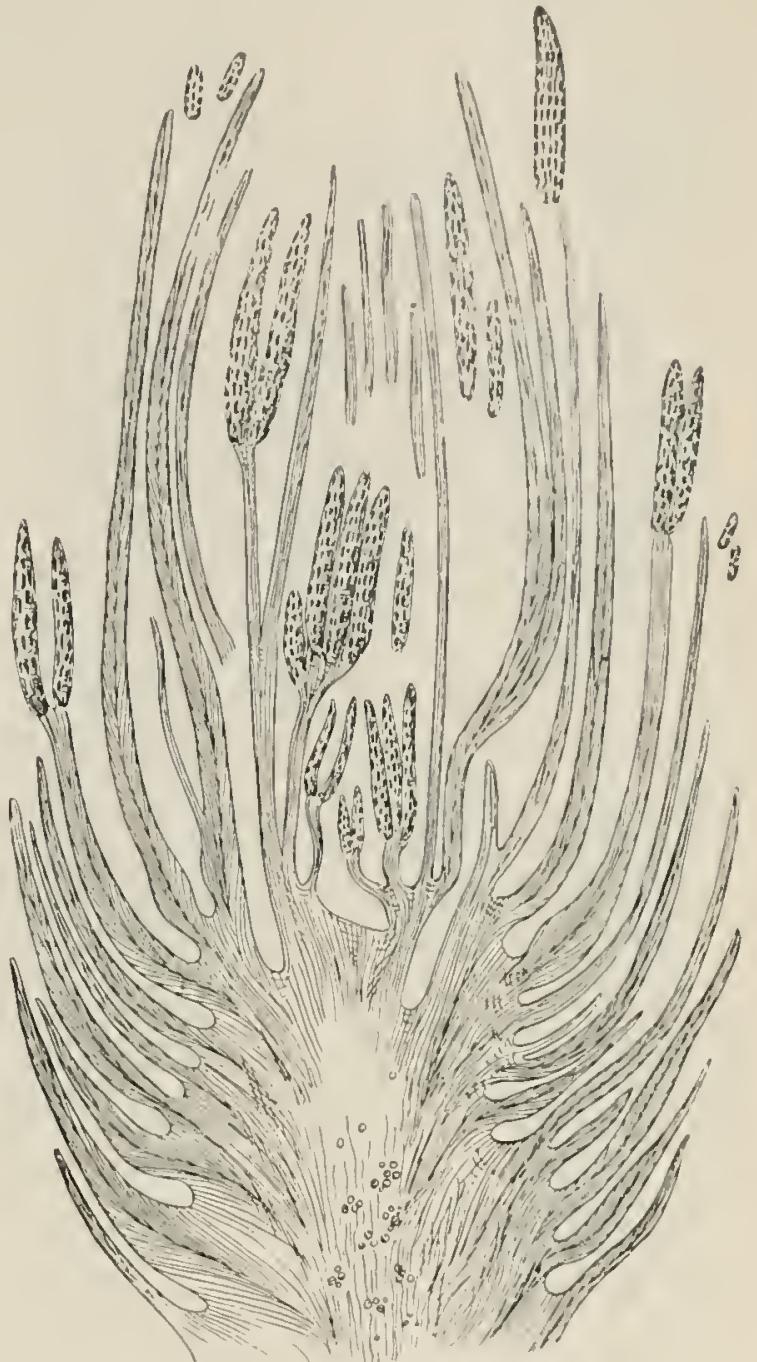

FIG. 205.-Cordaianthus Penjonii: longitudinal section of staminate strobilus, showing microsporangia borne on long stalks; throughout the sporangium region, but especially below it, are numerous sterile bracts; $X_{\text {Io. }}$. After ReNaUlt (3). stalk is a branch (pedicel), is an attempt to interpret this strobilus by the staminate strobilus of Gnetales or by certain types of angiosperm inflorescence, an attempt which singularly disregards the sequence of evolution.

The terminal and erect microsporangia of Cordaitales were 
regarded as a unique feature among gymnosperms until the terminal and erect microsporangia of Cycadofilicales were discovered. The Calymmatotheca type of stamen bears a terminal and erect synangium, in which the sporangia occur in various degrees of "coalescence." If such sporangia should fail to organize a

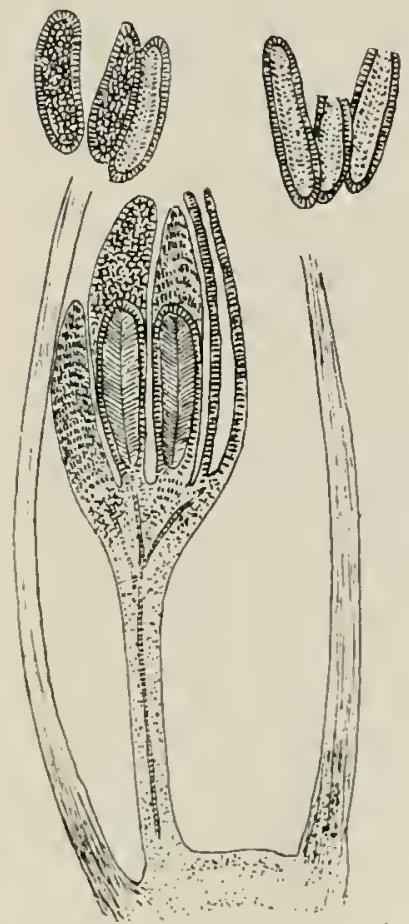

FIG. 206.-Cordaianthus Penjoni: section showing three stamens with their sporangia; the stamen in the middle bears four sporangia, the one farthest to the right having dehisced; $\times 23$. - After ReNault (3). synangium and should remain separate, such a stamen as that of Cordaitales would be the result.

\section{THE MEGASPORANGIUM}

The young ovulate strobilus can scarcely be distinguished from the staminate, the ovules at that stage being completely hidden by the overlapping bracts. Renault's description (3) of Cordaianthus Williamsonii will illustrate the structure of the strobilus (fig. 207). Upon a thick conical axis conspicuous bracts are inserted in spiral succession, and in some of their axils there arises a very short dwarf branch which bears some small bractlets and a terminal ovule.

The ovule (fig. 208) has two integuments, the outer one being described as thick and fleshy, the inner one delicate but later becoming hard. The two integuments are free from one another below, but are more or less united above. They may correspond to the outer fleshy and stony layers of the single integument of cycads and Ginkgo. There is nothing to indicate the presence of an inner fleshy layer. The nucellus is nearly distinct from the integument, and develops a prominent beak which contains a large pollen chamber. A single vascular strand enters the chalaza and sends out two systems of branches, one into the outer integument, and the other into the peripheral region of the nucellus. The freedom of integument and nucellus, and the occurrence of the inner set of vascular strands in the nucellus, are the striking features of the Stephanospermum type of seed, as 
described by Otrver ( 44 ), and probably represent a more primitive condition of the orule than that of the Lagenostoma type. As stated under Cycadofilicales, both types probably occurred in both Cycadofilicales and Cordaitales; but as yet onty the Lagenostoma type is known to belong to the former group, and only the Stephanospermum type has been associated with the latter group.

In Cordaianthus Grand 'Euryi (fig. 209) the bractlets borne by the short ovuliferous shoot are much larger, and a very prominent and resistant nucellar beak projects into the micropyle and forms a passageway to the large pollen chamber. The cells of the lover part of this beak are transversely elongated, narrowing the passageway.

The ovulate strobilus evidently differs from the staminate in being compound; that is, a branch arises from the axis of the strobilus to bear the orule. This character is distinct from any tendency shown by the strobili of the cycadophytes, and is evidently one that is continued in those groups of Coniferales

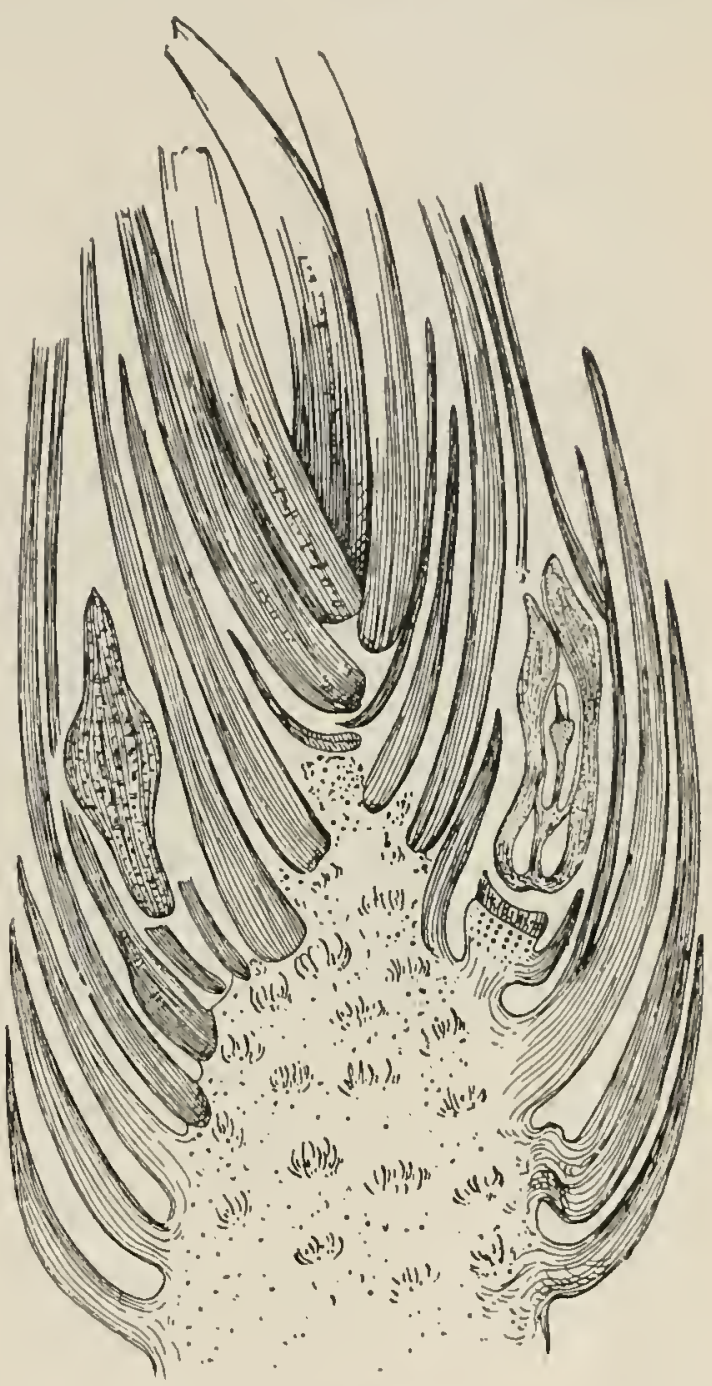

FIG. 207.-Cordaianthus IVilliamsonii: longitudinal section of strobilus, showing numerous sterile bracts and two orules; $X I 0$. - After Revault (3). (especially Abietineae) in which the "ovuliferous scale" is believed to represent a reduced axillary shoot. REnault suggests a more distant resemblance to Taxus, in which genus, as well as in Torreya, the terminal ovules are borne on short foliage-bearing shoots. In this comparison, however, while the ovuliferous branches are evidently similar, the compact strobilus of Cordaitales is lost in the branching of Taxus and Torreya. 
When the numerous detached paleozoic seeds were grouped as radiosperms and platysperms (I2, I4), it was supposed that the latter,

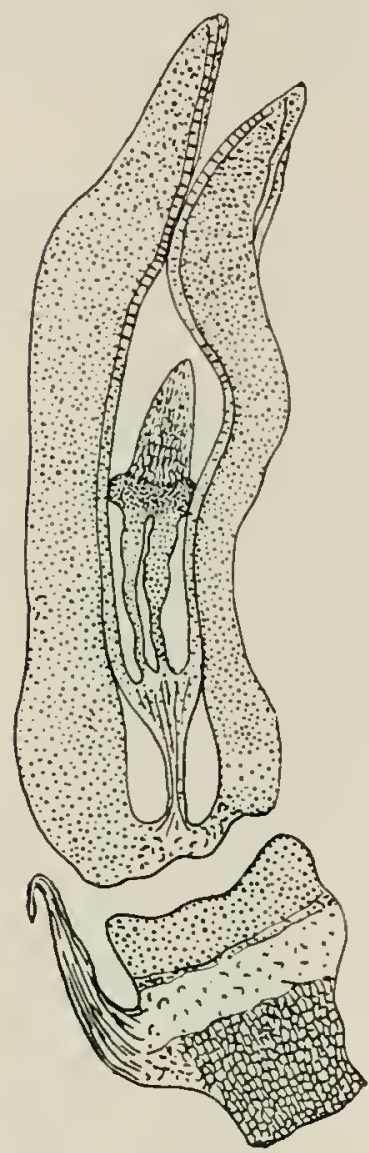

FIG, 20S. - Cordaianthus Williamsonii: longitudinal section of orule, showing upper portion of nucellus, lower portion of nucellus free from the integument, cavity which doubtless contained the female gametophyte, outer integument, inner integument free from the onter integument below but more or less applied to it above, bract, and secondary axis bearing ovule; $\times 35 .-$ After RENAULT (3).

at least, belonged to the Cordaitales, because such as had been definitely referred to the group were of the more or less flattened type. However, since the discovery that certain of the Cycadofilicales, as Aneimites and Pecopteris Pluckenetii, bore seeds of the platysperm type, it is evident that the reference of any seed to Cycadofilicales or Cordaitales must await the discovery of its actual connection. As a result, many detached seeds, heretofore referred with considerable confidence to Cordaitales, are now in uncertainty; but out of the vast numbers found, many of them must have belonged to this group. Grand 'Eury (I 7) has called attention to the fact that there are many more seed genera that probably belong to Cordaitales than there are shoot genera (Cordaites, etc.) to receive them.

Among those that seem most certain are those somewhat flattened seeds with heartshaped base that have been included by Renault in the genus Cordaicarpus (Cardiocarpus of Brongniart). The testa, derived from a single integument, is differentiated into outer fleshy and stony layers. There are two sets of vascular strands: one traversing the outer fleshy layer; the other forming a tracheal plate at the base of the relatively free nucellus, which gives rise to a tracheal mantle in the peripheral region of the nucellus, similar to that in Stephanospermum, but not so complete (I4). The usual nucellar beak is rery prominent and projects into the micropyle. The whole structure agrees so closely with that of the orules described 
above, under Cordainthus Williamsonii, that there can be no reasonable doubt that the seeds belong to Cordaitales. Cycadinocarpus of RENAULT is interesting from the fact that the inner set of vascular strands does not enter the nucellus, but is said to traverse the inner layer of the testa, which in this case must be the third or "inner fleshy" layer. This distribution of the vascular strands is the same as in the seeds of Cycadales.

The seeds known as Rhabdocarpus, formerly supposed to be forms of Cordaicarpus (Cardiocarpus) and therefore belonging to Cordaites, have been found by Grand 'Eury (I6) associated with leaves believed to be those of Porowylon. If this connection is confirmed, the inclusion of Poroxylon among the Cordaitales would seem to have passed the doubtful stage.

Since the investigation of the testa of the seeds of cycads by Miss Stopes ( 15 ), in which it was made clear that the testa is differentiated into three layers (outer fleshy, stony, and

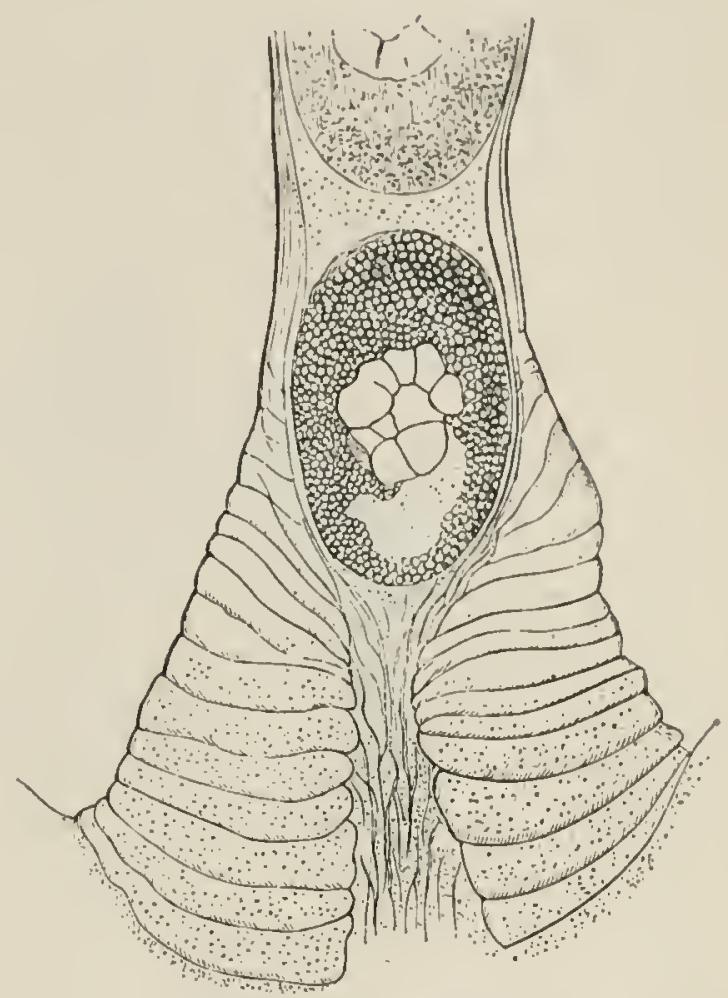

FIG. 209.-C'ordaianthus Grand 'Eurvi: section of beak of nucellus; werlged in the passageway are two large pollen grains, the lower one showing part of the surface of the exine and also the multicellular interior; $\times 225$.-After Renalitit (3). inner fleshy), the temptation is to read this structure into the interpretations of the seeds of Cordaitales and Cycadofilicales, and there seems to be enough confirmation of such an interpretation to justify it in some cases. It is conceivable that the inner fleshy layer, which in cycads contains the inner set of rascular strands, might be confused with the peripheral region of the nucellus, provided the testa and nucellus are organically continuous, as in modern seeds. In such cases the inner fleshy layer would be distinct only in the free part of the integument, and since in the testa stage it becomes merely a papery layer, it might not be recognizable 
in a fossil. Such confusion of inner fleshy layer and nucellus in many paleozoic seeds, however, in which the testa and nucellus are free, seems impossible. In an orule of this character, the inner set of vascular strands could not make the very evident connections with the region of the pollen chamber without traversing the nucellus. In such cases, therefore, it is by no means inconceivable that the inner fleshy layer of the testa was not represented.

In whatever character the seeds of Cordaitales differ in structure from modern seeds, these peculiarities are shared by Cycadofilicales; and this association is further emphasized by the entire absence of any trace of an embryo in any of the sectioned paleozoic seeds (p. 46).

\section{The gametophytes}

Pollen grains of the Cordaitales have been found in the sporangia, in the pollen chambers, and in the passageways ("necks") leading to them (figs. 206, 209). The grains are comparatively large, and with a rough outer coat; and they are said to be larger in the pollen chambers than in the sporangia, indicating growth after pollination. The striking feature, however, is the presence of a group of internal cells (fig. 209), which are said to be more numerous after pollination than before. Such a cell plexus has been observed in the pollen grains of Cycadofilicales, and was discussed in that connection (p. 49). It seems to be a safe inference that several, if not all, of these cells were spermatogenous, and that swimming sperms were liberated when the archegonial and pollen chambers had become continuous by the breaking down of the intervening tissue, as in Ginkgo and the cycads. Scott (I8) has called attention to the interesting fact that in 1896 Renault (6) suggested this possibility, before the announcement of the discovery of swimming sperms in Cycas and Ginkgo. No traces of pollen tubes have been observed in any of the paleozoic seeds, although pollen grains have been found in the pollen chamber after it had extended entirely through the nucellus to the megaspore membrane, bringing the pollen grains into direct contact with the female gametophyte. It is very probable that the sperms were discharged from the pollen grains about as from the microspores of modern heterosporous pteridophytes.

In pollen grains found in the pollen chambers of ovules not defi- 
nitely referred as yet to either Cordaitales or Cycadofilicales, similar groups of internal cells have been found, as in Stephanospermum (p. 50), indicating that the male gametophyte among paleozoic seed plants must have been more primitive in structure, in the amount of either prothallial or spermatogenous tissue or both, than in living seed plants. It is interesting to note, in this connection, that an excess of male prothallial tissue, as compared with the other living gymnosperms, has been found among the podocarps and araucarians.

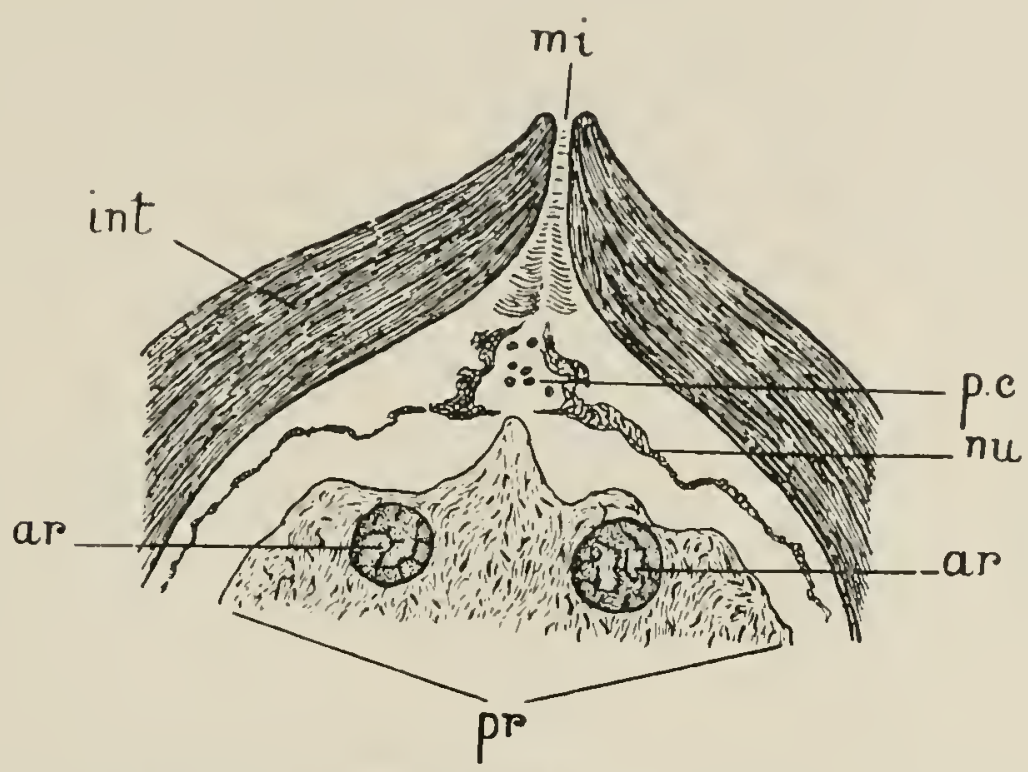

FIG. 210.-Cycadinocarpus angustodunensis: longitudinal sertion of upper fart of ovule; mi, micropyle; $i n t$, integument; $p c$, pollen chamber with pollen grains; $u$, nucellus; ar, archegonia; pr, female gametophyte.-After ReNault (2).

In some of the sections of the seeds of Cordaitales, the mature embryo sac, containing the female gametophyte (endosperm) with its archegonia, has been found, as in a species of Cycadinocarpus (fig. 210). In the figure cited it is evident that the endosperm has encroached upon the nucellus almost to the testa, and that it has dereloped a characteristic endosperm beak which supports the settling nucellar beak, as in Ginkgo, in which form Hirasé aptly likens the endosperm beak to a "tent pole." Two archegonia are crident in the section, and opened into the archegonial chamber which surrounded the base of the "tent pole" like a moat. This peculiar endosperm beak is one of the several characters that show a close connection between Cordaitales and Ginkgoales. 
Perhaps the most important testimony furnished by such sections as the one just described is as to the condition of detached paleozoic seeds. It is evident that when these seeds had formed a heavy testa and had dropped from the parent plant, there had been no such embryo-formation as takes place in modern gymnosperm seeds before shedding. It may be that fertilization had occurred, and that the proembryo had formed within the archegonium; but it is certain that there had been no further development of the embryo. The absence of embryos from paleozoic seeds, therefore, might be due to the fact that they had not formed when the seed was shed; and therefore the change in later times was a longer retention of the seed before shedding, accompanied by a later maturing of the testa; but more probably. the seeds sectioned had dropped prematurely (see p. 47 for a fuller discussion).

\section{History and distribution}

The Cordaitales were contemporaneous with the Cycadofilicales, disappearing from the records in the Devonian, along with the Cycadofilicales, occurring in great profusion during the Carboniferous, and not recognizable beyond the Paleozoic. So far as the historical records go, therefore, the Cordaitales are just as ancient seed plants as are the Cycadofilicales. It is only upon inference from comparative resemblance to ferns that a greater age is assumed for the Cycadofilicales.

The geographical distribution of Cordaitales, also, must have been as extensive as that of Cycadofilicales; and they probably formed extensive forests in connection with the arboreous pteridophytes. Their known distribution during the Carboniferous is only limited by our knowledge of the deposits of that period. They must have displayed a profusion of forms and structures that is meagerly shown by their known remains. It is not unreasonable to suppose that a fuller knowledge of their structure and variations will go far toward settling the problems connected with the origin of the later coniferophytes.

\section{Relationship to other gymnosperms}

The question of the origin of Cordaitales is a choice between two alternatives. They were either derived from the Cycadofilicales, 
or the two groups had a common origin from a still more ancient group of fernlike plants. 'The historical evidence favors the latter alternalive, for the two groups are distinct as far back as the record goes; but it must be remembered that this is negative evidence. On the other hand, although both groups are certainly extremely ancient, their similarities suggest so close a relationship, confirmed by the existence of series of anastomosing forms, that the other alternative is worthy of consideration.

On the whole, the structure of the seed is the most striking character common to Cordaitales and Cycadofilicales. It is no longer possible to distinguish their seeds. The free nucellus and integument that characterized certain seeds of both groups, the distribution of the two sets of vascular strands, the large pollen chamber, the absence of any visible embryo, are all characters that may be regarded as primitive and as indicating a close relationship of the two groups. As an alternative, it may be assumed that these resemblances do not indicate a phylogenetic connection of the groups so much as they do an early stage of seeds in general, and such seeds may have originated independently many times from the original fern stock. This claim can be met only by comparing the other structures of the two groups, to discover whether there is any indication of more progress in one than in the other, progress that would indicate that they are not at the same level of primitiveness.

The organization of strobili represents a distinct adrance beyond the condition of Cycadofilicales, and it is the same kind of modification as that suggested in the case of the Bennettitales (p. 87). It consists in the complete differentiation of sporophylls and foliage leaves, the consequent reduction in size of the sporophylls, and their aggregation into a strobilus by shortening the fertile axis. The association of bracts and sporophylls in the strobilus would be natural, some of the bracts (chiefly the outer ones) doubtless representing reduced foliage leaves, and some of them (notably the inner ones) being sterile sporophylls. A notable complication in the ovulate strobilus of Cordaitales is the fact that the primary axis of the strobilus bears only bracts, the ovules appearing on short secondary axes (a compound strobilus).

It is in the vegetative structures that there appears a distinct gradation from Cycadofilicales toward Cordaitales. It has been scen 
that the permo-carboniferous Poroxylon illustrates what must be regarded as a stage theoretically intermediate between the two groups. The general habit and the leaves are those of Cordaitales in all the essential features. In the vascular cylinder of the stem, the secondary wood is that of Cordaitales, but the primary xylem is mesarch as in Lyginodendron. The leaf traces of Poroxylon, leaving the central cylinder in pairs and finally becoming exarch in the leaves, are common to both Cycadofilicales (notably in Medullosa) and Cordaitales. Poroxylon is too recent to serve any phylogenetic purpose except to illustrate an intermediate stage that has persisted. It will be remembered, however, that almost identical forms have been discovered (I8) in the Lower Coal-measures of England; and similar forms of still greater age have been recognized. In fact, among the araucarioxylons (presumably the wood of Cordaitales) of the early Carboniferous there occur stems with mesarch primary xylem; and ScotT (9, 10) has arranged a series of such stems connecting the Lyginodendron type with the Cordaites type, some of which cannot be referred to either group without the foliage.

In view of the great antiquity of Cordaitales and Cycadofilicales, it is perhaps safer to conclude that the similarities and gradations described above are such as might be expected in two phyla diverging from a common stock and living under the same conditions. Whether this common stock is to be regarded as still more ancient Cycadofilicales or not, is a question that probably never will be answered. In any event, it seems clear that the Cycadofilicales, as we know them, retained more of the features of this ancient stock than did the Cordaitales; and that long after the Cordaitales became distinct, there began to arise from the Cycadofilicales two divergent branches, the Bennettitales and the Cycadales. At about the same time, the great phylum Coniferales probably began to emerge from the Cordaitales. and perhaps also the less conspicuous phylum Ginkgoales.

It will be useful to summarize the important resemblances of Cordaitales to the living groups Cycadales, Coniferales, and Ginkgoales, in order that their significance may be pointed out. This is especially necessary since there is a tendency to use similar characters at random as indicating immediate relationship. For example, the characters common to Cordaitales and Cycadales seem to include those of higher 
order than those common to Cordaitales and Coniferales; and yet the latter pair are regarded as much more closely related than the former pair.

The characters in common with the Cycadales are the large pith, the internal structure and mesarch bundles of the leares, the general structure of ovule and seed, and the swimming sperms. An inspection of these characters show's that they are primitive, and that they may be interpreted as characters which both groups have retained from some common and very distant ancestry. In other words, these characters are just such as might have been retained by divergent lines.

The characters in common with Coniferales are the lofty and branching habit, the character of the vascular cylinder, and especially the structure of the ovulate strobilus. These characters are distinctly not primitive, and suggest at once that the Cordaitales are intermediate between the Coniferales and the more primitive seed plants.

The characters in common with the Ginkgoales are those shared in general by the Coniferales, except the structure of the orule and seed, and the swimming sperms, which are also cycadean characters. The suggested conclusion is that Cordaitales also connect the Ginkgoales with the more primitive seed plants, and that the reproductive structures of the Cordaitales were retained by the Ginkgoales.

\section{LITERATURE CITED}

I. Wrlliamson, W. C., On the structure and affinities of the plants hitherto known as Sternbergiae. Mem. Manchester Lit. and Phil. Soc. 14:340-358. pl. Io. $185 \mathrm{I}$.

2. Grand 'Eury, C., La flore carbonifère du Département de la Loire. Mém. Acad. Sci. 24: pp. 624. pls. 38. I877.

3. Renault, B., Structure comparée de quelques tiges de la flore carbonifère. Nouv. Arch. Mus. Hist. Nat. II. 2:213-348. pls. 8. 1879.

4. Bertrand, C. E., et Renault, B., Recherches sur les Poroxylons. Archiv. Bot. Nord, France 3: pp. I47. figs. 79. I886.

5. Solms-Laubach, H., Fossil botany. English translation. I8gi.

6. Renault, B., Bassin houiller et Permien d'Autun et d'Épinac. IV. Flore fossile. pp. 557. 1896 .

7. Sсотт, D. H., On the primary wood of certain araucarioxylons. Annals of Botany I 3:615-6r9. I899.

8. - Studies in fossil botany. 1900. 
9. Scott, D. H., Primary structure of certain paleozoic stems. Trans. Roy. Soc. Edinburgh $40^{2}: 33^{1-365}$. pls. I-6. figs. 5. I902.

Iо. - - The old wood and the new. New Phytologist $\mathbf{I}: 25^{-30}$. 1902 .

I I. Worsdell, W. C., The evolution of the vascular tissue of plants. Bot. Gazette 34:216-223. figs. 7. 1902.

I2. Oliver, F. W., The ovules of the older gymnosperms. Annals of Botany I7: $45 \mathrm{I}-476$. pl. 24. figs. 20. I903.

i3. Stopes, Marie C., On the leaf structure of Cordaites. New Phytologist 2:9I-98. pl. g. I903.

I4. Oliver, F. IV., On the structure and affinities of Stephanospermum Brongniart, a genus of fossil gymnosperm seeds. Trans. Linn. Soc. London Bot. II. $6: 36 \mathrm{I}-400$. pls. $4 I-44$. I904.

I5. Stopes, Marie C., Beiträge zur Kenntniss der Fortpflanzungsorgane der Cycadeen. Flora 93:435-482. figs. 37. 1904.

i6. Grand 'Eury, C., Sur les Rhabdocarpus, les graines et l'évolution des Cordaitées. Compt. Rend. Acad. Sci. Paris 140:995-998. 1905.

I7. - Sur les graines de Sphenopteris, sur l'attribution des Codonos permum, et sur l'extrême variété des graines des fougères. Compt. Rend. Acad. Sci. Paris I4I:8I2-8I5. I905.

I8. ScotT, D. H., The early bistory of seed-bearing plants, as recorded in the carboniferous flora (The Wilde Lecture). Mem. and Proc. Manchester Lit. and Phil. Soc. 493: pp. 32. pls. 3. 1905.

I9. Oltver, F. W., "The origin of gymnosperms"; a discussion at the Linnean Society. New Phytologist 5:68-76, I4 I-I 48. I 906.

20. Scotт, D. H., "The origin of gymnosperms"; a discussion at the Linnean Society. New Phytologist 5:68-76, I4 I-I48. I906.

2 I. SEwARD, A. C., "The origin of gymnosperms"; a discussion at the Linnean Society. New Phytologist 5:68-76, I4 I-148. igo6.

22. WEIsS, F. E., "The origin of gymnosperms"; a discussion at the Linnean Society. New Phytologist 5:68-76, I4 I-I48. I9o6.

23. Scott, D. H., The present position of paleozoic botany. Progressus rei botanicae (ed. J. P. Lotsy) $\mathbf{I}^{\mathrm{I}}:$ I $39^{-2}$ I 7 . figs. 37. Igo6.

24. - The paleontological record. II. Plants. Darwin and modern science, pp. 200-222. Cambridge University Press. I909.

25. - Studies in fossil botany. Second edition. Vol. II. London. Igog.

26. Osborn, T. G. B., The lateral roots of Amyelon radicans Will., and their mycorhiza. Annals of Botany 23:603-6I I. pls. 46, 47. Igog.

27. Scott, D. H., and Maslen, A. J., On Mesoxylon, a new genus of Cordaitales (preliminary note). Annals of Botany 24:236-239. I9 Iо. 


\section{CHAPTER V}

\section{GINKGOALES}

Ginkgo biloba is the only living representative of a gymnosperm phylum that was well represented during the Mesozoic. It is almost unknown in the wild state, the only reports of its occurrence having come from travelers in the forest regions of western and southwestern China (28). Its extensive cultivation, however, first in China and Japan, and later in Europe and in the United States, has made it very accessible. It was long included among the Taxaceae as an exceptional member, and only since $\mathrm{I} 897$ has it been set apart as representing a group coordinate with Coniferales and Cycadales, and all subsequent morphological investigation has confirmed this position. The appropriate but antedated name Salisburia adiantifolia has sometimes been used for the plant, and now and then an additional species or two have been segregated, but the generic name Ginkgo must be accepted, and the segregates have had little recognition.

\section{The vegetative organs}

The tree has the general habit of a conifer, with central shaft and wide-spreading branches (fig. 2II), and attains a height of more than $30 \mathrm{~m}$., with a diameter exceeding $\mathrm{I} .5 \mathrm{~m}$. The deciduous foliage leaves are very characteristic in form and venation, and are so suggestive of the leaves of Adiantum that the common name "maidenhair tree" seems appropriate. The petiole is long and slender, the blade is broadly wedge-shaped and variously lobed, and the venation is conspicuously dichotomous (fig. 2I2).

The branches are dimorphic; one kind being long shoots that elongate rapidly and bear scattered leares; the other being the numerous dwarf shoots that elongate very slowly and bear few leaves in a cluster. The dwarf shoot elongates slightly each year, bearing a terminal group of leaves, and the older portion is covered with leaf scars of previous years. After several years a dwarf shoot may become a long shoot, bearing scattered leares; and then it may resume the slow growth of the dwarf shoot again; and in some cases it may branch (28). 


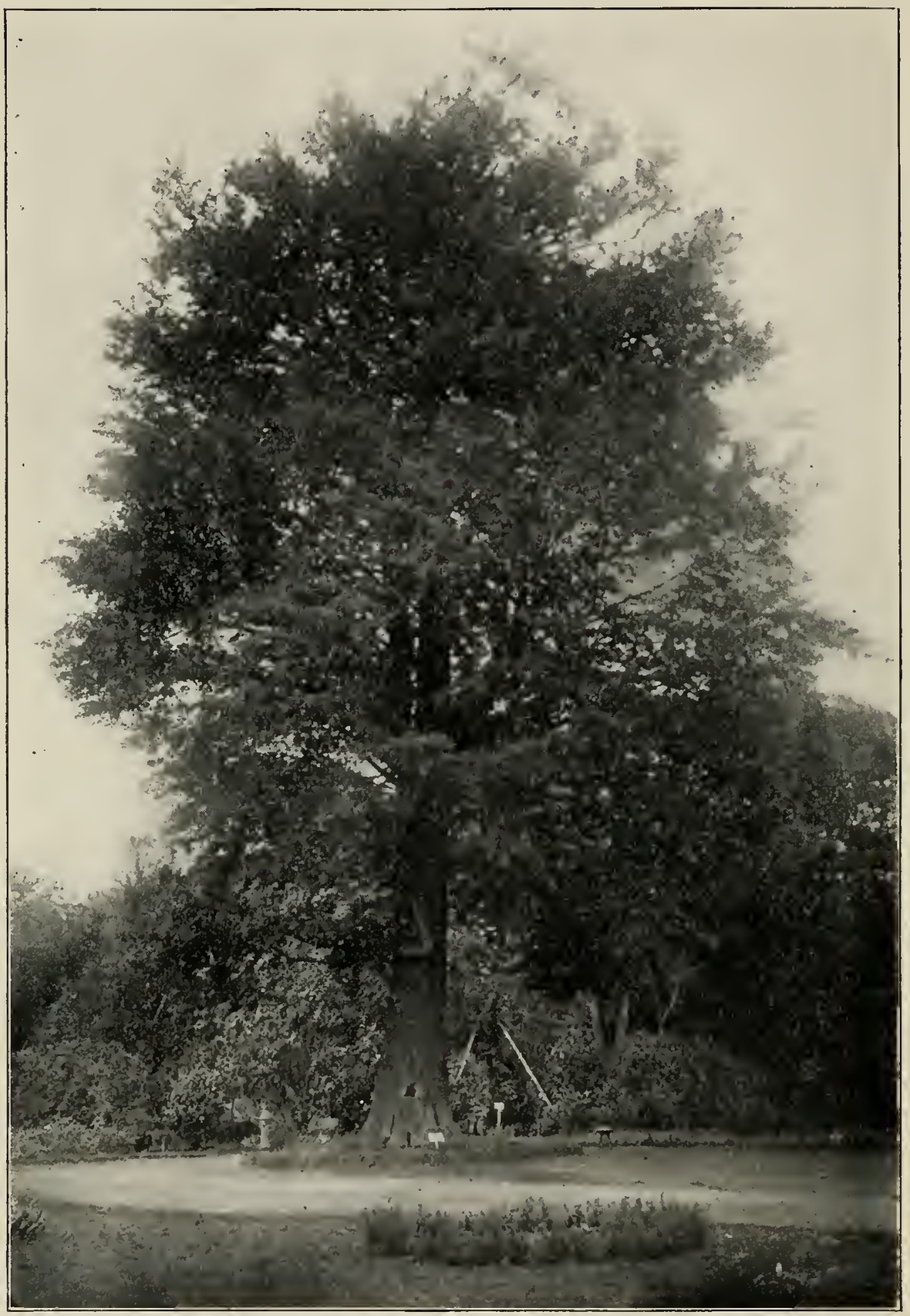

FIG. 2II.-Ginkgo biloba: orulate tree in the botanical garden of the Imperial University at Tokyo, Japan; the first "spermatozoids" discovered in gymnosperms were found by HiRAsÉ in material taken from this tree.-From photograph by MIYAKF. 


\section{VASCULAR ANATOMY}

The transverse section of the stem of Ginkgo shows the general features of Coniferales, namely, a comparatively narrow cortical zone, a thick and compact cylinder of secondary wood developed by a persistent primary cambium (in contrast with Cycadales), and a relatively small pith (in contrast with Cordaitales). In the dwarf shoots, however, the pith is large and the zone of wood comparatively narrow. The primary xylem is endarch, and there is no distinct

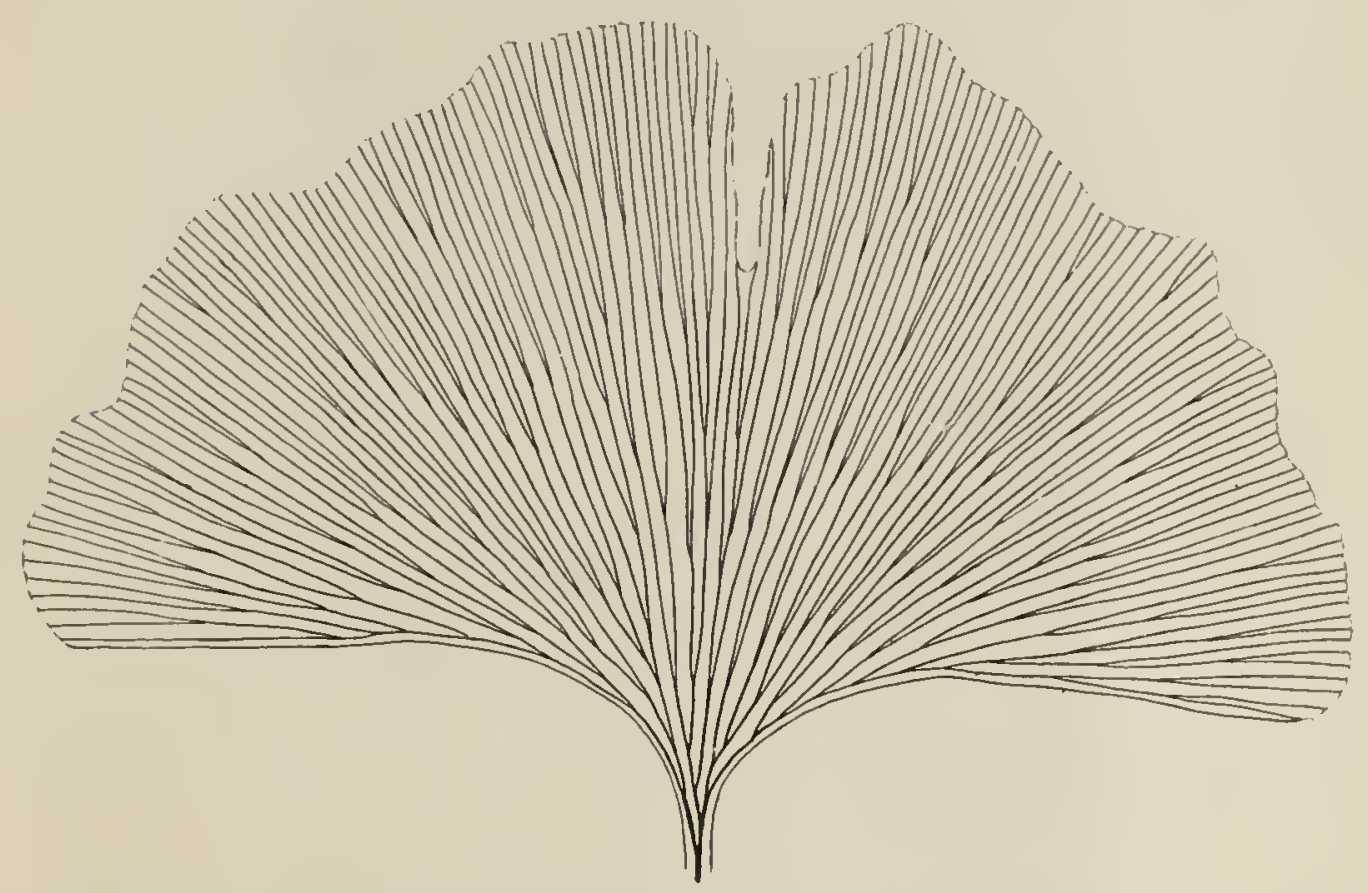

FIG. 212.-Ginkgo biloba: leaf showing bilobed character and dichotomous venation; slightly enlarged.-After Coulrer (54).

mesarch structure except in the bundles of the cotyledons (20) (fig. 2I3). The leaf trace is double, as in all the more primitive gymnosperms, each of the strands forking at the base of the blade, and the resulting four strands breaking up into the characteristic dichotomous system of reins, which may show now and then slight traces of centripetal wood, and therefore an indistinct mesarch structure.

The vascular anatomy of the seedling has been reviewed by HILL and DE FraINE (5I), whose summary contains the facts that Ginkgo differs from the cycads in the rotation of the protoxylem of the cotyledonary traces; that a single vascular strand enters the base of each 
cotyledon; that the bundles pass from mesarch to exarch while traversing the cotyledons; that each cotyledonary bundle gives rise to two protoxylem poles of the root; and that there may be an addition of protoxylem elements after the root structure has been organized.

The cycadean type of seedling is described (42) as consisting of four bundles at the base of each cotyledon and a tetrarch root, which generally becomes diarch below. Miss Thomas (48) has proved

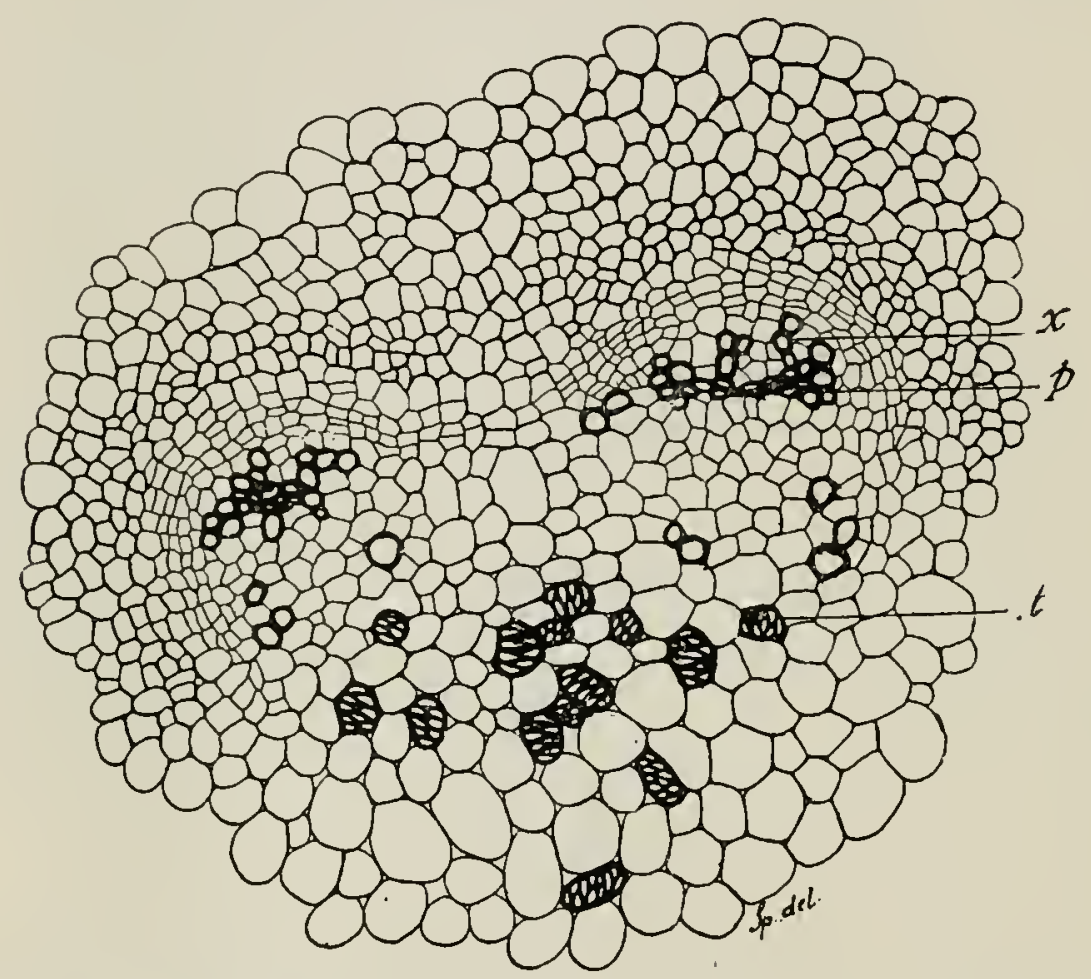

FIG. 213.-Ginkgo biloba: transverse section of cotyledon showing mesarch character of vascular bundle; $p$, protoxylem; $x$, metaxylem; $t$, "transfusion tissue"; $X_{15}$ 0.-After SprechrR (46).

this cycadean type for the Ginkgo seedling by showing that the apparently single bundle that enters the cotyledon is really a plexus of four bundles, separating into two double bundles in the petiole, and each of these separating into its two constituent bundles in the blade. It is in the cotyledons that a very distinct mesarch structure is developed (20). The relation of the number of protoxylem poles in the root to the number of cotyledons ( 12,39$)$, that is, a diarch root related to two cotyledons and a triarch root to three, is true only in an indirect way. The original root is tetrarch, and is related to the four cotyledonary strands from the transition region, and the diarch condition 
observed is a reduction from the tetrarch condition. In the case of three cotyledons, which sometimes occurs in Ginkgo, the vascular situation is modified, so that the root is ultimately triarch.

The testimony of the vascular anatomy shows that Ginkgo has departed farther from the primitive fern stock in this regard than have the Cycadales and the Cordaitales, only the foliar gaps and the mesarch bundles of the cotyledons remaining to indicate the connection in vascular structure $(36)$.

TIIE LEAF

There is great variation in the size and in the lobing of the leaves of Ginkgo. The blades are often deeply cut and with more than two lobes, and the same tree may show every gradation between deeply

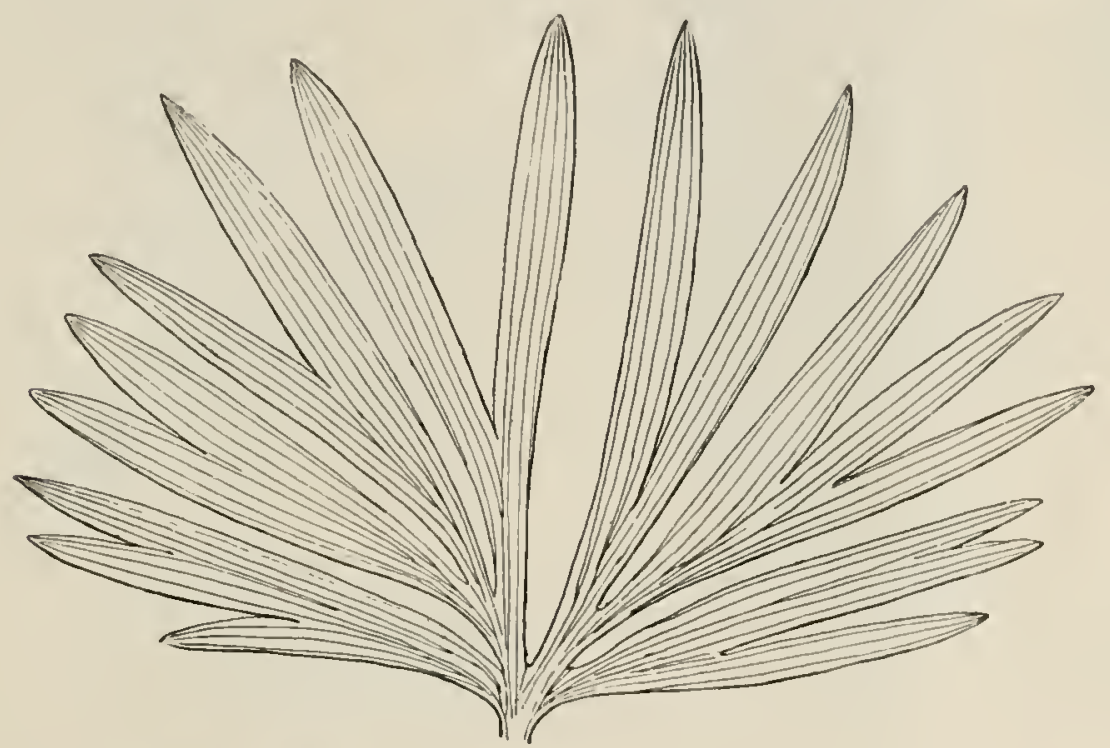

FIG. 2I4.-Baicra gracilis: leaf showing bilobed character, but each of the two principal lobes repeatedly dichotomous; regarded as a transition between Buiera and Ginkgo; natural size.-After Renault ( $9 a)$.

lobed leaves and those with nearly entire margins. The leaves of mesozoic species were much more divided, extreme forms being palmately dissected into numerous very narrow lobes (2S) (fig. 2r44). In the surviving genus Ginkgo, the lobed condition is always found in the leaves of seedlings (fig. 2, 5 ), and usually on the long shoots, leares from the top of a tree being particularly decply cleft. The leaves on the dwarf shoots are usually nearly entire, but when the bud of a dwarf shoot develops into a long shoot, the lobed character of 
the leaf is suddenly resumed, the contrast between the entire leaves of the dwarf shoot and the lobed leaves of the new long shoot being

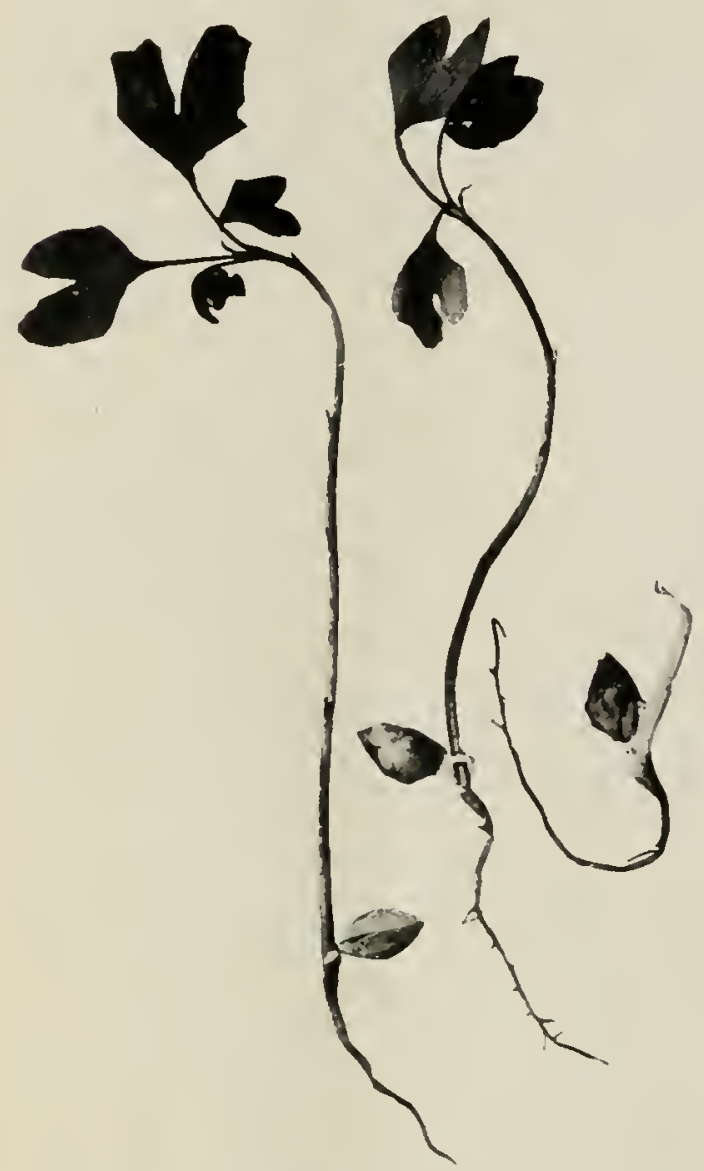

FIG. 215-Ginkgo biloba: seedlings showing deeply bilobed leaves; the seed and cotyledons have not yet fallen off. quite marked (fig. 2I6). The deep lobing is a juvenile character, and by many would be regarded as an illustration of recapitulation.

During development the blade is bent orer at the apex and the margins are strongly inrolled (8). The young leaves develop abun-. dant hairs, especially on the petiole; and the hairs are numerous on the scale leaves, forming a distinct woolly fringe to the petiole (28). The deciduous habit is a very rare one among gymnosperms, being shared with Ginkgo only by the coniferous genera Larix, Taxodium, and Glyptostrobus.

In anatomical structure the leaves of Ginkgo resemble in general those of Cycadales. There is an evident but not very thick cuticle; the stomata are mostly restricted to the abaxial surface, the guard cells being somewhat below the lerel of the epidermis; there is a distinct palisade tissue in the larger leaves, but not in the leaves of the dwarf branches; and between the reins the very loose inner mesophyll cells are elongated parallel with the plane of the leaf surface.

\section{The spore-producing members}

The strobili of Ginkgo are not only monosporangiate, but the plants are also dioecious, as in the Cycadales. Neither kind of strobilus is bracteate, as is usual among gymnosperms; and the ovulate strobilus has given rise to much discussion. 
THE MICROSPORANGIUM

- The staminate strobili consist of numerous microsporophylls rising in loose catkin-like clusters from the axils of the scale leaves developed at the summit of the dwarf shoot (figs, 2i6, 2I7). Comparing this strobilus with the staminate strobilus of Cordaitales, it
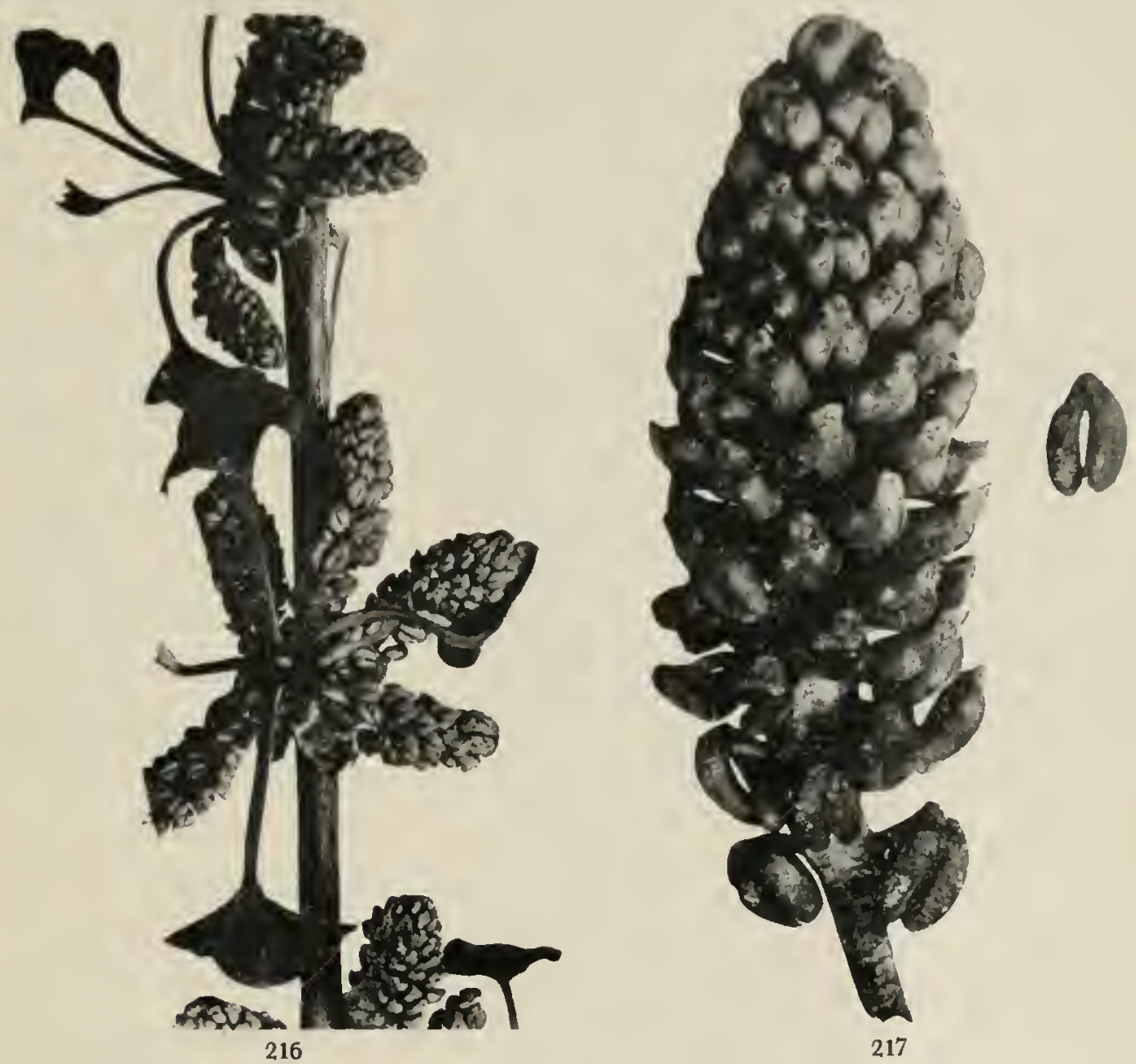

FIGS. 216, 217.-Ginkgo biloba: fig. 216, branch with dwarf shoots bearing staminate strobili and leaves; about natural size; fig. 2 I 7 , single staminate strobilus, showing character of individual stamens (a stalk ending in a knob and bearing two pendent sporangia); $\times 3.5$.-After Coulter $(54)$.

is evident that if the intermixed sterile sporophylls and bracts of the latter were eliminated, the general structure of the former would be obtained.

The strobili are first evident during the early summer of the year preceding the maturing of the pollen (53), but are hidden in buds that cannot be distinguished from leaf buds. The development of the sporophylls is in acropetal succession, and the older sporangia reach 
the mother cell stage before winter (47). Material collected during April (in Ohio) by Miss Starr (53) showed some sporangia in the mother cell stage and others with tetrads.

The mature sporophyll has a rather long stalk, which terminates in a knoblike enlargement, beneath one side of which usually two pendent sporangia are borne. In material grown in the United States there are often three or four sporangia; and Sprecher (47) cites cases of stamens with as many as seren sporangia. Occasional

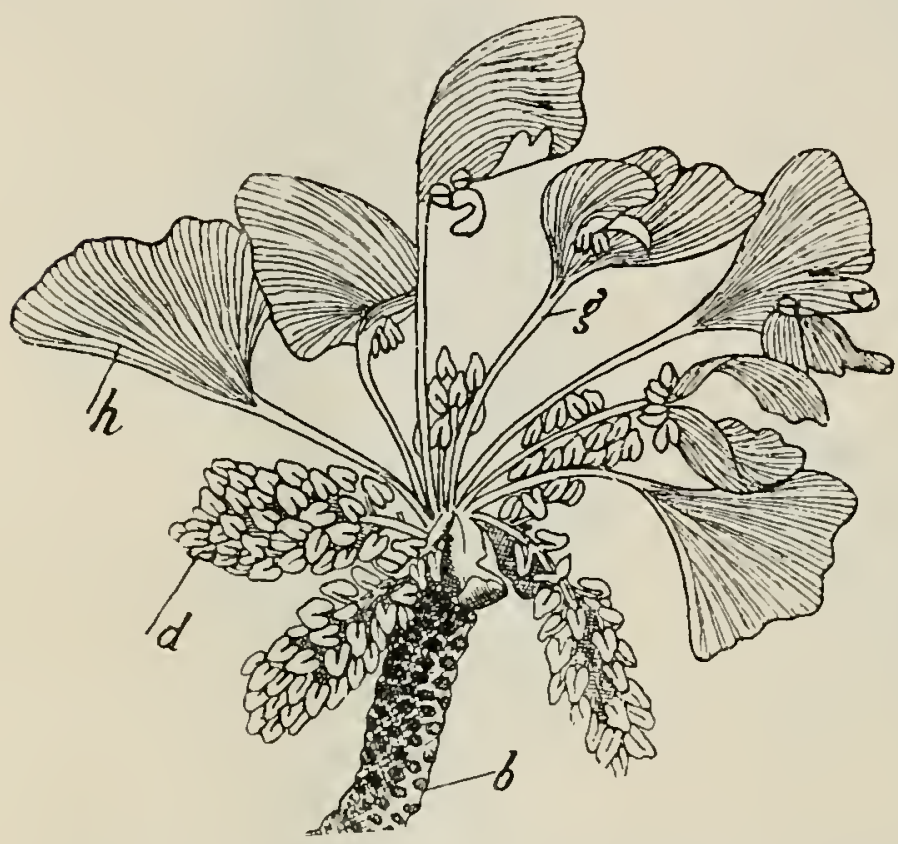

FIG. 2I 8.-Ginkgo biloba: dwarf shoot hearing normal strobili $(d)$, normal leaves $(h)$, and leaves with microsporangia $(g)$.-After FUJII ( 7 ). abnormalities occur which show even greater variation from the usual form (fig.. 2I8). The more or less expanded knob at the tip of the stalk may be regarded as representing a reduced lamina bearing sporangia pendent from its abaxial surface. The development of this knob has been studied by Miss Starr (53), to discover whether it gives such evidence of abortive sporangia as had been found in Torreya (40). The large mucilage cavities begin to develop like sporangia, and for some time there is a close resemblance to sporogenous tissue, but finally the walls disintegrate and a mucilage cavity is the result (fig. 22I). The fact that the stamen of Ginkgo sometimes bears more than two sporangia, and that certain fossil forms bear more than two regularly, strengthens the view that the mucilage ducts of the knob have replaced abortive sporogenous tissue. At the same time, it is recognized that the mucilage ducts elsewhere in Ginkgo, as in the leaves, pass through the same developmental stages.

Such a stamen suggests the Crossotheca ("epaulet") type among 
Cycadofilicales. The known stamens of Cordaitales are different (p. $\Upsilon_{72}$ ), but it cannot be supposed that the stamens of so great a grouj) were uniform in type.

In fact, in Antholithus Zeilleri, which is regarded as the staminate strobilus of $\mathrm{Bai}$ era (a mesozoic member of Ginkgoales), the sporangium-bearing structures are dichotomously divided, dorsiventral organs, the ultimate divisions of which bore eight sporangia (49). This structure seems to be widely different from the stamen of Ginkgo, so much so as to raise the question whether this Antholithus belongs to Baiera, and hence to the Ginkgoales; but if the sporangia are terminal, the parallel is found in the known stamens of - Cordaitales. If the sporangia are abaxial on the ultimate branches, rather than terminal, the reduction to a single branch would represent the stamen of Ginkgo. In either
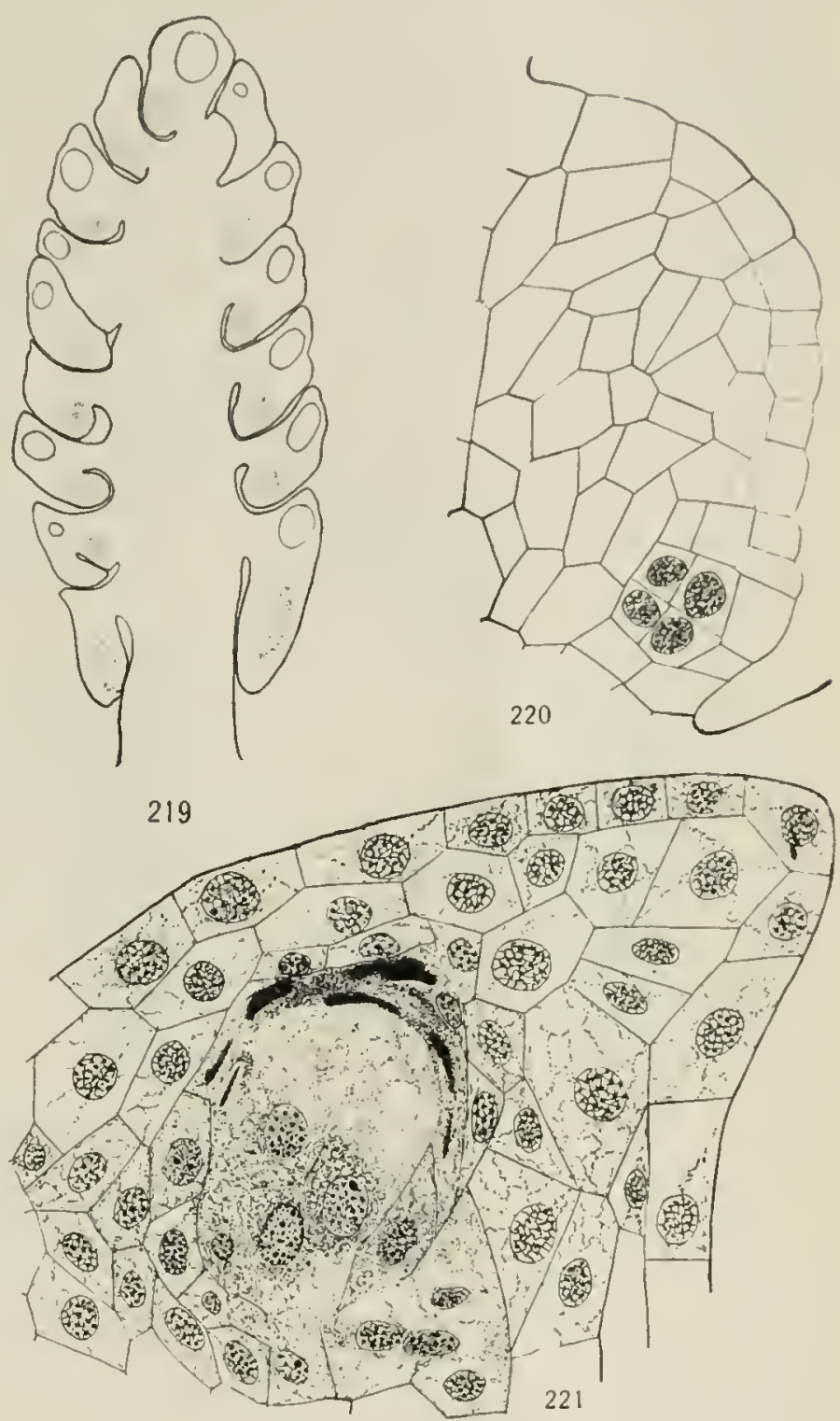

FIGs. 219-221.-Ginkgo biloba: fig. 219, young staminate strobilus in September, showing microsporophylls with sporogenous tissue and mucilage ducts; $\times 20$; fig. 220 , young sporangium; the four cells in which nuclei are shown have come doubtess from a single archesporial cell; the two inner cells are sporogenous and the two outer tapetal; $X_{4} 85$; fig. $22 \mathrm{I}$, a rather late stage in the formation of a mucilage duct in the hump; the sporogenous-like cells are brealing down and the surrounding cells resemble a tapetum; $\times_{4} 8_{5}$.-After Miss STARR (53). 
event, the structure emphasizes the interrelationships of Ginkgoales, Cordaitales, and Cycadofilicales.

The development of the microsporangium has been described by Miss StarR (53). Early in July the strobili which are to mature their pollen the following year can be recognized as small papillae in the axils of bracts, and before winter checks the growth the oldest sporangia at the base of the strobilus reach the mother cell stage (fig. 2 I9). Although the earliest stage was not seen, it was evident that a single hypodermal cell divides anticlinally and then periclinal divisions follow, or the order is reversed. The outer cells produce the wall of four to seven layers, and the inner cells a large group of sporogenous cells (fig. 220). The tapetum seems to be formed entirely from the peripheral cells of the sporogenous group. In the mature sporangium the hypodermal layer of cells (outermost wall layer) and the layer beneath it develop thickening bands in the walls, and in the upper part of the sporangium, near the mucilage cavity, the walls of deeper cells are also thickened. Ginkgo seems to be the only gymnosperm that develops an endothecium (32), in the sense that the layer or layers of cells that show the structure and function of an endothecium are hypodermal. The longitudinal slits of dehiscence of the two sporangia face one another, and lie at such an angle that the pollen is shed easily (32).

\section{THE MEGASPORANGIUM}

The ovulate strobili of Ginkgo are very much reduced, and are borne in groups at the summit of the dwarf shoot (fig. 222). The individual strobilus consists of a long stalk arising from the axil of a bract and bearing at its apex mostly two ovules, one of which usually aborts, although in favorable seasons it is by no means uncommon to find both ovules fully developed (fig. 223). Occasionally more than two orules appear, and the indications are that the strobilus of Ginkgo has been derived from one bearing several or perhaps many ovules (fig. 224).

About the base of the orule there is a more or less conspicuous cup or "collar," much more prominent in the young stages of the orule. This collar has been a prolific source of discussion, and a brief résumé of the views as to its nature and the nature of the strobilus 
will serve to illustrate the progress of interpretation, and especially will show the result of attempting to read the structures of a higher group into those of a more primitive one.

In I869 Van Tieghem (2) interpreted the stalk as a petiole; the two ovules as determined by the two characteristic lobes of the blade; the collar as a reduced aril; and hence the whole structure as a single megasporophyll (carpel). In I872 Strasburger (4) suggested that the stalk is a shoot; that the collar is the rudiment of the first pair of leaves of a secondary shoot; and hence that the whole

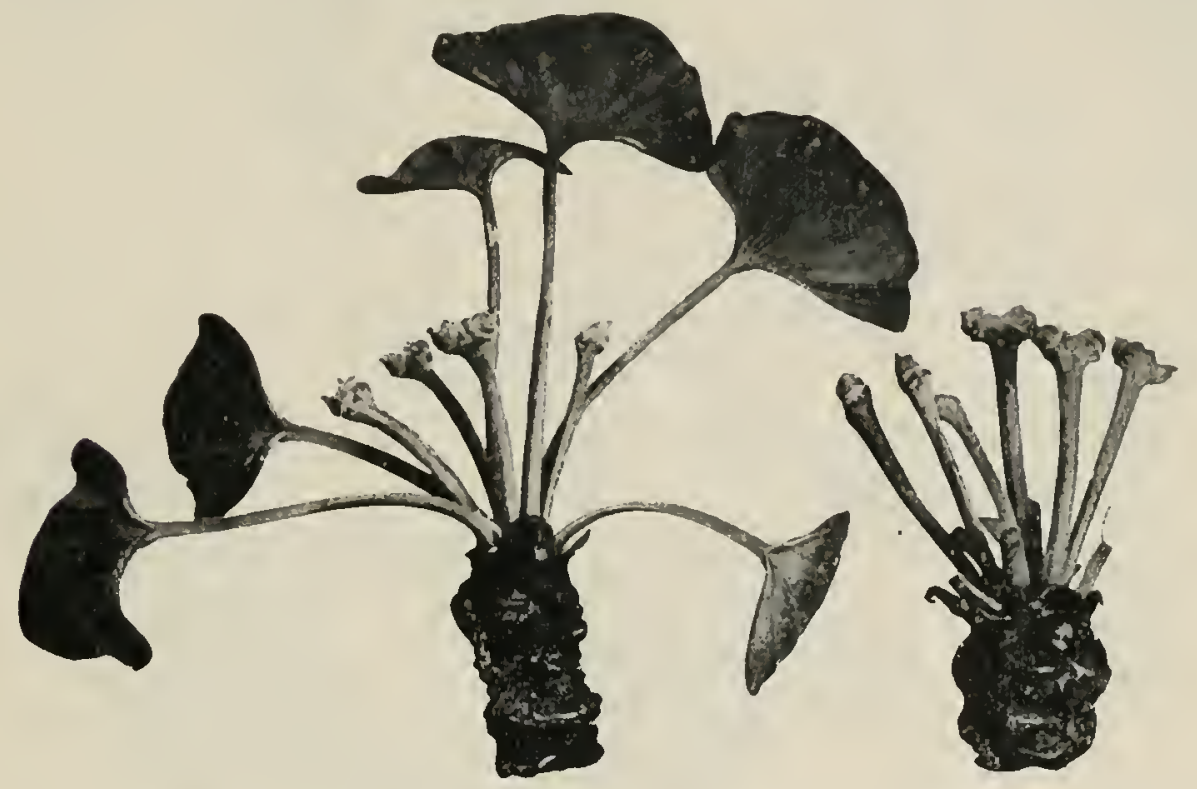

FIG. 222.-Ginkgo biloba: dwarf shoots with ovulate strobili; the leaves have been cut away from the shoot at the right; the female gametophyte in such ovules is in a very early free nuclear stage; $X_{\text {I }}$.5.-After Coulter (54).

structure is an inflorescence of two flowers in which the carpel is suppressed. In 1879 he modified (6) this view in so far as to conclude that the collar represents an aril. In I873 Eichler (5) interpreted the collar as the outer integument of the orule, which view is not necessarily inconsistent with the preceding views that it stands for an aril; later (Io) he called the collar a rudimentary carpel. In I890 Celakovsky (II) stated that the stalk is an axillary shoot bearing two or more carpels, but that each carpel is represented only by an ovule, which means that the existence of the carpel is only theoretical; later $(25)$ he reaffirmed these views with greater fulness of detail. In I 896 FUJII ( $\mathrm{I} 7$ ), after a study of abundant Japanese 
material, and especially taking into account numerous abnormal cases, came to the conclusion that the stalk is a shoot usually bearing two rudimentary carpels (megasporophylls) which are represented

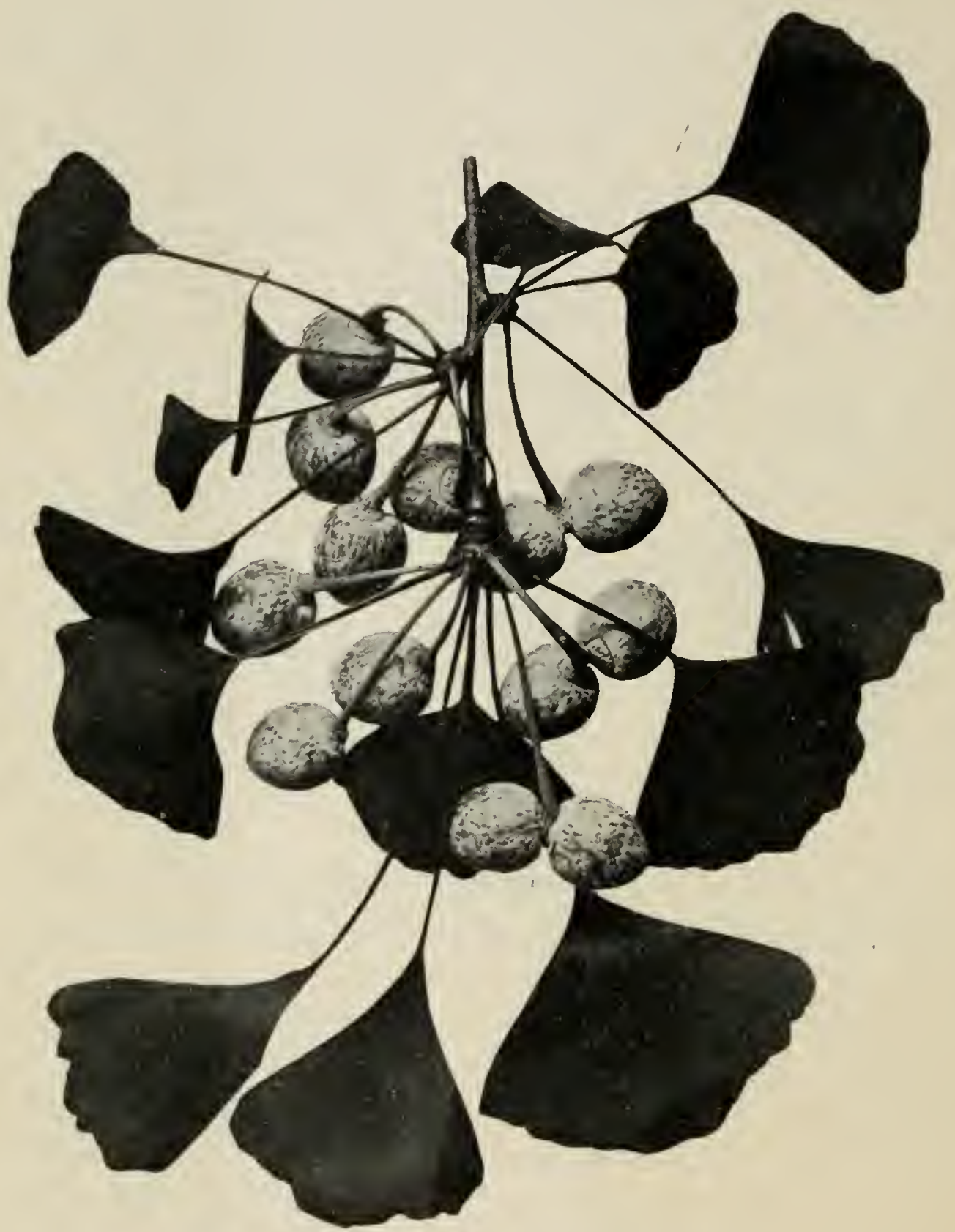

FIG. 223.-Ginkgo biloba: part of a long branch bearing dwarf branches with ovulate strobili.-After Couiter ( 54$)$.

by the two collars. The abnormal cases may be summed up as follows: ovules on more or less modified foliage leaves; intergrades from normal collars to blades bearing ovules; distinctly stalked orules; stalks 
bearing several ovules and terminating in a scaly bud (fig. 225). T In I gOo SEWARI) and GowaN (28) reviewed the whole situation, studied additional abnormalities, and coincided with the conclusions of FujIr. And now SHaw (50), investigating the vascular anatomy of the strobilus, dissents from the current view that the collar is a much reduced megasporophyll. It seems that the bundles of the collar show inverse orientation, and a comparison with La genostoma suggests that the collar of Ginkgo is a restige of the cupule that invested seeds of the Lagenostoma type. This claim for the cupule nature of the collar is most interesting, and if it is the true one, it even more strongly emphasizes the close connection of Ginkgoales and Cycadofilicales.

The evidence at present suggests that the structure under discussion is a strobilus bearing two or more megasporophylls, which are usually reduced to the so-called "collars," but which sometimes resume their original leaflike character. These abnormal oruliferous leares are most suggestive of the orulif-

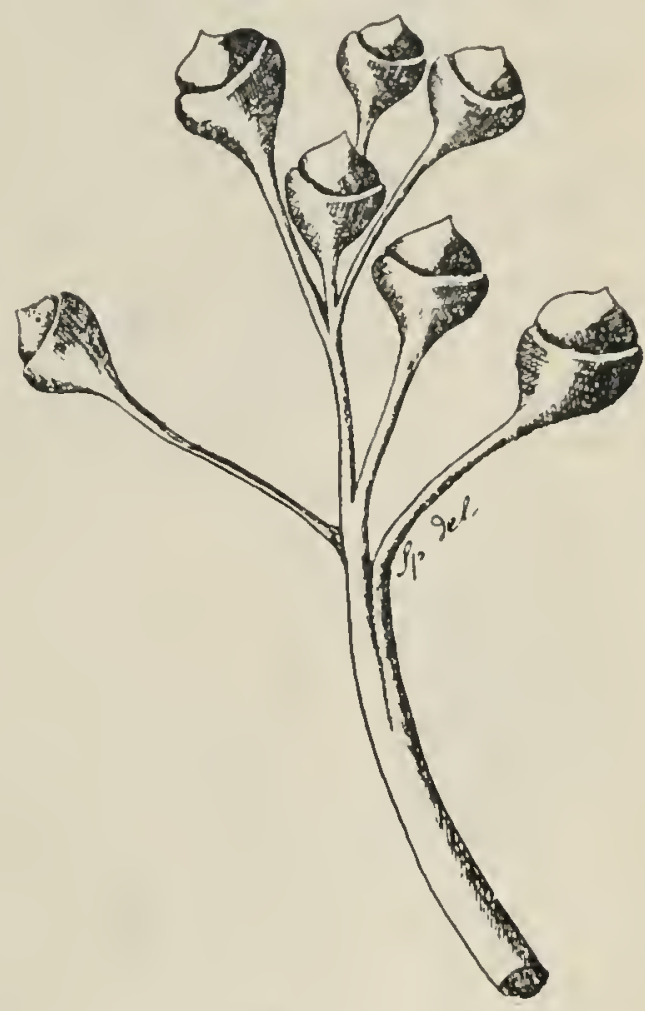

FIG. 224.-Ginkgo biloba: axis bearing seven ovules, each with a pedicel.-. Ifter Sprecher $(47)$. erous leaves of the Cycadofilicales, and hence of the origin of the ovulate strobilus of Ginkgo. While the stalk of the strobilus resembles the petiole of a leaf, it is quite different in its structure. A transverse section of a petiole shows the two bundles already mentioned as representing the double leaf trace; while a transrerse section of the stalk of a strobilus shows the four bundles which would be expected in a stem bearing two leaves (collars) at its apex (figs. 226, 227). When more than two orules are borne on one stalk, there are twice as many bundles in the stalk as there are orules at its apex, just as there should be if each collar were a mega- 
sporophyll. The evidence from "abnormalities," which may be interpreted as reversions, together with the testimony of the vascular

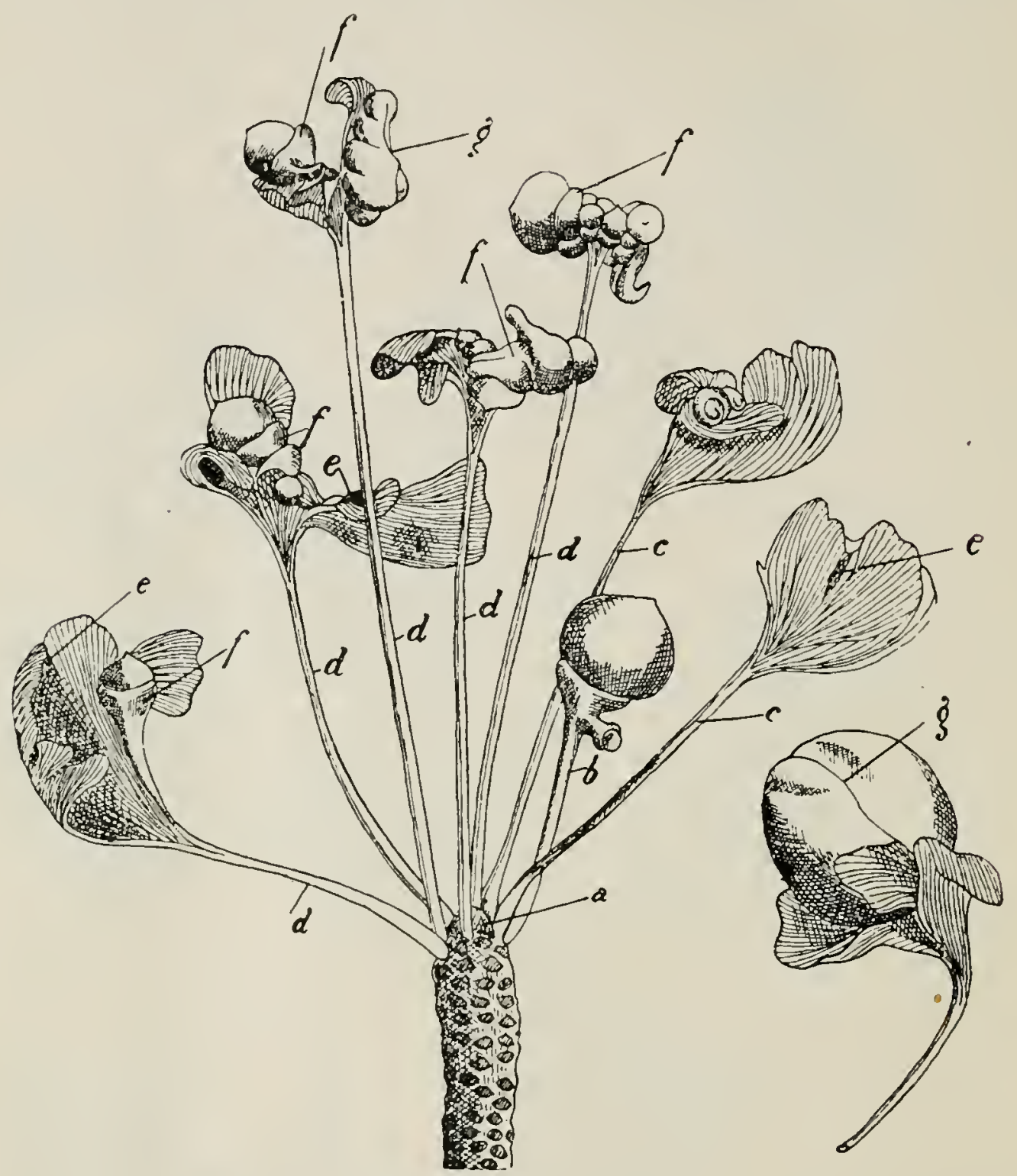

FIG. 225.-Ginkgo biloba: abnormalities in ovulate structure; $a$, bud; $b$, nearly: normal strobilus; $c$, leaf with irregular thickenings; $d$, leaves bearing orules; $f$, thickening at base of orule; $g$, longitudinal striation along the fleshy part of the seed.-After FUJII ( 17 ).

anatomy, strongly support the view that the stalk is a stem bearing two megsaporophylls (collars), each of which bears a single ovule.

The development of the ovule has been investigated by Miss Carothers (46), from material grown in northern Ohio. About the first of April no ovules are visible in the buds on the dwarf shoots, 


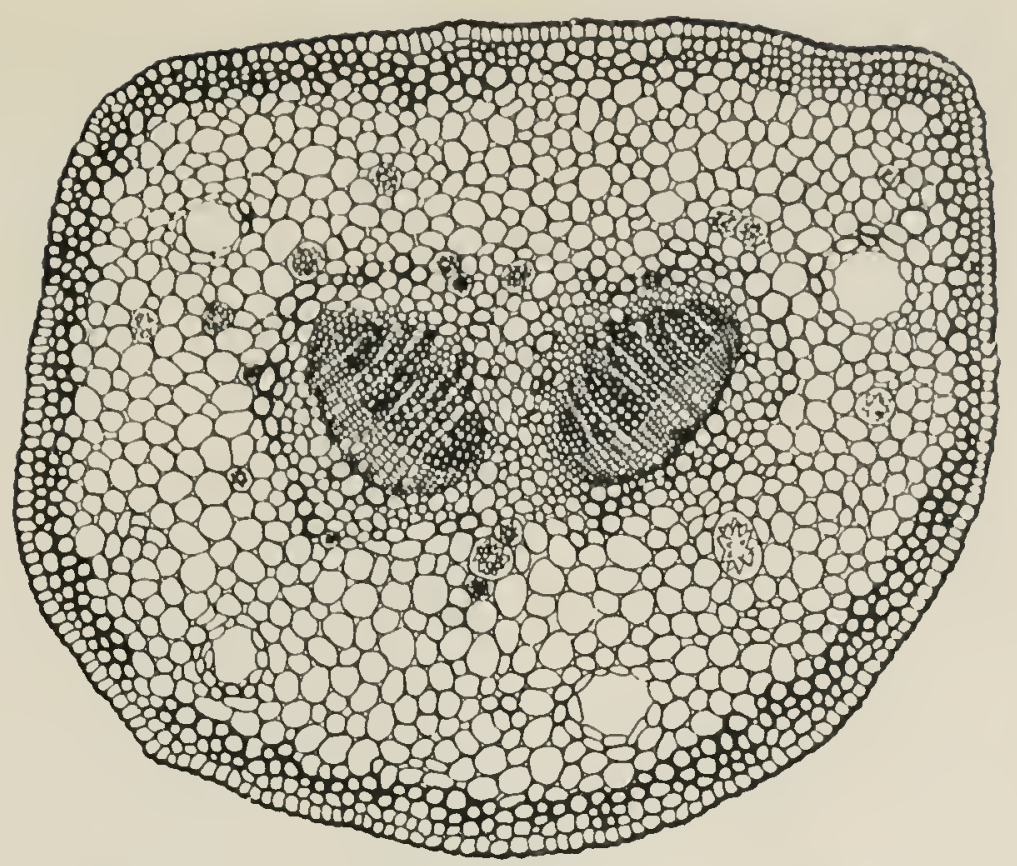

FIG. 226.-Ginkgo biloha: transverse section of leaf, showing two bundles.-After SPRECHER $(+7)$.

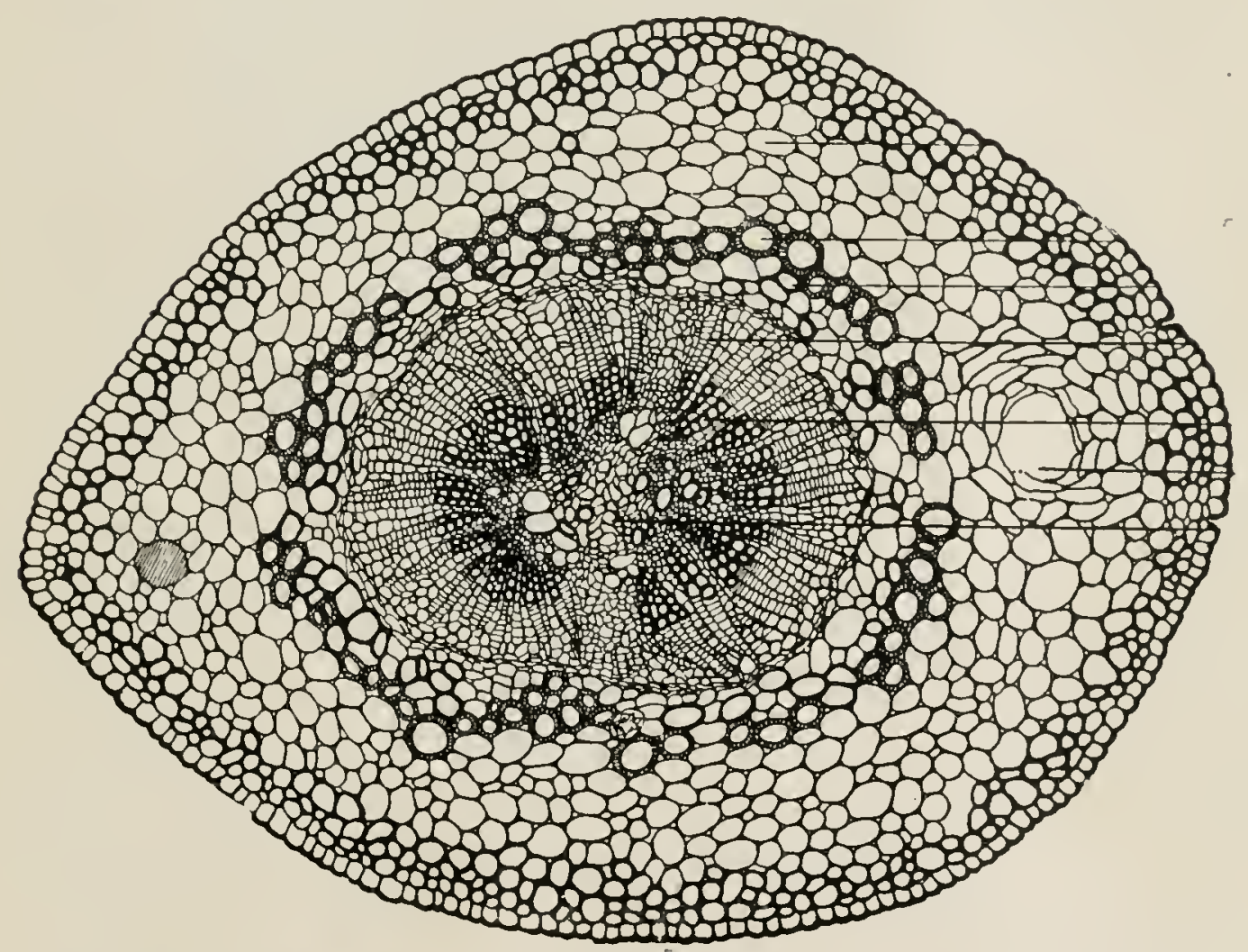

FIG. 227.-Ginkgo biloba: transverse section of the stalk of orulate strobilus, showing the general structure of a stem.-After SPRECHER (47). 
but two weeks later they are $0.25 \mathrm{~mm}$. long, the nucellus being homogeneous and not wholly inclosed by the integument (fig. 228). Not all the buds of the dwarf shoots are fertile, and the strobili in those that are range in number from one to six. In such a bud the sequence of structures from outside inward is as follows: brown bud scales, green scale leaves, foliage leaves, strobili, foliage leaves. About
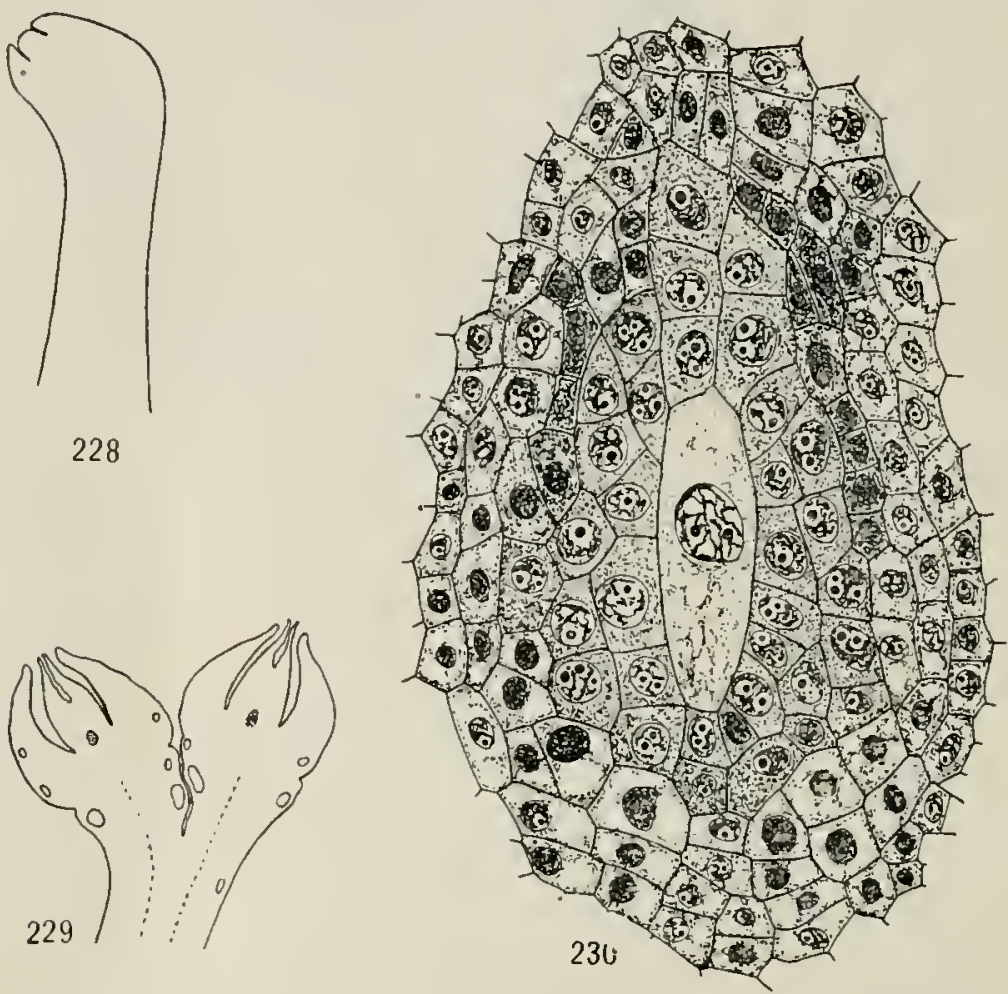

Figs. 228-230.--Ginkgo biloba: early stages in the development of the ovule; fig. 228, nucellus in April, not yet covered by integument; no archesporium can be distinguished at this stage; $X_{I_{5}} ;$ fig. 229, condition May I; $X_{I_{2}} ;$ fig. 230 , May I, megaspore mother cell surrounded by "spongy tissue"; $\times 325$--After Miss Carothers (46).

the first of May the orules are $0.75 \mathrm{~mm}$. long; the prominent nucellar beak has developed, in some cases protruding from the micropyle; a large pollen chamber has been formed, which often contains pollen grains developing tubes; and the sporogenous tissue is in all stages from immature mother cells to complete tetrads. According to Hirasé (22), the pollen chamber results from the exclusive growth of the external tissue of the beak, the inner tissue thus becoming ruptured and disorganized.

Usually one mother cell functions, two functioning mother cells 
being found in only one orule out of fifty at this stage. The derivation of the mother cell from a hypodermal archesporial cell could not be traced. It is recognizable in the midst of the so-called "spongy" tissue," which may or may not be sporogenous in origin (figs. 229, 230). PAX (13) evidently regarded this tissue as representing a many-celled archesporium; but whatever its morphological nature, its tapetal function is clear. In the mature mother cell there appears the peculiar "kinoplasmic mass" observed in the mother cells of Ta.vus, Larix, Taxodium, Thuja, and certain other gencra. The reduced number of chromosomes is eight; and although a linear tetrad is usual, one case of bilateral arrangement was observed, and two cases in which the upper cell of a row of three had divided longitudinally.

The history of the tapetal zone is as follows. During tetrad-formation, this glandular-looking tissue increases in bulk by cell division, encroaching actively upon the surrounding nucellar tissue until the last week of June. The absorbing cells soon become vacuolate and

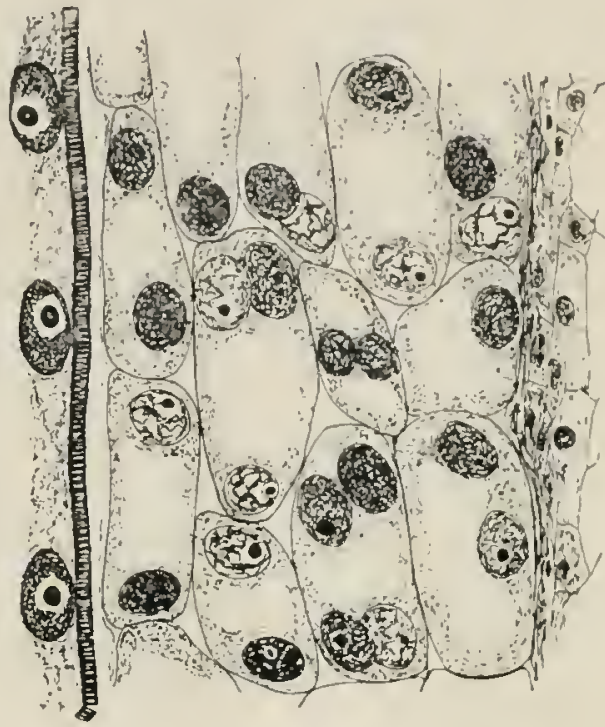

FIG. 231,-Ginkgo biloba: multinucleate stage of spongy tissue; bordering upon the spongy tissue at the left is the corispicuous megaspore membrane, and just beyond are three of the free nuclei of the endosperm; $\times 650 .-$ After Miss Carothers (46). finally multinucleate (fig. 23I). The megaspore membrane surrounding the gametophyte now shows the characteristics of its mature condition, although it has not reached its maximum thickness. After June, the tapetal zone in turn begins to be destroyed by the encroachment of the young gametophyte (endosperm), which at this time is still in the free nuclear stage, but the distinct membrane about it has been formed. By the time the centripetal grow th of the gametophyte is about one-third of the distance across the embryo sac, all of the tapetal zone has been crushed. It is evident that this zone of cells is one that digests and absorbs, performing the "tapetal function" for the mother cell and the early stages of the gametophyte. 
The single thick integument, forming a long and narrow micropylar tube, is at first homogeneous, but by the last of May three distinct layers have become differentiated. The outermost layer is a tissue of large, thin-walled cells with numerous mucilage cavities, and finally becomes the fleshy layer of the mature testa. The middle layer consists of small isodiametric cells, and later forms the stony layer of the testa. The innermost layer consists of large, loosely'

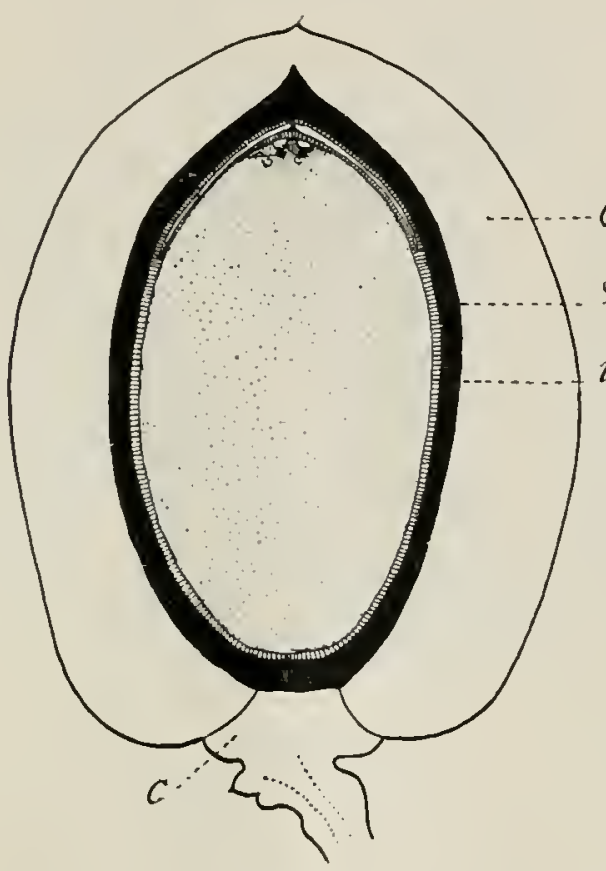

232

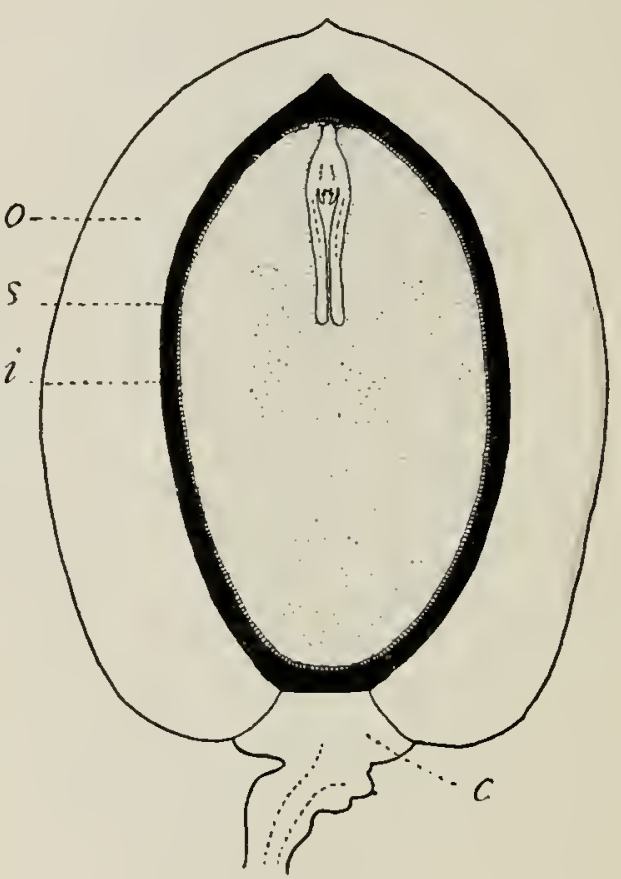

233

FIGS. 232, 233.-Ginkgo biloba: diagrams of ovules showing the stony layer (s) between the outer $(o)$ and inner $(i)$ fleshy layers, and the collar $(c)$; fig. 232, after the stony layer has become hard, but before the inner fleshy layer has become dry; the inner fleshy layer and the nucellus are shaded with lines; fig. 233 , after the inner fleshy laver and nucellus have become dry and papery; $\times 2$.

arranged, very thin-walled cells, which in the free portion of the integument are differentiated into two regions: the inner consisting of vertically elongated cells, a tissue restricted to the free portion of the integument; the outer consisting of transversely elongated cells, a tissue that extends the whole length of the orule just within the stony layer. This inner tissue is at first delicate and watery, but soon becomes crushed and dry, forming in the mature testa' a papery layer lining the stone and adherent to it (figs. 232, 233). This general structure of the testa is practically cycadean (p. I 28 ). It has come to 
be the habit to refer to these three layers as "outer fleshy," "stony;" and "inner fleshy."

At the base of the orule, two vascular strands enter the inner fleshy layer on opposite sides, through a gap in the stony layer, and continue along the surface of the layer, ending where the integument becomes free. One of the characteristic features of the Ginkgo testa is the suppression of one of the two sets of rascular strands characteristic of the more primitive gymnosperms. In this case the outer one, which traverses the outer fleshy layer, has been suppressed.

\section{The gametophytes}

THE FEMALE GAMETOPHYTE

The derelopment of the female gametophyte (endosperm) has also been investigated by Miss Carothers (46). As the functioning megaspore enlarges, a large vacuole holds its nucleus near the micropylar end. Since the megaspore, after its nucleus begins to divide, is always racuolate, the free nuclei are parietal from the beginning. About the middle of May there are 16 to 64 free nuclei, well separated in the very delicate cytoplasmic lining of the thin wall of the embryo sac. Up to this stage (64-nucleate) the free nuclear divisions are simultaneous, but later they become irregular, continuing until the first of July, when there are over 256 nuclei. During this period the ovule and the embryo sac are enlarging, and the megaspore membrane is becoming thicker.

Preliminary to wall-formation, a delicate membrane appears on the outer surface of the protoplast of the embryo sac, which is easily separable from the megaspore membrane, and may be called the endosperm membrane. To this endosperm membrane (not to the megaspore membrane, as has been supposed) the first walls of the endosperm are anchored, being laid down at right angles to it, and leaving the cells open toward the sac cavity (fig. 234). After the first walls are formed, centripetal growth of the endosperm begins, the innermost cells, open toward the center of the sac, always being larger than the outer ones and usually uninucleate, although they are sometimes binucleate and even trinucleate. In the tissue which has reached nearly to the center of the sac binucleate cells are common, 
and occasionally a multinucleate cell is observed; but in mature endosperm tissue the cells are uninucleate. Whether this is due to disorganization or fusion of nuclei, or to additional wall-formation, was not determined. Centripetal growth of the endosperm is rapid through July and August, the sac being filled with tissue by the last week of August. In the closure of the tissue at the center of the sac, there is no formation of a common wall, but two distinct abutting walls are formed, so that even in the ripe seed the tissue of the endosperm separates easily at the center by a cleavage plane.

As the centripetal development pro-

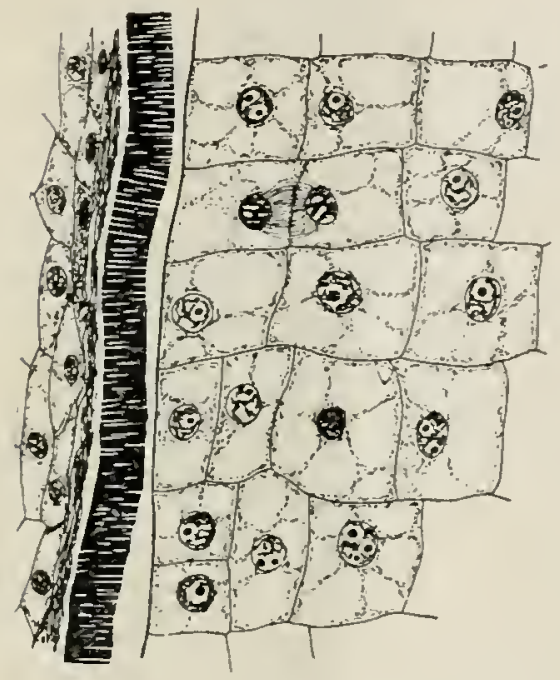

FIC. 234--Ginkgo biloba: walls of endosperm cells in contact with the endosperm membrane, and not extending to the megaspore menbrane; June 5; $\times 650 .-$ After Miss Carothers ( 46 ). ceeds, the whole gametophyte increases in bulk, the inner cells enlarging greatly and occasionally dividing, and those of the peripheral region multiplying. Soon after the appearance of walls and long before the sac is filled with tissue, the endosperm becomes green; and in a few weeks it is the greenest region of the orule, the spectroscope showing the presence of chlorophyll. The cells are early filled with starch, some of it doubtless formed by the green gametophyte itself. Outside of the gametophyte starch is abundant only in the outer region of the integument. The endosperm in its growth encroaches upon the nucellar tissues until it destroys not only the previously active tapetal zone, but also most of the undifferentiated nucellar tissue, whose living cells are separated from it by a mass of the dead cells of the tapetal zone. It is probably this zone of crushed cells that has been interpreted as a "tapetum" in certain fossil seeds (p. 37), but whether it was previously active as a tapetum in such cases cannot be determined.

When the endosperm has reached its full development, the endosperm membrane has become much thickened, and the megaspore membrane has become extremely thick and dense. As the endosperm 
is entirely free from the megaspore membrane, the latter is pushed outward by the development of tissue about the archegonial chamber, forming a roof over it. The megaspore membrane becomes differentiated into two layers, the inner one being very thin and serving as a base for the transiersely placed "rods" of the outer layer, as already noted in the cycads (p. I39). When the endosperm tissue has become closed at the center of the sac, the megaspore membrane has reached a thickness of over $6 \mu$. According to Thomson (4I, 43), the structure of the membrane is very similar to that of the Cycadales, but the inner layer is not so thick. His general conclusion is that Ginkgo is farther removed from the fern level in this regard than are the Cycadales, and less so than are the Coniferales, in which the megaspore membrane is variable in thickness and simpler in structure.

The archegonium initials, usually two in number (figs. 242, 243), but occasionally three, appear very early in the history of the gametophyte, the two-celled neck and a considerably enlarged central cell appearing before the tissue lining the embryo sac is equal in depth to the breadth of the central cavity. The development of the archegonium is exactly similar to that in the Cycadales, including the organization of the conspicuous nutritive layer of jacket cells. At the beginning of August (in Japan), when the tube nucleus is passing back into the pollen grain end of the tube, as described by Hirasé (22), the endosperm begins to develop a beak between the two archegonia. In about two weeks this beak resembles a small column, with its summit against the settling nucellar beak, "like a tent supported by its center pole." This endosperm beak much enlarges and modifies the archegonial chamber described above. Just before fertilization, early in September (in Japan), the small and ephemeral ventral canal cell is cut off, and the egg is matured (fig. 244). In this respect Ginkgo is more primitive than the cycads, in which no wall is formed between the ventral canal nucleus and that of the egg. IkENo (30) reports that in one instance he observed a ventral canal nucleus that had enlarged pari passu with the egg nucleus, whose maturation resembles that described under Pinus Laricio (p. 266). Hirasé states that about twenty weeks elapse between pollination and fertilization. 


\section{THE MALE GAMETOPHYTE}

The first account of the male gametophyte of Ginkgo is that given by Strasburger ( $\mathbf{I}_{5}$ ) in I 892 . It is of interest to note that HofMEISTER in $\mathrm{I} 863$ ( $\mathrm{I}$ ) predicted the finding of swimming sperms in the pollen tubes of gymnosperms; and in May I896, at a meeting of the Botanical Society of 'Tokyo, Hirasé announced (I8) the discovery of ciliated sperms, his preliminary paper (19) appearing in October of the same year, and his full paper (22) in 1898 . In this connection a detailed study was made of the development of the male gametophyte and of the phenomena connected with fertilization; and it is chiefly from this source that the following account is drawn.

The first division of the microspore is unequal, resulting in cutting off a small lenticular cell, which soon disorganizes and later appears like a cleft in the heavy spore wall. No such ephemeral vegetative cell has been discovered among the Cycadales, but such cells are characteristic of the Abietineae.

A second unequal division occurs, and a second small cell is cut off, which persists, and which is a second regetative cell. This cell also appears among the Abietineae, but in them it is ephemeral like the first. A single persistent regetative cell also appears in the Cycadales; so that Ginkgo resembles the Abietineae in having two vegetative cells, and the Cycadales in having one persistent cell.

After the two vegetative cells have been cut off, the remaining large cell may be regarded as the antheridium initial, although the ordinary structure of a multicellular antheridium has disappeared. This cell divides" equally, the smaller daughter cell, in contact with the persistent vegetative cell, being the generative cell, and the larger cell being the tube cell (fig. 235). The gametophyte is in this four-celled stage (ephemeral vegetative, persistent regetative, generative, and tube cells) when pollination takes place (fig. 236), during the last of April or early in May (in Japan).

The pollen chamber now begins to enlarge at the expense of the nucellar tissue at the side and beneath, carrying the grains deep into the nucellus. Early in June the chamber has enlarged greatly, forming a large irregular cavity, which extends nearly to the embryo sac. When the grains begin to put out their tubes, the opening to the pollen chamber becomes closed and remains so, the surrounding tissue 
becoming brown and forming at resistant beak that long persists as a cap on the satc. 'The pollen grains, carried well below the beak by the decpening of the chamber, send out their tubes in every direction into the adjacent nucellar tissue, but chiefly awaty from the cmbryo

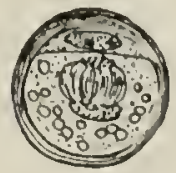

235

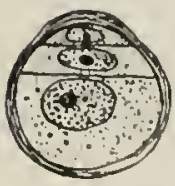

236

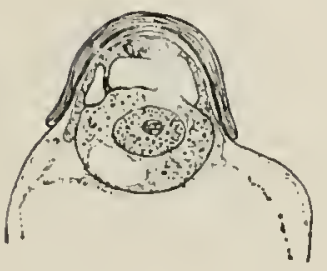

237

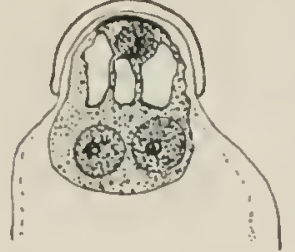

238

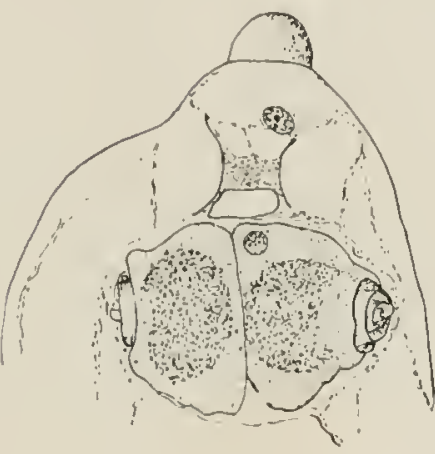

241

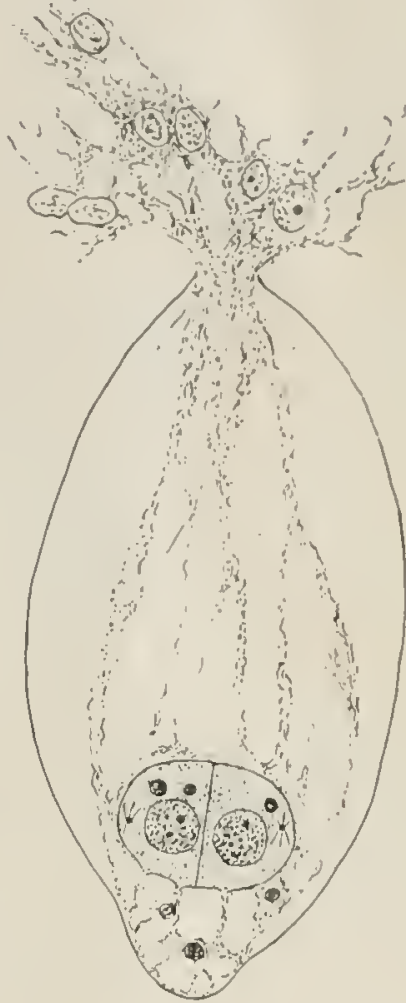

239

Figs. 235-240.-Ginkgo biloba: the male gametophyte; fig. 235, pollen grain, showing evanescent prothallial cell and persistent prothallial cell; the mitosis in the antheridium initial will form the generative and tube cells; April 24: $\times 5,500$; fig. 2.30 , pollen at the shedding stage, with prothallial, generative, and tube cells; $\times 500$; fig. 237 , part of pollen tube July $10 ; \times 500$; fig. 238 , the nucleus of the generative cell has

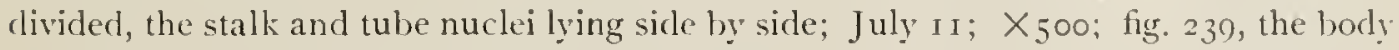
cell has divided; blepharoplasts are faintly visible; $X_{120}$; fig. 240 , the two sperns produced by the body cell; September II; X226. - After Hirasé (I6).

sac, and often directly toward the beak. Into these young tubes the tube nuclei pass, and remain there so long as the tube system is developing.

About the beginning of July, the tubes have penetrated the nucellar tissue deeply and have branched freely, the tube nucleus remaining where a tube begins to branch. This extensive system of branching 
tubes, as in cycads, seems to function only as a haustorial system. At this stage the generative cell has the appearance of being pushed away from contact with the persistent regetative cell, on account of the enlargement and development of vacuoles in the latter. The generative cell increases very much in size, its nucleus keeping pace with it; and these relative positions are maintained until just before fertilization, which occurs about ten weeks later. About the middle of July the generative nucleus divides to form the stalk and body nuclei, lying side by side and with no separating wall (figs. 237, 238).

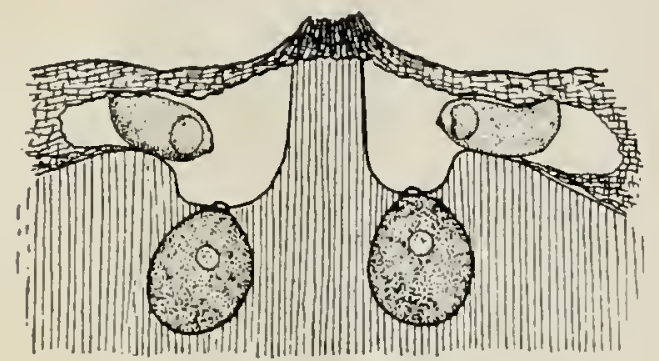

FIG. 24I.-Ginkgo biloba: upper part of femalc gametophyte, showing two archegonia, the beaklike process of the endosperm, and the swollen tips of two pollen tubes; September $0 ; \times 24$.-After HiRASÉ (I 6 ).

Hirasé says that the non-functioning stalk nucleus is gradually thrust out of the general cytoplasm by the growth of the functioning body nucleus and the organization of the body cell, and functions no further (see fig. I63). At the end of July, the much enlarged body cell is rich in contents, and its nucleus is very large. At this stage the two blepharoplasts appear and assúme their polar positions, the stage persisting for three weeks, that is, until the third week before fertilization.

At the beginning of August the tube nucleus begins to pass back to the pollen grain end of the tube, which it reaches in about two weeks, consorting with the body cell, and later with the sperms, until fertilization. During the return of the tube nucleus, the endosperm beak has developed between the two archegonia as described above, pushing up the megaspore membrane farther, and permitting the grain end of the pollen tube to penetrate to the region of the archegonial chamber, where, freed from pressure, it becomes very turgid (fig. 24I).

During the third week before fertilization (about the last of August) the body cell begins to divide, the division occurring in the axial plane of the spore, resulting in two sperm mother cells lying side by side and each containing a blepharoplast (fig. 239). In each mother cell the 
blepharoplast becomes bandlike, is attached to the nucleus, and forms the spiral, cilia-bearing band of two and a half coils in connection with the sperms. The details of the structure and behavior of the blepharoplast among Cycadales have been presented (p. I +2), and presumably they are approximately the same for the blepharoplast of Ginkgo. 'The mature sperms are oroid, varying between So and $110 \mu$ in length, and between 50 and $85 \mu$ in breadth, and are so directed that the two adjacent sperms lie base to base (fig. 2.40).

It is a little over four months from pollination to the formation of sperms, the time of which varies with the latitude. For example, in Tokyo sperms appear between September 7 and 22, the greatest number occurring September 17 and 18 ; in Sendai, 200 miles farther north, the optimum date is September 27; in Washington the range of time is from August 25 to September ro, with September I to 3 as the optimum period (29).

In $\mathrm{I}_{9} \mathrm{~S}$ several Japanese students investigated a large number of sperms, correcting a few of the earlier statements and extending the observations. Hirasé had described a peculiar "tail," which FujII (2I) and Miyake (23) showed to be an appearance that had no connection with the sperm. Hirasé had left the impression also that the mother cells were transformed directly into sperms; but FuJII and Mryake demonstrated that the sperms are formed within a sperm mother cell, and they observed the cilia vibrating and the sperm shifting its position within the mother cell. The sperms finally break through the wall of the mother cell and escape into the pollen tube, where they were observed "swimming from one end of the tube to the other like a pair of large infusoria." They were observed in active motion for two or three hours, the body readily changing its form under pressure. FuJII (26) observed also a sperm with two spiral bands, its sister sperm being normal; it is probable that the blepharoplast had divided before band-formation.

\section{FERTILIZATION}

The swollen tip (grain end) of the pollen tube, capped by the old wall of the pollen grain, contains two sperms, the tube nucleus, the persistent regetative cell, and whatever may remain of the stalk nucleus. At the time of fertilization, the turgid tip of the tube becomes 
curved, its apex being directed toward the archegonial chamber, and discharges its contents. The sperms have been observed swimming in the archegonial chamber, from which one of them passes to the egg and enters its cytoplasm. IkENo (30) states that the male nucleus slips from its cytoplasmic and cilia-bearing sheath upon entering the cytoplasm of the egg. At the time of fusion the two nuclei are very unequal, the female nucleus being about ten times larger than the male. The mode of fusion is said to be like that described by IkENo for Cycas revoluta; that is, the sperm nucleus gradually penetrates the egg nucleus before losing its own membrane. It has been determined that fertilization occurs while the ovules are still on the tree $(30)$.

\section{The embryo}

The embryo of Ginkgo has long been regarded as peculiar among gymnosperms, chiefly on account of the absence of a conspicuously elongated suspensor, such as occurs in Cycadales and Coniferales. The only suggested resemblance is the embryo of Bennettitales, in which no suspensor has been seen. ARnold (34) recognized a differentiation of the elongating proembryo into three regions: a micropylar haustorial region, a middle suspensor region, and an apical region which gives rise to the embryo proper. This interpretation conforms in general to the three regions found in other gymnosperm embryos.

Another peculiarity of the embryo of Ginkgo that has been remarked is the complete filling of the egg with proembryonic tissue, but this peculiarity has held only in comparison with the Coniferales, Dioon and perhaps other cycads having the same character.

In I904 Lyon (39) published an account of the embryogeny of Ginkgo, and the following description is largely based upon his results as confirmed by our own preparations. The first spindle is very broad and multipolar (30), and a series of simultaneous, free nuclear divisions follows, until the nuclei approximate 256 in number (fig. 245). The nuclei do not become parietally placed by the vacuolation of the cytoplasm, but are distributed more or less uniformly throughout the enlarging egg. At this stage wall-formation occurs, and the egg is filled by a proembryo consisting of undifferentiated tissue (fig. 246). 
'The cells of the micropylar two-thirds of the proembryo divide very' little or not at all, but the cells of the antipodal one-third form a

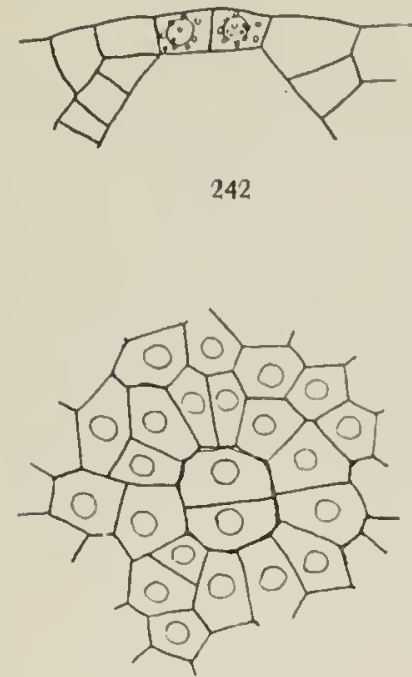

243

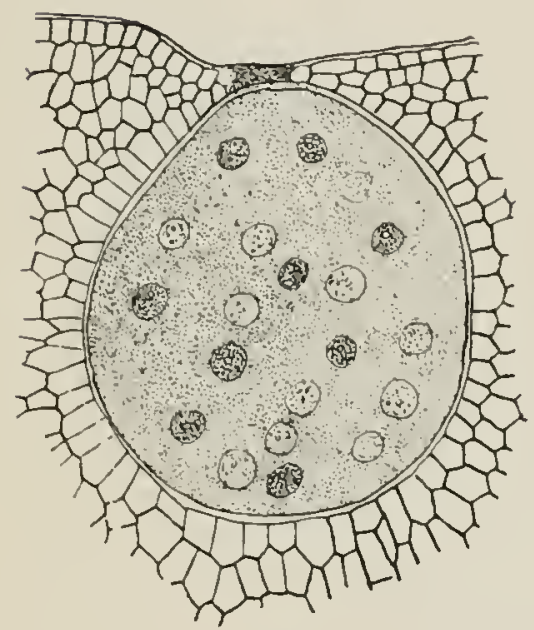

245

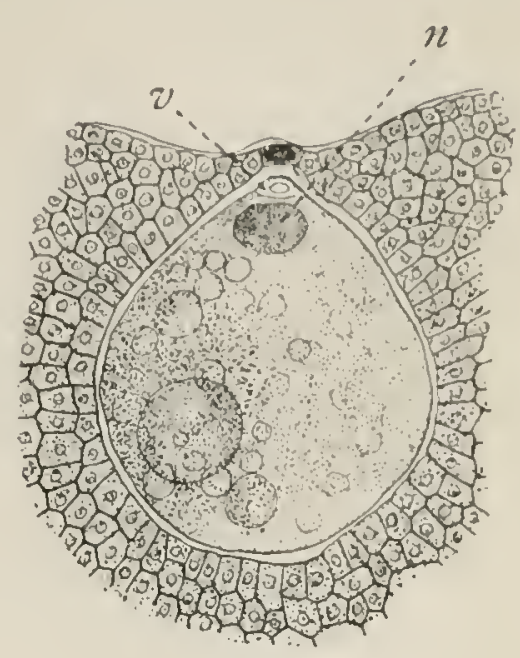

244

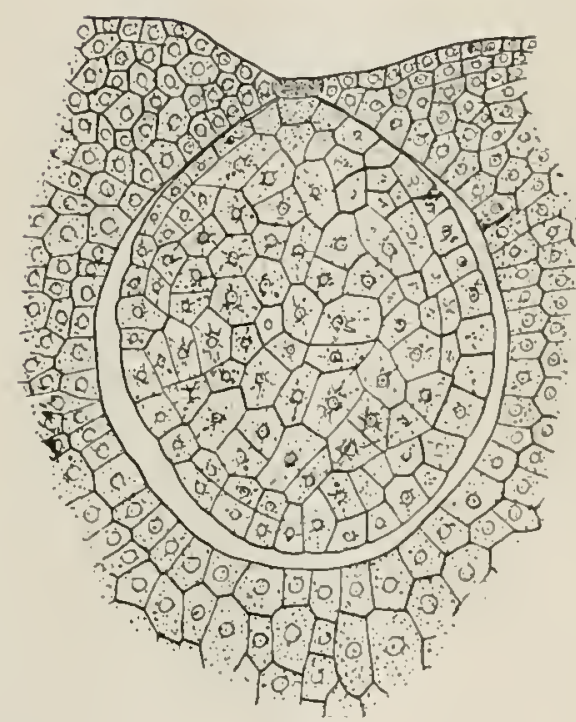

246

Figs. $2+2-246$. - Ginkgo biloba: archegonium and embryogeny; fig. 242 , longitudinal section of the neck of the archegonium, showing the two cells; $X_{160}$; fig. 243 , transverse section of the same; $X_{160}$; fig. 2.44, archegonium shortly before fertilization, showing ventral canal cell $(2)$ and egg nucleus $(n) ; \times 66 ;$ fig. 245 , free nuclear stage of the proembryo; $\times 66$; fig. $24^{6}$, later stage, showing that the tissue of the procmbryo has resulted from a segmentation of the entire eyg; $\times 66$. - Ifter Strasburger (4).

small-celled meristem which grows vigorously (fig. 247). This growing region invades the endosperm as a broad, blunt cylinder. the micropylar end of the proembryo being forced back through the 
neck of the archegonium, many of its cells being crushed. In the axis of the advancing cylinder two growing points are soon established, that of the stem at the end of the axis, and that of the root very close

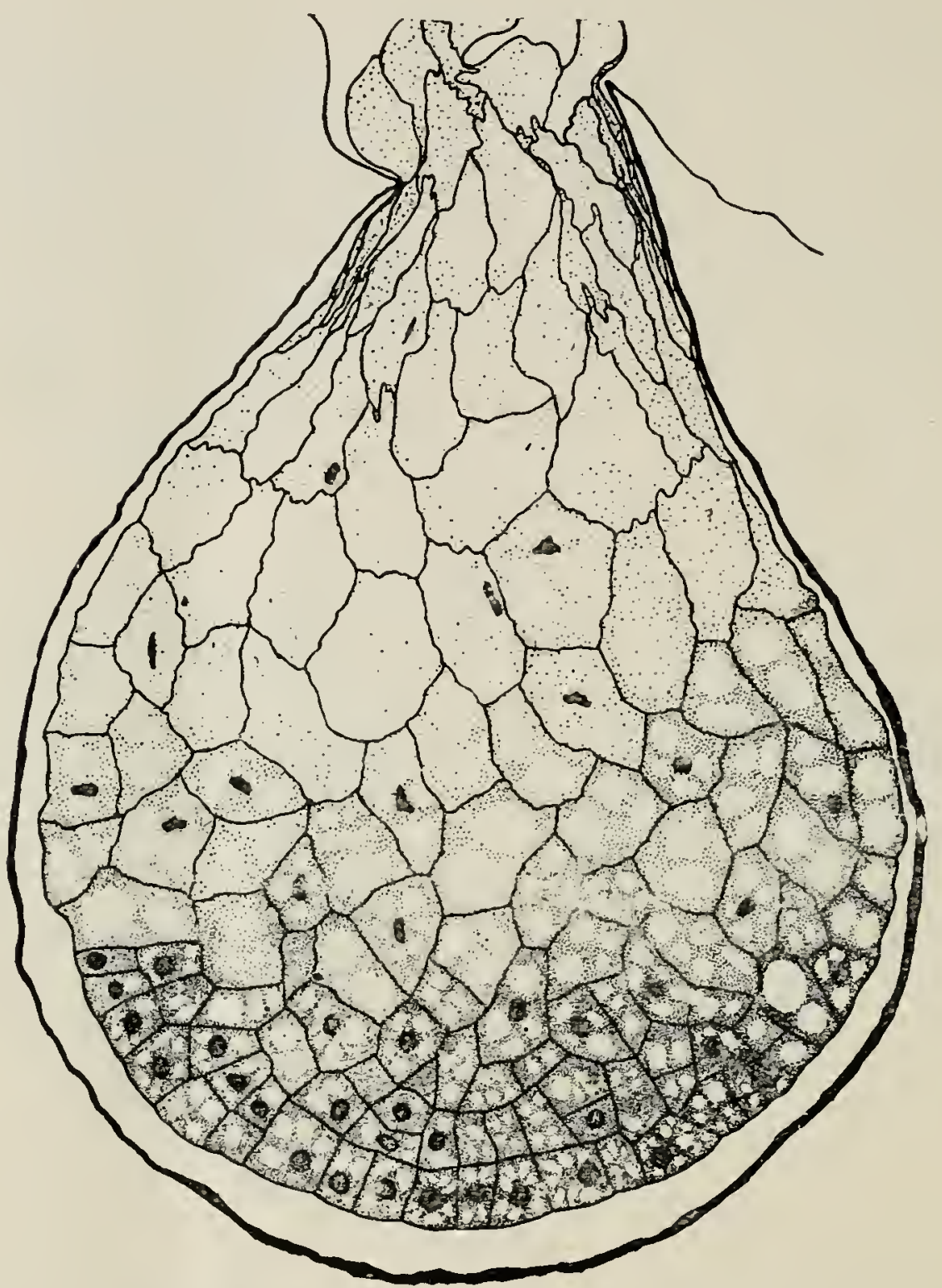

FIG. 247.-Ginkgo biloba: late stage of proembryo; the stem and root will be organized from the small-celled tissue at the apex; X 160 .-After Lyox (39).

to it, the two being separated by very few cells. Later the primordia of the two cotyledons appear in the peripheral region of the cylinder, beginning as crescentic mounds of tissue. From an examination of mature seeds, Lyon (39) claims that the proembryo sometimes gives rise to two embryos. 
This embryogeny is remarkable for the extensive development and massive growth of the proembryonic tissue, but in kind it resembles
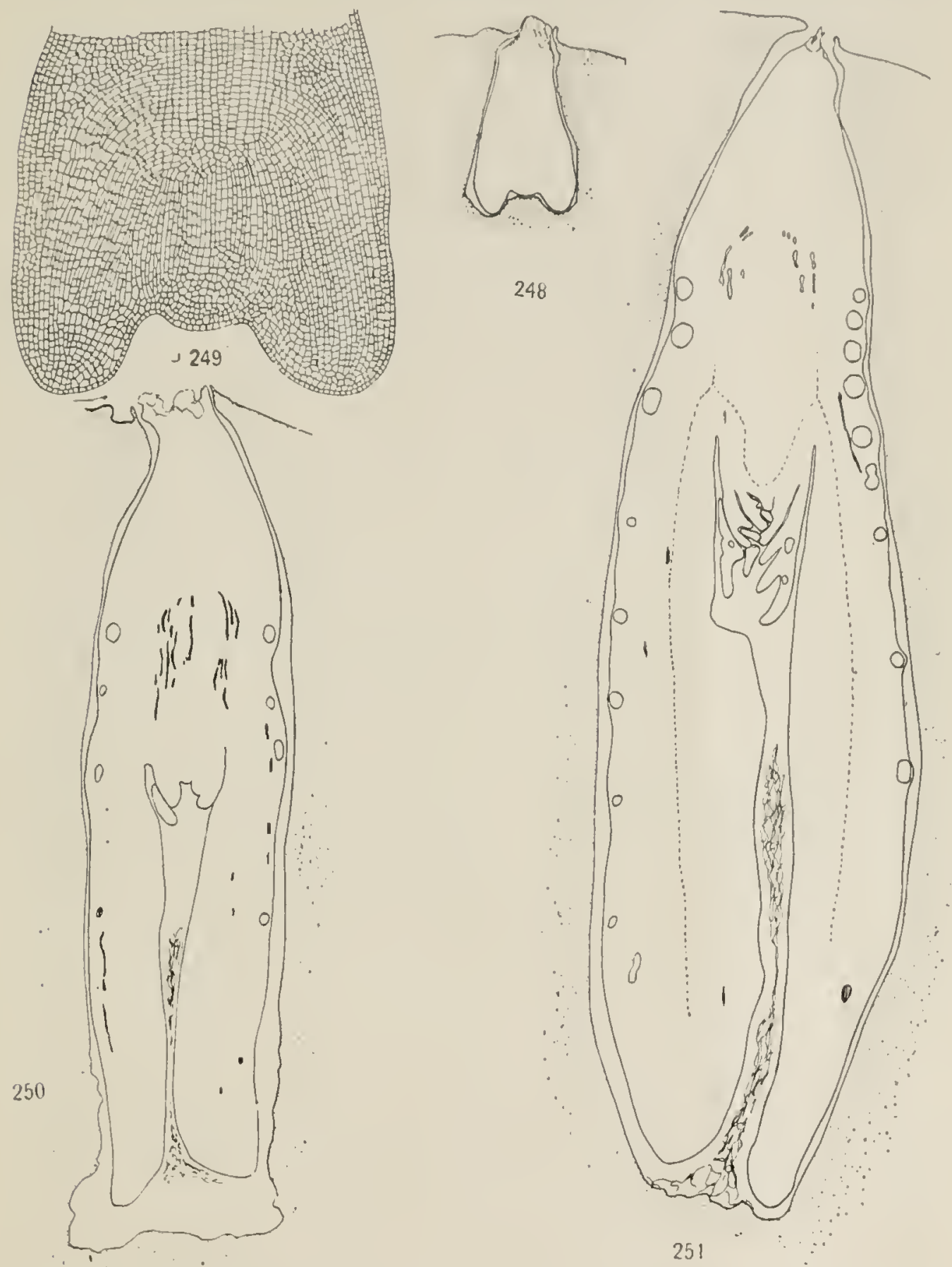

FIgs. $248-251$. - Ginkgo biloba: later stages in the development of the embryo; fig. 248 shows the upper part of the endosperm and the outline of the embryo; $X_{10}$; tig. 249, drawn on a larger scale from the same embryo, shows the differentiation into root and stem; $X_{40}$; fig. $25 \mathrm{c}$, embryo at about the stage shown in lig. $233 ; X_{15}$; fig. 251 , nearly mature embryo; $\times 10$. 
that of other gymnosperms, and particularly that of Dioon edule, in which there is a temporary segmentation of the entire egg. There is an extensive region of abandoned proembryonic tissue, abandoned in the sense that it does not enter into the structure of the embryo; a suspensor development, which in this case is very massive; and at the tip of the suspensor region the organization of an embryo (figs. $248,249)$.

Usually there are two cotyledons, but three are by no means uncommon. In all the Japanese material investigated by Lyox two cotyledons were present except in two cases; while I 5 per cent of the material from another source showed three cotyledons; and we have noted that material from northern Ohio sometimes shows three cotyledons. The cotyledons are normally equal and entire, springing apart when liberated from the seed. The former accounts of unequal and lobed cotyledons, united at the tip, seem to have been drawn from unusual material. The cotyledons are hypogean, as in the cycads, but they produce stomata, chiefly on the adaxial surface. From this Miss Wigglesworth (38) concludes that the cotyledons are true foliage leaves that have become hypogean.

Polyembryony occurs occasionally, LyoN often finding two developing embryos; but one of them usually became centrally placed and the other became abortive; in only one case were two mature embryos seen; in one seed three developing embryos were found. Cook (35) examined 200 seeds (from trees cultivated in Washington), and found four of them containing twin embryos about one-third as long as normal embryos; twenty-four of the seeds contained no embryos.

In germination the plumule is thrust out of the testa by the petiolelike elongation and arching of the bases of the cotyledons, the portions of the cotyledons that remain within the seed enlarging and functioning as haustorial organs, persisting through the first season. The first two or three leaves are small and scalelike, without any development of the characteristic blades (fig. 2 I5). The stem soon stops its rapid elongation for the season and puts forth at the apex a rather close crown of leaves, a large terminal bud being the only prominent one on the plant during the first winter. 


\section{History and distribution}

The leaves of Ginkgo are so characteristic that they are an unusually trustworthy evidence of the existence of the group during previous periods. Such leaves are found in abundance down to the coalmeasures, and some of them at least must have belonged to Ginkgoales, though some of them may have belonged to other groups. In fact, SEWARD (28) is inclined to think that all of the so-called Ginkgoales of the Paleozoic are Cordaitales. The genus Whitllesey from the Lower Carboniferous, distinguished by its short petioles, seems to be connected with Ginkgo itself by Ginkgodium, a recently described genus from the Lower Oolite of Japan (52).

The most important fossil leaf genus referred to Ginkgoales is the mesozoic Baiera, which differs from the leaves of Ginkgo in the shortness of the petiole and the repeatedly and deeply dichotomous blades (lig. 2I4), resulting in narrow, ribbon-like, greatly elongated lobes (I4). Such characters are not constant, for even in the existing Ginkgo the blade is quite variable (p. I89). Of great interest are the paleozoic leaves referred to Ginkgo and Baiera, which occur especially in the Permian. In reference to these, the general conclusion seems to be that they cannot be disentangled from the foliage of certain species of Cordaitales and of Cycadofilicales, and perhaps of Filicales. In any event, the evidence is conrincing that Ginkgoales were abundant and somewhat diversified during the Mesozoic, their greatest extension occurring during the Jurassic; and it is altogether probable that they existed near the close of the Paleozoic, associated with the Cordaitales and Cycadofilicales. The testimony of the mesozoic leares is confirmed by the discorery of staminate strobili, orulate strobili, and seeds. In a staminate strobilus (Antholithus Zeilleri) recently described by NATHORST (49) and associated with Baiera, the microsporophylls are very different in character from those of Ginkgo (p. I93), but this need not exclude the strobilus from Ginkgoales. "On the whole, the sum of fossil eridence is of sufficient weight to prove the great antiquity of the gymnospermous family now represented by the maidenhair tree" $(27)$, a group distinctly foreshadowed in paleozoic regetation.

Our chief knowledge of the diversity and wide distribution of Ginkgoales during the Mesozoic has come from the investigations of 
Heer $(7,9)$. Jurassic remains of the group have been found in every country, from the arctic regions to the south temperate regions, being abundant in England, throughout Europe, Siberia, China, Japan, North America, and Australia (37). The prominent genera were Ginkgo and Baiera, the former becoming more abundant in the more recent periods and in the more northern latitudes; the latter including the majority of the older representatives of the group.

\section{Relationship to other gymnosperms}

From the previous account it is evident that the question as to the origin of Ginkgoales is a choice between two alternatives: either they were derived from the Cordaitales, or the two groups became differentiated from a common stock. The historical evidence is all in favor of the former view, and the testimony of the comparative structures of the two groups seems equally convincing. The mesozoic Ginkgoales seem to hold the same relation to the paleozoic Cordaitales that the mesozoic Bennettitales hold to the paleozoic Cycadofilicales. In fact, the connections between the former pair seem closer and more definite than those between the latter pair. Just as the whole cycadophyte phylum retained characters of seed structure and swimming sperms that belonged to the ancient Cycadofilicales, so the Ginkgoales have retained the primitive characters of the Cordaitales. Of course one may imagine a primitive plexus of fernlike seed plants, related in some way to the Botryopterideae, which differentiated at various times into Cycadofilicales, Cordaitales, Ginkgoales, and perhaps other gymnosperm phyla (47), but however true this may be of the contemporaneous Cycadofilicales and Cordaitales, the historical as well as the morphological relation of Ginkgoales to Cordaitales indicates a more immediate connection between these two groups. ScotT (52) expresses the opinion that Ginkgo is "the one surviving member of an ancient stock, derived from the same cycle of affinity as the paleozoic Cordaiteae, once the dominant type of gymnosperms."

Among living gymnosperms, Ginkgo is to be compared with cycads and conifers. In the structure of the ovule and the seed, and in the details of fertilization, the resemblance is to the cycars; while in habit, stem structure, and vascular anatomy, the resemblance is to conifers. There has recently been a tendency to discover connections 
between Ginkgo and the Taxaceace $(4,47)$, in which family (iinkgo was placed by the earlier taxonomists as an aberrant member; a connection that will be discussed under Coniferales. The characters in common with the cycads are primitive, shared with Cycadofilicales and Cordaitales; while the characters in common with the conifers are distinctly advanced. At the same time, the foliage and the structure of the strobili are peculiar to Ginkgo. This combination of peculiar characters with others belonging to Cycadales and Coniferales justifies the separation of Ginkgoales as a coordinate group; and the nature of the characters justifies the conclusion that Ginkgoales represent a phylum that has retained certain primitive features in common with the cycadophytes, has advanced more in the direction of the Coniferales, and has developed certain peculiarities of its own.

\section{LITERATURE CITED}

I. Hofmeister, $\mathbf{W}$., On the germination, development, and fructification of the higher Cryptogamia. English translation. London. I 863.

2. Van Tifghem, Ph., Anatomie comparée de la fleur femelle et du fruit des Cycadées, des Conifères, et des Gnetacées. Ann. Sci. Nat. Bot. V. I0:269304. pls. 13-16. I 869 .

3. ——, Recherches sur le symétrie de structure des plantes vasculaires.

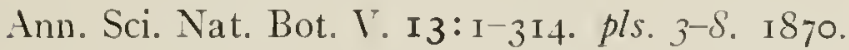

4. Strasburger, E., Die Coniferen und die Gnetaceen. i 872.

5. Eichler, A. IT. Sind die Coniferen gymnosperm oder nicht? Flora 56: $24 \mathrm{I}-247,260-272$. I 873 .

6. Strasburger, E., Die Angiospermen und die Gymmospermen. i $\$ 79$.

7. Heer, O., Zur Geschichte der Ginkgo-artigen Bäume. ExGlek's Bot. Jahrb. I : I-I3. I 880 .

8. Fankhauser, J., Entwickelung des Stengels und Blattes ron Ginkgo. Bern. I 882.

9. Heer, O., Flora fossilis arctica. I $868-188_{3}$.

9a. Renault, Cours de botanique fossile. Paris. I880-I884.

ro. Eichler, A. W., Coniferae in Exgler und Prantl's Natürlichen Pflanzenfamilien $2^{\mathrm{r}}: 108$. 1889 .

II. ČELAkorskî, L., Die Gymnospermen; eine morphologisch-phylogenetische Studie. Abhandl. Königl. Böhm. Gessell. Wiss. VII. 4: I-I 48. ı 890.

I2. DANgeARD, P. A., La mode d'union de la tige et de la racine chez les Gymnosperms. Compt. Rend. Acad. Sci. Paris I I0:253, 254. I 890.

13. PAx, F., Allgemeine Morphologie der Pflanzen mit besonderer Berücksichtigung der Blüthenmorphologie. 1890.

I4. Solms-Laubach, H., Fossil botany. English translation. i891. 
i5. Strasburger, E., Ueber das Verhalten des Pollens und die Befruchtungsvorgänge bei den Gymnospermen. I892.

i6. Hirasé, S., Études sur la fécondation et l'embryogénie du Ginkgo biloba. Jour. Coll. Sci. Imp. Univ. Tokyo 8:307-322. pls. 3I, 32. I895.

I 7. Fujı, K., On the different views hitherto proposed regarding the morphology of the flowers of Ginkgo biloba. Bot. Mag. Tokyo 10:15-25, 104-110. pl. I. 1896.

i8. Hirasé, S., (Announcement of the spermatozoid of Ginkgo). Bot. Mag. Tokyo Io: I 7 I, I 72. May I896. (Japanese)

I9. ——, (Preliminary report on the spermatozoid of Ginkgo). Bot. Mag. Tokyo I0:325-328. Oct. I896. (Japanese).

20. Worsdell, W. C., On transfusion tissue; its origin and function in the leaves of gymnospermous plants. Trans. Linn. Soc. Bot. II. 5:30I-3I9. pls. 23-26. I 897 .

2 I. FuJI, K., (Has the spermatozoid of Ginkgo a tail or not ?) Bot. Mag. Tokyo I $2: 287$-290. I 898 . (Japanese)

22. Hirasé, S., Études sur la fécondation et l'embryogénie du Ginkgo biloba. Jour. Coll. Sci. Imp. Univ. Tokyo I $2: 103^{-149 . ~ p l s . ~ 7-9 . ~} 1898$.

23. Mryake, K., (On the spermatozoid of Ginkgo). Bot. Mag. Tokyo I2:3.3-39. I898. (Japanese)

24. FUJII, K., (On the morphology of the spermatozoid of Ginkgo). Bot. Mag. 'Tokyo I3:260-266. pl. 7. I899. (Japanese)

25. Čelakovský, L., Die Vermehrung der Sporangien von Ginkgo biloba L. Oesterreich. Bot. Zeitschr. 50:229-237, 276-283, 337-34I. 1900.

26. Fujl, K., (Account of a sperm with two spiral bands). Bot. Mag. Tokyo I4: I6, I 7. Jan. I900. (Japanese)

27. Scott, D. H., Studies in fossil botany. I900.

28. Seward, A. C., and Gowan, Miss J., The maidenhair tree (Ginkgo biloba L.). Annals of Botany 14: 109-154. pls. 8-10. 1900.

29. Besser, E. A., Notes on the spermatozoids of Ginkgo. Science 1 3:255. I 90 I.

30. Ineno, S., Contribution à l'étude de la fécondation chez le Ginkgo biloba. Ann. Sci. Nat. Bot. VIII. I3:305-318. pls. 2, 3. I901.

31. Соok, Mel T., Polyembryony in Ginkgo. Bot. Gazette 34:64, 65. fig. I. I9O2.

32. Goeber, K., Morphologische und biologische Bemerkungen. I3. Ueber die Pollenentleerung bei einigen Gymnospermen. Flora 91:237-263. figs. 19. 1902.

33. МıуакE, K., The spermatozoid of Ginkgo. Jour. Applied Micr. 5: I773I 780 . figs. IO. I902.

34. Arnold, W., Beiträge zur Morphologie der Gymnospermen. VI. Ueber den Bau der Zellkerne im Embryo von Ginkgo biloba. VII. Die Embryobildung bei Ginkgo biloba. Ann. Inst. Agronomique et Forestière à NowoAlexandria $16: \mathrm{I}^{-22}$. I903. 
35. Соок, Mes T., Polyembryony in Ginkgo. Bot. Gazette 36: 142. I903.

36. JiFfrex, E. C., Comparative anatomy of gymnosperms in Coulter and Chamberiain's Morphology of angiosperms. New York. igoz.

37. Seward, A. C., Floras of the past; their composition and distribution. Rept. British Assoc. Adv. Sci. Section K I903: pp. 25.

38. IVigglesworti, Grace, 'The cotyledons of Ginkgo biloba and Cycas revoluta. Annals of Botany 17:789-791. I903.

39. Lyos, Harold L., The embryogeny of Ginkgo. Minn. Bot. Studies 3:275290. pls. 29-43. I904.

40. Coulter, Join M., and Land, W. J. G., Gametophytes and embryo of Torreya ta.ifolia. Bot. Gazette 39: I6 I-I 78. pls. A, I-3. 1905.

4I. Thouson, R. B., The megaspore membrane of the gymnosperms. Univ. 'Toronto Studies, Biol. Series no. 4. pp. 64. pls. 5. 1905.

42. Thomas, Ether N., "The origin of gymnosperms"; a discussion at the Linnean Society. New Phytologist 5:68-76, I4 I-I 48. I906.

43. Thomson, R. B., "The origin of gymnosperms"; a discussion at the Linnean Society. New Phytologist 5:68-76, I4I-I48. I906.

44 WEISs, F. E., "The origin of gymnosperms"; a discussion at the Linnean Society. New Phytologist 5:68-76, I 4 I-I 48. I906.

45. Wettstein, R. von, Der Ursprung des Pollenschlauches. Naturw. Rundschau 2 I : I 2. 1906.

46. Carothers, Ida Eleanor, The development of the orule and the female gametophyte in Ginkgo biloba. Bot. Gazette 43: I16-I30. pls. 5, 6. I907.

47. Sprecher, Andreas, Le Ginkgo biloba L. pp. 208. figs. 225. Genève. I907.

48. 'Thomas, Ethel N., A theory of the double leaf trace founded on seedling structure. New Phytologist 6:77-9I. figs. 4. I907.

49. Nathorst, A. G., Palaeobotanische Mitteilungen. VI. Antholithus Zeilleri, n. sp., mit noch erhaltenen Pollenkörnern aus den rhätischen Ablagerungen Schonens. Handl. Kgl. Svensk. Vetensk.-Akad. 43:20-24. pls. 2 and 4. I908.

50. Shaw, F. J. F., A contribution to the anatomy of Ginkgo biloba. New Phytologist $7: 85-92$. figs. I6-I8. I908.

5 I. Hill, T. G., and DE Fraine, E., On the seedling structure of gymnosperms. III. Annals of Botany 23:433-458. pl. 3o. I909.

52. Scott, D. H., Studies in fossil botany. Second edition. Vol. II. London. I909.

53. Starr, Avna M., The microsporophylls of Ginkgo. Bot. Gazette 49:5I-55. pl. 7. I9IO.

54. Coulter, J. M., Barnes, C. R., and Cowles, H. C., A textbook of botany. New York. IgIo. 


\section{CHAPTER VI \\ CONIFERALES (PINACEAE)}

The Coniferales are the representative gymnosperms of the present flora. They comprise 40 recognized genera, and approximately 350 species, constituting more than three-fourths of the present gymnosperm flora. They are characteristic of the temperate regions of both northern and southern hemispheres, presenting a sharp contrast to the Cycadales in their general geographical distribution.

Before discussing the morphology of this great group, it will be necessary to survey the material as it has been organized by taxonomists. Two families are recognized, the Pinaceae and the Taxaceae. Among the Pinaceae distinct strobili are formed, whose orerlapping scales protect the ovules, and whose seeds ripen dry; while among the Taxaceae distinct orulate strobili (in the ordinary sense) often are not formed, at least the orules are frequently freely exposed, and in any event the seeds develop a partially fleshy testa or an aril. Such characters are superficial, but they are accompanied by important morphological differences, so important in fact that the two families must be presented separately.

The Pinaceae include 29 of the genera and approximately 245 of the species, so that they are the dominant conifers. Four series of forms are recognized, two of which are doubtless artificial assemblages, but they serve at present to catalogue the material, and may be spoken of as tribes.

The Abictineae are spiral forms, and have almost completely distinct bract and ovuliferous scale, winged pollen grains, and needle leaves. They include 9 genera and approximately I 29 species, as follows: Pinus (75 species, throughout the northern hemisphere. mostly in extra-tropical regions); Cedrus ( 3 species, in Asia and northern Africa); Larix (8 species, in North America, Europe, and Asia); Pseudolarix (I species, in eastern China); Picea (I species, in the extra-tropical regions of the northern hemisphere); Tsuga (6 species, in North America, Mexico, and Asia); Pseudotsuga (2 species, sometimes merged with Tsuga, in North America); 
Ketelecria (2 species, in China); Abies (20 species, in North Imerica, Europe, and Asia). It will be seen that this tribe forms the prominent coniferous forest display of the northern hemisphere, and is entirely unrepresented in the southern hemisphere.

The Tavodineae are spiral forms, with almost completely coalescent bract and ovuliferous scale, and with wingless pollen grains. They include 8 genera and approximately 13 species, as follows: Sciadopitys (1 species, in Japan); Sequoia (2 species, in California); Cunninghamia ( s species, in China and Japan); Taiwania (105, I2 I) (1 species, in the island of Formosi); Arthrotaxis (3 species, in Tasmania and Victoria); Cryptomeria (I species, in northern China and Japan); Taxodium (2 species, in North America and Mexico); Glyptostrobus (2 species, in China). This assemblige of restricted genera is evidently artificial, and is scattered through North Americacastern Asia, and the Australasian region.

The Cupressineac are distinguished from the other tribes of Pina, ceac in being cyclic, and the strobili may ripen Peshy (as in Junip(rus). They include 10 gencra and approximately 83 species, as follows: Actinostrobus (2 species, in Australasia); Callitris (1 5 species in Australasia); Widdringtonia (5 species, in equatorial and south Africa and Madagascar); Fitzroya (2 species, in southern Chili and Tasmania); Thujopsis (I species, in Japan); Libocedrus (8 species, in California, Chili, New Zealand, New Caledonia, New Guinea, China, and Jajan); Thuja (4 species, in North America, Japan. China, and central Asia); Cupressus (I 2 species, in North America, Mexico, southeastern Europe, and temperate Asia); Chamaecyparis (4 species, in North America and Japan); Juniperus (30 species, in the mountains and extra-tropical regions of the whole northern hemisphere). This assemblage also gives evidence of artificiality, and presents some cases of remarkable distribution.

The Araucarineae are spiral forms, and have completely coalescent bract and ovuliferous scale (so' much so as to suggest a doubt of the double nature of the structure), solitary ovules, and free pendulous pollen sacs. They include 2 genera and approximately 20 species, as follows: Agathis (Io species, sometimes reduced to 4 , in the Malay Archipelago, Pacific Islands, New Caledonia, and New Zealand); Araucaria (Io species, in South America, New Caledonia, Australia, 
and the Pacific islands). The group is a very natural one, practically restricted to the southern hemisphere, and very distinct from the other tribes.

It is evident that it is impossible to include so many diverse forms in one continuous account. The tribes will be considered together when the characters justify it; but in many cases they must be treated separately.

\section{The vegetative organs}

The most conspicuous feature of the body of most of the Pinaceae is the central shaft, giving rise to a series of wide-spreading branches (figs. 252-254). In size the Pinaceae range from small shrubs to the largest trees. The "big trees" of California (Sequoia gigantea) attain a height of 95 meters, with a diameter of Io meters; but in diameter the "big tree of Tule" (Taxodium mucronatum) in southern Mexico far surpasses even the largest sequoias, for it has reached the surprising diameter of $I 7$ meters (fig. 255). The branches are dimorphic, the two forms being characterized as long shoots and dwarf (or spur) shoots. In some forms both kinds of shoots bear foliage leaves; but in Pinus the long shoots bear only scale leaves, while the dwarf shoots bear the only foliage leaves. In Sciadopitys the condition of Pinus obtains, except that the dwarf shoot is apparently replaced by the peculiar double needle leaf.

In the seedlings a very different behavior of the shoots may be observed. These juvenile forms are usually very transient, but they may be "fixed" by culture, so that the plant assumes a permanent appearance very different from its ordinary adult form. GoEBEL (58) has given an interesting résumé of this subject. For example, in Pinus the long shoots of seedlings bear foliage leaves, which may disappear from the long shoots in the second year, as in $P$. silvestris, or may continue for many years. These needle-like primary leaves are of simpler anatomical structure than the subsequent foliage leaves, especially in the matter of provision for controlling transpiration. In the juvenile forms of Larix the leaves persist during the winter, and even in adult trees the juvenile characters may appear in first-year shoots from adventitious buds, as we have observed also in Thuja occidentalis (fig. 256). It is among the Cupressineae, howerer, that 


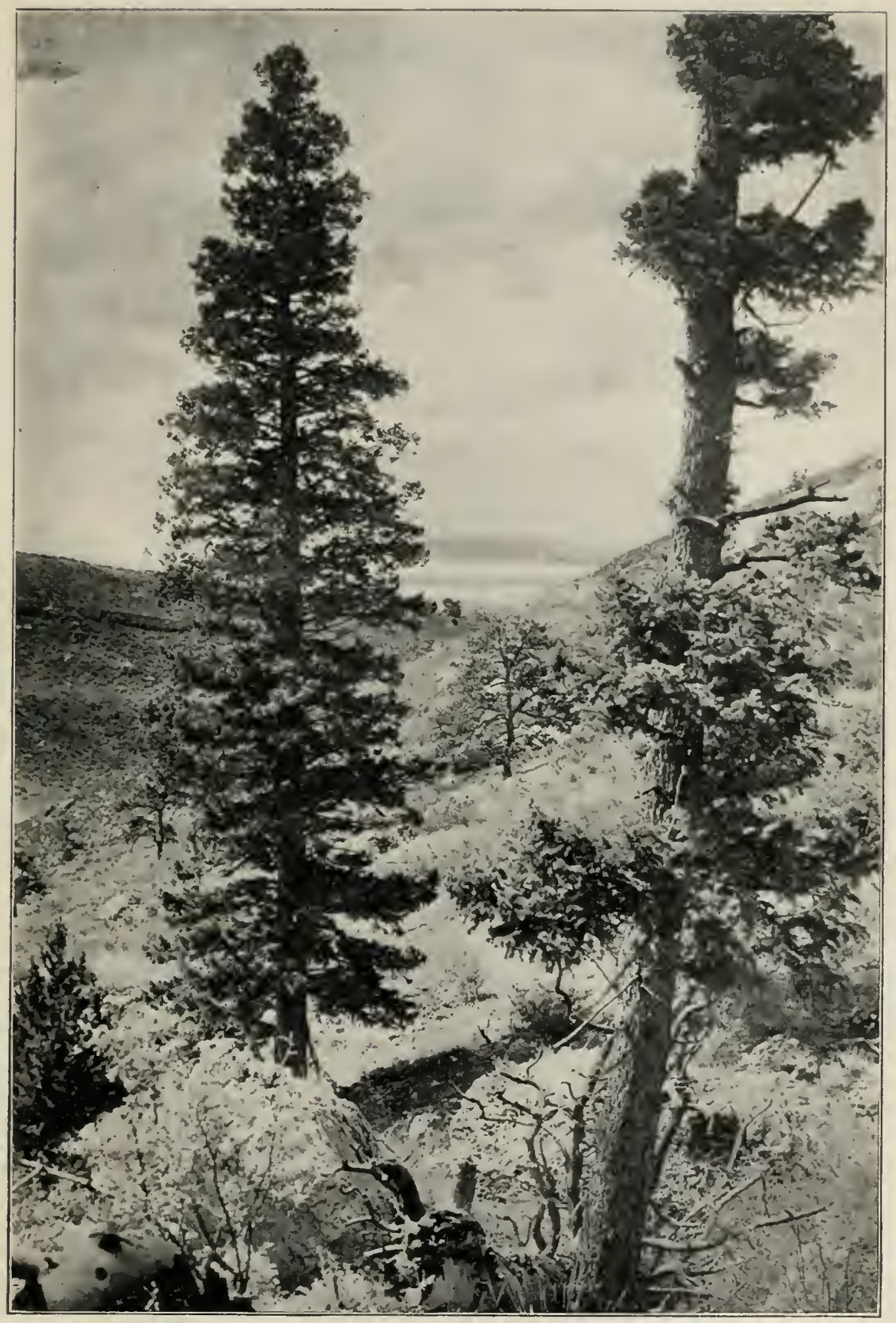

Fig. 252.-Pseudotsuga Douglasii: two specimens on the Laramie Mountains, Wyoming; the tree on the left is about $40 \mathrm{~m}$. high; between the two large trees and in the middle background is a specimen of Pinus ponderosa.-From photograph by L IND. 


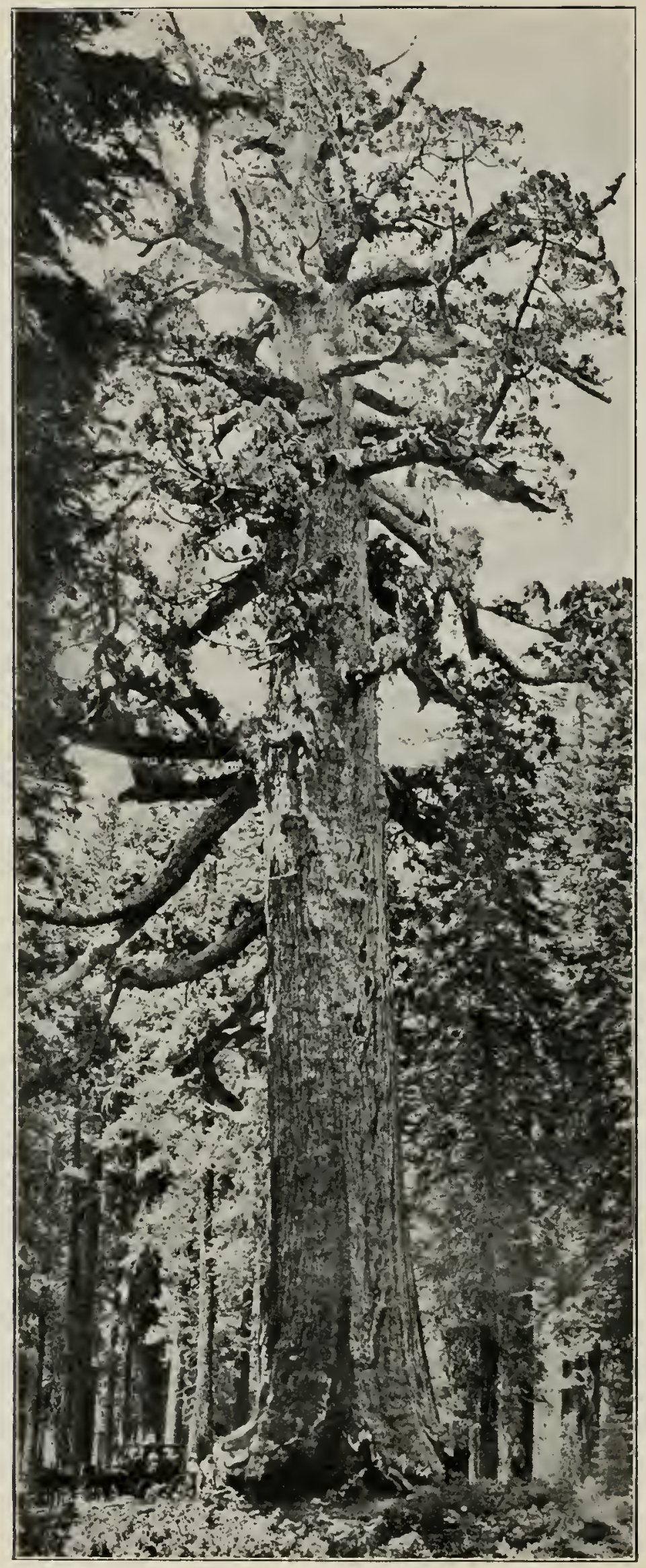

FIG. 253.- Seguoia gigantea: the trunk is $\mathrm{s}$ m. in diameter.-From photograph in possession of U.S. (reol. Survey: 
the greatest amount of work has been done in fixing juvenile forms. such relatively permanent forms being known in cultivation ats species of Retinospora. While some of the atdult forms of (upressineate, as Juniperus communis, retain the habit of spreading needles, others develop concrescent leaves upon their adult shoots, that is, leaves whose adaxial faces have become organically connected with the adjacent stem surface, so that they apjear as green scales. In such cases, the jurenile form, with its spreading needle leaves. presents a striking contrast with the adult form (fig. 256). In shoots from stumps or wounds, the juvenile form of leaf has been observed in Pinus, Thui', and Taxodium, a response quite in harmony with JEFFREY's interpretation of the appearance of resin ducts as a traumatic response. The juvenile forms of Sciadopitys, like those of Pinus, produce simple needle leaves upon long shoots, but later, scales appear instead of needles, and in their axils the peculiar double needle leaves are developed.

GoEbel suggests that the jurenile form probably repre-

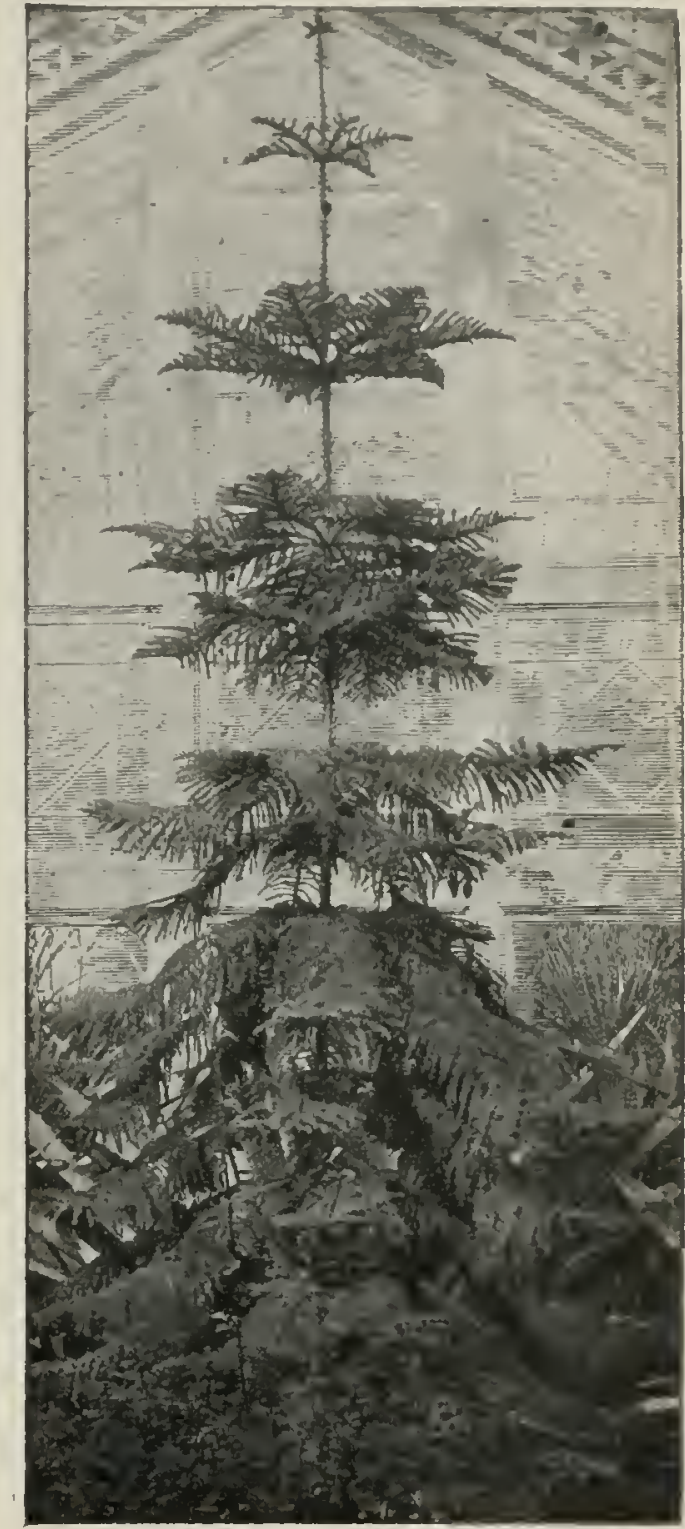

FIs. 254-1rulucaria cxcelsa: a specimen in the Washington I'ark (Chicago) conservatory. sents the more primitive form. It is certainly true that if the adult bodies of many of the forms. not mentioned above, be associated with these juvenile forms, a very consistent body is discovered for Pinaceae (and for Coniferales). It would follow that the replacement of foliage leaves 
by scales on the long shoots of Pinus and Sciadopitys, the peculiar double leaf of Sciadopitys, the deciduous habit of Larix, the concrescent leaves of many of the Cupressineae, are all derived characters, from forms with spreading and persistent needle leaves on all the shoots.

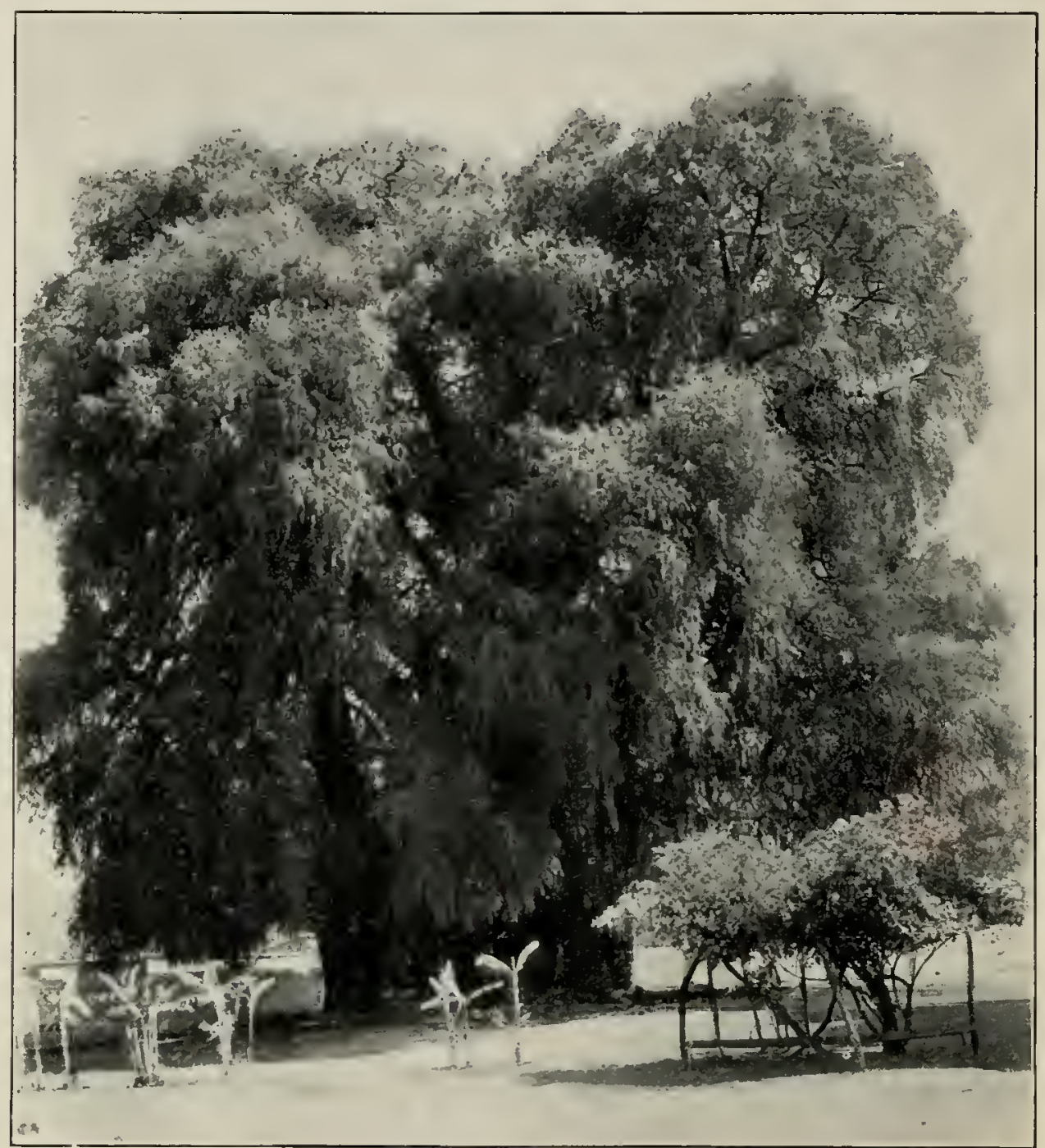

FIG. 255.-Taxolinm mucronatum: the "big tree of Tule"; at the height of $2 \mathrm{~m}$. the trunk is $17 \mathrm{~m}$. in diameter.

The dwarfing of certain forms is also remarkable, and is induced by culture in Japan to produce some extraordinary results. That extreme dwarfing may also be induced in nature has been shown by MaCMILLAN (94), who has recorded such cases growing in the crevices of the slate on the coast of Vancouver Island. The dwarfs observed 


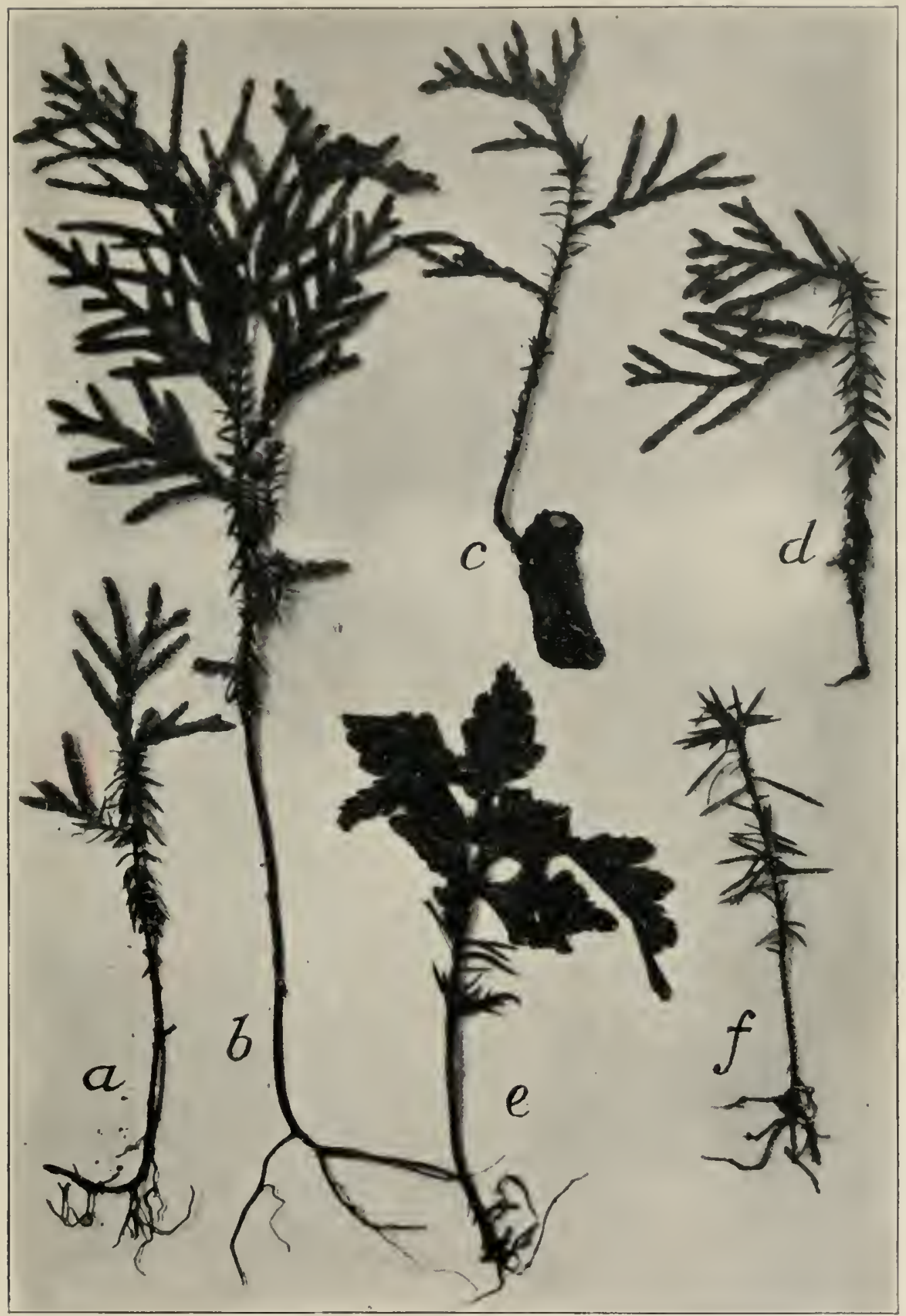

FIG. 256.--Juvenile leaves: $a-d$, Thuja occidentalis; $a, b$, seedlings; $c, d$, shoots from adventitious buds; $e$, f, seedlings of Phyllocladus rhomboidalis. 
there were Picea sitchensis, Tsuga heterophylla, and Thuia gigantea. In the case of the first species ("Sitka spruce"), the largest tree, 68 years old, was less than $60 \mathrm{~cm}$. high; another, 86 years old, was less than $30 \mathrm{~cm}$. high, with a trunk $1.8 \mathrm{~cm}$. in diameter; a third, 98 years old, was about $30 \mathrm{~cm}$. high, with a trunk $2 \mathrm{~cm}$. in diameter.

\section{VASCLLAR ANATOMY}

The anatomical structure of the stems of conifers, and especially of pines, has long been a farorite subject of study, and perhaps no vascular cylinder is more familiar (fig. 257). The mass of details thus accumulated need not be presented in this connection, for much of it has not been organized for morphological use. During recent years, however, great progress has been made in such an organization. and it should find its place in any presentation of the morphology of Coniferales.

A transwerse section of the stem shows a comparatively thin cortex. a thick vascular cylinder built up by a persistent primary cambium, and a small pith. These general features are the same as those of Ginkgo, but they are in contrast with the corresponding features of the other groups previously considered. The vascular cylinder is collateral endarch, and all traces of mesarch structure have disappeared from the Pinaceae, so far as investigated, except in the cotyledonary bundles of Juniperus and of certain species of Cupressus (I4I), and occasionally in the cotyledons of Tsuga canadensis, Pinus Pinea. and P. Gerardiana ( $\mathrm{I}_{54}$ ). In Juniperus the mesarch structure is not pronounced, and in the species of Cupressus referred to, it is indicated only by one or two centripetal xylem elements. It is to be expected that mesarch structure, at least in the cotyledons, will be discovered in more of the Pinaceae. If the "transfusion tissue," generally present in the leaves of gymnosperms as an auxiliary conducting system, is derived from centripetal xylem, as Worsdell has suggested (45), the mesarch condition in this stage may be regarded as characteristic of the foliar bundles in general, but it would be a later stage than true mesarch.

One of the most significant facts in connection with the vascular cylinder of Pinaceae is the occurrence of leaf gaps $(7 \mathrm{I})$. The presence of leaf gaps is a constant feature of the Filicales and Ophioglossales 
(Pteropsida) among pteridophytes ( $) .9$ ), and with them it is associated with large leaves. 'The contrast with Lycopsida (Lycoporliales, etc.), with small leaves and no leaf galys, is complete. Since the coni-

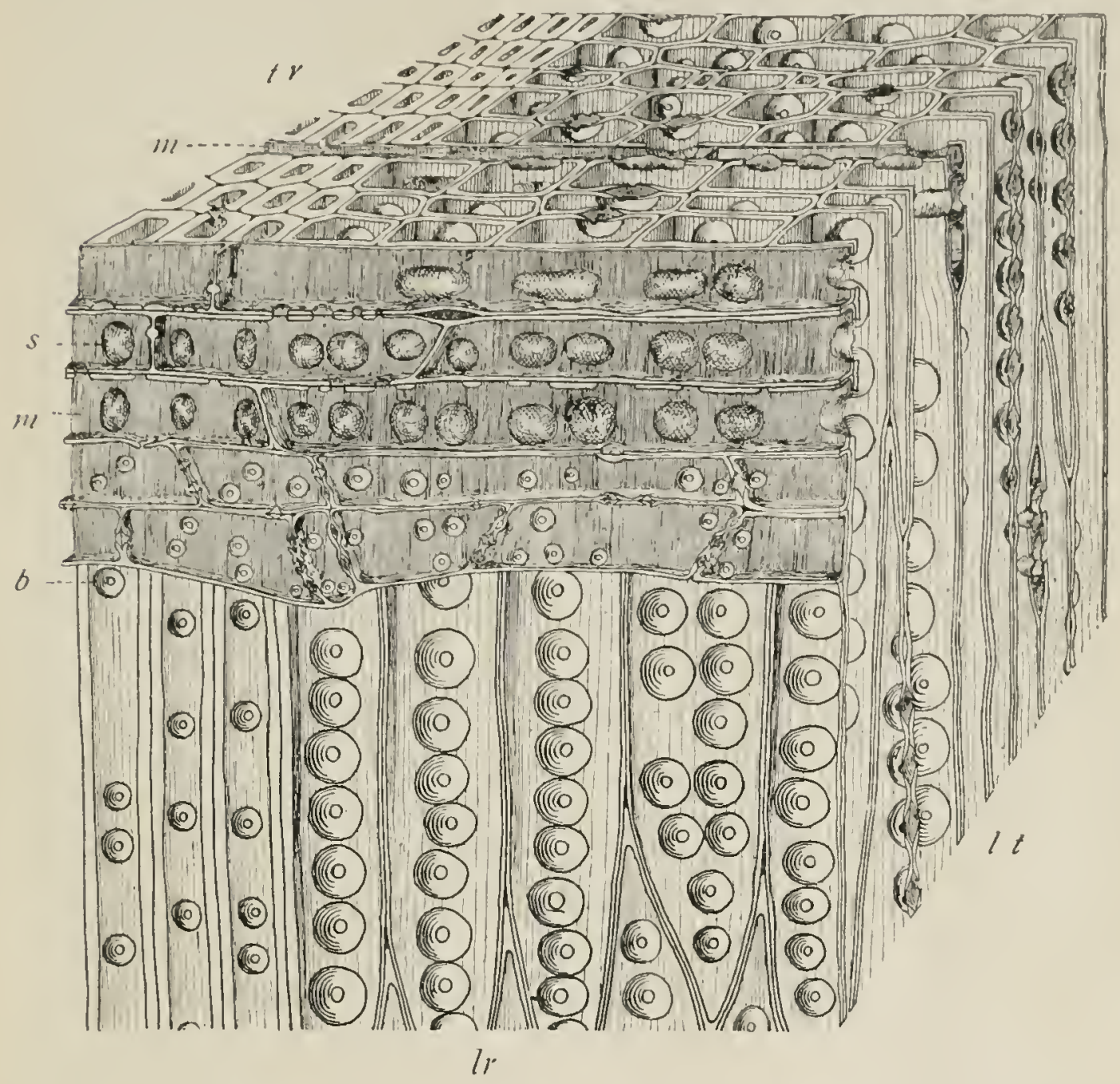

Fis. 257.-Pinus Laricio: a cube from the secondary wood, reconstructed from three camera drawings and showing various features of coniferous wood; in transverse section at the left a few rows of small thick-walled cells of the autumn wood are shown, and at the right the larger thinner-walled cells of the spring wood; ir, transierse section; $l r$, longitudinal radial section; $l t$, longitudinal tangential section; $m$; medullary ray; $b$, bordered pit; $s$, simple pit; $\times_{400}$

fers are characteristically small-leaved forms, they have suggested to some a phylogenetic connection with the Lycopodiales (30, 4I, 53); but the presence of leaf gaps associates them with the Filicales, and indicates that they have been derived from large-leaved ancestors. The persistence of leaf gaps when leaves are reduced in size makes 
their occurrence a character of the first importance. For example, the leaves of Thuja occidentalis are extremely reduced, but the leaf gaps are none the less in evidence; and the same is true of all the numerous conifers examined (77). The conditions, therefore, which resulted in the small leaves of conifers, did not result in obliterating the eridence of their derivation from large-leaved forms. As JEFFREY has stated it (77), the small leaves of conifers are of ecological rather than of phylogenetic interest. This is a good illustration of what he calls cenogenetic and palingenetic characters; the small leaves of Lycopodiales are doubtless palingenetic, but the small leares of conifers are cenogenetic. An old feature may reappear, therefore, in a recent form, without indicating any phylogenetic continuity. This fact is of great importance, for it compels a decision, in every occurrence of a primitive feature, whether it is really the retention of an ancient character (palingenetic) or the reappearance of an ancient character (cenogenetic). This decision must generally be a matter of opinion, but it is often made probable by its association with other characters.

As has been stated, in the more primitive groups of gymnosperms the so-called double leaf trace occurs, and this is naturally regarded by many as a primitive feature. Among the Pinaceae the double leaf trace is characteristic of the Abietineae, and is not a feature of the Cupressineae at least. Whatever the details may be for the other tribes, if this is a primitive character retained by the older types of gymnosperms, it has begun to disappear among the Pinaceae. From this point of view, one could predicate the presence of the double leaf trace in Araucarineae and its disappearance from Taxodineae. SEWARD (II 7 ) has called attention to the fact that the persistence of leaf traces, even in old trunlss, is characteristic of araucarians. CHAUVEAUD $\left(8_{3}\right)$ has dissented from the view that the double leaf trace is a primitive feature, calling attention to the fact that the trace connected with the cotyledons of Pinus and Abies is single, and in the course of ontogeny splits into two for the later leaves. He concludes that the double leaf trace is a secondary formation. The cotyledonary vascular strand has been found to be single in all the Pinaceae investigated, except in Araucarineae, and except that occasionally in a species of Cupressus (C.torulosa) there are found two separate 
strands in each cotyledon (I+I). 'The solitary strand in cach cotyledon of such polycotyledonous forms as CHaUveaud observed, however, may hold some relation to the number of cotyledons (p. 297), and so may not contradict the primitive character of the double trace.

A study of the rascular anatomy of seedlings of Pinaceac has developed some interesting facts. It will be remembered that the so-called cycadean type of seedling consists of three or four vascular bundles at the base of each cotyledon, which are connected with three poles of a tetrarch root that generally becomes diarch below (r20), a type of seedling that characterizes both Cycadales and Ginkgoales. Among Pinaceae, howerer, the cotyledonary strands (one for each cotyledon) are connected with the poles of a diarch root, excepting the Araucarineae, which have seedlings of the general cycadean type. On the basis of this character, therefore, the cycads, Ginkgo, and the araucarians are in the same general category (with numerous cotyledonary strands). The difference between the cycads and Ginkgo on the one hand and the araucarians on the other should be noted. While in the former groups the cotyledonary strands are definitely three, among the araucarians they are usually four to eight (154); while in A. Bidwillii they are twelve to sixteen (I6I). In this last form the protoxylem poles of the root are also quite variable in number $\left(5^{-7}\right)$, and their connection with the cotyledonary strands is complex and rariable. This pentarch to heptarch root becomes reduced finally to the diarch condition. The contrast of the cycads, Ginkgo, and the araucarians with the other Pinaceae, therefore, is that in the latter the cotyledonary strands are single and the primary structure of the root is diarch, while in the former groups the cotyledonary. strands are three or more and the primary structure of the root is tetrarch or some higher order, but eventually becomes diarch. The most obvious contrast is with the Cupressineae and certain Taxodineae, which have two cotyledons, each with a single rascular bundle at base; among the other Pinaceae the situation is complicated by polycotyledony ( 135 ).

In this connection attention may be called to the fact that in tracing the vascular bundles from the transition region of the seedling (the cotyledonary node) to the root, they become exarch. 'This persistent exarch character of the primary xylem of all roots was long ago 
remarked by VAN Tieghem (35), and is taken to mean that the most primitive type of xylem has persisted unchanged in the vascular system of the root.

The spiral vessels of the primary xylem, through various intermediate elements, grade into the characteristic tracheids of the secondary wood. These tracheids are arranged radially and have bordered pits that are usually restricted to the radial walls. The pits occur in a single linear series, except among the Araucarineae, in which they are multiseriate, that is, in two or more alternating series and so crowded that the pits are deformed by mutual pressure. This type of tracheid with multiseriate bordered pits is so characteristic, that when it was discovered entering into the structure of paleozoic woods, they were named Araucariowylon. As has been stated, much of the wood referred to Araucarioxylon has been found to belong to Cordaitales, so that it is no longer possible to distinguish the wood of Cordaitales and Araucarineae; but this situation has left the impression that the araucarian type of tracheid is more ancient than the other type (96). Attempts have been made to distinguish the various tribes and even genera of conifers by their tracheids, in the hope of applying the distinctions in the determination of fossil woods, but they have not been successful. BAILEY ( I $_{53}$ ) has recently illustrated this in the case of Picea, Larix, and Pseudotsuga, showing that such characters as wood parenchyma, spiral thickenings, and resin canals, often relied upon in determining the genera of fossil Abietineae, are too sporadic or variable to be used with any certainty.

The structure of the medullary rays has been found to furnish important characters for comparative study. The varying details of this structure are foreign to our purpose; but in general two types of ray are recognized: ( $\mathrm{I}$ ) the linear ray, consisting of a single series of cells in tangential section; and (2) the fusiform ray, which is broad enough to contain a resin canal (96). The medullary rays of the living Abietineae are so complex, with their parenchyma cells, ray tracheids, and elaborate system of resin canals, that they have been used as evidence of a highly specialized and modern group. A recent study of the ray tracheids of Cunninghamia by JEFFrey (143), however, has indicated the possibility that the simpler rays may have been derived from more complex ones. The marginal ray 
tracheids found occasionally in Cumninghamia, JEFFrJ:Y has found to be due to wounding, and he infers that this response brings back an ancestral feature, and that the ray of Cunninghamia has been derived from a more complex one. Since the ray tracheids described for certain Taxodineae and Cupressineae resemble those induced in Cunninghamia, the suggestion is made that this evidence favors the origin of these groups, in which ray tracheids are a vanishing character, from Abietineac, in which ray tracheids are an established character. In a recent study of the origin of ray tracheids by THoupson (r7o), complete transitions were observed, in the young root, from short tracheids extending between the rays to ray tracheids, both marginal and interspersed; the inference being that ray tracheids originate from tracheary tissuc. From a comparison of living and fossil forms, the conclusion is reached that while traumatic ray tracheids are evidently vestigial in Abies, their absence is an ancestral feature of the pines. It is evident that the whole subject of the phylogenetic significance of ray tracheids is more suggestive as yet than definite.

The resin canals have become of great service in discussions of the interrelationship of the tribes. In Pinus, Picea, Larix, and Pseudotsuga they form an anastomosing system in the secondary wood and cortex of both shoot and root, and also occur in the outer margin of the primary xylem of the root. In Abies, Pscudolarix; Cedrus, and Tsuga resin canals do not ordinarily occur in the secondary wood of either shoot or root, and are present in the center of the primary xylem of the root. JEFFREY (90) has discovered that in this latter group resin canals sometimes occur in the wood of the axis of the ovulate strobilus and in the first annual ring of vigorous shoots, and also that they may be induced in the secondary wood by injury. The inference is that resin canals in the secondary wood are a primitive feature of Abietincae; that they persist longest in the reproductive axes, leaves, and first annual rings; and that they may be recalled as a traumatic response. In Pseudolarix and Tsuga they have disappeared even from the cortex of all organs except the orulate strobilus and leaves. This reasoning leads to the conclusion that Pimus and its associated genera are the most primitive, and that the other genera are derived from the condition of Pinus by the disappearance 
of resin canals from the secondary wood. 'The same method of reasoning applied to the resin canals and their appearance as a traumatic response in Taxodineae and Cupressineae results in the conclusion that they have been derived from the Abietineae. This has been done by Jeffrey notably for Sequoia $(78)$. This genus was long supposed to be without resin ducts, but they were found in $S$. gigantea in the ovulate strobilus, in the first annual ring of vigorous branches of adult trees, and in leaf traces of very vigorous leaves of adult trees. In S. sempervirens resin ducts are absent from all these regions; but in both species resin ducts appear in the rood of both shoot and root as a result of injury. It was inferred that these resin ducts, appearing as a traumatic response, were an ancestral feature of Sequoia; and if so, the suggestion of connection with the Abietineae is inevitable.

Penhallow (96) has reached a very different conclusion from a study of the resin canals. According to his series, resin cells occur in the more primitive conifers. These cells are successively scattered, zoned, and segregated. Segregated resin cells may give rise to resin cysts, such as occur in Abies, Tsuga, and Sequoia. In Laitix, Pseudotsuga, and Picea the continuous system of resin canals shows its derivation from resin cysts by the constricted walls; while in Pinus the walls are no longer constricted and are lined by an epithelium. This series leads to the inference that the Abietineae are the most modern of conifers, and Pinus the most specialized genus.

The discussion of the interrelationship of tribes is deferred to a later section (p. 308), but the two views outlined above serve not only to emphasize the use that is being made of resin canals, but also the kind of facts in reference to them that are thought to be of service. It is evident that a series may be read in either direction, and that a traumatic response may not necessarily reveal an ancestral character.

The cotyledons have been found to be the last region of the body to lose the primitive features of the vascular bundle. If the mesarch structure has disappeared from all other regions of the body, it may have been retained by the cotyledons, which have been appropriately called the most "conservative" organs. For this reason, it is of interest to note that the resin canals are not found in the cotyledons of the Cupressineae, as witnessed by Actinostrobus, Callitris, Libocedrus, Thuja, Cupressus, and Jumiperus; but they occur in the cotyledons 
of the 'Taxodineae, als witnessed by Sciadopitys, Sequoia, and Cryptomeria (I4I); they are generally present (one or two) in the cotyledons of Abietineac; and there are several in the cotyledons of the Araucarineae ( 154 ).

Even tyloses have been used in the recent intensive study of the rascular anatomy of this group. Chryster (I4O) has found that they are restricted to Pinus, in which they occur in the heart of the root and in the first year's growth of the axis of the orulate strobilus. This restriction was demonstrated by an investigation of the root wood of thirty-two species representing thirteen genera, and of the cone axis of twenty-three species representing eight genera. He finds that, although they occur only in Pinus, they may be induced by wounding, and raises the question whether they may be a feature of phylogenetic importance as are the resin canals.

The latest anatomical character applied to the comparative study of the vascular anatomy is obtained from the "bars of Sanio," which are cellulose thickenings in the walls of tracheids and appear as horizontal or more or less semicircular markings, which stand out clearly with proper staining. Miss GerRy (I68) has investigated their occurrence and character among the Coniferales, finding them in thirty-five of the living genera, but lacking in the living and mesozoic araucarians. This emphasizes the distinctness of the araucarians from all the other Coniferales.

\section{THE LEAF}

The distribution of foliage leaves and scales is far from uniform among the Pinaceae. There may be foliage leaves only, as in Araucarineae and most Cupressineae; and in case there are both foliage leaves and scales, the two may occur on the same shoot, as in Abies, or on different shoots, as in Pinus.

The foliage leaves of Pinaceae are quite variable in form, from small discoid ones closely imbricated and appressed upon the axis ("concrescent"), as in many of the Cupressineae, to the characteristic free needles of the Abietineae, and the broad blades of some of the Araucarineae (Agathis) (figs. 256, 258). In general, the phyllotaxy is spiral, but in the Cupressineae it is cyclic. The foliage leaves are very persistent, functioning one to ten years, the basal growth permit- 
ting them to increase in size at base with the increase in the diameter of the axis. So far as recorded, the only deciduous forms are Larix, Taxodium, and Glyptostrobus.

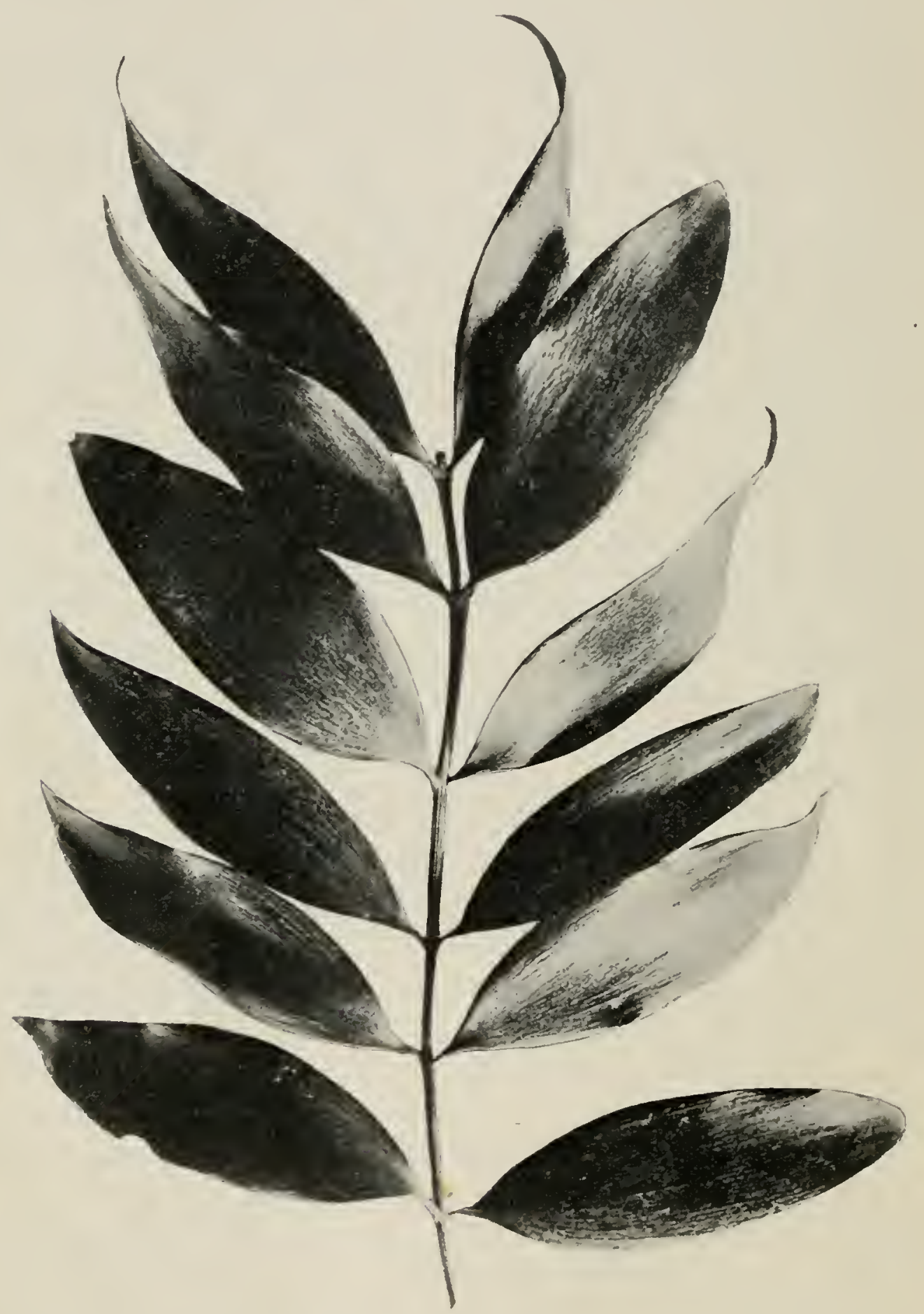

FIG. 258.-Agathis loranthifolia: a shoot one-half natural size.-Photographed from material furnished by Missouri Botanical Garden. 
The well-known structure of the leaf is of an extremely xerophytic type, which the section of a pine needle may illustrate (fig. 259). The epidermis consists of elongated, fiber-like cells, with strongly cutinized walls, the guard cells being deeply sunken. 'The rigidity of the leaf is due chiefly to the hypodermal layers or masses of elongated sclerenchymatous cells. The mesophyll is uniform throughout, and it is characterized by peculiar platelike "infoldings" of the wall.

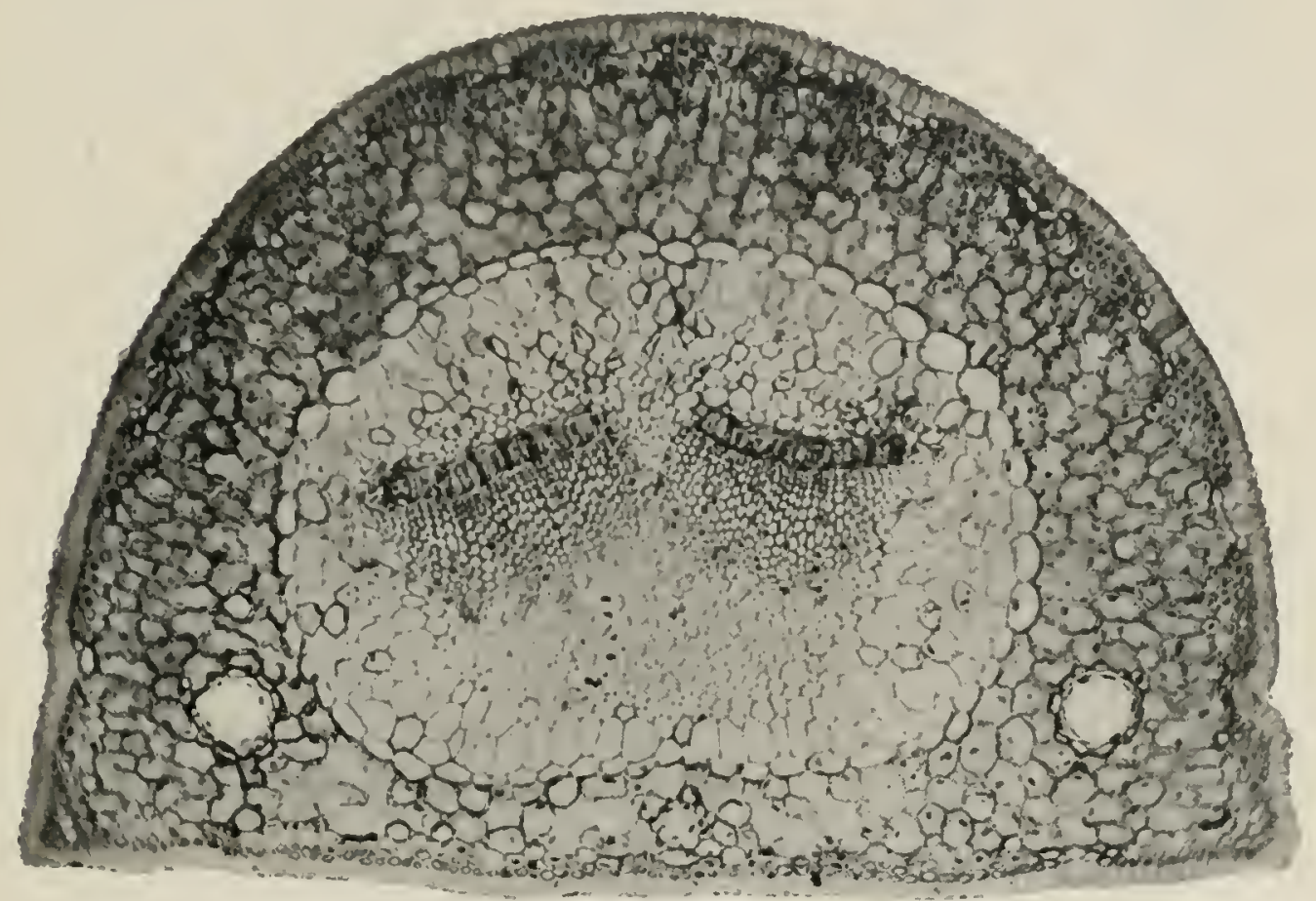

FIG. 259.-Transverse section of a pine needle, showing epidermis (in which are deeply sunken stomata) underlaid by several layers of heavy-walled cells (sclerenchyma), the mesophyll with characteristic infolded walls and containing resin ducts, the distinct bundle sheath (endodermis) surrounding the vascular region (stele), and the two parallel vascular bundles (xylem directed toward flat or adaxial face of leaf).

There is a single central bundle region, invested by a rery distinct sheath, and traversed by two parallel rascular bundles. The remaining tissue within the sheath is the so-called "transfusion tissue," and consists of two kinds of parenchymatous cells: (I) those without protoplasm and pitted, and (2) those with protoplasm and not pitted. The former cells are thought to represent in function an extension of the tracheid system, passing water from the xylem to the mesophyll; and according to Worspell (45) they have been derived from the 
centripetal xylem of the ancestral mesarch bundle. The latter cells are said to mediate between the mesophyll and the phloem in the transfer of food. The single vascular bundle as it enters the leaf divides into two strands that run parallel and near together within the common sheath. This is really the double leaf trace characteristic of the more primitive gymnosperms, and separating into its two constituents at the leaf base.

In the case of flat leaves the mesophyll differentiates into the palisade and spongy regions, and in the broader forms the cells of the central mesophyll may be more or less transversely elongated, and the entering vascular bundle breaks up into several more divergent strands.

\section{The spore-producing members}

The strobili of Pinaceae are monosporangiate, the two kinds occurring on the same plant (Abietineae, Taxodineae, and occasionally

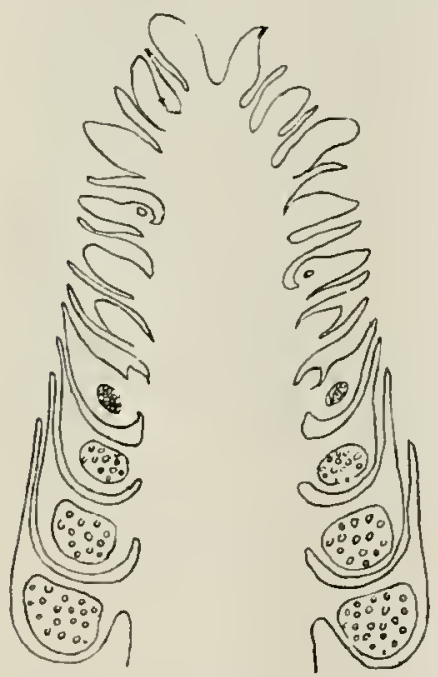

FIG. 260.-Bisporangiate strobilus of Pinus maritima: the three lowest sporophylls on each side of this section bear microsporangia; the next sporophyll above on each side bears a microsporangium and also a rudimentary ovuliferous scale in the axil; above these there is the structure of an ordinary ovulate strobilus; GoEBEL found hundreds of such cones upon one tree.-After Goebel ( 58$)$. in Cupressineae and Araucarineae) or on different plants (the prevailing condition in Cupressineae and Araucarineae). Bisporangiate strobili occur occasionally, having been reported for Picea excelsa (9), Pinus maritima (58), Abies sp., Pseudotsuga Douglasii ( I 54), and Sequoia (42) (figs. 260-262); and recently a remarkable plant of Juniperus communis has been described (97), which bears such strobili almost exclusively. In this last case, the strobilus consists of a few sterile bracts at base, then two or three whorls of staminate sporophylls, and at the tip the ovulate sporophylls; occasionally there is a whorl of sterile bracts between the stamens and the orules. Such a strobilus is interesting not merely because it is bisporangiate, but also because the relation of the 
two sets of sporophylls to one another is that found in the strobilus of Bennettiales, in the so-called "flower" of II'chitschia, and in the
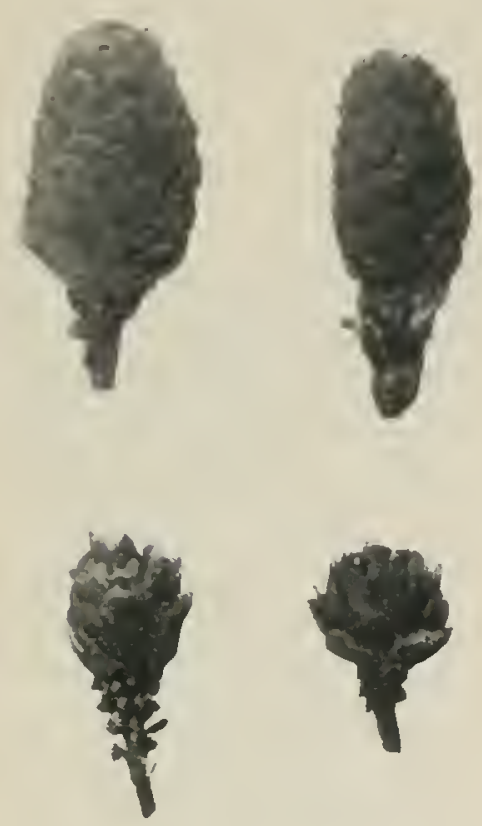
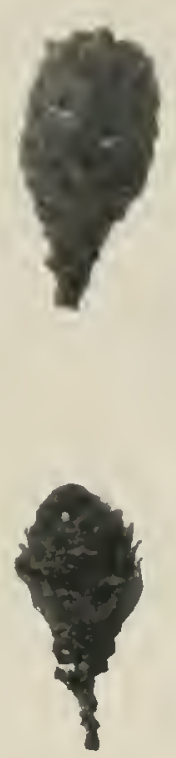
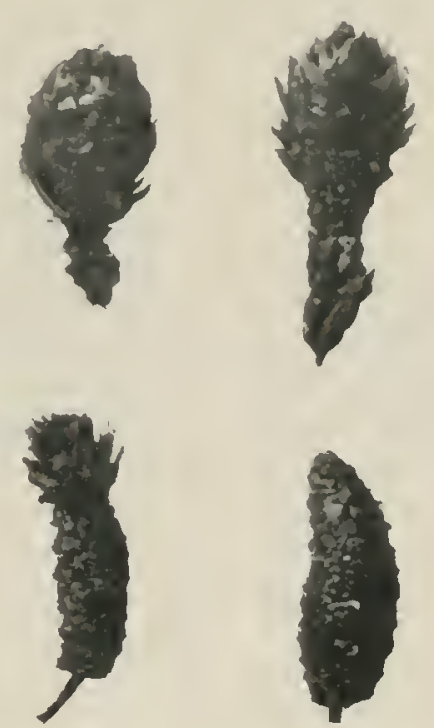

Fig. 26I.-Bisporangiate strobili of Abies: the staminate strobilus at the lower right corner is almost normal; all the others have microsporangia both above and below, with ovuliferous scales between.

angiosperm flower. It is to be expected that other cases of bisporangiate strobiili will be reported, but they are evidently of very rare occurrence among Pinaceae.

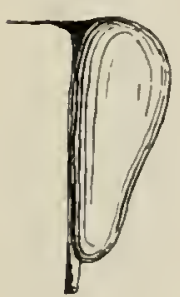

A

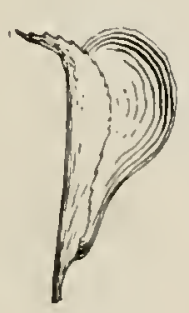

$B$

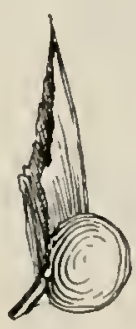

C

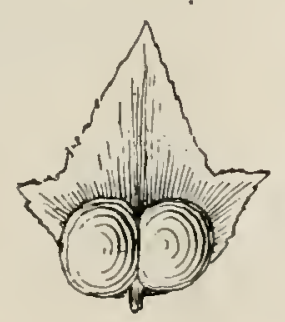

D

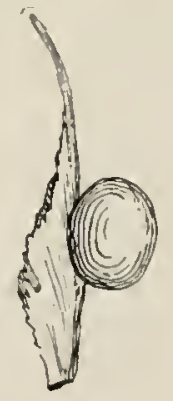

$E$

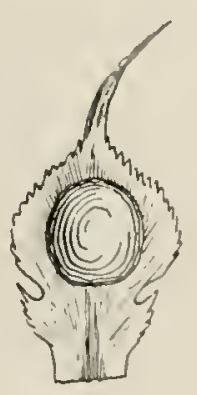

F

FIG. 262.-Microsporangia from the strobili shown in fig. 26I: $A$, normal sporophyll, side view; $B$, slightly modified sporophyll from the summit of a bisporangiate strobilus; $C, D$, side and front views of sporophylls from the sumnit of a bisporangiate strobilus; $E, F$, side and front views of sporophylls from the base of a bisporangiate strobilus. 


\section{THE MICROSPORANGIUM}

The microsporangiate strobili are never terminal on the primary axis or even upon the larger branches (figs. $263-265$ ). Their relation to the axes, foliage leaves, and scales is variable. Sometimes

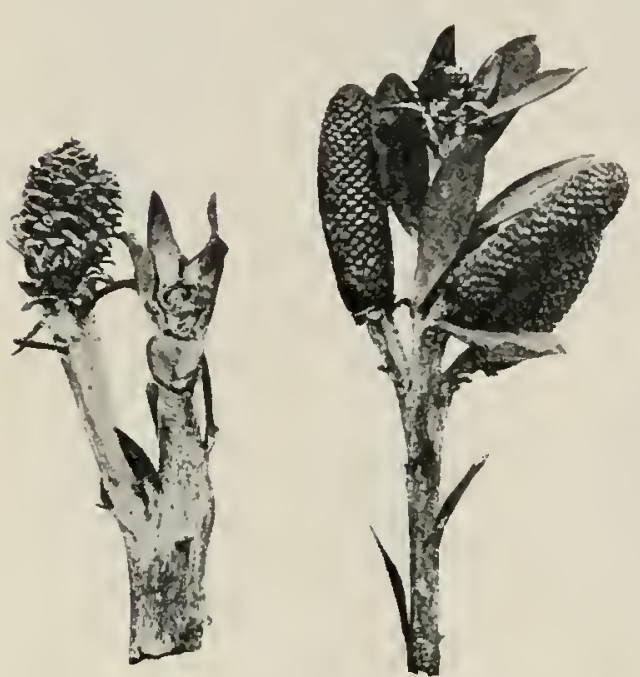

263

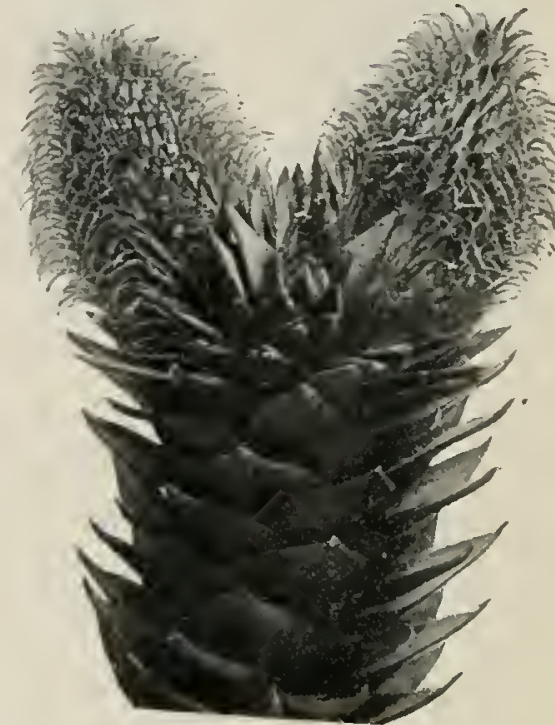

264

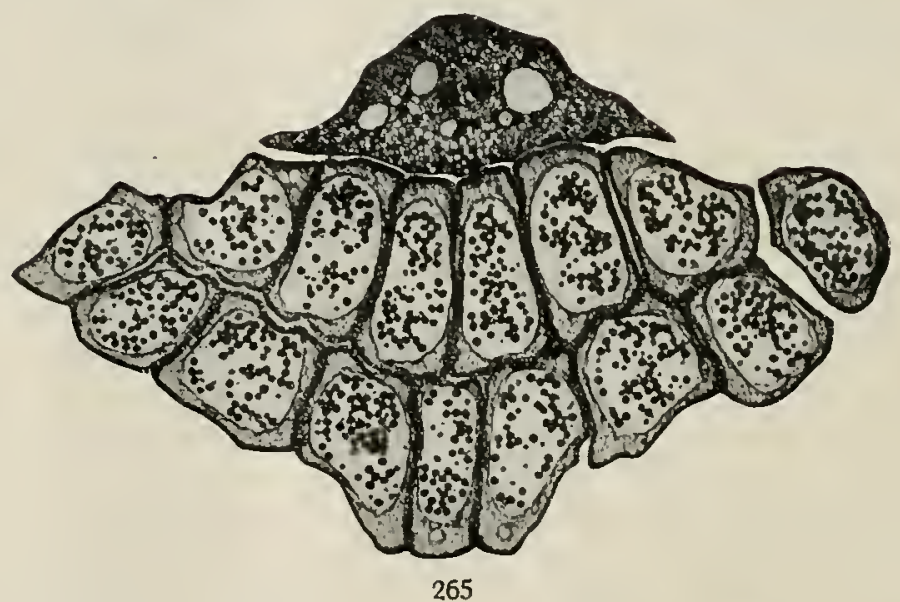

FIGS. 263-265.-Strobili of araucarians: fig. 263 , Agathis australis; staminate (right) and ovulate strobili of same age; fig. 264, Araucaria imbricula; two staminate strobili with a vegetative bud between them; fig. 265, Agathis bornensis; transverse section of sporophyll and pendent microsporangia.-From photographs by Thomson.

they appear terminal on small leafy shoots of the last order, and sometimes they occur in the axils of the leaves of stronger shoots. In Pimus they replace dwarf shoots in the axils of scales, being usually numerous and forming a cluster beyond which the parent axis continues its growth. 
The sporophylls follow the leaf arrangment; for example, they are spiral in the Abietineae, and cyclic in the Cupressineac. 'They are exceedingly variable in form, nearly every genus having a characteristic microsporophyll. In almost every case there is an evident differentiation into a stalklike base and an expanded terminal region (representing a lamina) bearing the sporangia. In some cases, as in Widdringtonia ( 159, I 76 ) a mong the Cupressineac, the lamina spreads as a peltate expansion, the several sporangia arising from the stalk and girdling it. In other cases, as in the Araucarineae, the lamina is represented by a knoblike enlargement, beneath one side of which the free sporangia hang, suggesting the stamen of Ginkgo, and also the Crossotheca ("epaulet") type among the Cycadofilicales (fig. 265). There is every gradation between this more or less peltate type and the bladelike expansion of the sporangium-bearing region in the plane of the stalk. The bladelike tip shows all degrees of development, from conspicuous (as in Cedrus and Cumninghamia) to much reduced (as in Pinus), and with its abaxial sporangia suggests the most primitive type of sporophyll, namely that of the Filicales, which was continued among the Cycadofilicales. So far as known, no living conifer has the type of stamen known to belong to some of the Cordaitales, namely a stamen with terminal and erect sporangia; but doubtless these two other types also belong to that great paleozoic group.

The number of sporangia is quite variable, being always two a mong the Abietineae, two to five (perhaps more) among the Taxodineae, two to six among the Cupressineae, and five to eight or more among the Araucarineae. It is to be remembered that these numbers apply only to living representatives of these tribes, and that they doubtless varied much more widely among their predecessors.

The development of the microsporangium is of the usual eusporangiate type, that is, the archesporium is a hypodermal layer of cells, varying in number, which divides periclinally to form the primary wall layer (outside) and the primary sporogenous layer (inside). 'The primary wall layer, by successive periclinal divisions, produces several wall layers (usually four or five in the Abietineae, three in Taxodium. and two or three in the Cupressineae), the innermost one of which forms a part of the conspicuous tapetum, and the outermost one sometimes developing as an endothecial layer $(70)$. While in general 
the mature sporangium wall, after the breaking-down of the inner layers, consists of two layers (epidermis and endothecium), in Widdringtonia ( 159 ) the mature wall of the small sporangium becomes one-layered, all the true wall layers within the epidermis disappearing. The primary sporogenous layer, by successive divisions, produces a mass of sporogenous cells, which finally reach the mother cell stage, at which time the tapetum forms a complete investment of glandular and sometimes binucleate cells.

In most of the recorded cases, the microsporangium passes the winter approximately in the mother cell stage (figs. 266-269). This is certainly true for Cupressus Lawsoniana (48), Pinus silvestris (126), Larix europea (74), Taxodium (76), and Juniperus communis ( 73$)$. In her study of Pimus, however, Miss FERGuson (87) states that in most species, while the sporogenous tissue is well developed before winter, the mother cell stage is not reached until the following spring; while in P. Strobus even the sporogenous tissue is not well developed until May. In Cryptomeria japonica (in California) LAWSON (93) found that the staminate cones appear early in October, the reduction divisions occur during the first week of November, and the microspores are rounded off by December. In Juniperus virginiana in the vicinity of Chicago, the pollen mother cell divides before development is checked by the cold weather. Observations have not been recorded for tropical species, but we have seen the Mexican Pinus patula (?) shedding pollen in September, which would indicate that the pollen had been matured without any resting period.

'These discrepancies show a wide seasonal variation in the development of the sporogenous tissue. Even in the cases first cited there is evident a certain amount of variation in seasonal range and rate of development. For example, in Pinus Laricio and Larix europea the mother cell stage is reached usually in October; while in Taxortium the staminate cones do not begin to develop until September or October, but they are in the mother cell stage at the arrival of winter (January or earlier in the southeastern United States); in both cases the mother cell stage is the winter stage, and the reduction divisions take place during the following spring (March to May), but in an early winter Pinus Laricio may not reach the mother cell stage, and a few sporogenous mitoses will then precede the mother cell stage the next spring. 
In the case of Pinus Laricio (in Chicago), about the first of May the mother cells are found in various stages of division, the sporangium usually having passed the winter in the mother cell stage or in a late stage of the sporogenous tissue. The divisions do not appear

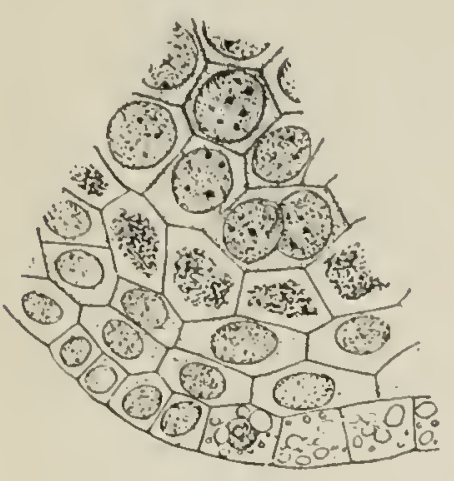

266

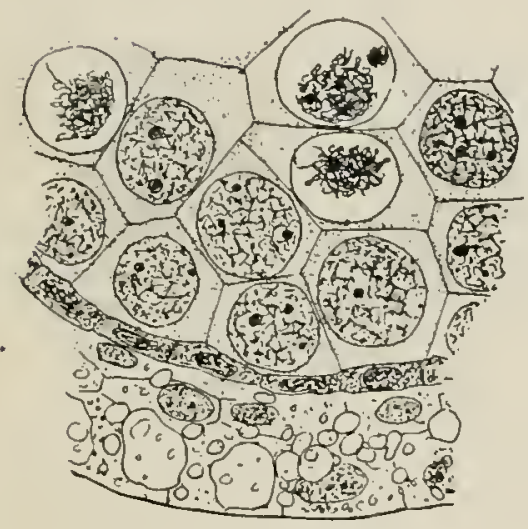

268

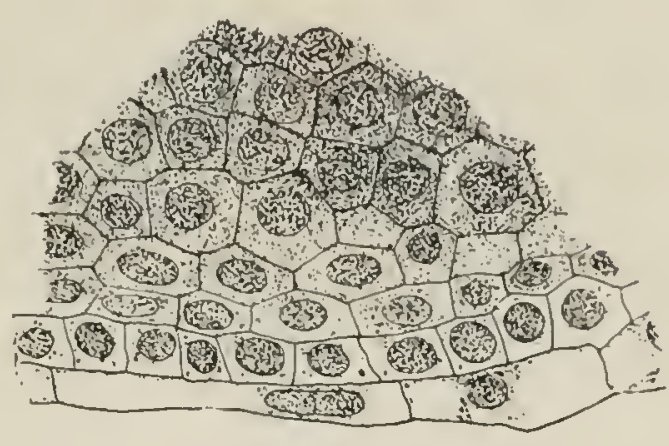

267

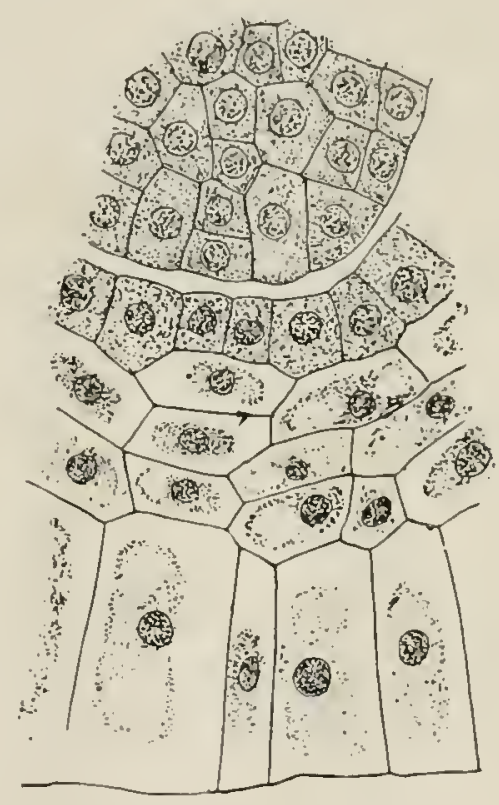

269

FIGS. 266-269.-Winter condition of microsporangia: fig. 266, Pinus Laricio on October I; fig. 267 , the same on January 3; fig. 268 , the same on April 4 , showing symapsis; while fig. 267 is probably in the mother cell stage, it is certain that sporogenous divisions sometimes occur in the spring; fig. 269. Taxus canadensis on October I, showing mother cell stage.-After ChaMBERLAIN (48).

to be simultaneous as among angiosperms, for in the same sporangium some mother cells are preparing for the first division, others contain completed tetrads, and others represent every stage between (fig. zor). In the same sporangium, also, the division may be simultaneous or 
successive, although the former seems to be the prevailing method; and the tetrad may be tetrahedral or bilateral. The wings of the spores begin to develop while they are within the mother cell (fig. 304). While winged pollen grains are a feature of Abietineae, it is interesting to note that in Pseudotsuga ( ${ }_{5} 6$ ) wings do not develop, so that winged and wingless pollen grains are found in the two tribes characterized by their wings (Abietineae and Podocarpineae).

GOEBEL (70) has called attention to the fact that the dehiscence of the microsporangia of gymnosperms is definitely related to their form and position, and favors the distribution of the spores. For example, the nearly related genera Picea and Abies differ in the dehiscence of their sporangia, the former being longitudinal and the latter transverse. The suggested explanation is that the upright strobilus of Picea requires a longitudinal dehiscence for a thorough discharge of spores; while a transverse dehiscence is more effective in discharging spores from the drooping strobilus of Abies. The Cupressineae were considered to be outside the range of the problem because their small and rather globular sporangia are not definitely oriented as in the other tribes.

\section{THE MEGASPORANGIUM}

The ovulate strobilus of Pinaceae has given rise to more discussion than any structure among gymnosperms. The great body of literature dealing with this subject has been traversed and outlined by Worsdell (62), to whose account we are much indebted for the following statement. The early discussions, which arose from the attempt to interpret an abietineous cone in terms of an angiospermous flower, have chielly a historic interest. To decide whether such a cone is a flower or an inflorescence does not seem important to the modern morphologist, for if it holds any relation to these things it is that of an ancestral structure which as yet has become neither flower nor inflorescence. The question of chief interest is whether the orulate strobilus of Pinaceae is to be regarded as simple or compound; that is, whether the orules are borne by axes of the first or second order.

Among the Abietineae the ovuliferous structures (from below upward) consist of a small bract, a very much larger oruliferous scale (usually becoming woody) coalescent with the bract at the rery 
base, and two inverted basal orules (figs. 270, 27r). Among the Taxodineac and Cupressincae there is a single bract or scale structure with two distinct apices (dorso-ventral) at the free and enlarged end and bearing one (Juniperus) to many (Cupressus) orules. In Juniperus this structure becomes fleshy in the organization of the so-called "berry." Among the Araucarineae there is a prominent bract, a ligule-like oruliferous scale (present in Araucaria, wanting in Agathis), and a single imbedded ovule some distance above the base (figs. 272,273 ). The discussion has centered about the nature of the oruliferous scale, and a brief outline of the development of the subject will be of interest.

Before 1827 , in which year ROBERT Brown announced gymnospermy (I), the orule was regarded as a pistil, and the related parts were variously interpreted. BROW's conclusion as to a naked orule was derived from a comparison of the so-called

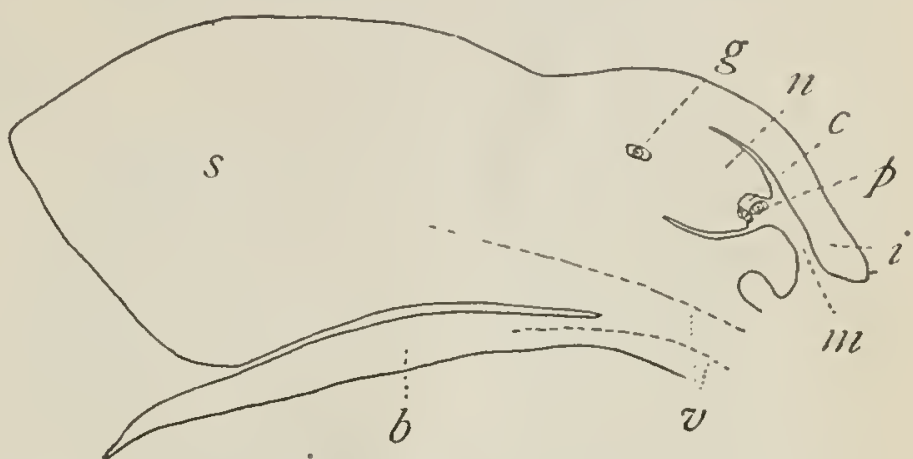

Fig. 270.-Pinus Laricio: diagram of ovule and associated structures; $b$, bract; $s$, ovuliferous scale; 2', vascular bundles; $m$, micropyle; $i$, integument; $p$, pollen grains; $c$, cavity in apex of nucellus; $n$, nucellus; $g$, embryo sac. "orule" (nucellus) of

cycads and conifers with the orule of angiosperms. His corollary was that the ovuliferous scale is an open carpel, but his statement that this so-called carpel is a leaf in the axil of a bract met strong opposition.

In I839 Schleiden called attention (2) to the fact that Brown's "folium in axilla folii" is a morphological impossibility, and that the oruliferous scale must be a flattened axis in the form of a placenta, the axial nature of placentas in general being one of Schlemen's peculiar views. This view of the branch nature of the oruliferous scale was concurred in later by Baillon, Dickson, Strasburger, and Masters, but without regarding the axis as a placenta.

In I $842 \mathrm{~A}$. BRAUN (3) first advanced the theory that the oruliferous scale represents the first two leaves of an axillary shoot, which are 
fused by their adaxial (posterior) margins. His illustrative material consisted of a cone of Larix; in which the ovuliferous scale was replaced by a short branch bearing two leaves transversely placed (that is, their margins adaxial and abaxial with reference to the main axis), the bract developing as a foliage leaf. This view was accepted later by Caspari, Parlatore, Oersted, Von Moml, Stenzel, Englemann, Willkomin, and Celakovskí.

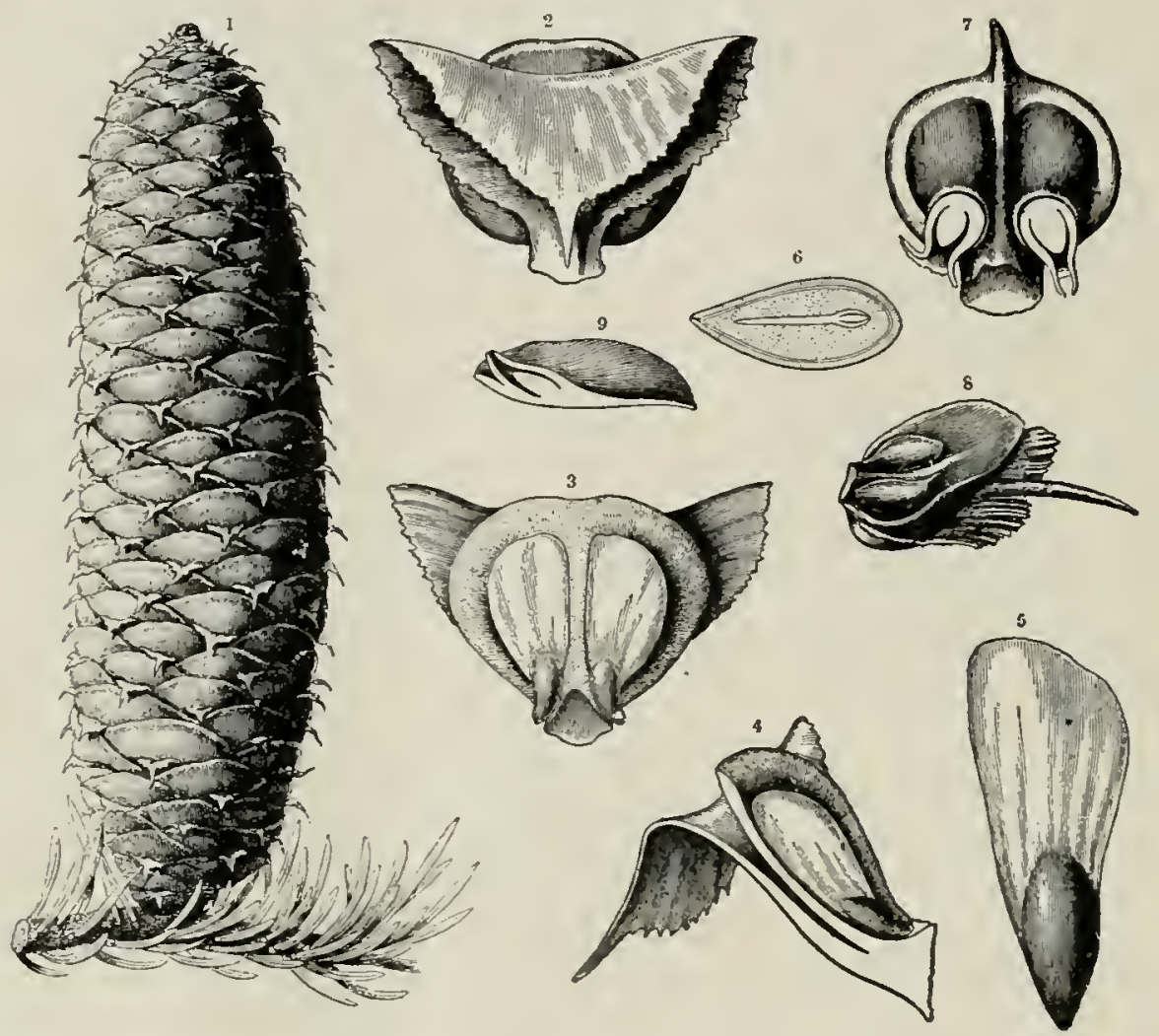

FIG. 2 †. -Orulate structures of various Abietineae: 1, Abics pectinata, orulate strobilus; 2 , dorsal view of its bract and ovuliferous scale; 3 , ventral view of same; 4 , longitudinal section of same; 5, a winged seed; 6 , longitudinal section of seed; 7, Pinus silvestris, ventral view of ovuliferous scale; 8 , Larix europaca, ovuliferous scale and bract with bristle; 9, longitudinal section of same.-After KerNer (4Ia).

It is of interest to note that as late as I860 BAILLON announced (7) his opposition to the claim of gymnospermy, a position which he maintained persistently, basing it upon the first really careful researches in the organogeny of the structures under discussion. He sustained Schleiden's riew that the oruliferous scale is an axis. but regarded it as an axillary shoot rather than a placenta.

In I860 Dickson recorded (9) some cones of Picea excelsa in which the lower bracts were replaced by stamens, while the upper bracts 
bore axillary oruliferous scales as in the normal cone. He concluded that stamens are to be homologized with the bracts of the oruliferous cone, and that the oruliferous scales are axes of the next higher order. Similar cones have been reported by Shaw (42) from Sequoia, and by Goebel (58) from Pinus. For some, such illustrations settle the sporophyll character of the bract in both cones, and to them the bract of the orulate cone is a carpel.

In I 860, also, Caspary (8) confirmed BRAUN'S conclusion, citing specimens in which branches occurred in the axils of the bracts, and bore the two halves of the ovuliferous scale as lateral appendages.

In I864 PARLA-

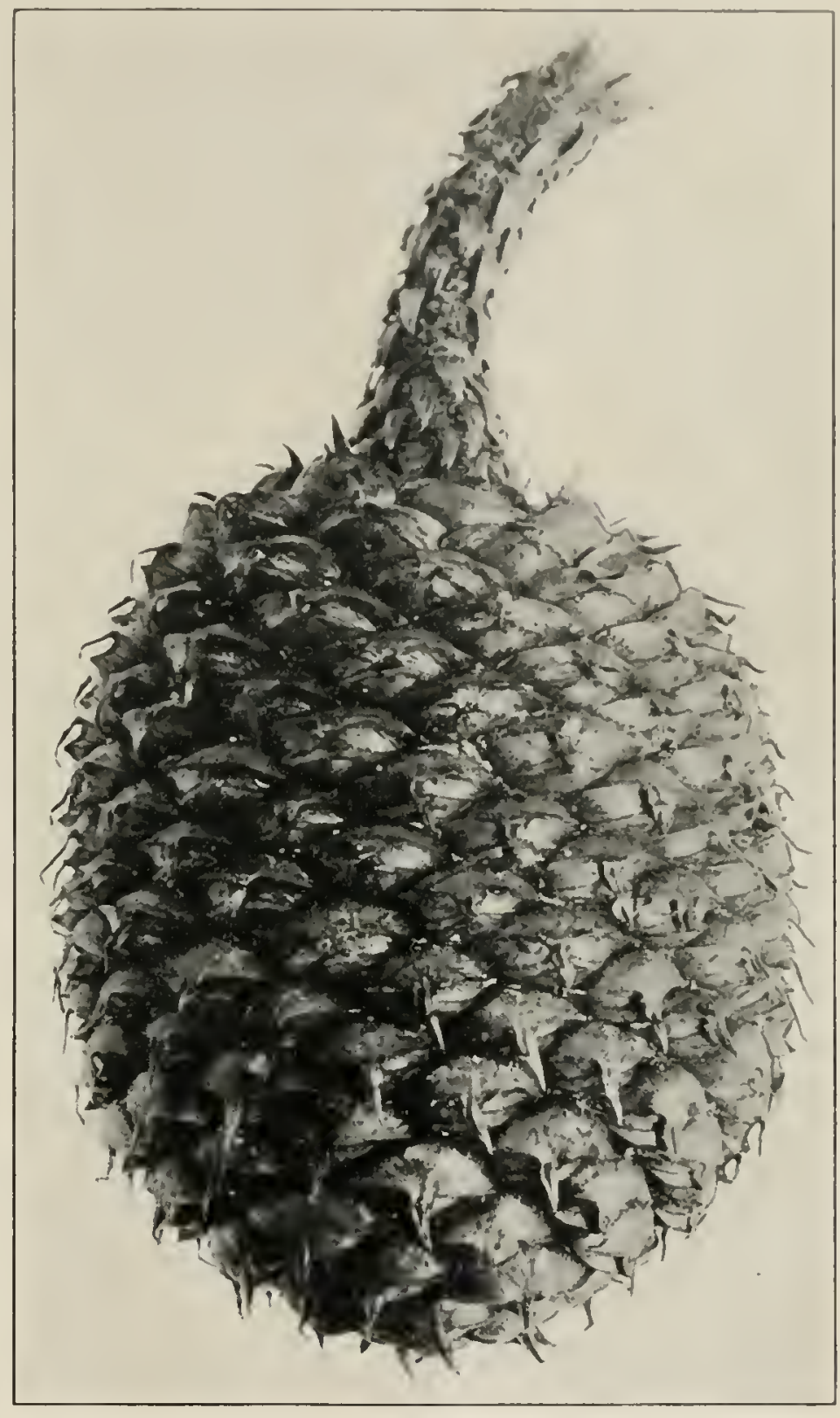

FIG. 272.-1raucaria excelsa: ovulate cone from a tree in the plaza at Jalapa, Mexico; one-half natural size. TORE recorded (I 2 )

a cone of Pinus Pinaster ( $P$. Lemoniana) in which an ordinary dwarf shoot with its two needle leaves sprang from the axil of every alternate bract, replacing the ovuliferous scale. His conclusions naturally accorded with those of BRALN. 
In I864, also, OERsted described (I I) some remarkable cones, in which the lowest bracts had the form of foliage leaves; in the axils of the next higher bracts were several scales as on a suppressed axis, the two outermost being the largest and opposite; higher up the bracts became gradually smaller and the axillary scales less numerous, but the two outermost scales gradually increased in size and became connate by their adaxial (posterior) margins, while rudimentary ovules appeared at their base; and in the uppermost part.of the cone the bract was reduced to its ordinary size, and the ovuliferous scales had fused into a single large broad structure dentate or bifid at apex.

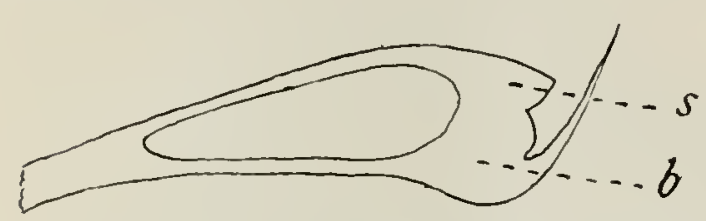

FIG. 273.--Araucaria excelsa: longitudinal section of bract $(b)$ and scale $(s)$ from cone shown in fig. 272 ; natural size.

One of the simplest explanations of these problematical structures was that proposed by SACHS (I4) in I 868, and afterward more fully elaborated by Eichler (I9). They claimed that the bract is a carpel, and the oruliferous scale a ligular outgrowth from its face, calling attention to a similar condition in the leaves of Isoetes and Selaginella. Such a ligular placenta does not appear among the Taxodineae and Cupressineae, and in these cases the bract is evidently an open carpel.

In I869 VAN TiEghem presented his conclusions (I6) based upon anatomical structure, a new point of view. He states that the bundles of the bract and of the oruliferous scale leave the main axis each in its own sheath, and therefore represent independent systems of bundles and independent members; that the upper bundle divides to form an arc (in transverse section) of bundles with inverse orientation, the arc arrangement showing that the axillary structure is a leaf and not a branch; and that the inverse orientation shows that the leaf belongs upon the suppressed branch opposite the bract. His conclusion was that the oruliferous scale is the first and only leaf of an axillary branch.

In I87 I VON MorrL further strengthened BRAun's position by the publication ( $\mathrm{I}_{7}$ ) of his studies of the peculiar "double leaf" of Sciadopitys. He showed that this leaf represents the first two leaves 
of an axillary shoot, which stand transversely, and which become coalescent by their adaxial (posterior) edges, the vascular bundles thus necessarily showing inverse orientation. As this normal behavior of the leares of Sciadopitys exactly parallels what was claimed by Braun for the oruliferous scale, the results of Vox Mont are almost in the nature of a demonstration.

In 1876 STENZEL described (2I) striking abnormalities in cones of Picea excelsa. In one cone leafy axes occurred in the axils of the bracts, the first two leares resembling oruliferous scales more than ordinary foliage leaves in texture. In other cones the abnormalities recorded by Dickson (9) were observed. In still other cones he found the two parts of the ovuliferous scale in all stages of coalescence. All of his material confirmed BRAUN's view that the ovuliferous scale is made up of the first two leaves of an axillary shoot, which stand transversely, and are connate by their adaxial edges. In revicwing Stenzel's paper, Englemann reported (20) similar abnormalities in cones of Picea Englemannii and Tsuga canadensis.

In 1879 ČELAKOVSKY $\dot{y}$ began publishing upon the subject, and has constructed a theory $(24,26,32,47)$ intended to unify the puzzling diversities of structure. He regards the ovuliferous scale as the representative of an axillary shoot, but formed directly rather than as an axis with two distinct lateral leaves, which is a statement of the ontogeny rather than of the phylogeny. In this scale he sees the modified and blended outer integuments of the two orules. There is, therefore, no true carpel present; it is represented by a single orule, which is borne by a branch of the second order. In brief, from the standpoint of phylogeny, this is the reduction of a leafy, oruliferous branch to its orules. The foliar origin of the outer integument is the thesis of $\check{C}$ ELAKOVSK' $\dot{Y}$, and this really brings one around again to the foliar nature of the ovuliferous scale and BRAUN's theory. A related view is that of KUBART (IO3), who from a study of Juniperus concludes that the ovuliferous scale is an aril.

In 1892 Bessey published $(67)$ the view that the staminate and orulate cones are strictly homologous, and that the oruliferous scale is a chalazal development of the orules. "The sporophyll enlarges or remains small just as the chalazal development of the orule into a scale is more or less pronounced." 
The oruliferous scale of Pinaceae, therefore, has been regarded successively an open carpel, a placenta, a flattened axillary shoot, the first two leaves of an axillary shoot, the first and only leaf of an axillary shoot, a ligule, fused outer integuments, and a chalazal outgrowth. To select among these views is more difficult than important. The testimony would seem to favor BRAUN's general view, and this would relate the megasporangia properly to the abaxial surface of their sporophylls, the relation held by the microsporangia. Moreover, it was evidently the situation in the ovulate strobilus of some of the Cordaitales at least, and the historical connection of Pinaceae and Cordaitales is fairly clear. Amid all the possible details of views, the really important fact is reasonably substantiated that the scale and its ovules, in Abietineae at least, in some way represent a modified axillary shoot, corresponding to the characteristic dwarf shoot of the group; and therefore, that the strobilus is a compound one, as among the Cordaitales and Gnetales.

Among Taxodineae and Cupressineae bract and scale form a single structure; but the two distinct and dorso-ventral apices, and the two sets of vascular strands with opposing orientation (the xylem of the one facing the xylem of the other), make the inference reasonable that the same structures are represented as occur among the Abietineae.

Investigators claim that the case of the Araucarineae is very different (figs. 272,273 ). In Araucaria a superficial examination seems to show a fused bract and ovuliferous scale, as in the Cupressineae, but those who have investigated the structure say that there is no such evidence of its double nature. Even if the ligule of Araucaria. be accepted as a vestige of the ovuliferous scale, there is no ligule in A gathis. It seems to be a needless forcing of the situation to regard the ovuliferous bracts of Araucarineae other than they seem, that is, simple sporophylls (II7), some of which are ligulate. In a recent study of the vascular anatomy of the ovuliferous structure of conifers, THomson (I64) has found definite evidence that the araucarian ovulate strobilus consists of simple megasporophylls. In the vascular supply bundle for sporangia (including microsporangia) there is developed an inverse orientation. Among the other tribes of Pinaceae there are two such orientations, indicating a different condition; while in the megasporophylls of podocarps there is the single inverse orien- 
tation. The conclusion seems evident that the oruliferous structure of araucarians and of podocarps is of the same nature, and that it is a simple megasporophyll. 'That in so large and ancient a group as the Pinaceae both simple and compound ovulate strobili should be represented, would not be strange. In fact this difference between the Araucarineale and the other three tribes only emphasizes other differences that indicate the long separation of the Araucarineac from the other Pinaceae.

The scales or bracts, whatever may be their morphological character, bear a variable number of ovules. Among the Abietineae the number is definitely two, and the orules are inverted; but in the other tribes of Pinaceae the number is variable. Among the Taxodineae the numbers range from two in Taxodium to seven to nine in Sciadopitys (arranged in a transverse row), and the ovules are all erect except in Cumninghamia, Sciadopitys, and sometimes Arthrolaxis. Among the Cupressineae the orules are all erect, and range in number from one or two in Juniperus and Actinostrobus to indefinite and often numerous in Cupressus and Callitris. Among the Araucarineae the solitary (sometimes two in Agathis) ovule is inverted.

One of the remarkable features of the development of the ovule of Pinaceae is the long period that often elapses between the first appearance of the ovulate strobilus and the maturing and shedding of the seed (fig. 274). The schedule for Pinus Laricio growing in Chicago is as follows. The strobilus begins to develop in the late fall and winter; in the spring the integument and nucellus of the young ovule are distinct, but there is no evident differentiation of sporogenous tissue; in May the mother cell is recognizable by its great increase in size (the stage found in the youngest evident cones); in October the endosperm is found as a parietal layer of free nuclei, in which condition the second winter is passed; in the following spring the endosperm begins to develop rapidly; and in June the archegonia are ready for fertilization, which takes place about the first of July, at least twenty-one months after the first organization of the ovule; in the following year the seed is shed, three winters being included between the primordium of the ovulate strobilus and the shedding of its seed. It is recognized that this schedule is an unusually long one, and how far it applies among Pinaceae is unknown. In 


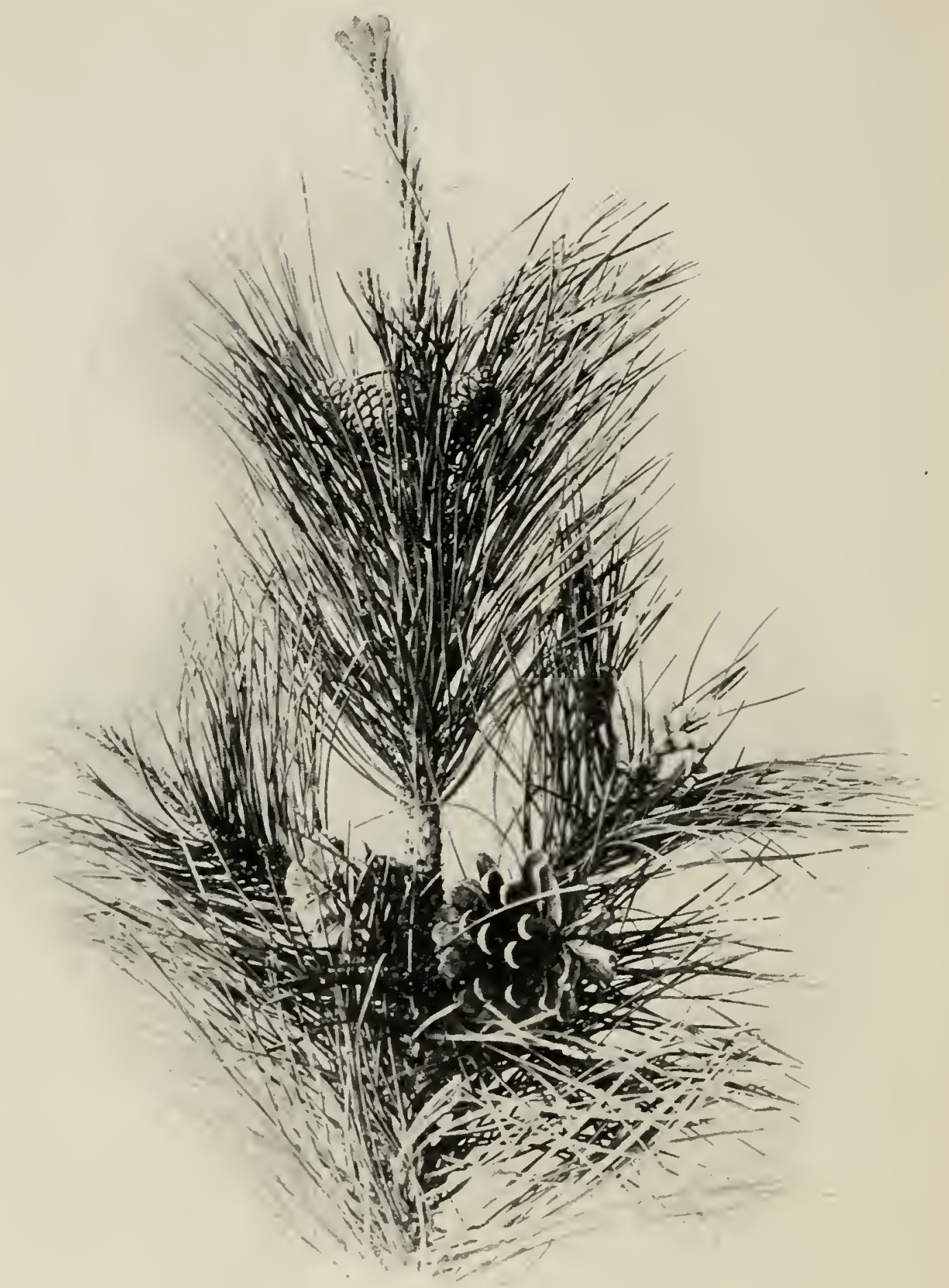

FIG. 274.-Pinus Laricio: branch from top of thrifty tree, June I; the four small strobili at the top are in the stage shown in fig. 280; in the strobili next below, which are a year older, the archegonium initials are distinguishable (fig. 289); the strobili next below, another year older, have shed their seeds; to the right is a cluster of staminate strobili just ready to shed pollen. 
Taxodium (76) the orulate strobili also begin in the early fall (in southeastern United States), grow during the winter, the mother cell is indistinct in March or April, and fertilization occurs in June, but the seed matures before the end of the year. These two schedules probably represent the extremes among Pinaceac, at least one winter and not more than three elapsing between the primordium of the strobilus and the shedding of the seed. So far as the investigations include a record of time, the mother cells are evident and dividing during the spring, from the first of March in California to the last of May in England.

The integument and nucellus are free from one another only in the region of the sterile cap of the latter. In the early stages of the orule they appear almost entirely free, but the later growth of the ovule is chiefly in the chalazal region, so that the free portion of the two regions appears only at the tip of the mature orule. An unusual freedom of nucellus and integument is reported for the Araucarineae (IO7), but complete freedom at the maturity of the ovule is recognized as a primitive feature characterizing certain paleozoic seeds, some of which doubtless belong to the Cordaitales. Cases of two separate nucelli within a common integument have been reported for Thuja (86).

In general the integument forms a more or less elongated but indefinite micropyle, but LAwson has described (156) a remarkable organization of the micropylar tube in Pseudotsuga Douglasii. A stricture of the integument midway between the apex of the nucellus and the mouth of the micropyle results in two micropylar chambers. The rim of the outer chamber is folded inward, and on the inner surface of the infolded portion numerous hairlike processes are developed. It is in this outer stigmatic chamber that the pollen grains lodge and germinate, the pollen tubes passing through the inner micropylar chamber to reach the apex of the nucellus. In Widdringtonia (159) the micropylar tube is remarkably long and slender, and since the integument is bilaterally winged, the ovule bears a remarkable resemblance to that of Welwitschia.

The integument differentiates into the three layers characteristic of all the groups previously considered; but the outer fleshy layer does not deserve its name, for it is represented only by a thin layer 
of cells that disappear with the maturing of the testa. The middle or stony layer in this case is the conspicuous one, the seed being said to "ripen dry"; while the inner fleshy layer is most largely and distinctly developed, as usual, in the free portion of the integument (fig. 275).

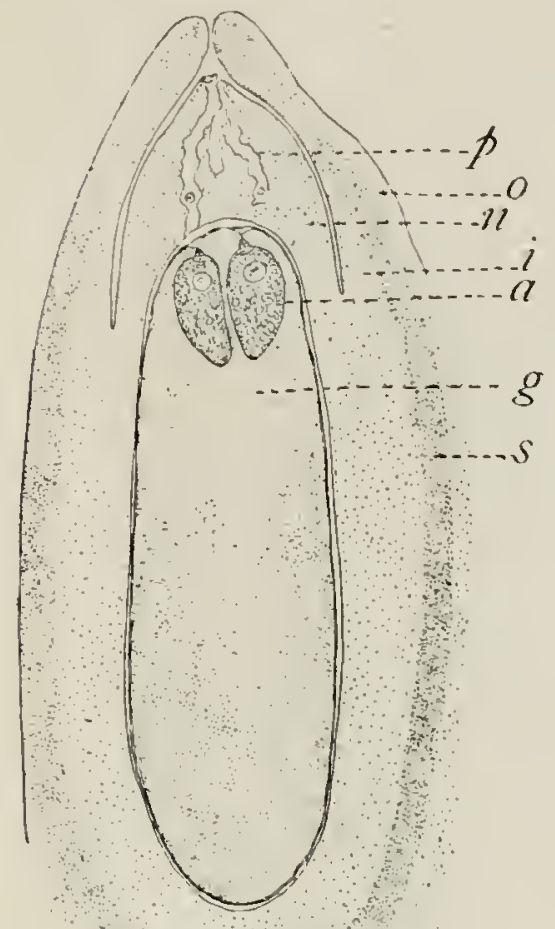

FIG. 275.-Pinus Laricio: longitudinal section of ovule; 0 , outer fleshy layer of integument; $i$, inner fleshy layer; $s$, stony layer; $p$, pollen tubes; $n$, free portion of nucellus; $g$, gametophyte; $a$, archegonia.

The vascular supply of the seed has been modified by this change in the structure of the testa. Both inner and outer sets of vascular strands have disappeared, the vascular connections ending in a more or less extensive tracheal plate at the base of the ovule.

The development of the sporogenous tissue has seldom been traced. In Larix: Strasburger (25) has demonstrated a hypodermal archesporial cell, which divides periclinally into an outer primary wall cell ("tapetal cell") and an inner primary sporogenous cell (figs. 276-279). The wall cell begins an extensive series of divisions, accompanied by divisions of the overlying epidermal cells, so that soon there is a large mass of sterile nucellar tissue capping the sporogenous cell. Presumably this description applies in a general way to the formation of the nucellar cap in all the forms, but in most cases the hypodermal cells are not distinguishable from the others, and the succession of divisions cannot be followed with any certainty. In Sciadopitys Lawson (175) describes the differentiation of a "pollen cushion" at the tip of the nucellus, consisting of a loose tissue of large thin-walled cells that receives the pollen grains. In general, the first clear evidence of sporogenous tissue is the appearance of one or more deep-lying mother cells, recognized first by their increasing size. It is probable that if there is a primary sporogenous cell formed as described above, it does not divide to produce sporogenous tissue, 
but is the mother cell, as in angiosperms. It seems more probable that in most cases mother cells are "picked out" directly from an undifferentiated mass of cells. In Widdringlonia (I 59) there is a remarkable early differentiation of the nucellus into peripheral and central regions, suggesting to $\mathrm{SAX}^{*} \mathrm{TON}$ that the central group of cells may be sporogenous; in fact, in a later paper $(176)$ be speaks

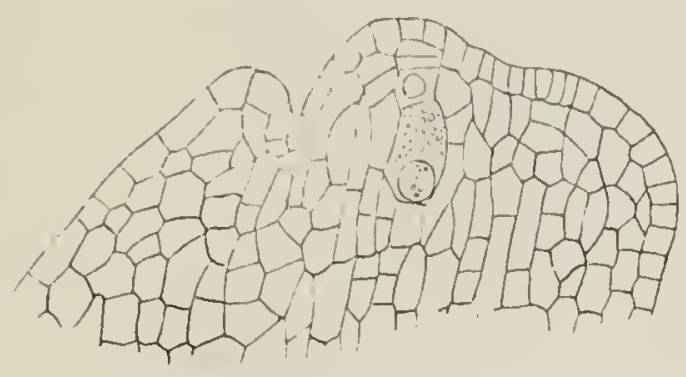

276

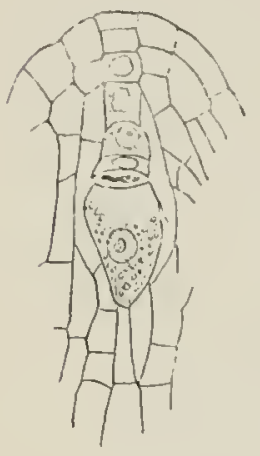

278

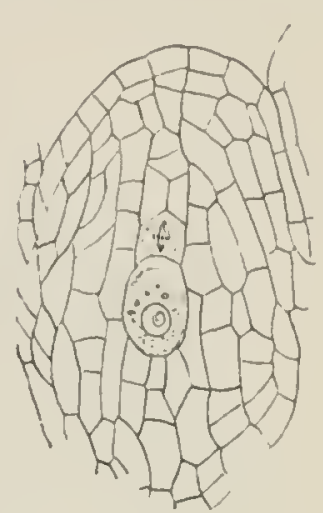

277

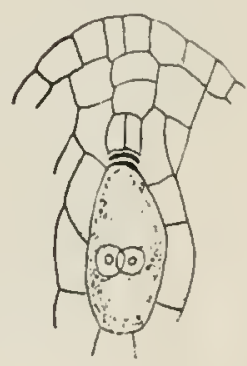

279

FIGS. 276-279.-Larix curopaea: fig. 276, longitudinal section of young orule, showing megaspore mother cell and tapetal cells, and at the left the beginning of the integument (March I); fig. 277, the mother cell has divided; fig. 278 , the row of megaspores, the innermost of which is functioning; fig. 279, the beginning of free nuclear division within the functioning megaspore; all $\times$ I50.-After Strasburger (25).

of "64 megaspore mother cells." In any event, only one of them was observed to function as a mother cell; although in the very similar Callitris two endosperm-filled sacs were observed lying in contact.

The number of distinct mother cells is variable. For example, in Pinus and Larix, and probably in all the Abietineae, the mother cell is usually solitary. Among the Taxodineae the mother cells are 
solitary in Taxodium ( 76$)$, three or four in Cryptomeria (93), and five or six in Sequoia (92); and among the Cupressineae, Thuja (86) occasionally has two or three mother cells, and Libocedrus (I3I) one to three. That the number of mother cells may be quite variable is shown by the case of Cunninghamia, in which one observer (64) reported several mother cells developing embryo sacs, and another

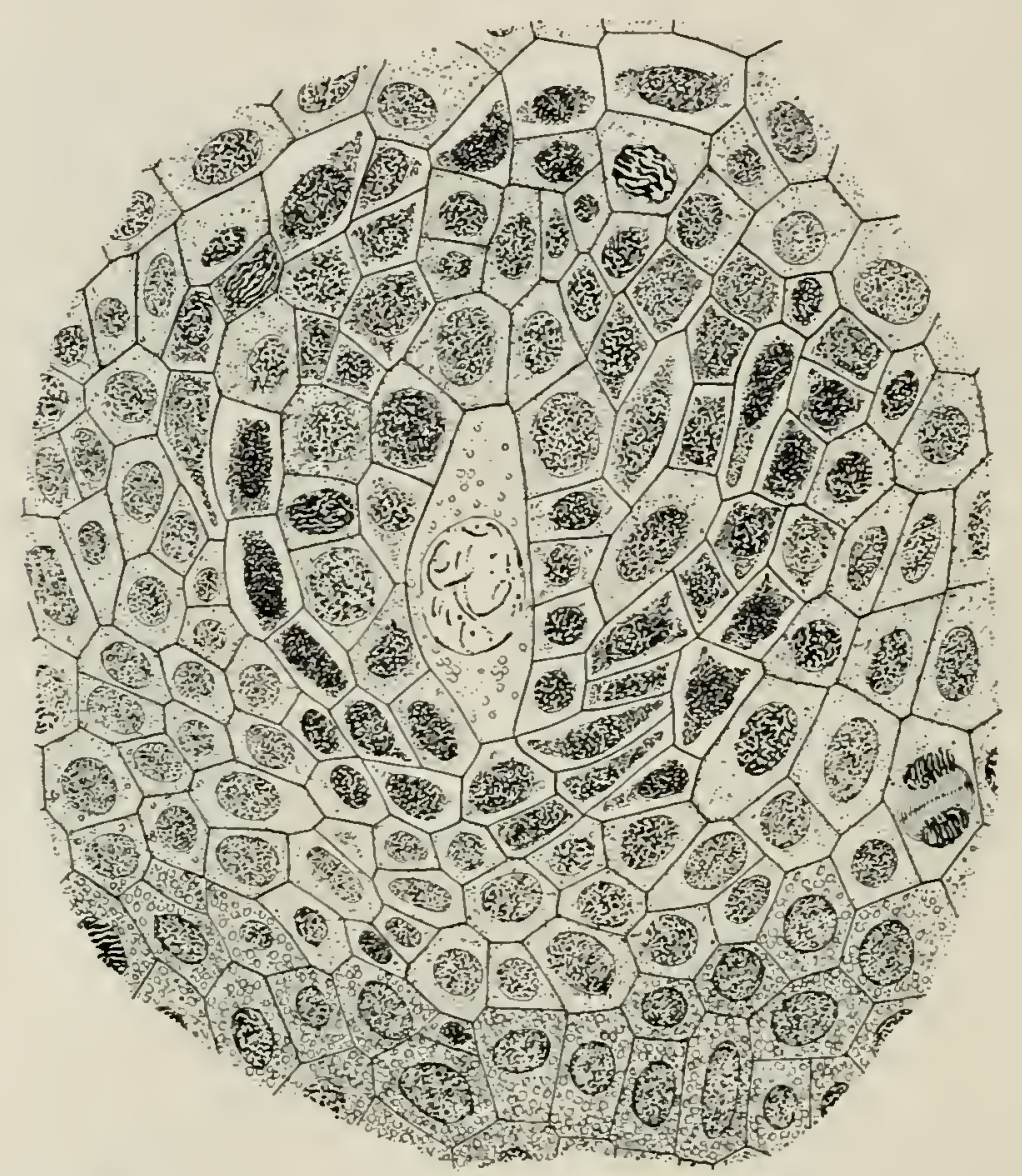

FIG. 280.-Pinus Laricio: longitudinal section of an ovule on June I, with megaspore mother cell in the center, surrounded by a region of more or less modified cells; nucleus of mother cell in prophase of reduction division; $\times_{500}$.

(I47, I80) reported a solitary mother cell. The season for the recognition and functioning of mother cells has been mentioned, ranging throughout all the spring months for different latitudes, but there is no clear evidence whether in any case the megasporangium passes the winter in the mother cell stage, as is often true of the microsporangium.

A well-marked feature of the Pinaceae is the derelopment of a more or less extensive zone of nutritive cells about the enlarging 
mother cell, which persists into the early stages of endosperm-formation (fig. 280). This conspicuous zone has been taken to represent sporogenous tissue; but the most usual mistake is to interpret it as endosperm tissue, overlooking the comparatively inconspicuous embryo sac, a mistake first made by HorMEISTER (Io) and later corrected by Strasburger (25). In the more recent literature of the subject it has been referred to as the "spongy tissue."

This differentiated region has been studied in considerable detail in Pinus (87) and Taxodium $(76)$, but it appears to be a general feature of Pinaceae, as distinct from Taxineae. In its later development it becomes differentiated into three zones: (I) a tapetal zone, consisting of large, glandular cells, that are evidently digestive and are very active during early endosperm-formation; (2) a tabular zone, consisting of flattened and finally disorganized cells; (3) a starch zone, consisting of cells rich in starch. This elaborate nutritive mechanism persists until the endosperm tissue invades the surrounding nucellar tissue. This region may not always be so complex as in Pinus, but the tapetal cells are always evident.

The megaspore mother cell, deeply placed in the nucellar tissue, initiates the two reduction divisions, and a linear tetrad is formed (fig. 28I). Sometimes the micropylar

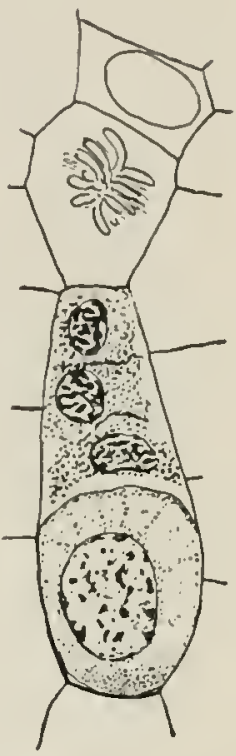

Fig. 28 I.-Pinus Laricio: a linear tetrad of four megaspores derived from the megaspore mother cell; the innermost megaspore enlarging and the others beginning to disintegrate; $\times 666$. daughter cell of the first division does not divide, so that there appears a row of three cells, as in Larix (25), Pseudotsuga (156), Taxodium $(76,86)$, and Juniperus (132), but the row of four cells has been observed in a sufficient number of cases to indicate that the full number of divisions is usual. In Sciadopitys, according to LAwson ( 175 ), the division of the mother cell nucleus is not accompanied by wall-formation, but walls appear in connection with the subsequent divisions of the two daughter nuclei; so that the tetrad comprises three cells, the middle one of which is binucleate. 'The 
tetrad is not always linear, Coker having reported $(85,86)$ that in Thuja, so far as he has observed, it is always tetrahedral. In case there are several mother cells, they may all form tetrads. In Sequoia sempervirens (92) the five or six mother cells form tetrads, and ten or twelve megaspores begin to germinate, only two or three continuing beyond the first division, and finally one becoming dominant (figs. 282,283 ). The sterile megaspores in this species are quite prominent,

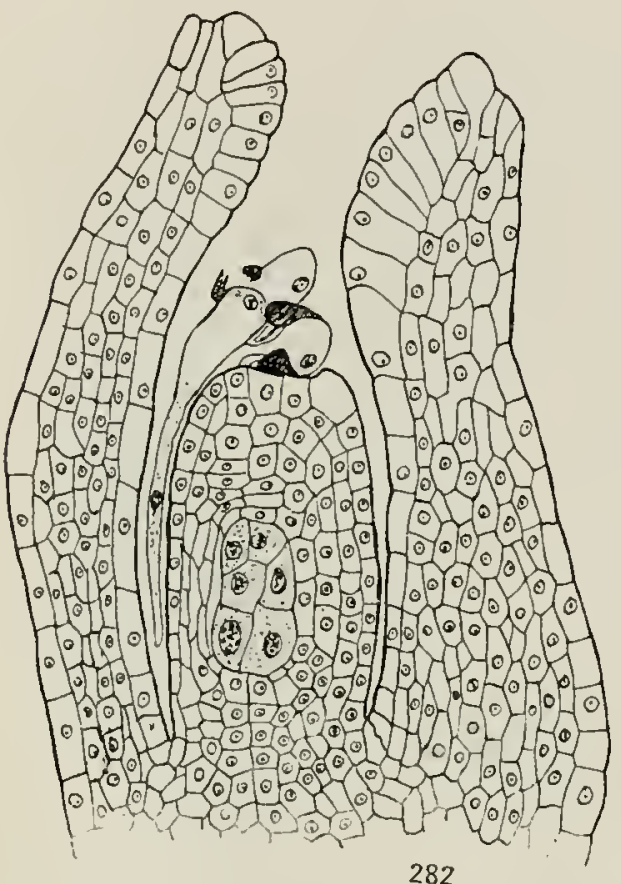

282

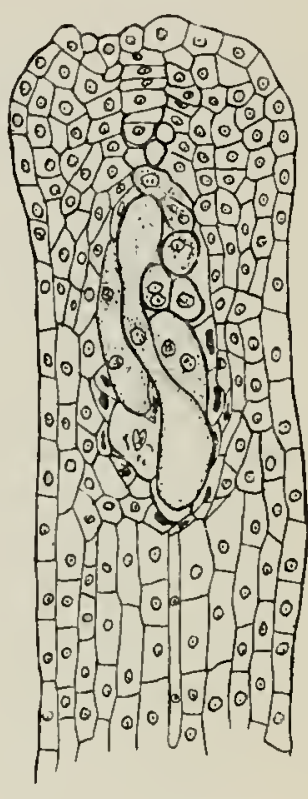

283

FIGS. 282, 283.-Sequoia sempervirens: fig. 282, longitudinal section of ovule, showing six megaspore mother cells; pollen tubes are growing down between nucellus and integument; March I2, 1902; $\times 8_{3}$; fig. $28_{3}$, longitudinal section of nucellus, showing eight germinating megaspores, each containing two nuclei; April 25, 1902; XII6.-After LAWSON (92).

being clustered about the upper third or fourth of the remarkably elongated functional megaspore (42). In Cryptomeria japonica (93) there are four tetrads formed, and the centrally placed megaspore of the group of twelve to sixteen functions. In Libocedrus decurrens (I3I) one to three tetrads appear, from which a single functioning megaspore is selected; and in Pinus silvestris $(36 x, \mathrm{I} 66)$ and Callitris two embryo sacs have been observed. It may be inferred that two or more mother cells and tetrads may occur in any of the Pinaceae, but thus far they seem to be especially characteristic of the Taxodineae and the Cupressineae. 
The chromosome numbers among gymnosperms seem to be prevailingly $\mathrm{I} 2$ and 24 , and the Pinaceac, so far as observed, conform to this, counts having been made in Pinus $(38,40,46,5 \mathrm{I})$, Larix (59), Thuja (72), Taxodium (76), Araucaria (104), and Callitris (159). In Sequoia sempervirens LAwson (92) obtained counts of I6 and 32 in the endosperm and first spindle of the embryo; and the same observer (93), without definite counting, has reported 9 or Io as the approximate haploid number in Cryplomeria, and 8 and 16 as the numbers in Sciadopitys (I75); while in Widdringtonia Saxton ( 159 ) has definitely counted 6 and I2.

\section{The gametophytes}

THE FEMALE GAMETOPHYTE

The development of the female gametophyte (endosperm) and of the archegonia of Pinaceae has long been known in outline for a few forms, through the early investigations of Hofmeistę (Io, I3) and Strasburger ( $15,18,22,25,3 \mathrm{I}$ ). The later investigations have filled in the outlines and have included a much wider range of forms. In general, the sequence of events is approximately uniform in all the Pinaceae observed, but differences in detail have been discovered whose significance and range are at present uncertain. It should be remembered that the megaspore begins to germinate early in the history of the ovule, that when its membrane becomes the boundary of the embryo sac there is still much of the nucellar tissue to be developed, and that the membrane continues to grow along with the growing endosperm.

The division of the megaspore nucleus is followed by a series of simultaneous nuclear divisions, until a large number of free nuclei have been produced. Early in this series of divisions the embryo sac, with its increasing capacity, begins to become vacuolate, and the large central vacuole restricts the free nuclei to the layer of cytoplasm lining the wall (fig. 284). In this parietal position free nuclear division continues. The number of free nuclei produced before wallformation is probably very indefinite. The case of Tavus (52), with its eight successive divisions resulting in 256 free nuclei, has been applied with too much assurance to Pinaceae. It may be that this number is a very common one among Pinaceae, but Miss Ferguson 
(87) estimated that in cases of Pinus under her observation 2,000 free nuclei were produced before wall-formation. This would mean approximately eleven successive divisions, but there is no reason to

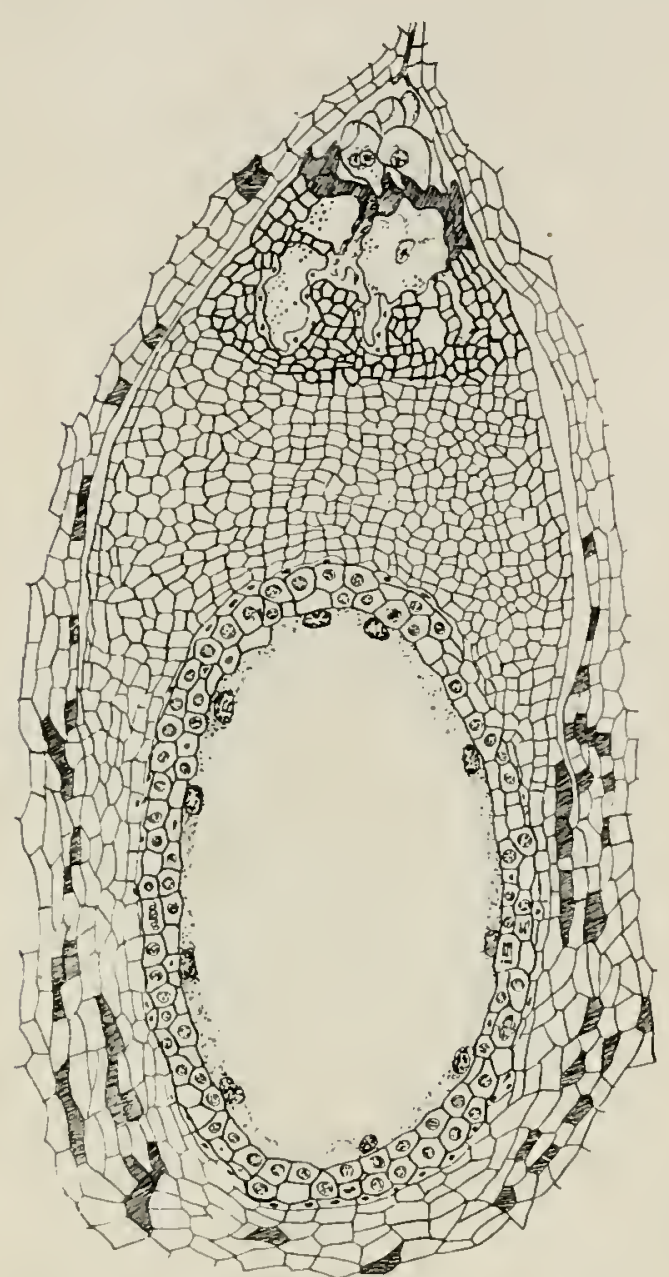

FIG. 284.-Pinus Strobus: longitudinal section of ovule, May 26, I 898 ; gametophyte in the free nuclear condition, and surrounding it is a jacket of spongy tissue mostly two cells thick; X62.--After Miss Ferguson (87). suppose that the regularity of the early divisions is continued by the later ones. This period of free nuclear division may be spoken of as the first stage of endosperm development.

The second stage of development is that of wall-formation, during which walls appear among the free and usually equally distributed nuclei, and a parietal layer of cells is formed, which are open toward the center of the sac. The third stage is that of centripetal growth, the parietal tissue growing toward the center of the sac from every direction, until the sac becomes filled up with tissue. In this centripetal growth the innermost cells are always open toward the center, and may become quite elongated. When the center has been reached by the abutting cells, end walls are formed by each open cell and the tissue is continuous throughout the sac. It will be noted that this outline is in general that which was given for Cycadales and Ginkgoales.

The details of the centripetal growth have been found to vary widely, but this growth has been studied in a close series in very few forms, so that no general conclusions are possible as yet. The case of Sequoia sempervirens was first described by ARNoldi (49) and later by LAwson (92). Free nuclear division occurs in the two 
extremities of the sac, so that when wall-formation occurs three distinct parietal regions are apparent (upper, middlle, and lower), the ends of the sac becoming filled with compact tissue while the middle region is hardly beyond the stage of free nuclei. In filling up the center of the sac with tissue, the belated middle region grows centripetally, its inner cells being open toward the center of the sac, as
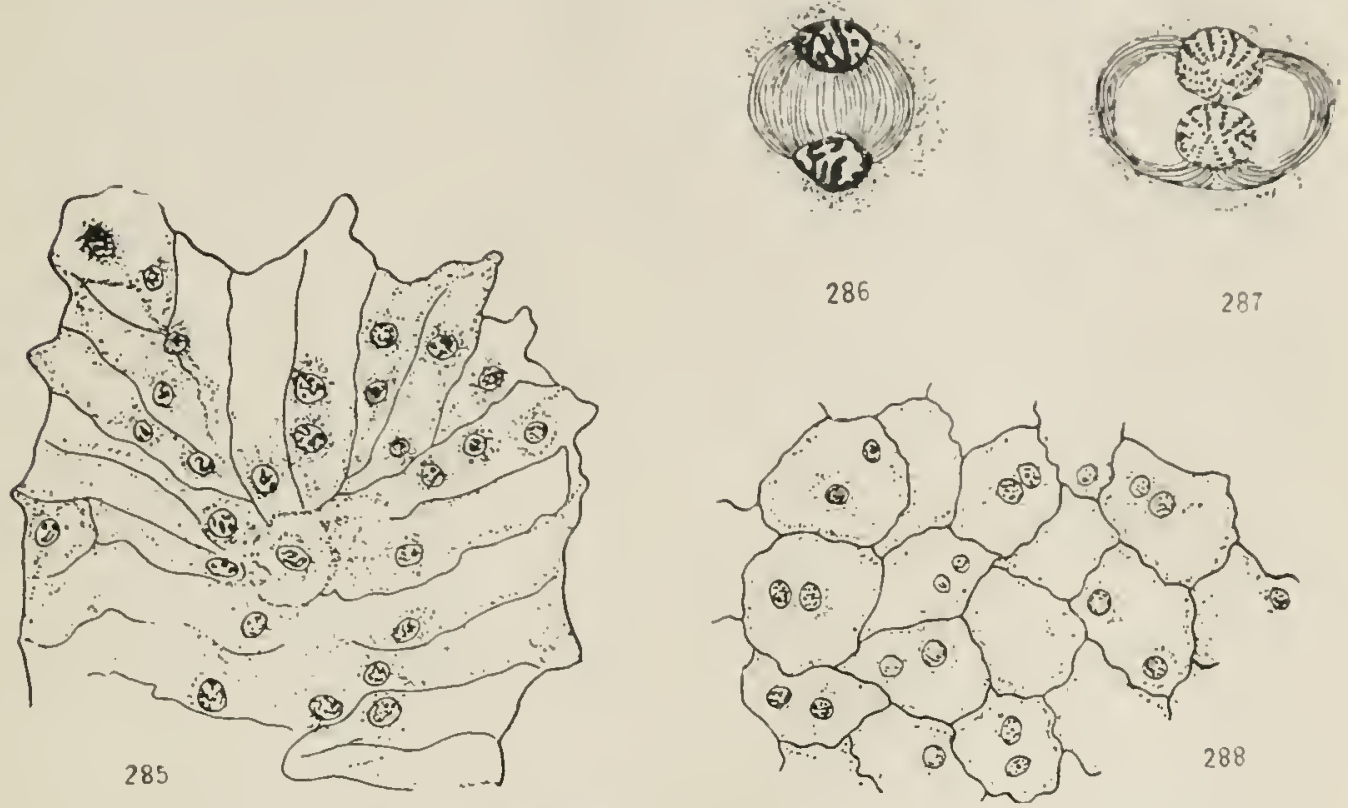

Figs. 285-288.-Cryptomeria japonica: development of the endosperm; fig. 285 , longitudinal section of upper portion of endosperm showing multinucleate condition and also that the walls are incomplete; May 26, $1902 ; \times 235 ;$ fig. 286 , telophase of the mitosis which is to result in the formation of a binucleate cell like those shown in

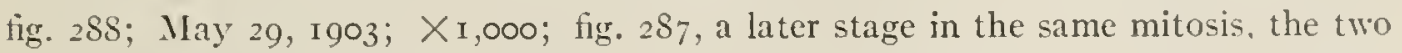
daughter nuclei completely inclosed by the kinoplasmic fibrils; $\times_{1,000 ;}$ fig. 288 , portion of the endosperm soon after free cell-formation; the membrane formed by the kinoplasmic fibrils has inclosed both daughter nuclei; the free cells crowded together resemble a tissue; Nay 29, 1903; X320.-After Lawsox (93).

usual. The details of this centripetal growth, as given by Arsoldr, are that when the centripetally growing walls have reached the center and the end walls have been formed, the result is a scries of radially elongated cells, which he calls "alveoli." In these cells nuclear division with wall-formation occurs, so that each alveolus becomes divided into several cells. In investigating Sequoia gigantea, the same investigator $(64)$ discovered that the endosperm development is uniform, and with no such regional differences and cell-formation by alveoli as are exhibited by its fellow species. LAwson's account 
(92) of the first wall-formation in Sequoia sempervirens is probably true for the first walls of endosperm in general. At the last division of the free nuclei (in this case at the two extremities of the sac), adjacent nuclei remain connected by the spindle fibers, which increase in number, and upon them cell plates are formed.

The details of endosperm-formation in Cryptomeria, howerer, seem to be the most peculiar (93). The sac is filled with tissue by centripetal growth as usual, but the formation of the permanent endosperm is the remarkable feature. The "primary" endosperm cells, that is, those open toward the center of the sac, elongate centripetally and by free nuclear division beome multinucleate (fig. 285 ). There is then a stage when "hundreds" of these nuclei divide about simultaneously, with no formation of a cell plate; but the kinoplasmic fibrils extending between each pair of daughter nuclei increase in number and curve outward on all sides, until both nuclei are completely surrounded by a sheath of fibrils, which fuse to form an inresting membrane. This method of free cell-formation goes on throughout the whole endosperm except in the region of the archegonium initials; the cells become crowded, thus resembling ordinary tissue composed of binucleate cells; and after this nuclear division accompanied by wall plates proceeds in the usual way (figs. 285-288).

In considering these cases of Sequoia and Cryptomeria, the secondary formation of cells by centripetally growing primary ones ("alveoli" of ARNOLDI) is common to both, whether the details of secondary cell-formation are the same or not. There is also suggested the possibility of a permanent secondary tissue which replaces the primary tissue, the development of the latter usually having closed previous investigations in this direction. Random reports of endosperm cells that are uninucleate, or binucleate, or multinucleate may find their explanation in stages of the development of permanent endosperm tissue.

More recently LAwsox ( ${ }_{5} 56$ ) has studied Pseudotsuga, and finds that in that form also free nuclear division occurs in the primary endosperm cells before cross-walls appear to form the uninucleate cells of the permanent tissue. SAxtox ( 159,176 ) has observed the same free nuclear division in the primary endosperm cells of Widdringtonia, but in this case the cells ustually become only binucleate (occa- 
sionally multinucleate), and this binucleate or multinucleate condition persists in the permanent tissue, as if the last stage of other forms were omitted in Widdringtonia.

The development of the archegonium follows the same course as that described for Cycadales and Ginkgoales. The archegonium initials, selected usually from the superficial micropylar cells of the endosperm, become recognizable by their size at various stages in the development of the endosperm tissue. In some cases they are differentiated almost as soon as wall-formation has occurred in the micropylar region; in other cases they are not evident until the endosperm tissue has reached an advanced stage of growth; and between these two extremes there is every intergrade. There is evident among Pinaceae, and notably among Coniferales in gencral, a tendency to develop archegonia earlier and earlier in the ontogeny of the gametophyte, a tendency that expresses itself somewhat irregularly but none the less clearly, and that reaches its extreme expression in the appearance of archegonium initials immediately after the free nuclear stage of the gametophyte (as in Torreya). The significance of this tendency may be appreciated when it is remembered that among Gnetales it has resulted in the differentiation of eggs during the free nuclear stage of the gametophyte, and therefore in the elimination of archegonia. This tendency will be discussed more fully later, in connection with a general consideration of evolutionary tendencies among gymnosperms.

An initial cell, recognizable usually in May or June, enlarges considerably and then divides by a periclinal wall into the primary neck cell (outer) and the central cell (inner) (figs. 289, 290). The primary neck cell divides by an anticlinal wall, and this division may be followed by others, the number of cells in the archegonium necks of Pinaceae being very variable. The adjacent cells of the endosperm grow faster than the neck cells, so that the neck opens in the bottom of a funnel-shaped depression, known as the archegonial chamber.

The central cell begins a remarkable increase in size, and about it a definite nutritive jacket of endosperm cells becomes differentiated, which may be referred to as the archegonial jacket or tapetum, and which must not be confused with he nucellar tapetum that invests 
the mother cell and its successors (fig. 29I). The cells of this jacket, which invests not only the central cell but also the succeeding egg, develop the usual features of tapetal cells, with densely staining cytoplasm and large nuclei; but their special feature is the conspicuous thickening and pitting of the walls bounding the central cell (and egg). At first it was supposed that through these pits the jacket cells emptied their contents into the enlarging central cell and egg

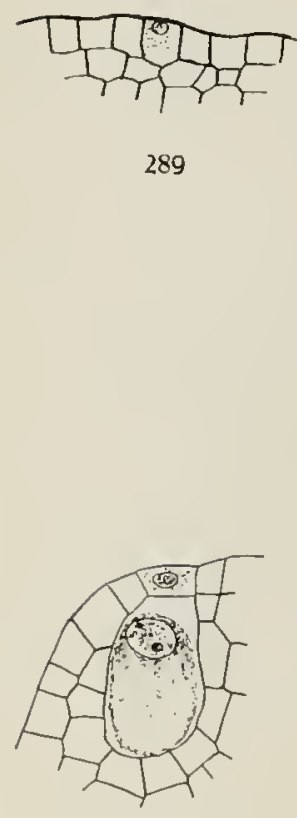

290

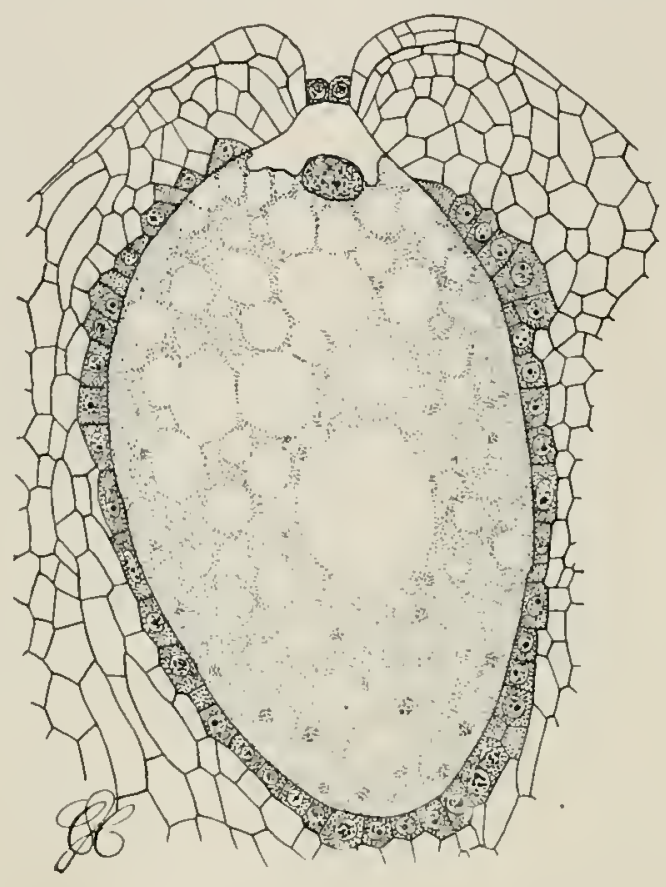

291

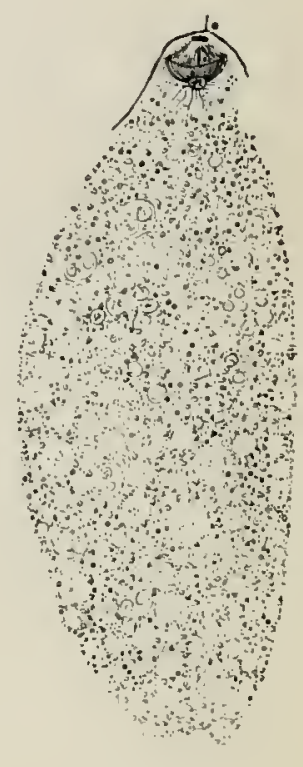

292

Figs. 289-292.-Pinus Laricio: development of the archegonium; fig. 289, archegonium initial, May 28; fig. 290, neck and central cells, June 2 ; fig. $29 \mathrm{I}$, central cell just before cutting off ventral canal cell, June I 8 ; fig. 292, cutting off ventral canal cell, June $2 \mathrm{I} ; \times$ IO4.

(28), including the bodily transfer of their nuclei. In this way the central cell and egg were thought to be packed with food, their cytoplasm being filled with large and deeply staining masses (more prominent in the egg) which were regarded as the nuclei contributed by the jacket cells. Even after Strasburger had shown that these deeply staining masses are not nuclear in nature, but that the best organized are the so-called "proteid vacuoles," ARNOLDr (55) described the behavior of the migrating nuclei, reporting them to become amoeboid in the jacket cells, to squeeze through the pits, and to regain their form in the central cell and egg. Nuclei were also 
said to pass from the next outer layer into the cells of the jacket, and the jacket cells were often seen emptied of all their contents. These details of observation have been mentioned chiefly to illustrate the dangers of such interpretations when the sections are more than one layer of cells in thickness. Migrating nuclei squeezing through walls can often be seen by cxamining several superimposed layers of cells. It is now known (II7) that these large pits of the archegonial jacket cells, in early stages, are closed by a membrane, which is perforated only by Plasmodesmen, so that under these conditions the bodily transfer of nuclei or any solid material is impossible. Just what the situation is in later stages is uncertain.

The central cell enlarges and receives food material for two or three weeks, its nucleus retaining the apical position, when it divides about simultaneously with the division of the body cell in the pollen tube $\left(76,1_{57}\right)$, to form the very small ventral canal cell and the very large egg (figs. 292-297). The ventral canal cell disorganizes and disappears with more or less rapidity; while the egg nucleus begins immediately a very rapid and a very great enlargement. It moves toward the center of the egg, and attains a size that seems out of all proportion to its original bulk and to the time involved. During maturation of the egg the characteristic changes occur in the nucleus which were described in connection with the egg of Cycadales.

The notable feature in connection with the development of this archegonium, as contrasted with that of pteridophytes, is the complete elimination of the neck canal cells. The general tendency among pteridophytes is to reduce the number of these cells, and among Filicales the reduction has reached the stage of a single uninucleate cell; but among gymnosperms even this has disappeared, and there is no trace of neck canal cells.

The behavior and character of the nucleus of the ventral canal cell, which is sister to the egg, has attracted attention. Usually its disorganization is very prompt, often beginning before it returns to the resting stage; and afterward its disorganized remains may be seen in various stages, even to the early stages of embryo-formation. The nuclei of the ventral canal cell and of the egg are at first exactly similar, apparently differing only in the quantity of cytoplasm involved in each case, and suggest that the ventral canal cell is an abortive 
egg (46). This view is confirmed by cases in Pinus in which the ventral canal cell is very much larger than usual, and its nucleus has reached the size of the egg nucleus and has passed through the same

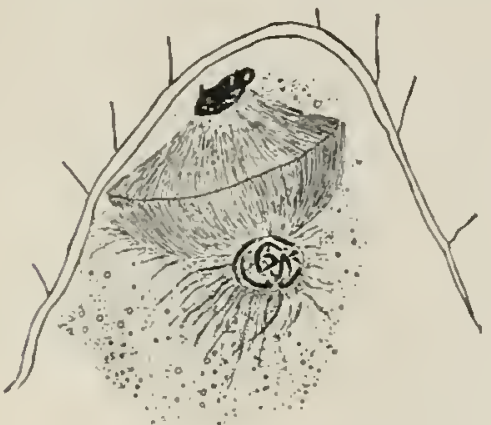

293

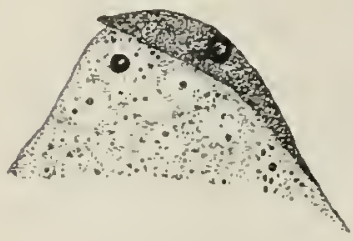

294

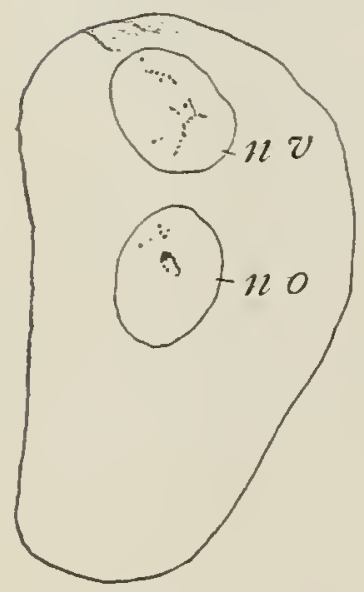

297

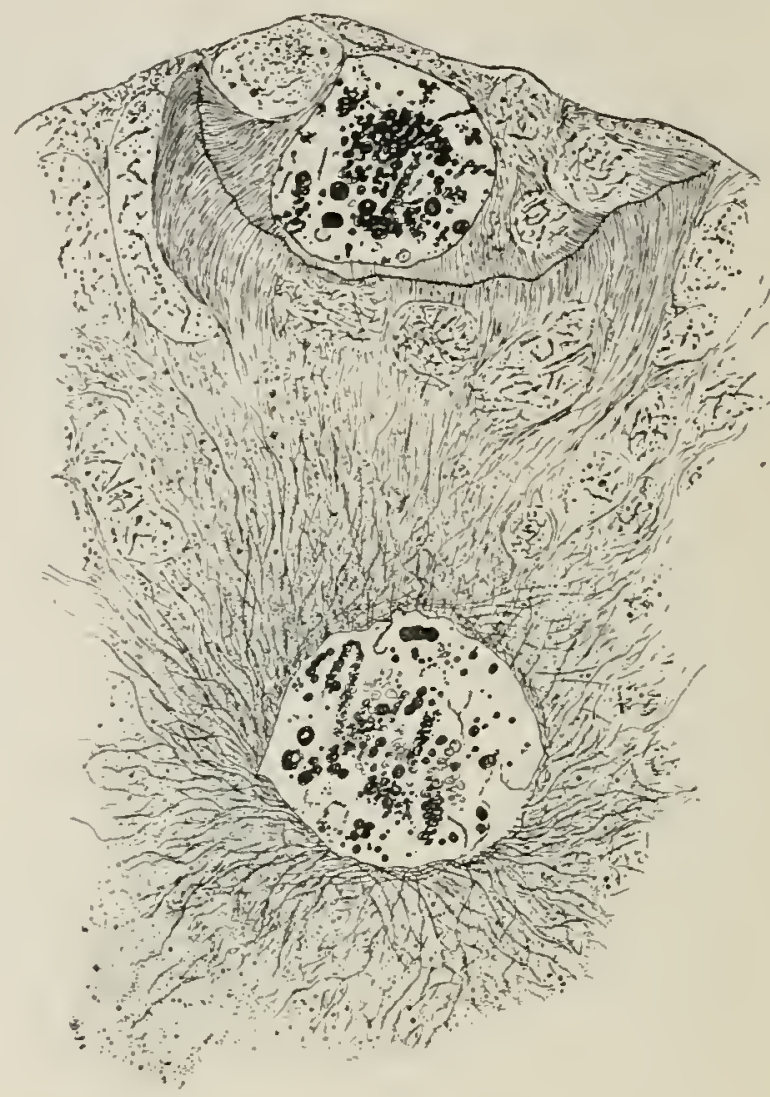

295

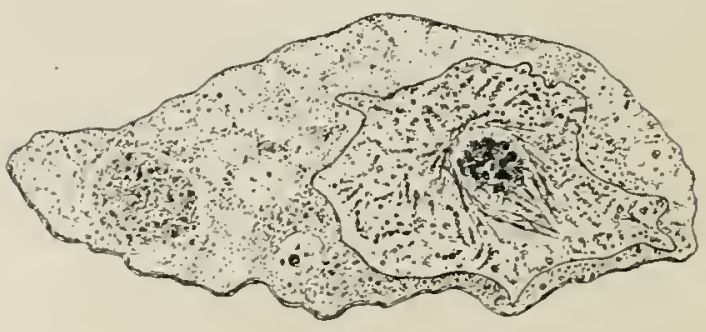

296

Figs. 293-297.-Pinus Laricio: formation of ventral canal cell; fig. 293, typical division, the ventral canal nucleus beginning to disorganize and the egg nucleus beginning to enlarge; $\times_{500}$; fig. 294 , disorganizing ventral canal cell; $\times_{500}$;ig. 295 , an unusually large spindle in cutting off rentral canal cell, the two nuclei being the same size and showing the same derelopmental changes; $X_{500}$; fig. 296 , a large rentral canal cell formed in this way; $\times_{500}$; fig. 297 , the wall separating the ventral canal cell from the egg has broken down, leaving both nuclei free in the cytoplasm of the egg; ni, nucleus of ventral canal cell; no, nucleus of egg; XIOO.-After ChamberLAIN $(5 \mathrm{I})$. 
maturation changes (5I. I26). A similar case was reported for Ginkgo by Irevo. Such a nucleus appears to be ready for fertilization. In Abies balsamea ( $\mathrm{O} g \mathrm{a}$ ) the rentral canal nucleus usually enlarges somewhat and persists until fertilization. There are also cases in which the wall separating such a ventral nucleus from the egg has been obserred to disappear, learing two similar nuclei free in the cytoplasm of the egg (5I); and such cqual nuclei have been observed in contact (fig. $298)$, as if fusing $(23,44)$. It scems reasonable to infer that the rentral canal cell is an abortive egg, which is occasionally organized as an egg, and which in that condition may be fertilized $\left(7^{2}\right)$, or may fuse with the egg nucleus. The rentral nucleus has also been observed to divide (after the fertilization of the egg), either by amitosis $(76)$ or mitosis $(72)$.

The account of the archegonium given above applies in general outline to all the Pinaceae, but

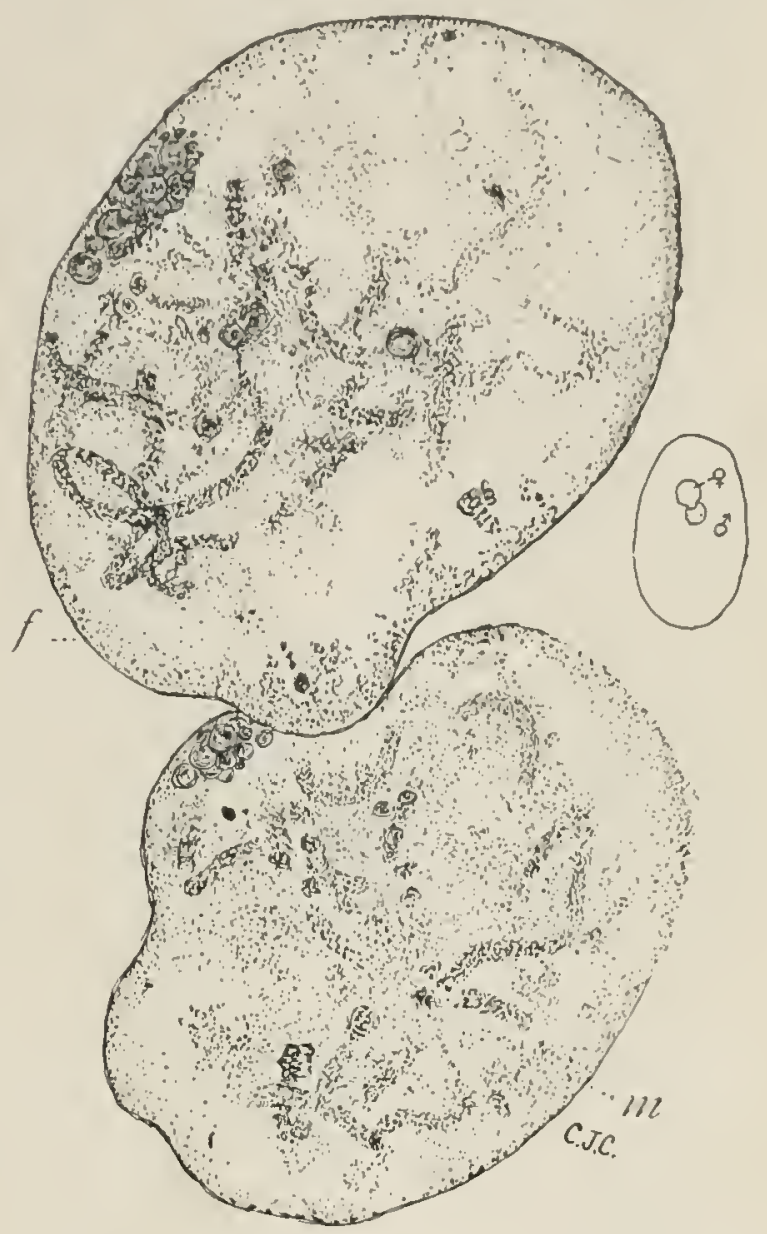

FIG. 29S-Pinus Laricio: conjugation of two nuclei which were described as male $(m)$ and female $(f)$, but which are doubtless the nuclei of the egg and ventral canal cell, as in fig. 297; both nuclei are in an early spirem stage; it is interesting to mote that the first record of fertilization in gymnosperms (Picea, reported by StrASBURger 22) was very probably a case of this kind; $\times 500 .-$ After Coulter $(44)$. there are differences among the tribes that must be considered.

Among the Abietineae the number of archegonia ranges from one to seren, with two to five as the usual range, the smallest among Pinaceae. The number of neck cells may be said to average about eight, arranged in two tiers, with four cells in each tier; but there 
may be only one tier or more than two tiers, more than four cells in each tier are known to occur, in some cases there are only two cells in a tier, and in Tsuga canadensis $(37,60)$ the neck is frequently two-celled, but often consists of three or four cells. It should be kept in mind that a two-celled neck is a feature of Cycadales and Ginkgoales, and for that reason it has been assumed to be the primitive type of neck. So far as we have observed, however, there is no typical number for neck cells, the two-celled neck occurring indiscriminately among Pinaceae, the number of cells developing apparently holding no definite relation to phylogenetic connections. A notable feature of the Abietineae is the formation of a true ventral canal cell, a distinct wall plate cutting it off from the egg. This is true only of the Abietineae among conifers; and if the elimination of the separating wall plate, resulting in the ventral canal cell being represented only by its nucleus, is an evidence of a further stage in the reduction of the axial row, the Abietineae are the most primitive conifers in this character. Even among them, as mentioned abore, occasionally the wall sometimes disappears, leaving the rentral nucleus free.

Among the Taxodineae the number of archegonia ranges from four to sixty (4-6 in Sciadopitys, 8-15 in Cryptomeria, Io-35 in Taxodium, 60 in Sequoia sempervirens), which is the largest range among Pinaceae. The number of neck cells ranges from two to eight (Sequoia 2 and occasionally 4, Taxodium 2-6 or more, Cryptomeria usually 4, Sciadopitys 4-8), forming a single tier. The neck cells of Sciadopitys are peculiar in being vertically elongated. In Sequoia sempervirens LAwSON reports (92) that the very numerous archegonium initials are differentiated deep in the endosperm of the micropylar region, and that the necks are pushed to the periphery of the endosperm by the elongating central cells, being directed toward the nearest pollen tubes, which have taken their positions before the archegonia were formed (92). It is in Cunninghamia ( $147, \mathrm{I} 80$ ) that the archegonium initials appear very early in the ontogeny of the gametophyte. A significant feature in connection with the archegonia of this tribe is their grouping, in some genera, into what may be called an archegonium complex. This means that the archegonia are grouped in contact, invested by a common archegonial jacket, and with a common archegonial chamber. Since 
this is a feature of the Cupressineae, its occurrence among the T'axodinea has tempted various investigators to use it as a reason for transferring certain genera of that tribe to the Taxodincae. The two tribes are confessedly artificial, but such a character is not a safe one, for the grouping of archegonia is often indefinite and variable. This complex has been found in Sequoia $(50,64)$, Taxodium (76), Cryptomeria (93), and Cunninghamia (147, I80), but it does not occur in Sciadopitys (175). Both species of Sequoia show an interesting transition between separate archegonia and an archegonial complex, the numerous archegonia occurring singly or in groups. In the three other genera observed there is sometimes a layer of endosperm cells between adjacent archegonia; and in Cumninghamia ( $147, \mathrm{I} 80$ ) the group of archegonia ( 5 in the preparation figured by Miyake) surrounds a central mass of endosperm tissue. Among gymnosperms there seems to be a sequence in the distribution of archegonia, the most primitive situation being numerous scattered archegonia, followed by fewer archegonia derived from superficial cells of the micropylar region, and then by their organization into a complex. In none of the Taxodineae has a ventral canal cell been discovered, but in all of them a ventral nucleus is cut off, which is sometimes very ephemeral.

Among the Cupressineae the number of archegonia ranges from five to about one hundred, the number in Thuija (72) averaging six, in Jumiperus communis ( 173 ) ranging from four to ten in a single complex, in Libocedrus (I3I) ranging from six to twenty-four in the complex, and in Widdringtonia ( 159,176 ) ranging from thirty to one hundred. The neck cells appear to be always in a single tier, and vary in number between two and eight, the number for Juniperus ( I $_{3}$ ) and Widdringtonia ( 176 ) being usually four, and Thuja (72) ranging from two to six. In Thuja the neck cells begin to disorganize as soon as they are formed, and are almost completely absorbed by the enlarging central cell (figs. 299, 300). In the whole tribe the archegonial complex is a feature, being compactly organizcd, with a distinct and common jacket and a common chamber. No ventral canal cell is formed, but the ventral nucleus is always cut off, as among the Taxodineae. The case of Widdringtonia ( 159, I 76 ) descrves special mention, and it scems to be duplicated in Callitris. Before 

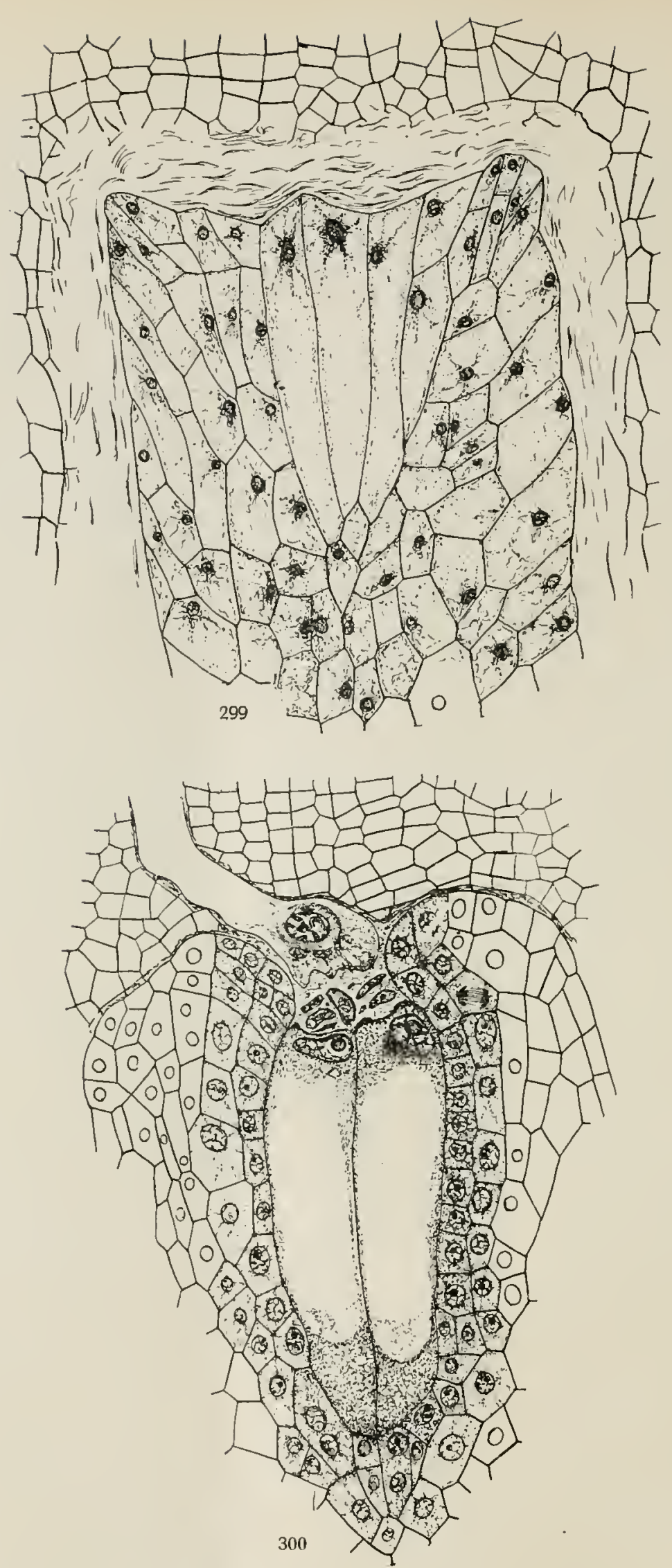

FIGS. 299, 300.-Thuja occidentalis: archegonium complex; fig. 299, longitudinal section of upper portion of endosperm with three of the elongated archegonium initials; $X_{450}$; fig. 300 , later stage with necks breaking down; the nuclei of the central cells have not yet divided to form the ventral canal nucleus and the egg nucleus; the pollen tube, with its body cell and stalk and tube nuclei, has almost reached the archegonium

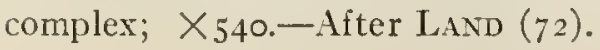


the archegonium initials are recognizable, the solitary pollen tube has passed down the surface of the endosperm just within the megaspore membrane, until it lies in contact with the upper third or eren the upper half of the elongated gametophyte, bearing in its tip the body cell. This position seems to determine the selection of archegonium initials, which begin to appear in groups beneath the surface, the groups being in the upper half of the gametophyte but not at its micropylar extremity. There is hardly a trace of a jacket layer, and no distinct complex. A very ephemeral ventral nucleus is cut off. The whole situation is more suggestive of Sequoia and the araucarians than of any other known forms.

Among the Araucarineae sufficient work has not been done to justify a general statement, but so far as known (II 7 ) the archegonia are numerous and scattered irregularly, as in Sequoia, and some of them are deep-seated, as in the same genus.

As the endosperm grows, the megaspore membrane grows also and thickens, finally differentiating into two layers, the outer one being completely suberized and the inner one containing cellulose. THomson (IO8) has made a comparative study of this membrane and finds it thickest and most completely developed among the Coniferales in the Abietineae; less dereloped by the Taxodineae and Cupressineae, among which it may be quite poorly developed, as in Libocedrus (I3I); while among the Araucarineae the suberized outer layer is wanting. He concludes that the condition of this membrane may be used as a test of the relative age of the gymnosperm groups, which when applied among Coniferales makes Abietineae the most ancient and Taxineae the most recent, in the latter tribe the megaspore membrane not appreciably dereloping.

Ordinarily the endosperm invades the tissue of the nucellus uniformly, but among the Araucarineae (I2I) this invasion may be irregular, resulting in an endosperm with a more or less dissected contour. This is the so-called "ruminated" endosperm, which of course is a misnomer, since it is the endosperm that is "ruminating" the nucellus. This unusual character among gymnosperms is also strongly developed by Torreya, in which connection it will be considered more in detail. 


\section{THE MALE GAMETOPHYTE}

The male gametophyte of Pinaceae has long been known in a general way, but the present knowledge of the functions of the cells dates from BelajefF's work in I89I on Jumiperus (33), and StrasBURGER'S work in I892 on a wider range of forms, notably Larix and Cupressus (38). Every year since has increased the number of forms observed, until now a fairly complete knowledge of the principal features of the male gametophyte is available. The onto-

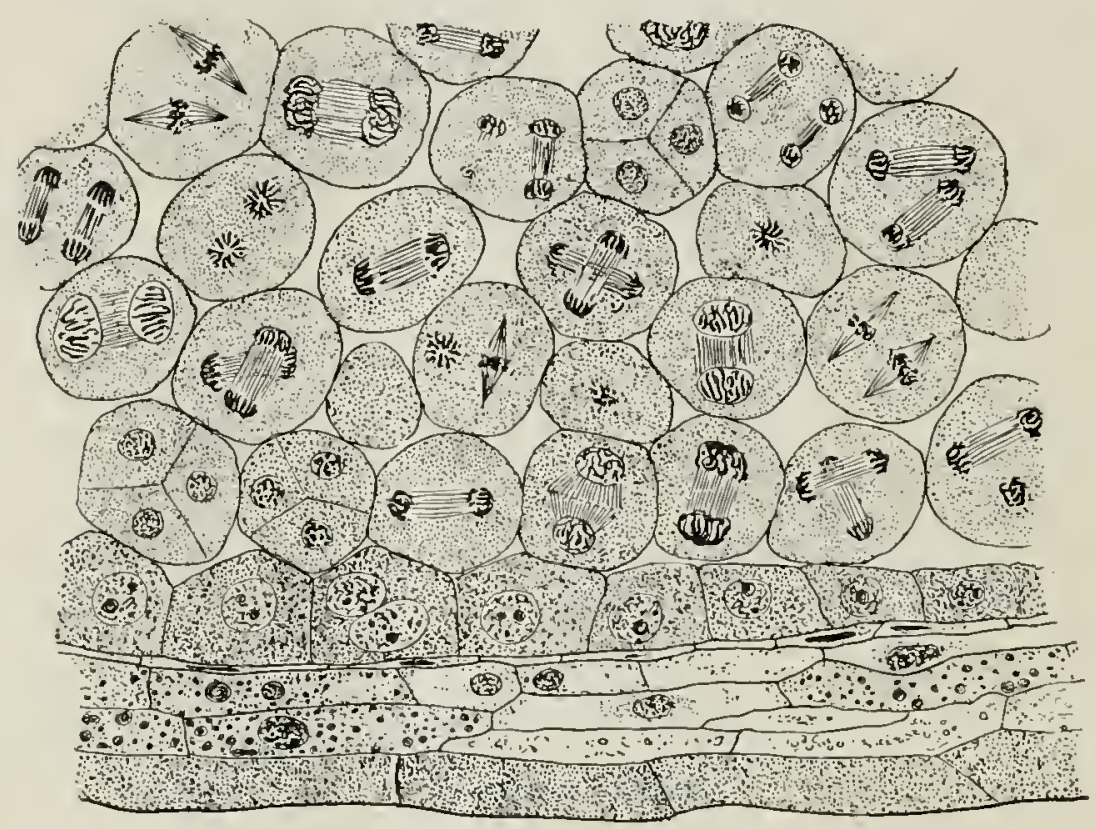

FIG. 301.-Pinus Laricio: part of microsporangium showing mitosis in pollen mother cells, May $3 ; \times 500$.

geny is comparatively uniform, so that a single account will include a general outline for all forms. For this purpose, the development of the male gametophyte of Pinus Laricio will be used.

About May 9 (in Chicago) the nucleus of the microspore of $P$. Laricio enlarges for the first division (fig. 305), a spindle is formed rapidly (fig. 306), and an equal division follows. Before the cell plate is organized, the nucleus nearer to the wall of the spore begins to disorganize, and the other begins to enlarge (fig. 307). In this way a lenticular and disorganizing cell is cut off against the spore wall (fig. 308). A second division follows immediately, the spindle being observed about May 25 (fig. 309). This division is a repetition 
of the first in details, and the two lenticular cells disorganize rapidly (fig. 3IO), become flattened against the spore wall, and very soon

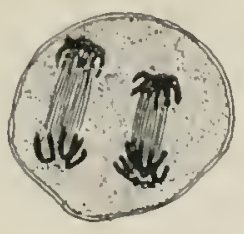

302

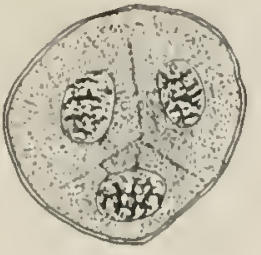

303

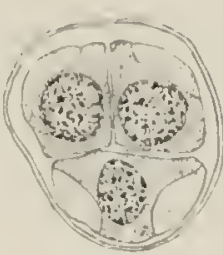

304

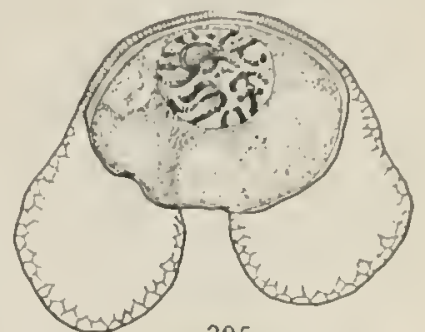

305

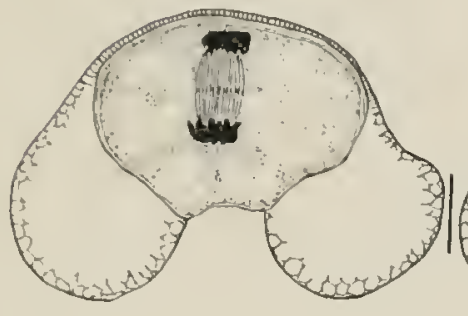

306
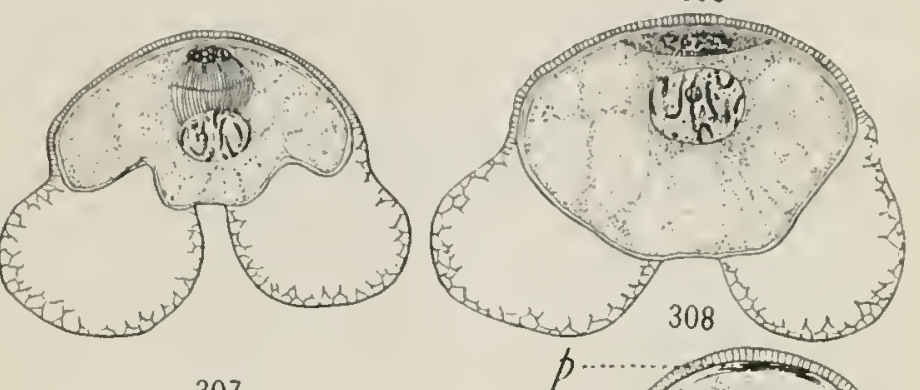

307

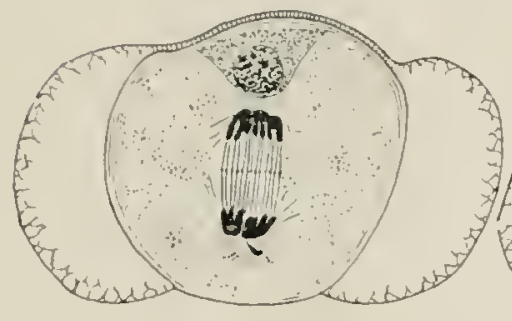

309
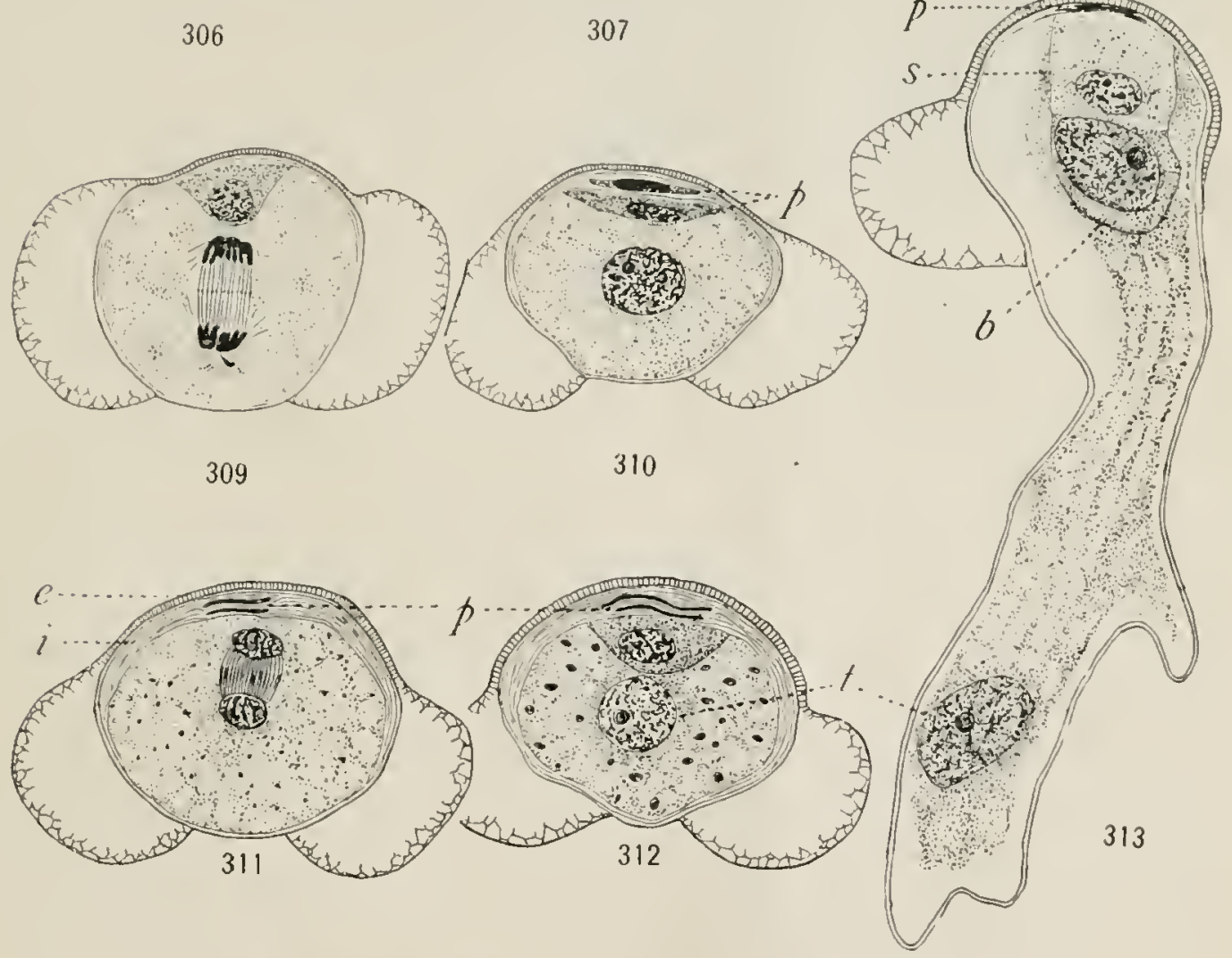

Figs. 302-3I3.-Pinus Laricio: a series from the formation of tetrads to the development of the pollen tube; $p$, prothallial cells; $s$, stalk cell; $b$, body cell; " $t$, tube nucleus; figs. 302, 303, May 3; fig. 304, May 1o; figs. 305-308, May 20; figs. 309-3II. May 25; fig. 3 I2, June 15 ; fig. 313, May r, nearly a vear after the stage shown in fig. 312 ; the exine $(e)$ is shaded with short radial lines, and the intine (i) with longitudinal lines; $\times 600$. 
appear merely as two thin and darkly staining disks, which are overgrown rapidly by the intine. These two eranescent cells represent the only vestige of the regetative tissue of the male gametophyte, and hence are called regetative (sometimes prothallial) cells. It will be recalled that only one such cell appears among the cycads, and that it persists; while in Ginkgo two appear, the first disorganizing while the second one persists.

The third (large) cell, which is sister to the second evanescent regetative cell, is an antheridial cell in the sense that it gives rise to the series of cells that represent the antheridium in function, but

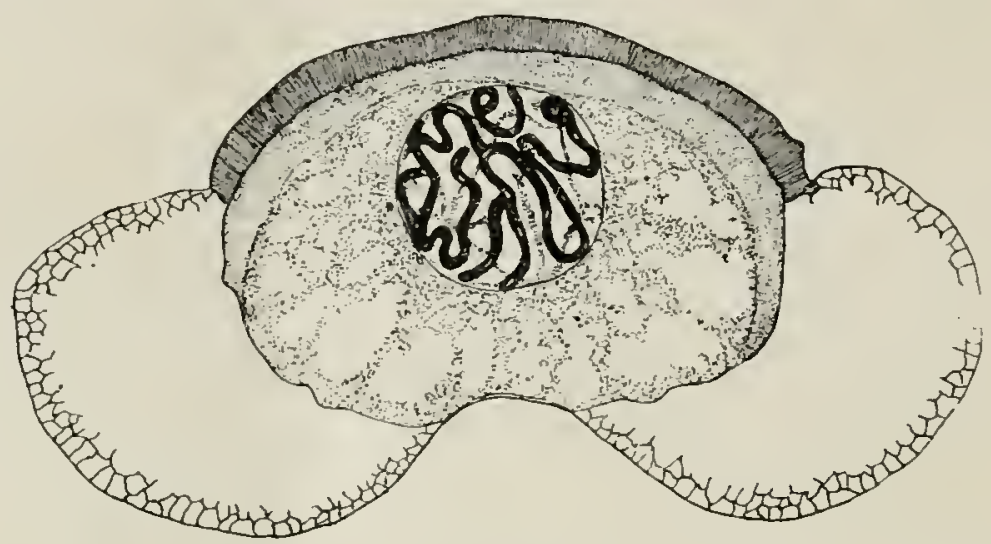

FIG. 3I4.-Pinus Strobus: microspore with nucleus in prophase of first division; the broad dotted portion of the wall was described as a third coat; June 7, I 898 ; XSio.-After Miss Ferguson $\left(8_{7}\right)$.

not at all in structure. The division of this cell follows immediately, giving rise to the generative cell (cut off against the evanescent vegetative cells) and the tube cell (the larger portion of the antheridial cell, containing the tube nucleus). This conspicuous tube nucleus was regarded as the generative nucleus until I89I, when BELAJEFF (33) discovered its true function. The exine and intine are differentiated quite early, and both are thickest at the prothallial end of the spore (figs. 305-3I2). Miss FERGuson (87) described a third coat, but it was evidently only the thicker intine of the basal region of the spore (fig. 3I4).

No further division takes place until the following spring, a period of about eleven months, and in this condition pollination occurs. As the pollen is being shed, a drop of mucilaginous substance secreted by the upper part of the nucellus appears at the apex of the ovule, 
and the pollen, caught in this pollination drop, is conveyed to the nucellus (fig. 3I5). The pollen tube begins to grow into the nucellus as soon as the spore is deposited, and continues to develop until it is checked by cold weather. The next spring the tube begins to renew its penetration of the nucellus during April, about a year after the pollen mother cell entered upon the reduction divisions, the large tube nucleus enters the tube, and at the same time the generative cell divides into the stalk cell (toward the regetative cells) and the body cell (toward the free cavity of the spore) (fig. 3I3). The stalk cell is sterile (persistently so among gymnosperms), and may represent the stalk cell of an antheridium, while the body cell may be the true primary spermatogenous cell. The pollen tube branches as it traverses the nucellus, not so extensively as do the tubes of cycads and of Ginkgo, but sufficiently to indicate its primitive haustorial function. After its second start, the pollen

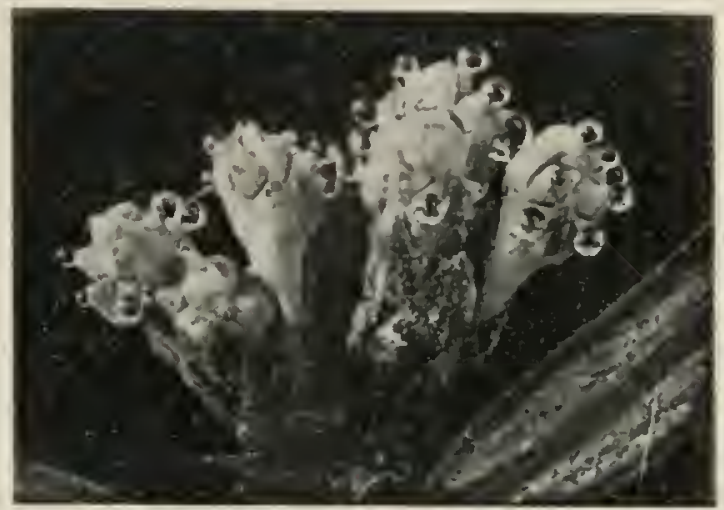

Fig. 315.-Cephalotaxus Fortunci: pollination drops at the tips of the numerous ovules; $\times 3.33$. -After Tison (I 7 I).

tube consumes about two months in traversing the nucellus, reaching the archegonium about the first of July.

'I he body cell rounds off, and becoming freed from the stalk cell passes into the tube. The separation of the body cell from the stalk cell frees the nucleus of the latter, and it also passes into the tube, where the nucleus of the body cell divides, forming two nuclei which do not become separated by a wall. The body cell, with its two nuclei, then passes down the tube, and when it has reached the tip, the four nuclei may be found grouped together, usually with the stalk and tube nuclei in advance. At this stage the contour of the body cell may be quite distinct (fig. 3I6), or rather indefinite (fig. 3 I 7 ), or its cytoplasm may have become so mingled with that of the pollen tube that the nuclei lie in a common mass of cytoplasm (fig. $3 \mathrm{IS}$ ).

The division of the body cell occurs just before fertilization, about two months after the division of the generative cell into stalk and body 
cells. The latter then divides and forms two equal male cells (as in Taxodium), or only two nuclei not separated by a wall (as in Pimus). It is this division which among cycads and in Ginkgo results in two sperm mother cells, which later produce and discharge two ciliated sperms. It is this contrast in spermatogenesis that must be

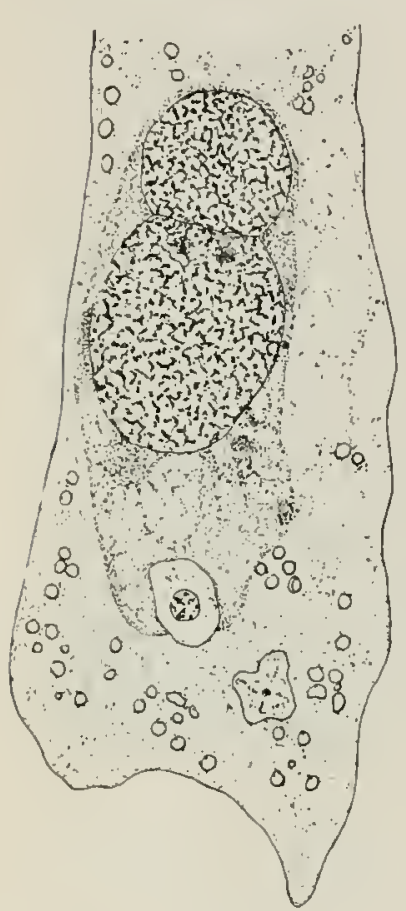

316

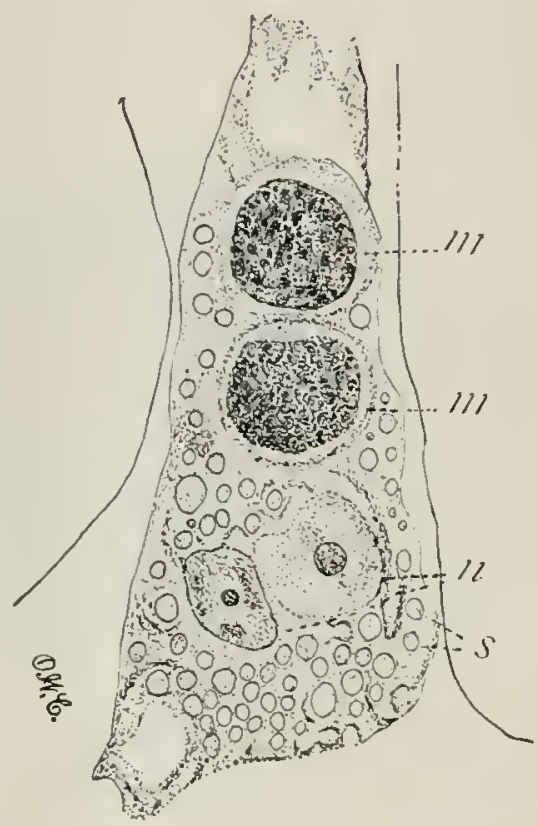

317

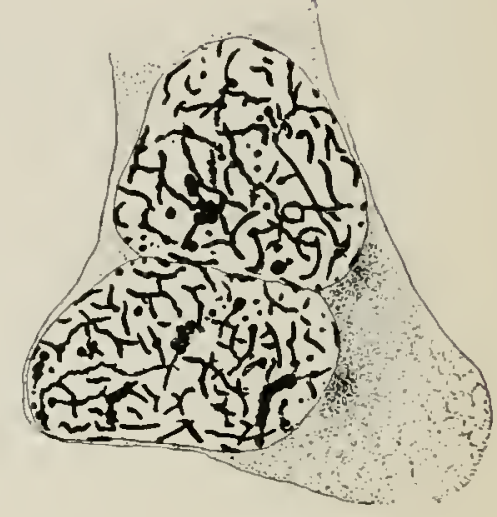

318

FIGS. 3I6-3I8.- Tips of pollen tubes containing the male nuclei: $m$, male nuclei; $n$, nuclei of tube and stalk cells; s, starch; fig. 3I6, Pinus Strobus; June I4, IS98; the body cell maintains its outline and the two male nuclei are unequal; $\times 236$; after Miss Ferguson (87); fig. 317, Pinus Laricio; the outline of the body cell is indistinct and the two male nuclei are equal; $\times 500$; after Coulter $(44)$; fig. 3 I $S$, Pinus Laricio; somewhat later stage than that shown in fig. 3I 7 ; the cytoplasm of the body cell has become continuous with that of the tube; the male nuclei are equal, and above them, but not shown, are the stalk and tube nuclei; $\times_{500}$; after CHAMBERLAIN (5I).

regarded as the most important contrast between Coniferales and the groups previously considered. In Coniferales a cell generation has been eliminated, and whether the daughter cells of the body cell (in forms like Taxodium) are called sperm mother cells or sperms makes very little difference. They are formed as are the sperm mother cells of the preceding groups, but they do not produce sperms; on the other hand, they function as sperms, but have no cilia. These non-ciliated cells, produced like mother cells and functioning like 
sperms, are called for convenience simply male cells. The disappearance of the wall between the two male cells, leaving the male muclei free in the cytoplasm of the body cell, represents a further stage in the reduction of the male element. The significant fact is the abandonment of the swimming sperm by Coniferales, and when one recalls the surprising persistence of swimming sperms in connection with the land habit, their final disappearance marks an epoch in the history of land plants. With the abandonment of swimming sperms, blepharoplasts in the body cell have disappeared, and the pollen tubes are utilized as sjerm carriers.

The appearance of two evanescent regetative (prothallial) cells is a feature only of the Abietineae, and even among them there is some fluctuation, the spores of Picea excelsa having been observed (I I) to produce one to three such cells. Among Taxodineae and Cupressineae no such cells occur, the vegetative tissue of the male gametophyte having been eliminated completely. In these tribes, therefore, the first division of the pollen grain produces the generative and tube cells. The ephemeral nature of the prothallial cells in Abietineae suggested for a time that they had escaped observation in the two other tribes, but the evidence is now too complete to warrant any such assumption. Among Taxodineae the absence of prothallial cells is known for Sciadopitys (I75), Cumninghamia (147, 180), Sequoia $(64,92)$, Cryptomeria $(85,93)$, and Taxodium $(76)$; and among the Cupressineae it is known for Callitris (85), Widdringtonia (159), Libocedrus (131), Thuia (72, 86), Cupressus (85), Chamaecyparis (85), and Juniperus (85). Since this list includes twelve genera of the eighteen included in the two tribes, there is no reason to expect that vegetative cells will be found in the remaining genera. In this feature, therefore, the Abictineac are in a more primitive condition than are the two other tribes.

Among Araucarineae, however, there is still another prothallial situation (figs. 3I9-32I). Two lens-shaped vegetative cells are cut off, as among Abietineae, but they are not ephemeral. Lopriore describes them (104) in Araucaria Bidwillii as giving rise to a tissue of about fifteen cells, whose walls presently disappear, freeing the nuclei, which then continue division, until twenty to forty-four (most frequently thirty-six) free nuclei were observed, no divisions occurring 


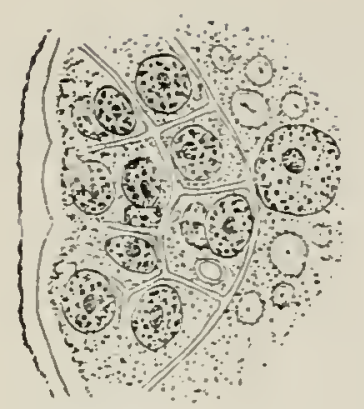

319

320

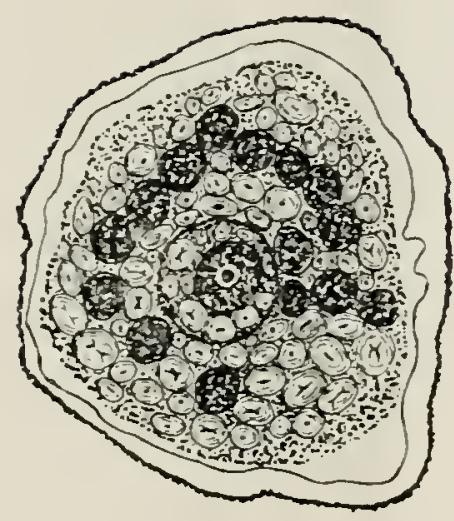

Figs.319-32r.—Araucaria Bidwillii: fig. 3 I9, portion of the prothallial end of the pollen grain, showing two prothallial cells, each of which has divided, giving rise to numerous cells; the next division of the nucleus beyond the prothallial complex will give rise to the generative cell and tube nucleus; $\times 666$; fig. 320 , later stage, transverse section, showing body cell in the center surrounded by nuclei which have been set free by the breaking down of the walls of the prothallial cells; $\times 666$; fig. 32I, pollen tube with numerous nuclei; on so small a scale the male nuclei and prothallial nuclei could hardly be distinguished; $\times 54$.-.After LOPRIORE (IO4). after the pollen tube begins to develop. Thomson (IоT) has also observed many supernumerary nuclei in the pollen tubes of Araucaria, as many as thirty being counted. It adds to the interest of this situation when it is known that the same condition exists among the Podocarpineae (Taxaceae), although the prothallial tissue is not so extensive in that tribe. If the two-celled prothallial tissue of Abietineae indicates a more primitive condition than no prothallial tissue, as noted above, is the many-celled prothallial tissue of Araucarineae (and of Podocarpineae) still more primitive? The only escape from an affirmative answer is to prove that the tissue formed by the two original vegetative cells is to be explained physiologically rather than phylogenetically; in other words, that it is cenogenetic and not palingenetic (p. 230).

Another variation of general importance is that observed in the relative size of the two male cells produced by the body cell, and also in the completeness of their organization as cells. Among Taxodineae 
(figs. 322-327) and Cupressineac (figs. 328-33I) usually two equal male cells are produced, and both cells may function and have been observed $(72,173)$ to function, since fertilization occurs in an arche-

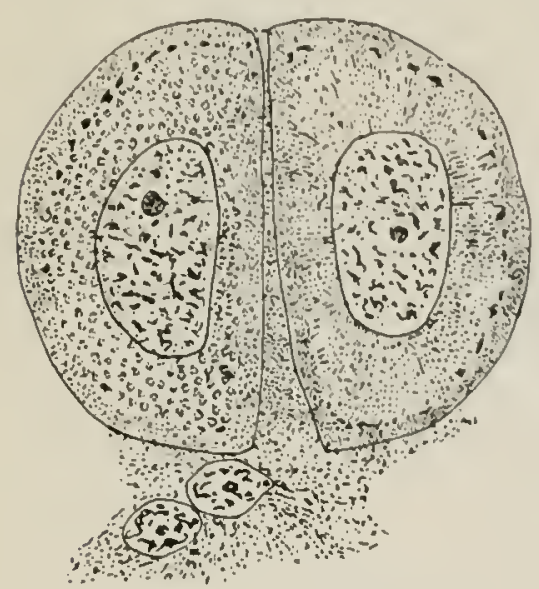

322

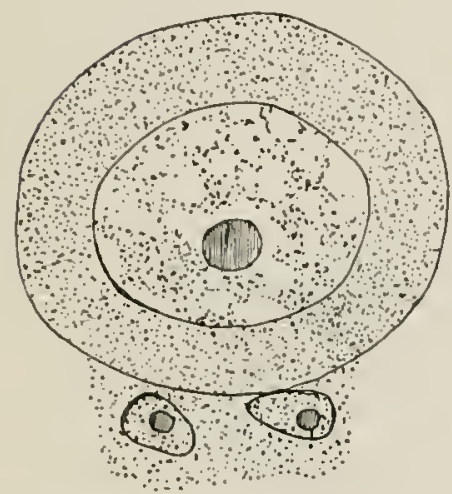

324

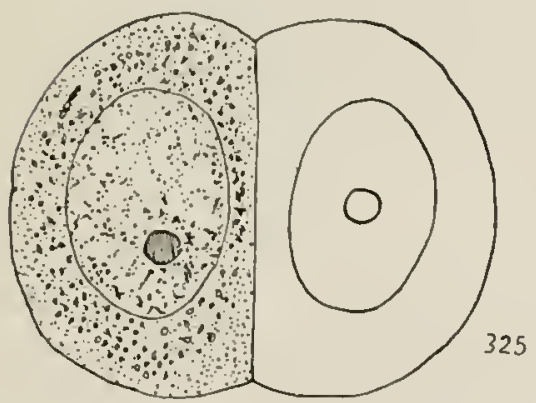

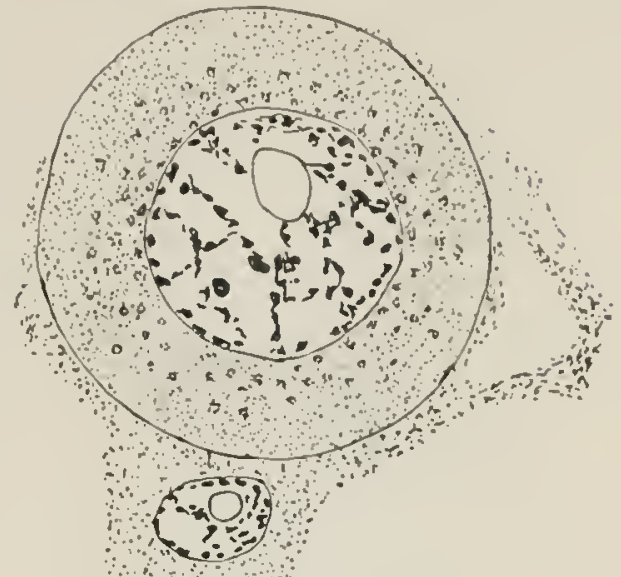

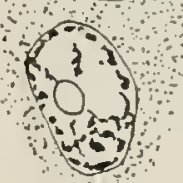

326

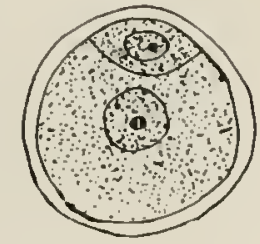

323

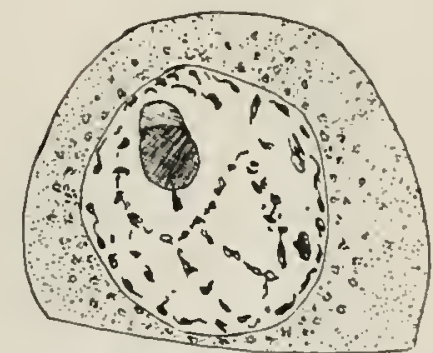

327

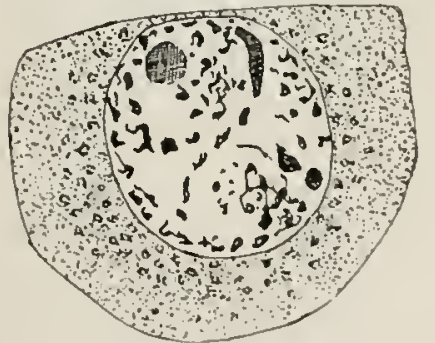

FIgs. 322-327.-Pollen tube structures of Taxodineac: fig. 322, Taxodium distichum; the two male cells with stalk and tube nuclei in advance; $X_{540}$; after Coker (76); figs. 323-325, Cunninghamia sinensis, fig. 323 showing the pollen grain with generative cell (no prothallial cells) and tube cell, fig. 324 the body cell with stalk and tube nuclei in advance, and fig. 325 the two male cells; $X_{430}$; after Mriake (147); figs. 326,327 , Cryplomeria japonica, fig. 326 showing the body cell with stalk and tube nuclei in advance, and fig. 327 the two male cells; $\times 666$; after LAwsox (93). 
gonial complex. Among the Abietineae, however, only one of the two male cells produced by a body cell can function, and this fact seems
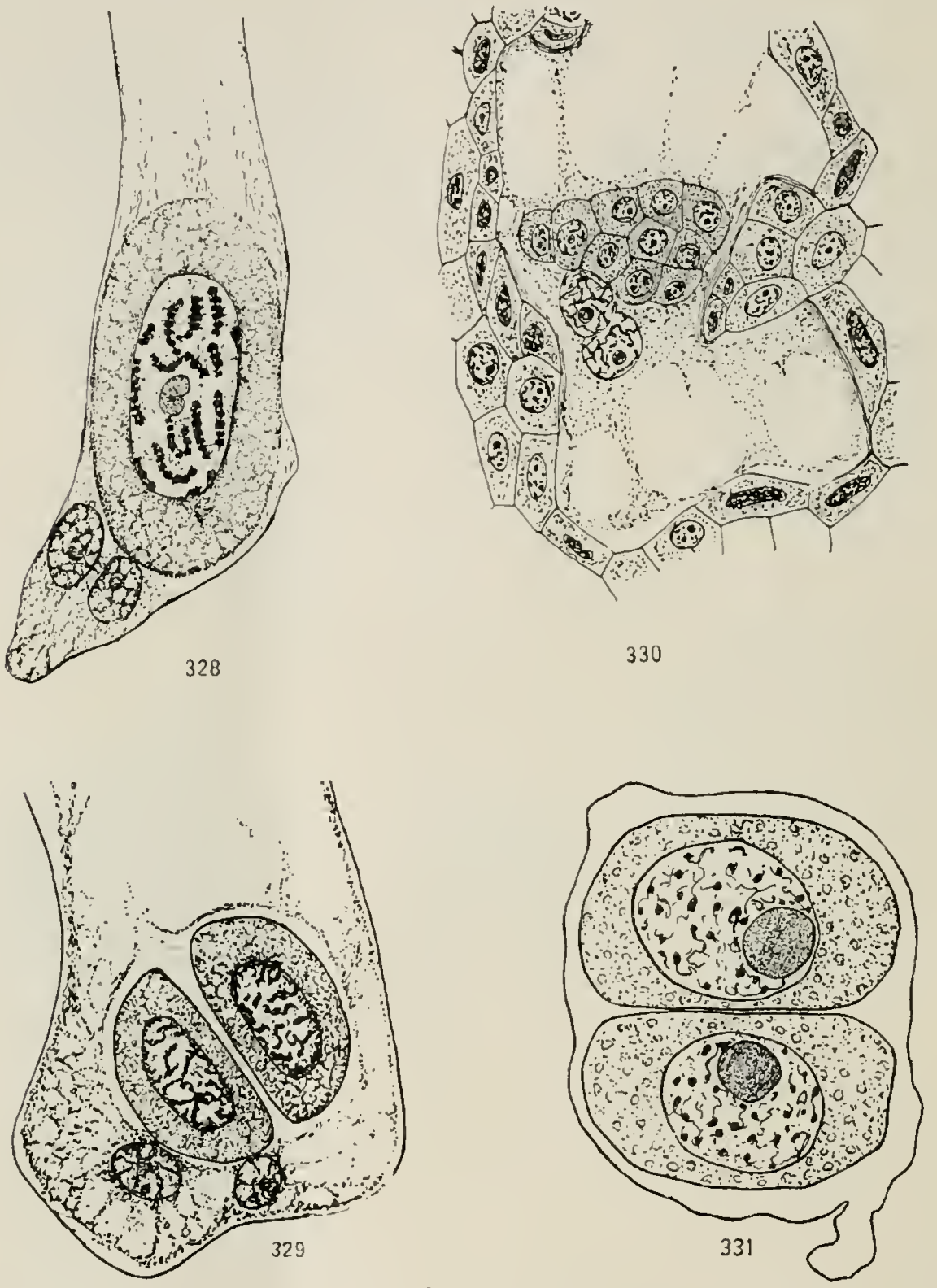

FIgs. 328-33I.-Pollen tube structures of Cupressineae: figs. 328, 329, Thuja occidentalis, fig. 328 showing the body cell with stalk and tube nuclei in advance, and fig. 329 the two male cells; $\times 560$; after LAND (72); fig. 330 , Cupressus Goveniana, end of pollen tube with complex of male cells, the stalk and tube nuclei in advance; $\times 350$; after Juel (9I); fig. $33 \mathrm{I}$, Libocedrus decurrens, the two male cells; after LAwSON (I 3 I).

to be related to the tendency to eliminate one of the male cells. In Tsuga canadensis (60) one male cell becomes larger than the other. 
In Pinus $(65,87)$ no wall is formed at the division of the body coll, the two male nuclei being frec in the general cytoplasm, and one of them, according to Miss Ferguson (87), soon becoming much larger than the other; a condition also observed in Pseudotsuga $\left({ }_{5} 5^{6}\right)$. In Picea excelsa (79) a cell plate appears on the spindle of the dividing body cell and at once disappears, leaving the two male nuclei free in the general cytoplasm. Just how far this tendency to eliminate one of the male cells has gone among the Abictincae remains to be discorered. An interesting test of this riew has recently been supplied by LAWSON (I75) in his study of Sciadopitys. The other genera of Taxodineac investigated have the archegonial complex and equal male cclls; while Sciadopitys has no archegonial complex and unequal male cells. It is possible to mistake inequality of cells and of nuclei in preparations, so that unusual care will be needed in accumulating these facts, but the tendency is evident enough. In Cupressus Goveniana a remarkable situation has been reported (9I), the body cell being said to give rise to a cell complex of four to twenty cells, eight or ten cells being the most frequent number (fig. 330). In Juniperus communis the body cell has been observed ( $\mathbf{I}_{73}$ ) occasionally to produce three or four male cells, but only two of them were considered capable of functioning. The only other cases known among gymnosperms, in which the body cell gives rise to more than two cells, are Microcycas, in which the body cell regularly produces sixteen or more sperms; and Ceratozamia, in which four sperms are formed occasionally (p. I47). The multiplication of male cells in such a form as Cupressus, with its large archegonial complex, might be expected, but at present no conclusions are safe in reference to these rare occurrences.

The condition of the male gametophyte at the time of pollination is of interest. The records are apt to be misleading if no consideration is given to the fact that some tribes have prothallial cells and others do not. So far as observed, the prevailing condition at shedding is the stage following the formation of the generative and tube cells. This means after one nuclear division among Taxodineae and Cupressineae, and after three divisions among Abietineae, but it is the same stage in the ontogeny of the gametophyte. Pollination at an earlier stage has been reported for Cupressus (86) and Junipcrus 
$\left(86, \mathrm{I}_{32}, \mathrm{I} 57\right)$, that is, the uninucleate spore is shed; but in both these genera the division to form generative and tube nuclei occurs on the nucellus, before tube-formation. Pollination at a later stage has been reported for Picea excelsa (79), in which the next division has occurred, the generative cell having produced the stalk and body cells. In Widdringtonia (I59, I76) the divisions are remarkably delayed. The spore is shed in the uninucleate condition, and since there are no prothallial cells there has been no division. Unlike Cupressus and Juniperus, however, whose pollen grains are shed in the same condition, the nucleus does not divide until after tube-formation, the generative and tube nuclei being observed only in the tubes. The single pollen tube penetrates the megaspore membrane and passes down inside of it for one-third to one-half the length of the gametophyte, and only after entering within the membrane does the generative cell divide. When the tube has reached the limit of its growth, its tip may contain only the large body cell, the stalk and tube nuciei having a tendency to disappear. Two of the numerous archegonia are fertilized by the two male cells.

The period that elapses between pollination and fertilization, which covers the activity of the pollen tube and the life of its contents, falls into two categories. One of them includes cases in which pollination occurs one season and fertilization the next. As has been mentioned (p. 275), this is true of Pinus Laricio, in which pollination occurs in June and fertilization about July first of the following year. It is also true of Juniperus communis ( 132, I57, I73), which has about the same period; and in both cases the generative cell does not divide until the second season. In Sciadopitys, however, Lawson (I75) reports that the generative cell divides during the first season into the body cell and a free stalk nucleus, and that the division of the body cell and fertilization do not occur until the second season. In Widdringtonia, also, SAxTON ( 176 ) reports that fourteen or fifteen months elapse between pollination and fertilization. In many other forms approximately the same periods have been observed. 'These long periods may escape recognition unless there is familiarity with the condition of adjacent structures and especially of the female gametophyte, for two similar pollen tubes may belong to two different seasons. 
The other category includes the cases in which pollination and fertilization occur during the same season. 'The records of these cases show considerable variation in the time of pollination, but remarkable uniformity in the time of fertilization, which falls in general between the middle of June and the middle of July. The period of pollen tube activity varies approximately as follows: Sequoia (92) and Cryplomeria (93) about fifteen weeks; Cunninghamia (I 47, I 80) about twelve weeks; Pseudotsuga ( $\left.5_{5} 6\right)$ about eight weeks; Tsuga (60) about six weeks; Thuja (72) and Picea (79) about four weeks. This perhaps fairly expresses the range of variation within a season, which allows for pollination from early in January to early in June. It is evident that this feature holds no relation to tribes, either in reference to periods of one season or of two scasons; or in reference to the longer and shorter periods of the single season; nor does the time of pollination seem to affect the time of fertilization.

The course of the pollen tube is various. Sometimes it is very direct through the nucellus to the archegonia, as in Cryptomeria (93), and probably in all forms with short periods; sometimes it is devious and branching, especially in forms with long periods; and in Sequoia (92) the tubes penetrate between integument and nucellus, as well as directly to the nucellus. In Widdringtonia (I59) the solitary pollen tube, after piercing the megaspore membrane, passes down the surface of the endosperm for one-third to one-half its length, and fertilizes the deep-seated and laterally placed archegonia (p. $27 \mathrm{I}$ ). In Pseudolsuga ( $5_{5}$ ) the pollen grains germinate in the outer micropylar chamber (p.253), and the numerous tubes pass in a tangle through the inner chamber on their way to the apex of the nucellus, which disintegrates in advance of the approaching tubes, so that there is little or no resistance to their passage. In this case it is an interesting fact that the body cell divides before the tip of the pollen tube reaches the nucellus. Among the Araucarineae Thomson (107, I2I) has made the interesting observation that the pollen grains are lodged on the ligule in Araucaria and on the bract nearer the micropyle in Agathis, and in this position send out their tubes, which grow along the surface of the ligule or bract for some distance before entering the micropyle.

Certain unusual occurrences in the course of spermatogenesis have been observed, which may be mentioned. Coker (86) observed 
a number of cases in Larix europea in which there is only one division in the spore mother cells, resulting in two daughter cells that function as microspores in the production of male gametophytes. This condition finds its parallel in the development of certain female gametophytes among angiosperms in which the second or both of the reduction divisions occur as the first divisions of the ordinary gametophyte, which in such a case is really formed by two or four megaspores. This case of Larix suggests that the second reduction division occurs in connection with the first division of the so-called microspore, and that two spores enter into the formation of the gametophyte. The same observer has also reported (86) that the generative cell is often free in the cytoplasm of the tube cell in Cupressus. In Cunninghamia MiYake (I47, I80) observed that in the division of the generative cell no wall is formed, and the bulk of the cytoplasm is organized in connection with the body nucleus, the stalk nucleus lying free in the cytoplasm of the tube; and the same observation has been made by Nichols (I73) in Jumiperus communis, and by LAwSON (I75) in Sciadopitys. This reduction is like that described by Hrkasé for Ginkgo (p. 208), and may possibly presage the final elimination of the stalk cell.

\section{FERTILIZATION}

The tip of the pollen tube having reached the megaspore membrane either penetrates it directly or flattens out upon it in a footlike expansion, sending out a small branch to pierce the membrane. The body cell divides about simultaneously with the central cell, so that the egg and the male cell are produced a very short time before their fusion; in Juniperus communis this period has been observed ( $\mathrm{I}_{73}$ ) to be approximately three days. In the case of isolated archegonia (Abietineae), the tube reaches the neck of the archegonium, crushes the neck cells, and comes into contact with the egg; in the case of an archegonial complex, the tube usually discharges its contents into the common archegonial chamber.

In addition to the two male cells, the tube contains the stalk and tube nuclei, and in general all four bodies are discharged into the cytoplasm of the egg, or into the chamber of an archegonial complex. In the latter case, two eggs are usually fertilized from a single pollen 
tube, as in Thuija (72), Taxodium (76), Sequoia (92), Cryptomeria (93), Libocedrus (I I), and Jumiperus (I73). The non-functioning male cell and the stalk and tube nuclei, which are carried into the peripheral region of the cytoplasm of the egg, gradually disintegrate there, but sometimes the male cell and the tube nucleus have been observed to divide amitotically, as in Pinus $(66,87)$. In the case of an archegonial complex, stalk and tube nuclei disintegrate in the chamber. A peculiar discharge of male cells is described by LAwSON (92) for Sequoia sempervirens, the male nuclei invested by very little cytoplasm passing out of the tube and leaving behind the enucleated male cells, which retain their form in the tube.

In general, the functioning male nucleus slips out of its cytoplasm in the peripheral region of the egg, and passes to the egg nucleus, increasing somewhat in size. This behavior has been observed in Pinus, Thuja (72), Cryptomeria (93), Juniperus (95), and Libocedrus (I3I). In Taxodium Coker (76) observed the complete male cell pass to the egg nucleus and infold it, the starch of the male cytoplasm being seen distributed uniformly about the fusion nucleus, and even accompanying it to the base of the egg. The same phenomenon has been observed recently by NICHOLS (I73) in the fertilization of Juniperus communis.

In fusion, the male nucleus presses inward the limiting membrane of the female nucleus, and the two remain distinct for some time (fig. 332). Evidence is accumulating that there is no fusion of the male and female chromatic substance, the two chromatic groups being distinct in Larix (54), Pimus (5I, 87) (figs. 332-337), Tsuga (60), Juniperus (I32, I73), and Cunninghamia (I80) (figs. 338-340). In Pimus the chromatin is in the resting stage as the pairing nuclei come into contact; but as the sperm nucleus begins to penetrate, both nuclei form distinct spirems, each of which breaks up into I2 chromosomes, the two groups remaining recognizable until the nuclear plate stage. As the 24 chromosomes become oriented in the nuclear plate, the two groups can no longer be distinguished, and it is impossible to determine whether any given chromosome was contributed by the sperm or by the egg. The chromosomes now split longitudinally and 24 go to each pole, where the two daughter nuclei pass into the resting condition. Consequently, there is no fusion of chromatin 


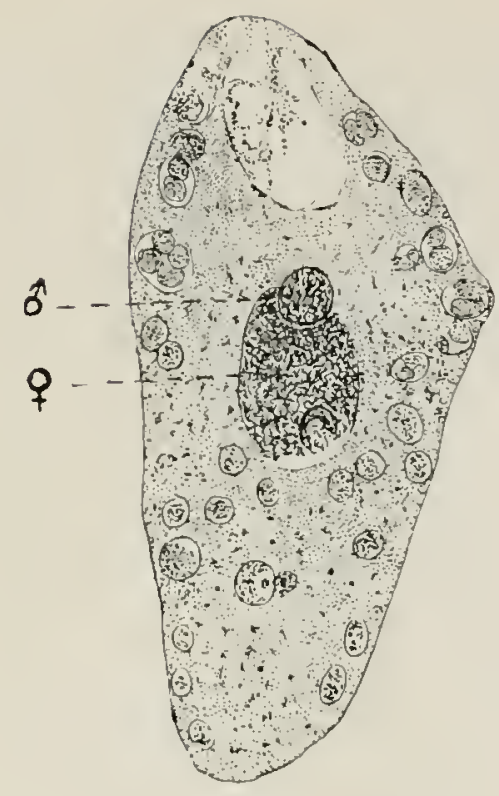

332
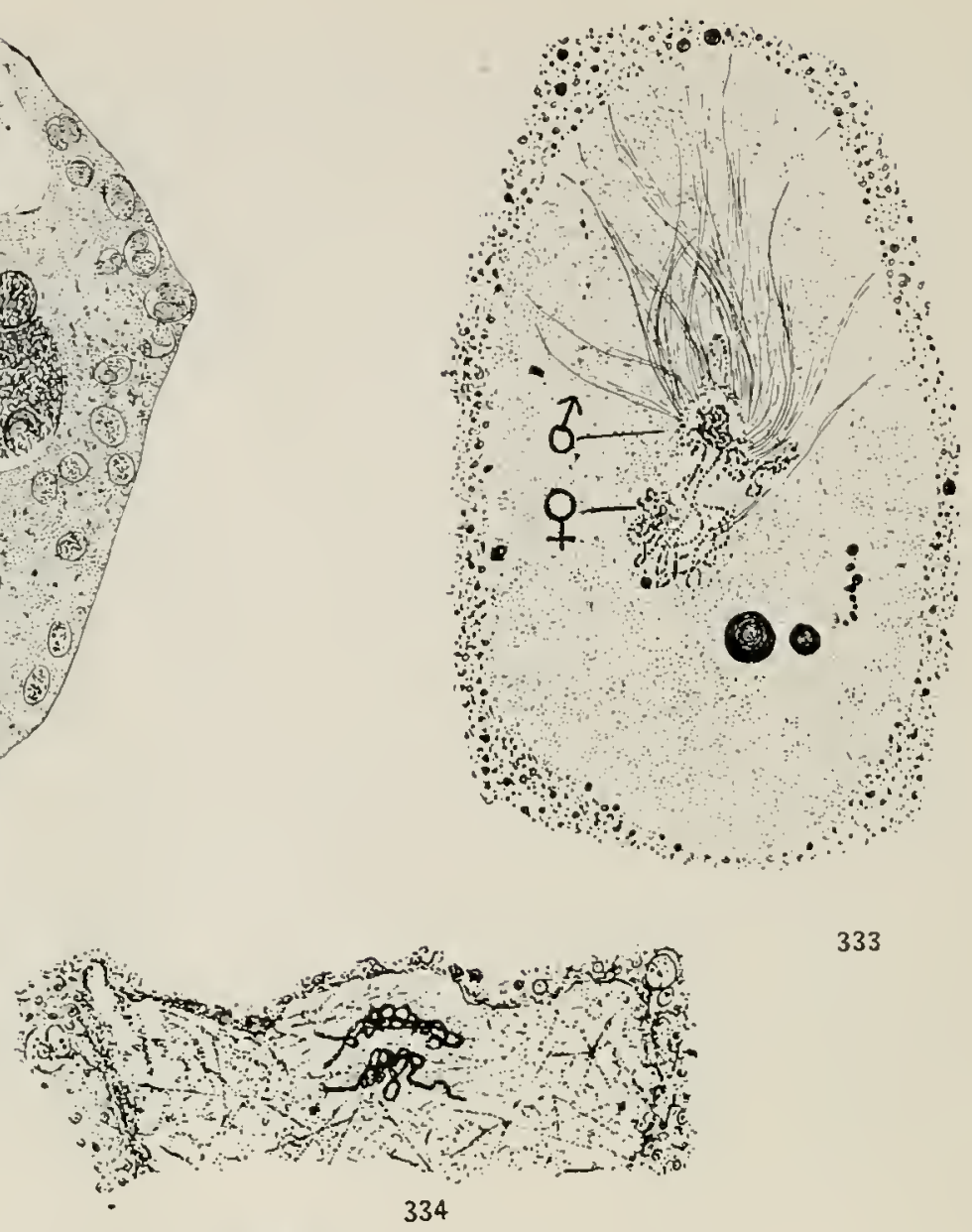

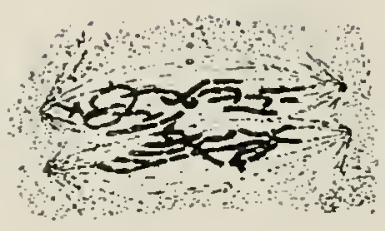

336

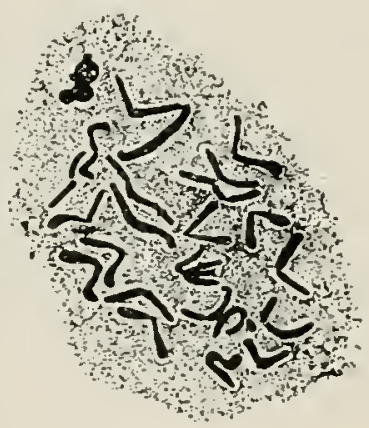

335

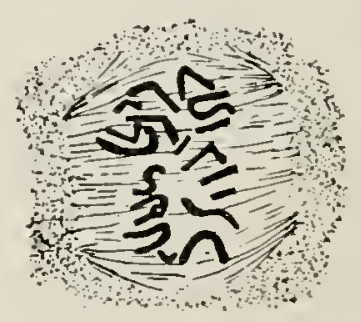

337

Figs. 332-337.-Fertilization in Pinus: fig. 332, P. silvestris, the sperm nucleus entering the egg nucleus, June 19; $X_{135}$; after Brackman (46); fig. 333, P. Laricio, the chromatin of the sperm and egg nuclei in the spirem stage within the limits of the egg nucleus; $\times 500$; after Chamberlain (5I); figs. 334-337, P. Strobus; fig. 334, a somewhat later stage than that shown in fig. 333 ; fig. 335 , the spirems of the egg and sperm nuclei after segmentation; fig. 336 , the two spirems after segmentation; the two halves of the spindle seem to indicate the paternal and maternal parts of the mitotic figure; fig. 337 , longitudinal section, showing the orientation of chromosomes at the nuclear plate, the egg and sperm chromosomes no longer distinguishable; $\times 3$ I5; after Miss Ferguson (87). 
during fertilization in the various species of pines which have been studied. In Tsuga it is stated that the two sets of chromosomes are associated, but remain distinct in the equatorial region of the first spindle. In Juniperus, while there are slight differences in details, the essential features are quite similar. Whether this independence

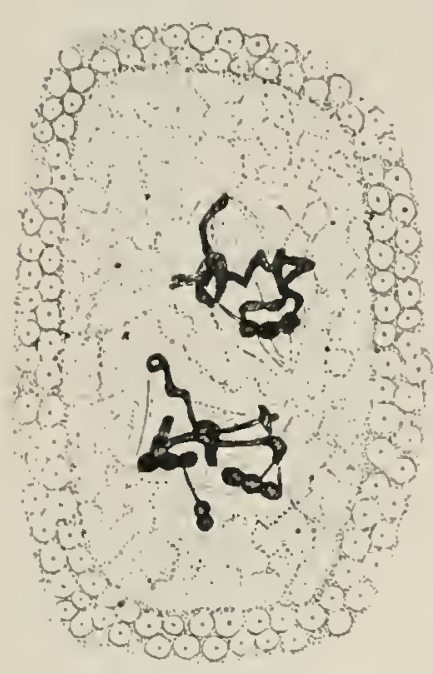

338

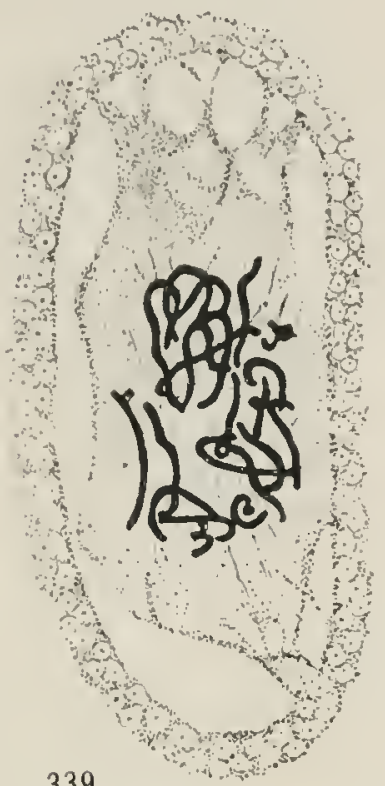

339

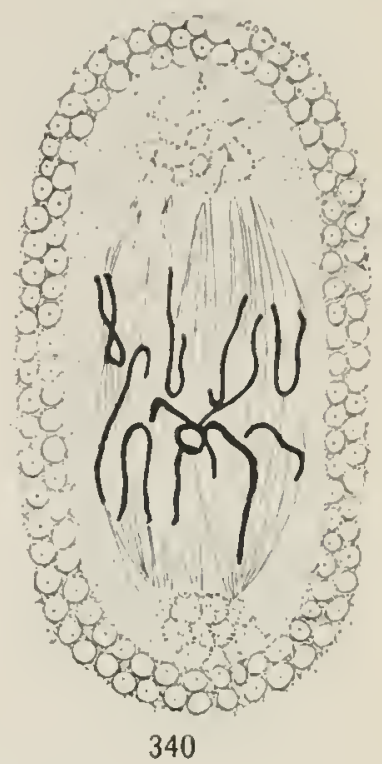

340

FIGS. 338-340.-Fertilization in Juniperus communis: fig. 338 , chromatin of sperm and egg nuclei in late prophase within the limits of the egg nucleus; fig. 339, later stage in which the egg and sperm chromosomes are no longer distinguishable; fig. 340 , first division of fertilized egg; $\times 520$.-After NoŔ́N (I32).

of male and female chromatin continues into succeeding cell generations or not is a most important question. In his investigation of Sequoia sempervirens, however, LAwson (92) concluded that in fusion the two chromatic masses form a common network, in which the male and female constituents become indistinguishable.

\section{The embryo}

The development of the embryo, as in the preceding groups, includes two general stages: (I) the development of the proembryo, which is the preliminary tissue developed in the base of the egg; and (2) the growth of the suspensor into the endosperm and the development of the embryo proper at its tip. Among Pinaceae the proembryo is a much less extensive tissue than among Cycadales and Ginkgoales, being a few cells at the base of the egg, the bulk of the egg functioning 
as a food reservoir. Since there seems to be a general tendency among gymnosperms to reduce the proembryonic stage of the embryo, the Pinaceae may be regarded as a more advanced group in reference to this character than the preceding ones.

\section{THE PROEMBRYO}

The development of the proembryo of Pinus Laricio may be taken as an illustration (figs. 34I-349). The fusion nucleus retains its central position in the egg, and organizes the largest spindle of the free nuclear series. It is worthy of note that this first spindle is almost always oblique (fig. 34I). The two daughter nuclei are very small

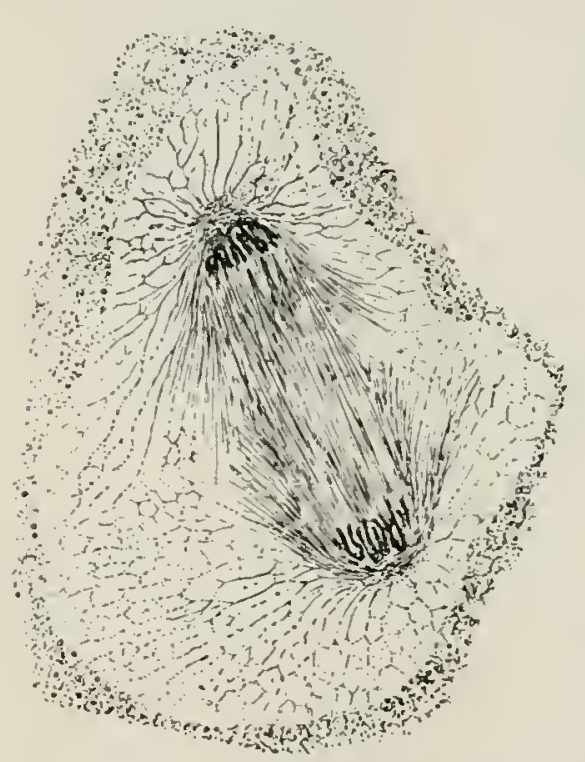

FIG. 341.-Pinus Laricio: first division of the nucleus of the fertilized egg; the entire mitotic figure is intranuclear; the two daughter nuclei resulting from this division are the first two nuclei of the sporophytic generation; $\times 500$.-After Chamberlain (5I). at first, but increase rapidly in size, and then divide simultaneously. The resulting four free nuclei, after increase in size, pass to the base of the egg, where they become arranged in a single plane (figs. 343,344 ). There follows a simultaneous transierse division, which results in two tiers of nuclei, with four nuclei in a tier (figs. 344346). With this division the first transverse walls appear in connection with the spindles, and almost at the same time vertical walls are formed in each tier on secondary transverse fiber connections established between the nuclei ( 129 ) (figs. $35^{\circ}-35^{2}$ ). This appearance of walls at the eightnucleate stage of the proembryo is a remarkably constant feature of the Pinaceae. The older accounts of

Pimus introduce rertical walls at the four-nucleate stage, but it is now discovered that a meshwork of fibrils was interpreted as a wall (fig. 350 ). It must be understood that the first walls do not appear after eight free nuclei are organized, but in connection with the organization of the eight-nucleate stage. The lower tier of four cells is completely walled, but the upper tier is open above, so that the nuclei are freely exposed to the general cytoplasm of the egg. 

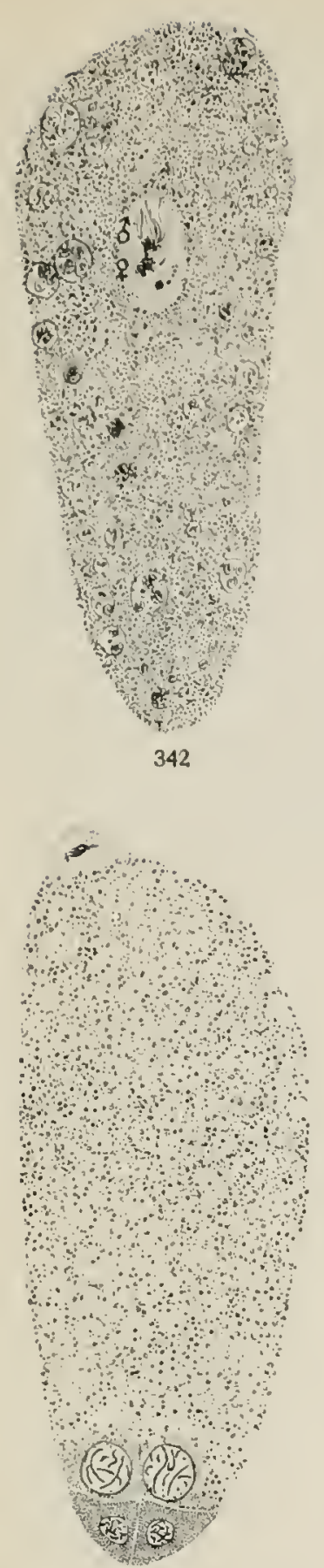

345

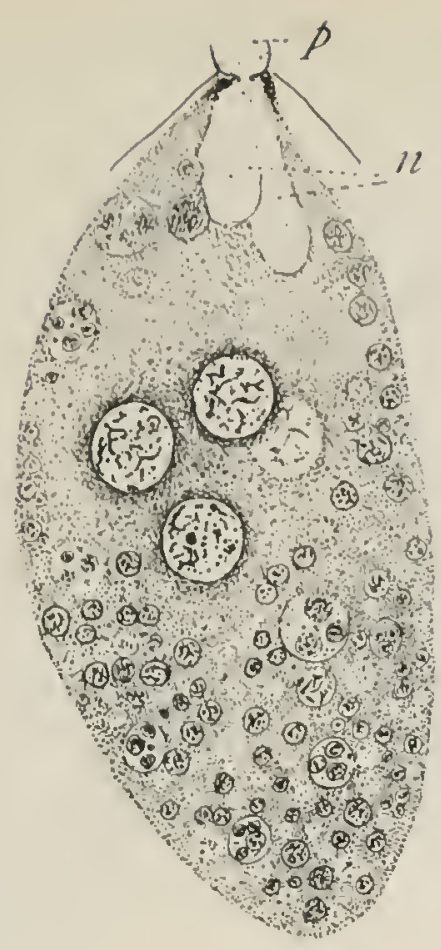

343

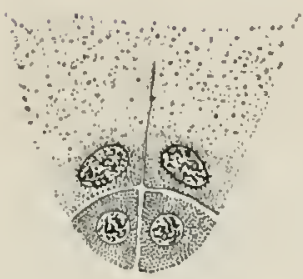

346

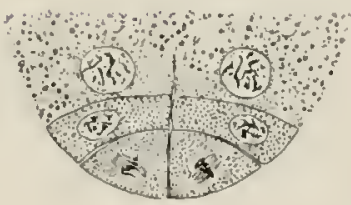

347
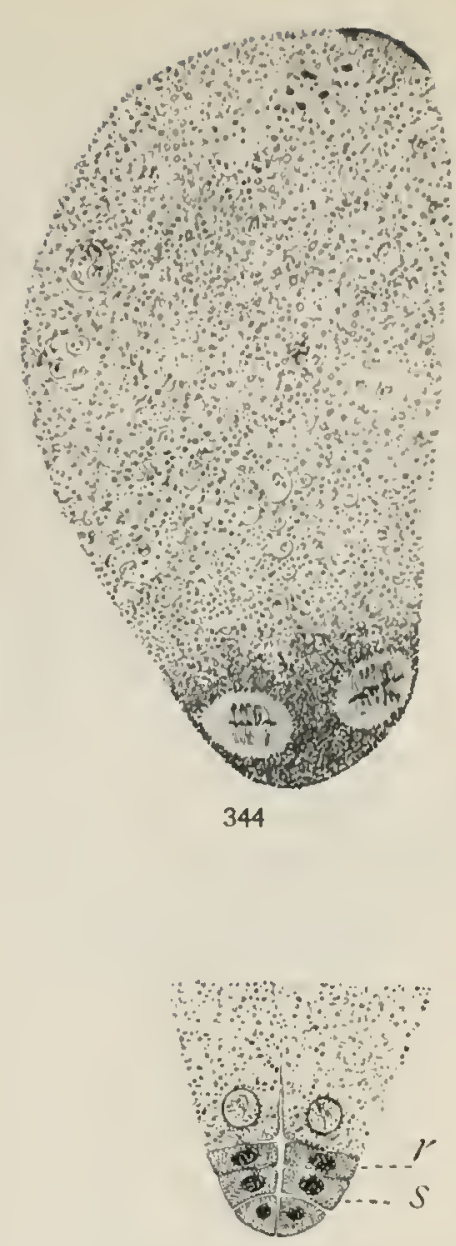

348

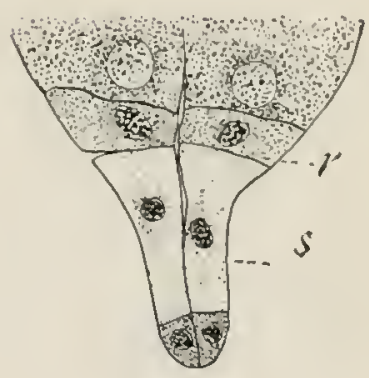

349

Figs. 342-349.-Pinus Laricio: early stages in the derelopment of the sporophyte; the term proembryo applies to all the stages except that shown in the last figure; fig. 342 , the chromatin of the egg and sperm nuclei within the limits of the egg nucleus, shown on a larger scale in fig. 333; fig. 343 , first four nuclei of proembryo, also numerous proteid vacuoles ( $p$, pollen tube; $n$, cavities caused by inrush of contents of pollen tube, or according to Miss FERGuson they are receptive vacuoles); fig. 344 , the four nuclei (two shown) dividing at base of egg; fig. 345 , eight-celled stinge; fig. 346 , somewhat later stage; fig. 347 , last division of proembryo; fig. $34 \$$, the complete proembryo, with four tiers of cells, four cells in a tier; $r$, rosette tier; $s$, suspensor tier; fig. 349 , suspensor tier beginning to elongate; figs. $342-344$, from material collected June 25 ; figs. $345-348$, July 2 ; X104. 
which is the plate or group of proembryonic cells remaining within the egg and mediating between the food supply of the egg and the suspensor. The size and generally active appearance of the four uppermost nuclei, exposed to the cytoplasm of the egg, indicate that they must remain functional for some time.

This account of the proembryo of Pinus probably applies equally well to all the Abietineae, although the account is not full for any other genera except Picea (79) and Pseudotsuga (156). The other

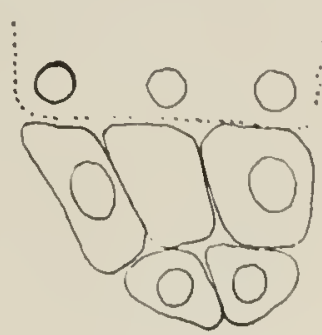

353

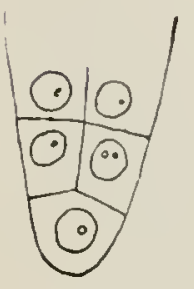

355

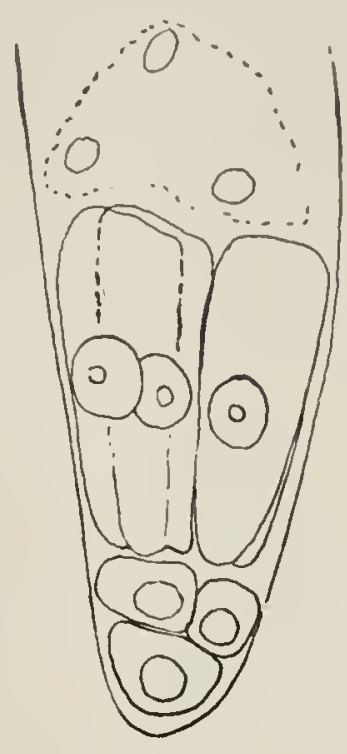

354

FIGS. 353-355.-Proembryo of Taxodineae: fig. 353, Taxodium distichum, sixteencelled embryo in three tiers, six cells in rosette, six in suspensor, and four below; $X_{280}$; after Coker (76); fig. 354, somewhat later stage of same; $X_{375}$; after ARNoLdi (64); fig. 355, Cunninghamia sinensis, proembryo of three tiers of cells; $\times 145 ;$ after MIYAKE (147).

tribes have received the chief attention recently, and deserve some separate mention.

Among the Taxodineae, the proembryo of Cryptomeria $(64,93)$, Taxodium (64, 76), Sciadopitys (64, 175), Sequoia (92), and Cunninghamia ( 147, I 80 ) have been investigated (figs. 353-355). In all of them, with the exception of Sequoia, wall-formation occurs at the appearance of the eight-nucleate stage, but there is considerable variation in the passage of free nuclei to the base of the eggr, even in the same form. For example, in Cryptomeria one observer (64) reports that the fusion nucleus passes to the bottom of the egg, while another observer (93) 
reports that four free nuclei (in one case six) pass to the bottom. There is agreement that the fusion nucleus of Taxodium passes to

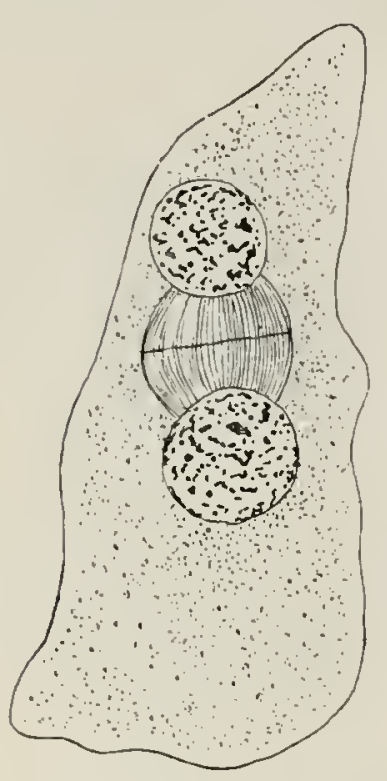

FIG. 356.-Sequoia sempervirens: first division of the fertilized egg, showing a wall forming between the two daughter nuclei; $\times_{5} 00$. -After Lawson (92). the bottom of the egg before division; while in Cunninghamia this position is taken at the two-nucleate stage, and in Sciadopitys at the four-nucleate stage (as in Pimus). The indications are that this movement occurs at any time before wall-formation, but most frequently after two divisions.

In general, also, the completed proembryo consists of three tiers of cells instead of the four observed in Pinus, the "rosette" tier not being present. The tiers may not contain the same number of cells, as the proembryo of Taxodium will illustrate. Preceding wall-formation the eight nuclei are arranged in two tiers, the upper containing six cells, the lower two. There is only one division of tiers after wall-formation, which divides the upper tier into the suspensor cells and the open cells; at the same time, the two basal cells divide by vertical walls to a tier of four cells. The completed proembryo, therefore, consists of six open cells, six suspensor cells, and four embryo cells.

The case of Sequoia sempervirens (92) is very peculiar among Pinaceac. There is no free nuclear division at all, a wall being formed at the first division, which results in two cells nearly filling the egg (fig. 356). Succeeding divisions result in a linear row of five large cells, the lowest forming the embryo, and the next upper one elongating to form the suspensor. The elimination of the free nuclear stage and the complete occupation of the

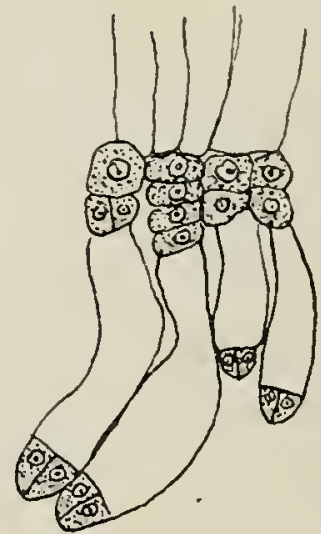

FIG. 357.-Sciadopity's verticillata: secondary suspensors.-After ARNOLDI (64). egg by a few embryonal cells are facts difficult to relate at present. 
The case of Sciadopitys (64, I 75) presents an interesting variation, but it is not so fundamental a difference as that shown by Sequoia. The four tiers of the proembryo, as in Pinus, consist of open cell, rosette, suspensor, and embryo ticrs, but the last is represented by
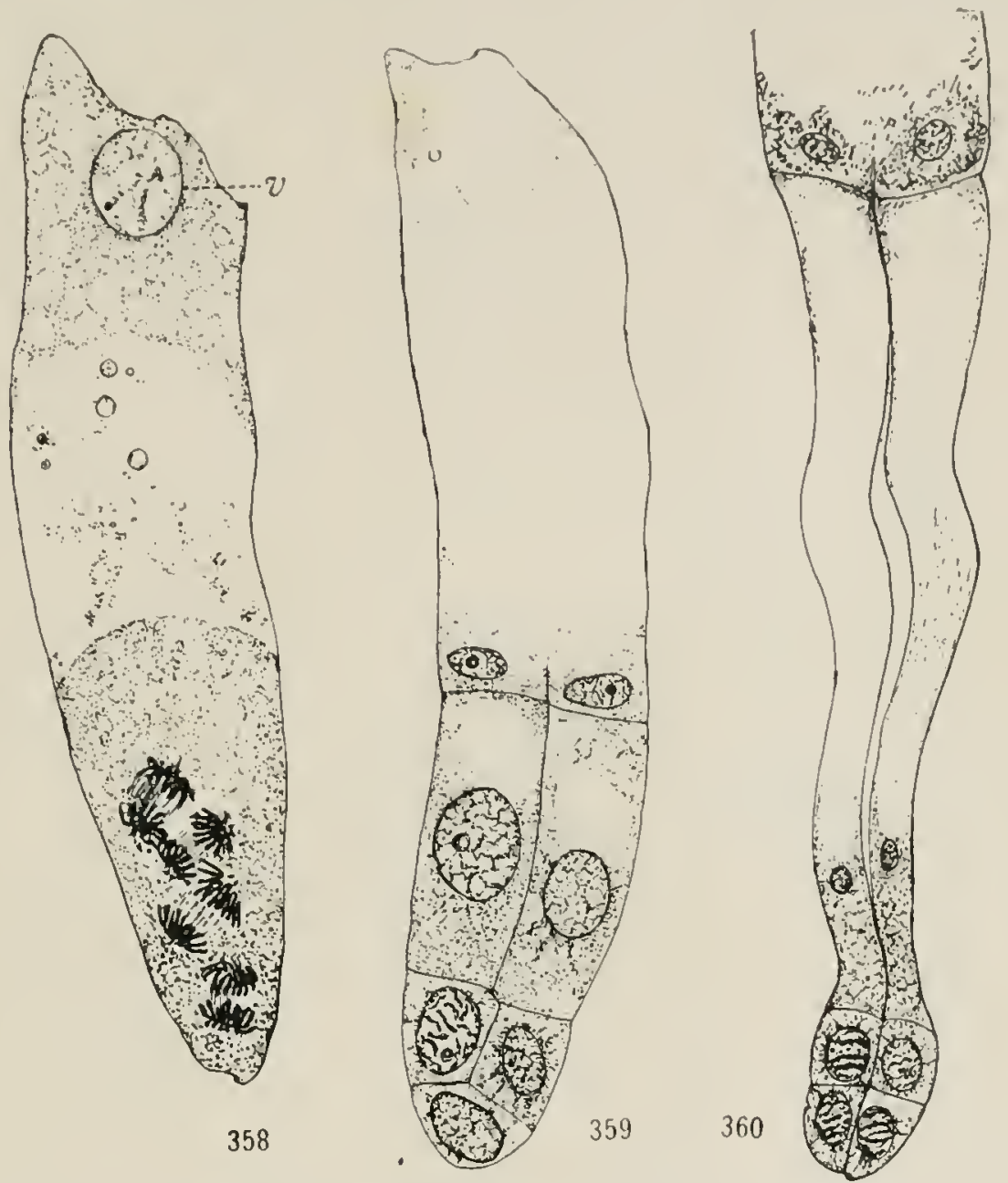

Figs. 358-360.-Thuja occidcntalis: proembryo and early embryo; fig. $35^{8}$, mitoses giving rise to eight nuclei; the first walls appear in connection with this mitosis; '', ventral canal nucleus; fig. 359 , later stage, after the organization of tiers; fig. 360 , continued elongation of the suspensor; $X_{425}$. - After LAND $(72)$.

a loose group of cells, which LAwSON (I75) says become about sixteen in number. The terminal cells of this group form the embryo, those just above form a secondary suspensor, and there are still some loose cells between the two susjensor regions (fig. 357).

Among the Cupressineae the proembryos of Thuja ( 72 ) (figs. $35^{8-360)}$, Jumiperus (95, I32) (figs. 36I-363), and Libocedrus (I3I) have beer investigated. In all of them wall-formation occurs 
at the eight-nucleate stage; but in Thuja and Libocedrus the nuclei pass to the bottom of the egg after the first division, and in Juniperus the fusion nucleus takes this position before dividing. Whether this indicates a general situation among the Cupressineae or not remains to be seen. As among the Taxodineae, the proembryo consists of three tiers of cells, the uppermost one being open above, but its nuclei

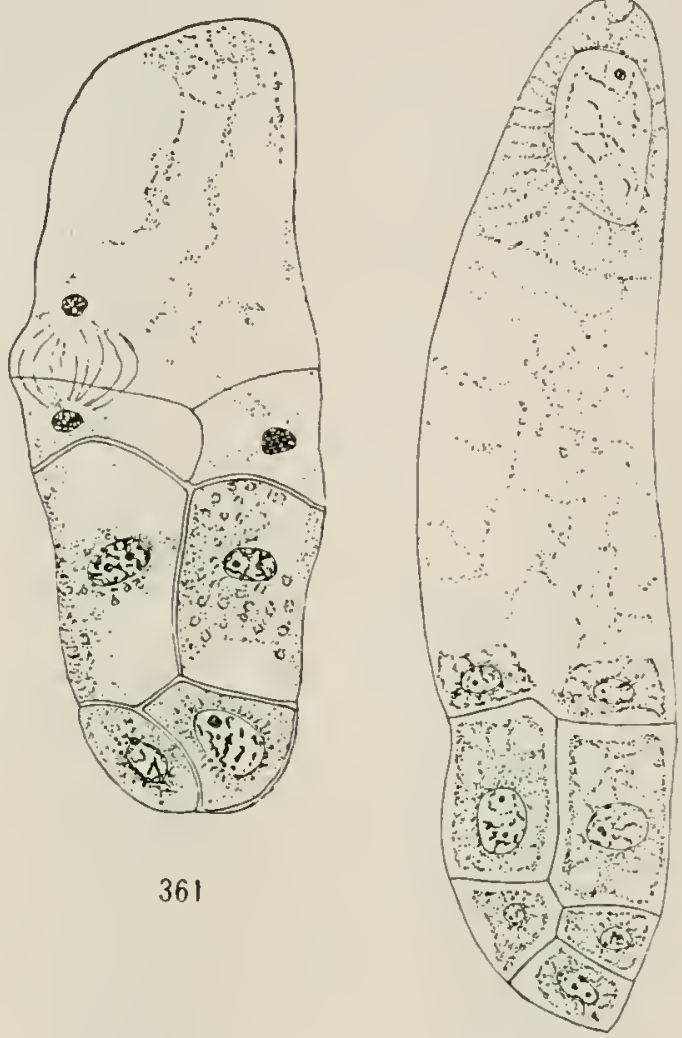

362

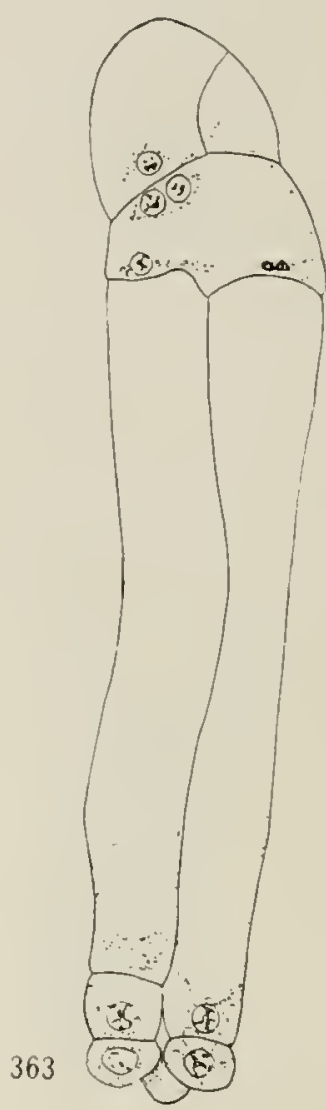

FIGS. 36I-363.-Juniperus communis: proembryo and early embryo; fig. $36 \mathrm{I}$, suspensor beginning to elongate; $X_{430}$; fig. 362 , about the same stage; the large nucleus at the top is "presumably the ventral canal nucleus"; $\times_{405}$; fig. 363 , continued elongation of suspensor; $\times 230 .-$ After NorÉx.

soon disintegrate in Thuja. The four cells of the embryo tier in Thuja are not in one plane, having a tetrahedral arrangement. In Widdringtonia and Callitris ( 159, I76) the details of proembryoformation have not been observed, but the completed proembryo completely fills the egg with a tissue of eight or more cells, resembling in general the proembryo of Sequoia. SAxTon states (I76), furthermore, that walls appear in the proembryo of Widdringtonia before the eight-nucleate stage, which probably means that they appear during 
the transition from the four-nucleate to the eight-nucleate stage, as in most Pinaceac. Only one of the cells of the procmbryo decelops the embryo, and the one next above forms the long suspensor, while the other proembryonal cells soon disalpear.

In these three tribes of Pinaceae, therefore, the proembryo consists of twelve to sixteen cells, arranged in three (Taxodineae and Cupressineae) or four (Abietineae) tiers, the fewer cells belonging to the Cupressineac; a statement that must exclude Sequoia, Widdringtonia, and Callitris. Unfortunately, the proembryo of none of the Araucarineae has been investigated.

\section{THE SUSPENSOR AND EMBRYO}

The suspensor cells elongate enormously, thrusting the embryo cells into the endosperm, and usually becoming very long and tortuous (figs. 364,365 ). In such cases as Pinus, in which there is a suspensor cell for each of the four embryo cells, four separate embryos may begin to derelop, which is the usual method, or all four cells may form a single embryo. Even in such cases as Taxodium, in which there is inequality in the number of suspensor and embryo cells, the former may or may not separate from each other, resulting in one or more embryos. Of course in such a case as Thuja, in which the embryo cells are not in one plane, and one of them is terminal, a single embryo is formed. Even a single embryo cell may give rise to two embryos, if the first division is vertical and the two daughter cells become organically dissociated. The indifference of these cells in reference to embryo-formation is rery marked, an embryo being formed by a group of proembryonic cells (the "embryo tier"), by any member of this group, or even by its daughter cell.

In many of the Pinaceae "embryonal tubes," haustorial in function, are developed from the basal cells of the embryo, and are found investing the end of the suspensor and the base of the embryo, sometimes being exceedingly numerous and conspicuous (figs. 365,366 ).

There is no definite sequence in the early divisions of embryoformation. Transverse or vertical walls may occur at any division, although in the case of an embryo dereloping from a single cell the first two or three divisions are generally transverse. The organization of the great body regions has not been investigated, so that between 


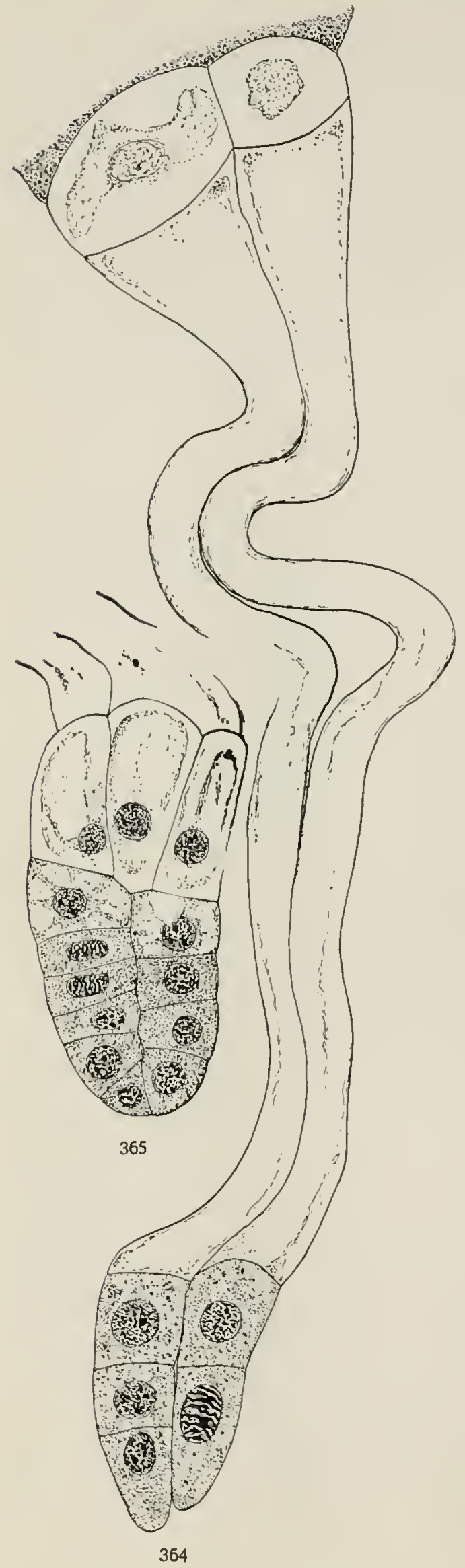

Figs. 364, 365.-Pinus Laricio: two embryos with long suspensors; in fig. 365 three young embryonal tubes may be seen between the embryo proper and the end of the suspensor. 
the earliest divisions and the beginning of the vascular system of the seedling there is a hiatus in our knowledge.

The only information in reference to the embryo of the Araucarineae is an carly account of Araucaria brasiliana by STRASBURGER (25) (figs. 367,368 ). The stem tip is not terminal, but is covered by a small group or layer of cells which is soon thrown off, and seems for a time to serve as an organ of penetration or protection. This terminal group of cells shifts the usual functions of the tiers of the procmbryo, the lowest tier developing this embryo cap, the middle tier producing the embryo, the tier next above (ordinarily the rosette) forming the suspensor. It is an interesting fact that this same feature is found also in the embryo of Cephalotaxus Fortunei (25) (figs. 369,370 ).

The origin of the testa is but little known in detail, but the region of its derelopment may be seen in fig. 275. Next to the endosperm is a dry, membranous layer derived from fleshy tissue; outside this is the hard layer, which in the upper region, at least, comes from the middle layer of the integument; the outermost layer, dry and incomplete, comes from fleshy tissue (fig. 37I).

The number of cotyledons among Pinaceae, involving as it does the origin of polycotyledony, is an interesting and im-

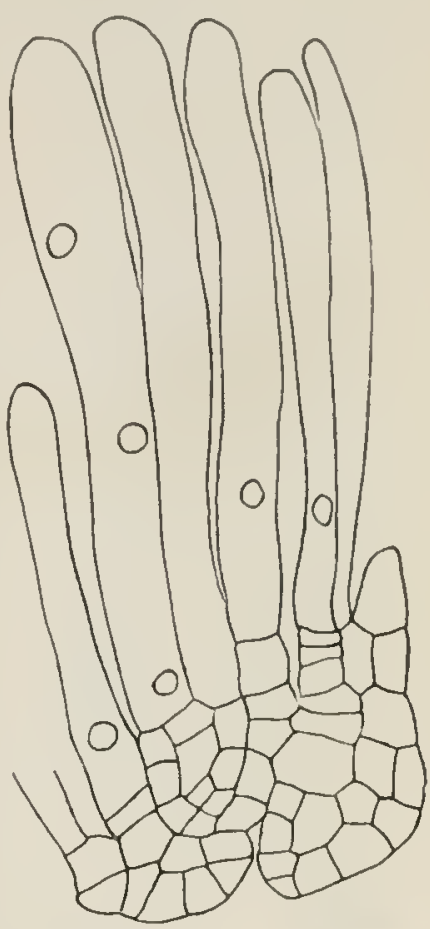

FIG. 366.-Taxodium distichum; apparently three embryos in a group uniting to form a single embryo; the embryonal tubes are conspicuous; $\times$ ISO.-. - Ifter СоKer (76). portant topic. The Bennettitales, Cycadales, and Ginkgoales have given the impression that the primitive number of cotyledons is two, but this still remains an open question. Among the Pinaceac the number varies from two to fifteen, and the fluctuations hold no relation to the tribes, except that the higher numbers are characteristic of the Abietineae, in which the recorded range is three to fifteen. Among the Taxodineae the range is two to six, two cotyledons appcaring quite uniformly in Sciadopitys, Cunninghamia, Sequoia sempervirens, and Arthrotaxis; two or three in Cryptomeria; and three to six in Sequoia 
gigantea. Among the Cupressineae the range is two to five, two being usual in Thuja, Callitris, Widdringtonia, and Actinostrobus; two or three in Libocedrus; and the whole range of two to five in the various species of Juniperus and Cupressus. Among the Araucarineae, A gathis has two cotyledons, and Araucaria two to four. These numbers will doubtless vary upon wider acquaintance with the forms, but they serve to illustrate that the fluctuations occur not only between tribes, but also within tribes and genera, and even species.

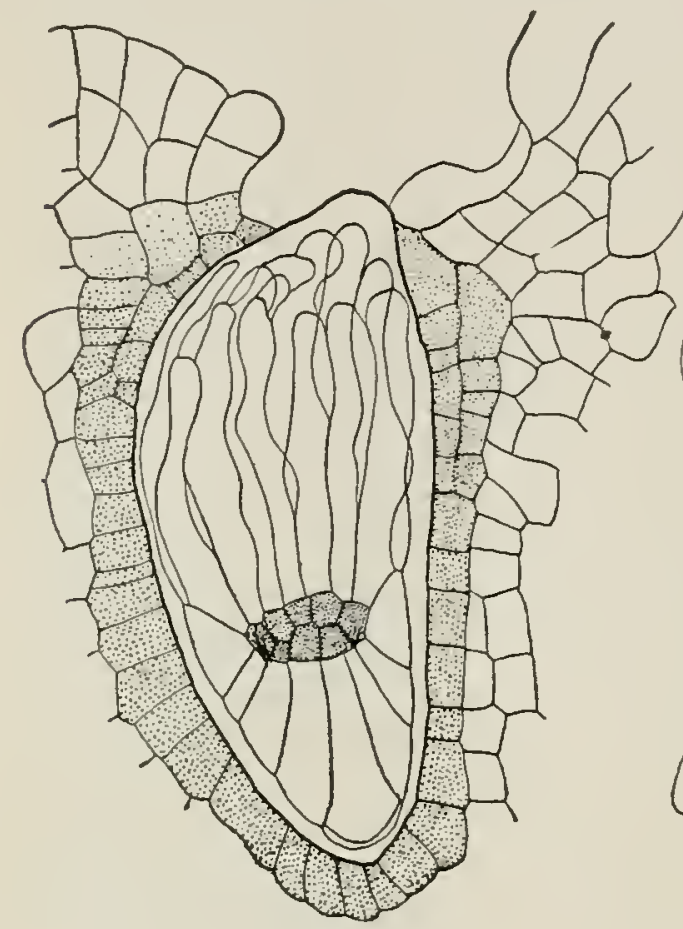

367

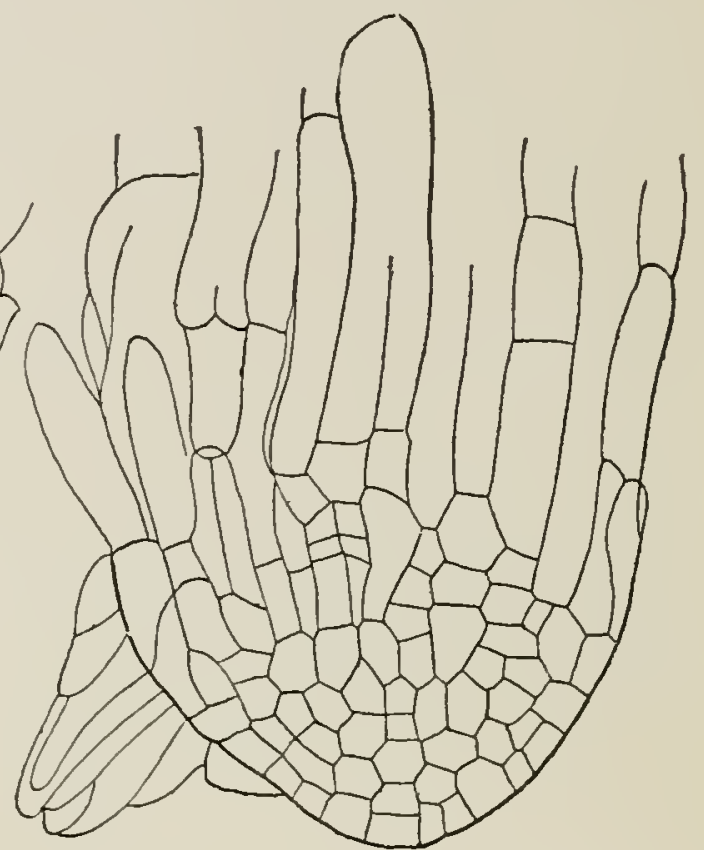

368

Figs. 367, 368.-Araucaria brasiliana: a proembryo filling the entire egg; only the shaded cells belong to the embryo proper, the wedge-shaped mass of cells below being the embryo cap; fig. 368 , later stage, showing the wedge-shaped mass of cells being thrust aside; $\times$ r53.-After Strasburger (25).

The explanation of this rariation is difficult, but there seem to be two alternatives: either the polycotyledonous condition is derived from the splitting of two ancestral cotyledons (I4I, I 54), or the dicotyledonous condition is derived from the fusion of more numerous cotyledons. In other words, it is a question whether polycotyledony is primitive or derived.

The argument for the derivation of polycotyledony from dicotyledony has been developed by Hill and De Fraine (I4I, I 54). This belief dates from Adanson and Jussieu, and was supported by 
Duchartre (5) and DANGEARD (36), the former calling attention to the inconstancy in the number of the cotyledons of polycotyledonous forms, and to the lack of any direct relation between these numbers and the connecting rascular strands. SACHS (27) and MASTERS (34) opposed this view, and so opinion has long been divided. Hill and DE FraINe find that among the Taxaccae and many Cupressineae the cotyledons are definitely two, each (except in podocarps) with a single vascular strand, and the root is diarch from the lirst. Among the Abietineae, in which there are three to many cotyledons, the vascular strand is single and the primary root structure is diarch, triarch, tetrarch, etc., the number of protoxylem poles bearing no obvious relation to the number of cotyledons, and variations occurring in the same plant. This lack of relationship between the number of cotyledonary strands and of root poles was noted by Chauveaud (68), who found in Pimus maritima such combinations as five cotyledons and a pentarch root, seven cotyledons and a tetrarch root, etc., the cotyledons in general being more numerous than the root poles. The argument further appeals to the occurrence of partially split cotyledons (Cupressus torulosa, Abies sibirica, Pinus montana gallica, Araucaria Cunninghamia), and to the fact that the cotyledons are often obviously in groups. Cases of transition are also cited, in which the strands are more or less divided, and this is accompanied

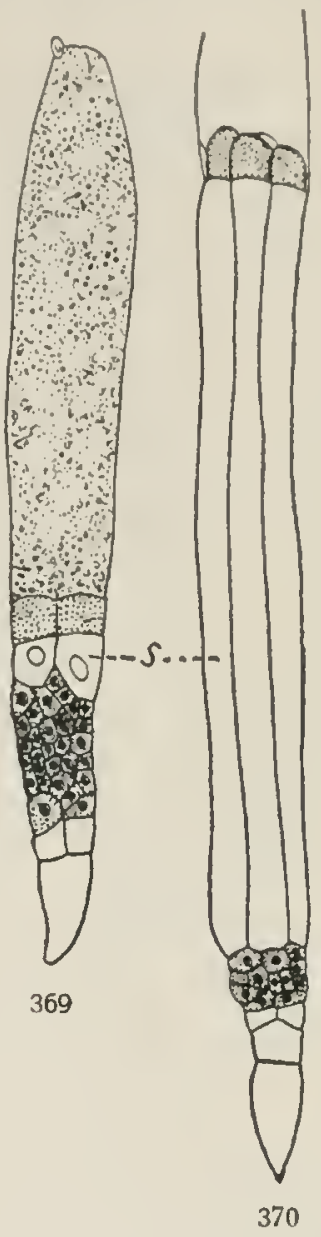

Figs. 369, 370.-Cephalotaxus Fortunei: fig. 369 , proembryo still within the egg; fig. 370, later stage showing the elongated suspensor $(s) ; \quad \times 63 .-$ ifter STRASBURger (25). by division of the cotyledon. As an illustration of this, three entire cotyledons were found in Pinus contorta Murrayana, one of which was much larger than the others and contained two separate strands, the conclusion being that one cotyledon had split into two and the other had remained entire. In the case of the higher numbers of cotyledons, 
the origin by splitting becomes difficult to explain, and it is believed that in some cases the number may be increased by the coming in of extra primordia, probably displaced from the first stem node to the cotyledonary node. The occurrence of more or less complete cotyledonary tubes was also found to be quite general, twenty species being cited.

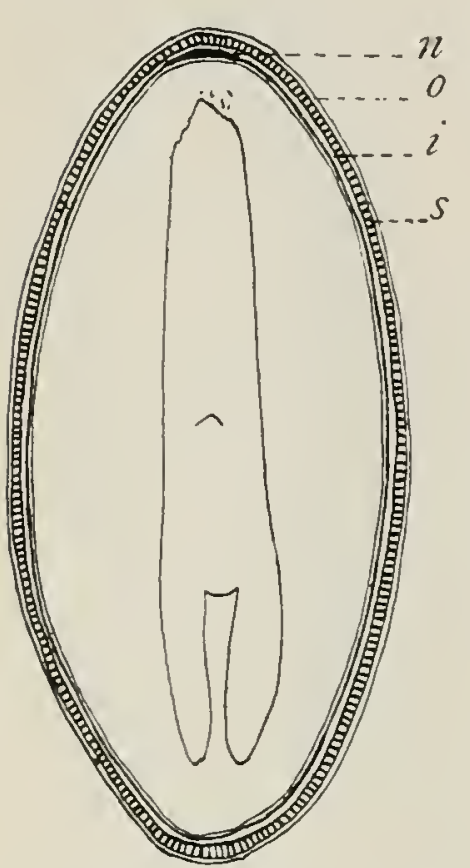

FIG. 371:-Pinus Laricio: diagram of longitudinal section of seed; the three layers of the seed coat are not separated from each other as shown in the diagram, but are tightly appressed, and the outer may be quite incomplete; $n$, remains of nucellus; $i$, remains of inner fleshy layer; $s$, hard layer; 0 , remains of the outer fleshy layer.

On the other hand, it must be remembered that these same facts may be used also as an evidence that the dicotyledonous condition has arisen from the fusion of more numerous cotyledons. It is evident that the question is at present an open one, but it must be remembered that probably our oldest group of Coniferales, older even than the Cycadales and Bennettitales with which we are acquainted, is the extreme illustration of polycotyledony, while the youngest of the Coniferales are dicotyledonous or nearly so.

It has long been expected that parthenogenesis would be found to occur among the Pinaceae, and recently SAxton has reported ( 58 ) that Pinus Pinaster ("cluster pine"), growing at Cape Town, is parthenogenetic, the nucleus of the egg dividing, and the divisions continuing to all stages of the proembryo, when there was no trace of pollen tubes in the nucellar cap, or tubes containing no nuclei were only part way through the nucellus. The series was close enough, and the comparison with stages in the normal embryo complete enough, to make the conclusion reasonably safe.

HAydon (I26) has made an interesting comparison between the theoretical and actual output of an ovulate strobilus of Pimus silvestris. It seems that such a strobilus might produce theoretically about I.500 proembryos, which means that number of successfully fertilized 
eggs; but that actually it produces 10 to 20 good embryos in as many sceds.

\section{Distribution}

The geographic distribution of Coniferales as a whole is in striking contrast with that of Cycadales, the former belonging to the temperate regions of both northern and southern hemispheres, and the latter belonging to the tropics and subtropics. The Pinaceac are massed chiefly in the northern hemisphere, and there is no crossing of the tropical belt by any genus except Libocedrus, which extends far into temperate South America by way of the Andes, and reaches Australia through the East Indian region. The main facts of distribution may be stated in connection with the tribes.

The Abietineac, including more than half the species of Pinaceae, are almost exclusively northern, the dominant genera, distributed throughout the temperate regions of the northern hemisphere, being Pinus, Abies, Picea, and Larix, genera which include I 55 of the 129 species of Abietineae. China contains two endemic genera (Pseudolarix and Keteleeria) and North America one (Psendotsuga); while Tsuga is North American and Asiatic, and Cedrus is Asiatic and North African. Both structure and distribution indicate a very natural group, which forms the chief gymnospermous forest display of the northern hemisphere.

The Taxodineae are a remarkable group geographically, for all the genera, eight in number, are narrowly restricted in range, and three of them are monotypic. If the tribe is at all natural, the distribution indicates a former wide extension, represented now by thirteen species in eight widely scattered and endemic genera. Four genera (Sciadopity's, Cunninghamia, Taiwania, and Glyptostrobus) occur only in the China-Japan region; two genera (Sequoia and Taxodium) are found in restricted areas of North America; while the remaining genus (Arthrotaxis) belongs to the southern hemisphere (Tasmania and Victoria). This distribution seems unnatural for a natural tribe, especially when contrasted with the distribution of Abictineae.

The Cupressineae are almost as remarkable in their distribution as the Taxodineae. Two genera, including more than half the species, range widely through the northern hemisphere, Juniperus belonging to the whole north temperate region, and Cupressus occurring in 
North America (including Mexico), southeastern Europe, and temperate Asia. Thuja and Chamaecyparis belong to North America and the China-Japan region, the former extending into central Asia; and Thujopsis is endemic in Japan. Four genera belong to the southern hemisphere, Actinostrobus and Callitris being restricted to the Australasian region, Widdringtonia occurring in equatorial and southern Africa, and Fitzroya with one species in southern Chili and the other in Tasmania. Libocedrus girdles the Pacific, being the only genus represented in both the northern and southern hemispheres, the general outline of its range being California, Chili, New Zealand, Australia, China, and Japan.

The Araucarineae are exclusively southern, Agathis belonging to the Malay Archipelago and the Pacific islands to New Zealand, and Araucaria occurring not only in the Australasian region but also in South America. This tribe is as characteristic of the southern hemisphere as are the Abietineae of the northern hemisphere.

By far the greatest display of Pinaceae in genera and species is that which borders the Pacific Ocean, the chief areas being western North America, the Australasian region, and the China-Japan region; and throughout the whole of this vast border region Libocedrus is represented.

The China-Japan region is notable for its eight endemic genera, six of which are monotypic (Pseudolarix, Sciadopitys, Cunninghamia, Taiwania, Cryptomeria, and Thujopsis), and the remaining two are each represented by two species (Ketelecria and Glyptostrobus). That such an assemblage of the genera of Pinaceae should have been preserved in this region after they had become extinct elsewhere is remarkable. The wealth of the coniferous flora of this region may be appreciated when it is understood that 87 species and 23 genera of Coniferales have been recorded from China (II3, I46), 42 of the species being endemic; while in Japan 48 species are recorded, I 5 of which are endemic.

Four of the genera of Pinaceae (Arthrotaxis, Actinostrobus, Callitris, and Agathis) are endemic in the Australasian region; and three (Pseudotsuga, Sequoia, and Taxodium) in North America.

These general facts of modern distribution can only be understood in connection with the more ancient distribution of genera and tribes, 
but the history of the Pinaceac is not in a condition as yet to supply such definite information.

\section{History}

The Coniferales are certainly very ancient, for remains of undoubted conifers occur from the later Paleozoic (Permian) on, and the total amount of material is enormous. Efforts have been made to determine the material upon the basis of anatomical structure, and the literature of paleobotany is full of names suggestive of affinities with modern genera, but the results have been disappointing. Beautifully preserved coniferous wood is common in Mesozoic deposits, but no means have been found to determine, without peradventure, even the tribes to which it belongs. Even the strong superficial resemblances of leaf-bearing twigs and cones cannot be relied upon to determine affinities. For example, Hollick and Jeffrey (I 55 ) have found that cretaceous coniferous remains referred with considerable confidence to Cupressineae, Podocarpineae, and Sequoia really belong to Araucarineae.

It would be a matter of very great interest if the affinities of the permian conifers could be determined, for it would go far toward determining the genetic relationships of the modern tribes. Recently new methods have been introduced, in connection with the study of mesozoic material, which promise to bring much nearer the knowledge of affinities, and with it some knowledge of the evolution of this most important group of gymnosperms.

In I900 ScotT concluded (6I) that there was no sure evidence of Abietineae below the Cretaceous. In the Wealden (lowest Cretaceous) there are dwarf shoots bearing fascicles of needle leaves, which are so characteristic of Pinus as to leave no doubt that forms allied at least to that genus existed; and at the same horizon abietineous wood occurs. Later Zeiller and Flichie $(82,88)$ reported the discovery of pine cones in the Jurassic of France. 'The discovery was interesting not only because it brought to light the oldest known pines, but also because the cones represented the two main series of existing pines (Strobus and Pinaster), and therefore the pines were already well differentiated in the Jurassic. Recently NATHORST (I48) announced the discovery of numerous winged pollen grains 
from the Triassic of Sweden, and concluded that pines flourished at that time. These discoveries carry the Abietineae, represented by Pimus and allied forms, through the Mesozoic, in a position to be connected with paleozoic gymnosperms. It must be recognized that cones and even winged pollen grains may not be sure evidence of Abietineae during the early Mesozoic, but they must be regarded as at least probable evidence.

The more detailed connection of living Abietineae with the paleozoic Cordaitales has been made by JEFFREY (I42) in his investigations of the gymnosperm remains from the Cretaceous of Staten Island (N.Y.), partly in connection with Chrysler (II2) and Holdick (I55). The investigations involved the development of a special technic in the treatment of fragments obtained from clay pits. The wood of these pines of the Middle Cretaceous, known as Pityoxylon, differs from that of living pines in the absence of marginal ray tracheids, highly resinous rays, and an association of certain features of hard and soft pines. It is inferred that these characters are ancestral for Pimus since they persist in the cones of existing species (II2). It was in connection with an investigation of the structure of the leaves of cretaceous pines, however, that the most interesting connection was made, for it resulted in the recognition of what is regarded as the direct ancestor of Pimus, which received the generic name Prepimus (142). This interesting form had deciduous dwarf shoots bearing numerous spirally arranged leaves, whose structure is most suggestive. There are paired resin canals continuous to the very base, well-marked centripetal xylem, and about the vascular bundles a complicated double sheath of transfusion tissue resembling that found in the leaves of some Cordaitales. Many of the true pines of the Cretaceous were found to have this sheath, but not the centripetal xylem; and JEFFREY regards the tissue adjacent to the protoxylem in the leaves of existing pines as a relic of the inner transfusion sheath rather than of centripetal xylem (p. Io). In this way a connection is established between living pines and paleozoic Cordaitales through cretaceous pines and Prepimus. If this connection is trustworthy, the Abietineae are as old as any tribe of the Pinaceae can be, and Pimus is the oldest genus.

If Sequoia be excluded from the Taxodineae, there is no evidence 
of the existence of that tribe before the end of the Cretaceous. Until recently, the oldest claim made for Sequoia was its occurrence in the Wealden (lowest Cretaceous) of Portugal; but Ziilleer and Flicire $\left(S_{2}, S 8\right)$ have announced cones of Sequoia from the Jurassic of France, which represent both the $S$. gigantea and the $S$. sempervirens types, and therefore the genus was already differentiated in the Mesozoic. Much doubt has been thrown upon these determinations by increasing knowledge in reference to the extensive araucarian flora of the Mesozoic, for cretaceous forms referred to Sequoia have proved to be araucarian. Of still greater uncertainty is Voltzia of the Upper Permian and Triassic (6I), which has been referred to the Taxodineac on the evidence of certain vegetative and cone characters, the cone scales being said to be two-lobed as in Cryptomeria. With the triassic Voltzia and the jurassic Sequoia in a state of uncertainty, the only safe conclusion is that Taxodineac are not older than the Cretaceous and that the most certain remains are those of the Tertiary.

The same statement may be made for Cupressineae, for although Cupressus-like twigs and cones have been described from the Jurassic, there is no reliable evidence of the tribe earlier than the Upper Cretaceous.

It is clear, therefore, that the Abietineae are much older than the Taxodineae and Cupressineae, and this historical relation farors the view that these two tribes have come from abietineous stock.

The Araucarineae are rival claimants with the Abietineac for antiquity, and the question as to the relationship of these two tribes is of great interest. It is now known that there existed an extensive araucarian flora during the Mesozoic, and that this was probably the dominant type of Coniferales at that time. Araucarians ranged from Greenland to Patagonia in one hemisphere, and from Spitzbergen to Cape Colony in the other, but apparently became almost extinct at the opening of the Tertiary, and are now restricted to South America and the Australasian region, having disappeared from North America, Europe, Africa, and practically all of Asia (I 8, I37). In our own country the Atlantic coastal plain eridently supported during the Mesozoic an abundant araucarian vegetation, and from the cretaceous clay pits of Staten Island alone, Hollick and JEFfrey

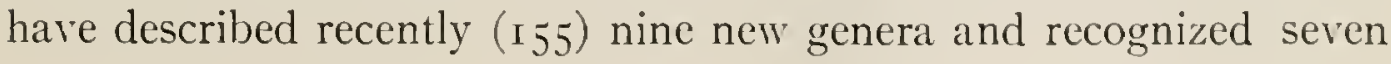


others; and SinnotT (I62) has added another new genus from Massachusetts. It was in connection with these studies that the general character of this flora was outlined. One of the important results was the discovery that coniferous remains which had been referred to Sequoia, Cupressineae, and Podocarpineae, on account of strong superficial resemblances, are really araucarians.

Two types of wood structure have been described (155), which seem to represent a phylogenetic connection of the living araucarians with some very ancient type. The anatomical characters of existing araucarians are summarized as follows: tracheids with radial bordered pits alternating or flattened by mutual contact; resin canals not formed as a traumatic response; medullary rays pitted only in contact with tracheids; and leaves not on dwarf shoots. One of the mesozoic types, including sereral genera whose wood has been named Brachyoxylon, differs in that there is an association of araucarian and abietineous pitting, the former being restricted to the ends of tracheids, and also in that resin canals are formed in response to injury, as in Abietineae. The other type is represented by the genus Araucariopitys ( 27 ), whose tracheids show the same association of araucarian and abietineous pitting, and in which traumatic resin canals are often present, but whose medullary rays have pits not only on the lateral walls but also on the other walls, as in Abietineae, and whose leaves are probably on dwarf shoots, as in Pinus. There are thus three types of araucarians, which show intergrading characters from the existing type through the two mesozoic types toward the Abietineae. These intergrading characters, if they have the ralue that has been assumed for them, seem to connect in some way the Araucarineae and the Abietineae, and this connection must have been a rery old one.

An abundant and world-wide araucarian flora during the Jurassic and Cretaceous would at least suggest the existence of the tribe in much earlier times, but the evidence from actual remains is not conrincing. The permian genus Walchia, whose leafy twigs are common, some of them bearing cones, has been referred to the Araucarineae. The habit is like that of some of the living araucarians; casts of the pith (Tylodendron) agree closely with Araucaria, the wood is of the Araucarioxylon type, and the small scaly cones suggest the same connection. Eren with all this agreement, howerer. the case is not 
proved, and the strongest evidence for such ancient araucarians is the abundance of mesozoic araucarians. The impression that the Araucarineac are the oldest of the Coniferales seems to have arisen, therefore, from the abundance of the Araucarioxylon type of wood in the Palcozoic; but since it is found that this palcozoic wood probably all belongs to Cordaitales (p. I65), the evidences of palcozoic araucarians look very scanty. SCOTT (I60) has expressed the judgment that "the direct palcontological cridence, apart from theoretical considerations, is favorable to the opinion that the Araucarincac have the longest fossil history, probably overlapping that of the typically palcozoic order Cordaitcac."

The gencral conclusion in regard to the antiquity of the four tribes of Pinaceac, thercfore, is that the Abietineae and the Araucarineae are much the oldest, both being certainly represented throughout the Mesozoic, and probably in the Permian, with no sure evidence as to which of the two is the older. The Taxodincae and Cupressineae are probably not older than the Cretaceous, and are recognized with certainty chiefly from the Tertiary.

Recently Miss Stopes and Fujir (i69) have uncovered the first glimpse of a cretaceous flora of northern Japan, the well-prescrved material permitting sections. The most common plant was a gymnosperm, whose vegetative structures were named I'ezonia. Constantly associated with its remains there were strobili, named Yezostrobus, and strongly suspected of belonging to it, but not found in actual organic connection. The small concrescent leares suggest the Cupressineae, but they are in a close spiral and differ in structure from those of any other gymnosperms, having a number of rascular bundles and broad bands of transfusion tissue. Its strobili, if Yezostrobus belongs to it, were composed of scales bearing single sceds in the middle, whose massive integument was cycadean (three-layered, and with vascular strands in the outer and inner fleshy layers), but whose nucellus was free to the base (fig. 45). This combination of characters has induced the authors to suggest the establishment of a new family of Coniferales, to be known as the Yezoniaceae. There is thus evidence of an abundant cretaceous gymnosperm flora in a region which has preserved a remarkable series of "endemic" genera of gymnosperms, and whose fossil flora may add very materially to 
their number. It is very probable, according to JefFrex, that Yezonia is the same as Brachyphyllum, the commonest conifer (araucarian) of the later Mesozoic in the Atlantic coastal region of the United States. Whaterer the peculiar anatomy of the leaves of Yezonia may suggest as to relationships, the structure of the seed, with its completely free nucellus, suggests either a remarkably persistent retention of an ancient character, or an abandonment of the idea that such a character is necessarily ancient. Moreover, in these detached seeds no embryos were found, adding force to the suggestion, made in connection with paleozoic seeds, that the absence of embryos is not a paleozoic character, but a character of seeds prematurely detached.

\section{Interrelationship of the tribes}

All the evidence of morphology, vascular anatomy, and history favors the belief that the Taxodineae and Cupressineae have been derived from the much more primitive stock of the Abietineae; and these two branches may be assumed to have arisen during the Mesozoic.

The discussion of relationship, however, has really to do with the Abietineae and Araucarineae, and to this discussion history can contribute nothing decisive. The apparent anatomical connection of these two tribes, suggesting genetic relationship, has been mentioned, and JEFFREY has concluded that the Araucarineae have been derived from the primitive stock of the Abietineae. The general outline of the argument is as follows. That abietineous wood with resin canals only as a result of injury (as in Cedrus, Abies, Tsuga, Pseudolarix) is less ancient than that in which resin canals are a normal feature (as in Pinus), is shown by the greater geological age of the latter; and this is indicated further by such a Pinus-like form as Prepinus, which, in addition to its resin canals, has foliar vascular bundles identical with those of Cordaitales. The inference is that a resin canal produced by wounding is a "reversionary character." These wound reactions occur in both of the fossil araucarian types of wood known as Brachyoxylon and Araucariopitys, but not in living araucarians; and since these two types show also a combination of araucarian and abietineous pitting, both in the secondary wood and 
in the medullary rays (p. 306), the movement of erolution seems to have been from the Abictinca toward the Araucarineac. It would follow that the modern araucarians have come from ancestors (like Araucariopitys) allied to the Abietineac through such intermediate forms as Brachyphyllum and its allies (with Brachyorylon wood). It is evident that these cretaccous types could not have made the actual connection with Abictineac, but they may represent the structure of much more ancient forms that did.

One objection to the abietincous origin of araucarians is that the latter were a dominant type during the Mesozoic, while the Abictineac seem to have been scantily represented. At present it is an assumption that the Abictineae were poorly represented, and so far as there is any proof to the contrary, Pinus may have been represented by as many species during the Cretaceous as now. At the same time it must be remembered that these resemblances and the historical record would be satisfied by the independent origin of the two tribes from such a common ancestry as the Cordaitales. Therefore, so far as the present evidence goes, it is satisfied with two alternatives: either the Araucarineae were derived from the Abictineae at a very early period, or the two tribes arose independently and about the same time from the same ancestral stock.

\section{Relationship to other gymnosperms}

The question of the origin of the Pinaceae was involved in the discussion of the interrelationship of the tribes. There seems no reason to doubt that the primitive stock came from the Cordaitales, either an abietineous stock alone, which gave rise to the other tribes, or such a-stock accompanied by a separate araucarian phylum. It must be remembered that Cordaitales include a range of forms much more extensive than the Cordaitineae (Cordaiteae), forms which show intergrading characters between Cordaitineae and Cycadofilicales. It is from such a plexus that Coniferales as a whole may be claimed to have been derived. To present the data which favor this connection with the Cordaitales would be to rehearse the facts of structure and of history that have been presented in connection with the two groups. With Cycadofilicales and Cordaitales in mind as the dominant paleozoic groups of gymnosperms, the latter as clearly 
leads to the habit and structure of Coniferales, as the former does to that of Cycadales. The habit of the body, the thick vascular cylinder, the entire leaves, the structure of the ovulate strobilus, are all conspicuous features of Cordaitales that are carried forward by the Coniferales, and are in strong contrast with the features of the cycadophytes. Apparently the most important change observed in the Coniferales is the abandonment of the swimming sperm with its associated pollen chamber. It must be remembered, however, that the record of this change is obtained by contrasting living conifers with paleozoic Cordaitales, and that there is really no evidence as to when it occurred or in what group.

There are two views as to the origin of Pinaceae which differ from the one expressed above, and which deserve mention.

In his investigation of the secondary wood of Coniferales, PENHALLOW (96, I33) has reached the conclusion that the Pinaceae have come from the Taxaceae (that is, a primitive taxad stock), which in turn are a phylogenetic branch from the Cordaitales. So far as the Cordaitean origin of conifers is concerned, this view agrees with the preceding one; but as to the primitive conifers, the two views are directly contradictory; and the latter view seems to be contradicted also by history, especially as the phylogenetic succession proposed is Taxodineae, Cupressineae, and Abietineae, with Pinus as the most modern genus. The conclusions are based upon the assumption that greater complexity of structure necessarily indicates a more modern form. It must be kept in mind, in connection with all these views, that the tribes as represented in our present flora are not thought of as ancestral forms, but that they represent the ends of successive branches that have arisen from a common coniferous stock. This investigator concludes also that the Araucarineae had an independent and direct origin from the Cordaitales, which is one of the alternatives mentioned above.

The other view referred to is that of SEWARD (IO5, II7, II 8), who has argued for the origin of Araucarineae from Lycopodiales. This is an older view (SACHs, Eichler, Potonié) that had passed out of notice in connection with recent work. SEwARD urges that the primitive character of araucarians is shown by (I) the gradual transition from ordinary foliage leares to sporophylls (also often green); 
(2) the uniform and simple character of the secondary wood, composed almost entirely of tracheids with multiseriate bordered pits; (3) the persistence of leaf traces, even in old trunks; (4) the simple sporophylls (each the homologue of a foliage leaf) in contrast with the double structure that characterizes the orulate cones of the other Pinaceae; and $(5)$ the very numerous and irregularly scattered archegonia, which are found in no other Pinaceae except Sequoia. Admitting the force of all these characters in proving the primitive character of any group) possessing them, they merely emphasize the fact that the araucarians are very distinct from the other Pinaceae, and must have been distinct for a very long time. Of course this claim is only preliminary to the attempt to establish a phylogenetic connection with the Lycopodiales, through some such form as Lepidocarpon. The objections to this connection are numerous, and perhaps the most fundamental one is the presence in araucarians of foliar gaps and of wood indistinguishable from that of Cordaitales (г 6 ). The gradual transition from foliage leares to sporophylls finds a parallel among the Cycadofilicales; and the cited characters of the archegonia are repeated in Sequoia and Widdringtonia. SEWARD and FORD (I05, II 8 ) have been so impressed by the isolation of Araucarineae among gymnosperms that they have proposed a group Arancariales, coordinate with Conifcrales, Cycadales, etc.

Scotr (160) has summed up the evidence in faror of the cordaitean origin of the araucarians, as against their lycopodinean origin, in effect as follows: (I) the stem structure, especially that of the wood, is cordaitean, and is unknown among lycopods; (2) the roots are essentially of cordaitean type (true of conifers in general), and show none of the peculiarities of the roots of lycopods; (3) the leares (with their numerous parallel bundles) agree with those of Cordaitales, and not with those of Lycopodiales (with a single foliar bundle); (4) the staminate strobili and sporangia are cordaitean, and differ absolutely from those of lycopods. The orulate strobilus seems to be the only support of the view that araucarians have been derived from lycopods.

The relation of the Pinaceae to the other living groups of gymnosperms may be inferred from the previous statements, and needs only a brief mention. The only connection with Cycadales is through the Cycadofilicales, and that is both very ancient and very problematical, 
involving as it does the question of the relationship of Cordaitales and Cycadofilicales. It is evident, therefore, that Cycadales and Coniferales are as far apart as the history of gymnosperms could make them. The connection of Pinaceae and Ginkgoales is much closer, for it is evidently made through their common ancestral group, the Cordaitales. These two groups, therefore, have many characters in common, but have carried forward differences that have made them distinctly divergent, and they are now as far apart as two groups with an immediate common ancestry can be. The relation of Pinaceae to Taxaceae is obscure, but the combined testimony of history and of structure suggests that the latter have been derived from the former. A fuller discussion of this is deferred until the Taxaceae are presented. The relation of Pinaceae to Gnetales is still more obscure, but a phylogenetic connection seems evident through Ephedra, which will be considered later. ${ }^{\mathrm{I}}$

I The literature cited for Pinaceae will be found under the general list for Coniferales, at the end of the next chapter. 


\section{CHAPTER VII \\ CONIFERALES (TAXACEAE)}

The Taxaceae were defined superficially (p.220) as conifers in which usually distinct orulate strobili (in the ordinary sense) are not formed, the ovules often being exposed freely, and in which the seeds develop a partially fleshy testa or an aril. 'These very general characters are accompanied by such peculiarities in the morphology that the family is presented separately from the Pinaceac. The Taxaceae include II genera and approximately ro5 species, two tribes being recognized.

The Podocarpineae (podocarps) are superficially recognized by their winged pollen grains, and are characteristic of the southern hemisphere. They include 6 genera and approximately 86 species, as follows: Podocarpus (6o species, throughout the southern hemisphere: West Indies and South America, tropical and southern Africa, Australasia to Japan), Dacrydium (I6 species, Australasia to the East Indies), Microcachry's (I species, in 'Tasmania), Pherosphaera (2 species, in Australia and Tasmania), Saregothaea (I species, in the Andes of Chili), and Phyllocladus (6 species, in New Zealand, Tasmania, and the East Indies). The dominant genus is Podocarpus, which holds the same conspicuous place among the conifers of the southern hemisphere that Pinus holds among the northern conifers. This great genus is also the only one of the podocarps represented in the northern hemisphere, extending into Japan from the East Indies (fig. 372). Phyllocladus is often regarded as representing a third tribe, intermediate between the other two, but its morphological characters clearly associate it with Podocarpineae (I 45, I74).

The Taxineae (taxads) have wingless pollen grains, and are found chiefly in the northern hemisphere. They include 5 genera and approximately ig species, as follows: Taxus ( 7 species, throughout the temperate and subtropical regions of the northern hemisphere; also in tropical Asia and the mountains of Mexico), Torreya (4 species, in the United States, Japan, and China), Cephalotaxus (6 species, in eastern Asia), Acmopyle (I species, in New Caledonia), 


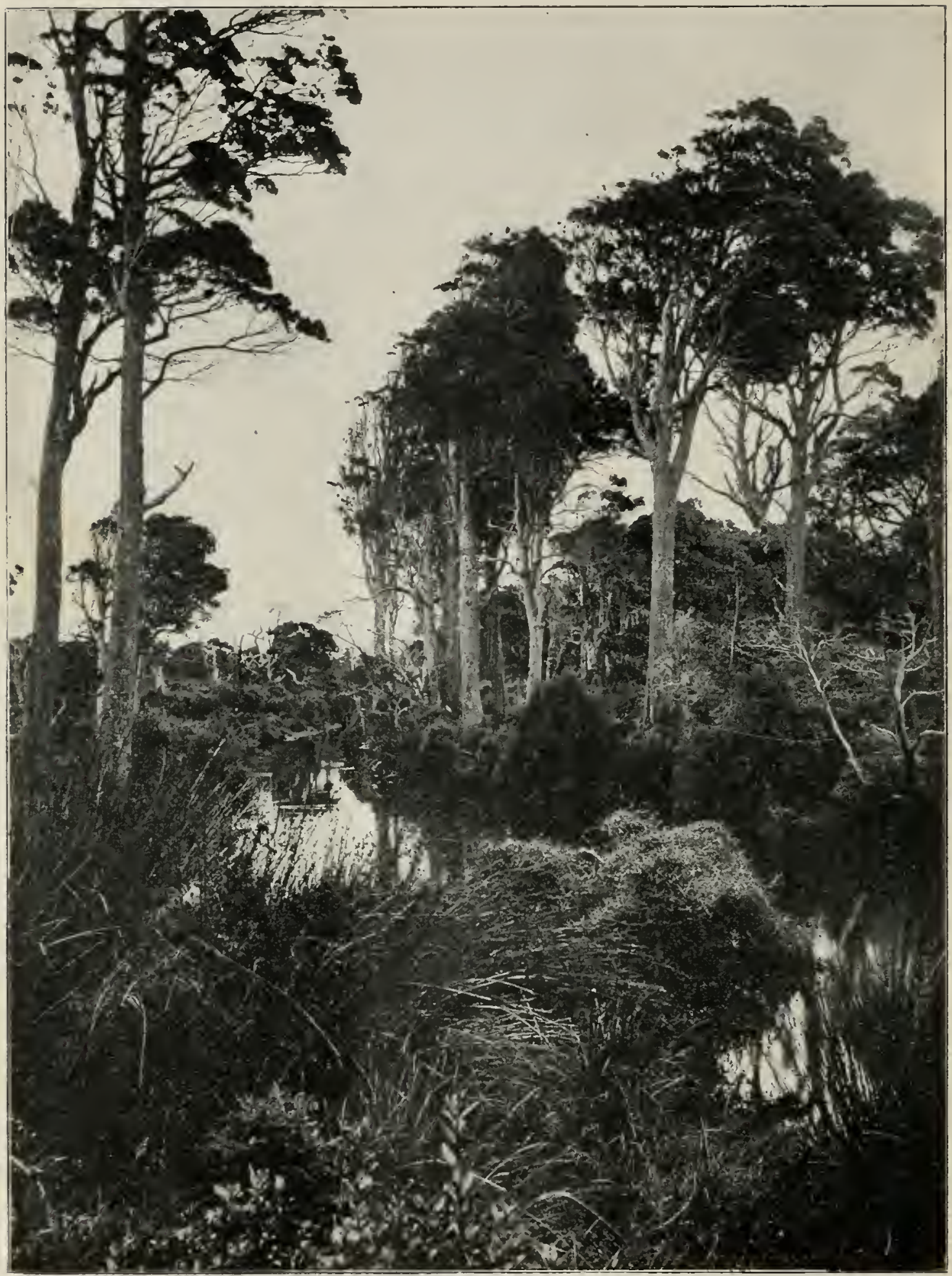

FIG. 372.-Podocarpus dacrydioides in a remmant of a forest of Taxaceae near Invercargill, New Zealand.-From photograph by J. Crosby Sumth. 
and Polypodiopsis (I species, in New Caledonia). 'The New Caledonian representation is so small, and the affinities of Polypodiopsis are so uncertain, that the tribe may be regarded as northern in its distribution, in contrast with the southern distribution of the podocarps. The difficulty of estimating the number of species may be illustrated by Tavus, at least 75 species of which have been described, 7 of which are recognized by BENTHAM and HOOKER; and these have been reduced to a single species by PIJger (8I).

The Taxaceae and Pinaceae have so many features in common that in the following account, to avoid needless repetition, attention will be called chiefly to the differences.

\section{The vegetative organs}

The general habit of the body of Taxaceae resembles that of Pinaceae. In some forms, also, the branches are dimorphic, the dwarf shoots of Phyllocladus being transformed into the characteristic phylloclads (fig. 373). The phylloclads are in the axils of small scalelike leares, which are at first green, but later become true scales, and are really developed by the primordia of foliage leaves; while in the jurenile forms the first leares are flat green needles, which are successively replaced by shorter and shorter ones until the adult form is reached, and the phylloclads themselves only gradually acquire their peculiar character (fig. $256, c, f$ ). It seems evident that this peculiar form has been derived from forms with ordinary spreading needles and axillary dwarf shoots.

\section{VASCULAR ANATOMY}

The structure of the stem is the same as that of Pinaceae, the vascular cylinder being collateral endarch. Among the taxads, howerer, the traces of ancient structure in the form of mesarch bundles are of more general occurrence than in any other tribe of conifers. Pronounced mesarch bundles occur in the cotyledonary strands of Cephalotaxus (45, IIO, I4I), and less obviously in those of Taxus (I IO, I4I) and Torreya (75); while one species of Cephalotaxus is reported to have a mesarch stem cylinder. Among the podocarps mesarch bundles occur in the phylloclads of Phyllocladus (II5), and there are apparently traces of centripetal xylem in the axis of 
the staminate cone of Saxegothaea (I 50 ). It is probable that mesarch bundles will be found to be a common feature of the cotyledons of all

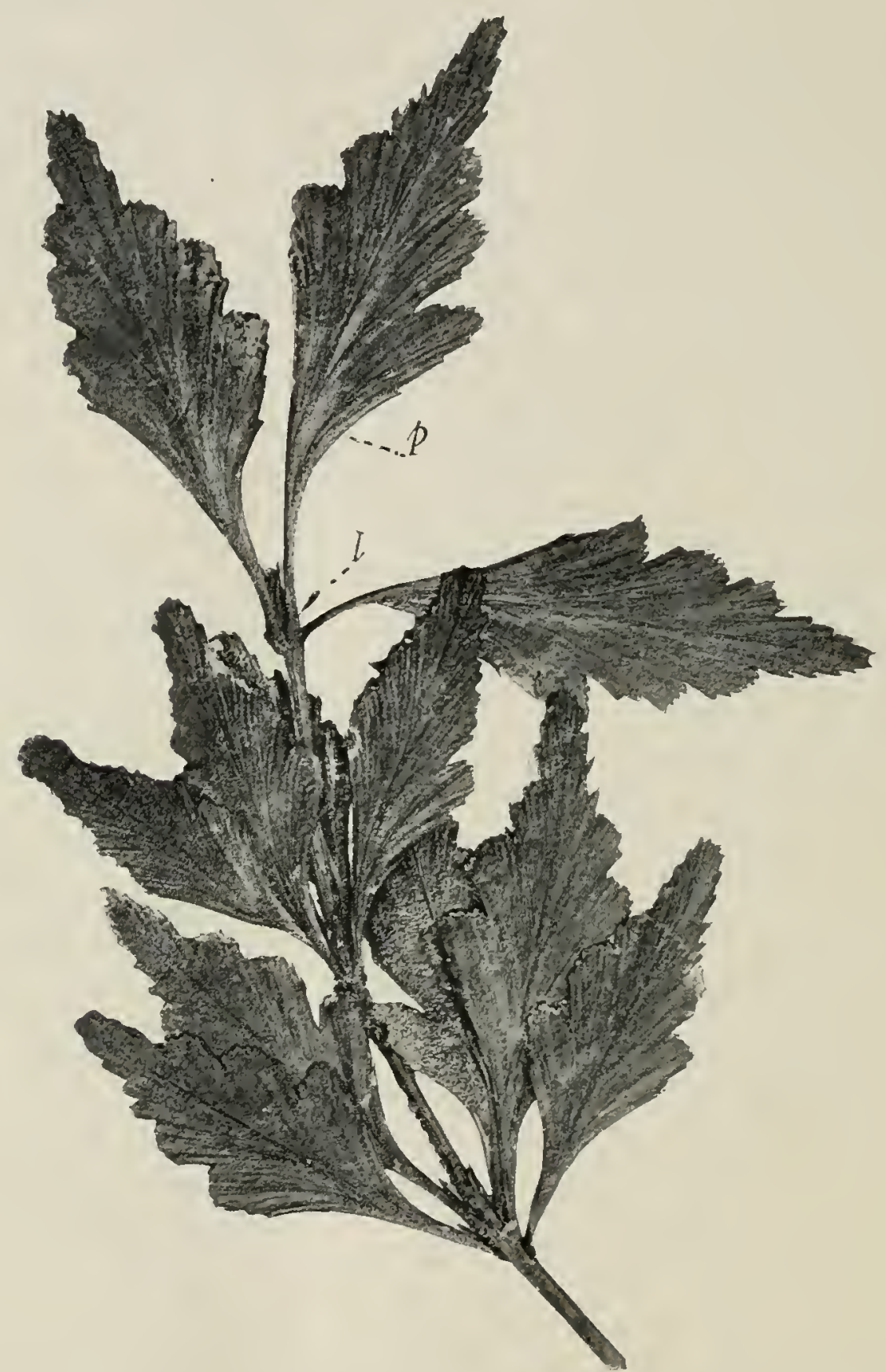

FIG. 373.-Phyllocladus rhomboidalis: portion of a small branch showing leaves $(l)$, from the axils of which come the phylloclads $(p)$; natural size.

Taxaceae, and that they will prove to be of common occurrence in the peripheral parts of the shoot. Howerer this may be, the number of cases reported already are sufficient to contrast the Taxaceae with the 
Pinaceae in this feature, which is barely represented in the latter family in Jumiperus and Cupressus, and in the cone scales of Araucaria.

The leaf trace is single, even the cotyledons being supplied by a single vascular strand, except those of Podocarpus, in which there are two entirely separate strands. In this feature Podocarpus (and perhaps other podocarps) differs from the taxads and most of the Pinaceae. In this case the two cotyledonary strands together form one pole of the primary diarch root (I4I).

The tracheids of the secondary wood are in general of the abictineous type, the bordered pits being uniseriate; but in Saxegothaca (I 50) the pits are flattened horizontally and occasionally tend to form two ranks, and in Dacrydium the pits are two-ranked and alternate. How far these araucarian tendencies will be found to prevail among the podocarps remains to be seen.

The medullary rays are simple as compared with those of Pinaceae, especially the Abietineae. In Saxegothaea, for example, they are one cell wide and rarely more than three cells deep. Resin canals are not present at all in taxads; they do not occur in the secondary wood of podocarps, so far as recorded, although they are found in the cortex; and they are said to be wanting in the cotyledons of all the Taxaceae. Further observation of the family for this feature, especially in connection with experimental work, will probably relate it in this regard much more definitely to the Pinaceae.

THE LEAF

The foliage leaves of Taxaceae are in general spirally arranged (opposite and decussate in Microcachrys), and are as variable as are those of Pinaceae. Among the taxads the free, bladelike needles prevail; while among the podocarps there is every gradation from the very small and closely overlapping and even concrescent leares of certain species of Dacrydium and of Microcachry's, to the large and broad leaves of some species of Podocarpus (fig. 374). In Phyllocladus there are no foliage leaves, their function being performed by the phylloclads, and leaves being represented only by scales (fig. 373).

The anatomical structure of the leaf is in general that of the leares of corresponding form among the Pinaceae (p. 23i). 


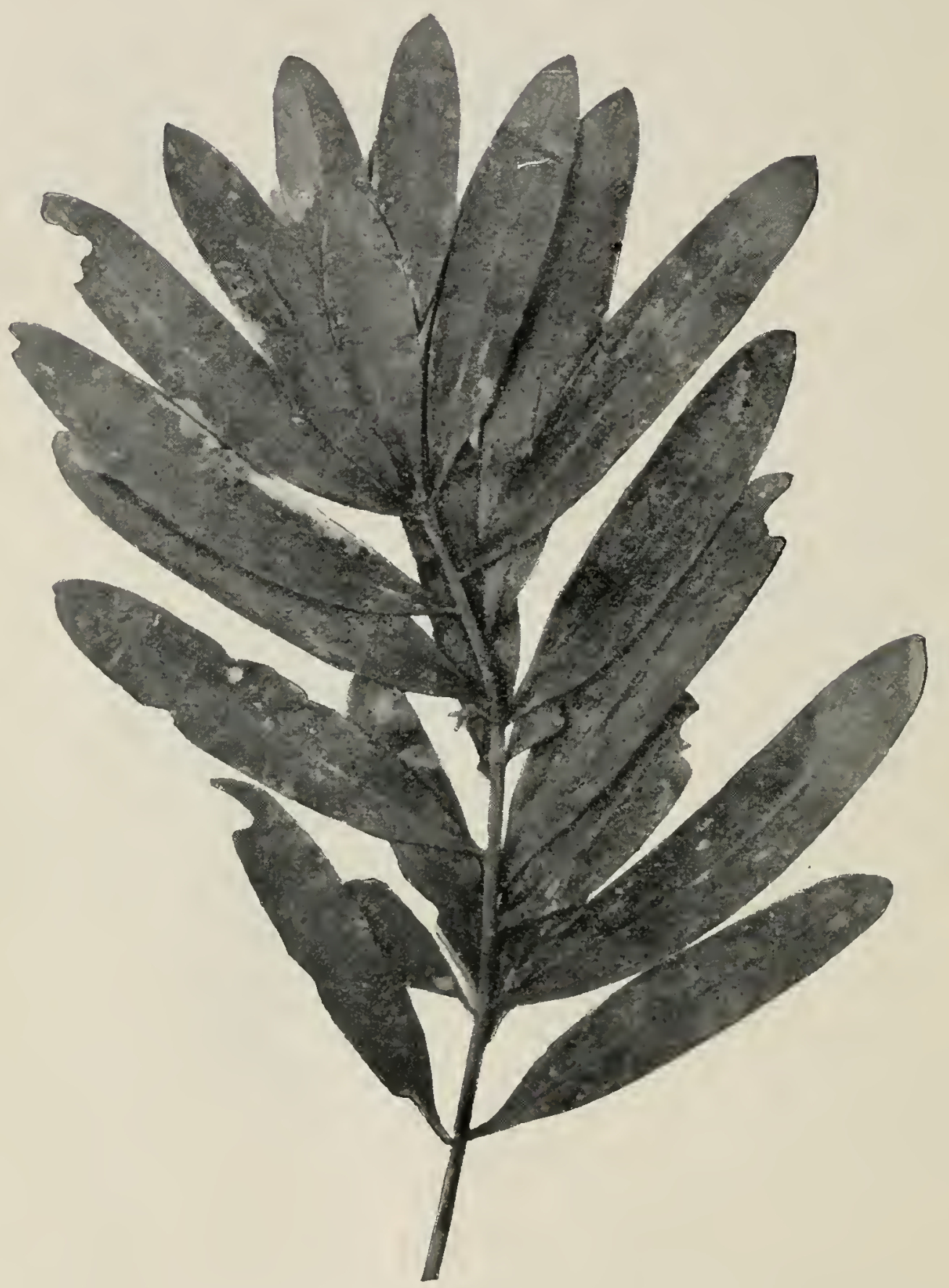

FIg. 374.-Podocarpus Purdicana: from a photograph of a herbarium specimen; two-thirds natural size. 


\section{The spore-producing members}

The strobili of 'Taxaceac are monosporangiate, and in the main the plants are dioccious, Saregothaca, some suecies of Podocarpus, and perhaps occasionally Phyllocladus being monoccious. The interesting observation has been made (I 49) that in a specimen of Sa.vegothaea growing in a greenhouse at $\mathrm{Lppsala}$, some of the branches are mostly staminate and others mostly orulate. No bisporangiate strobili have been reported, except a single case of Phyllocladus alpina ( $\left.\mathrm{I}_{5}\right)$, in which an orule was found at the base of a staminate strobilus. Although the statement is current that usually strobili are not formed among the 'Taxaceac, this refers to the orulate strobili, for the microsporophylls are as definitely organized into simple strobili as are those of Pinaceae. Even in the case of the orulate strobili, the statement must be taken with a good deal of allowance, for such strobili do occur, as in Microcachry's and Saxegothaea, but not always in the same conspicuous way as among the Pinaceae.

\section{THE MICROSPORANGIUM}

The staminate strobili are borne on short stalks in the axils of foliage leaves (scales in Phyllocladus), usually appearing upon young shoots of the same season (fig. 375). The relations of leares and strobili are such that if the axis of the shoot were shortened, becoming a dwarf shoot, it would be transformed into a compound strobilus; as it is, the staminiferous shoot often resembles a raceme ( 150 ). The strobili are generally solitary in the axils, but they may occur in pairs or in threes, as in Podocarpus (I39) and Saxegothaea (I50); and in Phyllocladus they are borne in clusters of two to eight at the tips of the lateral branches. In the monoecious Saxegothaea the orulate strobilus is terminal on the short branch in the axils of whose leaves the staminate strobili are borne. The size and form of the strobili are variable, ranging from 2 to $20 \mathrm{~mm}$. in length, and in form from linear to nearly spherical. The strobili consist externally of a variable number of overlapping sterile bracts, which sometimes completely envelop the tip, as in Torreya (ror), and sometimes form an involucrelike cluster at the base of the strobilus, as in Saregothaea (I50).

The sterile bracts (sporophylls) are replaced above by a more or less indefinite number of stamens. Among the taxads, disregarding 
the rather doubtful New Caledonian genera Acmopyle and Polypodiopsis, the stamens are of the peltate type; that is, the stalk is

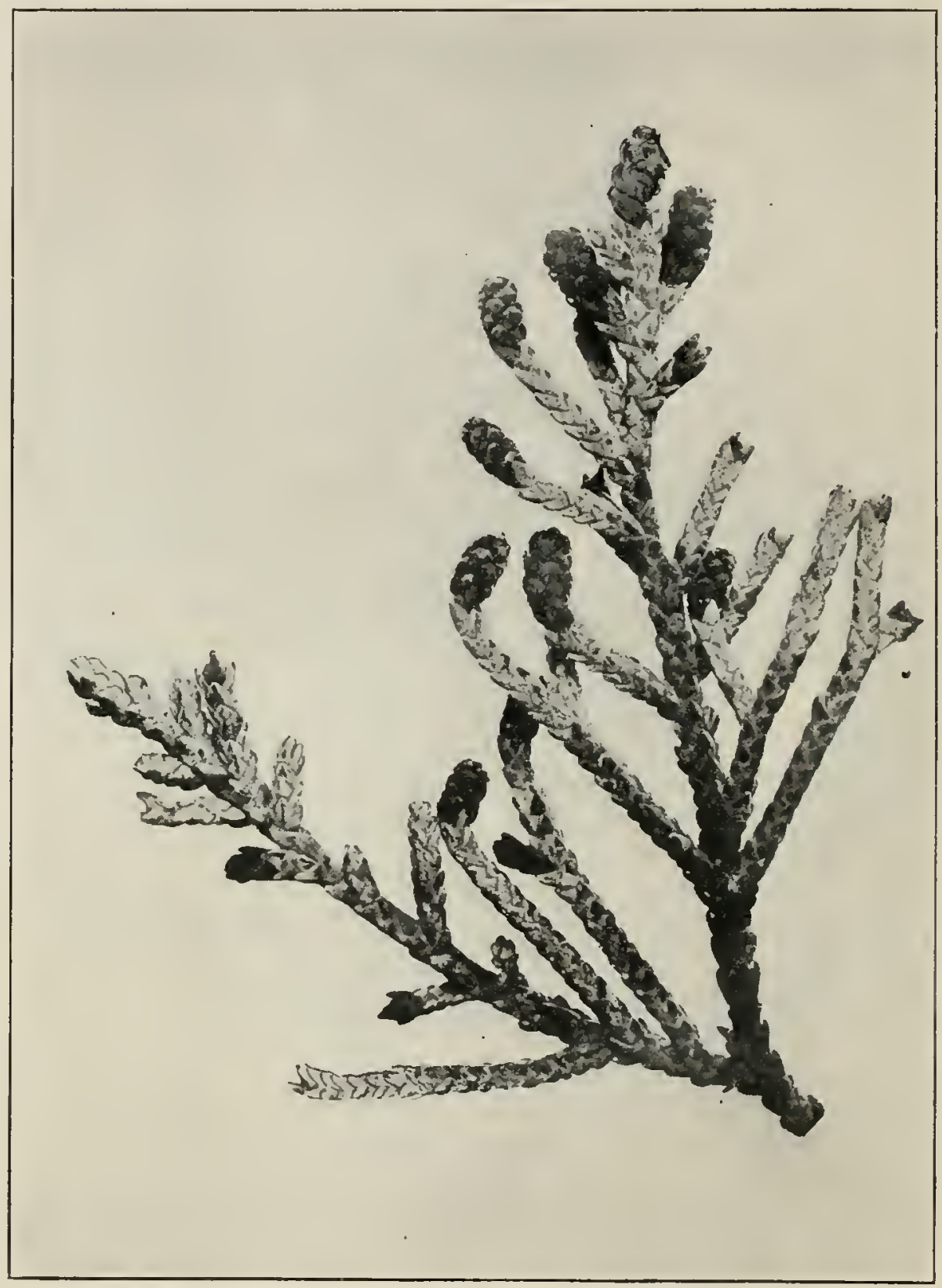

FIG. 375.-Microcachrys tetragona: branch with staminate strobili; $\times 2.25 .-$ After Thouson (I5I).

capped by a peltate expansion, from beneath which the sporangia are pendent. In Tavus the sporangia are four to seven in number, completely surrounding the stalk; in Torreya seven sporangia begin to develop, but only the four abaxial ones mature, so that the stamen 
appears one-sided with its pendent abaxial sporangria; while in Cephalotavis the sporangia range from four to two in number. 'The site of the three abortive sporangia in Torreya is occupied at maturity by a large adaxial resin cavity, and in some cases six or seven mature sporangia occur (98); whether there is such evidence of abortive sporangia in Cephalotaxus has not been determined. 'This type of stamen is very suggestive of that of the araucarians; and is represented among the Cycadofilicales by the so-called Crossotheca or "epaulet" type. Among the podocarps the stamens in general resemble those of the Abietineae, two sporangia being borne on the abaxial face of a bractlike sporophyll (sometimes pendent?), whose sterile tip is variously developed, from an inconspicuous point to a relatively broad expansion.

The details of the development of the microsporangium have not been followed, but at maturity the wall is three to five layers of cells thick, the one or two innermost layers forming a somewhat inconspicuous and short-lived tapetum. In Torreya taxifolia each sporangium begins as a single hypodermal archesporial cell, which divides to form the primary wall cell and the primary sporogenous cell. In the case of the three abortive adaxial sporangia, their primary sporogenous cells do not divide, but at this stage begin to break down, along with the intervening sterile cells, and form the large resin cavity.

The records of the winter condition of the microsporangia are too meager to form the basis of a general statement, but Tavus canadensis in Chicago (5I) and Torreya in England (98) pass the winter in the mother cell stage. In Torrcya tavifolia in Florida (IOI), the staminate strobili begin to be visible in June, the primordia of the stamens begin to appear in August, the primary sporogenous cells are recognizable early in September, the spores are in the shedding condition in April, and fertilization occurs in August, making a period of fifteen months from the first appearance of the staminate strobilus to fertilization. It seems safe to conclude that this species also passes the winter in the mother cell stage.

THE, MEGASPORANGIUM

The ovulate strobilus is often so much reduced among the Taxaceae as to lose the ordinary appearance of a strobilus; but in Saregothaca 
(I5O) it is made up of spirally arranged and imbricated bracts that form an ovoid cone, and in Microcachrys a definite strobilus is formed by the sporophylls, which occur in decussating cycles of four and thus give the appearance of a spiral arrangement. The case of Torreya

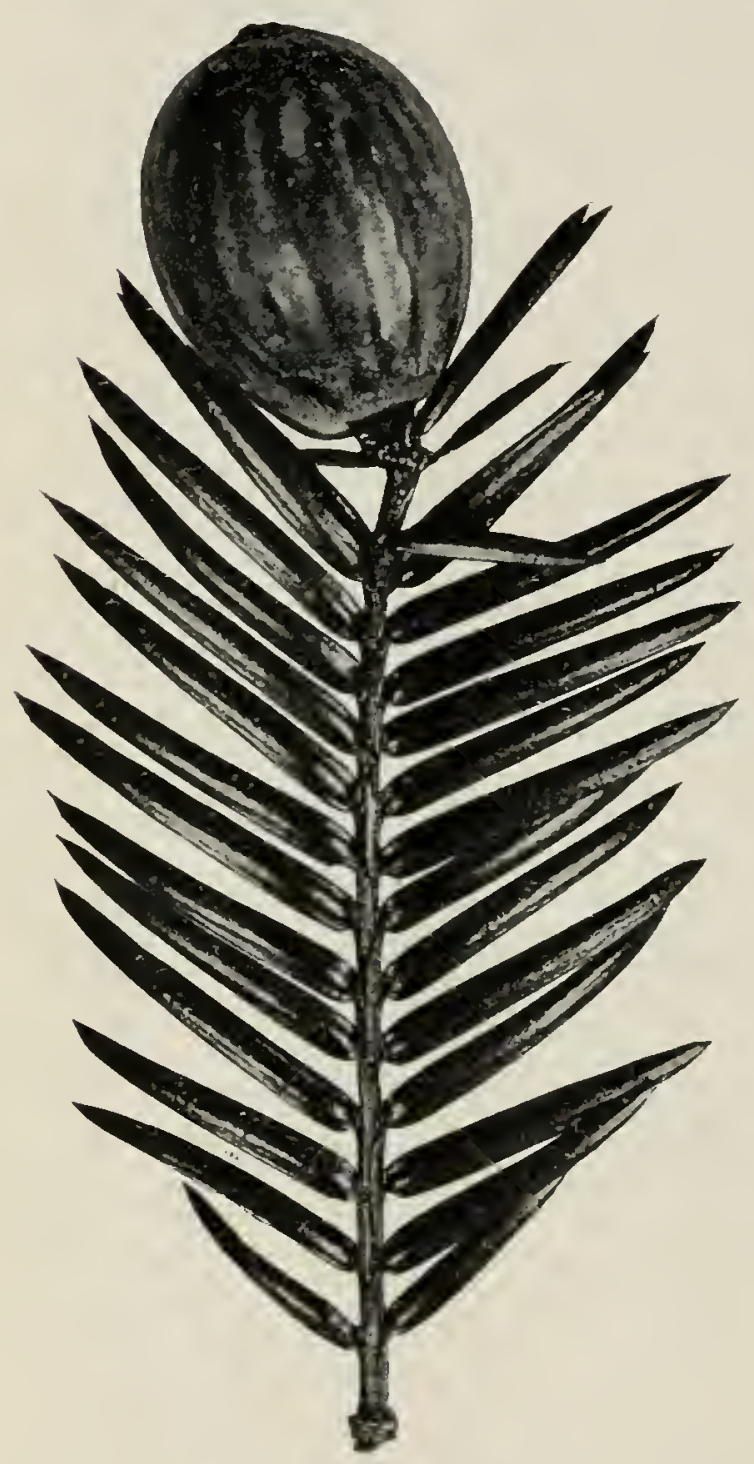

FIG. 376.-Torreya laxifolia: ovulate branch, April 7, r9o4; natural size.-After Coulter and LAND (IOI). taxifolia (IOI) may illustrate the general situation. In this form the strobili are borne in the axils of the lower leaves of short young shoots, usually a pair of them on a short axillary branch. In most cases there is only a single pair of strobili on a strobiliferous shoot, but frequently there are two pairs, and rarely three on the same shoot. Therefore, near the base of these shoots two to six strobili may occur, the upper pairs never maturing and usually only one of the lowest pair producing the large plumlike seed (fig. 376). A strobilus consists of four enveloping bracts and a single, terminal, erect ovule, resembling a simple orulate flower with a perianth of four bracts; but these are evidently the sterile bracts of a much reduced strobilus. The relation of the strobili to the young shoot is exactly comparable to the arrangement of the staminate strobili, the difference being that more of the latter mature and the stamens are numerous. In this sense, the whole oruliferous shoot may be regarded as corresponding to the compound ovulate strobilus of the Abietineae.

A general feature of Taxaceae, illustrated by Torreya, is the 
occurrence of very simple strobili, containing usually one orule, and borne in the axils of leaves of young shoots (hig. 377). Among the taxads and in Phyllocladus the solitary (two in Cephalotaxus) orule is erect, while among the rest of the podocarps it is inverted. Podocarpus has received its name from the fact that the orule is stipitate, usually arising conspicuously above the bracts (fig. 378).

In Savegothaea $\left(\mathrm{I}_{52}{ }^{2}\right)$ the solitary and more or less inverted orule is borne on the ovuliferous scale near the base of the adaxial face. The orulate cone of this genus, as stated above, is terminal on the short branch in the axils of whose leares the staminate strobili occur. Its peduncle is at first short and is clothed with bracts that envelop the strobilus, but later it elongates, rises above the bracts, and becomes relatively long and slender. The resemblance of this habit to that described for Podocarpus is evident, although the elongating structure is not the same in the two cases. In both Savegothaea and Microcachrys there is the same intergrading of bracts into sporophylls above and foliage leares

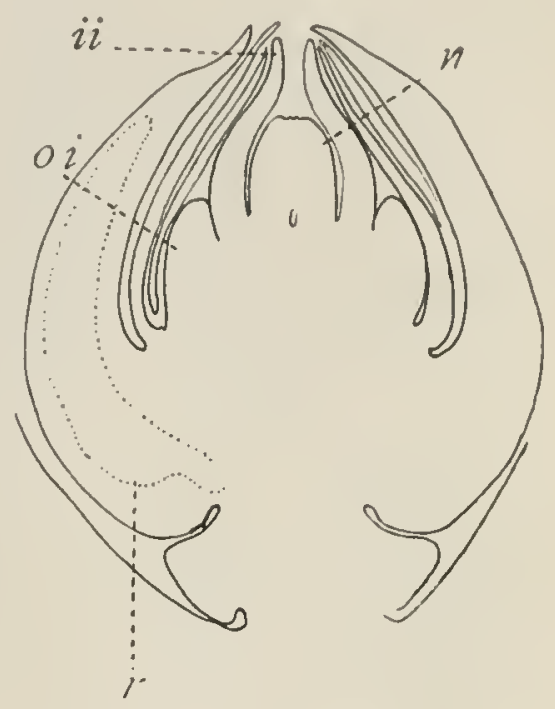

FIG. 377--Torreya taxifolia: ovulate strobilus showing enveloping bracts; $n$, nucellus; $i i$, inner integument; oi, outer integument; $r$, resin cavity; April 7 , r $904 ; \times 24 .-$ After Coulter and L.AND (IOI). below that characterizes the araucarians.

In Phyllocladus (144) the strobili are borne at the edge of the phylloclads near the base, occurring singly or in pairs, and consisting of six or eight thick bracts, each with an axillary erect orule. This position is understood when it is remembered that the phylloclad is a transformed divarf shoot.

It is difficult, and perhaps unprofitable, to compare this strobilus situation with that of the Pinaceae; but the two families exhibit the same general features in the position of the orules, and differ in the compactness of the strobiliferous region. It is in this feature that Saregothaea so impressed LrndeEy, who established the genus, that he regarded it as a transition form between Taxaceae and Pinaceac. 
In a study of the ovuliferous bracts of Saxegothaea and Microcachrys, Thomson (I64) has discorered an inverse orientation of the vascular bundle supplying the ovule, a feature which has been used to prove the double nature of the ovuliferous structure in Pina-

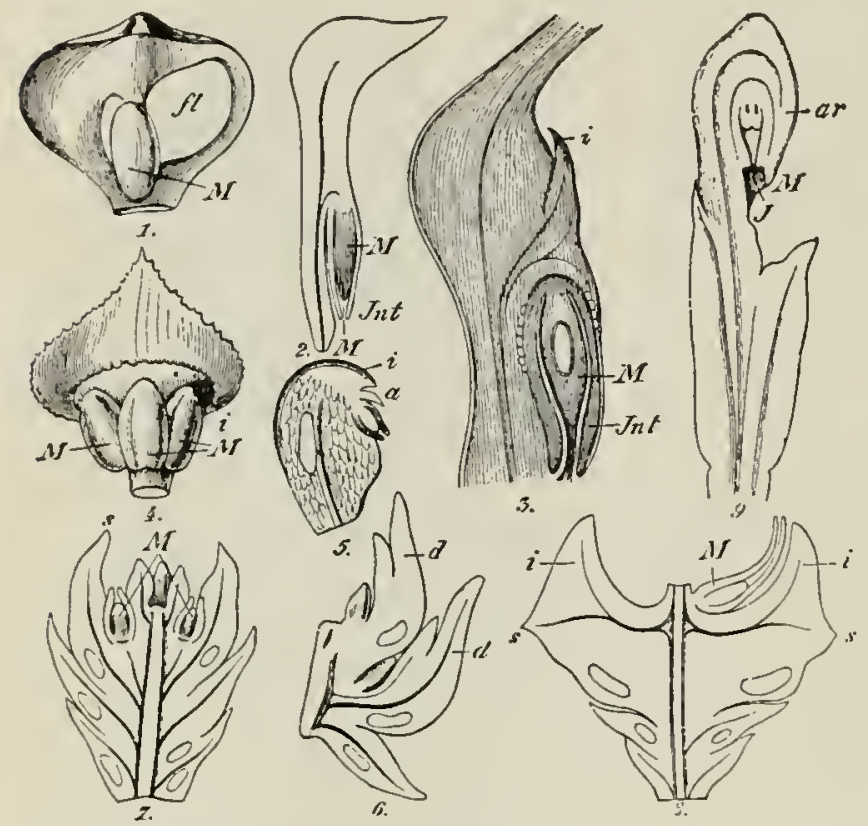

FIG. 378.-Ovulate structures of various conifers: $I$, Agathis australis, ovuliferous scale from inner side ( $M$, winged seed); 2, longitudinal section of $I$; 3 , Araucaria excelsa, longitudinal section of scale, etc., also showing the outgrowth (i) above the seed; 4 , Cunninghamia sinensis, ovuliferous scale, showing three ovules $(M)$, and an outgrowth $(i) ; 5$, Microcachrys tetragana, longitudinal section of oruliferous scale, also showing the arillus $(a)$ and the outgrowth (i); 6, Cryptomeria japonica, longitudinal section of part of the strobilus; $7, \delta$, Cupressus Lawsoniana, showing a young cone $(7)$ and a later stage $(8) ; 9$, Podocar pus macrophylla, longitudinal section, showing orulate structures and aril $(a r)$.- From ENGLER and Prantl's Nat. Pflanzenfam.

ceae. The same inversion, however, occurs in the supply bundle for the microsporangium, which is eridently borne upon a simple sporophyll. Among the Abietineae, Taxodineae, and Cupressineae, however, there is a double inversion in the ovuliferous structure, one related to the sporangial supply, and the other presumably related to the modified dwarf shoot; while among the Araucarineae only the sporangial inversion occurs. The conclusion is that among the Taxaceae and Araucarineae the ovuliferous structure is a simple megasporophyll; while among the Abietineae, Taxodineae, and Cupressineae it is a double structure.

The developmental periods of the orules of the Taxaceae have not been obtained in so many cases as among Pinaceae. In Torreya taxifolia (IOI) the ovulate strobilus is first apparent late in July (in Florida), the mother cells appear during the autumn or early winter and are in synapsis the next April, fertilization occurs during 
the summer, the proembryo is formed during the autumn and jasses the winter, the embryo is completed during the next season, and the seed is mature in the autumn. 'This involves two full years, from the appearance of ovules to the maturity of the seed. Taxus (IOO) and Cephalotavus (124) have approximately the same period, and the first winter is passed in the mother cell stage. While the total period in each of these three genera, which really constitute the taxads, is approximately the same, its distribution among the various events is strikingly different. In Torreya fertilization occurs four months after pollination, and the seed is mature fourteen months later; in Cephalotaxus fertilization occurs fourteen months after pollination, and the seed is mature four months later; while in Taxus fertilization follows pollination in two months. The only information concerning the podocarps, as yet, is that in Phyllocladus (I74) about a month intervenes between pollination and fertilization.

The current statements in reference to the integument among Taxaceae are confusing, because of the appearance of a second or outer integument, which arises considerably later than the inner one, and which has been variously called outer integument, aril, and epimatium. In Torreya (IOI) the outer integument develops the thick fleshy covering of the seed, which gives it a plumlike appearance; the inner integument differentiates into two layers, the outer of which is the stony layer, and the inner consists of several layers of thin-ivalled cells, distinctly differentiated only where the integument is free from the nucellus. It is natural to see in these three layers the outer fleshy, stony, and inner fleshy layers characteristic of the testa in cycads, Ginkgo, and the older gymnosperms; and to conclude that the two integuments have arisen from a single one, by delaying the development of the region that becomes the outer fleshy layer. These facts and the inference seem to hold good also in the case of Tavus, the only difference being that the outer fleshy layer ("aril" in this case) remains distinct from the inner one. In the case of Phyllocladus (I44), however, a different inference seems necessary; for the inner integument differentiates into all three layers, the difference being that the outer fleshy layer is represented by only two layers of cells, which are finally sloughed off. The outer integument arises late and 
grows very rapidly, soon inclosing the ovule, but the latter finally grows above it, and at last it is only a light leathery sheath about the base of the orule extending half way to its tip. From this it would appear that the outer integument or "aril" is a new structure, haring arisen in addition to all the old ones, and is not merely a dissociated outer fleshy layer. That this new structure should frequently take the character of this layer is not strange, for it holds the same general relation to the seed; and among the podocarps the tendency to develop the fleshy character extends far beyond the integuments. In Podocarpus it involves the bract on the stipe; while in Saxegothaea (150) the scales of the strobilus enlarge and fuse into a globular fleshy mass, much as in Juniperus. In the derelopment of the stony layer, the transformation of tissue begins at the apex of the integument and gradually extends downward until it completely surrounds the structures within.

In Torreya the integuments are entirely free from the nucellus at first, even after the mother cells are in synapsis. After that time intercalary growth begins in the chalazal region and continues until into the next season. As a consequence, in the mature seed the free region of integument and nucellus is at the very tip, and is not more than one-twentieth the total length of the seed. The same condition exists in Taxus, and perhaps in most of the genera; while in Phyllocladus the nucellus and integuments remain entirely free. The rascular connections of the ovule in Torreya and in Phyllocladus, Microcachrys, and Saxegothaea only are known, and the three latter genera are probably representative of Taxaceae in general. In Torreya, near the limit of the outer fleshy layer, there are two conspicuous and opposite vascular strands; while in Phyllocladus, Microcachrys, and Saxegothaea the vascular system ends at the base of the orule. It is to be expected that the distribution of the vascular strands should depend upon the presence and position of a fleshy region in connection with the seed. The seed of Torreya is regarded by Oliver (8o) as the most archaic of living conifers in its rascular anatomy. In addition to the two vascular strands in the outer fleshy layer (outer integument), the vascular plate at the base of the nucellus sends out branches into the nucellus, which connect with a"peculiar mucilaginous layer that may represent the tracheal mantle of some of the paleozoic 
seeds (p. +3). All the other conifers have lost all traces of their nucellar rascular systems.

In Savegothaed (I 49, I50, I52) there is a remarliable extension of the tip of the nucellus, which protrudes beyond the micropyle into an irregular, flaring apex, which is said to become corered by a sticky secretion and to act as a stigma, continuing to grow for about two months after pollination (fig. 379). This character appears, in less degree, in Araucaria.

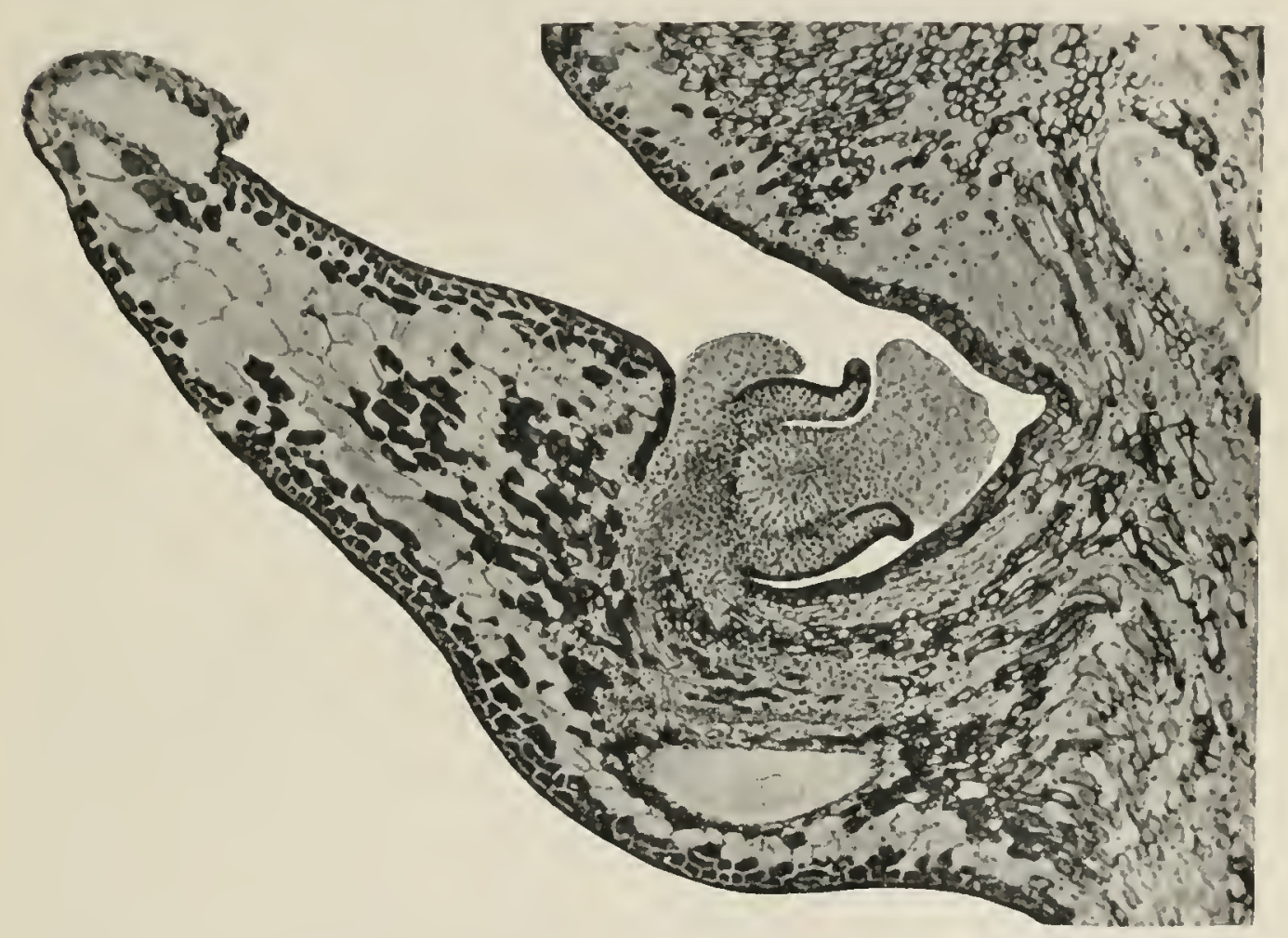

FIG. 379.- Saxegothaca conspicua: Iongitudinal section of orule, showing the stigma-like extension of the nucellus; $\times$ 50.-After NorÉx (I 49).

The development of the sporogenous tissue has been traced by Strasburger (IOO) in Tavis, and it is presumably the same in the other Taxaceae. The archesporium is a hypodermal plate, which divides periclinally as usual. The outer cells, in connection with the overlying epidermal cells, produce the large mass of sterile tissue that caps the nucellus. Each primary sporogenous cell (mother cell) is the innermost cell of a long row, and the number of mother cells is approximately the same as the number of archesporial cells (fig. 380). In most genera, apparently, these rows are not dis- 
tinct enough to follow, and the enlarging mother cell is the first evidence of its existence. The number of mother cells varies as among the Pinaceae, but the only recorded cases of more than one mother cell are Taxus, in which there are one to five, and Podocarpus, in which there are occasionally two. In Taxus the occasional appearance of more than one developing embryo sac has been known ever since HofMEISTER's investigations.

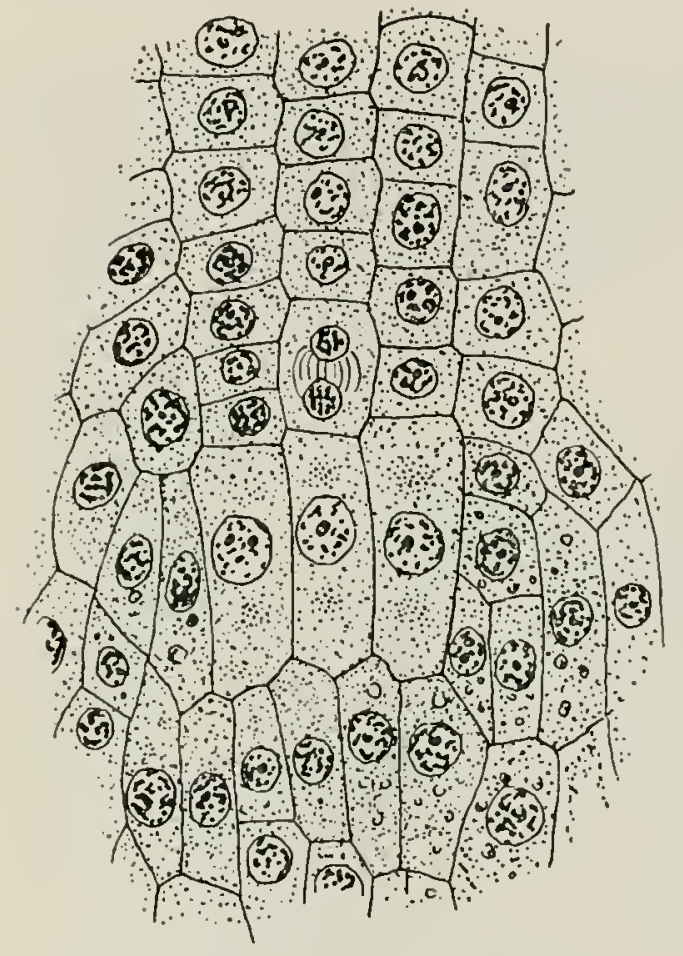

Fig. 380.-Tarus baccata: three megaspore mother cells, each at the end of a row of cells derived from a primary tapetal cell; $\times 375$.-Aiter StrasbURGER (100).

An important fact in connection with the megasporangium of taxads is the general absence of any tapetal zone about the megaspore and embryo sac, so. characteristic a feature of the Pinaceae. Among podocarps, however, "spongy tissue" occurs in Phyllocladus ( 174), Podocarpus (69), Dacrydium (I74), and Saxegothaea, which indicates that it is of general occurrence in the tribe. The general lack of differentiation of any glandular cells in taxads may be regarded either as a primitive character or a degradation.

The deep-seated megaspore mother cell usually forms a linear tetrad, the innermost megaspore functioning. As in

Pinaceae, the second division may not occur in the upper daughter cell of the mother cell, resulting in the row of three cells originally reported for Taxus, and also in Phyllocladus ( 174 ); but complete tetradformation has now been observed in a sufficient number of cases to establish it as the usual condition. Even the linear arrangement of the tetrad is occasionally departed from, as has been observed in Taxus (100). There are exceptions as to the functioning megaspore of a tetrad; while the innermost one usually functions, any one may function, and two contiguous ones have been observed to begin 
growth in Tasus (IOO). When the mother cells are more than one, several of them may begin to function. This functioning of more than one mother cell may not reach the synapsis stage, as observed in Taxus (I00), or it may proceed until the gametophytes are well formed, as has been reported in one case of Podocarpus coriacea (cultivated in Jamaica), in which two gametophytes were observed in one orule (69), and in one of them there were tracheids. If the presence of tracheids in female gametophytes means sporoplytic tissue, as has been shown among ferns, this is a case of incipient apogamy.

The number of chromosomes in Taxaceae has been determined for very few forms. In Podocarpus (I39) the numbers are I 2 and 24 , conforming to the numbers among the Pinaceae, so far as observed; but among the taxads they have been found to be 8 and I 6 in Taxus (I00) and Torreya (99). Whether this is a feature of the taxads, in contrast with the podocarps and Pinaceae, is a question that remains to be answered.

\section{The gametophytes}

THE FEMALE GAMETOPHYTE

The derelopment of the female gametophyte follows the general course described for the Pinaceae (p. 259), with free nuclear division, parietal wall-formation, and centripetal growth until the embryo sac is full of tissue (fig. $38 \mathrm{I}$ ). The racuolation of the sac depends upon the rate of its growth; but in general it occurs so that the free nuclei become parietally placed from the 2-nucleate to the 32 -nucleate stage. Actual counts of the number of free nuclei before wall-formation have been made for Taxus (52) and Torreya (IOI), and found to be 256 , representing eight successive divisions. Probably this represents the usual number of free nuclear divisions among conifers, although it must be expected that great variation and irregularity may occur. The behavior of the nuclei in the endosperm-formation of Taxus has been studied in detail by Strasburger (IOO), and no fusions or unusual conditions were discovered, as have been described for some of the Pinaceae. An idea of the amount of endosperm growth may be obtained from measurements made in Torreya taxifolia (IOI). At fertilization the endosperm consists of $400-800$ cells and measures 20 by $30 \mu$; while in the mature seed it measures $\mathrm{I}_{4}$ by $20 \mathrm{~mm}$. 
The archegonium initials become recognizable at various stages in the development of the gametophyte. In Taxus and Torreya. they appear as soon as the sac is full of tissue; in fact, any earlier differentiation would occur in the stage of free nuclei and would result in the selection of eggs and the elimination of archegonia. This tendency to differentiate the female sexual organ earlier and earlier

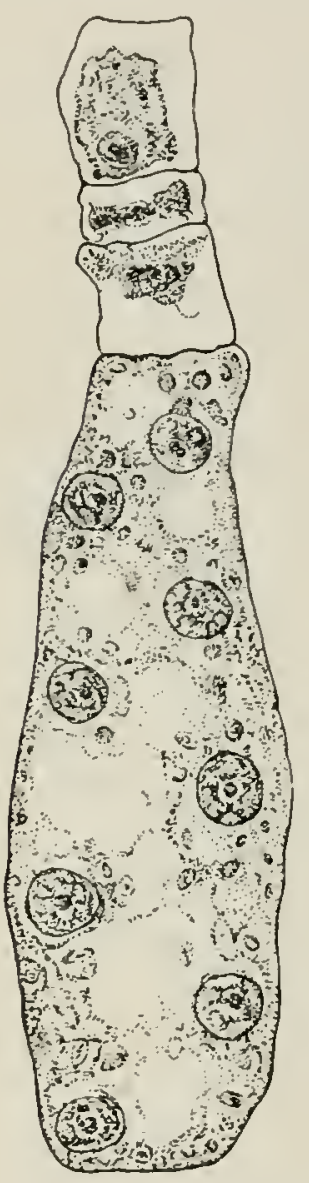

Fig. 38 I.-Tarus baccata: eight-nucleate stage of female gametophyte; $\times 375$. -After Strasburger (100). in the history of the gametophyte has been referred to under Pinaceae (p. 263); and in this feature Taxus and Torreya stand in an extreme position. In Cephalotaxus (I24), on the other hand, the archegonium initials do not appear until the endosperm is well developed; and in Podocarpus the gametophyte is two-thirds to three-fourths its full size when fertilization occurs. In some cases, therefore, the principal growth of the endosperm takes place after fertilization, and in other cases before fertilization.

The development of the archegonium is exactly as described for the Pinaceae (p. 263), and no archegonial complex is formed, each archegonium having its separate chamber and jacket (in case there is one). In Phyllocladus occasionally two archegonia occur in a common jacket (I74). The archegonial jacket, investing the central cell and later the egg, is not developed so constantly or so conspicuously as among the Pinaceac. In Phyllocladus (I44) it is conspicuous, consisting of a layer of cells with large nuclei or several nuclei; in Cephalotavus (I24) it is less conspicuous, frequently being interrupted by ordinary cells; while in Torreya (IOI) it is not evident until after fertilization and is then weakly organized. The condition of this jacket among Taxaceae is not known well enough to justify a general statement, but among the taxads, at least, it gives the impression of a vanishing structure, which finds its parallel in the disappearance of the 
jacket of the mother cell and early embryo sac ("spongy tissue") in the same group. The conspicuous archegonial jacket of Phyllocladus suggests that this structure may be as fully dereloped among podocarps as among Pinaceac. I peculiar situation is dereloped in Phyllocladus ( 174$)$ in the relation of the neck cells to the jacket cells. It had been observed ( 144 ) that the top of the archegonium is its widest part, the whole outline being roughly funnel-shaped, resulting in leaving the neck cells apparently detached. This is found to be due to the rapid centrifugal growth of the adjacent tissues at the upjer end of the endosperm, but the neck cells remain anchored to the jacket cells by a membrane.

In all the Taxaceae observed no ventral canal cell is formed, but a ventral nucleus is cut off by the central cell, which is more or less ephemeral. Attention has been called to the fact (p. 268) that this is a stage toward the elimination of the rentral canal cell, and it has been reached by all the conifers except the Abietineae and possibly the Araucarineae. 'The Taxaceae in which a rentral nucleus has been definitcly observed are Taxus, Cephalotavus (12-4, г zo), Phyllocladus (174), Podocarpus (69), and a somewhat doubtful case in Torreya. (99). The case of Torreya californica was an inference from a spindle seen twice in the central cell, and it is not always casy to distinguish a central cell from an egg. In Torreya taxifolia (то I) the series seemed to be close enough to detect a ventral nucleus if one was formed, but no trace was found, the nucleus of the central coll appearing like an egy nucleus from the very beginning. It is very unsafe to infer the absence of a ventral nucleus from a single investigation, but it is so very ephemeral in some cases that it may have disappeared entirely in other forms. So far as any general conclusion is safe, it may be said that among the Taxaceac the central cell does not cut off a ventral canal cell, but that a ventral nucleus appears which is sometimes very ephemeral, and that in some cases even the nucleus may not be formed. In Cephalotaxus drupacer (130) the ventral nucleus is so ephemeral that it degenerates before fertilization; while in Podocarpus (69) it has been observed to divide amitotically after fertilization.

Among the Podocarpineae the number of archegonia ranges from one to eleven, being one to four in Phyllocladus alpina (I+4), and 
seven to eleven in Podocarpus coriacea (69). This is a meager record, but it probably expresses the variability and range in number. There are four neck cells in Phyllocladus (I74); but in the Podocarpus investigated the number varies from two to twenty-five, the most common condition being three tiers of cells with four cells in each tier. This extreme variability seems to hold some relation to the arrival of the pollen tube, which permits an almost indefinite growth of the neck or does not allow it to extend beyond the two-celled stage.

Among the Taxineae the number of archegonia has the same range (one to eleven), being one (in one case two) in Torreya taxifolia (IOI), two to four (usually three) in Torreya californica (99), two to five (usually three) in Cephalotaxus Fortunei (I24), four in Cephalotaxus drupacea (I3O), and five to eleven in Tavus. The number of neck cells varies from two to six, always in one plane: two in Torreya taxifolia, two or three in Cephalotaxus drupacea, two to five in Cephalotaxus Fortunei, and four to six in Torreya californica. Such ranges in the number of archegonia and in the number of neck cells, even within a genus, indicate that such numbers have very little significance.

The comparative development of the megaspore membrane in Coniferales was referred to under Pinaceae (p. 27I). The Taxineae are peculiar in being the only tribe in which this membrane is really a negligible feature, developing none of the structure observed in the other tribes. If THomson's conclusions (I08) are true, this indicates that, so far as this feature is concerned, the taxads are the most recent of the conifers. Among the Podocarpineae, at least as evidenced by Phyllocladus (I74), Dacrydium (I74), Microcachrys (I64), and Saxegothaea, there is a megaspore membrane of the usual twolayered type.

Torreya furnishes a conspicuous illustration of à seed with "ruminated endosperm" (figs. 382,383 ). In a smaller degree this feature appears in the seed of Phyllocladus (especially in its early stages) and of the araucarians; but its extreme expression is exhibited by Torreya. In the study of Torreya taxifolia (IOI) an opportunity was given to investigate this so-called "rumination." In ordinary seeds the endosperm invades the surrounding tissue more or less uniformly, in the case of most gymnosperms obliterating most of the 


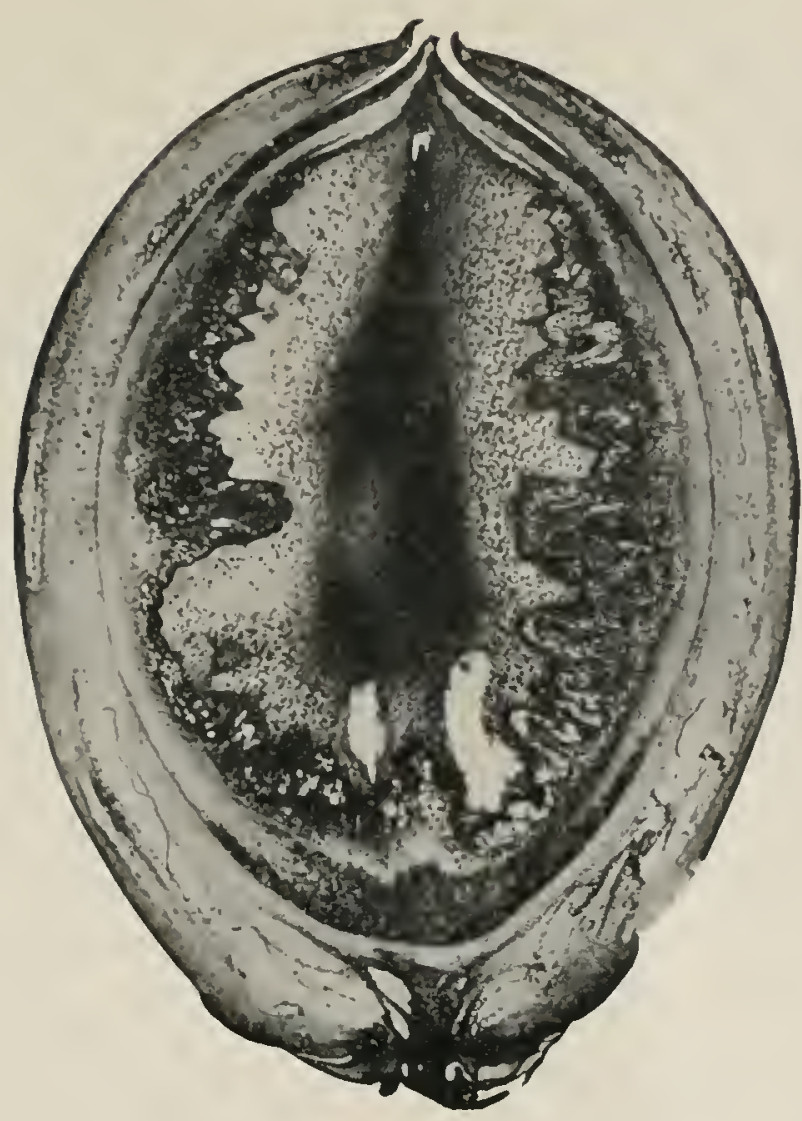

382

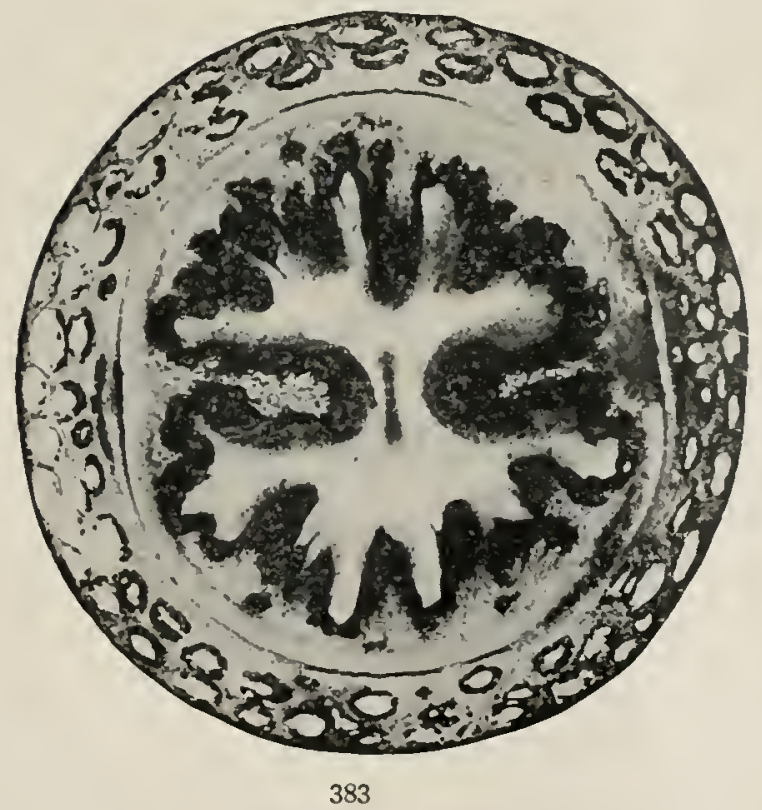

FIGS. $3 S_{2}, 3 S_{3}$. - Torreyd laxifolia: ovules showing "ruminating" endosperm; fig. $3 \delta_{2}$, longitudinal section of mature seed showing embryo, endosperm, and seed coats; $X_{3}$; fig. $3 \delta_{3}$, transverse section showing endosperm with storage region in the center, seed coats, stored food in the perisperm, and resin ducts in the outer portion; $x_{3}$.-After Coulter and LAND (IOI). 
perisperm. In Torreya, on the other hand, the invasion by the endosperm is irregular in the extreme. It is in the season after the proembryo has formed that the active invasion of the perisperm begins. The extension of the endosperm into the tip of the nucellus above the sac proceeds in the usual way, obliterating all of it except a fer peripheral layers of cells. This uniform invasion seems to be due to the fact that in this apical region (the original nucellus) the perisperm is not growing actively if at all. Below this small region at the tip, however, the perisperm is very active and evidently resists disintegration much more at certain points than at others. As a consequence, it becomes eroded by the irregularly advancing endosperm, and is left in the condition of a much dissected coast line. To the casual observer this results in an appearance suggesting that the endosperm is being invaded by plates of perisperm, but this is no more true than that the promontories of a dissected coast line are adrancing into the sea. The suggestion of an invading perisperm is further strengthened by the fact that within the perisperm bordering the endosperm a dark brown and finally black band of cells is developed, due to abundant food storage, but this really recedes as the endosperm adrances.

A transverse section of the mature seed of Torreya always shows a definite and deep constriction of the endosperm in the center, exactly opposite the two opposed vascular strands that run up on each side of the seed through the inner part of the outer integument (fig. $38_{3}$ ). This constriction is the transverse section of two opposite and deep longitudinal furrows in the endosperm, and it means that in this longitudinal plane the endosperm encounters the greatest resistance in invading the perisperm. This most resistant perisperm certainly seems to hold a very definite topographical relation to the principal rascular strands, and this relation may explain the resistance.

That endosperm is the aggressive tissue at erery point, even at the region of most resistant perisperm, is evident for several reasons. In no case are the peripheral cells of the the endosperm broken down; and in no case does there fail to appear one or two layers of disorganized cells of the perisperm in contact with the endosperm. In every case, also, the peripheral cells of the endosperm appear active and rery vigorous, and their different appearance in regions of more 
or less active encroachment is striking. In regions of active invasion the endosperm cells are radially elongated, and many of them are binucleate; while in regions of less active invasion the cells are more nearly isodiametric and rarely binucleate.

Another proof that endosperm is the encroaching tissue may be obtained from comparative measurements. At the time of fertilization the gametophyte usually measures 20 by $30 \mu$. In the mature seed the ordinary length of the gametophyte is $20 \mathrm{~mm}$., the greatest width being $\mathrm{I}_{4} \mathrm{~mm}$., and the least (at the deep constriction opposite the vascular strands) $\mathrm{I} .5 \mathrm{~mm}$. At this most resistant region of the perisperm, therefore, where it is hard to escape the conviction that the perisperm plate has cut the endosperm nearly in two, the endosperm has increased its diameter against the perisperm seventy-five times. The best reason, however, for concluding that the endosperm is the invading tissue in this case is that this is always the behavior of endosperm; and it is singular that the old explanation of "rumination" was ever suggested.

\section{THE MALE GAMETOPHYTE}

The male gametophytes of podocarps and of taxads are in such sharp contrast that the two tribes must be considered separately.

Among the Taxineae the gametophyte of Taxus naturally received early attention, and its principal features have been known since the pioneer work of BelajefF (33) and Strasburger (38). At that time it was not appreciated that the vegetative (prothallial) cells had been eliminated, much less that this elimination was a feature of all the taxads.

The development of the gametophyte of Torreya taxifolia (IOI) will serve as an illustration and for comparison. The first division of the microspore results in the generative and tube cells, separated from one another by a very delicate wall or membrane. In this binucleate condition (fig. $3 S_{4}$ ) the pollen grains are shed (late in March to early in April in Florida). Pollen tubes penetrate the nucellar cap at once, and occupy it for about four months. The generative cell divides early in the history of the tube, which contains almost from the first the large body cell and the stalk and tube nuclei (fig. $38_{5}$ ). Shortly before fertilization (about the middle of August), the body 
cell divides into two distinct and unequal male cells, the cytoplasm of the body cell being divided unequally (fig. 386). The behavior

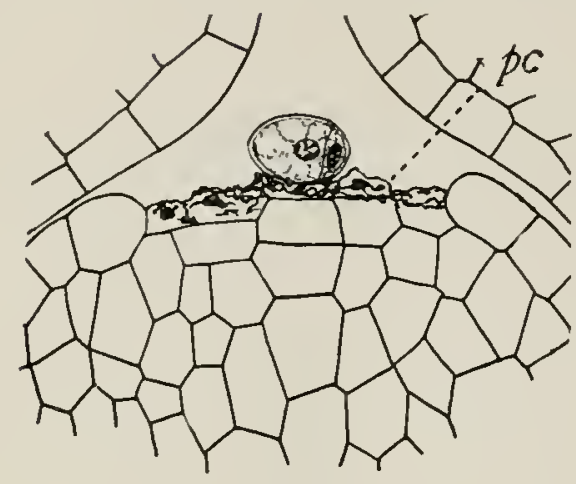

384

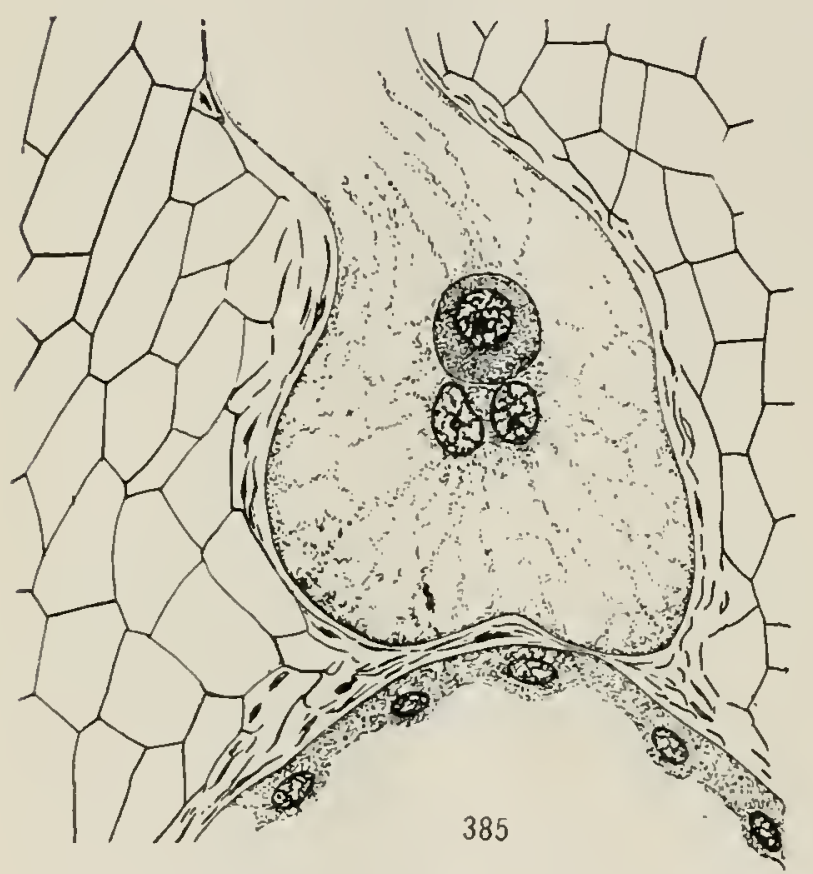

FIGS. $384,385 .-$ Torreya taxifolia: fig. 384 , tip of nucellus with pollen chamber (disintegrated tip of nucellus) containing a two-celled microspore, the smaller cell being the generative cell and the larger the tube cell; $p c$, pollen chamber; $\times 220$; fig. 385 , end of pollen tube in contact with embryo sac, which is in free nuclear stage; in the tube the stalk and tube nuclei are in advance of the body cell; $\times_{460}$. - After Coulter and LAND (IOI). of the tubes is interesting and suggestive. They may advance rapidly, reaching the female gametophyte at an early free nuclear stage ( 6 6-64 nuclei), or they may advance very slowly. The course may be very direct, resulting in a straight cleft through the tip of the nucellus, or it may be extremely devious. In one case observed the tube advanced directly half-way through the tip of the nucellus; then proceeded spirally downward and outward to the peripheral cells of the nucellus, several of which it destroyed; then turned abruptly inward, penetrated the nucellus at the level of the archegonium, crossed the top of the endosperm, and discharged into the archegonium on the opposite side. In another case a wandering tube penetrated the inner integument before turning back into the nucellus. Very frequently the tube pushes into the embryo sac at the free nuclear stage, making a deep invagination (often to the middle of the sac), and from this pocket it turns back 


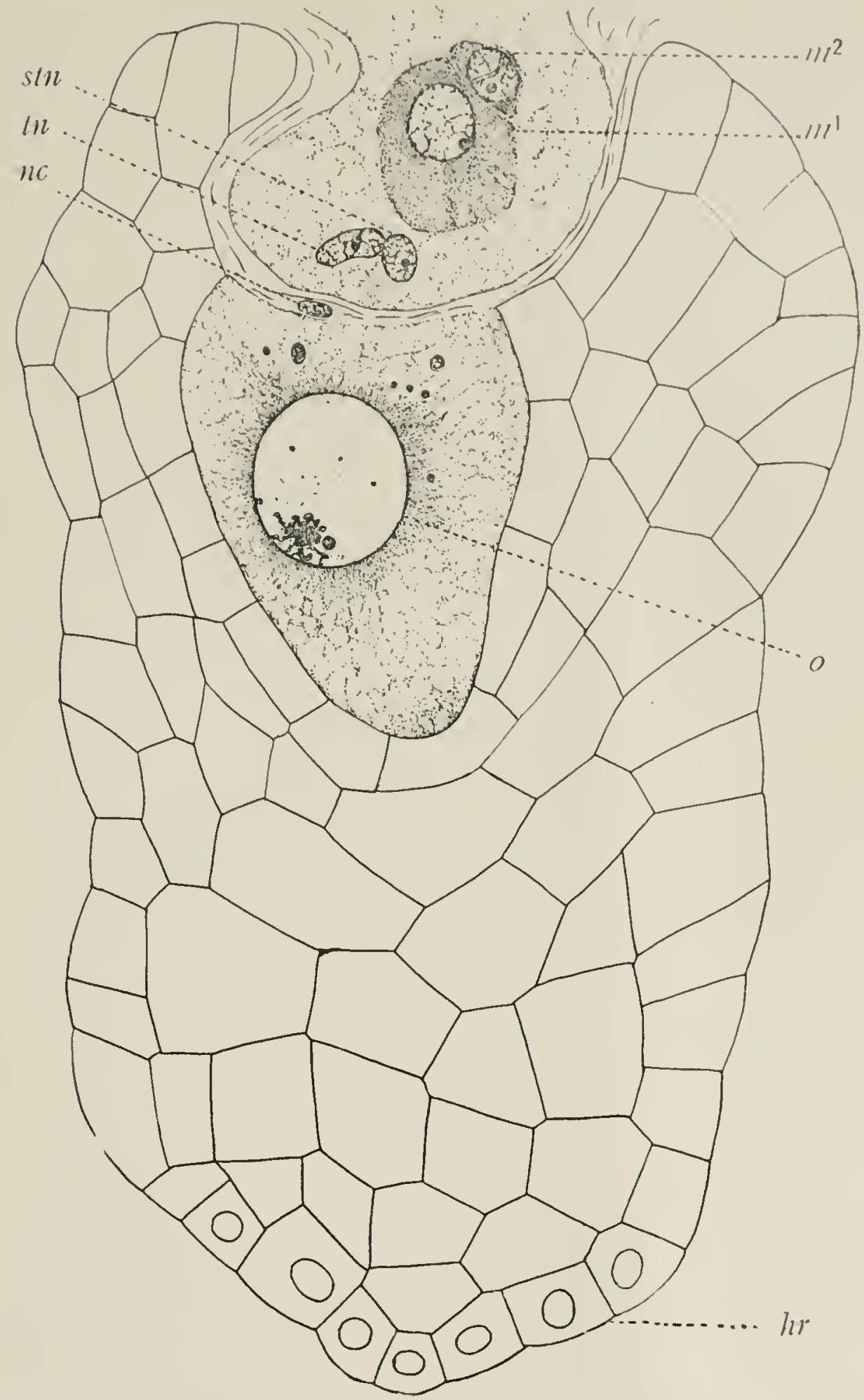

FIG. 386.-Torreya taxifolia: median longitudinal seçtion of female gametophyte, showing egg with large nucleus (o), the remains of a neck cell (nc), and antipodal haustorial cells $(h r)$; also the tip of a pollen tube in contact with the $\mathrm{cgg}$, showing stalk nucleus ( $(\mathrm{n} n)$, tube nucleus $(t n)$, and the two unequal male cells ( $m^{\mathrm{r}}$ and $m^{2}$ ); the upward growth of the endosperm cells forms a sheath around the pollen tube; August I 2, I904; $\times 460$.-After Coulter and LAND (IOI). 
into the nucellus. Torreya californica is said to differ in that male cells are not formed, but the two male nuclei are invested by the general cytoplasm of the body cell, and with no inequality (99).

In Taxus the microspore is shed in the uninucleate stage, the division into generative and tube cells occurring while the spore is resting on the tip of the nucellus, and the pollen tubes are in the nucellus only about two months before fertilization; otherwise the erents are exactly as in Torreya, including the formation of two very unequal male cells (fig. 387 ). In Cephalotaxus the first division of

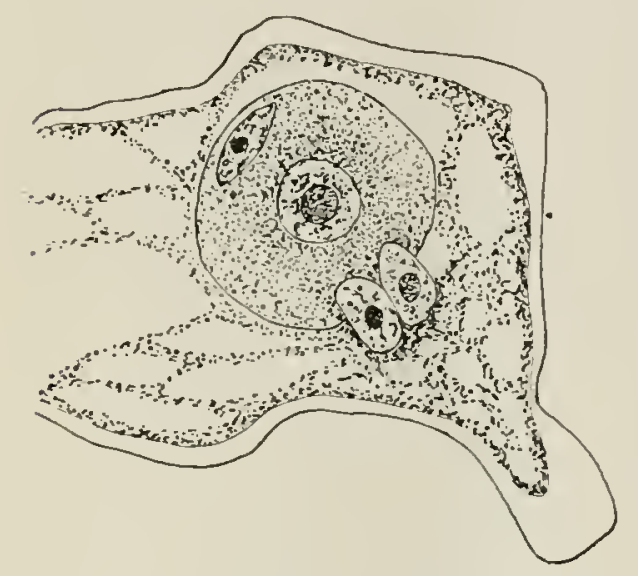

FIG. $38_{7}$.-Taxus baccata: tip of a poller tube with the two unequal male cells; the stalk and tube nuclei in adrance; $\times 200$.-After BeLajefF (33).

the microspore (to generative and tube cells) occurs before shedding, as in Torreya. Pollination occurs from January to March (varying with the species and the latitude), but no further division occurs until the following spring, when the generative cell divides, and the body cell and stalk and tube nuclei are found in the pollen tube; in fact, the tube does not penetrate the nucellus for nine to twelve months after pollination ( 124,130 ). The two accounts of Ceplatotavis differ as to the character of the male cells, which are said to be unequal in C. Fortunei (I24), and in $C$. drupacea (I3O) to be represented by two male nuclei, without wall-formation (fig. 388). The inequality of the cells in the former species is not so great as in Torreya and Taxus; and since inequality is chiefly that of the cytoplasm rather than of the nuclei, the absence of wall-formation in the latter species might result in no appearance of inequality. In both cases the tube reaches the female gametophyte quickly (in about ten days in C. drupacea); and in C. Fortunei it reaches the archegonium neck before the chamber is formed, so that the endosperm grows up about the tip of the tube and may bury the archegonia.

The features of the male gametophyte of Taxineae, therefore, are the absence of regetative (prothallial) cells, a feature shared with 
Taxodincae and Cupressineae among Pinaceae; and the unequal male cells, possibly related to the fact that the archegonia are not organized into a complex, a feature found among Abictincae. The exceptional condition in Cephalotavus is that the inequality of the male cells is not so marked, and may disappear entirely through lack of wall-formation.

The male gametophyte of the Podocarpineac has attracted so much attention that erery genus (except Pherosphacra) has now been investigated, and the peculiar condition of the regetative (prothallial) tissue is found to belong to all of them (figs. $389^{-}$ 396). It appears that this feature of the podocarps was first described and figured in 1896 by 'THiBOuT (43) for Podocarpus polystachy'a.

The first peculiarity of the tribe is that the pollen grains are winged, except in Savegothaea (1 $\left.49, \mathrm{r}_{50}\right)$,

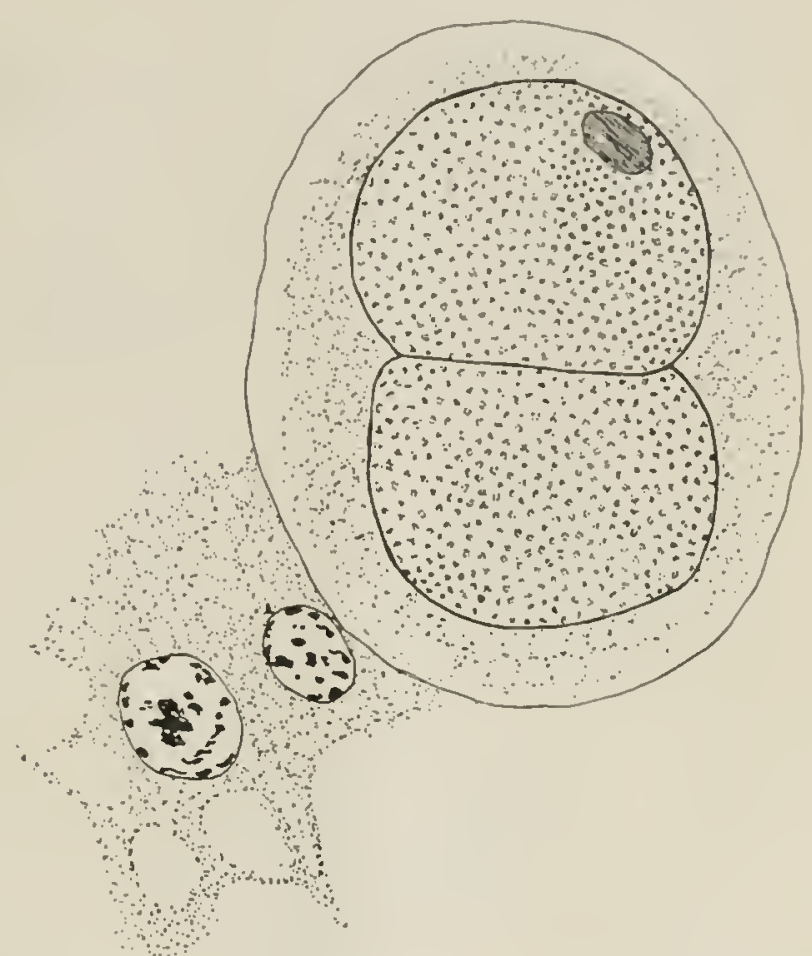

FIG. 388.-Cephalotaxus drupacea: the two sperm nuclei within the body cell; the stalk nucleus (smaller) and tube nucleus are in advance; May 23, I904.-After LAwSON (I30).

a character that has suggested a connection with Abietincae, the only other tribe of conifers with winged pollen grains. The situation in Microcachrys ( $15 \mathrm{r}, 163$ ), however, taken in connection with the wingless spores of Saxcgothaea, suggests that wings may have arisen quite independently in this tribe. In Microcachys the wings are not so definite in development or in number as in Podocarpus and Dacrydium, in which two well-dereloped wings occur. Thomsor (i63), examining sixty-four pollen grains, found fifty with three wings, nine with four, two with five, and three with six. In every case the wings are comparatively small, variable in size, and late in development. Three wings are also found in 
certain species of Podocarpus ( $P$. dacrydioides and $P$. ferruginea). In this feature, therefore, Microcachrys seems to be a transition form

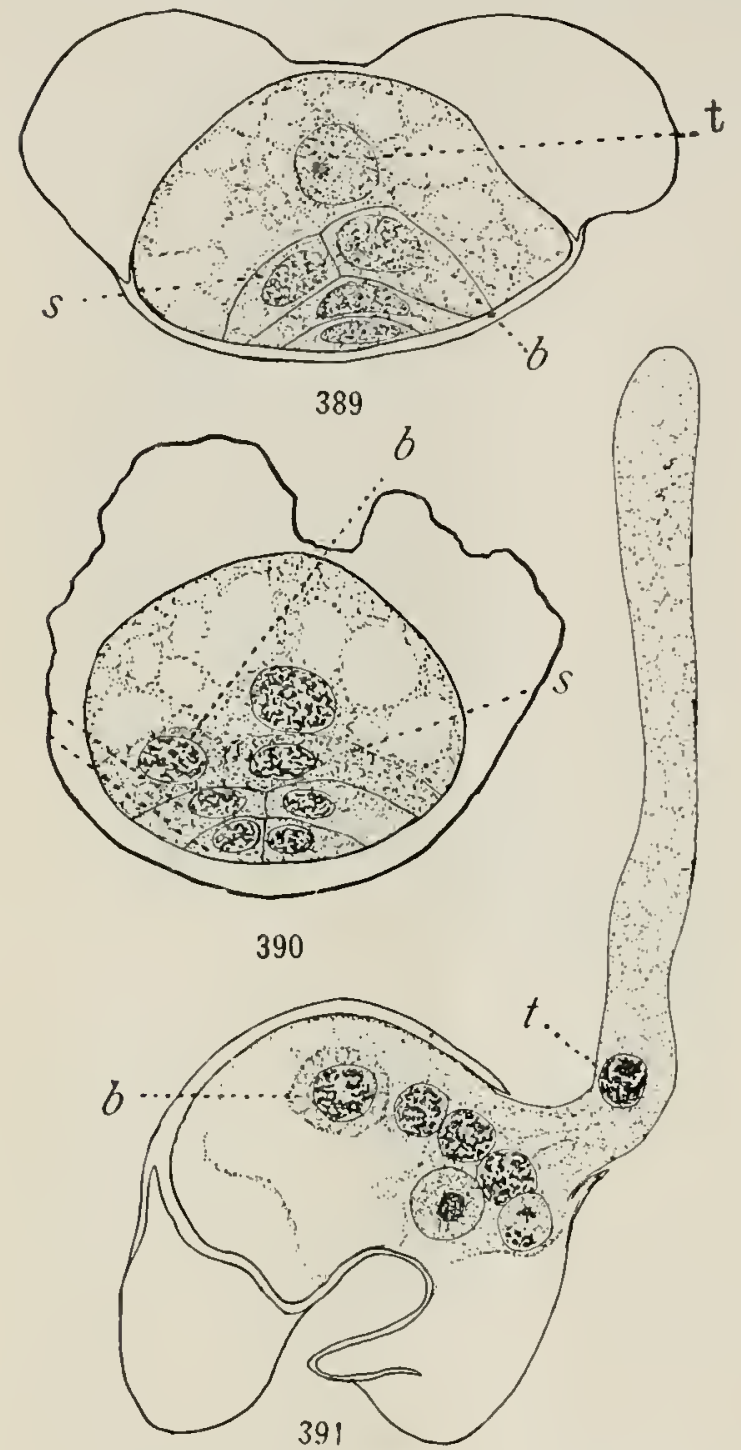

Figs. 389-391.-Male gametophyte of Dacrydium: $s$, stalk cell; $b$, body cell; $t$, tube nucleus; fig. $389, D$. Bidwillii, just after the division into stalk and body cells; the two prothallial cells have not divided; fig. 390 , $D$. cupressinum, later stage; both prothallial cells have divided; fig. 39I, D. laxifolium, showing the body cell and tube nucleus, and the nuclei of the stalk cell and of four prothallial cells; $X_{960}$.-After Miss Young ( $3^{6}{ }^{6}$. between Podocarpus and Dacrydium on the one hand, and Saxegothaea on the other.

In the development of the prothallial tissue, two cells are successively cut off, as among the Abietineae, but the peculiarity of the podocarps is that these cells usually divide, resulting in extreme cases in a tissue of eight cells. A further peculiarity of this tissue is that the walls break down and the nuclei become free, passing into the pollen tube with the body cell and stalk and tube nuclei (fig. 39I). It must be understood that these supernumerary cells are not formed as are the two original cells, that is, in the series of divisions from microspore to male cells, but represent a secondary and variable product of the two primary cells. The variability may be indicated as follows.

In Phyllocladus (I44) the two prothallial cells usually do not divide, and the first one begins to disorganize as soon as it is formed (occasionally persisting more or less), but the second one persists (fig. 392), and occasionally divides (I74). This is exactly the behavior of the prothallial tissue of 
Ginkgo, but in Phyllocludus the nucleus (or nuclei) becomes free. As a consequence, the spores on the tip of the nucellus are found to contain three or four nuclei, one or two of which are regetative, and the body cell. In Dacrydium ( 136 ) the generative cell is cut

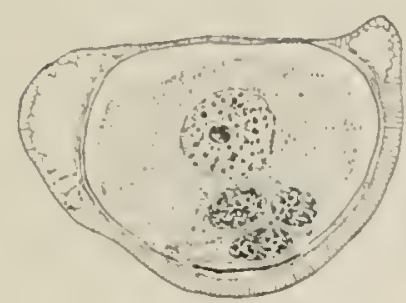

392

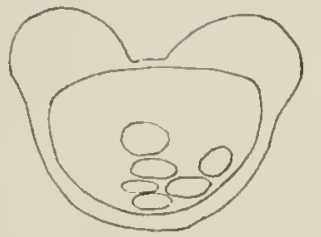

393

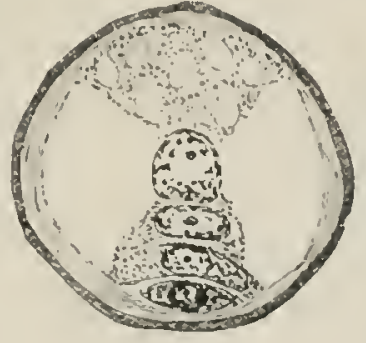

394
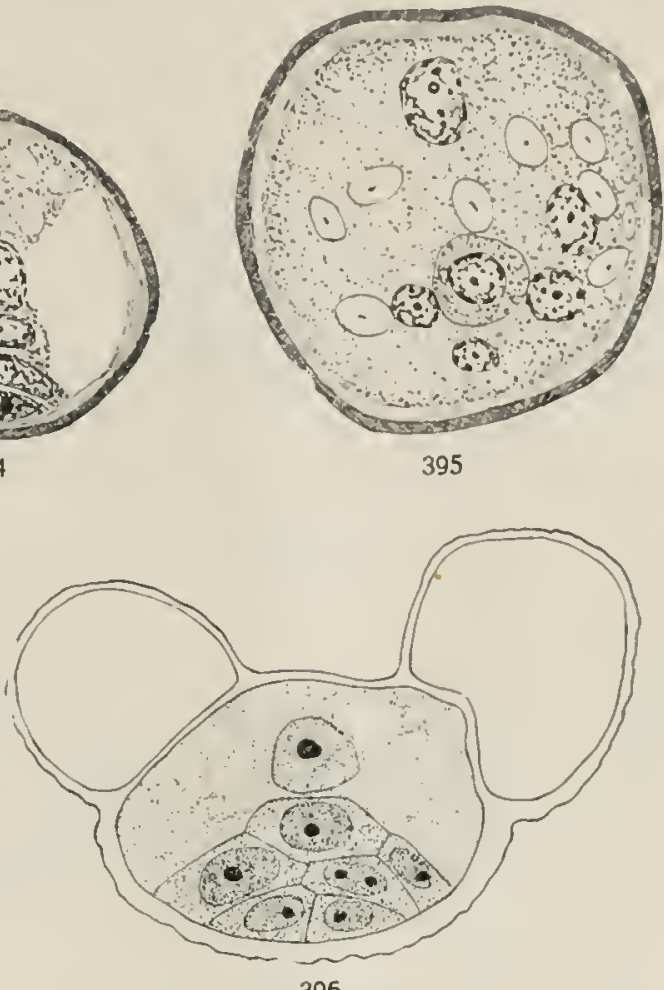

396

FIGS. 392-396.-Pollen grains of several podocarps: stalk, body, and prothallial cells evident; fig. 392, Phyllocladus alpina, showing an evanescent and a persistent prothallial cell, also stalk, body, and tube cells; $\ 950$; after Miss YouvG (I74); fig. 393, pollen grain of Microcachrys letragona at the shedding stage; after Thouson (163); figs. 394, 395, Saxegothaca conspicua; fig. 394, the two prothallial cells, the generative cell, and the tube cell are in a line; X700; after NORÉN (I49); fig. 395, later stage, showing body cell, and nuclei of tube, stalk, and three prothallial cells; also sereral large starch grains; $\times 700$; after NonéN (149); fig. 396, Podocarpus lolarra Hallii; the usual condition of pollen grain at the shedding stage, containing tube nucleus, stalk and body cells, and eight prothallial cells (only four shown) derived from the two primary prothallial cells; after BURLINGANE (I39).

off immediately after the two prothallial cells, and then it and the second prothallial cell divide. In some cases (D. Bidwillii) usually only the second prothallial cell divides, but in others (D. laxifolium. and $D$. cupressinum) both prothallial cells divide. The result is that at pollination the spore contains three or four free vegetative nuclei, in addition to the body cell and the stalk and tube nuclei 
(figs. 389-39I). In Microcachrys ( $15 \mathrm{I}, \mathrm{I} 63$ ) the situation in Dacrydium is repeated, three (more frequent) or four prothallial cells appearing, depending upon the division of one or both of the two primary cells (fig. 393); and the prothallial tissue of Savegothaea (I 49) is exactly the same (figs. 394, 395). In these three

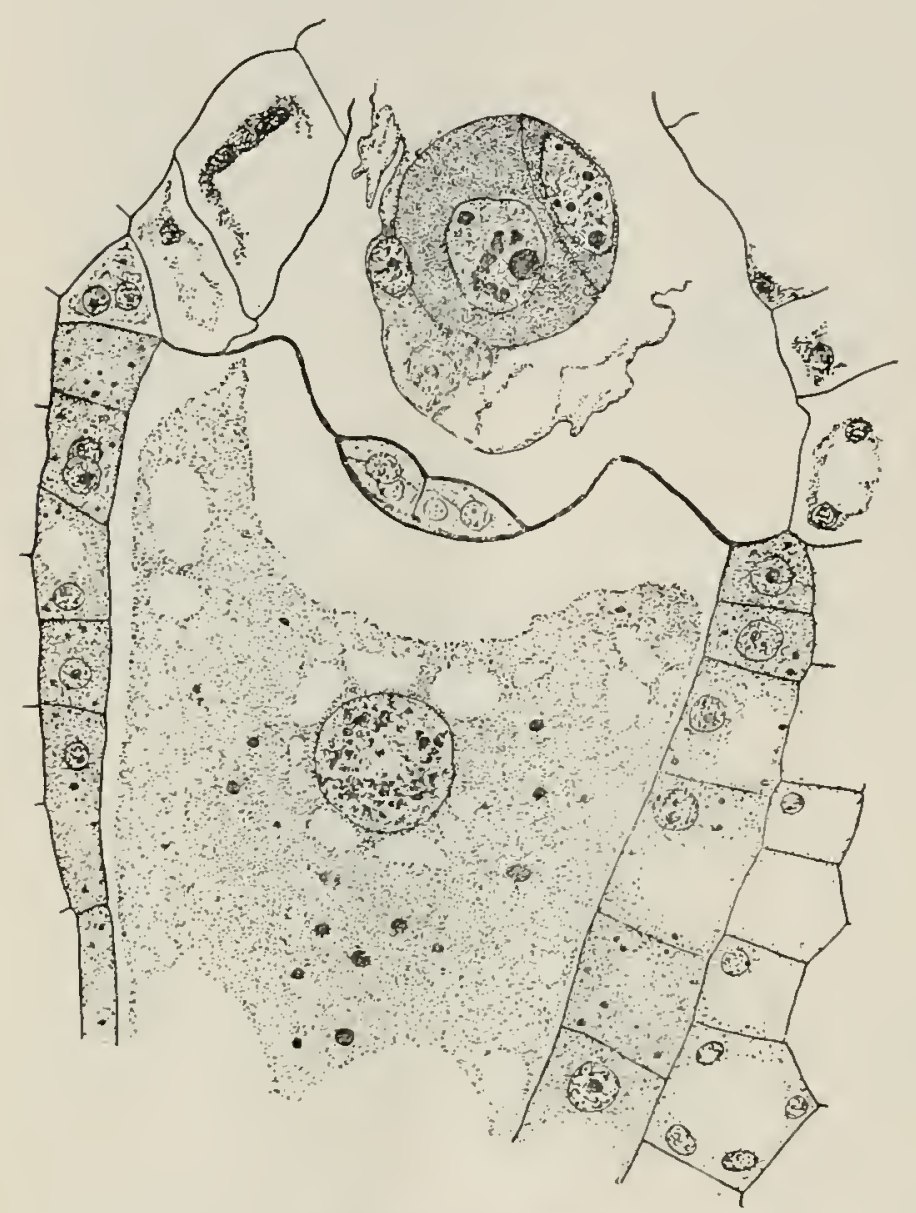

FIG. 397.-Phyllocladus alpina: the two unequal male cells, with the stalk and tube nuclei and one prothallial nucleus in advance; the archegonium shows a four-celled neck and a definite jacket; the egg is ready for fertilization; $\times 440 .-$ After Miss Young (174). genera, the second prothallial cell always divides and the first also may divide, and at pollination three or four free vegetative nuclei are found in the grain. Podocarpus is much more variable (69, I 28, 139), the number of prothallial cells and free nuclei varying from one to eight (fig. 396). Only one prothallial cell may be cut off, and it may not divide; but usually there are two primary cells, the second of which always divides and both of which may, and in both cases there may be still another division. Therefore, there may be one, three, four, six, or eight prothallial cells, and subsequently the same number of free regetative nuclei that swarm into the pollen tube.

This behavior of the male prothallial tissue among the podocarps is not only constant and striking, but it is the same in kind as that observed among the araucarians (p. 277), the only difference being that the vegetative cells and free nuclei in the latter group reach a 
much higher number than among the podocarps. The suggestion of a genetic connection between these wro tribes will be considered later.

The course of spermatogenesis in the podocarps, from the division of the generative cell just before fertilization, presents no unusual features. In Dacrydium ( $3_{3} 6$ ) it was observed that the generative

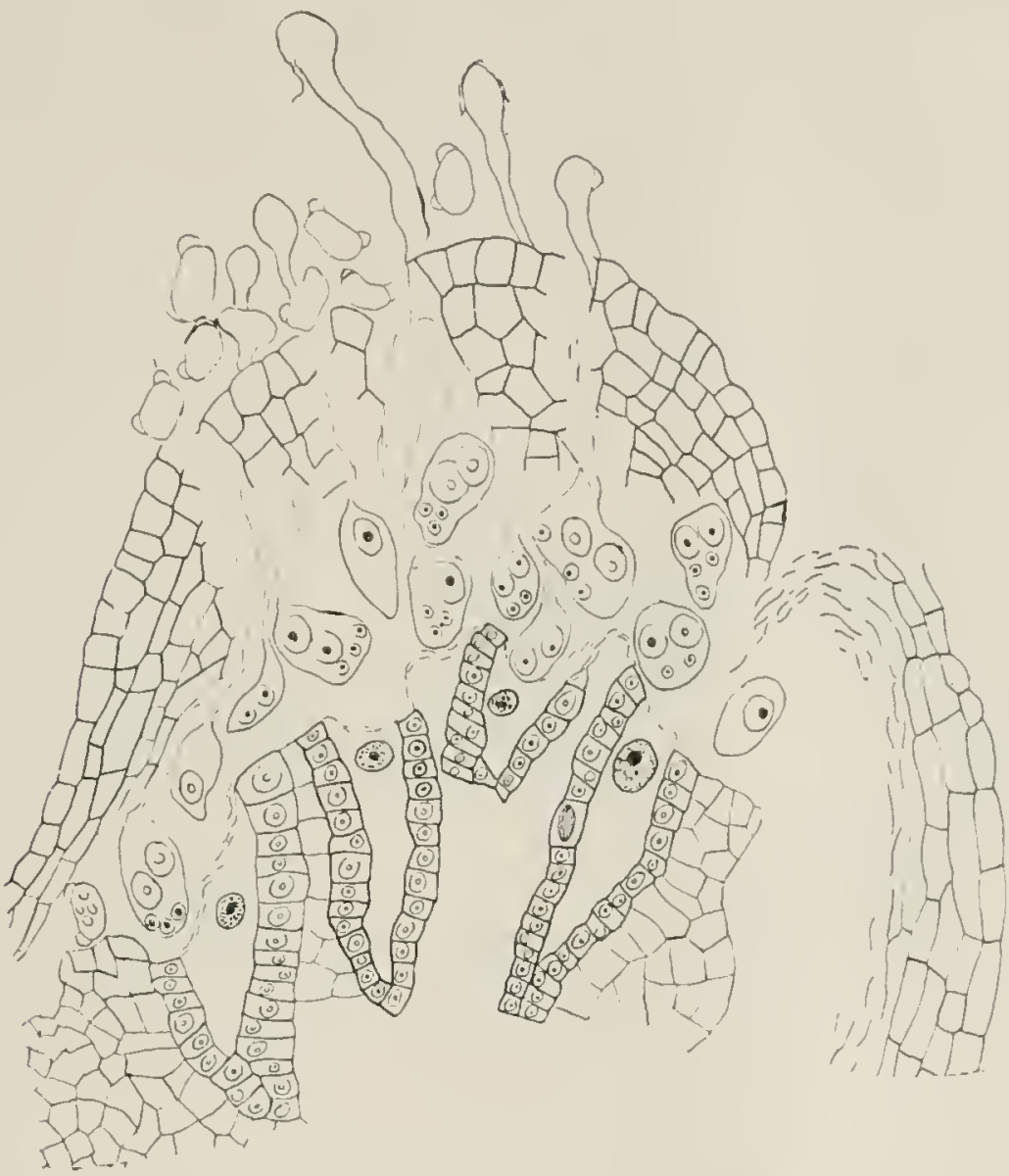

Fig. 398.-Phyllocladus alpina: apex of nucellus broken down by numerous pollen tubes; the top of the endosperm also somewhat disorganized; each archegonium is surrounded by a definite jacket; XISo.-After Miss KiLdAHL (I44).

cell divides anticlinally, the stalk and body cells being side by side and for some time indistinguishable. Presently one of them enlarges. rounds off, and becomes free, while the nucleus of the other becomes free by the disappearance of its wall or membrane. In the two genera in which the male cells have been observed, the two extremes of variation are represented. In Phyllocladus ( 174 ) the body cell divides to form two unequal male cells, only one of which functions (fig. 397); 
while in Podocarpus (69) only the nucleus of the body cell is said to divide and all of the cytoplasm to be organized in connection with one of the male nuclei as a male cell, leaving the other male nucleus thrust out at its periphery.

In Saxegothaea (I49) pollen falls not only on the extruded and broadly flaring tip of the nucellus, but sometimes also in the depression around the orule, and in this position pollen tubes develop and grow over the tissues to the micropyle. It will be remembered that this growth of pollen tubes to the micropyle from some distance outside is one of the features of the araucarians (p. 283).

\section{FERTILIZATON}

Among the Taxaceae the tip of the pollen tube discharges all of

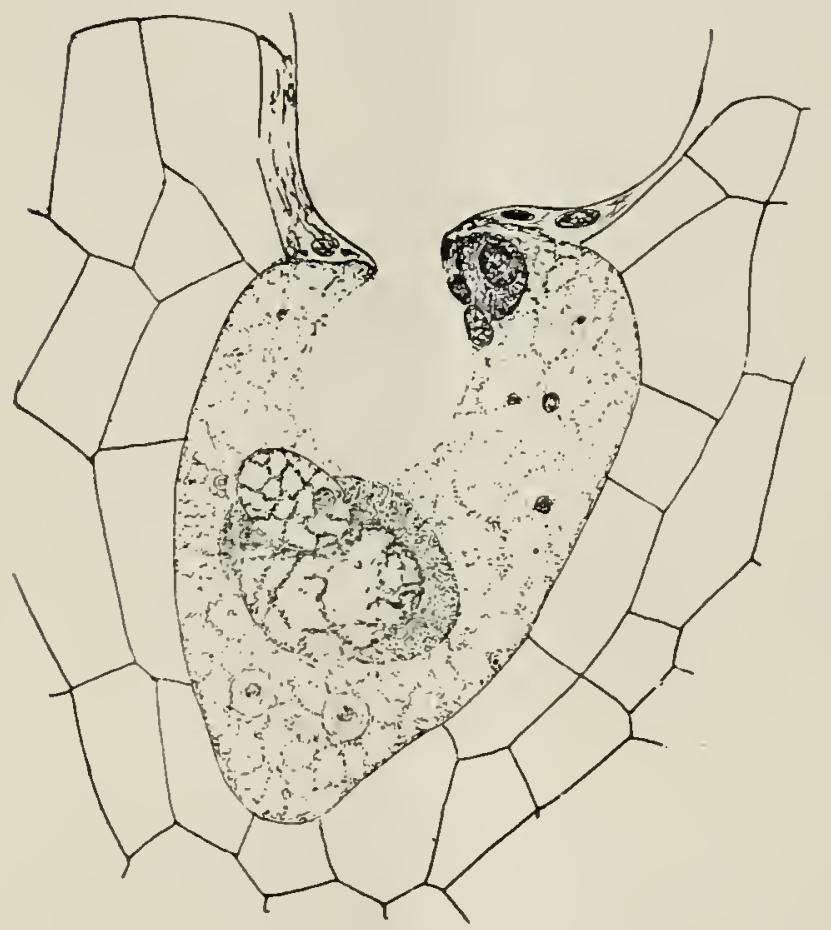

FIG. 399.-Torreya taxifolia: fertilization; the male nucleus is in contact with the egg nucleus; the cytoplasm of the male cell is closely applied to the egg nucleus; the functionless male cell and stalk and tube nuclei are in the upper part of the egg; August I2, 1904; $\times 460$. - After Coulter and LAND (IOI). its free contents into the cytoplasm of the egg, in the peripheral region of which there may be found both male cells or nuclei, the stalk and tube nuclei, and such prothallial nuclei as may be in the tube. All of these gradually disappear except the functioning male cell or nucleus, although sometimes they may still be distinguished in the early stages of the proembryo. In Cephalotaxus Fortunei the non-functioning male nucleus has been observed (55) to divide a mitotically, producing as many as six nuclei. In Phyllocladus (I74) the male cells are discharged outside the archegonium and pass between the separated neck cells.

In Torreya californica (99), Torreya taxifolia (IоI), Cephalo- 
taxus Fortunci (124), and Phyllocladus (144) the functioning male cell, with its complete investment of cytoplasm, has been observed to come in contact with the egg nucleus (figs. 399, 400). In this position, the male cytoplasm spreads from its own nucleus and invests the egg nucleus, and this investment is very evident in the fusion nucleus, and may persist in Torreya taxifolia as a distinct cytoplasmic sheath even about the four free nuclei at wall-formation. This sheath is recognizable on account of its abundant supply of food material, and is doubtless of service in the nutrition of the fusion nucleus. In Cephalotaxus drupacea (130), in which male cells are not formed, the two free male nuclei do not escape from the membrane of the body cell until at the time of discharge.

An interesting consequence of the early appearance and fertilization of the eggs of Torreya taxifolia may be men-

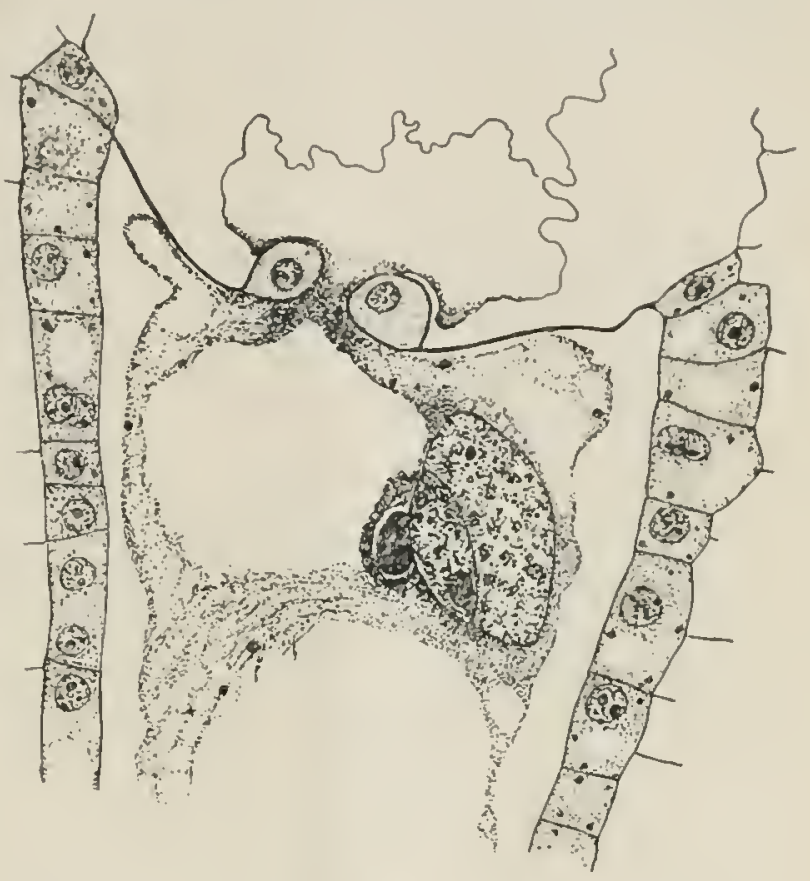

FIG. 400.-Phyllocladus alpina: fertilization; both male cells are shown, the one at the right is functional, and the one at the left is disorganizing; $\times 440$.-After Miss Young (174).

tioned. At this time the endosperm tissue has not grown, and in its subsequent development it grows about the tip of the pollen tube, incloses the fertilized egg, and forms quite a beak abore the embryo.

Critical observations of fertilization among the conifers are not numerous enough to form the basis of a general conclusion, but the evidence thus far indicates that the behavior of the male cytoplasm, in investing the fusion nucleus as a nutritive zone, is a feature of the Taxaceae; while among the Pinaceae the male nucleus slips from its cytoplasmic sheath in the periphery of the egg cytoplasm (with Tavodium and Juniperus as exceptions). Subsequent investigation may show that both methods belong indiscriminatcly to both families. 


\section{The embryo}

The two general stages in the derelopment of the embryo of Pinaceae are repeated among Taxaceae, but there is more variation in the character of the proembryo, and it more commonly fills the whole egg. The fact that among Pinaceae the proembryo usually occupies only a relatively small part of the basal region of the egg is not due to the small number of cells, for these may be just as numerous as among the Taxaceae, but is due to the large size of the egg at fertilization. The proembryo of Taxaceae also differs in the lack of uniformity of its tiers, the embryo-forming tier usually being represented by a single cell, while the suspensor and "rosette" tiers may be represented by a considerable number of cells; a fact that is probably due to the size and configuration of the egg.

\section{THE，PROEMBRYO}

The development of the proembryo of Torreya taxifolia (IOI) may be used as an illustration. The division of the fusion nucleus is followed immediately by a second division, and the four large free nuclei almost fill the small egg (fig. 40I). As a consequence, there is no such movement of nuclei toward the base as occurs in larger eggs. At this four-nucleate stage wall-formation occurs in the usual way by connecting fibers, the four walled cells completely filling the egg. Division of these cells continues until a proembryo of about twelve cells is produced, arranged more or less definitely in three tiers, as follows: five or six in the "rosette" tier, five or six in the suspensor tier, and one in the embryo-forming tier (fig. 402). Later divisions may result in a proembryo of eighteen cells. It is this twelve to eighteen-celled proembryo that persists, without further change, until the following spring. The relatively small egg, the very large nuclei, and the early appearance of walls are probably accountable for the tissue-filled egg. This account agrees with that given for Torreya californica (99).

In Cephalotaxus fertilization occurs later in the history of the gametophyte and the eggs are larger. In the two species investigated, $C$. Fortunei (I 24 ) and C. drupacea (I 30 ), four free nuclei are formed and then assume the basal position, in which nuclear division continues 
until eight or sixteen free nuclei are produced, when wall-formation occurs, the completed proembryo consisting of sixteen or thirty-two cells. 'These cells form fairly definite tiers above, but become more or less irregularly arranged below. Four regions or tiers may be recognized, at least so far as their functions are concerned: open tier (open above), suspensor tier, embryo-forming region, and region of the "penetrating cap," which last is a peculiar feature of the genus (figs. 369,370 ). In Taxus there are also sixteen free nuclei before wall-formation.

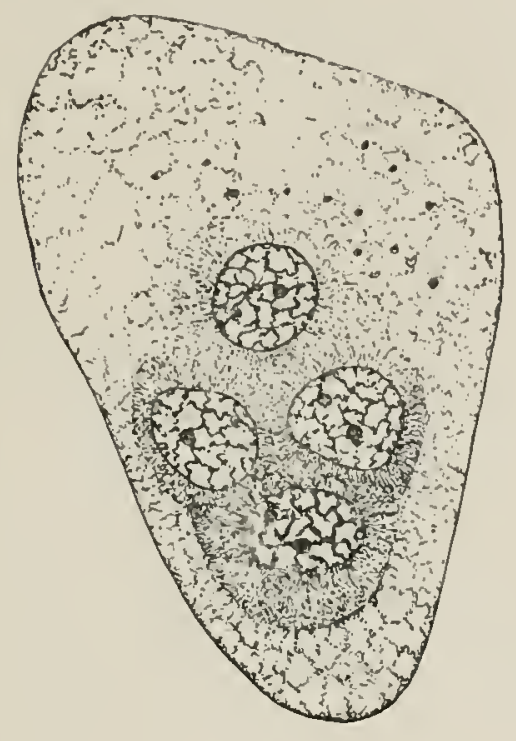

401

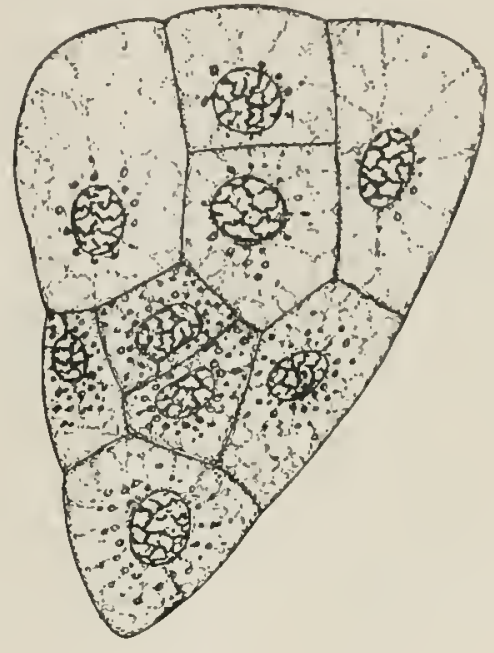

402

Figs, 401, 402.-Torreya tarifolia: fig. 401, four-nucleate stage of proembryo; August I 2, I904; $\times 460$; fig. 402 , proembryo showing the three tiers of cells; the entire egg is segmented; the proembryo passes the winter in this stage; August 27 , I904; X $460 .-$ After COUlTER and LAND (IOI).

Among the podocarps Podocarpus (69) and Phyllocladus (I+4) have been investigated. In the former genus the fusion nucleus assumes the basal position, and sixteen free nuclei appear before wall-formation. The three tiers of the completed proembryo are made up as follows: fourteen cells in the open tier, fourteen in the suspensor tier, and one binucleate cell in the embryo-forming tier. In Phyllocladus there are eight free nuclei before wall-formation.

Among the Pinaceae, with the possible exception of the araucarians, wall-formation in connection with the mitosis which gives rise to the eight-nucleate stage of the proembryo is a remarkably uniform 
feature. Among the Taxaceae, however, there is wall-formation in connection with the mitosis which produces the four-nucleate stage (Torreya), the sixteen-nucleate stage (Phyllocladus and sometimes Cephalotaxus), and the thirty-two nucleate stage (Taxus, Cephalotaxus, and Podocarpus). A large number of free nuclei before wallformation is a feature of the proembryos of Cycadales and Ginkgoales, and therefore it has been regarded as a primitive character. In general, this is probably true, but that it cannot be applied within a range of one or two divisions is evident from the fact that the extreme limits of free nuclei among conifers (two and sixteen) are found in Torreya and Taxus, two of the most closely allied genera.

\section{THE SUSPENSOR AND EMBRYO}

Suspensor-formation as observed in Torreya taxifolia (IOI) is probably true in general of all the genera of Taxaceae (fig. 403). Among Pinaceae the elongation characteristic of suspensor-formation so often appears to be definitely restricted to a single tier of proembryonic cells that it has produced the impression that the suspensor is necessarily an organ of definite origin. The elongation may involve every tier of the proembryo, and the suspensor is the total product of this elongation. In Torreya elongation begins in the uppermost tier ("rosette") of the proembryo, which is probably always the case when this tier is closed, and extends gradually downward, tier after tier, until it includes the proximal region of the meristematic cylinder produced by the embryo-forming cell. In this case, therefore, every tier of the proembryo "contributes" to the suspensor. The same phenomenon was observed in Thuja (72), among the Pinaceae.

Usually a single embryo is developed at the end of the suspensor, but in Podocarpus the constituent cells of the suspensor have been observed (69) to separate, resulting in the formation of several embryos from a single egg. Secondary embryos have been observed in Cephalotaxus ( 130 ) also to bud from the group of embryo-forming cells; and in Torreya such embryos have been seen (IOI) to bud from the suspensor region during the second season. In Cephalotaxus (I24, I30) a series of long haustorial "embryonal tubes" develop early from the proximal cells of the embryo.

The single embryo-forming cell of Torreya (IоI) develops a cylin- 
drical mass of meristematic cells, and this cylinder invades the endosperm, its basal cells contributing to the suspensor. Later, growing points are organized, the root tip being deep in the cylinder, and the two concave cotyledons completely surrounding the stem tip. The peculiarity of the embryo-formation in Cephalotaxus (25, I24, I30) has becn mentioned, in which the terminal cells of the proembryo form a persistent cap for the embryo during its advance through the cndosperm. That this same feature appears in Araucaria brasiliana (25) is a matter of interest (figs. 367,368 ).

So far as known, all of the Taxaceae are dicotyledonous. This has been regarded as a primitive feature, because Bennettitales, Cycadales, and Ginkgoales are dicotyledonous; but the relation of polycotyledony to dicotyledony may lead to a different conclusion (see p. 298).

Podocarpus Makoyi has been found (73) to be viviparous, the embryo continuing its development and the hypocotyl passing out of the micropyle while the seed is attached to the parent plant. It is probable that other species of Taxaceae will be found to show the same habit, as it is not uncommon in other groups of gymnosperms.

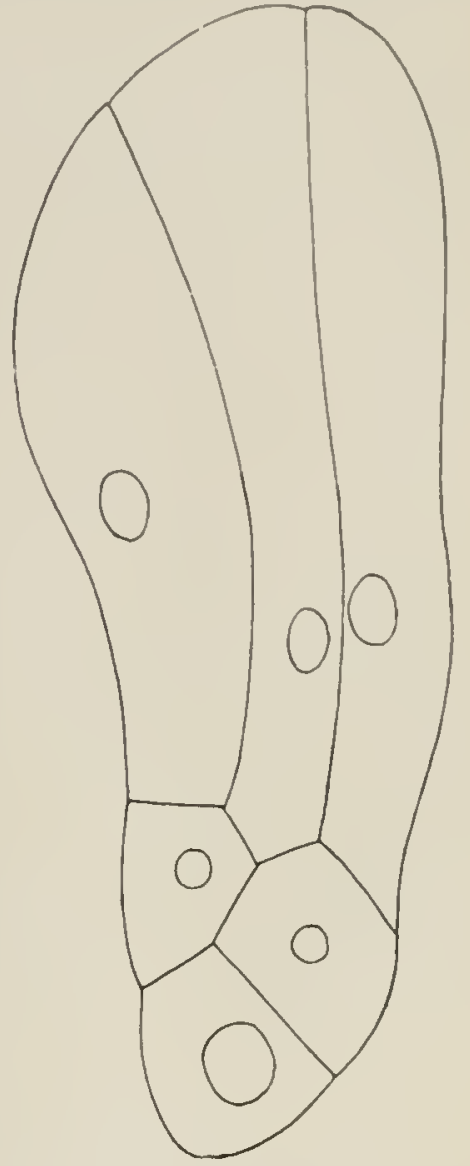

FIG. 403.-Torreya taxifolia: proembryo showing elongation of suspensor cells; April 7, I904; $\times 460$.-After Coulter and LAND (IOI).

\section{History and distribution}

The Taxaceae have not been recognized farther back than the Cretaceous, and so far as this negative evidence can be relied upon the family is comparatively a modern one among gymnosperms, certainly much younger than the Abietincae and the Araucarincae. It is possible that older Taxaceae existed, and that they have not been recognized among coniferous remains; but until they are recognized, the failure to find them carlier than the Cretaccous must be considered in any discussion of phylogeny. 
In the present geographic distribution of Taxaceae, the two tribes are in contrast, the podocarps belonging almost exclusively to the southern hemisphere, and the taxads as exclusively to the northern. This associates the former tribe geographically with the araucarians, and the latter with the three other tribes of Pinaceae.

Among Podocarpineae the genus Podocarpus is the only one that ranges through a hemisphere, and is the only one represented in the northern hemisphere by its extension into Japan. Both Dacrydium and Phyllocladus belong to the Australasian region, but extend northward into the East Indies; while Microcachrys and Pherosphaera are restricted to Australasia (chiefly Tasmania), and Saxegothaea to the southern Andes. The tribe as a whole is distinctly Australasian.

Among Taxineae the genus Tawus is the only one represented throughout the northern hemisphere, extending southward into tropical Asia and the mountains of Mexico. The other genera are much restricted, Cephalotawus being found only in Eastern Asia, Acmopyle and Polypodiopsis being restricted to New Caledonia, and Torreya being represented by four scattered species in Florida, California, Japan, and China. The general northern complexion of the group is evident, and the only endemic genus, excluding the two doubtful New Caledonian genera, is Cephalotaxus, all of whose six species occur only in eastern Asia.

\section{Relationship to other gymnosperms}

The opinions that have been expressed in reference to the relationships of the Taxaceae are so diverse that it is evident that the family presents a peculiarly difficult combination of resemblances. They have been called the oldest living conifers (I 33 ) and the most recent; they have been connected with Ginkyo through Cephalotaxus (I 24 , I34), and with Cordaitales on account of the structure of the ovuliferous shoot of Taxus (I34); and the podocarps have been related to the araucarians through Dacrydium and Saxegothaea (I5o).

In the absence of any history of the family, only the testimony of reproductive morphology and of vascular anatomy is available. In reviewing this testimony, it seems impossible to regard the family as a natural one, in the sense that all of its members belong to the same immediate stock. The tracheids of Dacrydium and Saxe- 
gothaea, the orulate cones of Microcachry's and Savegrothaen, the solitary orule, and above all the peculiar male prothallial tissue of all the genera suggest that the Podocarpineare are allied to the Araucarineac, a suggestion that the common and peculiar geographical distribution of the two tribes reinforces. 'This may mean only a common immediate ancestry; but the well-known age and wide mesozoic distribution of the araucarians, when taken in connection with the lack of evidence of podocarps before the Cretaceous, makes the conclusion reasonable that the Podocarpineae of today are a southern offshoot from the mesozoic Araucarineac; and they do not contradict any more ancient connection that the araucarians may have had with the Abietincae.

A recent conclusion as to relationships, suggested by Tison ( 165$)$, deserves mention. It is based upon a study of the vascular anatomy of Savegothaea conspicua, especially that of the orulate strobilus. From the behavior and distribution of the two systems of bundles found in the megasporophyll, one serving the sporophyll and the other the ovule, it is concluded that Savegothaca is more nearly related to the araucarians than to the podocarps, but that through Microcachry's it is connected with the latter so definitely that the araucarians, Saxegothaea, and the podocarps should constitute a single group comprising the three members indicated as subgroups. This conclusion depends upon the view that the structure of the ovulate cone, especially its vascular structure, is the paramount feature in determining relationship.

A recent study by Miss Gerry (I68) has thrown doubt upon the association of the podocarps with the araucarians. She has discorered that the "bars of Sanio" (p. 235), apparently a scrviceable character in the determination of coniferous woods, are present in all the Coniferales except the araucarians. This character dissociates the podocarps from the araucarians, and allies them more nearly with the Abietineae. Just how much this should outweigh the other characters which suggest an araucarian alliance is a matter of individual judgment, but it is clear that it must be taken into consideration.

The Taxineae present greater difficulties, for their resemblances are not so definite, and their combination of so-called primitive and 
advanced characters is more perplexing. This is indicated by Scotr's statement ( 160 ) that if any one of the tribes of conifers could be regarded as distinct in origin, it would be the taxads. It seems impossible to interpret the resemblances to Ginkgo as meaning anything more than the retention of common characters derived from a common ancestor, presumably in this case the Cordaitales. At the same time, it would seem impossible to connect the Taxineae, which have no history earlier than the Cretaceous, directly with the paleozoic Cordaitales. The only mesozoic stock they suggest is that from which the modern Abietineae, Taxodineae, and Cupressineae have come; and they differ from Abietineae in some of the important morphological features shown by Taxodineae and Cupressineae. The geographical association also enforces this suggestion, and the conclusion seems reasonable that the living Taxineae represent a phylum which was derived early from the abietineous stock, and which has retained cordaitean features that have disappeared among existing Abietineae, Taxodineae, and Cupressineae. The greatest objection to this connection lies in the structure of the ovulate strobilus, but the condition in Taxineae, as contrasted with that of the three tribes of Pinaceae, is one of those differences in degree rather than in kind (see p. 322) which mark ancient separation at a time when both groups bore more resemblance to their common ancestral stock.

The position of Phyllocladus among Taxaceae has given rise to such diversity of opinion that a summary of the evidence may be useful. The three alternatives are (I) to include it with Taxineae, (2) to include it with Podocarpineae, or (3) to constitute for it an intermediate tribe. The taxad resemblances are (I) structure of ovule, (2) symmetrical arillus, (3) ovulate strobilus, (4) mesarch bundles, (5) markings of tracheids. The podocarp resemblances are (I) male gametophyte, (2) structure of stamen, (3) winged pollen grains, (4) megaspore membrane, (5) "spongy tissue." The taxad features are, on the whole, more superficial and rariable; and the podocarp features are more fundamental, so fundamental, in fact, that an intermediate tribe seems unjustifiable. It seems evident that the testimony is strongly in favor of including Phyllocladus in Podocarpineae (I74). 


\section{LIST OF GENERA OF CONIFERALES, WITH APPROAIMATL NUMBBER OF SPECIES}

\section{A. Pinacfate \\ I. Abietineae}

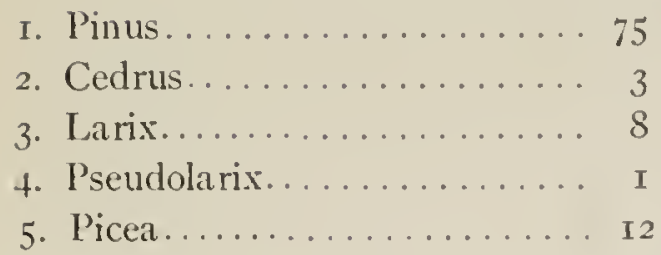

6. Tsuga............... 6

7. Pseudotsuga............ 2

8. Keteleeria.............. 2

9. Abies................. 20

\section{Taxodincae}

10. Sciadopitys.............. I

I4. Arthrotaxis............ 3

I I. Sequoia............... 2 I5. Cryptomeria.......... I

I2. Cunninghamia......... I I I Taxodium .......... 2

13. Taiwania........... I I $\quad$ I Glyptostrobus......... 2

III. Cupressineae

18. Actinostrobus.......... 2 23. Libocedrus.......... 8

I9. Callitris............ I5 24. Thuja............

20. Widdringtonia......... $5 \quad 25$. Cupressus........... I2

2I. Fitzroya............. 2 26. Chamaecyparis.......... 4

22. Thujopsis............ I 27 . Juniperus........... 30

IV. Araucarineae

28. Agathis Io 29. Araucaria. 10

B. Taxaceae

I. Podocarpineae

30. Podocarpus.............. 60

33. Pherosphaera.......... 2

3I. Dacrydium.............. I6

34. Saxegothaea........... I

32. Microcachrys.......... I

35. Phyllocladus

\section{Taxineae}

36. Taxus.............. 7

37. Torreya.............. 4

38. Cephalotaxus.
39. Acmopyle.

40. Polypodiopsis
I

I

\section{LITERATURE CITED}

I. Brown, Robert, Character and description of Kingia, a new genus of plants found on the S.IV. coast of New Holland, with observations on the structure of its unimpregnated ovulum and the female flower in Cycadeae and Coniferae. 1827. Included also in BRows's Miscellaneous botanical works I : I 866 .

2. Schleiden, M. J., Sur la signification morphologique du placentaire. Anm. Sci. Nat. Bot. II. I2:373-376. I839. 
3. Braun, A., Vortrag auf dem Congrès scientifique de France, roth session (Strassburg), pp. I7I, I72. I842 (communicated in Braun's Leben von C. Mettexius, p. 335. Berlin. I882).

4. Vox Mohl, Hugo, Ueber die männlichen Blüthen der Coniferen. Verm. Bot. Schriften, pp. 45-61. 1845. (Published as a dissertation, I837.)

5. Duchartre, P. E., Mémoire sur les embryons qui ont été decrits comme polycotylés. Ann. Sci. Nat. Bot. III. I0:207-237. pls. 7-10. I848.

6. Hofmerster, W., Embryobildung der Phanerogamen. Jahrb. Wiss. Bot. I:82-I88. pls. 7-IO. 1858 .

7. Bailion, H., Recherches organogéniques sur la fleur femelle des Conifères. Ann. Sci. Nat. Bot. IV. 14:186-199. pls. I2, I3. I860.

8. Caspary, R., De Abietinearum floris feminei structura morphologica. Ann. Sci. Nat. Bot. IV. I4:200-209. I860.

9. Dickson, A., Observations on some bisexual cones occurring in the spruce fir (Abies excelsa). Trans. Edinburgh Bot. Soc. 6:418-422. 1860.

io. Hofueister, W., Vergleichende Untersuchungen, etc. English translation. $\mathrm{I}_{86}$.

it. Oersted, A. S., Bidrag til Naaletroeernes Morphologi. Vidensk. Meddel. Nat. Foren. Copenhagen. r864.

I2. Parlatore, F., Studi organografici sui fiori e sui frutti delle Conifere. Opuscula botanica. I864.

I3. Hofueister, W., Lehre der Pflanzenzelle. I867.

I4. SACHS, J., Lehrbuch. I 868.

15. Strasburger, E., Die Befruchtung bei den Coniferen. r869.

r6. Van Tieghem, Ph., Anatonie comparée de la fleur femelle et du fruit des Cycadées, des Conifères, et des Gnetacées. Ann. Sci. Nat. Bot. V. Io:269304. pls. I $3-16$. I869.

17. Von Monl, Hugo, Morphologische Betrachtung der Blätter von Sciadopitys. Bot. Zeit. 29:17-23. IS7I.

i8. Strasburger, E., Die Coniferen und Gnetaceen. i872.

I9. Eichler, A. W., Sind die Coniferen gymnosperm oder nicht? Flora 54: $24 \mathrm{I}-247,260-272$. I873; and later papers.

20. Engetananx, G., Morphology of the carpellary scales of Coniferae. Amer. Jour. Sci. III. I $2: 469,470$. 1876 .

21. Stenzel, G., Beobachtungen an durchwachsenen Fichtenzapfen. Ein Beitrag zur Morphologie der Nadelhölzer. Nov. Act. Nat. Cur. 38:289350. pls. $12-15 . \quad 1876$.

22. Strasburger, E., Die Befruchtung und Zelltheilung. Jen. Zeitsch. 2:435-536. pls. 27-35. I877.

23. — Befruchtung und Zelltheilung. 1878 .

24. Čelakorshí, L., Zur Gymnospermie der Coniferen. Flora 62:257-264, $272-283.1879$.

25. Strasburger, E., Die Angiospermen und die Gymnospermen. 1879. 
26. Celakorshŕ, L., Zur Kritik der Ansichten ron der Fruchtschuppe der Abietineen. Abhandl. Königl. Böhm. Gesell. Wiss. VI. I I IS82.

27. SAchs, J., Textbook of botany. Second English edition. 1882.

28. Gorosciankin, J., Zur Kenntniss der Corpuscula bei den Gymnospermen. Bot. Zeit. 4I:825-83I. pl. 7 A. I883; Ueber den Befruchtung-I'rocess bei Pinus Pumilio. ${ }^{8} 88_{3}$.

29. Dl:BARY, A., Comparative anatomy of the vegetative organs of the phanerngams and ferns. Encrish translation. ISS4.

30. Renault, B., Cours de botanique fossile. Paris. I880-I884.

3i. Strasburger, E., Neue Untersuchungen, etc. IS 44.

32. CELAKorskŕ, L., Die Gymnospermen: cine morphologisch-phylogenetische Studie. Abhandl. Königl. Böhm. Gesell. ITiss. VII. 4: I-I 48. I89o.

33. BelajefF, W., Zur Lehre von dem Pollenschlauche der Gymnospermen. Ber. Deutsch. Bot. Gesell. 9:2So-286. pl. I8. ISgI.

34. Masters, M. T., Comparative morphology, anatomy, and life history of the Coniferae. Jour. Linn. Soc. London Bot. 27:226-332. figs. 29. IS9I.

35. Vas Tieghear, Ph., Traité de botanique. Paris. isgi.

36. Dangeard, P. A., Recherches sur les plantules des Conifères. La Botaniste 3:I26-204. pls. I3-I7. IS92.

36a. Farmer, J. B., On the occurrence of two prothallia in the embryo sac of Pinus. Annals of Botany 6:2 I3, 214. fig. 5. ISg2.

37. Mottier, D. MI., On the archegonium and apical growth of the stem in Tsuga canadensis and Pinus silvestris. Bot. Gazette $\mathrm{I}_{7}: \mathrm{I}_{4} \mathrm{I}-\mathrm{I} 43$. pl. 8. IS92.

$3^{S}$. Strasburger, E., Ueber das Verhalten des Pollens und die Befruchtungsvorgänge bei den Gymnospermen. Hist. Beitr. 4: I-I58. pls. I-3. 1892.

39. BelajefF, IV., Zur Lehre ron dem Pollenschlauche der Gymnospermen (Zweite Mittheilung). Ber. Deutsch. Bot. Gesell. i I : I96-20 I. pl. I2. I893.

40. Dixon, H. N., Fertilization of Pinus silvestris. Annals of Botany 8:2 I-34. pls. 3-5. I894.

4I. Canpbell, D. H., Mosses and ferns. New York. i 895.

4Ia. Kerner yon Marilaun, Das Pflanzenleben. Leipzig and Vienna. i8g6.

42. Shaw, IV. R., Contribution to the life history of Sequoia. Bot. Gazette $21: 332-339 . p l .24 .1896$.

43. Tнıвоuт, E., Recherches sur l'appareil mâle des gymnospermes. pp. 265. pls. I6. Lille. ISg6.

44. Collter, John M., Notes on the fertilization and embryogeny of conifers. Bot. Gazette 23:40-43. pl. 6. 1897 .

45. Worsdell, W. C., On transfusion tissue; its origin and function in the leaves of gymnospermous plants. Trans. Linn. Soc. London Bot. II. 5:301-319. pls. 23-26. I897.

46. Blackutax, V. H., On the cytological features of fertilization and related phenomena in Pinus silvestris L. Phil. Trans. Roy. Soc. B x $90: 395^{-}+26$. pls. 12-14. 1898 . 
47. Čelakovskí, L., Nachtrag zu meiner Schrift über die Gymnospermen. ENGLER's Bot. Jahrb. 24:202-231. I898.

48. Chamberlain, C. J., Winter characters of certain sporangia. Bot. Gazette 25: 1 25-I28. pl. II. 1898.

49. Arvoldi, W., Beiträge zur Morphologie einiger Gymnospermen. I. Die Entwickelung des Endosperms bei Sequoia sempervirens. Bull. Soc. Imp. Nat. Moscou r899: pp. 13. pls. 7, 8.

50. — - Beträge zur Morphologie und Entwickelungsgeschichte einiger Gymnospermen. II. Ueber die Corpuscula und Pollenschlauche bei Sequoia sempervirens. Bull. Soc. Imp. Nat. Moscou I899: pp. 8. pls. IO, II.

5I. Chamberlain, C. J., Oogenesis in Pinus Laricio. Bot. Gazette 27:268280. pls. 4-6. I899.

52. JäGER, L., Beiträge zur Kenntniss der Endospermbildung und zur Embryologie von Taxus baccata. Flora 86:24I-288. pls. I5-19. I899.

53. Potonıé, H., Lehrbuch der Pflanzenpalaeontologie. Berlin. 1899.

54. Worcicki, Z., (On fertilization in Coniferae). pp. 57. pls. 2. I899. (Russian)

55. Arvold, W., Beiträge zur Morphologie der Gymnospermen. III. Embryogenie von Cephalotaxus Fortunei. Flora 87:46-63. pls. I-3. I900.

56. ㄴ. Beiträge zur Morphologie der Gymnospermen. IV. Was sind die "Keimblaschen" oder "Hofmeister's-Körperchen" in der Eizelle der Abietineen? Flora 87:194-204. pls. 6, 7. I900.

57. Coker, W. C., Observations on the gametophyte and embryo of Taxodium distichum. Johns Hopkins Univ. Circ. I9:45, 46. I900.

58. Goebex, K., Organography of plants. English translation. pp. I53-r55. r9o0.

59. Juer, H. O., Beiträge zur Kenntniss der Tetradenbildung. Jahrb. Wiss. Bot. 35:626-659. pls. I5, I6. I900.

6o. Murrill, W. A., The development of the archegonium and fertilization in the hemlock spruce (Tsuga canadensis). Annals of Botany 14:583-607. pls. 3I, 32. I900.

6r. Scotт, D. H., Studies in fossil botany. London. I900.

62. Worsdell, IV. C., The structure of the female "flower" in Coniferae. Annals of Botany 1 4:39-82. I900.

63. - The vascular structure of the ovule of Cephalotaxus. Annals of Botany 14:3I7, 3I8. I900.

64. Arnold, IW., Beiträge zur Morphologie einiger Gymnospermen. V. Weitere Untersuchungen der Embryogenie in der Familie der Sequoiaceen. Bull. Soc. Imp. Nat. Moscou r9io: pp. 28. pls. 2.

65. Ferguson, Margaret C., The development of the pollen tube and the division of the generative nucleus in certain species of pines. Annals of Botany I 5: I93-223. pls. I2-I4. I90I. 
66. Freguson, Margarfit C., The development of the egre and fertilization in Pimus Strobus. Annals of Botany I 5:435-479. pls.23-25. $190 \mathrm{I}$.

67. Bessey, Chartis F., The morphology of the pine cone. Bot. Gazelle 33: I 57 -159. pl. $\delta$. I 902 .

68. Chauveaud, G., Passage de la disposition primitive à la clisposition sécondaire dans les cotylédons du Pin maritime. Extr. Bull. Mus. Hist. Nat. Paris. 1902.

69. Соккк, W. C., Notes on the gametophytes and embryo of Podocurpus. Bot. Gazette 33:89-107. pls. 5-7. 1902.

7о. GozBEL, K., Morphologische und biologische Bemerkungen. 13. Ueber die Pollenentleerung bei einiger Gymmospermen. Flora 91:237-263. figs. I9. 1902.

7I. Jeffrey, E. C., "The structure and development of the stem in the P'teridophyta and Gymnosperms. Phil. 'Trans. Roy. Soc. London B3 I95: 1 I9146. pls. 6. 1902 .

72. LAND, W. J. G., A morphological study of Thuja. Bot. Gazette 34:249259. pls. 6-8. I902.

73. Llovu, Francis E., Vivipary in Podocarpus. 'Torreya 2:113-117. figs. 3. 1902 .

74. Allex, C. E., The early stages of spindle formation in the pollen mother cells of Larix. Annals of Botany I7:218-312. pls. 14, 15. 1903.

75. Chick, Editi, The seedling of Torreya myrislica. New Phytologist 2:8391. pls. 7, S. 1903 .

76. Coker, W. C., On the gametophytes and embryo of Taxodium. Bot. razette 36: I-27, I I4-I 40. pls. 1-II. I903.

77. Jeffrey, E. C., Comparative anatomy of gymnosperms, in Coulter and Chamberlain's Morphology of angiosperms. New York. igo3.

78. - The comparative anatomy of the Coniferales. I. The genus Sequoia. Mem. Boston Soc. Nat. Hist. 5:44I-459. pls. 68-7I. I903.

79. Mrнke, K., On the derelopment of the sexual organs and fertilization in Picea excelsa. Annals of Botany I7:35I-372. pls. I6, I7. I903.

79a. - Contribution to the fertilization and embryogeny of Abies balsumea. Beilh. Bot. CentralbI. I4: 134-144. pls. 6-8. 1903.

8o. Olver, F. IV., The orules of the older gymnosperms. Annals of Botany' I $7: 45 \mathrm{I}-476$. pl. 24. figs. 20. 1903 .

Si. Pilger, R., Taxaceae in ENgler's Das Pflanzenreich. 1903.

S2. Zeiller, R., et Fliche, P., Découverte de strobiles de Sequoia et de Pin dans le Portlandien des environs de Boulogne-sur-Mer. Compt. Rend. Acad. Sci. Paris 137:1020-1022. 1903.

S3. Chauveaud, G., Le liber précurseur dans le sapin pinsapo. Ann. Sci. Nat. Bot. VIII. I9:321-333. 1904.

84. - Origine sácondaire du double faisceau foliare chez les sapins (Abies) et les pins (Pinus). Ann. Sci. Nat. Bot. VIII. I9:335-348. I904 
85. Coker, W. C., On the spores of certain Coniferae. Science N.S. I9:424. I904.

86. — On the spores of certain Coniferae. Bot. Gazette 38:206-2 г 3 . figs. 24. 1904 .

87. Ferguson, Margaret C., Contributions to the life history of Pinus, with special reference to sporogenesis, the development of the gametophytes, and fertilization. Proc. Wash. Acad. Sci. 6:1-202. pls. I-24. Ig04.

88. Fliche, P., et Zeiller, R., Note sur un florule portlandienne des environs de Boulogne-sur-Mer. Bull. Soc. Geol. France IV. 4:787-8r2. 1904.

89. Jefrrey, E. C., A fossil Sequoia from the Sierra Nevada. Bot. Gazette 38:32 I-332. pls. IS, I9. 1904 .

90. - The comparative anatomy of the Coniferales. II. The Abietineae. Nem. Boston Soc. Nat. Hist. 6: 1-37. pls. I-7. I904.

9i. Juel, H. O., Ueber den Pollenschlauch von Cupressus. Flora 93:56-62. pl. 3. 1904 .

92. LAwSON, A. A., The gametophyte, archegonia, fertilization, and embryo of Sequoia sempervirens. Annals of Botany 18: I-28. pls. I-4. I904.

93. - The gametophyte, fertilization, and embryo of Crytomeria japonica. Annals of Botany r 8:417-444. pls. 27-30. 1904.

94. MacMrllax, Coxway, Note on some British Columbian dwarf trees. Bot. Gazette 38:379-38I. figs. 3. I904.

95. NorÉN, C. O., Ueber Befruchtung bei Juniperus communis. Vorläufige Mitteilung. Arkir. Bot. Srensk. Vetensk.-Akad. 3: pp. I r. I904.

96. Pexhallow, D. P., The anatomy of the North American Coniferales, together with certain exotic species from Japan and Australia. Amer. Nat.

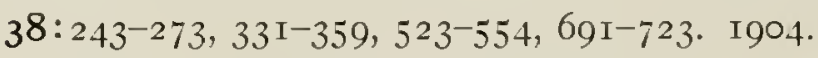

97. Renner, Otto, Ueber Zwitterblüthen bei Junipenus communis. Flora 93:297-300. figs. 3. 1904.

98. Robertson, Agnes, Spore formation in Torreya califormica. New Phytologist $3: 133-148$. pls. 3, 4. 1904 .

99. - - Studies in the morphology of Torreya californica. II. The sexual organs and fertilization. New Phytologist 3:205-216. pls. $7-9$. I904.

ioo. Strasburger, E., Anlage des Embryosackes und Prothalliumbildung bei der Eibe nebst anschliessenden Erörterungen. Festschrift zun siebzigsten Geburtstage von Ervst Haeckel. pp. I8. pls. 2. Jena. I904.

ior. Coulter, Johx M., and Laxd, W. J. G., Gametophytes and embryo of Torreya taxifolia. Bot. Gazette 39:16I-178. pls. A, I-3. 1905.

I02. Gothax, W., Zur Anatomie lebender und fossiler Gymnospermenhölzer. Abhandl. Preuss. Geol. Landesanstalt. Neue Folge. Heft 44. I905.

103. Kubart, Bruxo, Die weibliche Blüthe von Juniperus communis L. Sitzungsber. Kais. Akad. Wiss. Wien I 4 4: pp. 29. pls. 2. 1905. 
IO4. LOPRIORE, G., Ueber die Vielkömigkeit der Pollenkörner von Araucaria Bidwillii. Vorläufige Mitteilung. Ber. Deutsch. Bot. Gesell. 23:335-346. pl. I5. 1905 .

105. SEward, A. C., and Ford, Sibili.e O., The A raucarieae, recent and extinct. Abstract read before-Roy. Soc. London, December 1905.

.06. Sludsky, N., Ueber die Entwickelungsgeschichte des Juniperus communis. Vorläufige Mitteilung. Ber. Deutsch. Bot. Gesell. 23:212-2 I6. pl.6. I905. 107. Thomson, R. B., Preliminary note on the Araucarineae. Science N.S. $22: 88$. 1905 .

Io8. - The megaspore membrane of the gymnosperms. Univ. Toronto Biol. Series no. 4. Pp. 64. pls. 5. 1905.

rog. Hayata, B., Taimania, a new genus of conifers. Jour. Linn. Soc. Bot. 32:330-332. pl. I6. 1906.

I Io. HiLl, T. G., and DE Fraine, E., On the seedling structure of gymnosperms. Annals of Botany 20:47I-473. I906.

in. Hollick, A., and Jeffrey, E. C., Affinities of certain cretaceous plant remains commonly referred to the genera Dammara and Brachyplyyllum. Amer. Nat. 40: I89-2 I5. pls. I-5. I906.

i i . Jeffrer, E. C., and Chrisler, M. A., On cretaceous Pityoxyla. Bot. Gazette $42: \mathrm{I}-\mathrm{I} 5$. pls. I, 2. 1906.

II3. Masters, Maxwell 'T., On the conifers of China. Jour. Linn. Soc. London Bot. 37:410-424. I906.

I I4. Pollock, James B., Variations in the pollen grain of Picea excelsa. Amer. Nat. 49:253-286. pl. I. I906.

I 5. Robertson, Agnes, Some points in the morphology of Phyllocladus alpina Hook. Annals of Botany 20:259-265. pls. I7, I8. I906.

I 6. ScotT, D. H., "The origin of gymnosperms"; a discussion at the Linnean Society. New Phytologist 5:68-76, I4I-I48. I906.

II 7. SEwARD, A. C., "The origin of gymnosperms"; a discussion at the Linnean Society. New Phytologist 5:68-76, I4I-148. I906.

if S. Seward, A. C., and Ford, Sibille O., The Araucaricae, recent and extinct. Phil. Trans. Roy. Soc. London B I98:305-4II. pls. 23, 24. figs. 28 . 1906.

II9. Stopes, MARIE C., and FujII, $\mathrm{K}$., The nutritive relations of the surrounding tissues to the archegonia in gymnosperms. Beih. Bot. Centralb], 20: $1-24$. pl. I. 1906.

I 20. Thomas, Ethes, N., "The origin of gymnosperms"; a discussion at the Linnean Society. New Phytologist 5:68-76, I4 I-148. I 906.

I21. Thouson, R. B., "The origin of gymnosperms"; a discussion at the Linnean Society. New Phytologist 5:68-76, r4I-I48. I906.

I22. WEISS, F. E., "The origin of gymnosperms"; a discussion at the Linnean Socicty. New Phytologist 5:68-76, I 4I-I48. I906.

123. WORSDELL, II. C., "The origin of gymmosperms"; a discussion at the Linnean Socicty. New Phytologist 5:6S-76, 14 I-14S. I906. 
124. Coker, W. C., Fertilization and embryogeny in Cephalotaxus Fortunei. Bot. Gazette 43: I-10. pl. I. figs. 5. I907.

125. Hayata, B., On Taiwania and its affinity to other genera. Bot. Mag. Tokyo $2 \mathrm{I}: 2 \mathrm{I}-27$. pl. I. I907.

i26. Haydon, Walter T., The seed production of Pinus sylvestris. Proc. and Trans. Liverpool Biol. Soc. 22: I-32. figs. I6. I907.

127. Jeffrey, E. C., Araucariopitys, a new genus of araucarians. Bot. Gazette 44:435-444. pls. 27-30. I907.

128. Jeffrey, E. C., and Chrysler, M. A., The microgametophyte of the Podocarpineae. Amer. Nat. 4I:355-364. figs. 5. 1907.

129. Kildahl, N. Johanna, Development of the walls in the proembryo of Pinus Laricio. Bot. Gazette 44:102-107. pls. 8, 9. I907.

I30. Lawson, A. A., The gametophytes, fertilization, and embryo of Cephalotaxus drupacea. Annals of Botany 21:I-23. pls. I-4. I907.

I31. - The gametophytes and embryo of the Cupressineae, with special reference to Libocedrus decurrens. Annals of Botany 2I:28I-30I. pls. 2426. 1907 .

I32. NoréN, C. O., Zur Entwickelungsgeschichte des Juniperus communis. Uppsala Universitets Ärsskrift 1907: pp. 64. pls. 4 .

I33. Penhallow, D. P., A manual of the North American gymnosperms, exclusive of the Cycadales but together with certain exotic species. Boston. I907.

I34. Robertson, Agnes, The Taxoideae; a phylogenetic study. New Phytologist 6:92-102. pl. I. 1907.

I35. Thomas, Ethel N., A theory of the double leaf trace founded on seedling structure. New Phytologist 6:77-9I. figs. 4. I907.

i36. Young, Mary S., The male gametophyte of Dacrydium. Bot. Gazette 44: 189-196. pl. I9. I907.

137. Berry, EDward W., Some a raucarian remains from the Atlantic coastal plain. Bull. Torr. Bot. Club 35:249-260. pls. I I-I6. 1908.

138. - A mid-cretaceous species of Torreya. Amer. Jour. Sci. 25:382386. 1908 .

I39. Burlingame, L. L., The staminate cone and male gametophy te of Podocarpus. Bot. Gazette 46: 16 г-178. pls. 8, 9. figs. 9. 1908.

140. Chrysler, M. A., Tyloses in tracheids of conifers. New Phytologist 7 : I98-204. pl. 5. 1908.

I4I. Hill, T. G., and De Fraine, E., On the seedling structure of gymnosperms. I. Annals of Botany 22:689-712. pl. 35. figs. S. I908.

I42. Jeffrey, E. C., On the structure of the leaf in cretaceous pines. Annals of Botany 22:207-220. pls. I3, I4. I908.

I43. - - Traumatic ray tracheids in Cunninghamia sinensis. Annals of Botany 22:593-602. pl. 31. 190S.

I44. Kildaht, N. Johanna, The morphology of Phyllocladus alpina. Bot. Gazette 46:339-348. pls. 20-22. I 908 . 
145. Kildail, N. Jollanna, Athinilies of Phyllocladns. Bot. Gazette 46:464, 465. I908.

I46. Masters, Maxwell T., On the distribution of the species of conifers in the several districts of China, and on the occurrence of the same species in neighboring countries. Jour. I.imn. Soc. London Bot. 38: 198-205. Igo8.

147. Mryake, K., The development of the gametophytes and embryogeny of Cunninghamia (preliminary note). Bot. Mag. Tokyo 22:45-50. figs. I4. I908.

I48. Nathorst, A. G., Palacobotanische Mitteilungen. 1II. Lycostrobus Scottii, cine grosse Sporophyllähre aus den rätischen Ablagerungen Schonens. Handl. Kgl. Svensk. Vetensk.-Akad. 43:I-12. pls. 1, 2. I 908.

I49. NorÉn, C. O., Zur Kenntnis der Entwicklung von Saxegothaea conspicua Lindl. Svensk. Bot. Tidsskr. 2: I0I-I22. pls. 7-9. Igo8.

I50. Stiles, IT., The anatomy of Sa.regothaea conspicua Lindl. New Phytologist $7: 209-222$. figs. $2 S-34$. I908.

I5I. Thomson, R. B., Note on the pollen of Microcachrys. Bot. Gazette 46:465, 466. I 1908 .

I52. Tison, A., Le nucelle stigmatifère et la pollination chez le Saxegothaca conspicua. Compt. Rend. Acad. Sci. Paris 147: I37-I39. I90S.

I53. Bailer, Irving IV., The structure of the wood in the Pineae. Bot. Gazette 48:47-55. pl. 5. I909.

I54. Hill, 'T. G., and DE Fraine, E., On the seedling structure of gymnosperms. II. Annals of Botany 23: I89-227. pl. I5. figs. II. I909.

i55. Hollick, Arthur, and Jeffrey, E. C., Studies of cretaceous coniferous remains from Kreischerville, New York. Mem. N.Y. Bot. Garden 3:II38. pls, I-29. I909.

556. Lawson, A. A., The gametophytes and embryo of Pseudotsuga Douglasii. Annals of Botany 23: I63-180. pls. I2-I4. I 909.

I57. Ottley, Alice M., The development of the gametophytes and fertilization in Junipcrus communis and Junipcrus virginiana. Bot. Gazette 48:3 ${ }^{-4} 46$. pls. $I-4$. I909.

I58. Saxton, IV. T., Parthenogenesis in Pinus Pinaster. Bot. Gazette 47: 406409. figs. 7. 1909.

I59. - Preliminary account of the development of the ovule, gametophytes, and embryo of Widdringtonia cupressoides Endl. Bot. Gazette 48: I6II78. pl. II. figs. 3. I909.

- i6o. Scott, D. H., Studies in fossil botany. Second edition. Vol. II. London. I 909.

I6r. Shaw, F. J. F., The seedling structure of Araucaria Bidwillii. Annals of Botany 23:321-334. pl. 21. figs. 6. I909.

162. Sinnot, E. A. W., Paracedroxylon, a new type of araucarian wood. Rhodora I I : 165-I 73. pls. So, 8I. I909. 
163. Thomson, R. B., On the pollen of Microcachrys tetragona. Bot. Gazette $47: 26-29$. pls. I, 2, 1909 .

I64. - - The megasporophyll of Saxegothaea and Microcachrys. Bot. Gazette 47:345-354. pls. 2I-25. 1909.

r65. Tison, A., Sur le Saxegothaea Lindl. Mém. Soc. Linn. Normandie 23:139-160. pls. 9, I0. I909.

i66. Bartholomew, Mary, Abnormal prothalli of Pinus sylvestris. Notes Roy. Bot. Gard. Edinburgh 4:253-255. pl. 49. I909.

I67. Saxton, W. T., Development of the embryo in Pinus Pinaster Soland., with some notes on the life history of the species in Cape Colony. S. African Jour. Sci. 6:52-59. pl. 2. I909.

i68. Gerry, Elorse, The distribution of the "bars of Sanio" in the Coniferales. Annals of Botany 24: I I9-I24. pl. I3. I910.

i69. Stopes, Marie C., and Fujir, K., Studies on the structure and affinities of cretaceous plants. Phil. Trans. Roy. Soc. London B 201:I-90. pls I-9. I9IO. Abstract in Annals of Botany 24:23I, 232. I9IO.

I7o. Thompson, W. P., On the origin of ray tracheids in the Coniferae. Bot. Gazette 50:I0I-II6. figs. 6. I9I0.

I7 I. Tison, A., Remarques sur les gouttelettes collectrices des ovules des Conifères. Mém: Soc. Linn. Normandie 24:5 I-66. pls. 3, 4. I910 (?).

i 72. Coulter, J. M., Barnes, C. R., and Cowles, H. C., A textbook of botany. New York. I9Io.

I73. Nichols, GeORGE E., A morphological study of Juniperus communis var. depressa. Beih. Bot. Centralbl. 25:20I-24I. pls. 8-I7. figs. 4. I9Io.

174. Young, Mary S., The morphology of the Podocarpineae. Bot. Gazette 50:8I-I00. pls. 4-6. I9I0.

I75. Lawson, A. A., The gametophytes and embryo of Sciadopitys verticillata. Annals of Botany 24:403-42I. pls. 29-3I. I910.

i76. Saxton, W. T., Contributions to the life history of Widdringtonia cupressoides. Bot. Gazette 50:30-48. pls. I-3. 1910.

177. - Contributions to the life history of Callitris. Annals of Botany 24: July I9IO.

i78. Brooks, F. T., and Stiles, W., The structure of Podocarpus spimulosa (Smith) R. Br. Annals of Botany 24:305-318. pl. 21. 19 IO.

I79. Saxton, W. T., Notes on the anatomy of Widdringtonia and Callitris. S. African Jour. Sci. 7:282-286. figs. II. I9IO.

I80. Mryake, K., The development of the gametopytes and embryogeny in Cunninghamia sinensis. Beih. Bot. Centralbl. 27: I-25. pls. 1-5. figs. 2 I9IO.

i8 i. Vierhapper, F., Entwurf eines neuen Systemes der Coniferen. Abhandl. K. K. Zool.-Bot. Gesell. Wien 5: I-56. I910. 


\section{CHAPTER VIII}

\section{GNETALES}

This group includes three genera which differ remarkably in habit and geographical distribution. 'Their great diversity and scattered distribution suggest the existence of older and more widely distributed forms, but no such history has been discovered. They are notable among gymnosperms for the presence of certain angiospermous features, and for this reason they have been regarded often as a transition group between gymnosperms and angiosperms. The two most important resemblances to angiosperms are the occurrence of true vessels in the secondary wood, and the elimination of archegonia in IVelwitschia and Gnetwm. The presence of a "perianth" has also been cited as an angiospermous character, but it is not to be distinguished from the bracts associated with orules and stamens in other gymnosperms, as in Torreya.

The common characters that hold these three genera together in a single group are the compound strobili (both staminate and orulate) resembling inflorescences in which the simple and axillary strobili resemble flowers, the conspicuous micropylar tube, the opposite leares, the dicotyledonous embryo, the true vessels, and the absence of resin canals. No one of these characters is peculiar to Gnetales among gymnosperms, excepting the true vessels and the compound staminate strobilus; but the combination of characters makes the group very distinct.

The genera are Ephedra, with about thirty species growing in the arid regions about the Mediterranean, and in tropical to temperate Asia, North America, and South America; the monotypic Welwitschia (Tumboa), in an extremely arid and restricted region of western South Africa; and Gnetum, with about fifteen species growing in the tropical forests of America, Asia, and Africa.

The earlier knowledge of the group was included in the accounts published by Hooker (I), Eichler (2), Strasburger $(3,5)$, and

I The Brussels Congress (May 1910) included Wclwilschia among the genera conscrianda; therefore the name is used in this volume instead of the older Tumboa. 
BECCARI (4). Since that time there has been some fruitful investigation, but the comparative inaccessibility of the material has made the investigations less numerous and complete than the importance of the group would justify.

\section{The vegetative organs}

The species of Ephedra are low straggling shrubs, with longjointed and fluted green stems, and opposite scalelike leaves connate in a two-toothed sheath. True foliage leaves are generally lacking, and the whole habit is suggestive of a shrubby Equisetum (fig. 404).

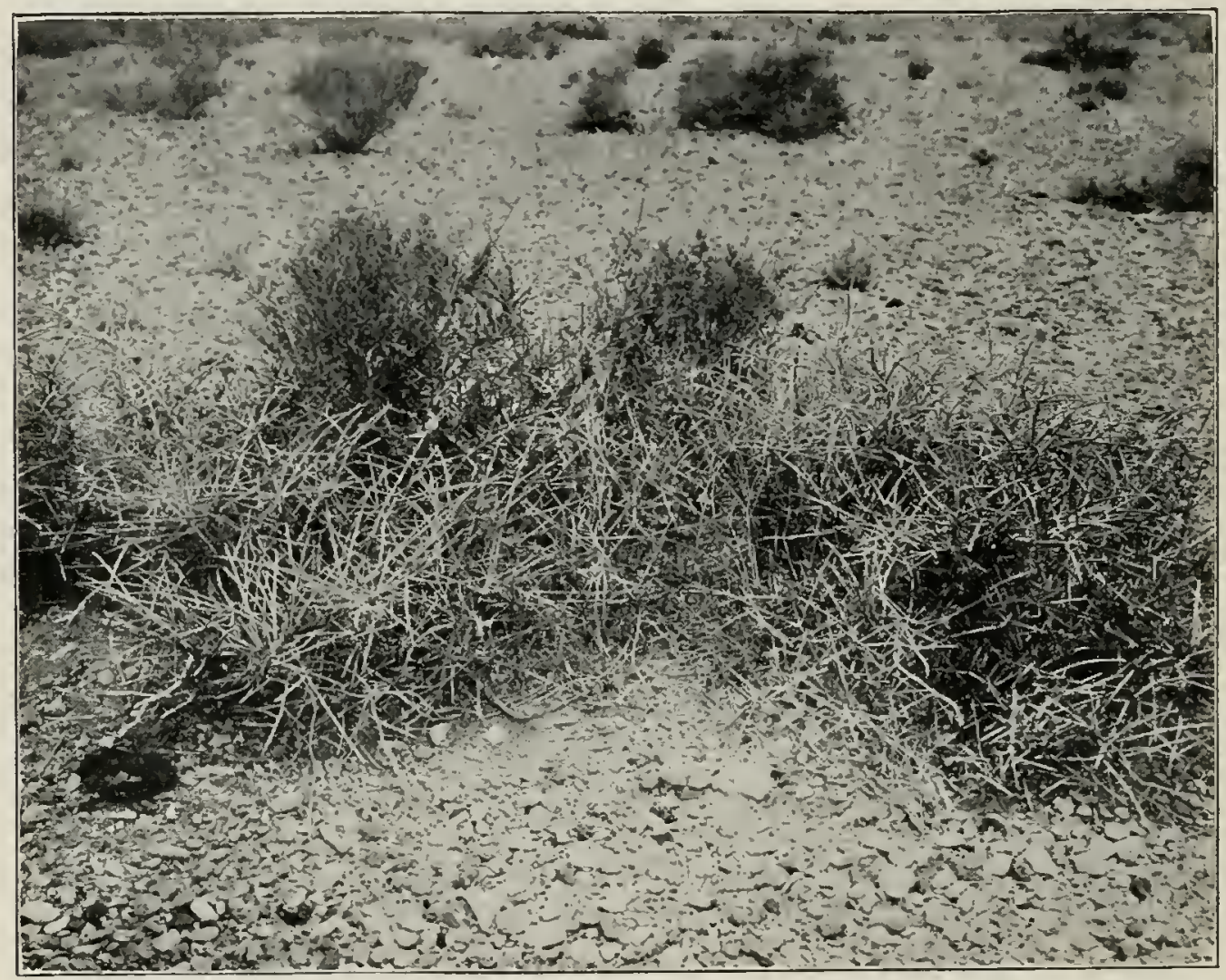

FIG. 404.-Ephedra sp., growing near Tucson, Arizona.-From photograph by D. T. MACDOUGAL.

Welwitschic is a plant of remarkable habit (figs. 405-407). The very tough body has the shape of a gigantic radish, which rises little above the surface of the ground, and whose crown is sometimes $3 \cdot 5$ to 4.5 meters in circumference. The broad top is more or less concave and somewhat two-lobed, and from the deep horizontal groove 
which separates the crown (shortened stem) from the rest of the body (tap root) two enormously long parallel-reined leaves arisc, which

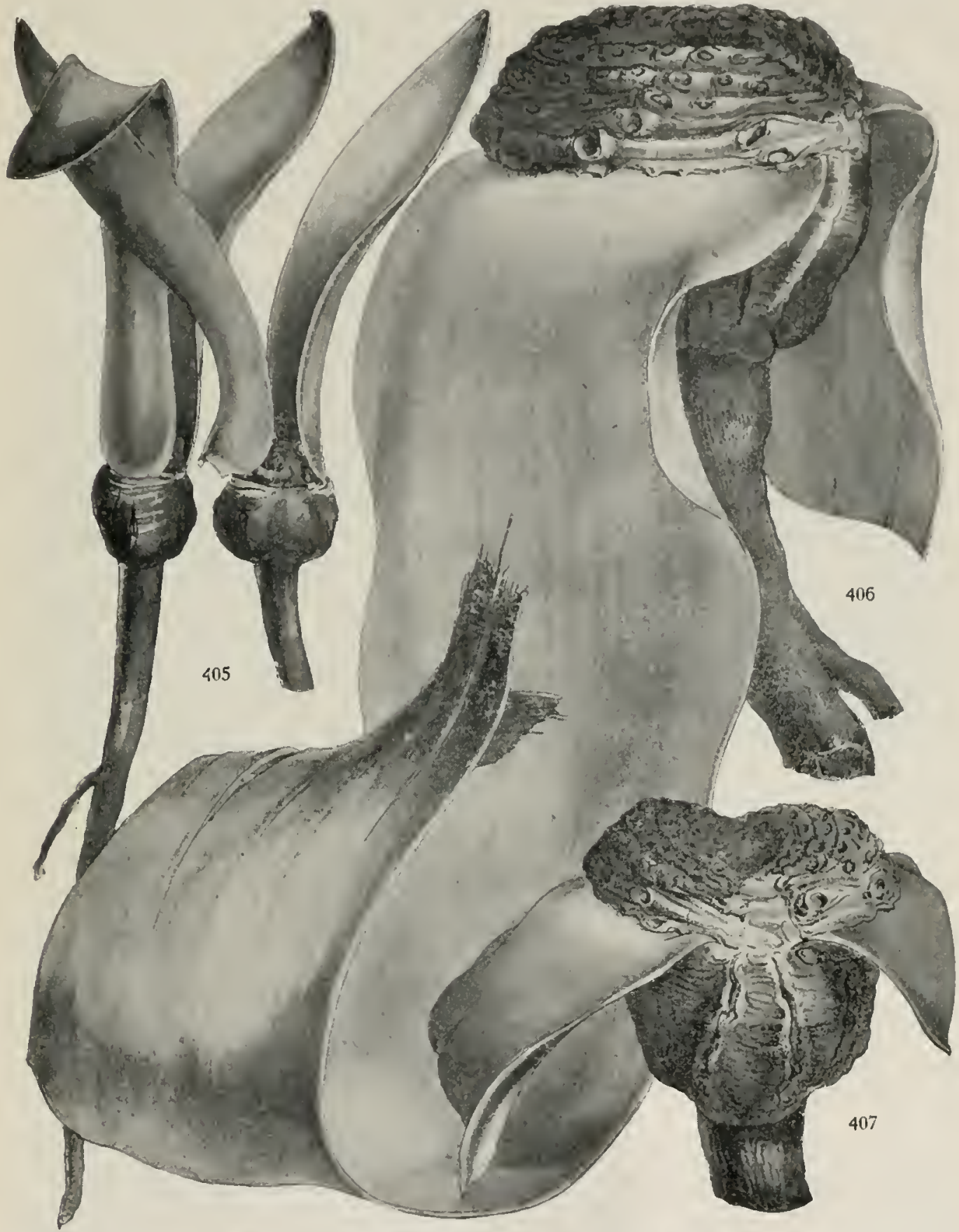

Figs. 405-407.-Welwitschia mirabilis: fig. 405, two views of the youngest specimen sent by WELWITSCH to HOOKER, showing the leaves in an entire condition; figs. 406,407 , side and top views of an older specimen, showing laceration of the end of the leaf; all one-half natural size.-After Hooker (I).

extend upon the ground sometimes for 3 to 3.5 meters, and become split into numerous ribbons (fig. 408). The single pair of opposite 
leaves succeeds the cotyledons (fig. 455), and is the only pair of foliage leaves produced, growing continuously at the base, where they are protected by the groove. These leaves last through the lifetime of the plant, which is said to reach more than one hundred years.

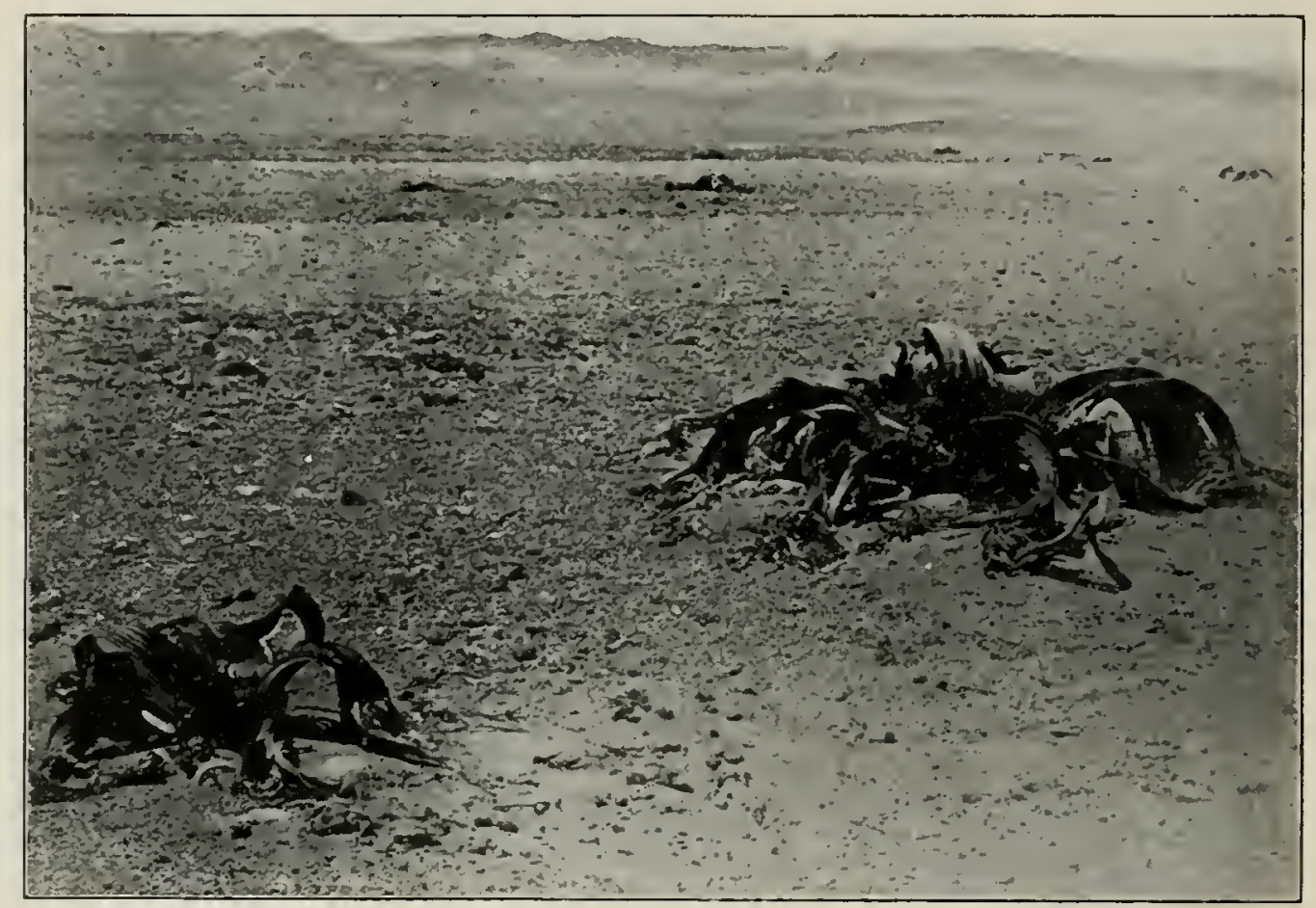

FIG. 408.-Welwitschia mirabilis: in the foreground are two plants with lacerated eaves; in the background are seven more plants.-From a photograph by H. ScHexck.

The species of Gnetum are either small trees or woody climbers, being among the lianas of tropical forests (fig. 409). The leares are leathery in texture, and are very suggestive of those of dicotyledons, the well-developed opposite leaves being lanceolate to ovate in outline and pinnately net-veined.

\section{VASCULAR ANATOMY}

So far as known, all traces of mesarch structure are lacking among the Gnetales, although it is altogether probable that it may be found in some peripheral members. However this may be, in this feature, as well as in others, the Gnetales seem farther removed from the ferns than any other group of gymnosperms, the only suggestion of connection being the foliar gaps.

In Ephedra there is a persistent primary cambium, but not much 


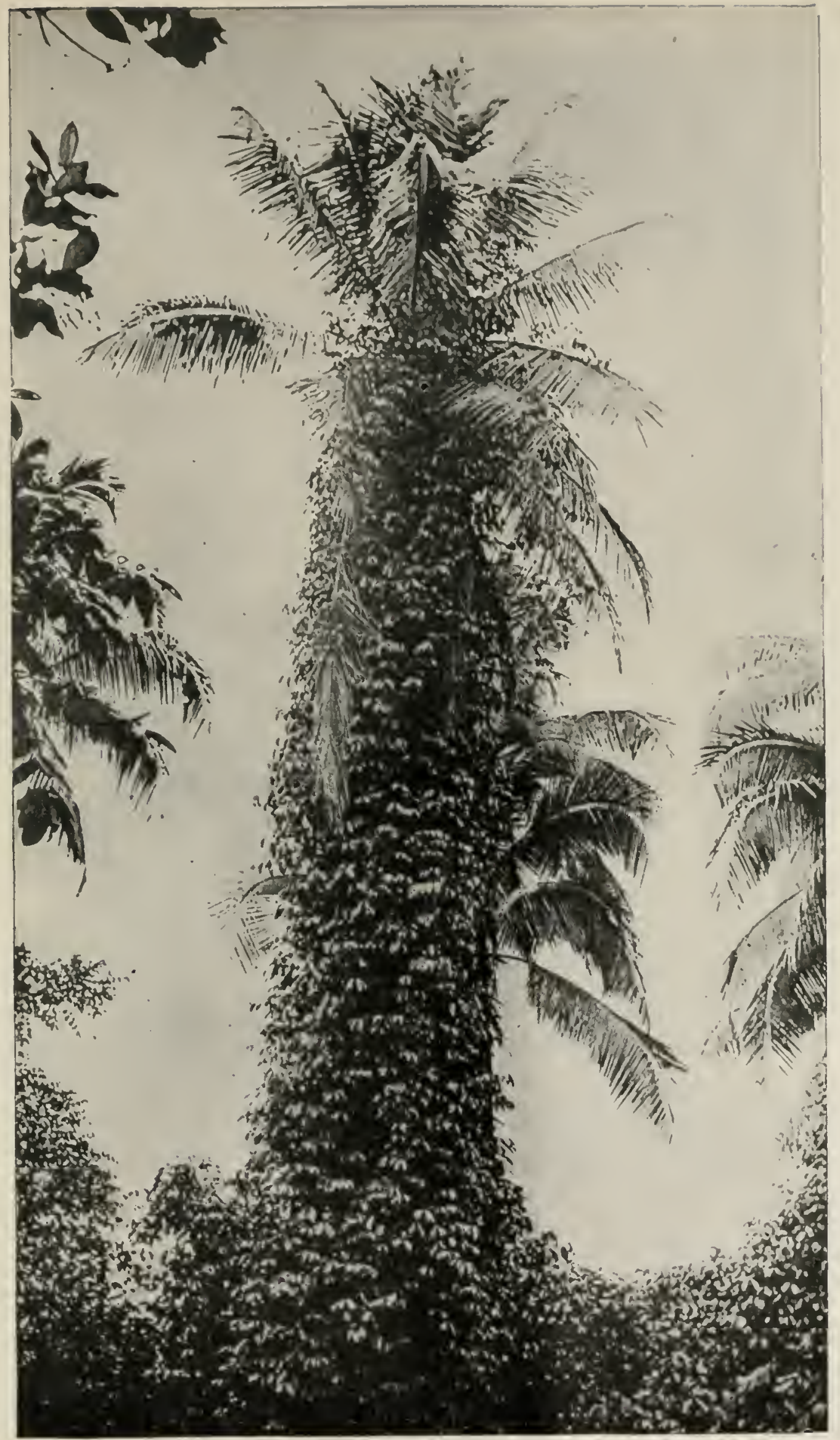

FIG. 409.-Gnctum ovalifolium: climbing on Cocos nucifera.-After G. KARSTEN (II). 
secondary wood-formation, so that the vascular cylinder does not become thick. The tracheary vessels are found in the inner region of the cylinder, and consist of broad vessels associated with ordinary gymnospermous tracheids. They are interrupted by oblique walls, and have bordered pits as well as simple pits, suggesting an intermediate condition between the characteristic gymnospermous tracheids and the true ressels. A peculiar anatomical feature of the genus is the diaphragm-like plate of cells which occurs at the base of each internode, rendering the stem easily separable at the nodes. The stomata occur upon the fluted stem in rows, and are sunken in urn-shaped depressions formed by mounds of cuticle.

In Welwitschia the vascular system of the stem is in a very confusing condition on account of the shortened axis. At the junction of the crown (the excessively shortened stem) and the huge tap root there is a broad plate of collateral bundles, made up of two plates in contact. The ressels of the upper plate connect with the leares and the strobili, and those of the lower plate with the system of ressels in the tap root. The primary cambium is short-lived, and irregular series of bundles suggest the existence of successive cortical cambiums, but the testimony is too vague to use in any general conclusion. It is reported that tracheids with bordered pits are entirely lacking, being replaced by simple pitted and spiral vessels, which suggests a further stage of advance in this feature than that exhibited by Ephedra. In connection with the vascular bundles there is a conspicuous development of fibrous sclerenchyma. A remarkable anatomical feature of the genus is the occurrence of the so-called "spicular cells," which are found in large numbers and are scattered throughout all the organs (figs. 4IO-4I2). They are very large cells, fusiform or branched, straight or variously curved, with greatly thickened walls, and often so closely packed and interlaced that they make the tissues extremely hard and tough. In the outer layers of the walls, and especially on the surface of the longer spicular cells, crystals of calcium oxalate are very conspicuous.

In Gnetum the primary cambium is also short-lived, and successive cortical cambiums produce concentric series of vascular bundles. This common feature of Gnetum and Welwitschia and its occurrence among the Cycadales is a fact of interest rather than of present sig- 
nificance. In Gnetum, as in Ephedra, the secondary wood contains true ressels associated with gymnospermous tracheids.

The vascular anatomy of the group needs a wider range of investigation than has been given to it, and this has been partially supplied by a recent investigation by Hill and De Fraine (28). The traces entering the base of each cotyledon are two in Ephedra, four (in two pairs) in Welwitschia, and four or five in Gnetum. The strands of the hypocotyl are inserted on the cotyledonary strands, and are four in Ephedra, eight or less in Welwitschia (quickly reduced to four), and a rariable number (about I2-I5) in Gnetum. The transition to root structure occurs in the lower region of the hypocotyl, and in all cases the primary root is diarch.

On the whole, the meager data available suggest a group
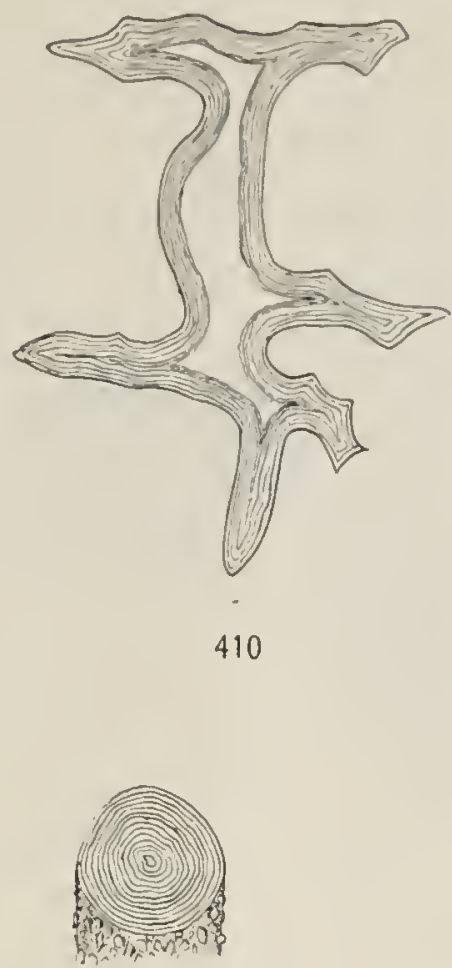

412

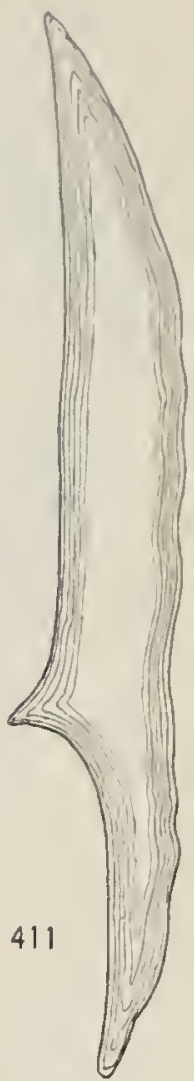

FIGS. 410-4I2.-II clwitschia mirabilis: spicular cells from the perianth of the staminate flower; fig. 410, a branching cell, the branching represented in one plane; fig. $4 \mathrm{II}$, a simple cell; fig. $4 \mathrm{I} 2$, the cut end of a long cell, with lumen almost closed and the surface covered by crystals of calcium oxalate; $\times 225$. farther removed from ferns than other groups of gymnosperms, and one that has developed more or less completely the true vessels characteristic of angiosperms.

THE LEAF

The opposite leares of Ephedra, reduced to a two-toothed and scaly sheath, certainly suggest ancestors with true foliage leaves, and occasionally such leares are developed now.

The single pair of long-lived parallel-reined leares of Jielwitsctio are remarkable. The stomata are in rows and deeply sunken, and 
the mesophyll sheaths a conspicuous, central, nearly colorless tissue which constitutes a water reservoir. This colorless middle tissue is

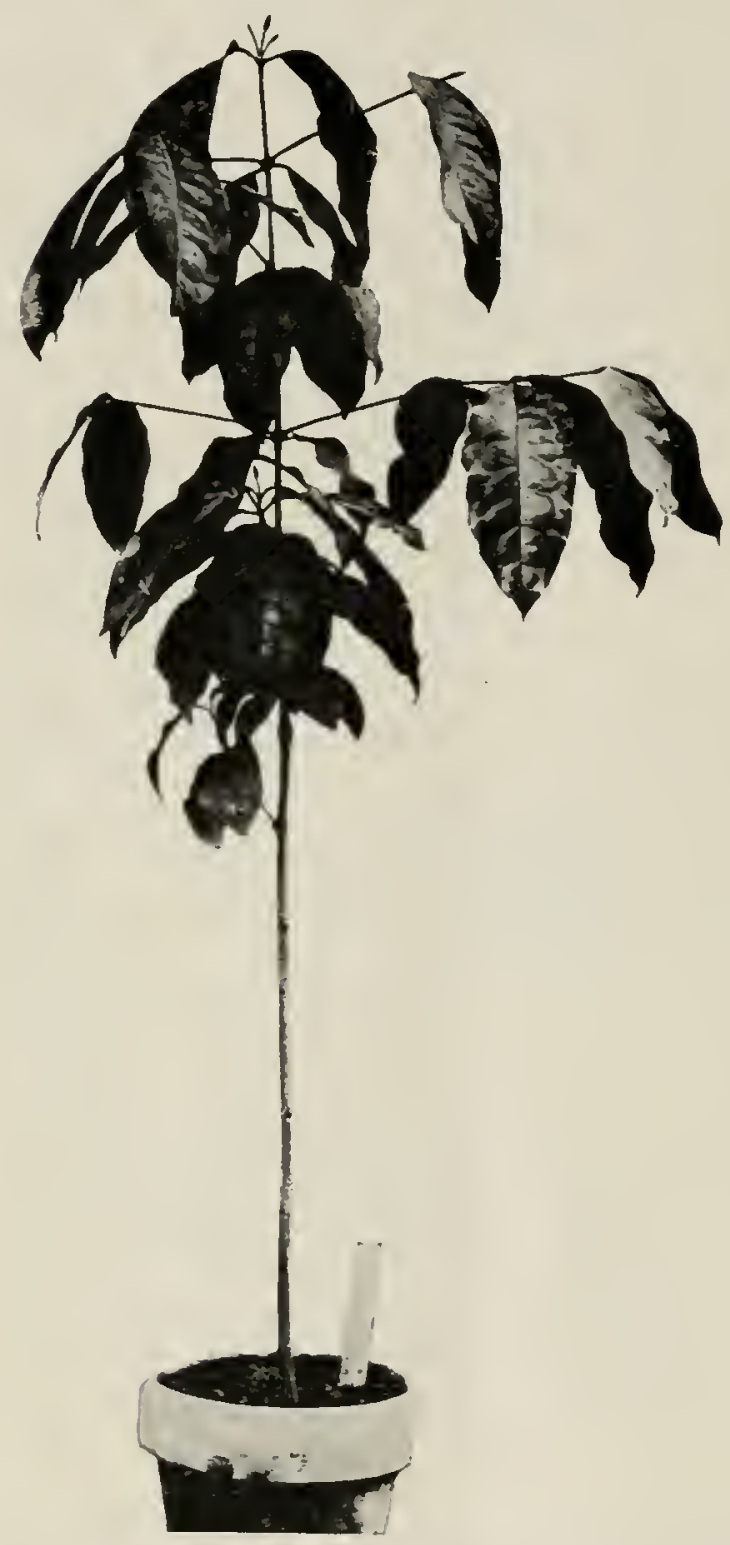

FIG. 4I3.-Gnetum Gnemon: from a photograph of a plant at the University of Chicago. traversed by the very numerous and strong parallel bundles, which are connected by transverse branches. These branches sometimes end freely in the mesophyll, or send out branchlets that end blindly. It follows that while the parallel course of the principal reins is monocotyledonous, the blind ending of some of the reinlets is dicotyledonous.

The leaves of Gnetum seem to differ in no essential feature from those of dicotyledons with leathery texture, being pinnately and reticulately reined, so that the plant, except when in fruit, might be mistaken for a dicotyledon (fig. 4I3).

This assemblage of leaves is more puzzling than suggestive, and if the genera are really of common ancestry, it implies a history and a range of forms that remain to be discorered.

\section{The spore-producing members}

The strobili of Gnetales are compound, each strobilus being a catkin-like cluster of simple axillary strobili, which resemble flowers, especially since their bracts are arranged like a perianth. While 
compound ovulate strobili occur among Cordaitales and Coniferales, compound staminate strobili are restricted to Gnetales. If the strobiliferous shoot of Torreya taxifolia, with its simple axillary strobili, were compacted into a strobilus, the condition among Gnetales would be attained. To avoid confusion we will call these simple axillary strobili of Gnetales flowers, to distinguish them from the compound strobilus which they make up. It must be remembered, however, that they are flowers only in the sense that the simple strobili of Taxus and Torreya are flowers. The whole group is prevailingly dioecious.

\section{THE MICROSPORANGIUM}

In Ephedra the flowers are monosporangiate and generally dioecious, arising from the axils of broad imbricate bracts, which in decussating pairs form a short, membranaceous strobilus (fig. 4I4). These strobili occur in pairs at the nodes, one arising from the axil of each of the opposite and minute scalelike leaves. Occasionally an orulate flower replaces a staminate one (i 8 ), so that the strobilus, but not the flower, becomes bisporangiate.

The staminate flower consists of two more or less connate scales ("perianth") investing a projecting axis that bears two or more sporangia. This stamen, which is evidently an axial structure, may remain simple, in which case it bears two sporangia; or it may branch somewhat above and bear several sporangia. The period of development is remarkably short, the staminate strobilus of $E$. Irifurca first becoming evident in December (in New Mexico), the mother cells in February, the reduction divisions in March, and pollination in April. A "resting period" of one month for the mother cell is a remarkably short one for a gymnosperm. The anthers mature in acropetal succession in the strobilus, and the only account of the development of the microsporangium of Gnetales is that of LAND for Ephedra trifurca (I8). In the organogeny of the flower the stamen appears first, and the "perianth" later, but before there is any differentiation of an archesporium. Apparently the archesporium is a single hypodermal cell (in transverse section), dividing periclinally as usual. The primary wall layer divides periclinally, but there are no further periclinal divisions, so that there is only a single layer 
between the epidermis and the tapetum. There are three or four successive divisions from the primary sporogenous cell to the mother cells, the tapetal cells enlarging about them and the wall cells becoming

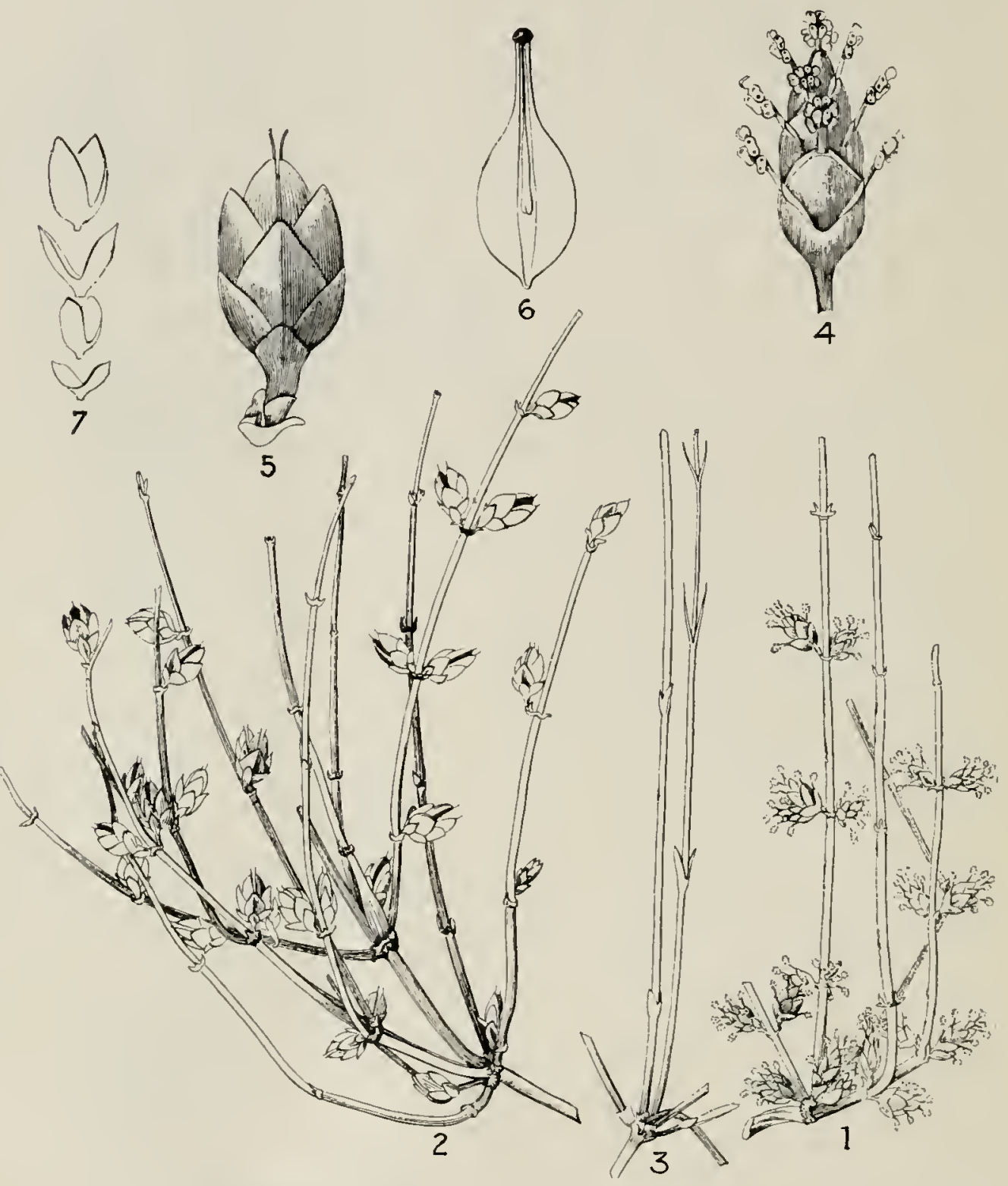

FIG. 414.-Ephedra antisyphilitica: I, staminate branches; 2, ovulate branches; 3 . sterile branches; 4 , staminate strobilus; 5 , ovulate strobilus; 6 , longitudinal section of seed; 7 , bracts of the ovulate strobilus.-After WATSON (2a).

flattened. There is not always the same stage of division in a sporangium, in some cases every stage from synapsis to completed tetrads being seen in passing from the upper part of a sporangium to the lower. In this division the 12 chromosomes are very evident. 
In Welwilschia the flowers are functionally monosporangiate and dioecious, but the staminate flowers are structurally bisporangiate (figs. 4I5, 4I6). They are borne in the axils of broad and closely overlapping bracts, whose decussating pairs form a conifer-like strobilus (figs. $4 \mathrm{I} 7,4 \mathrm{I} 8$ ). These strobili are produced upon branching axes which arise from the crown above the foliage leares, or rarely beneath then. PEARSON (20), from a field study of $\mathrm{W}$ elwitschia, states that it is probably partially if not wholly pollinated by insects, a statement which finds additional confirmation in the fact that just below the anthers there are glandular protuberances which, in sections, may be interpreted as nectaries (fig. $+15, t)$.

The staminate flower consists of two decussate pairs of free bracts, within which there is a whorl of six (rarely five or four) monadelphous stamens, each of which bears a terminal peltate group of three sporangia arranged in an approximately circular synangium. In the conter there is a single sterile ovule whose projecting micropylar tube is spirally coiled and cnds in a broad flaring expansion (figs. 4I5, +I6). It is very evident that the immediate ancestors of Welwitschia had bisporangiate flowers, a feature completely eliminated from most of the gymnosperms, if they ever possessed it. The only other gymnosperms that possess it are the Bennettitales, and they are

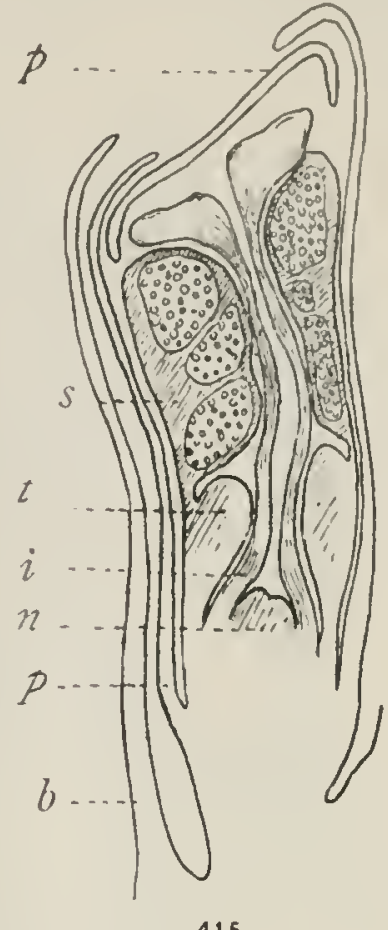

415

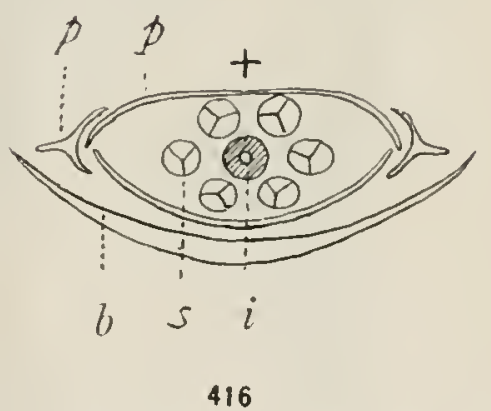

FIgs. 415, 4I6.-Welwitschia mirabilis: fig. 4I5, longitudinal section of the flower; $p$, bracts of perianth; $s$, trilocular anther; $l$, protuberance on the inner face of the stamen tube; $i$, inner integument, ending above in the expanded "stigma"; $n$, nucellus of sterile ovule; $b$, bract from the axil of which the flower arises; $X_{30}$; fig. $4 I 6$, diagram of transverse section of the flower at the level of $s$ in the preceding figure; + , axis of cone. 
too far removed from Welwitschia in other characters to suggest any immediate connection. It would be easier to imagine a bisporangiate offshoot from the Coniferales.

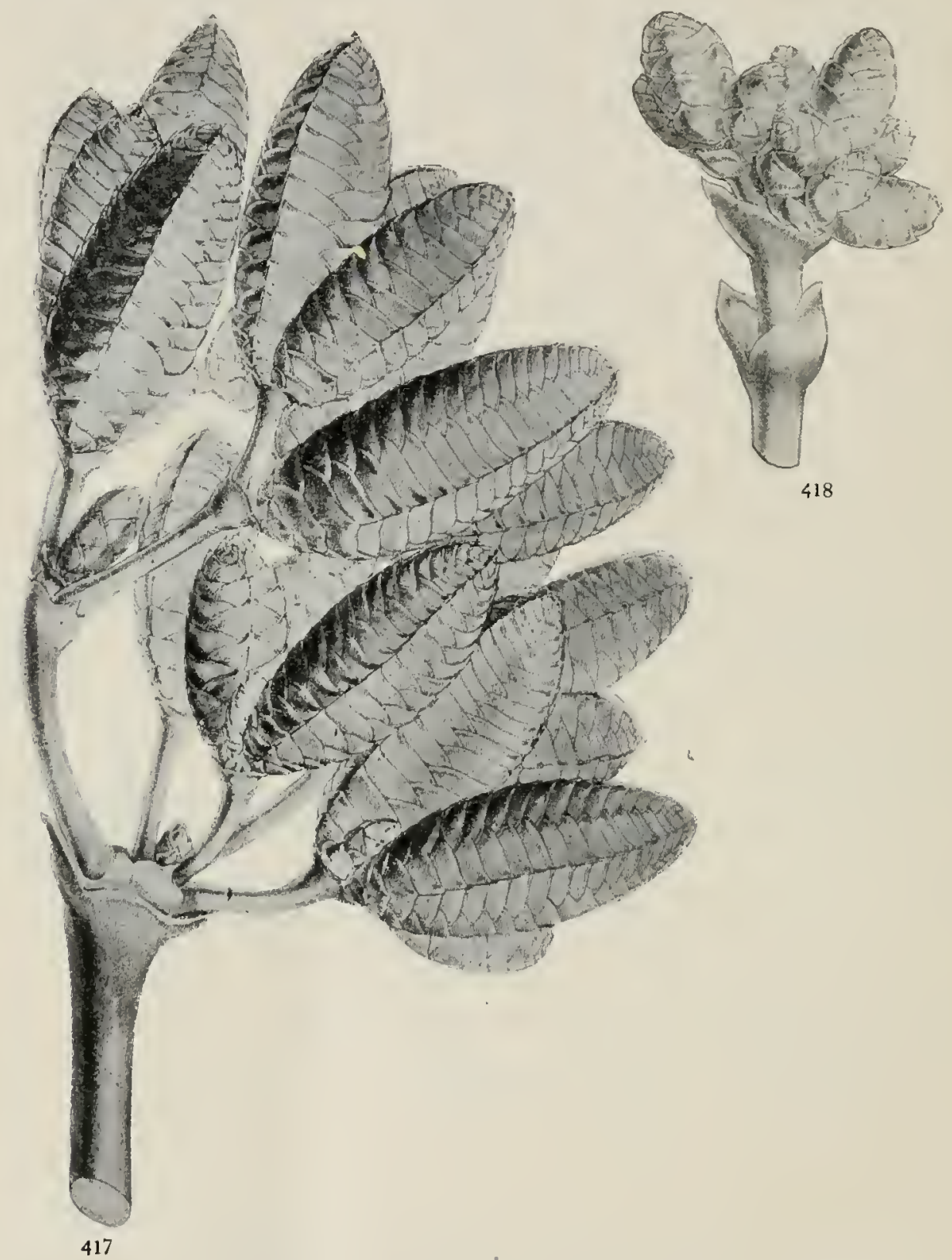

FIGS. 4I7, 4I8.-II'clwitschia mirabilis: orulate and staminate strobili; fig. 4I $\bar{\ddots}$, branch with numerous ovulate strobili; one-half natural size; fig. 4I8, branch with staminate strobili; natural size.-After HоOKER (I).

In Gnetum the flowers are monosporangiate and mostly dioecious, and are numerous in the axils of connate bracts, which form a series of contiguous but not overlapping cups (closer together in the stami- 

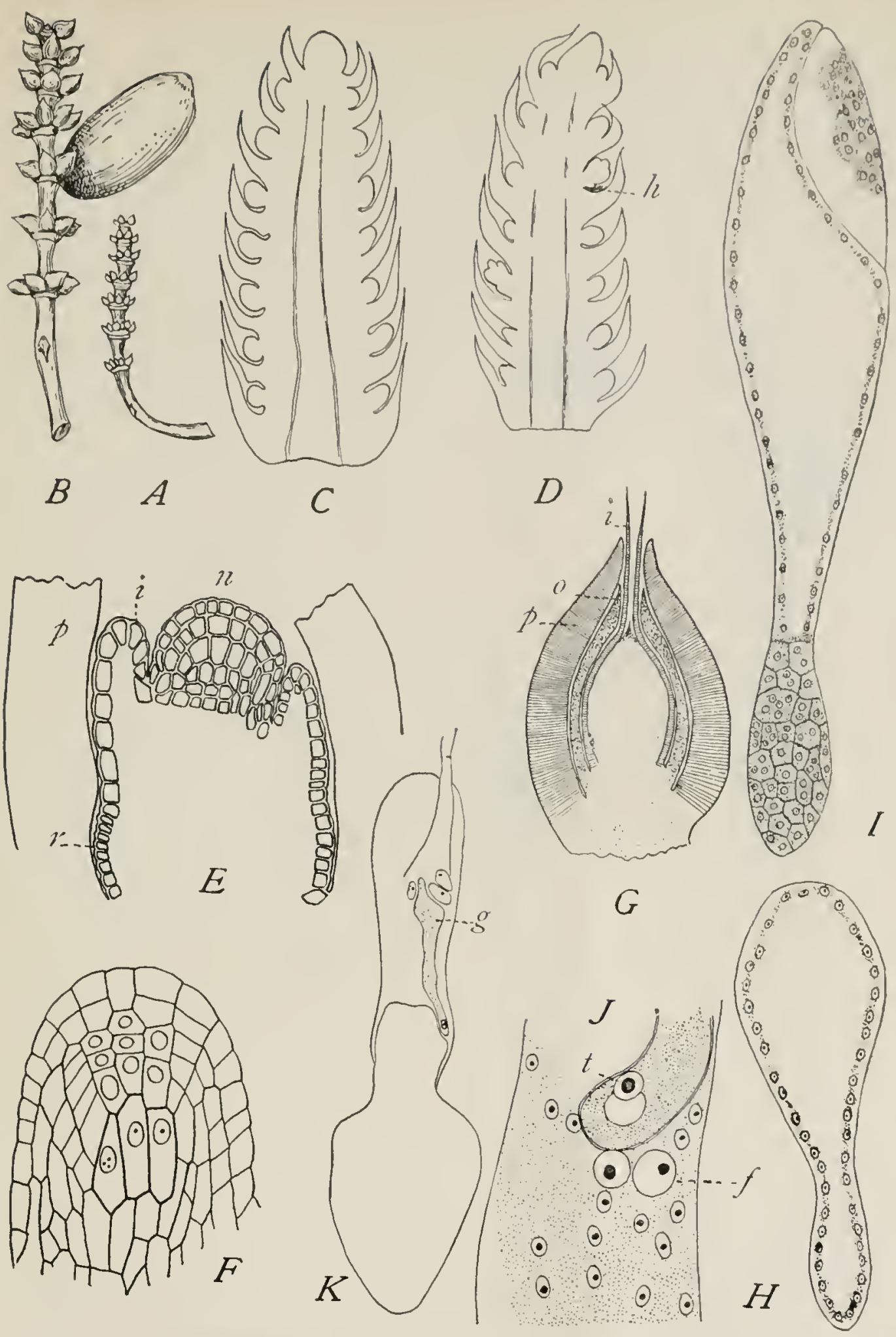

FIG 4I9.-Gnctum Gncmon: various phases of the life history; it, ovulate strobilus; $B$, strobilus upon which only one seed has matured; $C$, longitudinal section of a young ovulate strobilus, $X_{24} ; D$, later stage, showing orules and paraphysial hairs $(h), X_{45}$; $E$, longitudinal section of an immature ovulate flower, showing "perianth" $(p)$, inner integument $(i)$, rudimentary outer integument $(r)$, and nucellus $(n) ; F$, nucellus showing three mother cells; $G$, longitudinal section of a mature ovulate flower, showing the "perianth" $(p)$, outer integument $(o)$, and inner integument $(i), \times_{33} ; I I$, embryo sac with free nuclei in a parietal layer, and showing the beginning of the constriction which results in the antipodal and micropylar chambers; $I$, cell-formation in the "antipodal chamber," another sac which is being pushed aside is shown at the right above, $X_{50}$; $J$, upper portion of sac soon after fertilization, showing a pollen tube with its nucleus $(t)$, oospores $(f)$, and unfertilized eggs, $\times 340 ; K$, embryo sac, showing the suspensor-like development of the oospore $(\mathrm{g})$ advancing toward the "antipodal endosperm," $\times 50$.-All from LOTSY ( $5_{5}$ ) cxcepting $F$, which is after STRASBL"RGER (ro). 
nate than in the ovulate strobilus) and a slender cylindrical strobilus (figs. 4I9-422). The strobili are axillary or terminal, solitary or fascicled or even paniculate. The staminate flower resembles that of Ephedra, consisting of two coherent bracts investing a short axis

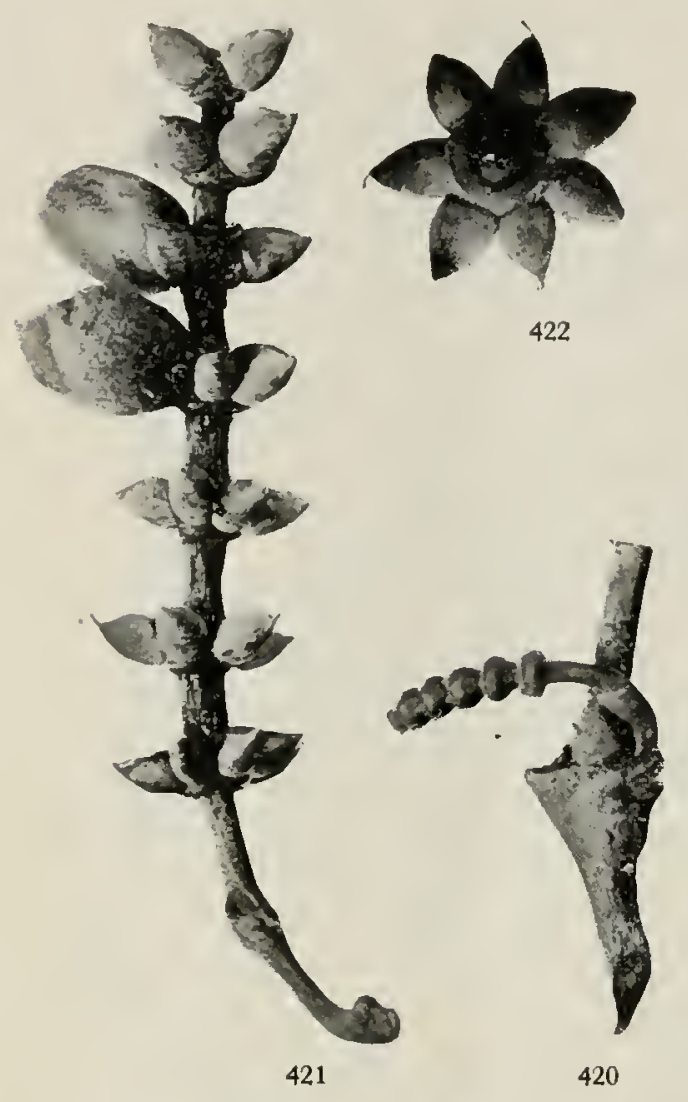

FIGS. 420-422.-Gnetum Guemon: ovulate strobili; fig. 420 , young strobilus with six cuplike whorls, the ovules projecting beyond the dense tufts of hairs; fig. 42I, a later stage, with three orules much larger than the rest; two orules in the second whorl show very well the projecting tip of the inner integument; fig. 422 , transverse view of the stage shown in the previous figure. that bears at its tip two sporangia. In the staminate strobilus of Gnetum also, as in Ephedra, ovulate flowers are frequently present.

It is tempting to see in these flowers (simple strobili) the essential features of the angiospermous flower, and to relate the strobilus to the catkin-like inflorescences of angiosperms. While the parts may hold the same general relations, these situations may have arisen in many regions of the gymnosperms, and none of them may have involved the history of the angiosperms.

\section{THE MEGASPORANGIUM}

In all the genera of Gnetales the ovulate flower consists of a single ovule invested more or less closely by a pair of bracts that are more or less connate in Epherdra, and completely so in Welwitschia and Gnetum. In fact, so complete is the coalescence and so close is the investment in Gnetum that this envelope has been regarded as an integument. In every case there are two integuments, appearing in basipetal succession, the inner one forming the micropylar tube. The elongated and projecting micropylar tube is a feature of the Gnetales, being neither spirally coiled nor expanded at the tip in Welwitschia, as in 
FIG. 423.-Ephedra trifurca: longitudinal section of ovule, showing nucellus with deep pollen chamber $(p)$, jnner (i) and outer $(o)$ integuments, and female gametophyte with reproductive, storage $(s)$, and haustorial (h) regions; $\times 4$ S. - After LAND (IS).

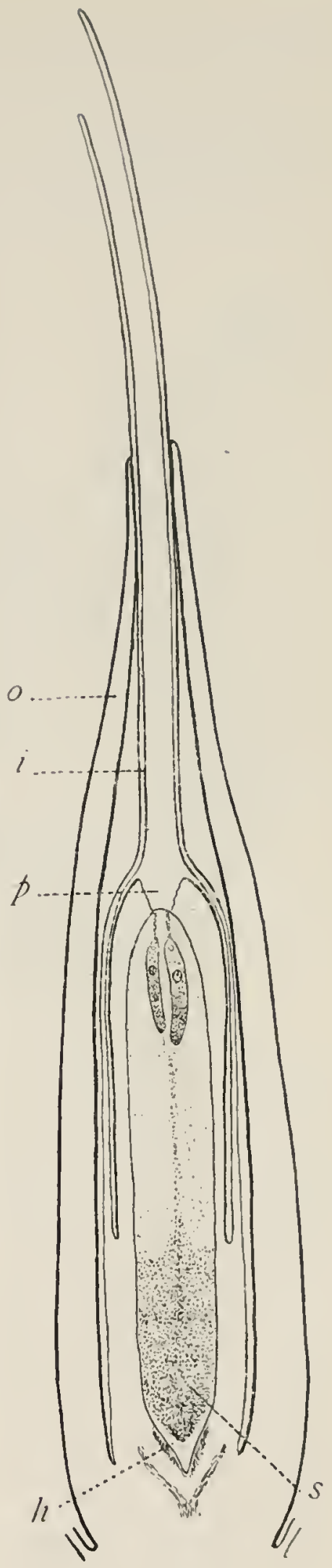


the sterile orule of the staminate flower, and with a lacerate tip whose lobes spread during pollination in Gnetum. The three genera differ so much in the details of the structure and development of the megasporangium that they must be considered separately.

In Ephedra trifurca (LAND I8, 23) the inner integument is free from the nucellus for more than half its length, and the two integuments are free from one another except at the base, and are multiple in origin (fig. 423). The inner integument, never more than two cells thick, appears first in two distinct parts, but the later development is zonal, so that when this integument elongates rapidly just before pollination and protrudes through the apex of the flower, the exposed tip is wide open and is slit a short distance down one side. It also contains two rudimentary rascular bundles, and there is every evidence that it consists of two fused members. The outer integument, which becomes several cells thick and later hard, appears first in four distinct parts, and contains as many rudimentary vascular bundles. Such a multiple origin of integuments was described in connection with the paleozoic Physostoma (p. 35), one of the Cycadofilicales.

Although the single hypodermal archesporial cell was not observed, its existence was evident from the subsequent stages, a parietal cell being cut off, which together with the overlying epidermal cells produces a large amount of sterile tissue above the mother cell. About the time that archegonium initials appear, the tip of the nucellus begins to be disorganized, and this disorganization gradually proceeds downward, until when the rentral nucleus is cut off there is a broad circular opening, narrowing below, from the tip of the nucellus to the endosperm (fig. $423, p$ ). This is the deepest pollen chamber known among gymnosperms, for it permits the pollen grains to rest upon the necks of the archegonia. The pollen chamber is finally closed by a plug formed by the endosperm cells, preventing the escape of the embryo into the chamber. The development of the megasporangium of Ephedra campylopoda, as described by Strasburger (3), is essentially the same, except that the archesporium is said to consist of a group of hypodermal cells.

In fruit the bracts of the strobilus become much modified in Ephedra, becoming red and succulent, or much enlarged and chaffy, and 
the "perianth" persists and becomes lignified. In E. trifurea only six months elapse between the first appearance of the orulate strobilus and the germination of the seed.

The development of the megasporangium of If chitschia is unknown, except that a group of mother cells is present beneath long rows of parietal cells, the inference being that a hypolermal archesporium of several cells is differentiated. No pollen chamber is developed in the nucellar cap, but it becomes riddled by the descending pollen tubes and the ascending prothallial tubes (fig. 424). In fruit the enlarged bracts of the strobilus become bright scarlet, and the seed is winged by the cxpanded perianth.

The three enrelopes investing the nucellus of Gnetum have given rise to much discussion, especially as they are said to arise in acropetal succession (4, 15). BECCARI (4) regarded the outermost one as a perianth; Strasburger (ro) and Čelakovský considered them all as integuments, the delicate middle one being only an outer layer of the inner integument; while Lotsy (I5) recognized only the innermost one as an integument. Usually

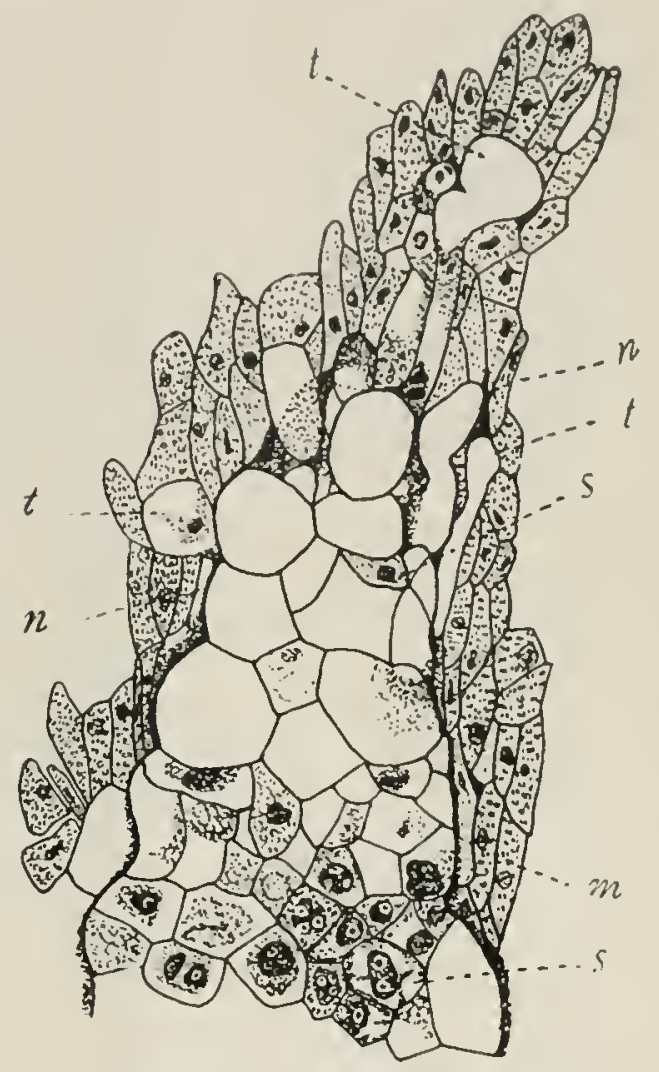

FIG. 424.-II clatilschia mirabilis: upper part of nucellus, with ascending prothallial tubes; $t$, prothallial tubes; $s$, sterile cells of fertile region of prothallium; $n$, nucellus; $m$, megaspore membrane; XI40.-After PEARSON (20). only orulate flowers are found in orulate strobili (fig. 425 ), but occasionally staminate flowers appcar. There are two kinds of orulate flowers (ro): those of the ovulate strobili, as described above; and those found with considerable regularity in the staminate strobili. The latter differ in having only two envelopes, the middle one of the complete flower being absent (fig. 426). These incomplete flowers usually do not function, but sometimes they develop 
far enough to contain embryo sacs (fig. 427). In the rare cases when they function, the three envelopes are said to develop (15), but, as shown in the preceding figure, only two envelopes may appear in ovules which have enlarged considerably. KARSTEN (9,
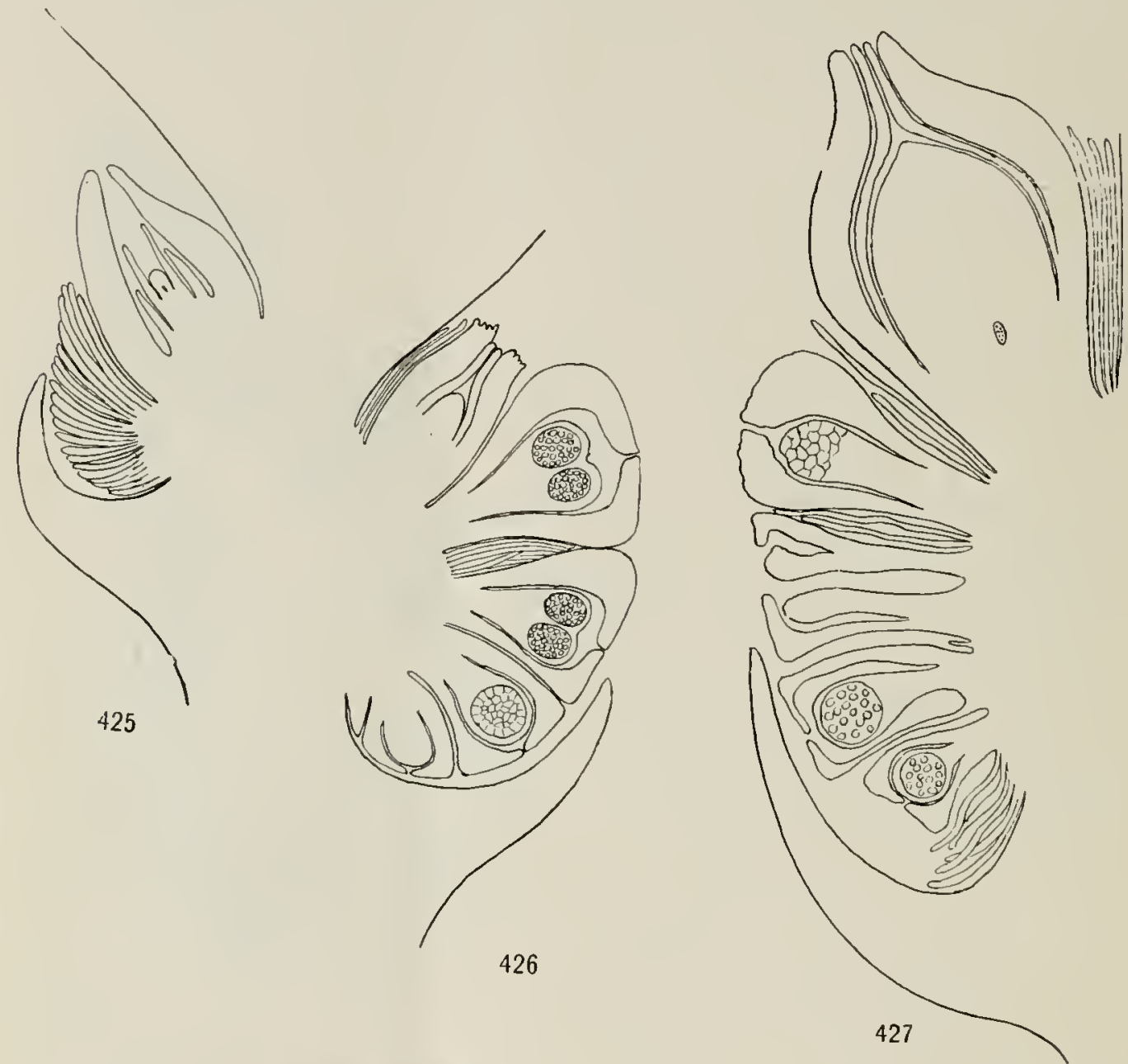

FIGS. 425-427.-Gnelum Gnemon: longitudinal sections, showing bract with cluster of flowers in the axil; fig. 425 , orule in orulate strobilus with two integuments and perianth; beneath the ovule is a dense tuft of hairs, so compact that they sometimes appear like a tissue; fig. 426, sterile ovule in staminate strobilus, showing only two envelops (inner integument and perianth); the oldest stamens are at the top, and in longitudinal radial section usually show only one sporangium (as in the third stamen from the top); fig. 427 , section from staminate strobilus, in which the ovule has developed to the free nuclear stage of the endosperm; all $\times 23$.

II, I2) has found that the middle envelope always appears in a rudimentary condition during the development of the incomplete ovulate flowers, but gradually disappears.

This confusion of interpretation has been cleared up (25) by a 
study of the orule and seed in comparison with those of other gymnosperms. The outermost envelope is undoubtedly the so-called perianth of Gnetales, very closely investing the orule, with its own rascular supply, and appearing before the integuments. This last fact gare rise to the impression that the three envelopes appear in acropetal succession. The seed becomes slightly stalked in this perianth, and the two integuments appear in basipetal succession. The inner one extends above to form the long micropylar tube, and at the maturity of the seed it completely invests the nucellus (at this time replaced by the endosperm) as a papery layer. The outer integument becomes differentiated into an outer fleshy layer and an inner stony layer, the latter completely investing the seed, the former being chiefly developed in the region of the nucellar beak. Two sets of vascular strands are present, the outer set traversing the fleshy layer of the outer integument, the inner set traversing the inner integument.

In Cycadophytes, Ginkgoales, and Coniferales a single integument becomes differentiated into a testa of three layers: outer fleshy, stony, and inner fleshy. In Gnetum the same three layers are present, but the inner fleshy one becomes differentiated in ontogeny as a separate integument. In all cases this innermost layer finally forms a papery lining of the stony layer. Among the Pinaceae the outer fleshy layer is represented in the integument, but it does not develop into the pulpy investment that characterizes the Cycadales, Ginkgoales, and Taxaceae. The rariation in the distribution of the vascular strands among these layers should be summarized. Among the more primitive Cycadofilicales and Cordaitales, in which the nucellus is relatively free from the integument, the outer set of strands traverses the outer fleshy layer (or integument) and the inner set traverses the peripheral tissue of the nucellus. In other Cycadofilicales and Cordaitales, however, and in Cycadales, in which the nucellus and integument are free only in the region of the nucellar beak, the inner set of vascular strands traverses the inner fleshy layer; and this is the condition of Gnetum, except that this layer has become differentiated as an inner integument. In Ginkgoales the outer set of strands (belonging to the outer fleshy layer) is suppressed; in Taxaceae the inner set (belonging to the inner fleshy layer) is suppressed; and in Pinaceae both are suppressed. 
The development of the sporogenous tissue in the orule of Gnetum has been described by Strasburger (3) for Gnetum Gnemon. The archesporium consists of a group of hypodermal cells which cut off wall cells by periclinal divisions, and the wall cells, together with the overlying epidermis, give rise to the usual thick mass of sterile tissue above the sporogenous region (fig. $4 \mathrm{I} 9, F$ ). Before pollination the

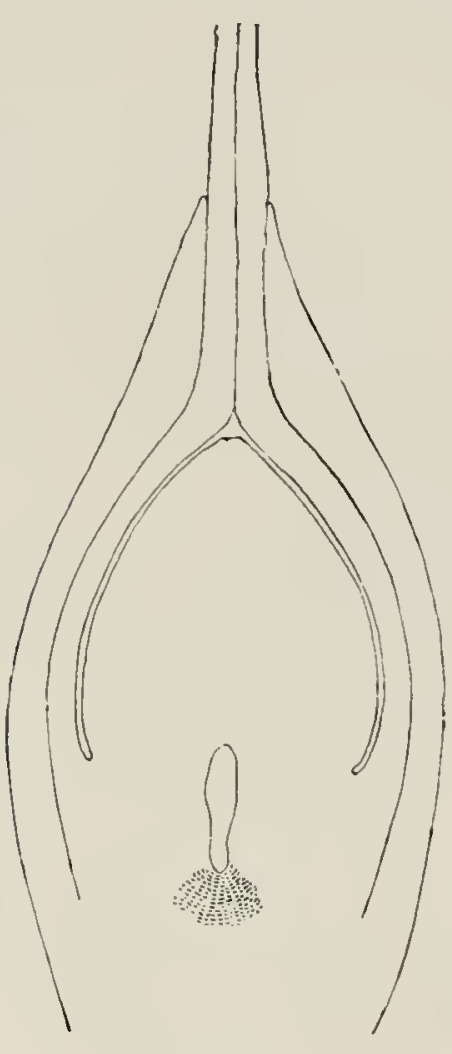

428

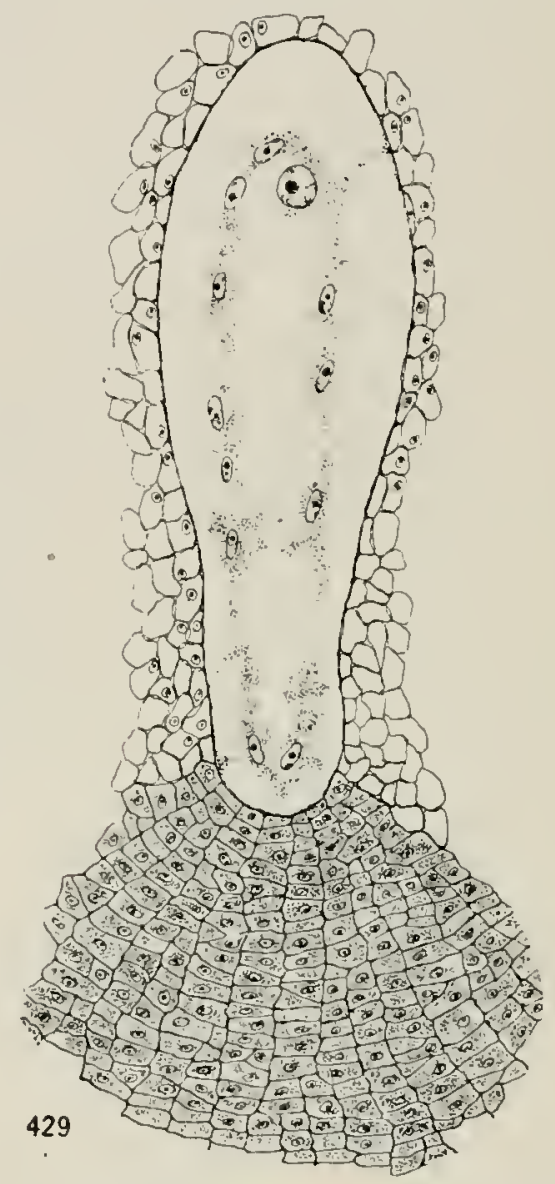

429

FIGS. 428, 429.-Gnetum Gnemon: fig. 428, diagram of longitudinal section of ovule, showing position of embryo sac and the "pavement tissue" beneath; $\times_{54}$; fig. 429 , the embryo sac and pavement issue more highly magnified; $\times 300 .-$ After Covlter (25).

cells at the tip of the nucellus become disorganized, resulting in an indefinite and shallow pollen chamber. The several primary sporogenous cells are said to divide in the formation of mother cells, but this would be a very unusual occurrence for a gymnosperm.

A remarkable differentiation of nutritive tissue occurs in the chalazal region of the ovule of Gnetum Gnemon (25) during the early stages of the embryo sac. At the eight-nucleate stage of the sac it is 
invested by the loose and undifferentiated tissuc of the nucellus. A little later, the cells at the chalazal end of the sac become strikingly differentiated, becoming more and more compactly arranged, gradually obliterating the intercellular spaces, and taking on the appearance of glandular cells (figs. 428,429). This compact "parement tissuce" gradually extends deeper into the chalaza, and spreads laterally below, becoming fan-shaped in longitudinal section, but with so definite a contour that it was mistaken by LoTsy (I5) for a compact antipodal tissue within the embryo sac (fig. 4I9, I). After the fertilization stage has been reached within the sac, this parement tissue begins to lose its glandular appearance, and later it is destroyed entirely by the growing endosperm.

A year later, the endosperm has destroyed all of the nucellar tissue except a very small amount at the tip. In destroying the nucellar beak, the central region of the endosperm ad-

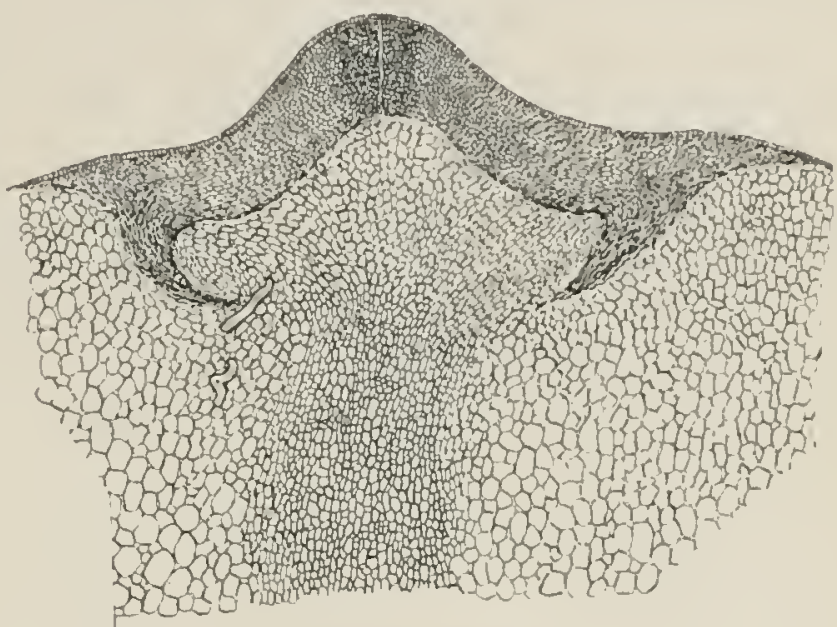

FIG. 430.-Gnetum Gnemon: tip of seed; small amount of tissue of nucellar beak not destroyed by endosperm; differentiation of central and peripheral regions of endosperm, the former having advanced into the center of the nucellar beak and spread laterally, resulting in crushing the nucellar tissue against the encroaching peripheral region of endosperm; sections of two suspensors shown; $\times 40$.After Coulter (25).

vances into the beak and then spreads laterally (fig. 430). In the meantime the peripheral region advances more slowly toward the beak, and as a consequence a ring of nucellar tissue is pinched between two growing masses of endosperm.

The division of the megaspore mother cell has been observed only in Ephedra (3, I4, I8), in which a linear tetrad is produced. Apparently the outer daughter cell of the mother cell frequently does not divide, for the earlier accounts describe a row of "three megaspores." A close series shows (г8) that in the same species this outer cell may divide completely, may divide incompletely, or may not divide at 
all. In no case does it divide until the inner daughter cell has completed its division (fig. 43I). This situation is so general that a row of three cells occupying the position of a tetrad hardly deserves attention. The chromosomes have been counted in Ephedra (18, 23) and in Gnetum (25), and in both the numbers are 12 and 24, conform-
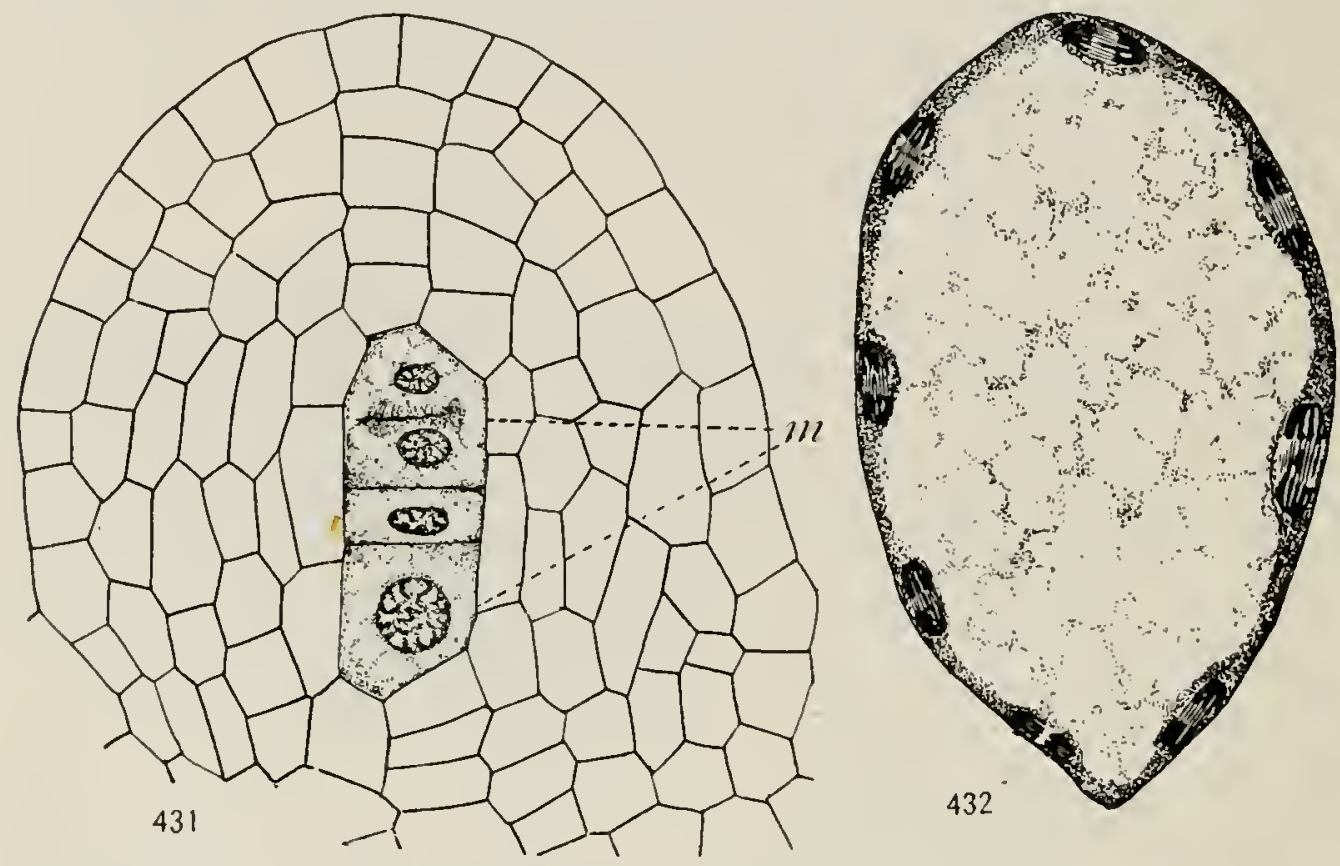

FIGS. 43I, 432.-Ephedra trifurca: fig. 43I, row of four megaspores, the lowest beginning to enlarge; fig. 432 , simultancous free nuclear division to form the $64^{-}$ nucleate stage of the female gametophyte; $\times 500$.-After Land $(18)$.

ing to the remarkably uniform condition of gymnosperms in this regard; although JACCARD (I4) reports 8 and I6 for Ephedra helvetica. If several tetrads are produced in a single ovule, several megaspores may begin to function, and in the case of Gnetum several contiguous embryo sacs with free nuclei may be formed.

\section{The gametophytes}

\section{THE FEMALE GAMETOPHYTE}

The development of the female gametophyte is so strikingly different in the three genera that they must be described separately.

The course of development in Ephedra was first outlined by STRASBURGER (3), and it conforms to that described for conifers, with free nuclear division, vacuolation accompanied by parietal placing, for- 
mation of parietal tissuc, and centripetal growth until the sac is full of tissue. The details have been given by Lavi for Ephedra trifurca (IS). At the division of the megaspore nucleus, the two daughter nuclei assume polar positions in the sac on account of the derelopment of a vacuole between them, which in fact surrounds the equatorial region of the spindle like a ring. These two nuclei divide simultaneously, and the four resulting nuclei assume equidistant positions at the periphery of the sac. Successive simultancous divisions follow rapidly (fig. +32 ), until approximately 256 free nuclei are formed, free nuclear division extending through a period of about twenty days.

With the appearance of the walls the endosperm is differentiated into distinct micropylar and antipodal regions, the former consisting of very loosely arranged cells with extremely delicate walls, and the latter of more compact cells. As the very rapid growth proceeds, the antipodal tissue becomes differentiated into storage and haustorial regions (fig. 423). The storage region comprises the greater bulk of the endosperm and is full of starch and other foods. In the center of it a column of thin-walled cells, richer in food than the others, extends from the haustorial region to the base of the archegonia, marking the path along which the embryo is to be thrust by the clongating suspensor. The haustorial region consists of the one or two outermost layers of endosperm cells at the antipodal end. The loosely arranged cells of the micropylar region, with their delicate and sometimes belated walls, are of interest in connection with the same region in Welwitschia, described below.

About April (in New Mexico) the archegonium initials begin to be differentiated, two being the usual number, although one or three sometimes occur. After the primary neck cell is cut off, it divides at once periclinally, and other periclinal divisions follow before anticlinal walls are formed which divide the cell of each tier into four cells. Eight such tiers of neck cells have been observed, and later divisions may result in six or eight cells in a tier. The appearance of regular tiers may be lost by the irregular planes of the later divisions, and the neck may resemble ordinary tissue (figs. $+33-435$ ). The minimum number of neck cells is probably thirty-two, but there may be many more. In any event, the archegonium neck of Ephedra is the 
longest one known among gymnosperms, and it is associated with the deepest pollen chamber. It follows that although the pollen grains
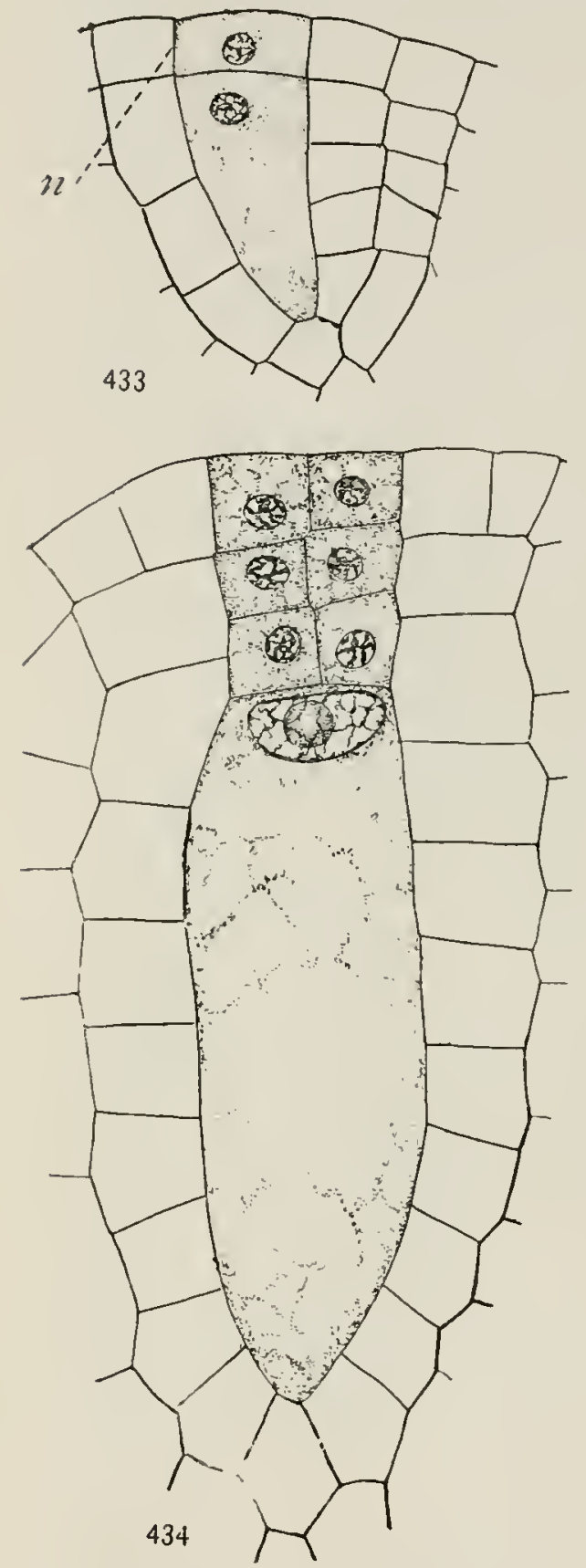

435

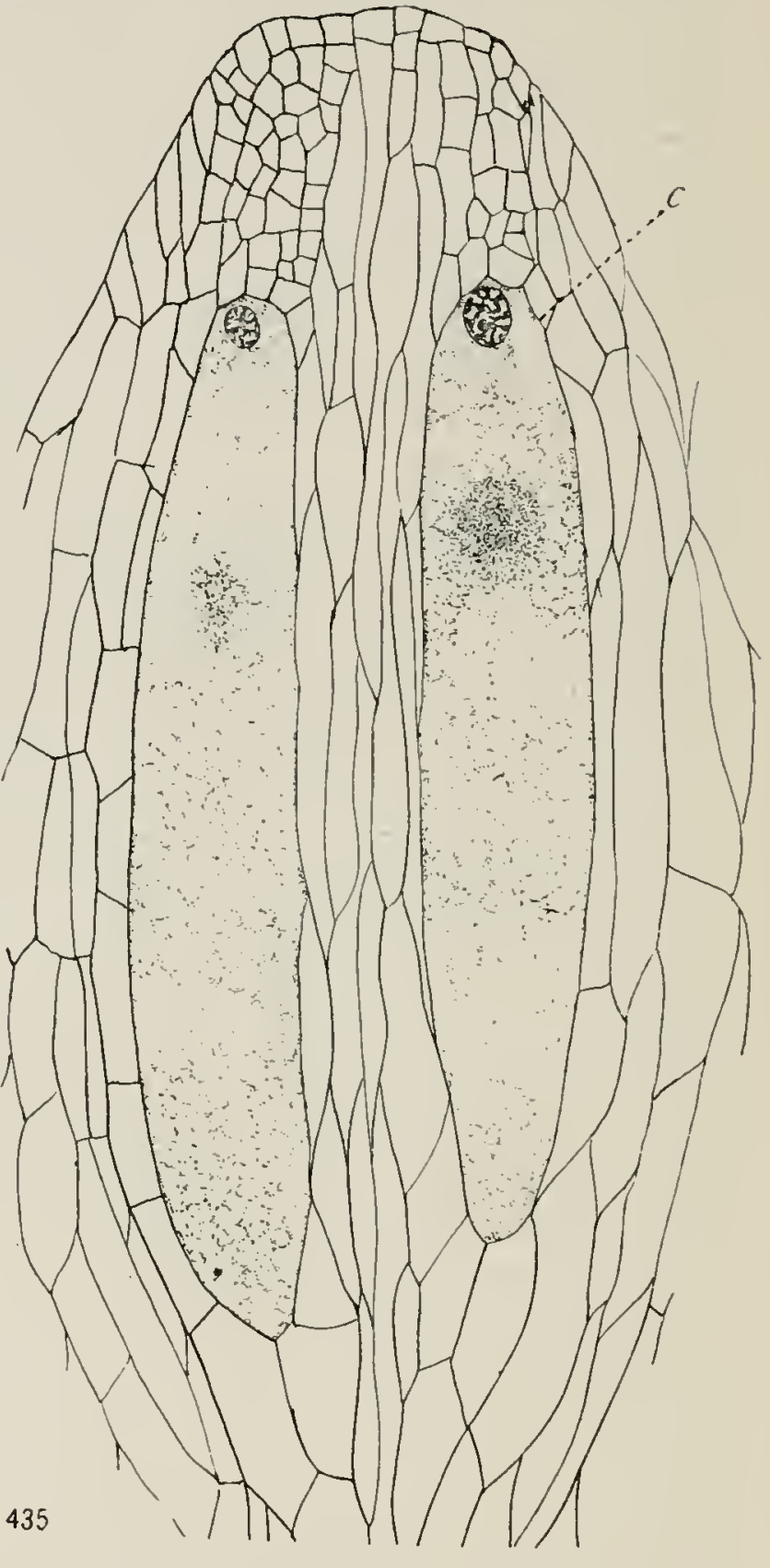

Figs. 433-435.-Ephedra trifurca: development of the archegonium; fig. 433, the neck $(n)$ and central cell; $\times_{500}$ fig. 434 , three tiers of cells in the neck, the central cell not yet divided; $\times_{500}$; fig. 435 , later stage, in which the neck can scarcely be distinguished from the surrounding cells; the central cell $(c)$ still undivided; $X$ I $2 .-$ After LAND (I8).

rest upon the neck of the archegonium, there remains much tissue for the tubes to penetrate. 
A zone of jacket cells (tapetum) is organized about the centrat cell, the cells being at first isodiametric, but with the elongation of the central cell they become much elongated and their walls become so thin as to be seen with difficulty. At the time of fertilization the walls separating the jacket cells from the egg break down altogether, and the contents of these cells are mingled with those of the egrg. Miss BERRIDGE and Miss SANDAY (22) have reported a remarkable beharior of the jacket cells of Ephedra distachy'a, claiming that the nuclei of the broken-down jacket cells escape into the egg, fuse in pairs, and produce proembryos. Such behavior was never observed in thousands of orules of E. trifurca (23), but occasionally jacket cells were found resembling the isolated proembryonic cells in appearance but nerer in function.

The ventral nucleus of Ephedra trifurca (I 8 ) is cut off during the first two wecks of April (in New Mexico), and there is no trace of a wall separating it from the egg. It remains in the upper part of the archegonium and becomes conspicuously enlarged.

The earlier account of the female gametophyte of Welwitschio was very perplexing, and although it is now found to have been inaccurate and even misleading, it suggested an unusual situation, which has been cleared up to some extent by PeArson $(27)$. The endosperm begins as usual with free nuclear division, and an embryo sac with approximately $\mathrm{I}, 024$ free nuclei was observed, representing ten successive divisions rather than the usual eight. Attention has been called to the fact, however, that in Pinus there may be as many as eleven such divisions, and that the number may well rary widely among gymnosperms (sce p. 259). These nuclei are distributed through the sac, so that when clearage of the cytoplasm by walls occurs the embryo sac is divided into multinucleate cells. Those in the micropylar region contain fewer nuclei than do the others, and these nuclei become the nuclei of free eggs. The cells of the lower three-fourths of the endosperm contain many nuclei, which are said to fuse and thus produce a uninucleate tissuc, and this primary endosperm tissue continues to grow both before and after fertilization. 'The multinucleate cells of the micropylar region, which were formerly mistaken for archegonium initials, send out tubes into the overlying nucellar tissue, into which the free nuclei pass, and these prothallial tubes 
meet the pollen tubes in the lower half of the nucellar cap. It is erident that archegonia are eliminated, and that this is associated with the fact that the sexual nuclei are differentiated before a uninucleate tissue is formed. An earlier differentiation is possible only in the free nuclear stage of the endosperm, before there is any wallformation; and this condition has been reached by Gnetum. The details of the formation of the permanent endosperm tissue of $\mathrm{Wcl}$ witschia need critical study, but the general outline of the situation is clear.

The embryo sac of Gnetum has long been noteworthy for its suggestion of that of angiosperms. Several species have been investigated by Karsten (9, I I, I2), and Gnetum Gnemon has been described by Lotsy ( I $_{5}$ ). The embryo sac of the last species has been regarded as illustrating a female gametophyte intermediate in structure between the tissue-filled sacs of Ephedra and Welwitschia on the one hand, and the sacs of the other species of Gnetumi, which contain only free nuclei at the time of fertilization. The antipodal end of the embryo sac was described as being filled with a compact endosperm tissue before fertilization, while the micropylar end contained free nuclei. Later investigation (25) has shown that the tissue referred to is a nutritive tissue developed in the chalaza in contact with the antipodal end of the sac, and that all the species of Gnetum, so far as known, have embryo sacs containing only free nuclei at the time of fertilization, as described by KARSTEN.

The endosperm of Gnetum begins with free nuclear division, and eight nuclei have been observed (25) grouped near the center of the sac before vacuolation. Later the vacuolation of the sac results in the imbedding of the nuclei in a thin parietal layer of cytoplasm surrounding a large central vacuole. The number of free nuclei has not been determined, but presumably it is quite indefinite. It is in this stage that fertilization occurs, for the free nuclei are potential egg nuclei, although a group near the antipodal end of the sac may be as distinctly regeta tive as are the antipodal cells of angiosperms. After fertilization, walls appear among the endosperm nuclei and a tissue is formed, which finally invades and destroys all of the nucellar tissue ( $\left.\mathrm{p} .38_{3}\right)$. Under such circumstances the formation of archegonia is impossible, free eggs being organized at the free nuclear stage 
of the endosperm. There can be no question that the embryo sac of Gnetum is strongly suggestive of that of angiosperms, in which the egg is also organized in the free nuclear stage of the gametophyte; but there is nothing in Gnctum to suggest the remarkable fusion of polar nuclei so characteristic of the angiospermous sac. It is at least a case of remarkable parallel development.

In all of the Gnetales the megaspore membrane is very thin, and according to Thomson (2I) this confirms the evidence from other structures that the group is relatively modern among gymnosperms.

THE MALE GAMETOPHYTE

The development of the male gametophyte of Gnetales was unknown, except for occasional glimpses, until the investigation of Ephedra trifurca by LAND (I 8 ), and it still remains the only complete account.

A short time after the rounding off of the spore, its nucleus divides, forming the first prothallial (vegetative) cell. This cell is pressed closely against the wall of the spore by the enlargement of its sister cell, from which it is separated by a wall, the only wall that appears in the spore (figs. 436-44I). A second division gives rise to the second prothallial cell and the antheridium initial, which are not separated from one another by a wall. The sccond prothallial cell and its nucleus become flattened also by the pressure of the growing antheridium initial, whose nucleus enlarges very much, and upon division produces the generative and tube nuclei. The generative nucleus becomes surrounded by a zone of cytoplasm differentiated from the general cytoplasm, the result being a free naked cell (fig. 439). The general cytoplasm still invests the second prothallial and tube nuclei, with no evident boundary between them. The nucleus of the generative cell divides, giving rise to the stalk and body nuclei, which remain invested by the cytoplasm of the generative cell, the body nucleus soon becoming much larger than the other. It is in this condition that pollination occurs (during the first two weeks of April), the spore containing five conspicuous nuclei (two prothallial, stalk, body, and tube) (fig. 44I). The short period of this species has been referred to ( $\mathrm{p} .37 \mathrm{I}$ ), only two months elapsing between the first appearance of the primordia of the sporangia and the five-nucleate grain, which is shed about two weeks later. 
After reaching the deep pollen chamber, the exine of the spore is sloughed off and the intine with its contents is completely freed. The two prothallial cells soon disappear, and the nucleus of the body cell divides to form two equal male nuclei. The tube nucleus mores around the cavity of the grain and comes to rest against the wall, and soon after the pollen tube is put out from this point of contact

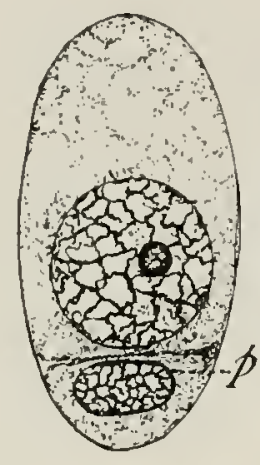

436

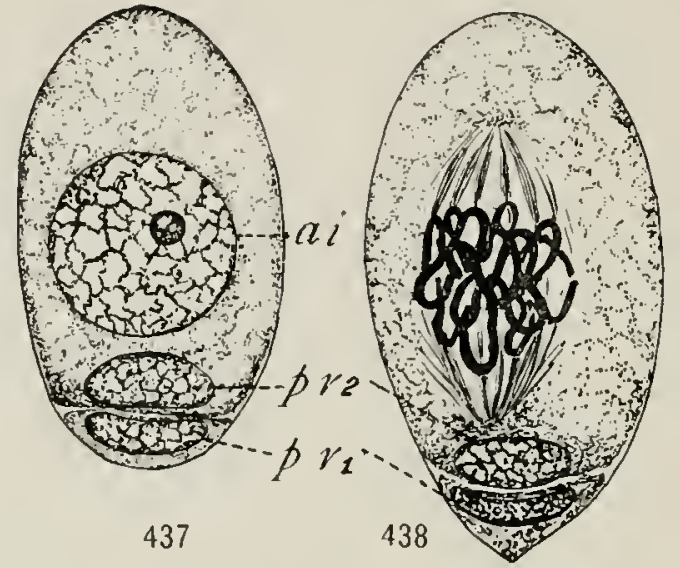

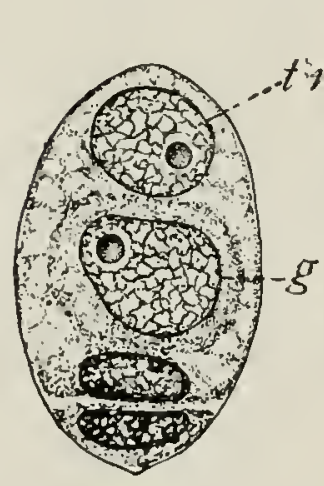

439

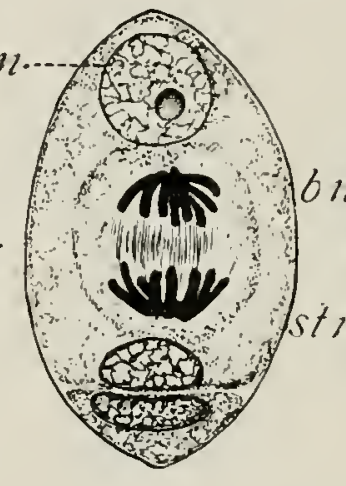

440

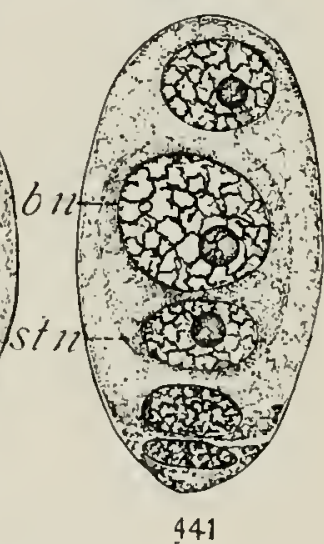

441

FIGS. 436-441.-Ephedra trifurca: germination of the microspore; $p$, first prothallial cell; $p r^{1}$ and $p r^{2}$, first and second prothallial cells; $a i$, nucleus of antheridium initial; $t n$, tube nucleus; $g$. generative cell; $b n$. nucleus of body cell; st $n$, nucleus of

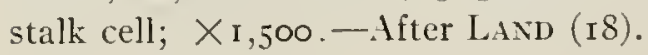

(figs. 442, 443). As previously stated, the greater number of pollen grains rest upon the necks of the archegonia, and fertilization is possible within ten hours, as shown by experiment. The tube forces its way between the neck cells, rarely destroying them in its passage.

In Ephedra distachya (22) the two male nuclei lying in the general cytoplasm of the body cell are said to be unequal. The equality or inequality of such cells should be based upon an estimate of their 
volume, rather than upon optical sections, which frequently appear to show an inequality that does not exist.

The male gametophyte of Welwilschia is known only from a few ligures by STRASBtrgkik (IO). which show a prothallial cell and the division resulting in the generative and tube nuclei; supplemented by the statement of PEARson (27) that the nucleus of the body cell divides to form two male nuclei. These glimpses agree with the corresponding stages in Ephedra, exeept the presence of a single prothallial cell, which may or may not have been accompanied by another one. Our only knowledge of the male gametophyte of Gnetum is from the statement and figures of Lotsy (15) from Gnetum Gnemon, showing
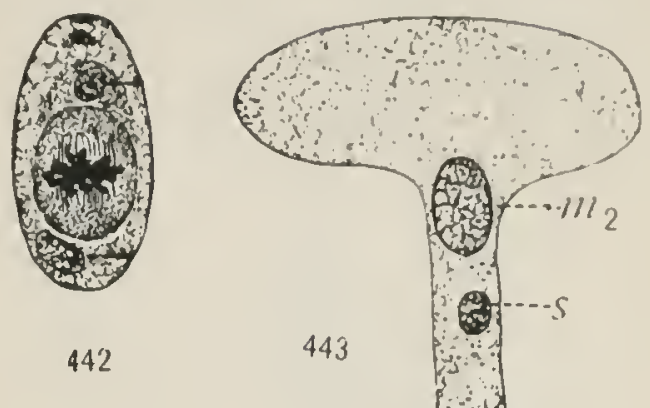

442

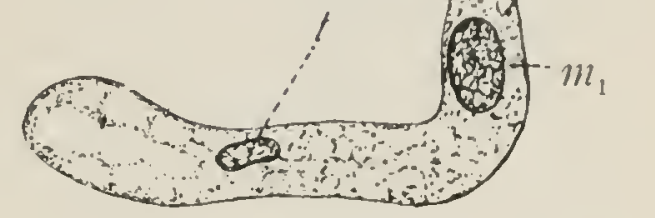

Figs. 442, 443.-Ephedra trifurcu: fig. 442 , pollen grain just before the formation of the tube; the nucleus of the body cell is dividing to form the two male nuclei; $X_{500}$; fig. 443 , the pollen tube; $m_{\mathrm{I}}$ and $m_{2}$, the male nuclei; $s$, nucleus of stalk cell; $l$, tube nucleus; $\times 500$.-After LAND (23). the tube nucleus and two male cells of the ordinary type in the tip of the pollen tube just before fertilization.

\section{FERTILIZATION}

The fertilization of Ephedra trifurca has been observed by LAND (23) and, as has been stated, it may occur within ten hours after pollination. The pollen tube forces its way between the neck cells of the archegonium and discharges all its contents into the cytoplasm of the much elongated egg. While the sperm and egg nuclei are fusing in the upper part of the egg, there may be seen in the overlying cytoplasm the ventral, second male, stalk, and tube nuclei. A dense and darkly staining mass of cytoplasm surrounds the fusion nucleus and extends downward through the long egg (fig. 444). This differentiated mass of cytoplasm appears first in spherical form in the upper third of the central cell, and does not disappear until the proembryonic cells are formed. In Ephedra dislachya it is reported (22) that the 


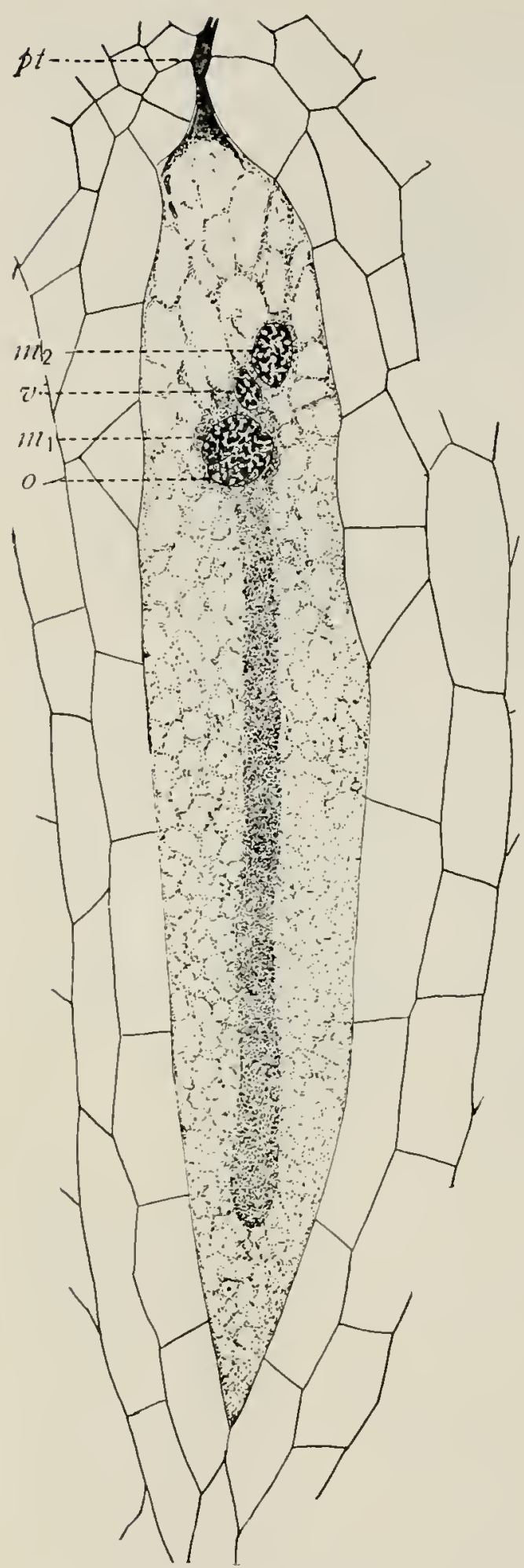

FIG. 444.-Ephedra trifurca: fertilization; $p t$, pollen tube; ventral nucleus; $m_{\mathrm{I}}, o$, fusing nuclei; $m_{2}$, second male nucleus; $\times 2$ I 5. - After LAND (23). functioning male nucleus slips out of its cytoplasmic sheath in the periphery of the egg, and probably this is true of the species of Ephedra in general.

In Welwitschia the pollen tubes and prothallial tubes come in contact in the nucellar cap. How the transfer of male cells or nuclei is effected has not been observed, but several eggs are fertilized in each ovule, and PeARson says (26) that the cytoplasm of the fusion nucleus is mainly that of the male cell, which would practicálly repeat the behavior observed in the sexual fusion of the Taxaceae and Taxodium.

In Gnetum (I5) one or more pollen tubes enter the embryo sac, and their tips are observed among the free nuclei (fig. 4I9, $J$ ). The tip of the tube becomes distended and discharges its contents (usually four nuclei), both male cells being free in the sac and functioning. Approximately as many eggs are fertilized as there are male cells discharged into the sac, that is, twice as many as there are entering pollen tubes. About the fusion nucleus a dense layer of cytoplasm appears and soon a cell membrane is formed. The discharge of male cells into an embryo sac 
containing free nuclei or cells, and the functioning of both cells discharged by a tube suggest the so-called "double fertilization" characteristics of angiosperms. The peculiarity of the angiosperm situation, however, is not that two male cells fuse with two cggs, but that one of them enters into a triple fusion which results in the so-called endosperm tissue.

\section{The embryo}

The development of the embryo of Gnetales differs widely from that of other gymnosperms; and the three genera differ so much among themselves that a separate account must be given for each.

In I872 Strasburger (3) described the remarkable embryoformation of Ephedra altissima, outlining a general situation which has proved to characterize all the species investigated (fig. 445). The principal features are as follows: free nuclear division up to eight nuclei; the organization of two to eight independent cells; the independent functioning of each proembryonal cell in the formation of a suspensor and an embryo. The free nuclear division up to eight nuclei repeats the early stage of the proembryo of most conifers; but the difference appears in the separate organization and functioning of the eight cells, resulting in a proembryo of eight independent cells rather than one consisting of a tissue of eight cells. Each functioning proembryonal cell elongates to form a suspensor-like tube, which emerges from the egg, penetrates the endosperm, and cuts off at its free tip an embryo-forming cell. This is quite like the embryogeny of conifers, except that several suspensors emerge from the egg in various directions, rather than a single one emerging from the base of the egg. It must be remembered, however, that among conifers the constituent cells of a suspensor may separate, and an embryo be formed at the tip of each one. This is exactly the case of Ephedra, for its proembryonal cells act independently in embryo-formation.

Fuller details of the embryogeny of Ephedra have been given by LAND for Ephedra trifurca (23). The behavior of the jacket cells and of the non-functioning male nucleus, during the development of the proembryo, is worthy of mention. Soon after fertilization, the extremely thin walls of the jacket cells disappear, and the contents of these cells become mingled with those of the egg. Shortly 
before the walls disappear the jacket cells become binucleate, the nuclei dividing mitotically and amitotically. Mitotic divisions may occur simultaneously in every cell of both layers of the jacket, or every division may be amitotic, or both kinds of division may occur in the same jacket. Amitotic divisions occurring at the upper end of the archegonium might pass easily for fusions. In some jacket cells the
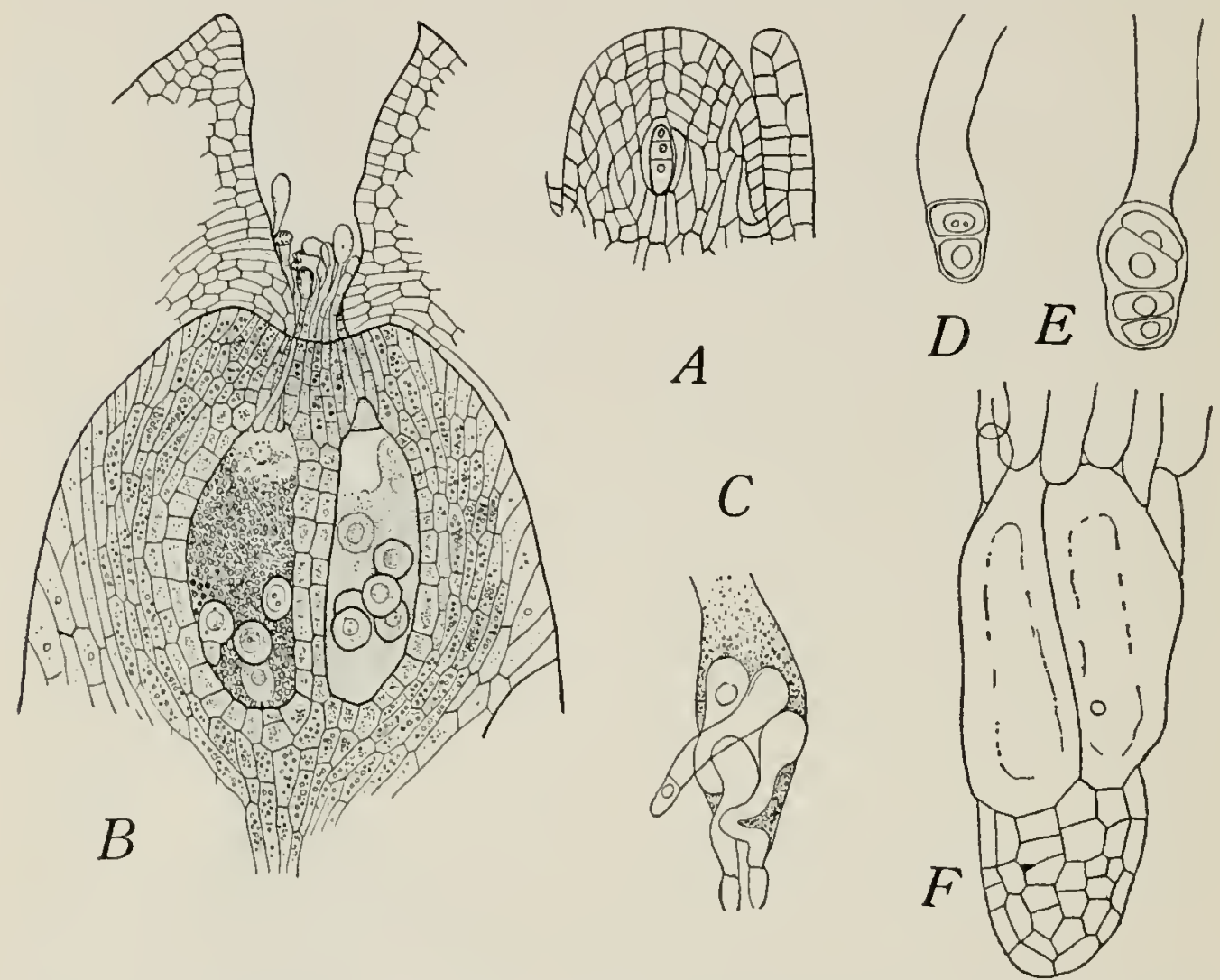

FIG. 445.-Ephedra: A, young ovule; $B$, upper part of female gametophyte after fertilization, showing the free cells of the proembryo within the two eggs; $\times 6_{4}$; $C$, suspensors developing from the free cells, passing from the egg into the endosperm, and each bearing at the tip an embryonal cell; $\times 64 ; D-F$, later stages in the development of the embryo; $\times 154 ; A, E$. campylopoda; $B-F, E$. altissima.-After StrasBURGER (3).

nucleus enlarges and becomes surrounded by delicate cytoplasmic radiations such as appear in connection with the unfertilized egg, suggesting the possibility of apogamy, but an investigation of thousands of orules failed to discorer any evidence that these egglike jacket nuclei ever function in the production of embryos. It is evident that Miss Berridge and Miss Sanday (22) discovered the same situation in Ephedra distachya, although they interpreted it differ- 
ently. To them the freed nuclei of the jacket cells appeared to fuse in pairs and to form the functioning procmbryonal cells; in other cases the jacket cells of either layer were thought to function directly

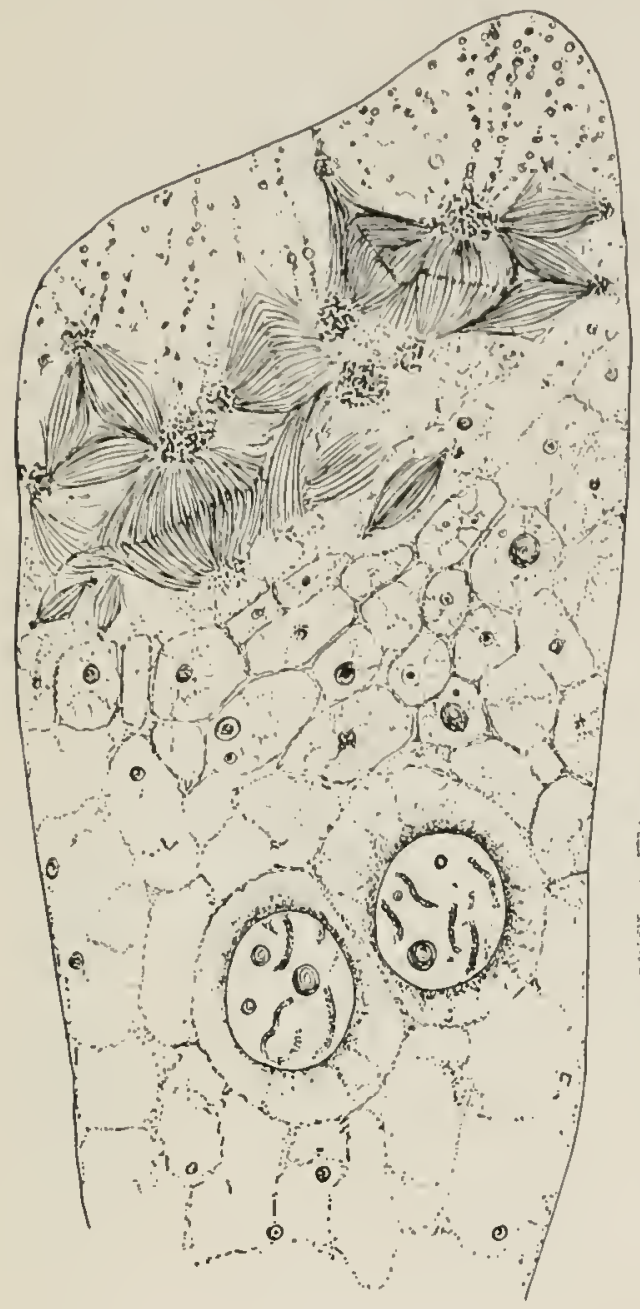

446

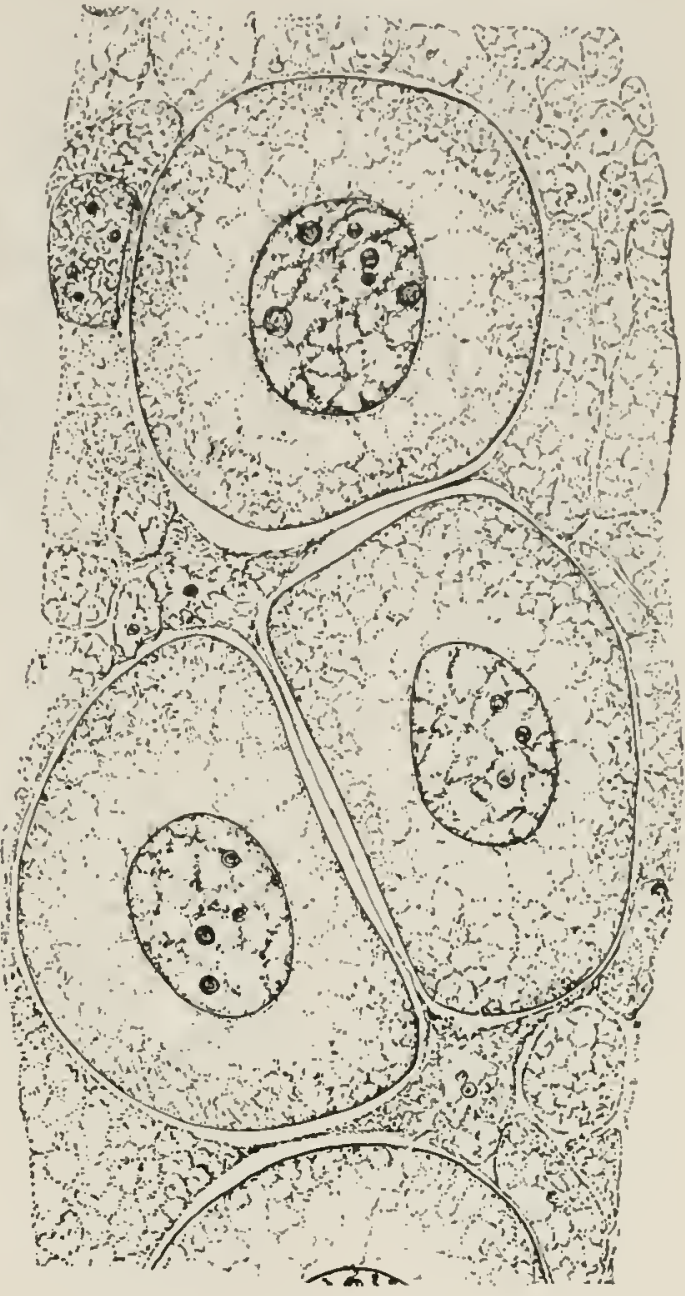

447

FIGS. 446, 447.-Ephedra trifurca: the proembryo; fig. 446, upper end of egg, showing a group of spindles derived from the second male cell; just below are numerous small cells which have come from jacket cells that have wandered into the egg, or from the division of non-functioning proembryonal cells, or from both; farther down are two functioning proembryonal cells; fig. 447, three of five functioning proembryonal cells; jacket nuclei in the egg cytoplasm; free masses of cytoplasm; also masses of cytoplasm remaining after the proembroynal cells have been carved out; $\times 500$.After LAND (23).

as proembryonal cells, in which case there had been migration of nuclei from adjacent jacket cells and nuclear fusion.

The non-functioning male cell enlarges and occupies the extreme upper part of the egg, a space previously filled by the adjacent jacket 
cells. As it disorganizes, an irregular group of spindles first appears, and then a number of minute cells (fig. 446). This ephemeral group of cells is produced probably by division of the non-functioning male nucleus, or it may be the joint product of the chromatin of this nucleus and of some of the jacket nuclei. In any event, its appearance in connection with the "second male nucleus" has suggested that it may be the physiological equivalent of the endosperm of angiosperms.

The formation of the embryo of Ephedra trifurca occurs as follows (23). The fusion nucleus gives rise to eight free nuclei, more or less unequal in size, and three to five of the largest enter into the organization of walled cells that can produce embryos (fig. 446). The free nuclei are usually irregularly distributed through the egg, or they may form a row through the middle. The proembryonal cells are isolated from the surrounding cytoplasm by the development of cleavage cracks, which finally carve out a more or less irregular sheath of cytoplasm for each nucleus (figs. 447,448 ). In general the lower cells are successful in producing embryos, but sometimes only the upper (micropylar) ones are successful. Each functioning proembryonal cell rounds out, and its nucleus divides. The two daughter nuclei are at first equal, but one soon becomes noticeably larger than the other. As a result of vacuolation the two nuclei become placed on one side of the cell (if it is one of the upper cells), or on the bottom of the cell (if it is the lowest one in the egg). Two papillae are put out by the wall adjacent to the two nuclei, but the papilla related to the larger nucleus elongates rapidly to form the suspensor and the other one disappears (fig. 449). In one case four nuclei were seen in a proembryonal cell. The suspensor develops directly toward the antipodal region if the proembryonal cell is the lowest one, but it advances outward and then downward if it is developed by one of the upper cells. The larger nucleus passes nearly to the end of the tube, and a cleavage plate, beginning at the wall, cuts it off in a terminal embryoforming cell (figs. 450, 45I). The other nucleus now enters the suspensor and functions as its nucleus, remaining at the lower end until it disintegrates. The suspensor elongates rapidly, thrusting the embryo-forming cell deep into the endosperm and remaining turgid until the secondary suspensor appears, when it collapses. The longest suspensor observed measured $3 . \mathrm{Imm}$. in length. 
The embryo cell divides transwersely, and this is followed by a succession of divisions in various planes until an ovoid mass of cells

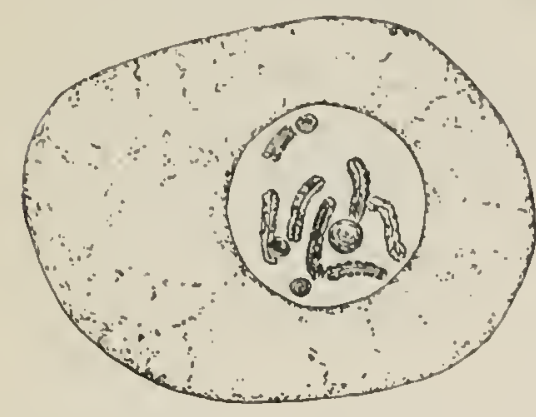

448

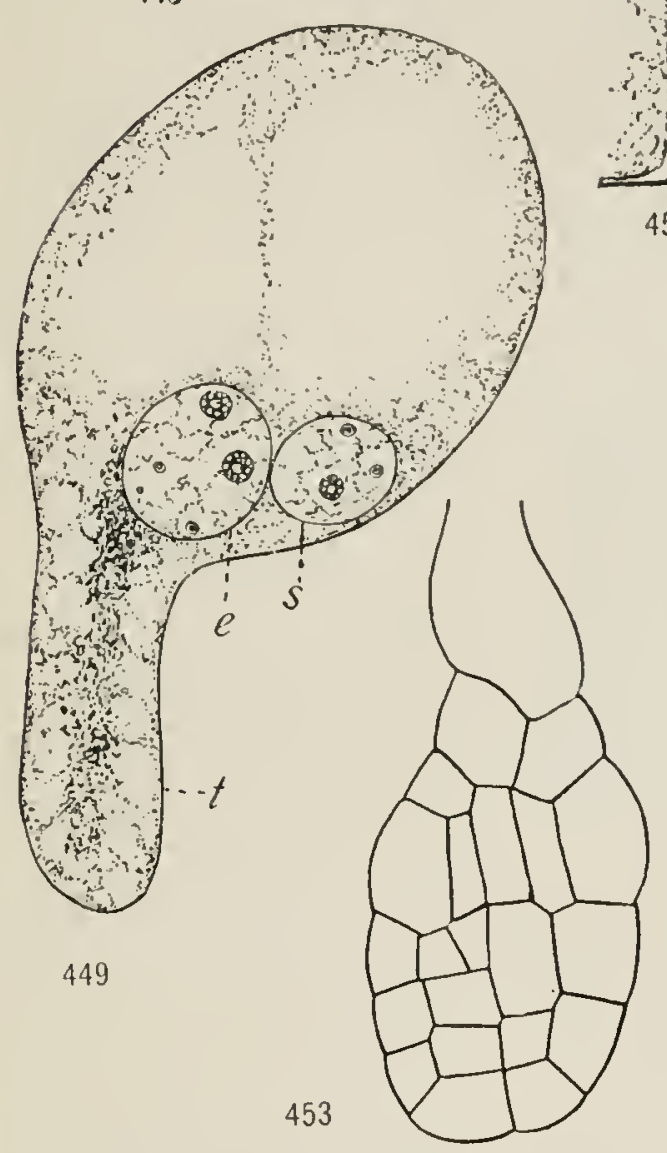

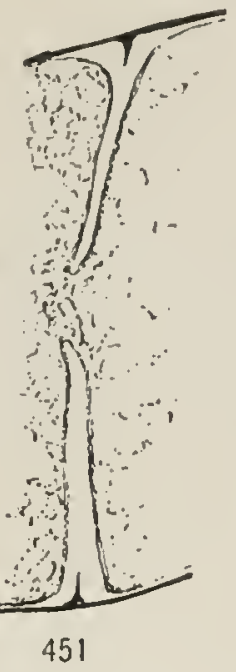
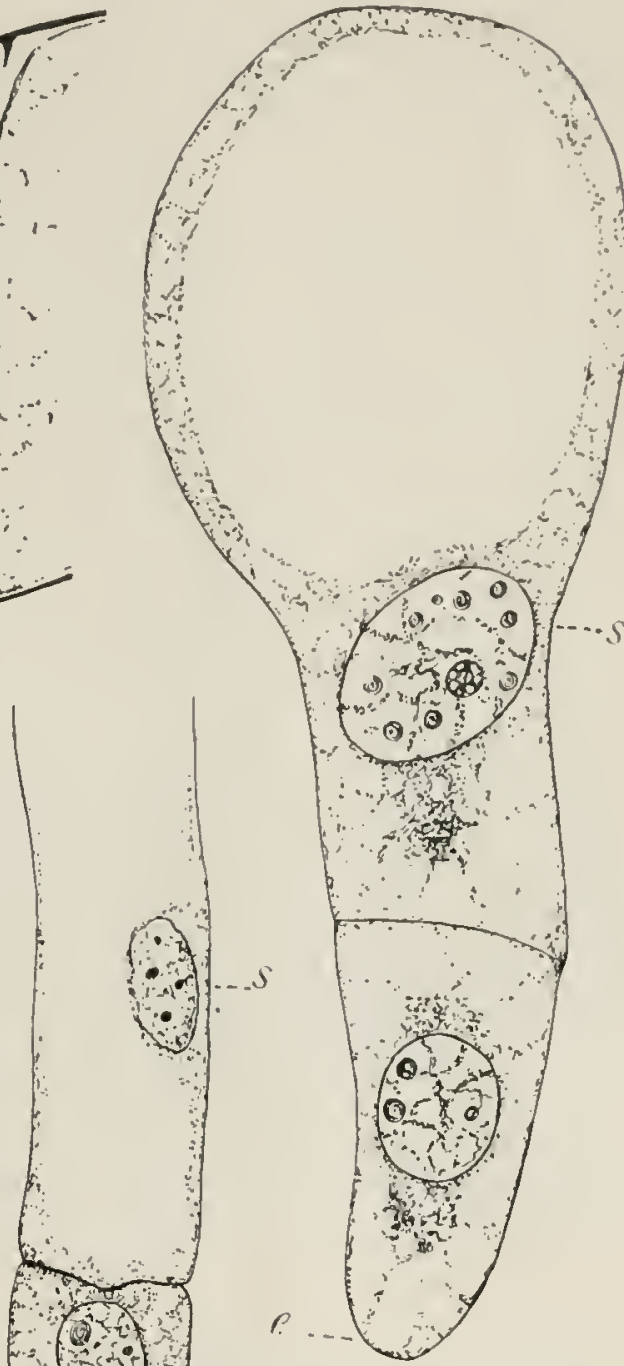

450

Figs. 448-453.-Ephedra trifurca: development of embryo; fig. 448 , one of the proembryos before the formation of the suspensor tube; $X_{500}$; fig. 449 , proembryo with two free nuclei ( $s$, of suspensor; $c$, of embryo) and a suspensor tube $(l) ; X_{500}$; fig. 450, a later stage, showing suspensor $(s)$ and embryo $(e) ; \times 500 ;$ fig. $45 \mathrm{I}$, character of the wall, nearly complete, which separates the suspensor and embryo; $X_{I, 900 \text {; }}$ fig. $45^{2}$, division of embryo initial cell; $s$, suspensor; $X_{500}$; fig. 453 , later stage of embryo and secondary suspensor; $\times 250$.-After Land (23).

is produced (figs. $45^{2}, 453$ ). The basal cells of this group elongate successively, forming a multicellular secondary suspensor, which 
merges insensibly into the root cap. There are thus three stages of suspensor-formation: the first elongation in connection with the nucleus which later becomes the nucleus of the embryo cell; the second and chief elongation in connection with the smaller nucleus of the proembryonal cell; and the formation of a secondary, multicellular

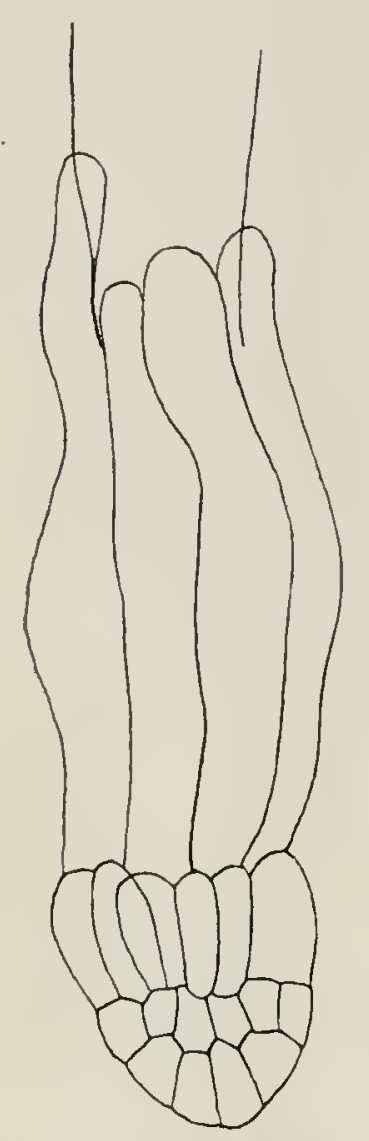

FIG. 454.-Welwitschia mirabilis: a young embryo consisting of a pyramidal group of cells, the basal ones giving rise to embryonal tubes.-After Strasburger (3). suspensor by the basal cells of the embryo. Although several embryos may begin to develop in a single orule, only one of them reaches maturity.

In Ephedra trifurca the occurrence of vivipary is evident, at least in some cases, numerous seedlings being observed to have emerged from the seeds while the strobili were still attached to the stem. In any event, the period of rest for the embryo must be very short, and favorable conditions for growth may eliminate it entirely. The whole period from the first appearance of the ovulate strobili to the "germination" of the seed is approximately six months.

In Welwitschia the fertilized egg, within the prothallial tube, behaves as does the proembryonal cell of Ephedra. As described by Pearson (27), it elongates toward the top of the endosperm, and the first nuclear division is followed by a cleavage wall which cuts off a terminal embryo cell. The general statement has been that in Welwitschia and Cnetum there is no free nuclear division in the first stages of embryo-formation, but that the first division of the fusion nucleus is accompanied by wall-formation, as in the angiosperms. This statement must be revised, for in Welwitschia the fusion nucleus produces two free nuclei, which are later separated by a wall that holds no relation to the spindle of the fusion nucleus. The suspensor cell of Welwitschia elongates extremely, becoming much coiled and persistent, and the embryo cell produces a pyramidal group of cells (about 
thirty-two at the time of observation), the basal ones of which develop numerous embryonal tubes that surround the lower part of the suspensor, while the terminal ones (a plate of eight cells) develop the embryo (fig. 454). The embryonal tubes are produced from the same region that develops as a secondary suspensor in Ephedra, but their function is not the same. In germination the young seedling of Welwitschia (BOwER 6.7) shows a well-developed root, a very long hypocotyl, and two small cotyledons; and between the root tip and the hypocotyl there is dereloped a very conspicuous footlike ("spadelike," 28) process that remains in the seed as a haustorial organ. At a later stage the cotyledons become more conspicuous, and the single pair of persistent leaves appears associated with them (fig. 4.55).

The embryo-formation of Gnetum is a repeti-

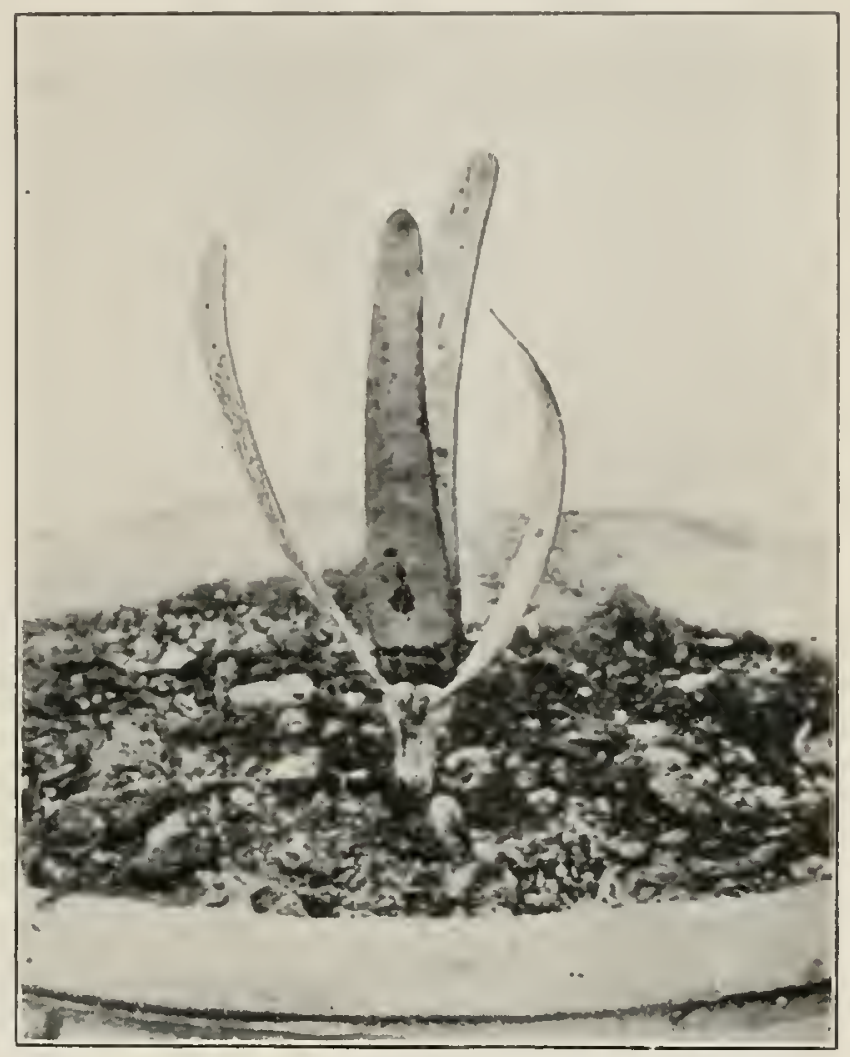

FIG. 455.-Welwitschia mirabilis: a young seedling, showing the cotyledons and the pair of persistent leaves; the bilobed crown is evident just above the insertion of the cotyledons; natural size. -From photograph by H. Schesck. tion of that of Welwitschia, at least in general outline. Lotsy's account ( $\mathrm{I}_{5}$ ) for Gnetum. Gnemon describes the extensive suspensor-like elongation of the fertilized egg, the penetration of the endosperm in various directions, the occasional branching of the tube, and the cutting-off of the embryo cell, but does not follow the nuclear divisions.

A recent investigation (25) of the same species has added some interesting details. When the endosperm is fully developed, having replaced the nucellus completely during the second season, its pe- 
ripheral region contains a tangle of long, tortuous, and branching suspensors, which are difficult to trace. During the formation of the suspensor by the fertilized egg, free nuclear division takes place,

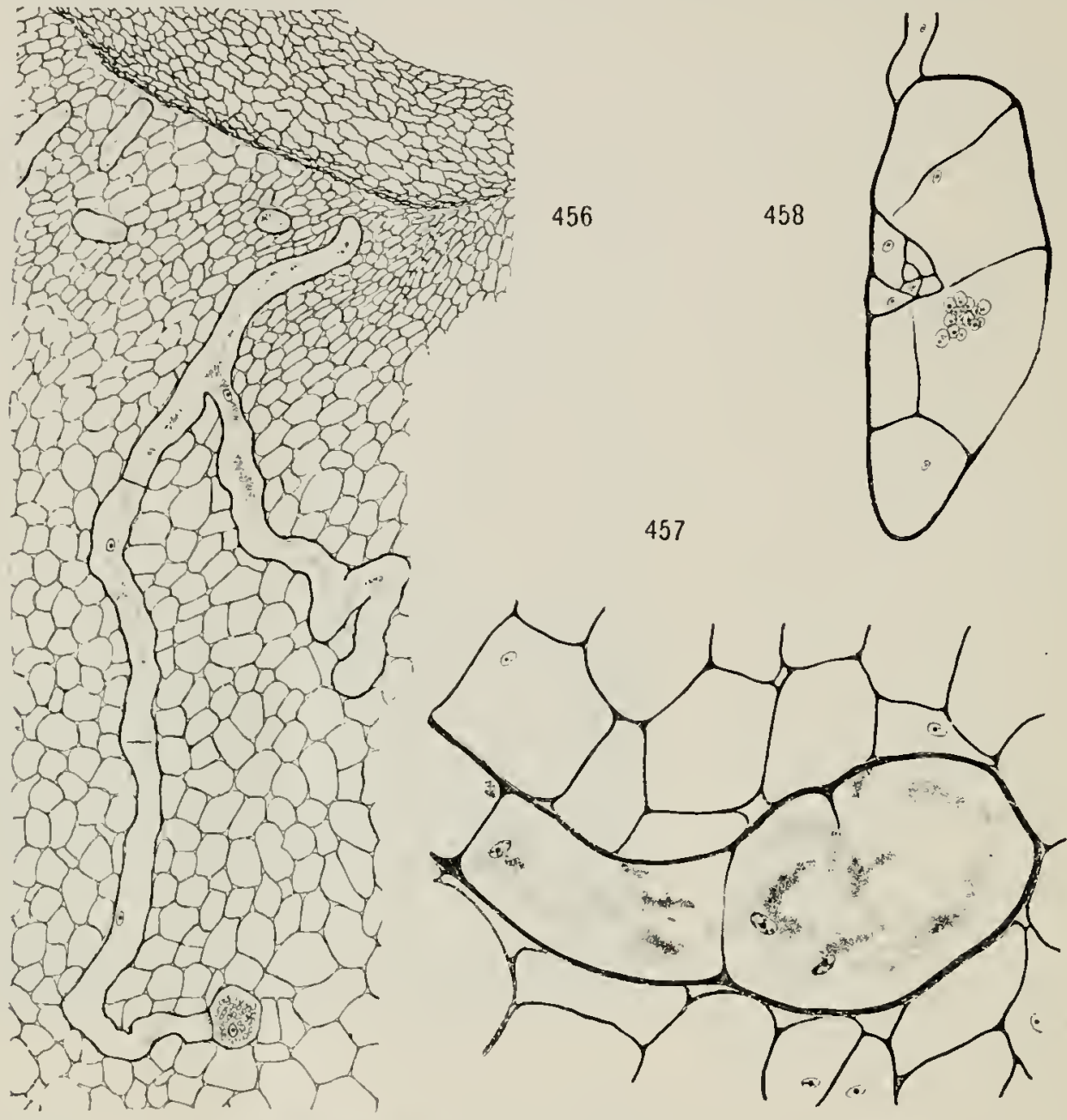

Figs. 456-458.-Gnetum Gnemon: development of embryo; fig. 456, a proembryo showing the branching, suspensor-like elongation of the egg, with free nuclei and cleavage walls; also the embryonal cell containing a nucleus and numerous starch grains; sections of other suspensors shown, and also a small portion of the undestroyed tip of the nucellus; $X_{40}$; fig. 457 , beginning of embryo-formation by the embryonal cell, showing free nuclei and the beginning of a cleavage wall; a cleavage wall in the suspensor is also shown; $\times 250$; fig. $45^{8}$, an embryo reconstructed from several sections, showing free nuclei, cleavage walls, and the beginning of uninucleate cells; $\times$ i40.-After Coulter (25).

resulting in a few nuclei (four in some cases) distributed along the suspensor (fig. 456). Usually between these nuclei transverse walls are formed by the development of cleavage plates from the wall of the suspensor. A cell at the tip of the suspensor is cut off in the same 
way, and contains one of the free nuclei, with which numerous starch grains are associated. In this terminal cmbryo cell free nuclear division continues, accompanied by clcavage walls, until a multicellular embryo is formed (figs. $457,45^{8}$ ). The formation of cleavage walls appears to continue until uninucleate cells are produced.

As in the case of Welwitschia, it had been supposed that in the embryo-formation of Gnetum the preliminary stage of free nuclear division, common to other gymnosperms, had been eliminated, and that the first nuclear division was accompanied by wall-formation, as in angiosperms. In Gnetum Gnemon, however, free nuclear division not only characterizes the proembryo, but also the early stages of the embryo. In comparing Gnetum with Ephedra it will be seen that the number of free nuclei formed by the egg in each case is approximately the same, the difference being that in Ephedra several suspensors are formed by independent proembryonal cells, while in Gnctum a single suspensor is formed by the fertilizcd egg.

The later stages of the embryo of Gnctum Gnemon have been described by Bower (8), the basal cells of the embryo group producing embryonal tubes, as in Welwitschia; and the young seedling showing the same endospermic foot (rodlike) attached between the long hypocotyl (bearing two small cotyledons) and the root. HiLL (26) has studied the germination of these species, and reports that the hypocotyl soon escapes from the seed coats, leaving behind a foot or sucker in close connection with the storage tissue. The cotyledons are at first small, but later enlarge somewhat and do photosynthetic work; and the rodlike foot in the center of the endosperm contains vascular tissue. This foot, reported for Gnetum and $\mathrm{W} / \mathrm{cl}$ witschia, needs investigation, for there is no such structure in Ephedra, the only genus of the Gnetales whose germination we have scen. In that genus the germination is as in Pinus, the cotyledons being pulled out of the testa and spreading, and there is left no structure imbedded in the endosperm. Whether this sucker-like outgrowth from the cotyledonary node of Gnetum and Welwitschia is to be regarded as a "foot," with all the morphological connections that that term implies, or merely a special "peg" such as appears in certain dicotyledons, is a question to be decided only by one's point of view. 
LoTsy has described ( $\mathrm{I} 7$ ) the occurrence of parthenogenesis in Gnetum Ula. When the embryo sac was full of loose tissue, no pollen tubes were found, but many of the loose cells behaved like fertilized eggs in sending out tubes.

\section{History and distribution}

At present Gnetales are unknown as fossils, but they give evidence of a considerable history (24). Their great dissimilarity in habit, structure, and habitat, associated with their widely scattered distribution, indicates a relatively large group of ancestors of somewhat general distribution. Even if this should prove to be the case, the group is doubtless a modern one among gymnosperms.

The present gcographic distribution of Gnetales has been indicated already (p. $3^{6}$ ). Ephedra is distinctly a genus of arid regions, its species ranging throughout the dry borders of the Mediterranean and extending eastward into the Caspian region of Asia, and in similar habitats in both North and South America. The species of Gnetum, on the contrary, belong to the tropical forests of both hemispheres; while Welwitschia is isolated from its congeners in a desert waste of western South Africa. The facts of this distribution can be stated, but their meaning is entirely obscure.

\section{Relationships}

The origin of Gnetales is very obscure, and in the absence of history any statement in reference to it must be regarded as a guess. It is clear that Ephedra is more closely related to the other gymnosperms than are Welwitschia and Gnetum; and that if it is to be connected with them at all, it is most reasonably connected with the Coniferales. This general connection is so uncertain that any attempt to select for it a particular family or tribe of conifers is peculiarly unprofitable. It must be understood that the connection referred to may mean only the parallel development of the two groups.

It is equally clear, whatever may be the connections of Ephedra with other gymnosperms, that it cannot be separated from Welwitschia and Gnetum. These two genera have many things in common with Ephedra, but they have more things in common with one another, and have advanced much farther in the development of angiospermous 
features. It is not worth while to arrange the three gencra in a series, for this would only involve the impossible determination as to whether Welwitschic or Gnctum is the more advanced in some selected direction. Certainly they can hold no such serial relation to one another. for they must represent divergent lines from some general common stock. So far as the features of the embryo sac can determine advancement, as measured by the angiosperms, Gnetum is more advanced than any other gymnosperm. All that is necessary, however, is to recognize the facts that the group as a whole, while elcarly related to other gymnosperms, is remarkable for its angiospermous features, and that Welwitschia and Gnetum are farther removed from the other gymnosperms in this regard than is Ephedra.

The most interesting question in connection with the relationships of Gnetales is their possible relationship to angiosperms. It was natural at first to regard them as the immediate progenitors of angiosperms, for their structures seemed to point irresistibly to that conclusion. When transition groups were in vogue, there was no better illustration of one than the Gnetales. But those who are now claiming a phylogenetic connection between Gnetales and angiosperms do not claim it in the sense that the former is a transition group. To many it seems very improbable that there is any connection between the two groups, except one so distant that it does not fall within the claim of connection. After a critical cytological investigation of the female gametophyte and of fertilization in Gnetum, Strasburger has concluded (I9) that it is impossible to derive the angiospermous embryo sac from that of Gnetum, and that such resemblances as do exist are illustrations of phylogenetic parallels.

Arber and PARkin (24) have applied their strobilus theory of angiospermous descent to an interpretation of the origin of Gnetales, and the result may be regarded as combining the two views mentioned above. This theory was referred to in connection with the Bennettitales (p. 74). These authors do not regard the Gnetales as a very modern group, in spite of the fact that they are unknown as fossils. It is claimed that the three survivors of this ancient group have "proanthostrobili" (an "anthostrobilus" is an axis bearing both microsporophylls and megasporophylls, with the latter above the former; and a "proanthostrobilus" is one in which the orules are gymno- 
spermous), a fact apparent in the staminate "flower" of Welwilschia, and made true for all other flowers of Gnetales by inferring the suppression of one set of sporangia. The conspicuous illustration of a proanthostrobilus among gymnosperms is of course found among the Bennettitales. Based upon this strobilus situation, the Gnetales are regarded as a phylum of gymnosperms having a common ancestry with angiosperms, the two phyla in many particulars following parallel lines of development. It hardly seems necessary to name hypothetical groups, but these common bisporangiate ancestors have been called "hemiangiosperms." Thus the Gnetales have not given rise to the angiosperms; and yet the resemblances of the two are satisfied by the parallel development of two lines from a common ancestry. The gymnosperm connection naturally involves the Bennettitales, and all those groups whose monosporangiate condition may be the result of the suppression of one set of sporangia. It is recognized that in the evolution of strobili among gymnosperms there were probably two distinct tendencies: a monosporangiate strobilus (Cycadales, Cordaitales, Ginkgoales, Coniferales), and a bisporangiate strobilus with the anthostrobilus arrangement of sporophylls (Bennettitales, Gnetales, and leading to angiosperms).

\section{LITERATURE CITED}

I. НоокеR, J. D., On Welwitschia, a new genus of Gnetaceae. Trans. Linn. Soc. London $24: \mathrm{I}-48$. pls. $1-4$. I863.

2. EichleR, A. W., Ueber Welwitschia mirabilis, etc. Flora 47:459-464, $473-479,489-496,508-5$ 10, 5 1 $3-520$. 1863 .

2a. Watson, Sereno, Botany of King's Exp. 187r.

3. Strasburger, E., Die Coniferen und die Gnetaceen. 1872.

4. Beccari, O., Della organogenia dei fiori feminei del Gnetum Gnemon L. Nuovo Giorn. Bot. Ital. 7:91-99. I877.

5. Strasburger, E., Die Angiospermen und die Gymnospermen. i879.

6. Bower, F. O., On the germination and histology of the seedlings of $\mathrm{Wel}$ witschia mirabilis. Quart. Jour. Micr. Sci. 2I:15-30. pls. 3, 4. I88I.

7. ——, On the further development of Welwitschia mirabilis. Quart. Jour. Micr. Sci. 21:571-594. pls. 22, 23. I88I.

8. - The germination and embryology of Gnetum Gnemon. Quart. Jour. Micr. Sci. 22:278-298. pl. 25. 1882 .

9. Karsten, G., Beiträge zur Entwickelungsgeschichte der Gattung Gnetum Bot. Zeit. 50:205-215, 221-231, 237-246. pls. 5, 6. 1892 . 
ro. Strasburger, E., Ueber das Verhalten des Pollens und die Befruchtungsvorgänge bei den Gymmospermen. Ilist. Beitr. 4:1-158. pls. I-3. 1892.

II. Kanstex, G., Untersuchungen üler die Gatung Gnetum. Ann. Jarrl. Bot. Buitenzorg I I : 195-21S. pls. 17-19. 1893 .

12. - Zur Entwickelunusgeschichte der Gattung Ginetum. Cors:s Beitr. Biol. Pflanz. 6:337-382, pls. $8-1$, 1893 .

13. JACCARD, P., le développement du pollen de l'Ephedra helzelica. Archiv. Sci. Phys. et Nat. 111. 30:280-282. I893; rev. in Bot. Centralbl. Beih. $4: 230.1894$.

r4. - Recherches enbryologiques sur l'Ephedra heletica. Bull. Soc. Vaudoise Sci. Nat. 30: pls. 10. I894; rev. in Bot. Centralbl. 6I: III-Ir3. I 895 .

15. Lorsi, J. P., Contributions to the life history of the genus Gnetum. Ann. Jard. Bot. Buitenzorg II. I: 46-II4. pls, 2-II. I899.

r6. Lignier, O., La fleur des Gnétacées est-elle intermédicire entre celle des gymnospermes et celle des angiospermes? Bull. Soc. Linn. Normandie $Y$. $7: 55-7$ r. I903.

7. Lotsr, J. P., Parthenogenesis bei Gnetum Ula Brongn. Flora 92:397-404. pls. 9, Iо. 1903.

I8. Laxd, W. J. G., Spermatogenesis and oogenesis in Ephedra trifurca. Bot. Gazette 38: I-r8. pls. I-4. rgo4.

19. Strasburger, E., Anlage des Embryosacks und Prothallimbildung bei der Eibe nebst anschliessenden Erörterungen. Festschr. siebzigsten Geburtstage von ERnst HaEckel. pp. r8. pls. 2. Jena. I904.

20. Pearson, H. H. W., Some observations on Welwitschia mirabilis Hooker. Phil. Trans. Roy. Soc. London B I 98:265-304. pls. 18-22. 1906.

21. Thonson, R. B., "The origin of gymnosperms"; a discussion at the Linnean Society. New Phytologist 5:68-76, r 4 r-1 48.1906.

22. Berridge, Ethel. M., and Sanday, Elizabeth, Oogenesis and embryogeny in Ephedra distachya. New Phytologist 6:128-134, I67-174. pls. 3, 4. 1907.

23. Lavd, IV. J. G., Fertilization and embryogeny in Ephedra trifurea. Bot. Gazette 44:273-292. pls. 20-22. 1907.

24. Arber, E. A. Newell, and Parkin, John, Studies in the evolution of the angiosperms: the relationship of the angiosperms to the Gnetales. Annals of Botany $22: 489-5$ r 5 . 1908.

25. Coulter, Johx M., The embryo sac and embryo of Gnetum Gnemon. Bot. Gazette 46:43-49. pl. 7. I 908 .

26. Hill, T. G., The germination of Gnetum Gnemon L. Jour. Roy. Hort. Soc. $34: 1,2$. I 908 .

27. Pearson, H. H. W., Further observations on Welwitschia. Phil. Trans. Roy. Soc. London B 200:331-402. pls. 22-30. rgog.

28. Hill, T. G., and DE Fraine, E., On the seedling structure of gymosperms. IV. Gnetales. Annals of Botany 24:319-333. pls. 22, 23. 1910. 


\section{CHAPTER IX}

\section{EVOLUTIONARY TENDENCIES AMONG GYMNOSPERMS}

The gymnosperms have been presented group by group, but they should be viewed also as a whole. It would be possible to summarize the facts in reference to each structure, but this not only would involve needless repetition, but also would fail to distinguish between the facts that are significant and those that are relatively insignificant. There is no better way in which to develop a clear picture of a great group than to select those facts of structure that enter into its general evolutionary history. This has nothing to do with differences among species, or eren among genera, which may be left to the taxonomist; but it deals with those general tendencies to change structures which can be noted in passing from the most ancient gymnosperms to the most recent.

While the discovery of these tendencies aids in reaching conclusions in reference to the phylogenetic connections of the groups of gymnosperms, it must be remembered that the tendencies are facts and the phylogenetic conclusions are very uncertain inferences. Moreover, a general tendency expresses itself throughout a great group, and has to do with the transition from ancient to modern forms, rather than with the breaking up of the group into several phylogenetic lines. Failure to remember this fact has been responsible for much sterile inference as to relationships, similar stages in some general tendency being assumed to mean immediate genetic connection. The organism is a plexus of structures, and must be considered in its totality when relationships are being considered. Among the general tendencies leading to the origin of seed plants, that which resulted in heterospory must be regarded as of paramount importance; and yet it is clear that heterospory arose several times, and probably many times, independently, as the natural result of a general tendency among pteridophytes. To put into the same genetic group all heterosporous pteridophytes would be regarded now as a morphological absurdity; and yet there have been repeated sugges- 
tions of relationship, especially among conifers, on the basis of certain features of the female gametophyte, for example, features which represent a stage in a general change that may occur in a number of independent lines.

In passing from the ancient to the modern gymnosperms, it becomes erident that groups differ as to the rapidity with which they respond to a general tendency to change, and it is this difference that helps to constitute groups. A modern group, for example, may associate a number of ancient features with others that are recent; or all of the ancient features may have been changed. This has been called the "lagging behind" of certain structures, but this should not imply that they are held back and will come forward later; it simply means that for some reason they have not responded to the general tendency among gymnosperms to change in a certain direction. The retention of an old structure must not be confused with the reappearance of an old structure. For example, it seems clear that the most ancient gymnosperms were large-leaved forms, from which the small-leared conifers were derived; and yet small-leaved pteridophytes may have been more ancient than large-leaved ones. If this be true, the appearance of small leaves among conifers is the reappearance of an ancient feature, and not its retention. To prove the retention of an ancient feature demands the establishment of its phylogenetic continuity.

\section{PHYLOGENY}

Before sketching the general erolutionary tendencies among gymnosperms, it will be of service to outline what seems to be a reasonable conclusion as to the phylogenetic connections of their groups. This statement and those that follow will be all the more clear if freed from the details upon which they are based and also from citations. Those who know the facts and the investigators do not need their recital; and those who do not know them would only be confused by their recital. In connection with the following statement, the accompanying diagrams (figs. 459-46r) will assist in indicating the historical connections of the groups, and also to some extent the relative periods of time involved.

The paleozoic groups Cycadofilicales and Cordaitales represent the historical background of gymnosperms. They are of equal age, 


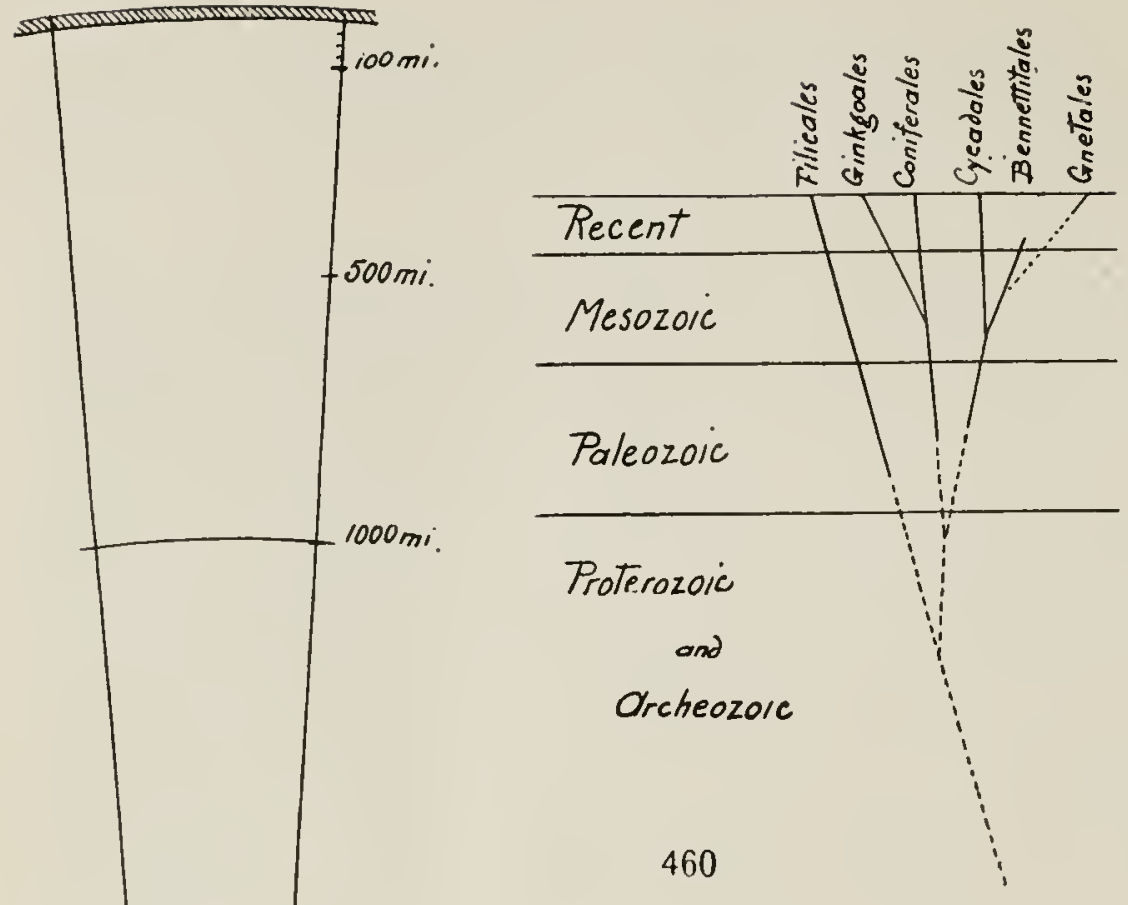

FIGS. 459, 460.-Diagrams indicating the historical connections of the gymnosperm groups and the relative periods of time involved: fig. 459 , a sector of the earth, showing to scale the thickness of the superficial deposits (shaded) from which fossil records have been obtained; fig. 460, the suggested historical connections of the gymnosperm groups, all contained within the shaded region of fig. 459.-Prepared by Sister Helen ANgela. 
so far as the records are available, and are so connected by intergrading (or rather anastomosing) forms that their relationship) seems

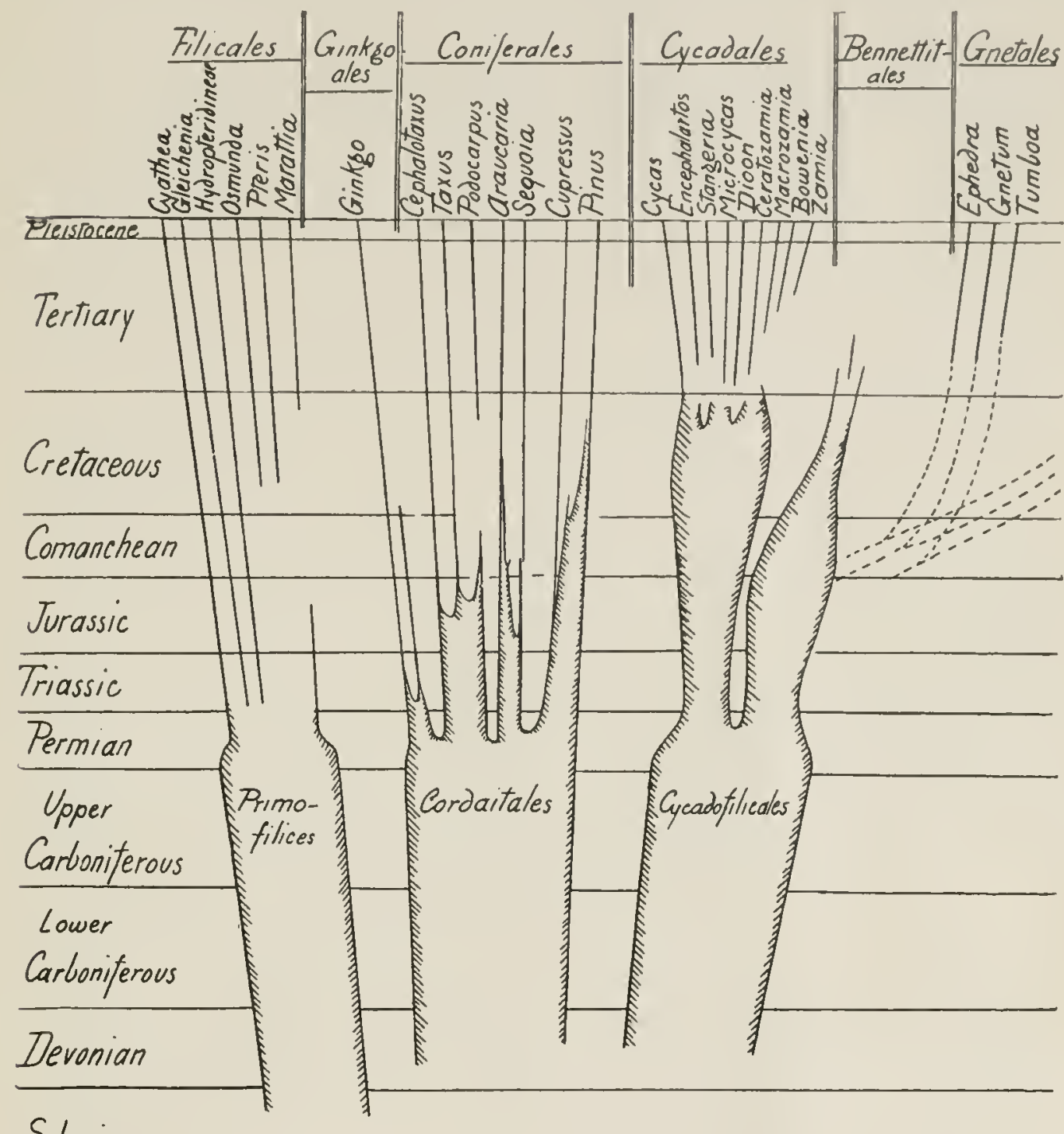

Silurian

\section{Ordovician}

\section{Cambrian}

FIG. 461.- I more detailed diagrammatic presentation of the connections suggested in fig. 460.-Prepared by Sister HelEN ANGela.

erident. The Cycadofilicales are so fernlike in every feature except their seeds, that their derivation from some ancient fern stock 
(called provisionally Primofilices) is as certain as phylogenetic connections can be. The origin of the Cordaitales, therefore, presents two alternatives: either they arose independently from the same ancient fern stock, or they were differentiated from the Cycadofilicales very early. To choose between these alternatives is not very important, but the latter one seems to be the more reasonable, because the Cordaitales (as we know them) are much more removed from the ferns than are the Cycadofilicales. If this conclusion be accepted, it follows that gymnosperms began with Cycadofilicales more ancient than any yet known; that Cordaitales branched off from Cycadofilicales earlier than our present records; and that the two groups constituted the extensive gymnosperm flora of the Carboniferous.

This paleozoic display of gymnosperms was succeeded by a mesozoic display, in which at least four groups are recognized. From the Cycadofilicales there arose the mesozoic Bennettitales and the Cycadales; and from the Cordaitales the mesozoic Ginkgoales and Coniferales were derived. The Bennettitales have been traced almost to the Paleozoic, and their structure, as well as the habit of some of the earlier forms, makes their connection with Cycadofilicales appear convincing. The relation of the Bennettitales to the Cycadales is not so clear; either the two groups were differentiated from a common stock that arose from the Cycadofilicales and continued into the Mesozoic, or the Cycadales were differentiated early from the Bennettitales. The records indicate that the Cycadales are much younger than the Bennettitales, and were much more scantily represented during the Mesozoic; and therefore the latter alternative seems to be the more reasonable. In any event, the only question at issue is whether the gymnosperm stock which came from the Cycadofilicales into the Mesozoic is to be called Bennettitales or a BennettitalesCycadales plexus (a "common stock"); and it is altogether probable that this stock has already been assigned to the Bennettitales in the description of cycadophyte forms from the Triassic and Jurassic. In the gymnosperm flora of today, therefore, the Cycadales, although relatively a modern group, are the nearest representatives of the paleozoic Cycadofilicales.

The Ginkgoales and Coniferales have both been traced into late and independent paleozoic connection with the Cordaitales, and were 
well displayed during the Mesozoic. The Ginkgoales, while widely distributed during the Mesozoic, apparently were never a large group; and this group has continued as a single line into the present flora, and has retained certain features of the Cordaitales which the Coniferales have lost. The Coniferales, on the other hand, began that extensive differentiation during the Mesozoic which has resulted in six recognized tribes in our present flora. Among these tribes the earliest to be recognized are the Abietineac and the Araucarineae, and their very early separation is so evident as to raise the question whether they may not be independent in origin. In any event, the other tribes recognized in our present flora were of later origin; the Taxodineae and the Cupressineae, and possibly the Taxineae, arising from the mesozoic Abictineac; and the Podocarpineac possibly arising from the mesozoic Araucarineac.

The connections of the Gnetales are altogether obscure, and every opinion as to their origin must be regarded as very tentative. Although they have not been discovered as fossils, the great amount of differentiation they show and their widely scattered geographical distribution indicate a considerable history. Evidence seems to be accumulating that they may have been derived from the Cupressineae, or at least that they are closely related to that tribe in origin.

\section{VASCULAR ANATOMY}

The central cylinder of the Cycadofilicales, like that of ferns, was protostelic, siphonostelic, or polystelic. Whatever may be the genetic connection of these types of cylinder, the siphonostele is the type that was carried forward in the evolution of gymnosperms. This siphonostele was made up of collateral mesarch bundles, developed secondary wood composed of tracheids, and the bundles of all its peripheral connections were concentric or at least mesarch.

Among the gymnosperms the universal tendency was to eliminate the centripetal xylem, a tendency carried forward from the ferns, until the collateral mesarch bundles of the central cylinder became collateral endarch; and more gradually the bundles of the peripheral regions became collateral mesarch and finally collateral endarch. So early was this accomplished for the central cylinder that a collateral endarch cylinder is a feature of gymnosperms in general. 
From what has been said as to the rariable rate of change among the members of a great group, it would be expected that mesarch and concentric bundles might be found in peripheral parts of certain species or genera whose allies had completely eliminated centripetal xylem, or might occur occasionally in any species or genus. It is an interesting fact that centripetal xylem appears to linger longest in the cotyledons; and the number of gymnosperms in which it is known to occur in this organ, regularly or occasionally, is increasing rapidly.

In the development of secondary wood, the general tendency a mong gymnosperms is to increase it in amount, so that a thick vascular cylinder is built up by the primary cambium. This tendency is apparent among the Cordaitales, but it reaches its most conspicuous result in the Coniferales and Ginkgoales. This changed also the general topography of the stem, both pith and cortex being much reduced in relative amount. The Bennettitales and Cycadales responded feebly if at all to this tendency, one of their features being the retention of the general stem structure of the Cycadofilicales. In these groups the primary cambium is either short-lived or functions very slowly, and in some forms secondary cambium produces cortical bundles; but the formation of secondary rood never prevents the formation of a large pith and an extensive cortex. It is in these groups also that the concentric and mesarch bundles are most common in the peripheral members, being found somewhere in all forms; while among the Coniferales the centripetal xylem has been almost completely eliminated. In vascular anatomy, therefore, the Cycadales have retained more ancient features than any other living group.

The vascular condition among Gnetales can hardly be spoken of in connection with general tendencies; but the appearance of true vessels associated with the tracheids of the secondary wood is too important to omit. In any event, these true ressels of the secondary wood suggest that in the evolution of the vascular cylinder the original tracheids of the secondary wood are finally and gradually replaced by true ressels.

\section{THE LEAF}

The leaves of gymnosperms may be used to illustrate a structure that exhibits no general evolutionary tendency, but responds more or 
less directly to the conditions of living. 'The most ancient gymnosperms possessed ample, fernlike leaves, and under appropriate conditions this type of leaf persisted, ats in the tropical cycads of today. The conifers, however, have developed a very different type of leaf, one that was well under way among the Cordaitales, and which reaches an extreme expression in small and rigid needles or concrescent scales. This cannot be regarded as the result of a general tendency among gymnosperms, quite unrelated to conditions of liring, such as is shown by the persistent progressive changes of other structures. The leaf is too variable a structure, and too closely related in its work to external conditions to permit such an explanation of its changes.

It would be interesting to know the conditions in which needles and concrescent disks were established; but in the absence of any such knowledge, the sharply contrasted geographical distribution of Cycadales and Coniferales may suggest that the conditions of change were associated with the evolution of the land areas and of the climate of the temperate regions.

\section{THE STROBILUS}

The Cycadofilicales are the only gymnosperms without strobili. Although the sporophylls differ more or less from the fernlike foliage leaves or their branches, they are not aggregated into a strobilus distinct from the rest of the shoot. The organization of a strobilus by the shortening of the sporophyll-bearing shoot is a conspicuous feature of gymnosperms, and it must have been derived from the condition observed among the Cycadofilicales.

The Cordaitales were the first gymnosperms to produce strobili, and this is one of their conspicuous contrasts with Cycadofilicales. The record of the structure of their strobili is meager, but it show's several tendencies in strobilus-formation. Of primary importance is the fact that the strobili are monosporangiate, and this monosporangiate character prevails throughout the Ginkgoales and Coniferales. Among the Gnetales, a group probably related to the general coniferophyte phylum, bisporangiate strobili occur in Welwitschia. If this connection be accepted, therefore, these bisporangiate strobili have been derived from monosporangiate strobili. It is not necessary to associate in one genetic connection all of the bisporangiate gymno- 
sperms, for that condition doubtless appeared independently several times, just as the monosporangiate strobilus is known to have appeared at least twice in distinct phyla (coniferophytes and cycadophytes).

Another fact in reference to the strobili of Cordaitales, which must stand for the most ancient gymnosperm strobili, is that they included both simple and compound strobili. The staminate strobilus was simple, that is, its sporophylls were borne directly upon the axis of the strobilus; and this type of staminate strobilus persisted throughout the Ginkgoales and Coniferales. Among the Gnetales the staminate strobilus is compound, the individual simple strobili being borne on axes of the second order in the axils of sterile bracts which make up the general strobilus. There is an evident relationship betrieen the. compact compound staminate strobilus, such as occurs in Ephedra and in Welwitschia, and the short foliage branch bearing axillary simple staminate strobili, as in Torreya. Even in Gnetum the compound staminate strobilus is a loose one; and among the taxads there is a tendency to compact the staminate strobiliferous branch. The conclusion is that the staminate strobilus is quite persistently simple, but that in the more modern members of the phylum it tends to become compound, a condition accomplished by compacting a short strobiliferous shoot.

The orulate strobilus of Cordaitales was compound, at least in the very few specimens sectioned; that is, the ovules were borne on short secondary and bractlet-bearing axes that arose in the axils of the sterile and overlapping bracts that constituted the strobilus. This compound ovulate strobilus is a distinctive feature of the Coniferophytes, prevailing among the Pinaceae and characterizing the Gnetales. That simple ovulate strobili may have been derived from it is quite possible. For example, in Torreya the ovulate strobili are simple and are axillary on short leafy branches, just such a branch as could have arisen through the elongation of the axis of a compound ovulate strobilus, so that the sterile bracts could be replaced by foliage leaves. It may be said that the change may have taken place in the other direction, and that the short leafy strobiliferous branch was compacted into a compound ovulate strobilus; but it must be remembered that the Cordaitales with their compound orulate strobili are very old, and that the Taxineae with their leafy strobiliferous branches 
are relatively very recent. Of course it may be discovered that the Cordaitales included also forms with simple strobili on leafy shoots. This possibility is further emphasized by the fact that the orulate strobili of the Araucarincae, and of their allies the Podocarpineae, are simple. The former tribe is a very old one, and its connection with the Cordaitales is either direct or nearly so, so that it is altogether probable that such orulate strobili occurred in that group. The connection of the Taxineae with the Cordaitales, however, appears to be so remote, and their relation to groups with compound orulate strobili seems to be so much more inmediate, that it is more reasonable to suppose that their ovulate strobiliferous branches have arisen from compound strobili in the way described above.

Long after the Cordaitales had established their simple staminate and compound ovulate strobili, strobili appeared in the cycadophyte phylum, being found in Bennettitales and Cycadales; and even in the living $C y$ cas the loose ovulate strobilus retains the cridence of its origin from the separated sporophylls of Cycadofilicales. The cycadophyte strobilus has always been simple, and this may be related to the more compact habit of body, with its lack of free branching. The most remarkable feature of the early strobili of this phylum, however, is their bisporangiate character, the two sets of sporophylls holding the same relation to one another that is held by the stamens and carpels of angiosperms; and this marks the Bennettitales as a unique group among gymnosperms. The monosporangiate tendency, however, which characterizes the coniferophytes, is shown by the Cycadales among cycadophytes, and it was either established directly, or it arose from an early differentiation of the bisporangiate strobilus of the Bennettitales. The evidence of history favors the latter vierr, but the probabilities of the situation favor the former. In any event, both monosporangiate and bisporangiate strobili were established among cycadophytes.

\section{THE STAMEN}

Among gymnosperms the stamen may be regarded as a very conservative structure, retaining throughout most of the phyla its fernlike characteristics. Its form perhaps became almost as much differentiated among the Cycadofilicales as it ever became among gymno- 
sperms. In this primitive group, in addition to microsporophylls resembling fernlike leaves with abaxial synangia, there appeared others that have been spoken of as the Crossotheca ("epaulet") and the Calymmatotheca ("cupule") types, and in all probability still others will be discovered. All of these types were continued among the coniferophytes, with varying details of minor importance. Among some of the Gnetales either the sporophyll has become very reduced, or it has become suppressed, so that the microsporangia are cauline; but eren in Welwitschia the old terminal synangium is evident.

Among the cycadophytes, on the other hand, only what may be regarded as the most ancient type of microsporophyll has been retained, that is, the fern type with abaxial sporangia (often synangia). Among. the Bennettitales, there is so little departure from the old type that its microsporophylls resemble pinnate fern leaves with abaxial synangia; and even among the Cycadales the more or less leaflike microsporophylls show the same character. If there is any tendency in the stamens of this phylum worth noting, it is the tendency shown among the cycads to reduce the sterile apex of the sporophyll to a more compact peltate expansion.

The microsporangium of gymnosperms is a very consistent structure, originating from the hypodermal layer of cells, and developing a wall of several layers, the innermost one of which is differentiated as the tapetum. The only general tendencies to be observed are the gradual replacement of synangia by separate sporangia, and the more rapid elimination of all evidences of an annulus (in the general sense). It is noteworthy that in both these particulars the cycadophytes, with their much more recent connection with the Cycadofilicales, are far behind the coniferophytes.

THE OVULE

The origin of the orule of gymnosperms remains in obscurity. While the stamen and its sporangia repeat the corresponding structures of ferns, the ovules of Cycadofilicales and of Cordaitales are so well organized, even in the modern sense, that their connection with the sporangia or synangia of ferns is entirely a matter of inference. This means a tremendous gap between the somewhat hypothetical Primofilices, on the one hand, and the Cycadofilicales and Cordaitales, 
as we know them, on the other hand; a galp which there seems to be small probability of filling up with intermediate forms. In this presentation the only thing possible is to take the orules of the paleozoic forms as representing the oldest known orules, and to note the general changes that have occurred since.

To select the most primitive type of orule from among the paleozoic forms that have been investigated is impossible, unless it is assumed that those orules which are most unlike the modern ones represent the most primitive type. This may or may not be true, but it is the only available criterion; and by using it, we obtain the following result. The oldest orule had a single integument entirely free from the nucellus; in testa-formation this integument differentiated into three layers, the outer fleshy, the stony, and the inner fleshy; the orule was supplied with two sets of vascular strands, the outer set traversing the outer fleshy layer, and the inner set traversing the peripheral region of the nucellus; and the beaked tip of the nucellus broke down more or less completely within the firm and resistant epidermis to form a pollen chamber. If these are really the features of the most primitive known orules, the changes become very apparent, and they represent general tendencies, for they appear in every phylum.

In the first place, the integument and nucellus, instead of remaining separate, develop separately only in the region of the nucellar beak. So early was this change that it probably represents the condition of the majority of palcozoic orules, a condition which has persisted ever since. The method of development is very evident, the integument appearing first as a distinct annular growth about the base of the young nucellus, but later its basal meristematic zone becoming indistinguishable from that of the nucellus. In all probability the change was brought about by the earlier appearance of the integument, and the result has been more or less variability in the amount of freedom from the nucellus.

The three-layered testa persists remarkably throughout gymnosperms, varying chiefly in the amount of development of the outer fleshy layer. The stony layer is always strongly developed, and at the maturity of the seed the inner fleshy layer always forms for it a papery lining. A strong development of the outer fleshy layer, resulting in fleshy seeds, continues throughout the cycadophyte phylum 
and the Ginkgoales, and is a feature of some of the Taxaceae. Among the Pinaceae the outer fleshy layer perhaps is represented in the young integument, but does not develop, so that the stony layer is the conspicuous superficial feature of the seed. The probability is that the stony layer would not develop superficially in any event, so that it would not be necessary to regard a layer or two of cells overlying it as representing the outer fleshy layer. The development of the outer fleshy layer among the Cycadales and Ginkgoales is phylogenetically continuous from the Cycadofilicales and Cordaitales; but among the Taxaceae there is probably no such continuity, but a reappearance of the activity of this layer in certain genera. Among the Gnetales, and apparently in certain Cordaitales, the single integument of the other gymnosperms is replaced by two integuments, the inner fleshy layer having become differentiated as a delicate inner integument, which appears earlier than the heavier outer integument, which gives rise to the outer fleshy and stony layers. In Gnetum the outer fleshy layer develops the pulpy investment characteristic of the primitive seeds; but in Ephedra this layer behaves as among the Pinaceae. If any general tendencies can be inferred from these facts in reference to the integument and testa, they are seen in the abortion of the outer fleshy layer in the largest group of living gymnosperms, and in the differentiation of the three-layered integument into two integuments.

The vascular supply of the ovule exhibits a very evident progressive change. When the integument and nucellus become free only in the region of the nucellar beak, the inner set of vascular strands is shifted from the peripheral region of the nucellus to the inner fleshy layer, and this situation persists among the cycadophytes. Curiously enough, it reappears in Gnetum, but in that case it is associated with the presence of the two integuments. Among Ginkgoales the outer set of strands is suppressed; among Taxaceae the inner set is suppressed; and among Pinaceae both sets have disappeared. The general tendency, therefore, is to eliminate the vascular strands from the ovule; but it is puzzling to find both sets absent from the older Abietineae, and one set still present among the younger Taxineae.

The presence of a pollen chamber is one of the most conspicuous 
features of the primitive orule, and its association with fertilization by ciliated sperms is so evident that it is natural that the two clisappeared simultaneously with the establishment of Coniferales, but the abruptness of the disappearance is eridently more apparent than real. The presence of an extraordinarily deep pollen chamber in Ephedra can hardly be regarded as a contradiction to this general statement, for in that case it is evidently of secondary origin, associated with a remarkably massire archegonium neck.

\section{THE FEMALE GAMETOPHYTE}

The female gametophyte of gymnosperms exhibits a progressive series of changes which is significant because it leads toward the angiosperm condition. At this point the rery important historical record fails, and the entire testimony must be obtained from living forms, which do not represent a series, but the ends of many series. For this reason, and also because such progress is always very unequal in different forms, various stages of advancement may be expected to be found in forms grouped in a single alliance. The scries, therefore, is not so much one which conforms to recognized groups, as a series of stages each of which may be exhibited by members of various groups.

The general development of the gametophyte is quite uniform; and since the same sequence of events occurs among the heterosporous pteridophytes, it may be inferred that a knowledge of the ancient gymnosperms would not materially change this situation. The general sequence referred to in the development of the gametophyte is as follows: free nuclear division, usually accompanied by vacuolation which results at some stage in parietal placing; the formation of walls, resulting in a parietal tissue; the centripetal growth of this tissue until it reaches the center of the embryo sac; and the final growth of the gametophyte until it reaches its mature size. In certain cases there may be no parietal placing, the free nuclei remaining distributed throughout the embryo sac; and therefore there is no centripetal growth, but general wall-formation throughout the sac. The details of the formation of permanent endosperm tissue from the primary walled cells are variable and perhaps very important from the evolutionary point of view, but the range of forms from which 
these details have been obtained is far too small to make them of present service in this connection.

The general tendency which runs through gymnosperms as a whole, and which reaches its extreme expression among angiosperms, is to mature the eggs earlier and earlier in the ontogeny of the gametophyte. In the most primitive condition of the gametophyte, the eggs do not appear until the endosperm is nearly full grown; and other gametophytes can be selected and arranged in a series showing the gradual slipping-back of the egg in the ontogeny of the gametophyte, until in such a form as Torreya the archegonium initial is differentiated as soon as wall-formation has taken place. A conspicuous illustration of the inequality of response to such a general tendency. among related forms is furnished by Torreya and Cephalotaxus, the archegonia not appearing in the latter genus until the gametophyte is well grown. The next stage is illustrated by the situation in $W^{\prime} \mathrm{cl}$ witschia, in which eggs are matured before wall-formation is complete, resulting in the elimination of archegonia. The extreme stage in this progressive series of changes among gymnosperms is illustrated by Gnctum, in which eggs are maturcd at the stage of free nuclear division, the most embryonic stage of the female gametophyte.

So far as the living forms are concerned, the Cycadales and Ginkgoales show little, if any, response to this tendency; and therefore possess the most primitive type of female gametophyte among living gymnosperms. Among the Coniferales, on the other hand, all the stages are found, up to the one just preceding the elimination of archegonia; and this stage is attained by Irelwitschia and Gnetum.

The general tendency of the archegonia among gymnosperms is to eliminate the rentral canal cell. The gymnosperms are distinguished from the pteridophytes by the complete elimination of neck canal cells, and this tendency to suppress all of the axial row except the egg continues among gymnosperms. Among the living forms a walled rentral canal cell is retained only among the Abietineae and by Ginkgo, so far as known; but it seems to be a safe inference that it was present among the ancient gymnosperms. In the other living groups the wall has disappeared, and the rentral canal cell is represented by a free nucleus. In certain forms even this nucleus may 
have disappeared; and of course there is no trace of it when the archegonia are eliminated.

The distribution of archegonia ma be considered in this connection, although the tendeneies do not appear to be general. It is becoming erident that the position of archegonia is related to the position of the pollen tube, which sometimes reaches the embryo sac before the archegonium initials are selected. In cases where the pollen tube assumes a lateral position in reference to the gametophyte (as in Sequoia and Widdringlonia), it has been demonstrated that the latter responds by the selection of numerous deep-seated and laterally placed archegonium initials. It may be inferred, therefore, that the usual micropylar position of archegonia is due to the usual micropylar position of the tip of the pollen tube. It may be that $n$ umerous scattered and rather indefinitely placed archegonia were a feature of ancient gymnosperms, but there is no evidence for it; on the contrary, the few sections of paleozoic ovules that reveal archegonia, and also the archegonia of heterosporous pteridophytes, suggest the opposite conclusion. In any event, they tend to become definite in number and are then organized in two ways: either as individual archegonia, each with its own jacket and chamber; or as an archegonial complex, with a common jacket and chamber. The latter may seem to be a specialized condition, exhibited chiefly by Cupressineac, but it also seems to be the natural condition from which to derive the free eggs of Whelwitschia and Gnetum when airchegonia are eliminated from the ontogeny.

\section{THE MALE GAMETOPHYTE}

It is perhaps impossible as yet to determine the character of the male gametophyte of the paleozoic gymnosperms. The evidence is accumulating that it comprised many more cells than do the gametophytes of most living gymnosperms; but it is not demonstrable whether these supernumerary cells were vegetative or spermatogenous. There are instances of supernumerary cells of both kinds among living gymnosperms, so that they furnish no clue; and the same is true of heterosporous pteridophytes. The balance of probability, however, is in favor of the view that they were in the main spermatogenous. 
In any event, starting with the known condition among heterosporous pteridophytes, the tendency among gymnosperms has been to reduce and finally to eliminate the vegetative (prothallial) tissue, and to reduce the sperm mother cells to two.

In certain groups (as Abietineae) the prothallial cells are two in number; in others (as cycads) there is one prothallial cell; and in still others (as Taxodineae, Cupressineae, and Taxineae) prothallial tissue has been eliminated. Such prothallial cells as do appear are sometimes persistent and sometimes ephemeral; so that the evidence of a disappearing tissue is complete, and it actually has disappeared in what are recognized as the most modern groups. The situation common to Podocarpineae and Araucarineae is usually cited as an illustration of a more extensive and therefore a more ancient prothallial tissue, which connects directly with the "multicellular" pollen grains of Cordaitales. This may be true, but all of the extra cells are clerived from two primary ones, which hold a definite place in the ontogeny of the gametophyte; and therefore the extra cells may represent a secondary tissue that holds no phylogenetic relation to the more extensive prothallial tissue of older forms. In any event it is ephemeral, breaking down and liberating its nuclei.

The number of sperm mother cells is so rigidly two, that this reduction may be said to have been accomplished by all living gymnosperms, whatever may be the fact in reference to the paleozoic gymnosperms. It is interesting to note that the very few instances of a greater number of sperm mother cells occur in a group characterized by its retention of ancient features (Cycadales), and in another group characterized by its very modern features (Cupressineae). While phylogenetic continuity of multiple sperms is safely claimed for Microcycus, no such claim could be maintained for Cupressineae.

The greatest epoch in the history of the male gametophyte of gymnosperms, however, was the abandonment of ciliated sperms, and this occurred in connection with the establishment of Coniferales. It is not generally appreciated that five of the seven recognized primary groups of gymnosperms possess ciliated sperms, and that the modern type or truly terrestrial type of sperm was introduced by the conifers. It must not be supposed that the earliest conifers necessarily did not possess ciliated sperms, for these may have persisted among the 
meso\%oic conifers. In fact, in certain living forms the sperms resemble very closely those of cycads with cilia lacking. The abandonment of ciliated sperms also affected the pollen chamber, the pollen tulbe, and the cell generations in spermatogenesis. The pollen chamber disappeared; the pollen tube ceased to be exclusively a branching haustorial organ and became a sperm-carrier; while the last cellgeneration in spermatogenesis was omitted. It is this condition of spermatogenesis that is carried forward by angiosperms to a still greater stage of reduction. Just what cells are eliminated and what cells remain is a question of small importance. The significant fact is that spermatogenesis is shortened, and the ultimate cells, although non-ciliated, are physiologically sperms.

\section{FERTILIZATION}

We have reserved for this topic, in addition to what it specifically includes, a more detailed discussion of the sperm of gymnosperms and certain related phenomena of spermatogenesis and oogenesis. Using the term sperm in a physiological sense, what appears to be a reduction series can be arranged, extending from the highly differentiated motile sperms of cycads and Ginkgo, presumably representative of the sperms of the extinct groups, to the free male nuclei of Pinus. Among the Taxodineae, Cupressineac, Taxineae, and Podocar pineae (certainly in Phyllocladus) the sperm is a distinctly organized cell ("male cell"). In such genera as Sequoia and Thuja these male cells closely resemble the young sperms of a cycar immediately after the division of the body cell. No restigus of blepharoplasts have been found in the so-called male cells, but this negative evidence is not yet convincing. In every case, also, they have been reported as arising directly by division of the body ceii, which means that they are not formed as sperms within a spermi mother cell. It must be remembered, however, that apparently competent observation maintained for a time this same origin for the sperms of one of the cycads. Therefore, it is not an unreasonable expectation that some of the male cells may be found to be formed within sperm mother cells. In some genera, as Taxus and Torreyc, the two male cells have become unequal, one being much smaller than the other and not functioning. The inference is that reduction 
is proceeding in the direction of the elimination of one of the male cells. Among the Abietincae and Araucarineae the sperms are not distinctly organized cells, but are male nuclei lying free in the cytoplasm of the body cell, and this cytoplasm is not always sharply delimited from that of the pollen tube. That male cells and male nuclei have been derived from swimming sperms is a reasonable inference, and if our proposed phylogeny is true, this series of changes has taken place in the evolution of Coniferales. Such changes do not indicate necessarily the relative ages of the groups in which they are observed, but rather their relative rapidity in different groups.

Oogenesis among gymnosperms does not cover so great a range of reduction, but it is none the less evident. What must be regarded. as the most primitive condition among gymnosperms is the association of a definite ventral canal cell with the egg, as in Ginkgo and Pinus. Among cycads and many conifers, however, the wall between nuclei of the ventral canal cell and of the egg has been eliminated, so that finally the former cell is represented only by its nucleus; and in Torreya it is probable that even this nucleus does not appear. A further simplification of oogenesis is shown by Welwitschia and Chetum, in which no definite eggs are formed, but the egg is represented only by a nucleus in a more or less definite sheath of cytoplasm.

There are certain combinations of characters among the Coniferales that may prove to be correlations, but the range of observation is too limited as yet to establish such a claim. In any event, they deserve consideration. From those forms (Thuia, for example) with definitely organized male cells (the most primitive condition of the sperm among conifers) both the male prothallial cells and the wall separating ventral and egg nuclei have been eliminated (probably the most advanced condition of these structures among conifers). On the other hand, those forms (Pinus, for example) which do not organize definite male cells have retained the male prothallial cells. Three structures are concerned in these combinations, and in all of them there is evident a tendency toward elimination, or at least simplification. It is further evident that this tendency is not shown by all three structures simultaneously. The inferences are that the several lines have proceeded independently, and that the condition of no one of these structures indicates the relative age of the plant to which it 
belongs, but does indicate the relative rapidity of the changes. For example, it cannot be claimed that Pinus is ancient because it has male prothallial cells, or that it is modern because its sperms are only male nuclei; the only claim that can be made from these facts is that the simplification of sperms has gone on more rapidly in the Pinus line than the elimination of male prothallial cells. Doubtless the same conclusion applies to all characters used in phylogeny, even to those derived from vascular anatomy. The relative position of any form in a scheme of classification can be determined only by averaging all its characters; and its relative age in a scheme of phylogeny can be determined only by the sure testimony of history.

The beharior of the chromatin in the final stages of oogenesis in gymnosperms seems to be unique. At the nuclear division giving rise to ventral and egg nuclei the chromosomes are very small. The rentral nucleus soon disintegrates, but the chromosomes of the egg nucleus form a spirem. A period of maturation follows, for which there is no satisfactory account of the behavior of the chromatin. The coarse reticulum of the egg is not chromatin, for most of it may remain after chromatin again becomes demonstrable. Whatever may be the suggested explanation, it is certain that chromatin has not yet been traced from the telophase of the ventral nucleus mitosis to the spirem of the resting egg nucleus with any such certainty as has been done among pteridophytes and angiosperms.

Fertilization has been studied more thoroughly in Pinus than in any other gymnosperm, and perhaps it represents the general situation. In this case the discharge of the pollen tube injects all of its contents into the cytoplasm of the egg. One of the male nuclei comes into contact with the female nucleus and the nuclear membranes at the surface of contact break down, so that the chromatin of the two nuclei becomes surrounded by the membrane of the egg nucleus. Aspirem is formed from the chromatin network of each of the sex nuclei, and each spirem segments into 12 chromosomes. In the fusion nucleus, therefore, there are 12 male and I 2 female chromosomes, which do not fuse, but which become so mixed that they cannot be distinguished. Each chromosome splits and finally 24 chromosomes pass to cach pole to form the first two nuclei of the sporophyte generation. In this so-called act of fertilization, therefore, there is no blending of the 
chromatin contributed by the two parents. Whether a blending occurs as the two groups of chromosomes pass from the telophase of the first mitosis into the resting reticulums of the daughter nuclei has not been determined, but it is possible that the male and female chromatin may remain distinct throughout the life history.

In all the genera investigated, more or less cytoplasm enters the egg with the male nucleus. In the cycads the entire sperm enters the egg, and the cilia may continue to more in this environment, but the nucleus soon slips out from its cytoplasmic sheath and advances toward the egg nucleus. In other forms, as Torreya, Juniperus, and Taxodium, the cytoplasm of the male cell invests the fusion nucleus and takes part in the formation of the proembryo. In most genera, however, no such cytoplasm is visible, and the proembryo is formed from a rather small portion of the basal region of the egg. quite remote from any cytoplasm that may have entered the egg with the male nucleus.

\section{THE EMBRYO}

The absence of embryos from the seeds of paleozoic gymnosperms has been taken to indicate that some great change connected with embryo-formation was introduced by the mesozoic gymnosperms. It would be of extreme interest to know the ancient condition, but we know only what it has become. In fact, the evidence is by no means clear that the embryogeny of paleozoic gymnosperms differed in any general way from that of later gymnosperms. Attention has been called $(\mathrm{p}, 47)$ to the fact that the paleozoic seeds sectioned had dropped from their plants just as abortive seeds do, and that no sections of paleozoic seeds in connection with their plants have been obtained. Among Bennettitales attached seeds are the only ones sectioned, and they contain embryos. Until sections of attached paleozoic seeds persistently show the absence of embryos, it is not profitable to imagine what may have been the changes in embryodevelopment in passing from the Paleozoic into the Mesozoic. Whatever may have been the changes, if any, the proembryo has become the structure showing steady and progressive changes.

The first stage in the development of the proembryo is free nuclear division, followed by wall-formation; and in the most primitive 
condition the free nuclei are so numerous that wall-formation results in a tissue that fills the eggr. 'The tendency is to reduce the number of free nuclear divisions, resulting in a reduction of the amount of proembryonic tissue, so that more and more of the general cytoplasm of the egg is left free from the tissue. The procmbryo of Ginkgo has retained a very primitive character, and illustrations of carly stages in the reduction of the proembryo may be observed among the cycads. In Zamia, for example, which illustrates the extreme amount of reduction among cycads, the proembryo is a relatively small amount of tissue at the base of the egg. Among the Coniferales this reduction has been carried forward to a much greater extent, sixteen free nuclei appearing sometimes, eight free nuclei being the prevailing number, and four free nuclei being occasionally attained. This results in a proembryo consisting of a small and definite number of cells, with distinctly distributed functions. Now and then among gymnosperms (as in Sequoia) there is no free nuclear division, but these are interesting rather than significant exceptions. Even among the Gnetales it is found that a certain amount of free nuclear division precedes wall-formation. That this reduction of the free nuclei before wall-formation is significant is shown by the fact that among angiosperms free nuclei have disappeared, and wallformation accompanies the first division of the fusion nucleus.

The vascular structure of seedlings, and especially the rascular plate with its cotyledonary connections, has become so important a factor in discussions of phylogeny, that at our request Sister Helen ANGela has prepared the following brief comparative statement of the situation among gymnosperms.

"Since the hypocotyl, cotyledons, and primary root are the first organs formed in the embryo proper, it is reasonable to suppose that they depart less widely from the generalized condition than do those structures which develop later under the influence of the various external factors that tend to create diversity. If in addition we could say that developmental factors are the same within all seeds, and that all embryos develop under similar conditions, we should have strong ground for broad generalizations. But such a statement, of course, would be far from the truth. Conspicuous examples of the factors which must be reckoned with in any such attempt are the 
varying amounts of endosperm-formation in different sceds, the great diversity in thickness and induration of seed coats, the presence or absence of the phenomenon of rest, the slowness or rapidity of germination. And the extremes of hypogeal and epigeal development are found side by side in the oldest living gymnosperms, Ginkgo and Pinus, with no historical evidence as to which is the more primitive method.

"Taking the facts as we find them, however, we cannot but be impressed by the fairly harmonious testimony of certain evolutionary tendencies manifested not only by the group as a whole, but by each of the living orders. An inspection of the diagrams (fig. 462) will help to make these tendencies apparent. The most obvious tendency, perhaps, is that to reduce the cotyledons to the fixed number two: Series $A$ represents conditions as they are found among the Cycadales, which, though younger than the Coniferales, are conceded to have retained more primitive anatomical features. Though the order as a whole is dicotyledonous, its more fernlike members are frequently observed to be polycotyledonous; and cases of cotyledonary lobing have been reported of many genera. The number of cotyledons when fixed is fixed at two. Ceratozamia cannot be regarded as an exception, for it is dicotyledonous in the proper sense of that term. Among the Coniferales the tendency to reduce the cotyledons to the fixed number two is even more striking, as indicated by series $B$ of fig. 462. Cupressus, Sequoia, and the Abietineae, which must be regarded as the oldest members of the Pinaceae, are characteristically polycotyledonous; while the more modern members of that family, as well as all the Taxaceae investigated, are dicotyledonous. Ginkgo, though older than the Cycadales and as old as the Abietineae, resembles the former order in having fewer cotyledons; three is not an uncommon number, but two is the usual one. In the modern order Gnetales the fixed number is two. The inclination to revert to the apparently primitive condition has not been lost by the angiosperms; Anemone, Salicomia, and Oenothera are frequently found with three cotyledons.

"A second tendency that appears from comparative study is the teridency to reduce the root poles to the fixed number two. In the most primitive Abietineae and the more fernlike members of the 
Cycadales, the primary root is polyarch. Even Araucaria, which is exceptional in many respects, has been reported with six root poles, although two is the usual number. In the Coniferales the reduction in number of root poles is closely related to the reduction in number
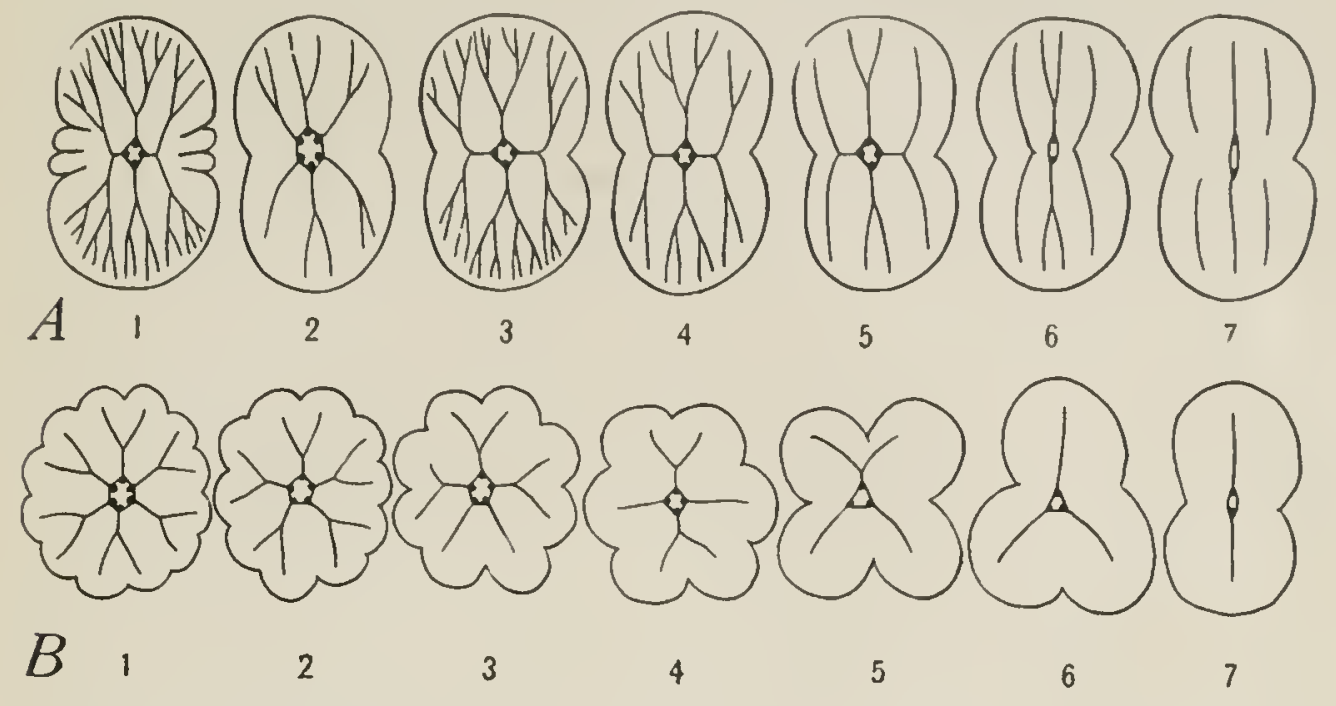

2

3
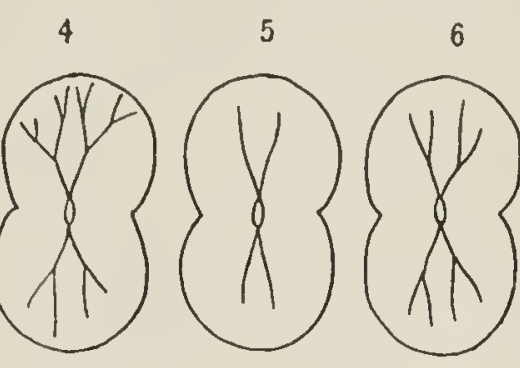

7

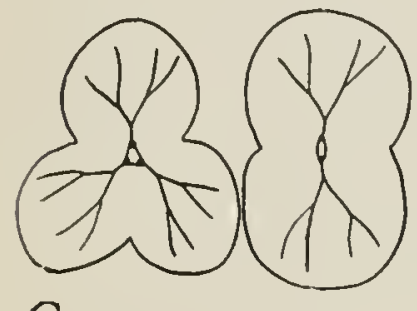

C ।

2

3

4

5

6

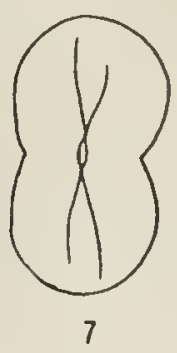

FIG. 462.-Diagrams illustrating the cotyledonary node of gymnosperms and its vascular connections with the cotyledons: the lobes indicate cotyledons.-.Prepared by Sister Heley ANGela.

Series A, Cycadales: I, Dioon spimulosum (occasional); 2, D. cdule (occasional); 3, D. spinulosmm, Ceratosamia, Microcycas; t, D. cdulc; 5, Zamia floridama, Cycas spp.; 6, Cycas siamensis; 7, C. Secmannii.

Series B, Coniferales: $I-6$, various species of the Pinaceae; 7 , Libocedrus, Ta.us, Cicphalotarus.

Series C, Ginkgoales, Gnetales, and exceptional Coniferales: 1, 2, Ginkgo biloba; 3. 4, Arancaria spp.; 5, Podocarpus; 6, 7, Gnetales.

of cotyledons, for when the dicotyledonous condition is reached, the root is diarch. Among the Cycadales, on the other hand, although some have reached the diarch state, the characteristic root is tetrarch, the intercotyledonary poles persisting after the dicotyledonous condition is attained. An important consideration here, however, is the fact that there is often a reduction in the number of poles in 
individual roots, the first-formed portion being tetrarch and the tip diarch. In Ginkgo the diarch root is the one commonly found, though here also tetrarchy and triarchy sometimes occur. The root of Gnetales is diarch.

"At this point, also, comparison with the angiosperms is instructive. Both tetrarch and diarch roots occur among the Archichlamydeae. According to Miss Thomas, the anatomy of the cotyledonary node of Liriodendron tulipifera, Clematis Hendersonii, species of Quercus, of Ricinus, and even some Compositae, resembles in every respect that of Cycas and Dioon.

"A third tendency made apparent by this comparison of seedling anatomy is that to reduce the cotyledonary vascular strands to the fixed number two. The Coniferales are the only order to work out this tendency to the end; the dicotyledonous conifers (except Araucaria and Podocarpus) have just two such strands, one for each cotyledon. The Cycadales, although they have not reached that condition, show a tendency toward it in two ways: by restricting the branching of both median and lateral strands, and by eliminating the lateral ones altogether; and both of these tendencies are carried into the angiosperms. The cotyledon in Ginkgo and the Gnetales receives two strands, which often dichotomize.

"Two very interesting facts are brought out by the diagram in the third row of fig. 462 (series $C$ ). One of these is the strong resemblance between Ginkgo and the Gnetales; the other is the disclosure that in this feature of seedling anatomy, as well as in many other respects, Araucaria and Podocarpus stand aloof from the other conifers and show a marked resemblance to Ginkgo. These two facts may or may not be significant; the series was constructed merely to show that they exist." 


\section{SUMMARY OF LITERATLRE CITEI)}

Alden, C. E., The early stages of spindle formation in the pollen mother cells of Larix. Annals of Botany 17:218-312. pls. It, 15. 1903.

Angela, Sister Helex, The embryo of Ceratozamia; a physiological study. Bot. Gazette 45:412-4I6. figs. 7. 1908.

_- The seedling of Ceratozamia. Bot. Gazette 46:203-220. pls. 12-16. 1908 .

-_- Vascular anatomy of the scedling of Microcycas calocoma. Bot. Gazette $47: 139-147$. pls. 5, 6. 1909 .

, The extrafascicular cambium of Ceralosamia. Bot. Gazette 47: $150-152$ pl. 7. 1909 .

Arber, E. A. Newelt, On some new species of Lagenostoma, a type of pteridospermous seed from the Coal-measures. Annals of Botany 19:326-328. 1905 (abstract).

, On the past history of ferns. Annals of Botany 20:215-232. I906.

—_, "The origin of gymnosperms"; a discussion at the Linnean Society. New Phytologist 5:68-76, I4 I $^{-148 .}$ i 906.

- - and PARkin, John, On the origin of angiosperms. Jour. Linn. Soc. London Bot. 38:29-80. rgo7.

- - On a new pteridosperm possessing the Sphenopteris type of foliage. Annals of Botany 22:57-62. pl. 6. 1908.

tionship of the angiosperms to the Gnetales. Annals of Botany $22: 48 q^{-5} 15$. 1908.

Arvold, W., Beiträge zur Morphologre einiger Gymnospermen. I. Die Entwickelung des Endosperms bei Sequoia sempervirens. Bull. Soc. Imp. Nat. Moscou I899: pp. 13. pls. 7,8 .

-_-, Beiträge zur Morphologie und Entwickelungsgeschichte einiger Gỵmnospermen. II. Ueber die Corpuscula und Pollenschlauche bei Sequoia sempervirens. Bull. Soc. Imp. Nat. Moscou I899: pp. 8. pls. Io, II.

-_- Beiträge zur Morphologie der Gymnospermen. III. Embryogenie ron Cephalotaxus Fortunei. Flora 87:46-63. pls. I-3. 1900.

——, Beiträge zur Morphologie der Gymnospermen. IV. Was sind die "Keimbläschen" oder "Hofmeister's-Körperchen" in der Eizelle der Abietineen? Flora 87:194-204. pls. 6, 7. 1900.

_-__, Beiträge zur Morphologie einiger Gymmospermen. V. Weitere Untersuchungen der Embryogenie in der Familie der Sequoiaceen. Bull. Soc. Imp. Nat. Moscou 190 I: pp. 28. pls. 2.

—_, Beiträge zur Morphologie der Gymnospermen. VI. Ueber den Bau der Zellkerne in Embryo von Ginkgo biloba. VII. Die Embryobildung bei Ginkgo biloba. Ann. Inst. Agronomique et Forestière à Nowo-Alexandria I6: I-22. 1903 . 
Balley, Irving IV., The structure of the wood in the Pineae. Bot. Gazette 48:47-55. pl. 5. 1909 .

Baillon, H., Recherches organogéniques sur la fleur femelle des Conifères. Ann. Sci. Nat. Bot. IV. I4: I86-I99. pls. I2, I3. I860.

Bartholomew, Mary, Abnormal prothalli of Pinus sylvestris. Notes Roy. Bot. Gard. Edinburgh 4:253-255. pl. 49. I909.

Beccari, O., Della organogenia dei fiori feminei del Gnetum Gnemon L. Nuovo Giorn. Bot. Ital. 7:91-99. I877.

BelajefF, W., Zur Lehre von dem Pollenschlauche der Gymnospermen. Ber. Deutsch. Bot. Gesell. 9:280-286. pl. I8. I89 I.

— - Zur Lehre von dem Pollenschlauche der Gymnospermen (Zweite Mittheilung). Ber. Deutsch. Bot. Gesell. I I : 194-20 I. pl. I2. I893.

Benson, Margaret, On a new lycopodiaceous seedlike organ. New Phytologist I $: 58,59$. fig. 3. $\mathbf{1 9 0 2 .}$

-, The fructification of Lyginodendron Oldhamium. Annals of Botany I 6:575, 576. figs. 31 . I902.

structure. Annals of Botany I8: I6I-I77. pl. II. I904.

- On the contents of the pollen chamber of a specimen of Lagenostoma oz'oides. Bot. Gazette 45:409-412. jigs. 2. 1908.

-

Berridge, Ethel M., and Sanday, Elizabeth, Oogenesis and embryogeny in Ephedra distachya. New Phytologist 6: 128-134, 167-174. pls. 3, 4. 1907. Berry, EDward W., Some araucarian remains from the Atlantic coastal plain. Bull. Torr. Bot. Club 35:249-260. pls. II-I6. I908.

—_, A mid-cretaceous species of Torreya. Amer. Jour. Sci. 25:382-386. I908.

Bertrand, C. E., et Renault, B., Recherches sur les Poroxylons. Archiv. Bot. Nord. France 3: pp. 47. figs. 79. 1886.

Bessey, Charles E., The morpology of the pine cone. Bot. Gazette 33:157I59. $p l .8$. 1902.

Bessex, E. A., Notes on the spermatozoids of Ginkgo. Science I3:255. 1901. Blackilan, V. H., On the cytological features of fertilization and related phenomena in Pinus silvestris L. Phil. Trans. Roy. Soc. London B I90:395426. pls. I2-I 4. I 898 .

Bower, F. O., On the germination and histology of the seedlings of Welwitschia mirabilis. Quart. Jour. Micr. Sci. $21: 15-30$. pls. 3, 4. I88r.

- - On the further development of Welwitschia mirabilis. Quart. Jour. Micr. Sci. 2 I $: 57$ I-594. pls. 22, 23. I88 I.

—_- The germination and embryology of Gnetum Gnemon. Quart. Jour. Micr. Sci. $22: 278-298$. pl. 25. 1882.

Braun, A., Vortrag auf dem Congrès scientifique de France, Ioth session (Strassburg), pp. I 7 I, I72. I 842 (communicated in BRAUN's Leben von C. METTENiUS, p. 335. Berlin. 1882). 
Brongnlart, A., Recherches sur l'organisation des tiges des Cycadées. Ann. Sci. Nat. Bot. I. I6:389-402. pls. 20-22. I 829 .

-_ Recherches sur les graines fossiles silicifiés. Paris. r88 I.

Brooks, F. 'T., and Stiles, IV., The structure of Polocarpus spinulosa (Snith) R. 13r. Annals of Botany 24:305-318. pl. 21. 1910.

Brown, Robert, Character and description of Kingia, a new genus of plants found on the S.W. coast of New Holland, with observations on the structure of its unimpregnated ovulum and the female flower in Cycadeac and Coniferae. 1827. Included also in BRowN's Miscellaneous botanical works I: I866.

Browne, LADY ISABEL, 'The phylogeny and interrelationships of the Pteridoplyta.

V. Filicales. New Phytologist 7:230-253. 1908.

Burlingane, L. L., The staminate cone and male gametophyte of Podocarpus. Bot. Gazette 46: 16r-r78. pls. 8, 9. figs. 9. 1908.

Butterworti, J., Some further investigation of fossil seeds of the genus Lagenostoma (Williamson) from the Lower Coal-measures. Men. and Proc. Manchester Lit. and Phil. Soc. 4r: $1-4$. I897.

Calowell, Otis II., Microcycas calocoma. Bot. Gazette 44:ir8-IfI. pls. IO-I3. figs. I4. 1907 .

Campbell, D. H., Mosses and ferns. New York. I895.

Carothers, Ida Eleanor, The development of the ovule and the female gametophyte in Ginkgo biloba. Bot. Gazette 43: II6-I30. pls. 5, 6. I907.

CARruthers, W., On gymnospermatous fruits from the secondary rocks of Britain. Journal of Botany 5:r-2r. r867.

, On fossil cycadean stems from the secondary rocks of Great Britain. Trans. Linn. Soc. Bot. 26:675-708. pls. 54-63. 1870.

CASPARY, R., De Abietinearum floris feminei structura morphologica. Ann. Sci. Nat. Bot. IV. I4:200-209. I860.

Čelakovskī, L., Zur Gymnospermie der Coniferen. Flora 62:257-264, 272283. 1879.

- Zur Kritik der Ansichten von der Fruchtschuppe der Abietineen. Abhandl. Königl. Böhm. Gesell. Wiss. VI. I I : I882.

- Die Gynmospermen: eine morphologisch-phylogenetische Studie. Abhandl. Königl. Böhm. Gesell. Wiss. VII. 4:I-48. I\$9o.

-, Die Vermehrung der Sporangien vou Ginkgo biloba L. Oesterreich. Bot. Zeitsch. 50:229-237, 276-283, 337-341. 1900.

_- Nachtrag zu meiner Schrift über die Gymnospermen. ExGler's Bot. Jahrb. 24:202-23I. I898.

Chamberlain, Charles J., Winter characters of certain sporangia. Bot. Gazette 25: I25-I28. pl. II. IS98.

-, Oogenesis in Pinus Laricio. Bot. Gazette 27:268-28o. pls. 4-6. IS99. (with Coulter, J. M.), The embryogeny of Zamia. Bot. Gazette 35: 184-194. pls. 6-8. 1903.

, The orule and female gametophyte of Dioon. Bot. Gazette $42: 321-358$. pls. I3-15. figs. 9. 1906. 
Chamberlain, Charles J., Preliminary note on Ceratozamia. Bot. Gazette $43: 137.1907$.

_- Spermatogenesis in Dioon edule. Bot. Gazette 47:215-236. pls. 15-18. figs. 3. 1909 .

_- Dioon spinulosum. Bot. Gazette 48:40I-4I3. figs. 7. 1909.

- - Fertilization and embryogeny of Dioon edule. Bot. Gazette 50:Dec. I9ro.

Chauveaud, G., Passage de la disposition primitive à la disposition sécondaire dans les cotylédons du Pin maritime. Extr. Bull. Mus. Hist. Nat. Paris. I902.

-, Le liber précurseur dans le sapin pinsapo. Ann. Sci. Nat. Bot. VIII. I9:32I-333. 1904 .

-, Origine sécondaire du double faisceau foliare chez les sapins (Abies) et les pins (Pinus). Ann. Sci. Nat. Bot. VIII. 19:335-348. I904.

Chick, Edith, The seedling of Torreya myristica. New Phytologist 2:83-91. pls. 7, S. 1903 .

Chrysler, M. A. (with Coulter, I. M.), Regeneration in Zamia. Bot. Gazette 38: $45^{2-} 45^{8}$. figs. 8. 1904 .

-_- (with Jefrery, E. C.), On cretaceous Pityoxyla. Bot. Gazette 42: I-I5. pls. I, 2. 1906 .

- (with Jefrrey, E. C.), The microgametophyte of the Podocarpineae. Amer. Nat. 4I:355-364. figs. 5. 1907 .

_- Tyloses in tracheids of conifers. New Phytologist 7:198-204. pl.5. I908.

Coker, W. C., Observations on the gametophyte and embryo of Taxodium distichum. Johns Hopkins Univ. Circ. 19:45, 46. 1900.

_- Notes on the gametophytes and embryo of Podocarpus. Bot. Gazette 33:89-107. pls. 5-7. 1902 .

- On the gametophytes and embryo of Taxodium. Bot. Gazette $36: \mathrm{I}-27$, II 4 -I 40. pls. I-II. I903.

, On the spores of certain Coniferae. Science N.S. I9:424. 1904.

, On the spores of certain Coniferae. Bot. Gazette 38:206-213. figs. 24. 1904.

-, Fertilization and embryogeny in Cephalotaxus Fortunei. Bot. Gazette 43:I-10. pl. 1. figs. 5. 1907.

Conpton, R. H. (with South, F. W.), On the anatomy of Dioon edule Lindl. New Phytologist 7:222-229. Igo8.

Constantin, J., et Morot, L., Sur l'origine des faisceaux libéro-ligneux supernuméraires dans la tige des Cycadées. Bull. Soc. Bot. France 32:173. I885. Соok, Mel T., Polyembryony in Ginkgo. Bot. Gazette 34:64, 65. fig. I. I902. -, Polyembryony in Ginkgo. Bot. Gazette 36: 142. I903.

Coulter, John M., Notes on the fertilization and embryogeny of conifers. Bot. Gazette 23:40-43. pl. 6. I897.

, and Chamberlain, C. J., The embryogeny of Zamia. Bot. Gazette 35: I84-194. pls. 6-8. 1903. 
Conlter, John M., and Chrstefr, M. A., Regeneration in Zamia. Bot. Gazelte $38: 45^{2-458 . ~ f i g s . ~ 8 . ~} 1904$.

, and LAN1), IV. J. G., Gametophytes and embryo of Torreyd laxifolia. Bot. Gazette 39:161-178. pls. A, I-3. 1905.

, The embryo sac and embryo of Ginetum Cinemon. Bot. Gazette 46: $43^{-}$ 49. pl. 7. 1908 .

___ Evolutionary tendencies among gymnosperms. Bot. Gazette 48:8 I-97. I 909.

-, Barnes, C. R., and Cowles, H. C., Text book of botany. New York. 1910.

DangEard, P. A., La mode d'union de la lige et de la racine chez les Gymnospermes. Compt. Rend. Acad. Sci. Paris I I0:253, 254. I 890.

-, Recherches sur les plantules des Conifères. La Botaniste 3: 126-204. pls. I.3-17. I 892 .

DEBARY, A., Comparative anatomy of the vegetative organs of the phanerogams and ferms. English translation. I 884 .

DE Fraine, E. (with Hill, T. G.), On the seedling structure of gymnosperms. Annals of Botany 20:471-473. I906.

(with Hill, T. G.), On the seedling structure of gymnosperms. I. Annals of Botany 22:689-7i2. pl. 35. figs. 8. 1908.

- (with HıLL, T. G.), On the seedling structure of gymnosperms. II. Annals of Botany 23:189-227. pl. I5. figs. II. I909.

- (with Hili, T. G.), On the seedling structure of gymnosperms. III. Annals of Botany 23:433-458. pl. 30. 1909 .

- (with Hitl, T. G.), On the seedling structure of gymnosperms. IV.

Gnetales. Annals of Botany 24:319-333. pls. 22, 23. 19 Io.

Drckson, A., Observations on some bisexual cones occurring in the spruce fir (Abies excelsa). Trans. Edinburgh Bot. Soc. 6:4I8-422. I 860.

Dixion, H. N., Fertilization of Pinus silvestris. Annals of Botany 8:2I-34. pls. 3-5. I894.

Dorety, Helen A., see Angela, Sister Helen.

Douliot, H. (with Van Tieghem, Ph.), Sur la polystélic. Ann. Sci. Nat. Bot. VII. 3:275-322. pls. I3, I t. I 886 .

Duchartre, P. E., Mémoire sur les embryons qui ont été décrits comme polycotylés. Ann. Sci. Nat. Bot. III. I0:207-237. pls. 7-10. 1848 .

Eichler, A. W., Ueber II elwilschia mirabilis, etc. Flora 47:459-464, 473-479, $489-496,508-5$ 10, $5^{1} 3^{-520 .} 1863$.

272. 1873 .

- Coniferae in ENgler und Prantl's Natürlichen Pflanzenfamilien $2^{\mathrm{I}}$ : I08. т 889 .

Engetitann, G., Morphology of the carpellary scales of Coniferae. Amer. Jour. Sci. III. I $2: 469,470.1876$. 
Enrico, C. V., Contribuzione alla conoscenza della morphologia e dello sviluppo del fascio vascolare delle foglie delle Cicadacee. Annales di Bot. I : Iog-I I I. pls. 8, g. 1903 .

Fankhauser, J., Entwickelung des Stenzels und Blattes von Ginkgo. Bern. 1882.

Farier, J. B., On the occurrence of two prothallia in the embryo sac of Pinus. Annals of Botany 6:2 I3, 214. fig. 5. I892.

Faull, J. H., The anatomy of the Osmundaceae. Bot. Gazette $32: 381-420$. pls. I4-I7. I9Or.

Ferguson, Margaret C., The development of the pollen tube and the division of the generative nucleus in certain species of pines. Annals of Botany I5: 193-223. pls. I2-I4. I9OI.

-, The development of the egg and fertilization in Pinus Strobus. Annals of Botany I 5:435-479. pls. 23-25. I $90 \mathrm{I}$.

- Contributions to the life history of Pinus, with special reference to sporogenesis, the development of the gametophytes, and fertilization. Proc. Wash. Acad. Sci. 6:1-202. pls. 1-24. I904.

Fliche, P. (with Zeiller, R.), Découverte de strobiles de Sequoia et de Pin dans le Portlandien des environs de Boulogne-sur-Mer. Compt. Rend. Acad. Sci. Paris 137:1020-1022. 1903.

—_ - et Zeiller, R., Note sur un florule portlandienne des environs de Boulogne-sur-Mer. Bull. Soc. Geol. France IV. 4:787-8I 2. I904.

Ford, Sibille C. (with Seward, A. C.), The Araucarieae, recent and extinct. Abstract read before Roy. Soc. London, December 1905.

- (with Seward, A. C.), The Araucarieae, recent and extinct. Pliil. Trans. Roy. Soc. London B I98:305-41 I. pls. 23, 24. figs. 28. 1906.

Fraine, E. De, see De Fraine.

FUJII, K., On the different views hitherto proposed regarding the morphology of the flowers of Ginkgo biloba. Bot. Mag. Tokyo Io:15-25, I04-I IO. pl. I. I896.

—_- (Has the spermatozoid of Ginkgo a tail or not?). Bot. Mag. Tokyo I 2:287-290. I898. (Japanese)

- (On the morphology of the spermatozoid of Ginkgo). Bot. Mag. Tokyo I 3:260-266. pl. 7. I899. (Japanese)

-_, (Account of a sperm with two spiral bands). Bot. Mag. Tokyo I4: I6, I7. Jan. I900. (Japanese)

- (with STOPEs, MARIE C.), The nutritive relations of the surrounding tissues to the archegonia in gymnosperms. Beih. Bot. Centralbl. 20:I-24. pl. I. 1906 .

- (with Stopes, Marie C.), Studies on the structure and affinities of cretaceous plants. Phil. Trans. Roy. Soc. London B 20I:I-90. pls. I-g. I910; abstract in Annals of Botany 24:231, 232. I910.

Gerry, E., The distribution of the "bars of Sanio" in the Coniferales. Annals of Botany 24:IIg-I24. pl. I3. I9I0. 
Gozise, K., Outlines of classification and special morphology. Enghlish trans. lation. I 887 .

, Organography of plants. Einglish translation. Igoo.

, Morphologische und biologische Bemerkungen. I3. Leber die Pollenentleerung bei einiger Gymnospermem. Flora 91:237-263. figs. 19. 1902.

Goroscrankin, J., Zur Kenntniss der Corpuscula bei den Gymnospermem. Bot. 7eit. $4 \mathrm{I}: \mathrm{S}_{25}-8_{3}$ I. pl. $7: 1$. I $88_{3}$; Ueber den Befruchtung-P'rocess bei l'inus Pumilio. $\mathrm{ISS}_{3}$.

Gothas, IV., Zur Anatomie lebender und fossiler Gyomospermenhölzer. Abhandl. Preuss. Geol. Landesanstalt. Neue Folge. Heft 44. 1905.

Gowax, Miss J. (with SEward, A. C.), The maidenhair tree (Ginkgo biloba L.). Annals of Botany 14:109-15t.pls. 8-10. I900.

Grand 'Eury; C., La flore carbonifère du Département de la Loire. Mém. Acad. Sci. 24" pp. 624. pls. 38 . I877.

— Sur les rhizomes et les racines des fougères fossiles et des Cýcadofilices. Compt. Rend. Acad. Sci. Paris I 38:607-6ı. I904.

—- Sur les graines des Neuropteridées. Compt. Rend. Acad. Sci. Paris I 39:23-27, 782-786. I904.

- Sur les graines trouvées attachées au Pecopteris Pluckenetii Schlot. Compt. Rend. Acad. Sci. Paris 140:920-923. figs. 2. I905.

Rend. Acad. Sci. Paris 140:995-998. 1905.

—- Sur les graines de Sphenopleris, sur l'attribution des Codonospermum, et sur l'extrême variété des graines de fougères. Compt. Rend. Acad. Sci. Paris I4I:SI2-SI5. I905.

- Sur les inflorescences des fougères avec graines, etc. Compt. Rend. Acad. Sci. Paris 143:764. I906.

Hayata, B., Taiwania, a new genus of conifers. Jour. Linn. Soc. Bot. 32:330332. pl. I6. 1906.

- On Taiwania and its affinity to other genera. Bot. Mag. Tokyo 2I:2I27. pl. I. I907.

Hasdon, Walter T., The seed production of Pinus sylvestris. Proc. and Trans. Liverpool Biol. Soc. 22: I--32. figs. I6. I907.

Heer, O., Zur Geschichte der Ginkgo-artigen Bäume. ExGler's Bot. Jahrb. I : I-I3. I 880 .

- Flora fossilis arctica. I868-I88 3 .

Hill, T. G., On secondary thickening in recent Pteridophyta. New Phỵtologist 5:208-2 I4. 1906 .

of Botany 20:47I-473. 1906.

, The germination of Gnetum Gnemon L. Jour. Roy. Hort. Soc. 34: I, 2. I 908 .

- and DE FraINe, E., On the seedling structure of grmnosperms. I. Annals of Botany 22:689-712. pl. 35. figs. S. I908. 
Hill, T. G., and De Fraine, E., On the seedling structure of gymnosperms.

II. Annals of Botany 23:189-227. pl. 15. figs. II. 1909.

- - and De Fraine, E., On the seedling structure of gymnosperms. III.

Annals of Botany 23:433-458. pl. 30. 1909 .

- , and DE Fraine, E., On the seedling structure of gymnosperms. IV.

Gnetales. Annals of Botany 24:319-333. pls. 22, 23. 1910.

Hirasé, S., Études sur la fécondation et l'embryogénie du Ginkgo biloba. Jour.

Coll. Sci. Imp. Univ. Tokyo 8:307-322. pls. 31, 32. I 895.

, (Announcement of the spermatozoid of Gingko). Bot. Mag. Tokyo I0: I7I, I72. May I8g6. (Japanese)

-, (Preliminary report on the spermatozoid of Ginkgo). Bot. Mag. Tokyo

I $0: 325-328$. Oct. I 896 . (Japanese)

__ Études sur la fécondation et l'embryogénie du Ginkgo biloba. Jour.

Coll. Sci. Imp. Univ. Tokyo I2:103-149. pls. 7-9. I898.

Hofmeister, W., Vergleichende Untersuchungen der Keimung, Entfaltung, und

Fruchtbildung höherer Kryptogamen und der Samenbildung der Coniferen.

pp. 179. pls. 33. Leipzig. 1851. English translation. London. 1863.

_- Embryobildung der Phanerogamen. Jahrb. Wiss. Bot. I:82-I88.

pls. 7 -IO. ${ }_{1} 85^{8}$.

- Lehre der Pflanzenzelle. I867.

Hollick, A., and Jefrrey, E. C., Affinities of certain cretaceous plant remains commonly referred to the genera Dammara and Brachyphyllum. Amer. Nat. 40: I89-215. pls. I-5. 1906.

- - and JefFreY, E. C., Studies of cretaceous coniferous remains from Kreischerville, New York. Mem. N.Y. Bot. Garden 3:1-I38. pls. $1-29$ Igog.

Ноокеr, J. D., On Welwitschia, a new genus of Gnetaceae. Trans. Linn. Soc.

London 24: I-48. pls. I-I4. I863.

Hutrox, J. (with Lindeey, J.), Fossil flora of Great Britain. I8zo.

Ikexo, S., Das Spermatozoid von Cycas rezoluta. Bot. Mag. Tokyo ro: 367 , 368. 1896.

___ Vorläufige Mittheilung über die Spermatozoiden bei Cycas revoluta. Bot. Centralbl. 69: I-3. I897.

_- Untersuchungen über die Entwickelung der Geschlechtsorgane und den Vorgang der Befruchtung bei Cycas revoluta. Jahrb. Wiss. Bot. 32:557-602. pls. 8-IO. I898.

- C Contribution à l'étude de la fécondation chez le Ginkgo biloba. Ann. Sci. Nat. Bot. VIII. I3:305-3I8. pls. 2, 3. I90I.

Jaccard, P., Le développement du pollen de l'Ephedra helvetica. Archiv. Sci.

Phys. et Nat. III. 30:280-282. I893; rev. in Bot. Centralbl. Beih. 4:230. I894.

-, Recherches embryologiques sur l'Ephedra helvetica. Bull. Soc. Vaudoise Sci. Nat. 30: pls. Io. I894; rev. in Bot. Centralbl. 61:111-113. I895. 
JäGrR, L., Beiträge zur Kenntniss der Endospermbildung und zur Embryologie von T'a.vus baccalu. Flora 86:241-288. pls. 15-19. 1899.

JEFFREY, E. C., The structure and development of the stem in the Ptericlophrita and Gymmosperms. Phil. Trans. Roy. Soc. London B I95:119 I 46. pls. 6. 1902 .

Comparative anatomy of gymmosperms in CoulTer and CIAAMERLAlN"s Norphology of angiosperms. New lork. rgoz.

-, The comparative anatomy of the Coniferales. I. 'The grenus Sequoia. Mem. Boston Soc. Hist. 5:44I-459. pls. 68-71. 1903 .

- A fossil Sequoia from the Sierra Nevada. Bot. Gazette 38:32 I-332. pls. IS, 19. 1904 .

-_- The comparative anatomy of the Coniferales. II. The Abietineae. Mem. Boston Soc. Nat. Hist. 6:1-37. pls. I-7. 1904.

(with Hollick, A.), Affinities of certain cretaceous plant remains commonly referred to the genera Dammara and Brachyphyllum. Amer. Nat. 40: I89215. pls. I-5. 1906.

, and Chrysler, M. A., On cretaceous Pityoxyla. Bot. Gazette 42:1-15. pls. I, 2. 1906.

-, Araucariopitys, a new genus of araucarians. Bot. Gazette $44: 435^{-} 444$. pls. $27-30.1907$.

-, and Chrysler, M. A., The microgametophyte of the Podocarpineae. Amer. Nat. 41:102-107. pls. 8, 9. 1907.

-, On the structure of the leaf in cretaceous pines. Annals of Botany 22:207-220. pls. 13, 14. 1908 .

-, Traumatic ray tracheids in Cunninghamia sinensis. Annals of Botany 22:593-602. pl. 3I. 1908 .

, Are there foliar gaps in the Lycopsida? Bot. Gazette 46:24I-25S. pls. I\%, 18. I908.

- (with Hollick Arthur), Studies of cretaceous coniferous remains from Kreischerville, New York. Mem. N.Y. Bot. Garden 3:1-138. pls. I-29. 1909 .

Juel, H. O., Beiträge zur Kenntniss der Tetradenbildung. Jahrb. Wiss. Bot. 35:626-659. pls. I5, I6. I900.

- Ueber den Pollenschlauch ron Cupressus. Flora 93:56-62. pl. 3. I904. Juranyi, L., Bau und Entwickelung des Pollens bei Ceratozamia longifolia Miq. Jahrb. Wiss. Bot. 8:382-400. pls. $31-34.1872$.

Karsten, G., Beiträge zur Entwickelungsgeschichte der Gattung Gnctum. Bot. Zeit. 50:205-215, 22I-23I, 237-246. pls. 5, 6. I 892 .

-_- Untersuchungen über die Gattung Gnetum. Ann. Jard. Bot. Buitenzorg I I : 195-218. pls. I7-19. IS93.

- - Zur Entwickelungsgeschichte der Gattung Gnetum. Cons's Beitr. Biol. Pflanz. 6:337-382. pls. 8-II. I893.

Kerner yon Marilaun, Das Pllanzenleben. Leipzig and Vienna. isg6. 
Kinston, R., On the fructifications of some ferns from the Carboniferous formation. Trans. Roy. Soc. Edinburgh $33^{\mathrm{I}}:$ I37-156. pls. \&. figs. 7. I887.

-, On the various divisions of British Carboniferous rocks, as determined by their fossil floras. Proc. Roy. Soc. Edinburgh I2:183-257. I893I894.

- On the fructification of Neuropteris heterophylla Brongniart. Proc. Roy. Soc. London 72:487. 1904 (abstract); Phil. Trans. Roy. Soc. London B I 97: I-5. pl. I. I904 (full paper).

- Preliminary note on the occurrence of microsporangia in organic connection with the foliage of Lyginodendron. Proc. Roy. Soc. London 76:358360. pl. 6. 1905 .

-, 'The early history of seed-bearing plants as recorded in the carboniferous flora. Wilde Lecture. Mem. and Proc. Manchester Lit. and Phil. Soc. 49: no. I2. pp. 32. pls. 3. I905.

-, On the microsporangia of the Pteridospermae, with remarks on their relationships to existing groups. Phil. Trans. Roy. Soc. London B I98: 4I $3^{-445}$. pls. $25^{-2}$ S. I906.

Kildahl, N. Johanna, Development of the walls in the proembryo of Pinus Laricio. Bot. Gazette 44:102-107. pls. 8, 9. 1907.

-, The morphology of Phyllocladus alpina. Bot. Gazette 46:339-348. pls. 20-22. I908.

—- Affinities of Phyllocladus. Bot. Gazette 46:464, 465. 1908.

Kubart, Bruno, Die weibliche Blüthe von Jumiperus communis L. Sitzungsber. Kais. Akad. Wiss. Wien I I4: pp. 29. pls. 2. I905.

LAND, W. J. G., A morphological study of Thuja. Bot. Gazette 34:249-259. pls. 6-8. I902.

- Spermatogenesis and oogenesis in Ephedra trifurca. Bot. Gazette 38: I-I8. pls. I-4. 1904 .

(with Coulter, J. M.), Gametophytes and embryo of Torreya taxifolia. Bot. Gazette 39: I6I-I 78. pls. $A, r-3$. r905.

- Fertilization and embryogeny in Ephedra trifurca. Bot. Gazette 44:273292. pls. 20-22. 1907 .

LAxG, W. H., Studies in the development and morphology of cycadean sporangia.

I. The microsporangia of Stangeria paradoxa. Annals of Botany I I :42 I438. pl. 22. 1897 .

- Studies in the development and morphology of cycadean sporangia. II. The ovule of Stangeria paradoxa. Annals of Botany 14:28r-306. pls. I7, I8. 1900 .

LAwson, A. A., The gametophyte, archegonia, fertilization, and embryo of Sequoia sempervirens. Annals of Botany $\mathrm{I} 8: \mathrm{x}-28$. pls. I-4. r9o4.

Annals of Botany I8: 4 r 7-444. pls. 27-30. I904.

- The gametophytes, fertilization, and embryo of Cephalotaxus drupacea. Annals of Botany $2 \mathrm{I}: \mathrm{I}-23$. pls. I-4. I907. 
LAwsox, A. A., The gametophytes and embryo of the Cupressineate, with special reference to Libocedrus decurrens. Annals of Botany 2 I :281-30I. pls. 2.f26. 1907 .

, The gametophytes and embryo of Pseudotsugu Douglasii. Annals of IBotany 23: 163-1So. pls. 12-14. I909.

-, 'The gametophytes and embryo of Sciudopilys ierlicillalu. Annals of Botany 24:4c3-42 I. pls. 29-3I. I9 I0.

Life, A. C., The tubercle-like roots of Cycas revolula. Bot. Gazette 3I:265-27I. figs. IO. I90 I.

Lignier, O., Le fruit du Williamsonia gigas Carr. et les Bennettitales, documents nouveaux et notes critiques. Mém. Soc. Linn. Normandie 2 I : 19-56. figs. 9. 1903.

_- La fleur des Gnétacées est-elle in termédiare entre celle des gymnospermes et celle des angiospermes? Bull. Soc. Linn. Normandie V. $7: 55^{-71}$. I903.

_- Notes complémentaires sur la structure du Bennelfiles Morieri. Bull. Soc. Linn. Normandie V. 8:3-7. figs. 3. 1905.

-_. Le iruit des Bennettitées et l'ascendance des Angiospermes. Bull. Soc. Bot. France IV. 8:I-I7. I908.

- Végétaux fossiles de Normandie. IV. Flore jurassique de Mamers (Sarthe). Université de Caen. pp. 48. pls. 2. I9 Io (?).

Lindley, J., and Hutton, J., Fossil flora of Great Britain. I830.

Lloyd, Francis E., Vivipary in Podocarpus. Torreya 2: I I 3 I 7. figs. 3. 1902.

Lowax, J., Some new features in relation to Lyginodendron Oldhamium. Annals of Botany r6:601, 602. 1902.

Lopriore, G., Ueber die Vielkörnigkeit der Pollenkömer von Araucaria Bidwillii. Vorläufige Mitteilung. Ber. Deutsch. Bot. Gesell. 23:335-3ł6. pl. I5. 1905 .

Lorsy, J. P., Contributions to the life history of the genus Gnetum. Ann. Jard. Bot. Buitenzorg II. I:46-I I4. pls. 2-II. I899.

—- Parthenogenesis bei Gnelum Ula Brongn. Flora 92:397-404. pls. 9, IO. 1903.

Lyox, Harold L., The embryogeny of Ginkgo. Minn. Bot. Studies 3:275-290. pls. 29-43. I904.

MacMlllan, Conway, Note on some British Columbian dwari trees. Bot. Gazette 38:379-38I. figs. 3. I904.

Maslen, Arthur J. (with Scott, D. H.), The structure of the paleozoic seeds Trigonocarpus Parkinsonii Brongniart and Trigonocarpus Oliveri, sp. nov.

I. Annals of Botany $21:$ S9-134. pls. II-I4. 1907.

(with Scott, D. H.), On IIesoxylon, a new genus of Cordaitales (preliminary note). Annals of Botany 24:236-239. I9 Io.

Masters, Maxwell T., Comparative morphology, anatomy, and life history of the Coniferae. Jour. Linn. Soc. London Bot. 27:226-332. figs. 29. I89 I.

_- On the conifers of China. Jour. Linn. Soc. London Bot. 37:410-424. I906. 
Masters, Maxwell $T$., On the distribution of the species of conifers in the several districts of China, and on the occurrence of the same species in neighboring countries. Jour. Linn. Soc. London Bot. 38:198-205. 1908.

Matte, H., Une anomalie de structure dans l'écaille ovulifère de Ceratozamia mexicana. Bull. Soc. Linn. Normandie V. 7:52-54. I903.

-, Recherches sur l'appareil libéro-ligneux des Cycadées. pp. 233. pls. I6. figs. 264 . I904.

- Compléments à la structure mériphytaire du Bowenia spectabilis Hord. Compt. Rend. Assoc. Fr. Adv. Sci. r905:409-416.

-_- Sur la structure de l'embryon et des germinations du genre Zamia L. Bull. Soc. Sci. et Méd. de l'Ouest I8: nos. 2 and 3. 1909.

Mettenius, G. H., Beiträge zur Anatomie der Cycadeen. Abh. K. Sachs. Gesell. Wiss. 7:565-608. pls. I-5. 1861.

Miquel, F. A. W., Monographia Cycadearum. I84I.

Mirake, K., (On the spermatozoid of Ginkgo). Bot. Mag. Tokyo r2:33-39. I898. (Japanese)

_- The spermatozoid of Ginkgo. Jour. Applied Micr. 5: I773-1780. figs. IO. 1902 .

- - On the development of the sexual organs and fertilization in Picea excelsa. Annals of Botany 17:351-372. pls. 16, 17. 1903.

- - Contribution to the fertilization and embryogeny of Abics balsamea. Beih. Bot. Centralbl. 14: 134-r 44. pls. 6-S. r9o3.

-..-. Ueber die Spermatozoiden von Cycas revoluta. Ber. Deutsch. Bot. Gesell. 24:78-83. pl. 6. 1906.

- - The development of the gametophytes and embryogeny of Cuminghamia

- (preliminary note). Bot. Mag. Tokyo 22:45-50. figs. 14. 1908.

- - The development of the gametophytes and embryogeny of Cunninghamia sinensis (full paper). Beih. Bot. Centralbl. 27: I-25. pls. I-5. figs. 2. 1910.

Morot, L. (with Constantin, J.), Sur l'origine des faisceaux libéro-ligneux supernuméraires dans la tige des Cycadées. Bull. Soc. Bot. France 32: 73. 1885.

Mottier, D. M., On the archegonium and apical growth of the stem in Tsuga canadensis and Pinus silvestris. Bot. Gazette $\mathrm{r} 7: \mathrm{r} 4 \mathrm{r}-\mathrm{I} 43$. pl. 8. I892.

MÚrRILL, W. A., The development of the archegonium and fertilization in the hemlock spruce (Tsuga canadensis). Annals of Botany 14:583-607. pls. 3I, 32. 1900.

Nathorst, A. G., Beiträge zur Kenntnis einiger mesozoischen Cycadophyten. Handl. Kgl. Svensk. Vetensk.-Akad. 364: I-28. pls. I-3. 1902.

-_- Palaeobotanische Mitteilungen. I. Pscudocycas, eine neue Cycadophytengattung aus den cenomanen Kreideablagerungen Grönlands. Handl. Kgl. Svensk. Vetensk.-Akad. 42: I-Ir. pls. I-3. 1907.

- Palaeobotanische Mitteilungen. III. Lycostrobus Scottii, eine grosse Sporophyllähre aus den rhätischen Ablagerungen Schonens. Handl. Kgl. Svensk. Vetensk.-Akad. 43:1-12. pls. I, 2. 1908. 
Nathorst, A. G., Palacobotanische Mitteilungen. IV. Ueber die Untersuchung kutinisierter fossiler Pflanzenteile. Mandl. Kigl. Siensk. Vetensk.-Akar!. 43:1-13. pls. I, 2. 1908.

- Palacobotanische Mitteilungen. V'. Antholithus \%eilleri, n. sp., mit noch erhaltenen Pollenkörnern aus den rhäitischen Nblagerungen Schonens. Handl. Kgl. Srensk. Ietensk.-Akad. 43:20-24. pls. 2, 4. 1908.

_-_-, Palacobotanische Mitteilungen. V'll. Handl. Kul. Siensk. Vetensk.Akad. 43: no. 8. 1909.

- Palaeobotanische Mitteilungen. VIII. Handl. Kgl. Siensk. Vetensk.Akad. 45 : no. 4. rgro.

Nicuods, GEORge E., A morphological study of Juniperus communis var. de pressa. Beih. Bot. Centralbl. 25:201-24r. pls. 8-17. figs. 4. 19ro.

Noréx, C. O., Ueber Befruchtung bei Juniperus communis. Vorläufigc Mitteilungen. Arkir. Bot. Srensk. Vetensk.-Akarl. 3: Pl). I1. I904.

- - Z Zur Entwickelungsgeschichte des Juniperus communis. Uppsala Universitets Arskifift I907: pp. 64. pls. 4 .

_- Zur Kenntnis der Entwicklung ron Saxegothaea conspicua Lindll. Srensk. Bot. Tidsskr. 2:101-122. pls. 7-0. I908.

Oersted, A. S., Bidrag til Naaletroeernes Morphologi. Vidensk. Meddel. Nat. Foren. Copenhagen. I864.

Oliver, F. W., On some points of apparent resemblance in certain fossil and recent gymnospermous seeds. New Phytologist $\mathrm{I}: 145^{-15} 4$. figs. f-6. I902. , The orules of the older gymnosperms. Annals of Botany $x 7: 451-476$. pl. 24. figs. 20. 1903 .

, and ScotT, D. H., On Lagenostoma Lomaxii, the seed of Lyginodendron. Proc. Roy. Soc. London 7I:477-48I. I903; reprint in Annals of Botany I 7:625-629. I903.

- A new pteridosperm. New Phytologist 3:32. I904.

— - Notes on Trigonocarpum Brongn. and Polylophospermum Brongn., two genera of paleozoic seeds. New Phytologist 3:96-104. pl. 2. I904.

- - On the structure and affinities of Stephanospermum Brongniart, a genus of fossil gymnosperm seeds. Trans. Linn. Soc. London Bot. I1. 6:36I400. pls. $41-74$. 1904 .

—- and Scotт, D. H., On the structure of the paleozoic seed Lagenostoma Lomaxii, with a statement of the eridence upon which it is referred to Lyginodendron. Proc. Roy. Soc. London. Jan. 21, 1904 (abstract preprint); Phil. Trans. Roy. Soc. London B 197:193-247. pls. 4-10. 1904 (full paper).

, Ueber die neuentdeckten Samen der Steinkohlenfarne. Biol. Centralbl. 25:40I-4I8. figs. 6. 1905 .

—_, "The origin of gymnosperms"; a discussion at the Linnean Society. New Phytologist 5:68-76, 141-1 48 . 1906.

—_, Pteridosperms and angiosperms. New Phýtologist 5:232-242. 1906.

___ On Physostoma clegans Williamson, an archaic type of seed from the I'aleozoic rocks. Annals of Botany 23:73-II6. pls. 5-7. figs. 10. 1909. 
Osbors, T. G. B., The lateral roots of Amyelon radicans Will., and their mycorhiza. Annals of Botany 23:603-6i I. pls. 46, 47. I909.

OtTley, Alice M., The development of the gametophytes and fertilization in Juniperus communis and Juniperus virginiana. Bot. Gazette 48:3I-46. pls. I-4. I909.

PARkix, Johx (with Arber, E. A. Newell), On the origin of angiosperms. Jour. Linn. Soc. London Bot. 38:29-80. 1907.

- (with Arber, E. A. Newell), Studies in the evolution of the angiosperms: the relationship of the angiosperms to the Gnetales. Annals of Botany $22: 489-515$. I908.

Parlatore, F., Studi organografici sui fiori e sui frutti delle Conifere. Opuscula botanica. I864.

Pavolini, A. F., La Stangeria paradoxa Th. Moore. Nuovo Giom. Bot. Ital. r6:335-35r. rgog.

PAx, F., Allgemeine Morphologie der Pflanzen mit besonderer Berücksichtigung der Blüthenmorphologie. I89o.

Pearson, H. H. W., Notes on the South African cycads. I. Trans. S. African Phil. Soc. I6:341-354. pls. 6-8. 1906.

- Some observations on W'elwitschia mirabilis Hooker. Phil. Trans. Roy. Soc. London B 198:246. I906.

-_- Further observations on Welwitschia. Phil. Trans. Roy. Scc. London B 200:33I-402. pls. 22-30. 1909.

Pexhallow, D. P., The anatomy of the North American Coniferales, together with certain exotic species from Japan and Australia. Amer. Nat. 38:243273, 33 I-359, 523-554, 69 I-723. I 904 .

—_ A manual of the North American gymnosperms, exclusive of the Cycadales but together with certain exotic species. Boston. I907.

Pilger, R., Taxaceae in Exgler's Das Pflanzenreich. I903.

Pollock, Janes B., Variations in the pollen grain of Picea excelsa. Amer. Nat. 49:253-286. pl. I. 1906.

Potonié, H., Lehrbuch der Pflanzenpalaeontologie. Berlin. 1899.

- Cycadofilices in Engler und Prantl's Natürlichen Pflanzenfamilien $2^{\mathrm{r}}: 780-798.1902$

ReinkF, J., Parasitische Anabaena in Wurzelen der Cycadean. Gött. Nachr. I07. I 872 .

Rexault, B., Recherches sur la fructification de quelques végétaux provenant des gisements silicifiés d'Autun et de Saint Etienne. Ann. Sci. Nat. Bot. VI. $3: 5^{-29}$. pls. I-4. I 876 .

----, Structure comparée de quelques tiges de la flore carbonifère. Nouv. Arch. Nus. Hist. Nat. II. 2:213-348. pls. S. I879.

- Cours de botanique fossile. Paris. I880-I884.

(with Bertrand, C. E.), Recherches sur les Poroxylons. Archiv. Bot. Nord. France 2: pp. I47. figs. 79. 1886. 


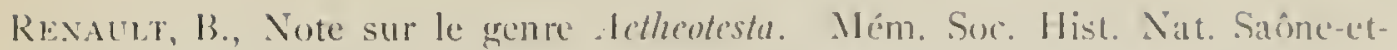
Loire, pl). 156, 158.1887 .

_-_-, Bassin houilter et Permien d'Autun el d'lépinac. IV. Flore fossile. Part 11. pl). 578. pls.63. Paris. I 896 .

Rwaxer, Orto, Ueber Zwitterblithen bei Juniperus communis. Flora 93:297300. figs. 3. 1904.

Robertson, Amanes, Spore formation in Torreya californicu. New Phytologist 3: $13.3^{-1} 4$ S. pls. 3, \% 1004 .

-.- Studies in the morphology of Torreyel californica. II. 'The sexual organs and fertilization. New Phýtologist 3:205-2 I6. pls. 7-0. 1904.

- Some points in the morphology of Phyllocladus alpina Hook. Innals of Botany 20:259-265. pls. I7, IS. I906.

_-_, The Taxoideae; a phylogenetic study. New Phytologist 6:92-102. pl. 1.1907 .

SAblox, Lecherc Du, Recherches sur la tige des fougères. Ann. Sci. Nat.

Bot. VII. I I : I-I6. pls. I, 2. Isgo.

SACHS, J., Lehrbuch. 1868.

-, 'T'exthook of botany. Second English edition. i 882.

Sanday, Elizabeth (with Berkidge, Ethel M.), Oogenesis and embryogeny in Ephedra distachya. New Phytologist 6: I28-134, I67-1 74. pls. 3, 4. 1907.

SAxton, IV. 'T., Parthenogenesis in Pinus Pinaster. Bot. Gazette 47: $006-409$. figs. 7. I909.

-_- Development of the embryo in Pinus Pinaster Soland., with some notes on the life history of the species in Cape Colony. S. African Jour. Sci. $6: 52-59 . p l .2$. I 909 .

-, Preliminary account of the development of the ovule, gametophytes, and embryo of lliddringtonia cupressoides Endl. Bot. Gazette 48:16I-178. pl. II. figs. 3. I gog.

I8. pl. 2. igro.

- - Contributions to the life history of Widdringtonia cupressoides. Bot. Gazette 50:30-48. pls. $I-3$. I9 Iо.

-_.., Contributions to the life history of Callitris. Annals of Botany 24: July I9I0.

-._. Notes on the anatomy of II iddringtonia and Callitris. S. African Jour. Sri. 282-286. figs. IJ. May 1910.

Schleiden, M. J., Sur la signification morphologique du placentaire. Ann. Sci. Nat. Bot. II. I $2: 373-376$. 1839 .

Schnemer, A., Mutualistic symbiosis of algae and bacteria with Cycas rezoluta. Bot. Gazette I 9:25-32. pl. 3. I 894 .

Scott, D. H. (with Willianson, W. C.), Further observations on the organization of the fossil plants from the Coal-measures. III. Lyginodendron and Heterangium. Phil. Trans. Roy. Soc. London B 186:703-779. pls. I\&-21. I 896. 
ScotT, D. H., The anatomical characters presented by the peduncles of Cycadaceae. Annals of Botany I I :399-419. pls. 20, 21. I897.

_- On the structure and affinities of fossil plants from the paleozoic rocks. III. Medullosa anglica, a new representative of the Cycadofilices. Proc. Roy. Soc. London 64:249-253. I899 (abstract); Phil. Trans. Roy. Soc. London B I9I:8 I-I26. pls. 5-13. I899 (full paper).

-, On the primary wood of certain araucarioxylons. Annals of Botany I 3 : 6 I 5-6I9. I 899 .

- Note on the occurrences of a seedlike fructification in certain paleozoic lycopods. Proc. Roy. Soc. London 67:306-309. I900.

- - Studies in fossil botany. London. I 900.
- , On the structure and affinities of fossil plants from the paleozoic rocks.

IV. The seedlike fructification of Lepidocarpon, a genus of lycopodiaceous cones from the Carboniferous formation. Phil. Trans. Roy. Soc. London B I94:29I-333. pls. 38-43. I90I.

, Primary structure of certain paleozoic stems. Trans. Roy. Soc. Edinburgh $40^{2}: 33^{1-365}$. pls. I-6. figs. 5. 1902.

, The old wood and the new. New Phytologist I :25-30. I902.

- (with Oliver, F. W.), On Lagcnostoma Lomaxii, the seed of Lyginodendron. Proc. Roy. Soc. London 71:477-48I. I933; reprint in Annals of Botany I 7:625-629. I903.

- (with Oliver, F. W.), On the structure of the paleozoic seed Lagenostoma Lomaxii, with a statement of the evidence upon which it is referred to Lyginodendron. Proc. Roy. Soc. London. Jan. 2I, I904 (abstract preprint); Phil. Trans. Roy. Soc. London B I97:193-247. pls. $4^{-10 .}$ I904 (full paper).

-, What were the carboniferous ferns? Jour. Roy. Micr. Soc. I9052: I 37-I 49. pls. I-3. figs. 32, 33 .

- 2 , The sporangia of Stauropteris Oldhamia Binney. New Phytologist 4: II 4-120. figs. 2. 1905 .

—_ The fernlike seed plants of the carboniferous flora. Sci. papers Internat. Bot. Congress Vienna. I905.

- - - The early history of seed-bearing plants, as recorded in the carboniferous flora (The Wilde Lecture). Mem. and Proc. Manchester Lit. and Phil. Soc. $49^{3}$ : pp. 32. pls. 3. 1905.

__ "The origin of gymnosperms"; a discussion at the Linnean Society. New Phytologist 5:68-76, I 4 I-I 48. igo6.

- On Sutcliffia insignis, a new type of Medulloseae from the Lower Coalmeasures. Trans. Linn. Soc. London II. 7:45-68. pl. 4. I906.

-_ The present position of paleozoic botany. Progressus rei botanicae (J. P. Lotsi) I ${ }^{\mathrm{I}}:$ I $39-217^{-2}$. figs. 37. 1906.

_- The occurrence of gerninating spores in Stauropteris Oldhamia. New Phỵtologist 5: I 70-I 72. 1906. 
ScotT, D. H., and MastFa, A. J., The structure of the paleozoic seeds Trigonncarpus Parkinonsii Brongniart and Trigonocarpus Oliveri, sp. nox. I. Amnals of Botany $21: 89-134$. pls. II I\%. I907.

_- - Studies in fossil botany. Second edition. Vol. I. 1,ondon. 1908.

, The paleontological record. II. Plants. Darwin and modern science.

PP. 200-222. Cambridge University Press. I 909.

-... Studies in fossil botany. Second edition. Vol. II. I.ondon. I929.

- and MasLe., A. J., On Mesorylon, a new genus of Cordaitales (preliminary note). Annals of Botany 24:236-239. I9 Iо.

SEllards, E. H., Codonotheal, a new type of spore-bearing organ from the Coalmeasures. Amer. Jour. Sci. IV. 16:87-95. p!. \&. I90.3.

- _ - Notes on the spore-bearing organ Codonotheca and its relationship with Cycadofilices. New Phytologist 6: $175^{-178 . ~} 1907$.

SEWARD, A. C., Notes on the Binney collection of Coal-measure plants. II. Megaloxylon, gen. nor. Proc. Cambridge Phil. Soc. Io: I58-I74. pls. 57. I 899 .

, and Gowax, Miss J., The maidenhair tree (Ginkgo biloba L.). Annals of Botany $14: 109-154$. pls. 8-IO. 1900 .

- Floras of the past; their composition and distribution. Rept. British Assoc. Sci. Section K I903: pp. 25.

- , and Ford, Sibille O., The Araucarieae, recent and extinct. Abstract read before Roy. Soc. London, December 1905.

_._. Notes on cycads. Proc. Cambridge Phil. Soc. I 3:293-302. 1906.

, "The origin of gymnosperms"; a discussion at the Linnean Society.

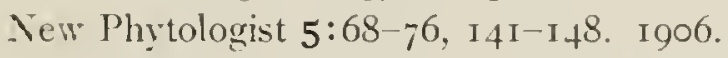

, and Ford, SibIlle O., The Araucarieae, recent and extinct. Phil. Trans. Roy. Soc. London B 198:305-4II. pls. 23, 24. figs. 28. 1906.

Shaw, F. J. F., A contribution to the ana tomy of Gingko biloba. New Phytologist $7: 85-92$. figs. I6-IS. I9o8.

-_- The seedling structure of Araucaria Bidaillii. Annals of Botany 23:32I-334. pl. 2I. figs. 6. 1909.

SHaw, II. R., Contribution to the life history of Sequoiu. Bot. Gazette 2I:332339. pl. 24. 1896 .

Sincott, E. A. IV., Paracedroxylon, a new type of araucatian wood. Rhodora I I : 165-173. pls. So, S1. 1909.

Sucdskr, N., Ueber die Entwickelungsgeschichte des Juniperus communis. Vorläufige Mitteilung. Ber. Deutsch. Bot. Gesell. 23:212-2I6. pl. 6. 1905. Smith, Frances Grace, Morphology of the trunk and development of the microsporangium of cycads. Bot. Gazette 43:187-204. pl. I0. 1907.

- Development of the orulate strobilus and young orule of Zamia fori. dana. Bot. Gazette 50:128-141. figs. 22. 1910.

Smith, Isabel S., The nutrition of the egrin in Zamiu. Pot. Gazette 37:346-352. figs. 6. 1904 . 
Sokolowa, Mlle C., Naissance de l'endosperme dans le sac embryonnaire de quelques gymnospermes. Moscou. I880.

Solms-Laubach, H., Die Sprossfolge der Stangeria und der übrigen Cycadeen.

Bot. Zeit. 48: I77-187, I93-199, 209-2I5, 225-230. I890.

- Ueber die Fructification von Bennettites Gibsonianus Carr. Bot. Zeit. 48:789-798, 805-81 5, 82 I-833, 843-847. pls. 9. Io. I89o.

- - Fossil botany. English translation. I891.

South, F. IV., and Compton, R. H., On the anatomy of Dioon edule Lindl.

New Phytologist 7:222-229. I go8.

Sprecher, Andreas, I.e Ginkgo biloba L. pp. 208. figs. 225. Genève. I907. Starr, Anna M., 'The microsporophylls of Ginkgo. Bot. Gazette 49:5I-55. pl. 7. I9IO.

Stexzel, G., Beobachtungen an durchwachsenen Fichtenzapfen. Ein Beitrag zur Morphologie der Nadelhölzer. Nov. Act. Nat. Cur. 38:289-350. pls. $12-15.1876$.

Sterzel, J. T. (with Weber, O.), Beiträge zur Kenntniss der Medulloseae.

XIII. Ber. Naturwiss. Gesell. Chemnitz. pp. I02. pls. 9. figs. 33. I896. Stiles, IV., The anatomy of Saxegothaea conspicua Lindl. Svensk. Bot. Tidsskr. 2: IOI-I 22. pls. $7^{-9}$. I 908 .

- - (with Brooks, F. T.), The structure of Podocarpus spinulosa (Smith) R. Br. Annals of Botany 24:305-318. pl. 21. I910.

Stopes, Marie C., On the leaf structure of Cordaites. New Phytologist $2: 9$ I98. pl. 9. I903.

- Beiträge zur Kenntniss der Fortpflanzungsorgane der Cycadeen. Flora 93:435-482. figs. 37 . I904.

- - On the double nature of the cycadean integument. Annals of Botany I $9: 56$ I-566. I905.

__ A new fern from the Coal-measures: Tubicaulis Sutcliffi spec. nov. Mem. and Proc. Manchester Lit. and Phil. Soc. 50: I-30. pls. I-3. Igo6.

_-_- and FUJI, K., The nutritive relations of the surrounding tissues to the archegonia in gymnosperms. Beih. Bot. Centralbl. 20:I-24. pl. r. I906.

__ - and FUJII, K., Studies on the structure and affinities of cretaceous plants.

Phil. Trans. Roy. Soc. London B 20I:I-90. pls. I-9. I910; abstract in Annals of Botany 24:23I, 232. I9IO.

Strasburger, E., Die Befruchtung bei den Coniferen. i 869.

-... Die Coniferen und die Gnetaceen. i 872.

-, Ueber Zellbildung und Zelltheilung. 1876 .

—, Die Befruchtung und Zelltheilung. Jen. Zeitsch. $2: 435^{-5} 3^{6}$. pls. $27^{-} 35$. 1877 .

___ Befruchtung und Zelltheilung. i 878 .

__ Die Angiospermen und die Gymnospermen. I 879.

- Neue Untersuchungen, etc. $188_{4}$.

—, Histologische Beiträge 3: I5I. I89 I. 


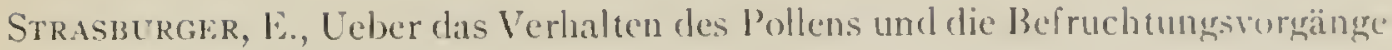
bei den Ciymnospermen. IS92.

_- Anlage des Embryosackes und Prothalliumbitdung bei ler Fibe nebst anschliessenden Erörterungen. Festschrift zum siebzigsten Geburtstage

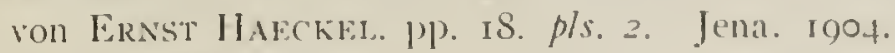

Stur, D., Zur Morphologie und Systematik der Kulm- und Karbonfarne. Sitzungsb. Akad. Wiss. Wien 88: pp. 21 4. figs. \&. 1883.

Tanstey, A. G., Lectures on the evolution of the filicinean rascular system. II. The Botryopterideac. New Phytologist 6:53-68. figs. 22. I907.

Thinout, E., Recherches sur l'appareil mâle des gymnospermes. Pls. 265. pls. I6. Lille. I896.

'Thiessen, Reinhard, The vascular anatomy of the seedling of Dioon cdule. Bot. Gazelte 46:357-380. pls. 23-29. 1908.

Thouas, Etmeı. N., "The origin of gymnosperms"; a discussion at the Linnean Society. New Phytologist 5:68-76, 141-148. 1906.

- _ , A theory of the double leaf trace founded on seedling structure. New Plyytologist 6:77 91. figs. f. 1907.

Thompsos, Wr. P., On the origin of ray tracheids in the Coniferae. Bot. Gazette 50: 101-i 16. figs. 16. 1910.

Thouson, R. B., Preliminary note on the Araucarineae. Science N.S. 22:88. 1905.

-, The megaspore membrane of the grimnosperms. Univ. Toronto Biol. Series no. 4. pp. 64. pls. 5. 1905.

-, "The origin of gymmosperms"; a discussion at the Linnean Society. New Phytologist 5:68-76, I41-1 48. 1906.

- Note on the pollen of Microcachrys. Bot. Gazette 46:465, 466 . I -, On the pollen of Microcachrys tetragona. Bot. Gazette 47:26-29. pls. I, 2. 1909 .

, The megasporophyll of Saxcgothaea and Vicrocachrys. Bot. Gazette $47: 345^{-354}$. pls. 21-25. 1909 .

Tison, A., Le nucelle stigmatifère et la pollination chez le Survgothaca conspicua. Compt. Rend. Acad. Sci. Paris 147: 137-139. 1908.

—-, Sur le Sawgothaca Lindl. Mém. Soc. Linn. Normandie 23:139-160. pls. 9, IO. I909.

Treub, M., Recherches sur les Cycadées. Ann. Jard. Bot. Buitenzorg 2:32-53. pls. $I-7$. I88 I (date of preprint, volume date being I885).

- Recherches sur les Cycadées. 3. Embryogenie du Cy'cas circinalis. Ann. Jard. Bot. Buitenzorg 4: I-I I. pls. I-3. I884.

VAx Tieghem, Ph., Anatomie comparée de la fleur femelle et du fruit des Cycadées, des Conifères, et des Gnetacées. Ann. Sci. Nat. Bot. V. ro:269-304. pls. $13-16$. I869.

- Recherches sur le symétrie de structure des plantes vasculaires. Ann. Sci. Nat. Bot. I. I 3: 1-3 I t. pls. 3-8. I870. 
Van Treghen, Ph., et Douliot, H., Sur la polystélie. Ann. Sci. Nat. Bot. VII. 3:275-322. pls. I3, I4. I 886 .

- - Traité de botanique. Paris. ISgI.

Vierhapper, F., Entwurf eines neuen Systemes der Coniferen. Abhandl. K. K. Zool.-Bot. Gesell. Wien 5: I-56. I9ic.

Vox Mohl, Hugo, Ueber den Bau des Cycadeenstammes. Abh. K. Acad. München I : $397^{-442 . ~ I 832 ; ~ r e p u b l i s h e d ~ a n d ~ r e v i s e d ~ i n ~ V e r m i s c h t e ~ S c h r i f t e n, ~}$ pp. I95-2II. I845.

—_- Ueber die männlichen Blüthen der Coniferen. Verm. Bot. Schriften, pp. 45-6I. I845. (Published as a dissertation, I837.)

—_, Morphologische Betrachtung der Blätter von Sciadopitys. Bot. Zeit. 29:17-23. 187 I.

WARD, LESTER F., The Cretaceous formation of the Black Hills as indicated by the fossil plants. Igth Annual Report U.S. Geol. Survey. I9oo.

-_- Description of a new genus and twenty new species of fossil cycadean trunks from the Jurassic of Wyoming. Proc. Wash. Acad. Sci. I:253-300. pls. I4-2I. I900.

- - Elaboration of the fossil cycads in the Yale Museum. Amer. Jour. Sci. IV. I $0: 327-345$. pls. 2-4. I900.

Waruing, E., Recherches et remarques sur les Cycadées. Oversigter Vidensk. Selsk. Forh. I877.

-, Contributions à l'histoire naturelle des Cycadées. Oversigter Vidensk. Selsk. Forh. I879.

Watson, Sereno, Botany King's Exp. i87 I.

Webber, H. J., Peculiar structures occurring in the pollen tube of Zamia. Bot. Gazette 23:453-459. pl. 40. I897.

-... The development of the antherozoids of Zamia. Bot. Gazette 24: I6-22. I 897 .

- - Notes on the fecundation of Zamia and the pollen tube apparatus of Ginkgo. Bot. Gazette 24:225-235. pl. IO. 1897 .

-_- Spermatogenesis and fecundation of Zamia. U.S. Dept. Agric., Bur. Pl. Ind., Bull. 2. pp. го०. pls. 7. Ig0 I.

Weber, O., und Sterzel, J. T., Beiträge zur Kenntniss der Medulloseae. XIII. Ber. Naturwiss. Gesell. Chemnitz. pp. 102. pls. g. figs. 33. I 896.

WEISS, F. E., "The origin of gymnosperms"; a discussion at the Linnean Society. New Phytologist 5:68-76, I 4 I-148. 1906.

Wettstein, R. von, Der Ursprung des Pollenschlauches. Naturw. Rundschau 2I : I 2. I906.

White, David, The seeds of Aneimites. Smithson. Miscell. Coll. 47:322-33I. pls. 47, 48. 1904 .

—_, Fossil plants of the group Cycadofilices. Smithson. Miscell. Coll. 47 : 377-390. pls. 53-5.5. I904.

IVieland, G. R., A study of some American fossil cycads. I. The male flower of Cycadeoidea. Amer. Jour. Sci. IV. 7:223-226. pls. 2-4. I899. 
Wieland, G. R., A study of some American fossil cycads. II. The leaf structure of Cycadeoidca. Amer. Jour. Sci. IV'. 7:305-30S. pl. 7. 1809.

- A study of some American fossil cycads. III. The femile fructification of Cycadcoidea. Amer. Jour. Sci. IV. 7:383-39r. pls. \$'10. 1899.

, The Yale collection of fossil cycads. Yale Sci. Monthly 6: I-I I. pl. I. 1900.

-_- A study of some American fossil cycads. IV. On the microsporangiate fructification of Cycadeoidea. Amer. Jour. Sci. IV. I I :423-436. I901.

, The proembryo of Bennettiteac. Amer. Jour. Sci. IV'. I8: $445-447$. pl. 20.1904 .

- American fossil cycads. Publ. no. 34, Carnegie Institution of 11 ashington. pp. 296. pls. 50. figs. 13S. 1906.

- Historic fossil cycads. Amer. Jour. Sci. IV. 25:93-101. 1908.

, The Williamsonias of the "Mixteca Alta." Bot. Gazette 48:427-441. figs. IO. I 909 .

Wiggleswortif, Grace, The cotyledons of Ginkgo biloba and Cycas rerioluta. Annals of Botany 17:789-791. I903.

Vild, G., On Trigonocarpum olivaeforme. 'Trans. Manchester Geol. Soc. 26: pl). 15. pl. 2. 1900.

Willianson, W. C., On the structure and affinities of the plants hitherto known as Sternbergiae. Mem. Manchester Lit. and Phil. Soc. 14:340-358. pl. 10. 1851 .

, Contributions towards the history of Zamia gigas. 'Trans. Linn. Soc. Bot. 26:663-674. pls. 52, 53. т87o.

- On the organization of the fossil plants of the Coal-measures. IV. Dictyoxylon, Lyginodendron, and Heterangium. Phil. Trans. Roy. Soc. London $\mathrm{B}$ I63:377-408. pls. 22-31. 1873 .

- On some fossil seeds from the Lower Carboniferous beds of Lancashire. Rep. 45th Meeting British Assoc. (1875): I59-160. 1876.

- On the organization, etc. VIII. Ferns (continued) and gymnospermous stems and seeds. Ann. Mag. Nat. Hist. 18:268-273. 1876 (preliminary notice); Proc. Roy. Soc. London 25:68-73. 1877 (abstract); Phil. Trans. Roy. Soc. London B 167:213-270. pls. 5-16. 1878 (full paper).

-, On the organization, etc. X. Phil. Trans. Roy. Soc. London B I7I: 49.3-539. pls. I4-2I. 1880.

- On the organization, etc. III. Phil. Trans. Roy. Soc. London B I74: 459-475. pls. 27-37. 1883 .

, On the organization, etc. XIII. Phil. Trans. Roy. Soc. London B I 78: 289-304. pls. 21-24. I 887 (p. 299).

, On the organization, etc. XVII. Phil. Trans. Roy. Soc. London B 18 1 :89-106. pls. 12-15. 1890.

, and ScotT, D. H., Further observations on the organization of the fossil plants from the Coal-measures. III. Lyginodendron and Hetcrangium. Phil. Trans. Roy. Soc. Lonrlon I3 186:703-779. pls. IS-21. 1896. 
Worsoeld, IV. C., Anatomy of stems of Macrozamia compared with that of other genera of Cycadeae. Annals of Botany I0:601-620. pls. 27, 28. 1896.

-, On transfusion tissue; its origin and function in the leaves of gymnospermous plants. Trans. Linn. Soc. Bot. II. 5:30I-3I9. pls. 23-26. I897.

- The structure of the female "flower" in Coniferae. Annals of Botany I $4: 39-82$. I900.

- The anatomical structure of Bowenia spcctabilis. Annals of Botany 14: I 59, I60. I900.

- - The vascular structure of the ovule of Cephalotaxus. Annals of Butany I $4: 3$ I 7,3 I8. I900.

- _ - The affinities of the mesozoic fossil Bennettites Gibsonianus. Annals of Botany 14:7I7-721. I900.

- The evolution of the vascular tissue of plants. Bot. Gazette 34:2 I6223. figs. 7. 1902.

- - The structure and origin of the Cycadaceae. Annals of Botany 20: I29I59. figs. I7. I905.

—_ "The origin of gymnosperms"; a discussion at the Linnean Society. New Phýtologist 5:68-76, I 4 I-I 48. I9o6.

Woycicki, Z., (On fertilization in Coniferae). pp. 57. pls. 2. I899. (Russian) Ioung, MARY S., The male gametophyte of Dacrydium. Bot. Gazette 44: r89Ig6. pl. I9. 1907 .

- The morphology of the Podocarpineae. Bot. Gazette 50:8I-Io0. pls. 4-6. I9IO.

ZACH, Franz, Studie iiber Phagocytose in den Wurzelknöllchen der Cycadeen. Oesterreich. Bot. Zeitsch. 60:49-55. pl. 2. I9io.

Zeiller, R., Elements de palaeobotanique. I900.

— landien des environs de Boulogne-sur-Mer. Compt. Rend. Acad. Sci. Paris I37: I020-1022. I903.

(with Fliche, P.), Note sur un florule portlandienne des environs de Boulogne-sur-Mer. Bull. Soc. Geol. France IV. 4: $787-8$ I 2. 1904.

- Une nourelle classe de Gymnospermes: les Pteridospermées. Rer. Gen. Sci. I6:718-727. figs. 7. 1905. 


\section{INDEX}

Pages containing illustrations are indicated by italic figures.

\section{A}

Abies, strobilus 239,276

Abictineac 220; archegonium 207; distribution 301 ; history 303; procmbryo $288,289,290$; prothallial tissue 277

Adiantum, amphiphloic siphonostele 6; lcaf gap $I O$

Agathis, microsporangium 240; shoot 236 ; strobilus $2.70,327$

Amphiphloic siphonostele 5; Adiantum 6

Amyelon $I 7 I$

Aneimites 24; seed 39, 40

Angiocycads 74

Antholithus 193

Anthostrobilus 74

Araucaria, embryo 297, 298; habit 225; ovuliferous bract $24 \delta$; prothallial tissue 278 ; strobilus $270,247,324$

Aracarineae 22I; archegonium 27I; distribution 302 ; history 305 ; prothallial tissue 277,278

Araucariopitys 306,308

Archegonium, Abietineae 267; Arancarineae 27r; Cordaitales I79; Cupressincae 269; Cycadales I 33, I 35, I 36, I37, I 38 ; evolutionary tendencies 420; Ginkgoales 205, 208, 211; Gnetales 385, 386; Pinaceae 263, 264, 266, 267; Taxaceae 330; Taxodineac $26 \mathrm{~S}$

\section{B}

Baiera, leaf $I \delta 9$

Bars of Sanio, Pinaceae 235

Bennettitales 65 ; distribution $\mathrm{S}_{5}$; $\mathrm{cm}$ bryo 67; history 85 ; leaf $7 \mathbf{1}$; male gametophyte $S_{2}$; megasporangium 78 ; microsporangium 75 ; relationship 86 ; strobilus $72,73,76,79,80,81,82$; vascular anatomy 70 ; vegetative organs 66
Bennettites, seed $\delta_{3}, \delta_{f}$ : strobilus 79

Blepharoplast $1+2$

Botryopterideac 54

Botryopteris 54

Brachyoxylon 306, 30s

Brachyphyllum 308

C

Calamopitys 20

Calymmatotheca 27

Cephalotaxus, embryo 299; male cell 339; pollination drops 275

Ceratozamia, embryo $155 ;$ megaspore 127; megasporophyll I24, I3I; vascular plate $90.100,101,103$

Chromosomes, Gnetales 384; Pinaceac 259; Taxaceae 329

Cladosiphonic siphonostele 9

Cladoxylon 20

Codonotheca 28,29

Colpoxylon 20

Coniferales 220; archegonium 263, 26 t, 270,330 ; chromosomes 259,329 ; distribution 30r, 349; embryo $2 S_{i}, 288$, $289,290,291,292,293,294,295,296$, $297,298,299,346,347,349$; female gametophyte $259,260,261,329,330$, 337 ; fertilization $284,286,287,344$, $3+5$; history $303,3+9$; interrelationship of tribes 308 ; juvenile leaves 227 ; leaf $235,236,237,317,318$; list of genera 353; male gametophyte 272 , $273,276,335,336,337,339,340,342$; megasporangium 244, 254, 255, 256 . 321,327 ; mcgaspore 257,258 ; megaspore membrane 271 ; microsporangium $239,240,241,243,272,319$; microspore 274; microsporophyll 239, 240; relationship 309. 350 ; seed 300 ; seedling 23I; stamen 3I9; strobilus $238,239,240,244,246,247,319,320$, 
$321,322,323,324$; vascular anatomy 228,3 I5; vegetative organs 222,3 I5; ventral canal cell 266,267

Coniferophytes 59

Conostoma 37

Cordaianthus 173,175 ; ovules 176 , 177 ; microspore 177 ; stamen 174

Cordaitales 163 ; archegonium 179 ; distribution ISo; embryo ISo; female gametophyte 179 ; history I80; leaf I68, I69, I70; male gametophyte $I 77$, I78; megasporangium I74; microsporangium I72, I73, I74; microspore 177; relationship I 80 ; root 171 ; stamen I74; strobilus $172, I 73,175$; vascular anatomy 165 ; vegetative organs 164

Cordaites, leaf 169,170 ; root $17 I$; stem section $165,166,167 ;$ strobilus 172

Cotyledon, evolutionary tendencies $42 \mathrm{~S}$, 429; Pinaceae 297

Crossotheca 25,26, 27,28,29

Cryptomeria, female gametophyte $26 I$; male gametophyte 279 ; strobilus 324

Cunninghamia, male gametophyte 279; proembryo 291; strobilus 324

Cupressineae 22I; archegonia 269, 270; distribution 301; history 305; male cell 28o; proembryo 293, 294; prothallial tissue 277

Cupressus, male gametophyte 280 ; strobilus 324

Cycadales 9I; archegonium I33, I35; distribution 156 ; embryo ${ }_{5} 50, I_{5}$, $152,153,154,155$; female gametophyte 132,137 ; fertilization 148 , I50; history I56; leaf IoS, IOQ, IIO; male gametophyte I39, I4I, I43, I44; megasporangium I 21 ; megaspore 127 ; megaspore membrane 139 ; megasporophyll 124, I3I; microsporangium II4, II, 119 , 120 ; microspore 140 ; microsporophyll $I 16, I 17$; relationship I57; root II $2, I I 3$; seedling structure 98 , 99, I00, IOI, 102, 103, 104, 105, 106; sperm $I 45,146,147$; strobilus 114 , $122,123,125$; vascular anatomy 93 ; vegetative organs 93

Cycadella, ramentum 70
Cycadeoidea, microsporophyll 77 ; seed $\delta_{4} ;$ strobilus $73,76, \delta 0, \delta_{1}, \delta_{2}$; synangium 78 ; trunk 57

Cycadinocarpus, ovule section 179

Cycadofilicales $\mathrm{I}$; distribution $5 \mathrm{I}$; embryo 46 ; female gametophyte 48 ; history $5 \mathrm{I}$; leaf $I, 2 \mathrm{I}, 22,24$; male gametophyte 49 ; megasporangium $3 I$; microsporangium $25,26,27,28,29$; microspore 49,50 ; origin 55 ; relationship 5 I , 58; seed $31,32,33,34,35,36$; $38,39,40,42,43,44,45$; vascular anatomy I2; vegetative organs 3

Cycadophytes 59

Cycadoxylon 16, I7

Cycas, archegonium 135; embryo 152; leaf $I O 9, I I I$; male gametophyte 143 ; megaspore membrane 139 ; megasporophyll 124 ; microsporophyll $I I 7$; root tubercle II 3 ; seed I 30 ; sperm 145 ; strobilus 123 ; ventral nucleus 136

\section{D}

Dacrydium, male gametophyte 340

Dadoxylon I 68

Dioon, archegonium I33, I35, I $3 \delta$; embryo 153,154 ; female gametophyte I32; fertilization 149 ; habit 92, 94; leaf $I I O, I I I$; male gametophyte $I 4 I$; megaspore membrane 139 ; megasporophyll 124; microsporangium 120 ; microsporophyll II6; ovule $126, I 28$, I29; pollen tube $I 2 \delta$; seedling structure 104, I05; sperm I46; strobilus I22, I 25; ventral nucleus 136

Dorycordaites 164

\section{E}

Ectophloic siphonostele 5; Osmunda 7 Embryo, Bennettitales 83, 84; Cordaitales 180; Cycadales 150, I51, I52, 153, I54, 155; Cycadofilicales 46; evolutionary tendencies 426; Ginkgoales 210, 2II, 2I2, 213; Gnetales 393, $394,395,397,398,400$; Pinaceae 287 , $288,289,290,291,292,293,294,295$, 296, 297, 298, 299; Taxaceae 346, $347,348,349$ 
Embryonal tubes, Pinaceac 295, 296, 297

Encephalartos, archegonium 135; megitsporophyll 124, I31

Endarch 10, II

Endosperm, see female gametophyte

Epliedra, archegonium 356; embryo 394, 395, 397; fenale gametophyte 377, 384 f fertilization 392; habit 364 ; malc gametophyte 390, 391; megalspore 385 ; ovule 377 ; strobilus 372

Euanthostrobilus 74

Evolutionary tendencies 406

Exarch Io, II

\section{$\mathrm{F}$}

Female gametophyte, Cordaitales 179; Cycadales 132; Cycadofilicales 48; evolutionary tendencies 4I9; Ginkgoales 203, 204, 20S; Gnetales 375, $377,379,382,38_{3}, 38_{4} ;$ Pinacente 259. 260, 261; Taxaceae 329, 330, 337

Ferns, paleozoic 52 ; relationship to Cycadofilicales 5 I

Fertilization, Cycadales I48, I 50; evolutionary tendencies 423; Ginkgoales 209; Gnetales 391, 392; Pinaceae 284, 2S6, 2S7; Taxaceae $3 \mathrm{t}+3+5$

Flower, Gnetales 37 I, 372, 373, 375, 377, 380

\section{G}

Gametophytes, sce male gametophyte and female gametophyte

Ginkgo, archegonium 20S, 2II; cotyledon section $I \delta \delta$; embryo $2 I I, 2 I 2$, 213; female gametophyte 204, 208; habit $I \delta 6$; leaf $I \delta 7, I 90$, I99; male gametophyte 207; ovulate strobilus 195, 196, 197, 198; ovule 195, 196, I97, I9S, 200, 20I, 202; peduncle section I99; seedling 190; staminate strobilus $191,192,193$

Ginkgoales, archegonium 205, 20S, 211 ; distribution 215; embryo 210, 2II, 212, 213; female gametophyte 203, 204, 208; history 215 ; leaf 187,189 , 190, 199; male gametophyte 206, 207; megasporangium 194, 200, 201, 202; megaspore membrane 204, 205; nicrosporangium 191, 192, 193; microsporophyll 191, 192, I93; peduncle section 199; relationship 2r6; secelling 188 , 190; stroljilus 190, 191, 192, 193, 195, $196,197,108$; vascular anatomy 157; vegetative organs 185

Gleichenia, protostele 5

Ginetales 363; archegonium 385, 356; chromosomes $3 \$_{4}$; distribution 402 ; embryo 393, 394, 395, 397, 39S, 400; female gametophyte $375,377,379$, $382,383,384 ;$ fertilization 391, 392; history 402 ; leaf 369 ; male gametophyte $389,390,391$; megasporangium $375,376,377$; megaspore $3 S_{4} ;$ ovule $376,377,3 \delta 0,3 \delta 2 ;$ microsporangium 37 ; relationship 402; seedling 399; stamen $380 ;$ strobilus $370,372,374$, $375,376,380$; vascular anatomy 366 ; vegetative organs 364

Gnetopsis 37

Gnetum, embryo 400; female gametophyte $375,382,3 \delta_{3}$; flower 375 ; habit 367,370 ; megasporangium 375 ; ovule $376,3 \delta o, 3 \delta_{2} ;$ strobilus 375 , 376,380

\section{$\mathrm{H}$}

Hemiangiosperms 74

Heterangium 12

Juniperus, fertilization $2 \delta 7$; proembry:o 294

\section{K}

Kaloxylon 14

L

Lagenostoma $31,32,33,34,35$; microspore 19

Larix, megasporangium 255; strobilus 246

Leaf gap 9; Adiantum $I 0$

Leaf, Bennettitales $7 \mathrm{I}$; Cordaitales 168 , I69, I70; Cycadales IOS, I09, 110; Cycadofilicales $I, 21,22,24$; evolutionary tendencies 4 I2; Ginkgoales IS7, IS9, Igo; Gnetales 369, 370; 
Pinaceae 235, 236, 237; Taxaccae 317,318

Libocedrus, male gametophyte 280

Lyginodendron $I_{3}, I+15, I 6$

\section{M}

Male cell, evolutionary tendencies 423; Pinaceae 276, 277, 279, 280; Taxineae 338,339

Male gametophyte, Bennettitales $S_{2}$; Cordaitales 177, I78; Cycadales I.39, IfI, I43, It4; Cycadofilicales 49; evolutionary tendencies 42I; Ginkgoales 206, 207; Gnetales 389, 390, 39I; Pinaceae 273, 276; Podocarpineae $339,3+0,3+2$; Taxaceae 335 , $337,339,340,342$; Taxineae 335,337

Marattiaceae, paleozoic 53

Medullary ray, Pinaceae 232

Medullosa $17,78,19$; seed 38, to

Megaloxylon I 5

Megasporangium, Bennettitales 78 ; Cordaitales I74; Cycadales I2I; Cycadofilicales 3I; Ginkgoales I94, 200, 201, 202; Pinaceae 244, 254, 255, 256; Taxaceae 321, 327

Megaspore, Cycadales 127; Pinaceae 257,258 ; Gnetales 384

Megaspore membrane, Cycadales I39; Ginkgoales 204, 205; Pinaceae 271; Taxaceae 332

Megasporophyll, Cycadales $124,130,131$

Mesarch Io, II

Nicrocachrys, male gametophyte 3.1 ; strobilus 320,324

Microcycas, female gametophyte I37; megasporophyll I3I; secdling structure 106 ; sperm 147

Microsporangium, Bennettitales 75; Cordaitales I72; Cycadales II4, II 8 , I19, I20; Cycadofilicales 25, 26, 27, 28, 29; Ginkgoales I91, I92, I93; Gnetales 37I; Pinaceae 239, 240, 24I, 243, 272; Taxaceae 319

Microspore, Cordaitales I77; Cycadales 140; Pinaceae 274

Microsporophyll, Bennettitales 77; Cycadales 116,117 ; Pinaceae 239, 240, 24I
Neuropteris 23, 24; frond $t ;$ seed 38,40

$\mathrm{O}$

Osmunda, ectophloic siphonostele 7

Ovule, Cordaitales $174,175,176,177$;

Cycas 130; Dioon 126, 128, 129; erolutionary tendencies $4 \mathrm{I} 6$; Ginkgoales $195,196,197,198,200,201,202$; Gnetales $376,377 \cdot 380,382$; Pinaceae 245, 25I, 254; Taxaceae 322, 323, 324

\section{$\mathrm{P}$}

Pachytesta $4 \mathrm{I}$

Paleozoic ferns 52 ; seeds 42

Parthenogenesis, Pinaceae 300

Pecopteris 23; seed 40

Phyllocladus, archegonium $3+2,3+3$; fertilization 345; jurenile leaves 227 ; male gametophyte $34^{1}, 34^{2}$; pollen tube 343 ; shoot 316

Phyllosiphonic siphonostele 9

Phylogeny 407, 408, 409

Physostoma 34, 36; microspore 50

Pinaceae 220; archegonium 263, 264, 270; chromosomes 259; distribution 301 ; embryo $287,288,289,290,291$, 292, 293, 294, 295, 296, 297, 298, 299; female gametophyte $259,260,261$; fertilization $284,286,287$; history 303 ; interrelationship of tribes 308 ; juvenile forms 222, 227; leaf $235,236,237$; male gametophyte $272,273,276$; megasporangium 244, 254, 255, 256: megaspore 257, 258; megaspore membrane 27I; microsporangium 239, $270,241,243,272$; microspore 274 ; microsporophyll 239, 240; ovule $25 \mathrm{I}$, 254; prothallial tissue 277,278 ; relationship 309; seed 300 ; seedling 231; strobilus $238,239,240,244,246,247$, 252; vascular anatomy 228 ; vegetative organs 222; ventral canal cell 266 , 267

Pinus, archegonium 263, 264; embryo $288,289,290,296$; female gametophyte 260; fertilization 286 ; leaf section 237; male gametophyte 273, 276; 
megasporangium 256; megaspore 257 ; microsporangiam 273, 272; microspore $27+$; ovule $2+5,25+$; secondary wood section 220; seed 300; strobilus $23 \delta^{\circ}, 2+5,2 f^{6}, 252 ;$ rentral canal cell 266,267

ritys ros

Pityoxylon 304

Platysperms +2

Podocarpineac 313; archeronium 33I; male gametophỹte $339,370,372$

Porlocarpus, habit $3 I f$; leaf $31 S$; male gametophyte 371 ; strobilus 324

l'olycotyleclony 297

l'olystele 5.8

Poroxylon, stem 166

Prepinus 304: $30 \mathrm{~S}$

Primofilices $5 t$

Proangiosperms 75

Proanthostrobilus $7+$

Proembryo, Ephedra 395; Pinaceac 288 , $289,290,291,292,293,294 ;$ 'Taxaccate $3+6,3+7,3+9$

Prothallial tissue, Pinaceac 277,278 ; Podocarpineac 339

Proto itys 20

Protostele 4; Gleichenia 5

Pseudotsuga, habit 223

Pteridophytes, vascular anatomy 4

Pteridostrobilus 75

Pteris, polystele $\delta$

R

Rachiopteris 13

Radiosperms 42

Resin canal, Pinaceae 233

Retinospora 225

Root, Cycadales I I 2, 113

\section{$\mathrm{S}$}

Saxegothaea, male gametophyte $34 I$; orule 327

Sciadopitys, proembryo 292

Seed, Cycadofilicales $31,32,33,34,35$, $36,38,39$, to; paleozoic 42; Pinaceac 300; Stephanospermum 42, 43; Taxaceae 325 ; Torreya 332,333

Seedling, Cycadales 98, 99, 100, 101, 102, $103,104,105,106$; evolutionary temelencies 427; (iinkgroales 188, 1yn; Pinaceac 231; Welwitschiat 390

Sequoia, habit 22f; megaspore $2 j 8$; procmbryo 202

Siphonostele 4 ; amphiphloic 5, 0 ; clatosiphonic 9 ; cetophloic 5, i; phyllosiphonic o

Solenostele 5

Sperm, Cycadales $1+5,146,1+7$; evolutionary tendencies +23

Sphacrostoma 37

Sphenopteris 22

Spicular cells. Welwitschia 360

Stamen, Cordaitales I7f; evolutionary tendencies +15; Ginkgoales 191, 1y2, I93; Gnetales 371, 380; Pinaceae 2.1; Taxaceac 3 I 9

Stangeria, megaspore 127 ; megasporophyll 130; microsporangium II9

Stauropteris 30

Stephanospermum 42, +3 ; microspore $+9.50$

Strobilus, Bennettitales $72,73,76,79$, So, $S_{1}, S_{2}$; Cordaitales $172,173,175$; Cycadales IIt, I22, I23, I25; erolutionary tendencies 413; Ginkgoales I 90, I9I, I92, I93, I95, I96, 197, I98; Gnetales $370,372,37+375,376,380$; Pinaceac $238,239,270,244,246,247$. 252; Taxacear 319, 320, 321, 322, 323,324

Suspensor, Pinaceae 295; Taxaceae 348 , $3+9$

Sutcliffia 20

Synangium, Cycadeoidea $7 \delta$

\section{$\mathrm{T}$}

Taxaceae 220; archegonium 330; chromosomes 329; distribution 349; embryo $346,347,348,349$; female gametophyte $329,330,337$; fertilization $3+4,3+5$; history 349 ; leaf 317.318 ; megasporangium 321, 327; megaspore membrane 332 ; microsporangium 319 ; relationship 350 ; stamen 3 r9; strobilus $319,320,321,322,323,324 ;$ vascular anatomy 315; vegetative organs 315 
Taxineae 313; archegonia 332; male cell $337,338,339 ;$ male gametophyte 335 , 336,337

Taxodineae 22I; archegoniun 268; distribution 301; history 304; male cell 279; proembryo 29I, 292; prothallial tissue 277

Taxodium, embryo 297; habit 226; male gametophyte 279; proembryo 29I

Taxus, female gametophyte 330 ; male cell 338; megasporangium 328; microsporangium 243

Thuja, archegonium 270; juvenile leaves 227; male gametophyte 280; proenibryo 293

Torreya, embryo 347, 349; female gametophyte 337; male gametophyte 336, 337; microspore 336; ovulate branch 322; ovulate strobilus 323 ; seed 332,333

Trigonocarpum 4I, 44, 45

Tumboa 363

Tyloses, Pinaceae 235

\section{$\mathrm{V}$}

Vascular anatomy, Bennettitales 70 ; Cordaitales I65; Cycadales 93; Cycadofilicales I2; endarch IO, II; evolutionary tendencies 4 II ; exarch IO, II;
Ginkgoales I87; Gnetales 366; leaf gap 9, IO; mesarch Io, II; Pinaceae 22S; polystele 5, $S$; protostele 4, 5; Pteridophytes 4 ; siphonostele $4,6,7$, 9; solenostele 5; Taxaceae $3 \mathbf{I}_{5}$

Ventral canal cell, Pinaceae 265, 266, 267; Taxaceae 33 I

Ventral nucleus, Cycadales I 36

\section{II}

Welwitschia, embryo 398 ; female gametophyte 379; flower 373 ; habit 365 , 366; seedling 399; spicular cells 369 ; strobilus $37+$

Williamsonia, habit 68.69

\section{I}

Yezonia 307

Yezostrobus 307

Z

Zamia, embryo I5I; fertilization I5O; habit II2; leaf $I I O$; male gametophyte Ift; megaspore I27; megasporophyll I2.; microspore I.to; microsporophyll II 7 sperm I $45 ;$ stem apex II5; stem section 96

Zygopteris 54 ; sporangium 55 




UI Coulter, John Merle

643 Morphology

G99C7

Biolled.

PLEASE DO NOT REMOVE CARDS OR SLIPS FROM THIS POCKET 


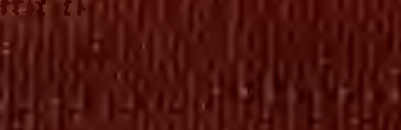

af

(1)

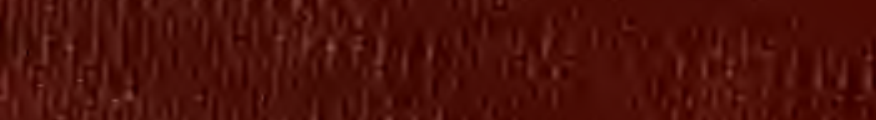

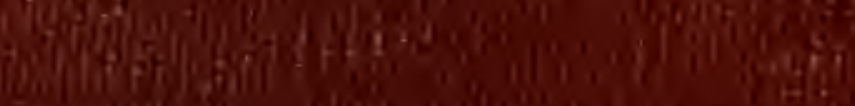

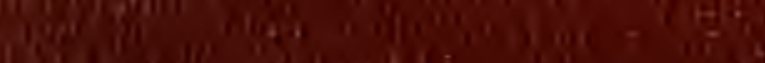

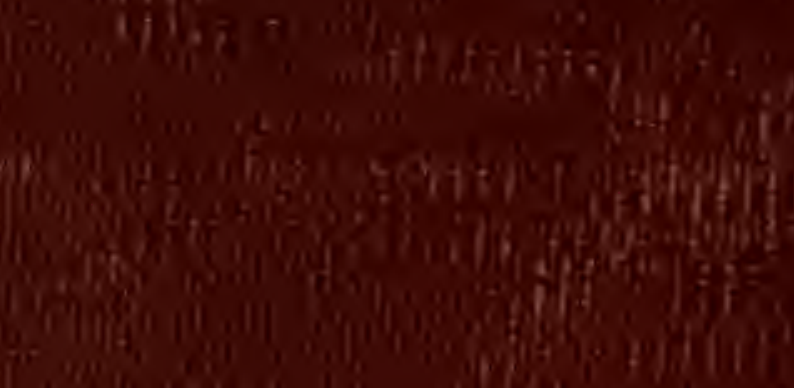

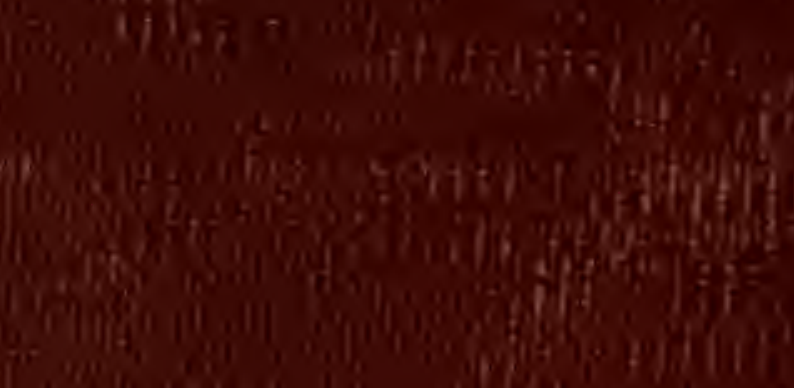

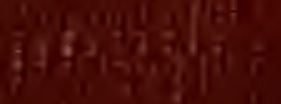

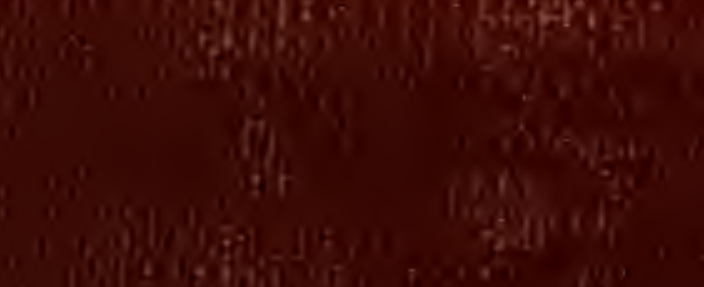
Iffify. 